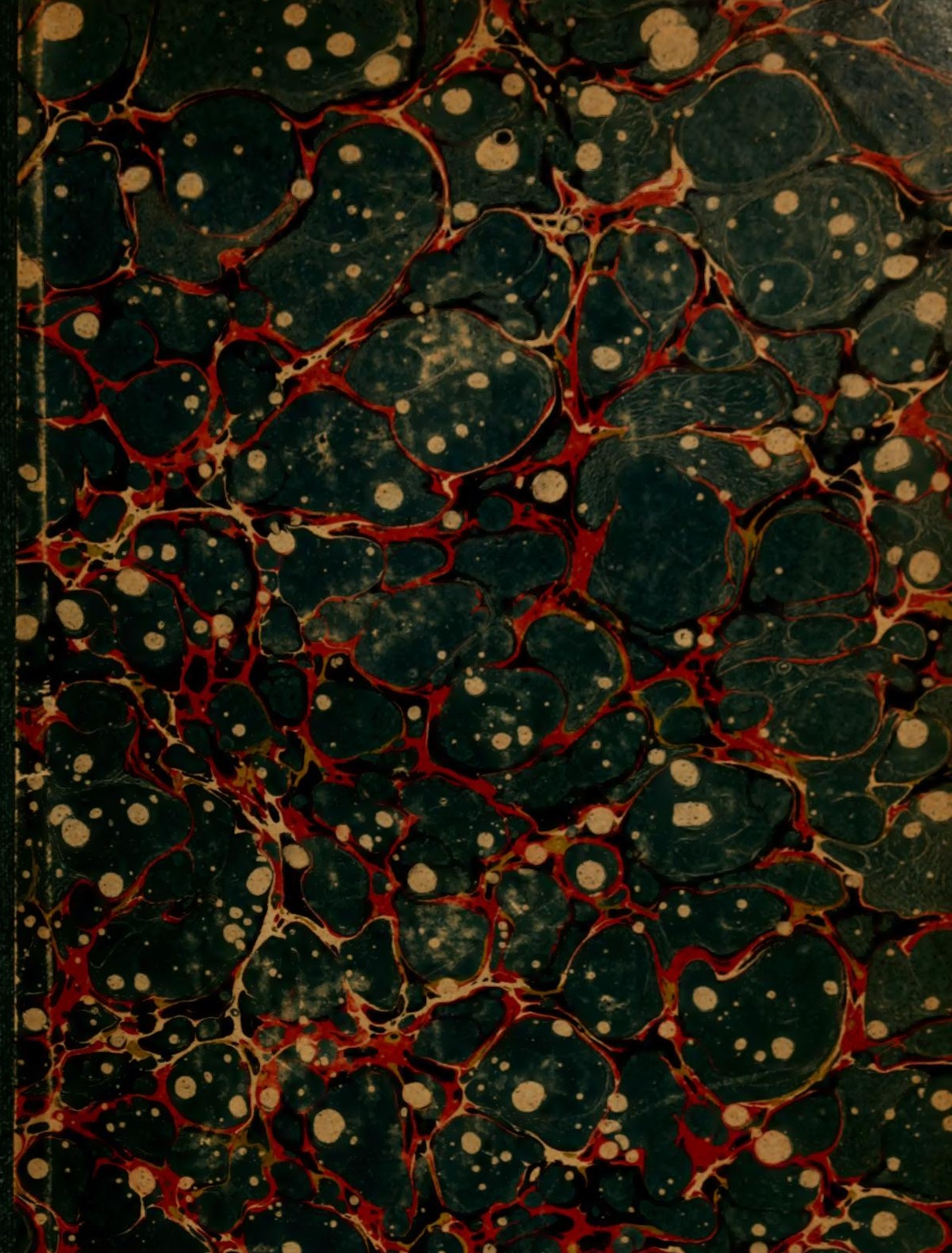

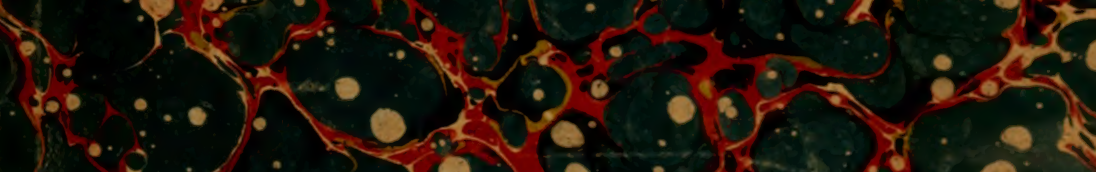


Columbita College

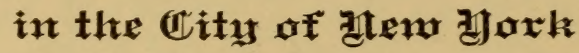

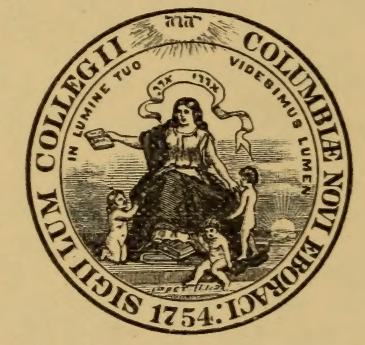

\section{Itiluxaxy.}






bomplumentis of

of'Lameon-ociubur. 



\section{BULLETIN}

OF THE

\section{AGRICULTURAL EXPERIMENT STATION}

OF THE

\section{UNIVERSITY OF TENNESSEE}

STATE AGRICULTURAL AND MECHANICAL COLLEGE.

Vol. V. APRIL, I892. $\quad$ No. 2.

The Grasses of Tennessee.-Part I.

These Bulletins will be sent upon application, free of charge, to any Farmer in the State.

KNOXVILLE, TENNESSEE, U. S. A. 


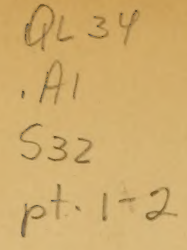

\title{
THE AGRICULTURAL EXPERIMENT STATIION
}

\section{OF THE UNIVERSITY OF TENNESSEE.}

\author{
BOARD OF CONTROL : \\ O. P. TEMPLE, \\ JAMES PARK, D. D. \\ R. H. ARMSTRONG. \\ J. W. GAUT. \\ TREASURER: \\ JAMES COMFORT.
}

THE STA TION COUNCIL IS COMPOSED OF ITS OFFICERS:

Prof. F. LAMSON-SCRIBNER, Director and Botanist.

Prof. CHAS. F. VANDERFORD, Assistant Director.

Dr. C. W. DABNEY, JR., Chemist.

PAUL F. KEFAUVER, Agriculturist.

R. L. WATts, B. Ag., Horticulturist.

J. B. McBRYDE, Assistant Chemist.

The Station has facilities for analyzing and testing fertilizers, cattle foods, milk and dairy products ; seeds, with reference to their purity or germinating power; for identifying grasses and weeds, and studying forage plants; for investigating the diseases of fruits and fruit trees, grains and other useful plants; for making reports on injurious insects, and the best means of combating them.

The Bulletins and Reports will be sent, free of charge, to any farmer within the State.

Packages by express, to receive attention, should be prepaid.

All communications should be addressed to the

DIRECTOR OF THE

AGRICULTURAL EXPERIMENT STATION, Knoxvilile, Tenn.

Fo The Experiment Station building, containing its offices, laboratories and museum, and the plant-house and horticultural department, are located on the University grounds, fifteen minutes walk from the Custom House in Knoxville. The Experiment farm, stables, milk laboratory, etc., are located one mile west of the University, on the Kingston pike. Farmers are cordially invited to visit the buildings and experimental grounds. 


\title{
GRASSES OF TENNESSEE.
}

\author{
PART I. \\ BY F. LAMSON-SCRIBNER.
}

This first part on The Grasses of Tennessee is designed for farmers and agricultural students of this State; affording the former a handy reference book for information as to the general character and qualities of our grasses, and giving the latter a concise account of the characters of the grass family, together with a key for determining the tribes and genera into which the species are classified. It is believed that this bulletin will enable the intelligent farmer to become familiar with the terms applied to the various parts of grasses, thus making it possible for him to speak or write understandingly about any one of the many kinds which he may find upon his farm or in his immediate neighborhood.

There is included in this part

(I) An index or alphabetical list of the native and introduced or cultivated grasses of the State. After each common or English name the Latin name is given; and after the Latin name, are given all the English names of each known to the writer, together with brief observations on the habits or agricultural value of the species.

(II) Illustrations and descriptive terms. This includes a special series of figures obtained from various sources, and used here to illustrate the leading botanical characters of grasses, and the terms employed to designate them. They also serve to illustrate to some degree the species they represent.

(III) Characters of the grass family (Graminex), with a key for the identification of the genera which may be found either growing wild or under cultivation within the State. The genus thus determined, the reader is expected to refer to Gray's "Manual," or Chapman's "Southern Flora," for the determination of the species. In some cases the species may be made out by reference to section I.

(IV) An enumeration of the books and pamphlets wholly or in part devoted to grasses, in the possession of the Station, or in the private library of the writer. One may here learn the titles and something of the size and scope of the more important works on grasses, both popular and scientific.

In Part II it is proposed to fully describe, and so far as possible, illustrate all of the grasses of the State. Part I is introductory to this. 


\section{(I.) A LIST OF THE NATIVE AND CULTIVATED GRASSES OF TENNESSEE.}

The published English names and synonyms, as well as the botanical names, are given in alphabetical order; all the English or "common" names known to the writer are included, together with brief observations regarding the character and habits of the grasses enumerated. A number of species possessing no local or common names are omitted.

African Cane-Pennisetum spicatum.

African Sugar Cane-Sorghum saccharatum.

Agropyrum caninum $R$. \& S.-Bearded Wheat-grass, Awned Wheat-grass.

This grass is recordeu by Gattinger as occurring within the State in cultivated grounds, but not frequent. It is a native of the more Northern States, especially in the mountain regions. It differs from cultivated wheat in its more slender growth and perennial habit, and from its near relative, $A$. ripens, in having a strictly fibrous root and longer-bearded flowers. We are

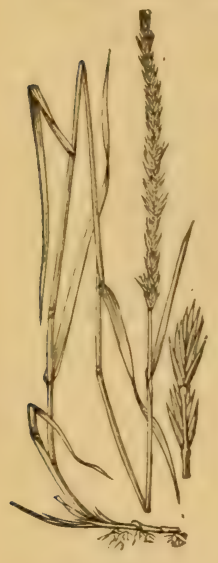

Fig. 1. Couch-grass, Agropyrum repens not aware that its agricultural value has been tested.

Agropyrum repens, Beauv-Couch-grass, Witchgrass, Quitch-grass, Quick-grass, Quack-grass, Quake-grass, Wheat-grass, Creeping Wheatgrass, Dog-grass, Dutch-grass, Durfa-grass, Durfee-grass, Devil's-grass, Chandler's-grass, Scutch-grass, Twitch-grass, Fin's-grass.

This, like $A$. caninum, is reported by Dr. Gattingeras occurring sparingly within the State in cultivated grounds. It is abundant in fields, etc., in the Eastern and Middle States, and although of considerable value for hay, its strong, creeping roots (really underground stems) which spread rapidly in all directions, render it a dangerous pest, hardly less difficult to eradicate than the well known Johnson-grass. 
Agrostis alba, Linn-Herd's-grass, Bent-grass. English Bent.

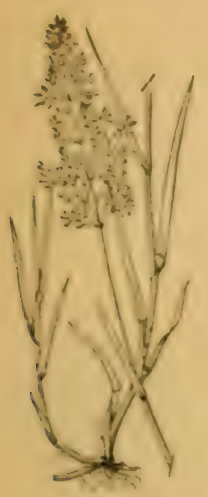

F1g. 2.

Red-top. Agrastis alba.

White Bent, Bonnet-grass, White-top, Dewgrass, Fiorin, Marsh Bent-grass.

Herd's-grass has long been known to our farmers, and in its several forms is deemed especially valuable for permanent meadows and pastures where the land is not too dry. On good soil it yields well and makes excellent hay.

\section{Agrostis arachnoides, Ell--Spicler-Bent-grass.}

This is a delicate, low-growing species, which Dr. Gattinger reports as being found on argillaceous soils, in the glades and highlands of Middle Tennessee. It has no agricultural value.

Agrostis canina, Limn-Brown Bent, Dog's Bent, Mountain Red-top, Rhode Island Bent, Finetop, Furze-top, Burden's-grass.

Our native forms of this species are low grasses, chiefly confined to the mountain region, growing sparingly in moist locations. The taller, cultivated form, is, we think, a European introduction, and its seeds may be obtained from New York or Philadelphia seedsmen: It makes a close sod and is considered valuable for permanent meadows or pastures.

Agrostis dispar, Michx.-Caid to be the same as Asrostis elatu.

Agrostis elata, Trin.-Southern Bent, Tall Thin-grass.

This is a common native species, growing usually in dry soil, in open woods or along thicket borders, attaining the height of two or three feet. It is a late growing species, not usually blooming before October. It has no recognized agricultural value.

Agrostis perennans, Tuck.-Thin-grass.

This is a common grass, of clelicate habit, growing in moist. open woods and shaded places, but does not appear until the early autumn months, flowering in September and October. Of little agricultural value.

Agrostis scabra, Milld--Rough Bent, Fly-away-grass, Tickle-grass, Hair-grass, Fool-hay.

Rough Bent is one of the most common of our native species of Agrostis, usually growing in dry soil, in old fields and along road ways. It has very fine root-leaves, comparatively short stems, and a very large, loosely flowered panicle. It is not considered of any agricultural value.

Agrostis stolonifera. Linn-Creeping Bent, Fiorin.

This is simply one of the forms of Agrestis alla (see above.) 
with low, spreading stems and a rather dense habit of growth. It is particularly valuable as a pasture grass.

Agrostis vulgaris, With.-Herd's-grass, Bent, Fine-top, Fine Bent, Rhode Island Bent, Furze-top, Tall Red-top, Burden'sgrass, Red-top, Summer Dew-grass, Borden's grass.

This is not recognized as being botanically distinct from Agrostis alba, already noted.

Alabama Guinea-grass.-Sorghum Halapense.

Alopecurus aristulatus, Michx.-Wild Water Fox-tail.

A grass of low habit, occasionally found along the borders of ponds and ditches, blooming in May. It has a head something

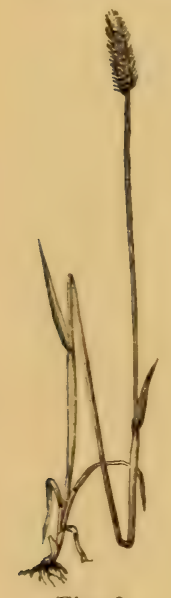

F1g. 3.

Meadow Fox. tail.-Alopecurus pratensis.

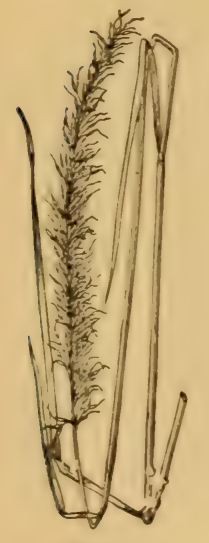

Fig. 4.

Wood-grass.

Andropogon nu.

like Timothy, only very much smaller. We are not aware that it forms any considerable element in our native forage.

Alopecurus pratensis, Linn--Meadow Fox-tail, English Fox-tail.

A valuable grass for moist meadows and pastures, particularly on account of its earliness, often blooming in April. It has been introduced here from Europe along with other cultivated grasses, and is deserving of more attention than it appears to have received.

American Canary-grass.-Phalaris intermedia.

Andes, Grass-of-the.-Arrhenatherum avenaceum.

Andropogon argyræus, Schult.-Silver Beard-grass.

A native species, found occasionally along the borders of woods, less common in open fields. It grows to the height of two or three feet, and is noticeable for its silvery-white "heads," which appear in September.

Andropogon furcatus, Michx.-The same as Andropogon provincialis.

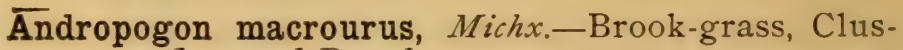
ter-flowered Beard-grass.

This is rather a stout-growing species, similar in habit to broom sedge, but more robust, and although pretty generally distributed over the State, it is far less common than that grass. It blooms from September to October.

Andropogon nutans, Linn.-Indian-grass, Reed-grass, Wild Oat-grass, Bushy Blue-stem, Wood-grass.

This is a stout, perennial grass, four to six feet high, growing in dry soil, along borders of fields, 
or open woods. It rarely occurs in sufficient abundance to be of any value, and when it has bloomed, its stems are tor stout and woody to be eaten by stock. It is not to be recommended for cultivation.

Andropogon provincialis, Lam,- Big Blue-stem, Finger-spiked Beard-grass, Finger-spiked IVood-grass, Finger-spiked Indian-grass, Blue-stem, Blue-joint, Blue Bent (in R. I.), Bluegrass, Turkey-foot.

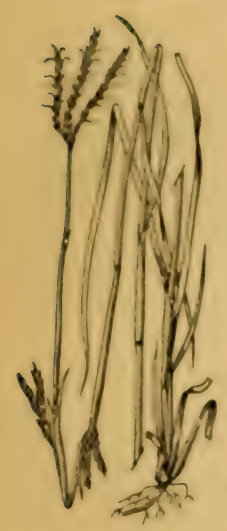

Flg. 5 .

Blue Bent. Andropogon pro. vincialis.

This is a strong-growing, native grass, found throughout the State in dry soil, though rarely seen in cultivated lands. In some sections of the country it is valued both for hay and pasture. When young it is readily eaten by stock, the stems being very leafy, but after flowering, the stems become hard and woody, and of little value. In certain soils, or under certain conditions, this grass might be worth cultivating. It grows to the height of three or four feet, and, like all the Andropogons, blooms late in the season.

Andropogon scoparius, Michx.-Little Blue-stem, Indian-grass, Purple Wood-grass, Wire-grass, Brown-grass, White Bent, Broom Sedge, Broomgrass.

This is a comparatively slender grass, growing to the height of one or two and a half feet, frequenting old fields and the borders of woods, particularly in the mountain districts. It has some value as a native forage plant, and by some is known as "mountain sedge." Distinct from Andropogon Virginicus.

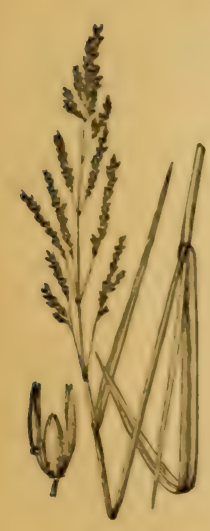

Fig. 6.

Johnson-yrass. Andropegon ser. ghum, var. Halapensis.

Andropogon Sorghum, Brot. Subspecies sativus, Hack.-Includes the cultivated varieties of Sorghum.

A number of varieties are cultivated here, either for the production of molasses, or for silage.

Andropogon Sorghum, Brot, var. Halapensis, Hack.Johnson-grass, Cuba-grass, St. Mary's-grass, False Guinea-gras's, Mean's-grass, Guinea-yrass (see Panicum jumentorum), Egyptian Millet, Egyptian-grass, Green Valley-grass, Alabama Guinea-grass, Australian Millet, Morocco Millet, Evergreen Millet, Arabian Millet, Syriangrass. (Sorghum Halapense).

Johnson-grass is now pretty well known in Tennessee, having been introduced quite generally over the State. There are a few who still regard it as a valuable grass for hay, and certainly its rield is very large; but there are a great many more who 
are ready to offer a handsome reward to any one who will free their lands from this species. It has strong, underground stems, which grow deeply, taking the soil completely. This habit makes Johnson-grass exceedingly difficult to eradicate, for the least fragment of these underground stems, if left in the soil, serve to produce a new plant. Unless we wish to give the land up forever to this grass, we should not think of cultivating it.

Andropogon Virginicus, Linn.-Broom Sedge, Broom-grass, Virginia Beard-grass, Sedge-grass.

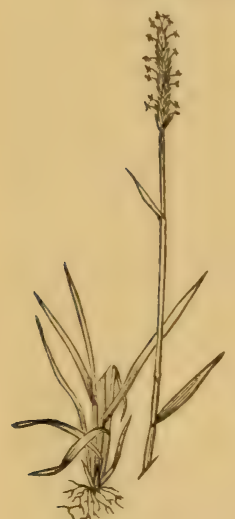

Fig. 7 .

Sweet Vernal grass.

Anthoxanthum odo. ratum.

There is probably no native grass better known to our farmers than this, and, although when quite young it affords excellent grazing, it is, on the whole, one of our worst weeds, rendering the formation of permanent meadows almost impossible. Constant tillage seems to be our only means of keeping this grass from occupying our land.

Annual Meadow-grass-Poa annua.

Anthoxanthum odoratum, Linn.-Sweet Vernalgrass, Sweet.scented Vernal-grass, Sweetscented Spring-grass, Sweet-scented-grass, Vernal-grass.

A low, slender perennial with a close, narrow "head." This grass has been introduced from Europe, and is valued on account of its earliness and sweet odor when dry. It can only be recommended in mixtures for pasture.

Arabian Millet, or Arabian Evergreen Millet.-Sorghum Halapense.

Aristida dichotoma, Michx.-Poverty-grass.

A low and much branched annual, common in dry, sterile soil, or open fields. Wholly worthless.

Aristida purpurascens, Poir.-Beard-grass.

Allied to the last and growing in similar situations, but taller and much less branched. Of no value.

Arrhenatherum avenaceum, Beauz.-Tall Oat-grass, False Oatgrass, Tall Meadow-Oat-grass, Evergreen-grass, Oat-grass, Grass-of-the-Andes, French Rye-grass.

A highly valued grass, both for winter grazing and for hay. It has been introduced into this country from Europe, where it is regarded as one of the best fodder grasses. As it stands in rather loose tufts, it is best to mix the seed with those of other grasses in order to thicken the sward. It grows rapidly, blooms early, and when cut, dries out readily, and when dry, keeps well. It is not regarded as a suitable grass for moist soils. 
Arundinaria gigantea, Chapm.-Cane, Large Cane (A macheorma, Michx.)

Dr. Gattinger reports this grass as growing along the large streams of the State." It ranges in height from ten to forty feet, with a diameter of from $1 / 2 \mathrm{in}$. to $3 \mathrm{in}$. The plants bloom but once, and when the seeds mature, the cane dies. These cancs are used for many purposes, such as for making fishing rods, scaffolds for drying cotton, splits for baskets, mats, etc. When young and tender, the leaves and stems are readily eaten by stock.

Arundinaria tecta, $M$ uhl.-Small Cane, Reed, Switch Cane.

Similar in habit to Arundinaria gigantea, but smaller in size and more generally distributed over the eastern part of the State, and occasionally found in swamps high up on the mountains. (In our late manuals this grass is named Ar. macrosper. ma var. suffruticosa, Munro.)

Asprella Hystrix, Willd.-Bottle Brush, Hedge-hog grass.

A rather slencler grass, three to four feet high, occasionally seen here in moist woodlands. Of no value.

Austin-grass.-Panicum Texanum.

Australian Millet.-Sorghum Halapense.

Australian Oats.-Bromus unioloides.

Australian Prairie-grass.-Bromus unioloides.

Awned Wheat-grass.-Agropyrum caninum.

Avena flavescens, Linn.-Yellow Oat-grass.

Vellow Oat-grass forms loose tufts, eighteen inches to two feet high. It has only recently been introduced into this crumtry, and its seeds placed on the market. It grows well on al. most all kinds of soil, and a good yield is tolerably certain. It is especially valuable for permanent pastures. The sceds are light, weighing only about five pounds to the bushel. It should only be used in mixtures, as when sown alone the pro. duct is small.

Barley-grass, Wild.-Hordeum pratense.

Barn grass.-Panicum Crus-galli.

Barn-yard grass.-Panicum Crus-galli.

Beard-grass.-Polypogon Monspeliensis. Aristidi purpurea, A. purfurascens, $A$. virgata; also applied to species of Andropogon.

Beard-grass, Finger-spiked.-Andropogen froimilailis.

Beard-grass, Naked.-Generic name for species of Grmmen. 
Beard-grass, Short-leaved.-Gymnopogon brevifolius.

Beard-grass, Silver.-Andropogon argyraus.

Beard-grass, Virginia.-Andropogon Virginicus.

Beard-grass, Woolly.-Erianthus saccharoides.

Bearded Darne1.-Lolium temulentum.

Bearded Wheat-grass.-Agropyrum caninum.

Bengal-grass.-Setaria Italica.

Bent-grass, or Bent.-Generic name for species of Agrostis; applied oftentimes to $A$. alba and $A$.vulgaris.

Bent, Blue.-Andropogon provincialis.

Bent, Brown.-Agrostis canina.

Bent, Creeping.-Agrostis stolonifera.

Bent, Dog's.-Agrostis canina.

Bent, English.-Agrostis alha.

Bent, Fine.-Agrostis vulgaris.

Bent, Marsh.-Agrostis alba.

Bent-grass, Panic.-Panicum agrostoides.

Bent, Reed.-Calamagrostis Canadensis.

Bent, Rhode Island.-Agrostis vulgaris and $A$ canina.

Bent, Rough.-Agrostis scabra.

Bent, Southern.-Agrostis elata.

Bent, Spider.-Agrostis arachnoides.

Bent, White.-Agrostis alba, Andropogon scoparius.

Bermuda-grass.-Cynodon Dactylon.

Big Blue-stem.-Andropogon provincialis.

Black Bent.-Panicum virgatum.

Black Oat-grass.-Stipa avenacea.

Blue Bent (of R. I.).-Andropogon provincialis.

Blue-grass.-Poa pratensis, Poa compressa, Andropogon provincialis.

Blue-grass, English.-Poa pratensis, Festuca elatior.

Blue-grass, Kentucky.-Poa pratensis.

Blue-grass, Smaller.-Poa compressa.

Blue-grass, Texas.-Poa arachnifera.

Blue joint-grass._Calamagrostis Candensis, Andropogon provincialis.

Blue-stem.-Andropogon provincialis.

Blue-stem, Big.-Andropogon provincialis.

Blue-stem, Bushy.-Andropogon nutans. 
Blue-stem, Little.-Andropogon scoparius.

Bonnet-grass.--Agrostis alba. .

Borden's grass.-Agrostis vulgaris.

Bottle-grass. - Setaria giauca and Setaria viridis.

Bottle-Brush-grass.-Asprella Hystrix.

Bottom-grass.-Panicum Texanum.

Bouteloua curtipendula.-The same as $B$. racmosa.

Bouteloua racemosa, Lag.-Tall Grama, Hairy Mesquit, Muskitgrass. (B. curtipendula.)

This valuable pasture grass has been found at several points within the State. It is a tufted perennial, one to three feet high, and forms a dense sod, which resists well the tramping of stock. It is deserving attention, and we believe that in many places our pastures would be greatly improved by its introduction.

Branching Spear-grass.-Eragrostis tenuis.

Bristly Foxtail.-Setaria Germanica and S. zerticillata.

Briza media, Linn.-Quaking-grass.

A pretty annual grass, sometimes cultivated for ornament, and for winter bouquets. Of no agricultural value.

Brome-grass.-Generic name for species of Bromus.

Brome-grass, Californian.-Bromus carinatus.

Brome-grass, Fringed.-Bromus ciliatus.

Brome-grass, Smooth.-Bromus racemosus.

Brome-grass, Soft.-Bromus mollis.

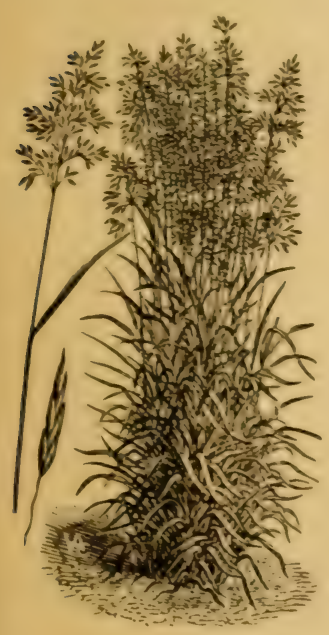

Flg. 8 .

Hungartan Brome-grass Bromus inermis.
Brome-grass, Willard's.-Bromus secalinus.

Bromus ciliatus, Linn.-Swamp Chess, Fringed Brome-grass.

A native grass, frequent in open woodlands, growing to the height of three to five feet, with drooping panicles. It is a perennial, but has no recognized agricultural value.

Bromus inermis, Leyss.-Hungarian Bromegrass, Couch Brome, Awnless Bromegrass.

This is a recently introduced grass from Europe, of considerable promise both for hay and pasture. It is strongly stoloniferous and quickly makes a thick, firm sward. It has grown exceedingly well in our grass plots, and young plants from fall-sown seed 
survived the winter when many other varieties were destroyed by frosts. The strong perennial character of this Brome-grass, and its unusual drought-resisting powers, are qualities which recommend it for many portions of the State. It thrives well on dry loose soil, but, of course, the better the soil the greater the yield. Its nutritive value is comparatively low, and in undertaking its cultivation the fact that it produces long underground stolons, which are difficult to eradicate from the soil, should be kept in mind.

Bromus mollis, Linn.-Soft Chess, Soft Brome-grass.

A European grass sometimes met with in cultivated grounds. It is an annual and a weed, similar in character to the next.

Bromus racemosus, Linn.-Smooth Brome-grass, Upright Chess.

More common than the last, but with smooth leaves and spikelets, often mistaken for Cheat.

\section{Bromus Schraderi.-Same as Bromus unioloides.}

Bromus secalinus, Linn-Chess, Cheat, Willard's Brome-grass.

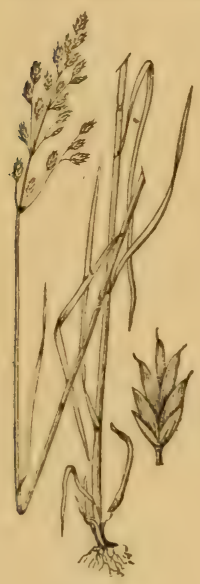

Fig. 9, Chess.

Bromus secalinus.

This is an annual introduced from Europe, and is more or less abundant in grain fields over the State, and should be classed as a troublesome weed. The idea that Cheat or Chess is degenerated wheat is simply an idea without any foundation in fact. Cheat seeds will produce Cheat, and only Cheat, and it is certain that wherever these plants appear, they were preceded by the seed, which may have been introduced with the grain, or brought by birds or animals from other fields.

Bromus unioloides, Willd.-Rescue-grass, Schrader's Brome-grass, Australian Oats, Australian Prairie-grass.

This annual grass has been introduced into this State and cultivated in some places. It grows to the height of two or three feet, and yields a large amount of forage, and makes fairly good hay. It is well adapted here to winter grazing, and possesses some value on that account.

\section{Bromus Willdenovii. - Same as Bromus unioloides.}

Brook-grass.-Andropogon macrourus.

Broom Corn.-Sorghum saccharatum, variety.

Broom-grass.-Andropogon scoparius and A. Virginicus.

Broom Sedge.-Andropogon Virginicus; also applied sometimes to Andropogon scoparius.

Brown Bent-grass.-Agrostis canina. 
Brush, Bottle-Asprelli Hystrix.

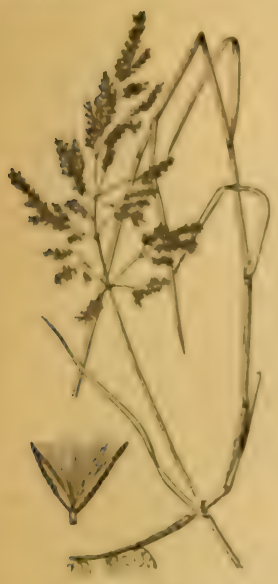

Fler. 10.

small lieved-irrass. Calamagrostis Canadensis.

Bull-grass. - Spartina cynosuroides, Paspalum purpur. ascens, Tripsacum dactyloides.

Bunch-grass, Early.-Eatonia obtusatu.

Bur-grass.-Cenchrus tribuloides.

Burden's-grass.-Agrostis rulgaris, A. canina.

Bushy Blue-stem.-Andropogon nutans.

Buzzard-grass (local).-Eleusine Indica.

Calamagrostis Canadensis. - Blue-joint grass. Sand-grass, Red-top Canadian Small-Reed, Fowl Meadow-grass.

A native grass, but limited to the higher mountains of East Tennessee. Of no agricultural value here.

Calamagrostis Nuttalliana.-Reed Ient-grass, IVild ()ats. (Calamagrostis corritata is the same).

Calf-kill.-Holcus lanatus.

Canada Lyme-grass.-Elymus Canadensis.

Canadian Small-Reed.-Calamagrostis Canadensis.

Canary-grass. - Generic name for species of Phalaris; applied especially to Phalaris ianariensis.

Canary-grass, Reed.-Phalaris arundinacea.

Canary-grass, Southern.-Phalaris intermedia.

Canary-grass, Stewart's._-Phalaris intermedia

Candy-grass.-Eragrostis minor.

Cane.-Arundinaria gigantea, Chapm.

Cane, African.-Pinnisetum spicatum, the same as Pennisctum tiphoilcum, Pers.

Cane, Chinese Sugar.--Sorghum succharatum, S. a'ulgare.

Cane, Large.-Arundinaria tecta, and A. gigantea.

Cane, Small.-Arundinaria tecta.

Cane, Sugar.-Sorghum vulgare.

Carpet-grass.-Sporobolus Indicus.

Catch-fly-grass.-Leersia lenticularis.

Cat's-tail-grass.-Phleum pratense.

Cat-tail Millet._Pennisetum spicatum. Setaria Italica.

Cenchrus tribuloides, Linn._-Sand-bur, Sand-spur. Hedge-hog-grass. Bur-grass, Cock-spur-bur.

Reported as occurring along the sandy banks of the Mississippi River. It is a low, much-branched grass, with a short "head," 
which is made up of a number of burs that are covered with sharp, stiff spines. It is a vile weed.

Chamæraphis glauca and C. viridis.-Setaria species.

Chandler's grass.-Agropyrum repens.

Cheat.-Bromus secalinus.

Chess.-Bromus secalinus.

Chess, Soft.-Bromus mollis.

Chess, Swamp.-Bromus ciliatus.

Chess, Upright._Bromus racemosus.

Chicken Corn.-Sorghum cernuum.

Chinese Sugar Corn._-Sorghum saccharatum, S. vulgare.

Chinese Wheat.-Sorghum vulgare.

Chocolate Corn.-Sorghum vulgare.

Chrysopogon nutans, Benth.-Same as Andropogon nutans.

Cinna arundinacea, Linn.-Indian Reed, Wood Reed-grass, Sweet Reed.

A tall, leafy grass, three to seven feet high, frequent in shaded swamps and damp woods, and sometimes found along streams in wet meadows. For such places it may possess some agricultural value.

Cinna pendula, Trin.-Slender Reed-grass, Drooping Reed-grass.

A much more slender grass than the last, and apparently limited to the cold mountain woods in the upper and eastern part of the State. Of no agricultural value.

Cock's-foot, Rough.-Dactylis glomerata.

Cluster-flowered Beard-grass.-Andropogon macrourus.

Cock's-foot.-Panicum Crus-galli.

Cockspur Bur.-Cenchrus tribuloides.

Comb-grass, Meadow.-Eragrostis pectinacea.

Common Manna-grass.-Glyceria fuitans.

Common Meadow-grass._Poa trivialis.

Cord-grass, Freshwater.-Spartina cynosuroides.

Corn, Broom.-Sorghum saccharatum; now called Andropogon sorghum, variety saccharatus, Hack.

Corn, Chicken.-Sorghum cernuum.

Corn, Chocolate.-Sorghum vulgare, var.

Corn, Dura.-Sorghum vulgare; see Andropogon Sorghum, var. vulgaris.

Corn, Guinea.-Sorghum cernuum, same as Andropogon Sorghum, var. cernuus, Hack. 
Corn, Indian.-Zeu Mays.

Corn, White Egyptian.-Sorghum cernum.

Couch-grass.-Agropurum repens.

Crab-grass.-Panicum sanguinale, Eleusine Indica.

Crab-grass, Slender.-Panicum filiforme.

Crab-grass, Sprouting.-Panicum proliferum.

Creeping Bent-grass.-Agrostis stolonifera.

Creeping Meadow-grass.-Eragrostis reptans.

Creeping Poa.-Poa compressa.

Creeping Soft-grass.-Holcus mollis.

Creeping Spear-grass.-Poa compressa.

Creeping Wheat-grass.-Agropyrum repens, ( $T$ riticum repens.)

Crested Dog's-tail grass--Cynosurus cristatus.

Crop-grass.-Eleusine Indica. (Crab-grass is probably a corruption of Crop-grass).

Crow-foot-grass.-Eleusine Indica.

Cuba-grass._-Sorghum Halapense.

Cut-grass.-Leersia oryzoides.

Cut-grass, European.-Leersia oryzoides.

Cut-grass, Rice-Leersia oryzoides.

Cut-grass, Virginia.-Leersia Virginica.

Cynodon Dactylon, Pers.-Bermuda-grass, Reed-grass, Scutchgrass, Dog's-tooth-grass, Wire-grass.

This is another of those grasses with a dual character, a most valuable plant under certain conditions, and a veritable pest when growing where it is not wanted. It is tuo well

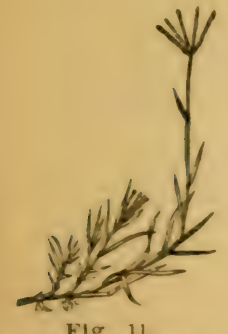

Flg. 11.

Bermuda-grass Cynodon Dactylon known to need any description, and we will only add that we regard it as a valuable pasture-grass for the eastern part of the State at least, but its introduction into new land should be made with caution on account of its habit of taking complete possession of the soil, and the difficulty presented in exterminating it. It is strictly a summer grass here, for its leaves and stems are turned brown by the first frosts of autumn. It is propagated by means of sets or rooting stems. These are chopped up with a cutting-knife, and then sown broadcast or dropped in shallow furrows and lightly covered with earth. For holding steep banks, or binding sandy soil subject to wash, this grass is especially valuable. 
Cynosurus cristatus.-Crested Dog's-tail-grass.

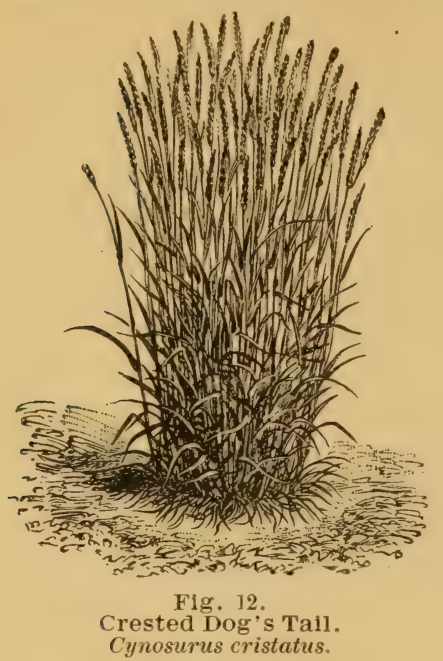

This is a perennial grass, recently introduced into this country from Europe, where it is used in mixtures to form bottom grass either in hay or in pastures. It possesses a highly nutritive value, and succeeds well in almost any kind of soil excepting those which are very sandy, and as it is deep rooted, it withstands drought better than some other species, and it is said to thrive well in shade. It is doubtless of some value in lawn mixtures.

Dactylis glomerata, Linn.-Orchardgrass, Rough Cock's-foot.

This is one of the best known and most popular of our cultivated grasses. It w1ll grow well on any soil excepting that which is very wet. It grows well in the shade, no grass being equal to it in this respect, excepting perhaps, the rough-

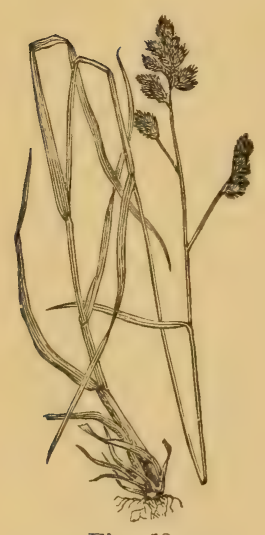

Fig. 13.

orchard-grass.

Dactylis glomerata. stalked meadow-grass. In pastures it affords a good bite earlier than any other grass excepting the meadow foxtail. It affords a great amount of aftermath, being exceeded in this respect only by Kentucky blue-grass. Owing to its habit of growing in clumps or tussocks, the land should be seeded heavily, using two and a half or three bushels to the acre. When sown with other grasses, its tendency to form tussocks is very much diminished, and we would recommend that clover, or possibly red-top, always be mixed with our orchard-grass. Although not adding materially to the bulk of hay produced, they will improve its quality and help make a much better sward.

Danthonia compressa, Austin--Tennessee Oat-grass, Mountain Oat-grass.

This is a common grass upon our higher mountains, and forms the chief bulk of the forage on the so-called "balds." It was fully described and figured in Bulletin No. 4, Vol. II.

Danthonia sericea, Nutt.-Silky Oat-grass, Taller Wild Oat-grass, Silky-flowered Oat-grass.

While Danthonia compressa appears to prefer a moist or damp situation, Danthonia sericea is found in very dry soil on the lower 
foot-hills and along the crests of ridges and bluffs so frequent in the eastern part of the State. This species grows to the height of two or three feet, is soft-hairy all over, and is of a much stouter habit than Danthonia compressa, but it does not appear to form a sod, and our attempts at cultivating it have been unsuccessful.

Danthonia spicata. Beau- - Wild (Oat-grass, White-t(1), ()]d Fog, June-grass, Poverty-grass.

Danthonia spicata is common in dry, thin soils, and its presence is usually indicative of impoverished lands. It resembles very much Lanthonia compressa, but cloes not usually grow so tall, and its leaves are much shorter and more curly. It is a grass of no agricultural value.

Darnel-Lolium temulentum.

Darnel, Bearded.-Lolium temulentum.

Dennett-grass.-Elymus striatus.

Deschampsia flexuosa, Griscb.-Hair-grass, Wood Hair-grass.

We have seen this grass on Roane Mountain and on Lookout Mountain, and probably it may be found upon all the mountains of East Tennessee. The slender stems are one to three feet high. and the leaves, which are chiefly at the base, are very slencler. almost thread-like. It is a grass of no agricultural value.

Devil's-grass.-Agropyrum repens. (Triticum repens.)

Dew-grass.-Agropyrum repens.

Dew-grass.-Agrostis alba.

Dew-grass, Summer.-Agrostis vulgaris.

Deyeuxia Canadensis, Hook.-Calamagrdstis Canadensis, which see.

Diarrhena Americana, Beauv.-Twin-grass.

"Rich soil amongst rocks, here and there."-(Cattinger.) A perennial native grass with rather strong, running root-stocks, which throw up unbranched culms, two to three feet high. ()f no value.

Dog or Dog's-grass.-Agropyrum repens.

Dog's Bent.-Agrostis canina.

Dog's-tail grass.-Eleusine Indica.

Dog's-tail grass, Crested.-Cynosurus cristatus.

Dog's-tooth grass.-Cynodon Dactylon, Eleusine Indica.

Doura Corn.-Sorghum vulgare.

Downy Oat-grass.-Avena pubescens.

Downy Persoon - Trisetum subspicatum, var. mollc.

Downy Triple-awn.-Aristida stricta.

Drooping Reed.grass.-Cinna pendula. 
Drop-seed grass.-Generic name for species of Sporobolus; also applied to species of Muhlenbergia (e. g. Sporobolus compressus, Muhlenbergia Mexicana.)

Duck-grass.-Poa serotina.

Durfa or Durfee-grass.-Agropyrum repens. (Triticum repens.)

Durra Corn.-Sorghum vulgare.

Dutch-grass.-Agropyrum repens.

Dwarf Meadow-grass._Poa annua.

Early Bunch-grass.-Eatonia obtusata.

Early Meadow-grass.-Poa annua.

East Indian Millet.-Pennisetum spicatum.

Eaton's grass.-Eatonia Pennsylvanica.

Eatonia obtusata, Gray.-Early Bunch-grass, Prairie-grass.

A form of this grass is reported by Gattinger as occurring in the "Highlands." We do not know that it has any agricultural merits.

Eatonia Pennsylvanica, Gray.-Eaton's grass.

This is a native species which we have occasionally seen growing here in moist meadows. It is usually of a paler green than other grasses, and stands out conspicuously among them on this account. It grows to the height of two or three feet, and has a rather long and narrow panicle. There is another species of Eatona ( $E$. Dudleyi) which is common in our woods, blooming in April or early in May. Its stems are much more slender than those in the other species, and its leaves are shorter, being rarely more than two or three inches long. Of no agricultural value.

Egyptian-grass - Sorghum Halapense.

Egyptian Millet.-Pennisetum spicatum, Sorghum Halapense.

Eleusine Indica, Gertn.-Goose-grass, Dog's-tail grass, Yard-grass, Crow-foot-grass, Wire-grass, Crab-grass, Crop-grass, Dog'stooth grass, Buzzard-grass.

This is an exceedingly common annual growing in dooryards and cultivated grounds, particularly in rich soils. The stems are somewhat flattened, many springing from a single root, and each terminated by two to several spikes, which stand out like the fingers of a hand or the toes of a crow's foot.

Crow-foot grass, or yard-grass, are the names which are usually applied to this species. It is only rarely called crab-grass, which name really belongs to Panicum sanguinale. Some authors have spoken of it as being nutritious, and good for grazing or soiling and for hay, but we have always regarded it as a weed, and sometimes a troublesome one. 
Elymus Canadensis, Linn.-Canada Lyme-grass, Will Rye, Ter. rell-grass.

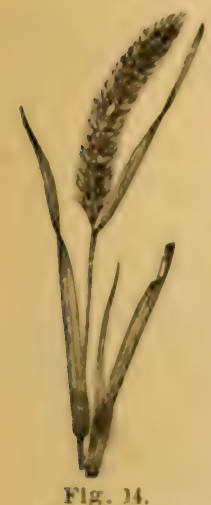

1.yme-grass

Elymus Canadensis.

This grass is frequently met with in low thickets along streams, and in rich, open woods. It has a leafy stem, three to five feet high, with a more or less nodding head, which resembles that of rye. It is a perennial, of no agricultural value here.

Elymus striatus, Willd-Dennett-grass, Slender Hairy Lyme-grass.

This grass grows in similar situations with the last, but is more slender and not so tall. The head is smaller and decidedly more bristly in appearance.

Elymus Virginicus, Linn.-Lyme-grass, Smooth Rye grass, Terrell grass, Wild Rye, Virginia Lymegrass.

This species is much more common than the two last named, growing in low meariows and in rich soil, along the banks of rivers and streams. The stems are leafy, two or three feet high, with erect spikes or heads, three to five inches long. Although presenting an appearance of a grass of good quality, we doubt its being worth cultivating. It forms no sward, although its roots are perennial, and by the time it blooms, the lower leares on the stalks are all dead.

English grass.-Poa pratensis.

English Bent-grass.-Agrostis alba.

English Blue-grass. - Festuca elatior.

English Fox-tail.-Alopecurus pratensis.

English Rye or Ray-grass.-Lolium perenne.

Eragrostis Frankii, Meyer.-Short-stalked Meadow-grass.

A diffusely branched annual grass, three to eight inches high, often met with in low, sandy grounds. It is remarkable for its strong, disagreeable odor. Of no agricultural value.

Eragrostis major, Host.-Stink-grass, Pungent Meadow-grass.

A rather showy, much branched annual grass, introduced into this country from Europe, and common here in rich cultivated soils, about gardens, etc. The more or less spreading stems are one to two and a half feet long, and, when fresh, the whole plant emits a sharp, unpleasant odor.

Eragrostis minor, Host-Candy-grass, Strong-scented Meadowgrass, Stink-grass.

This, like the last, is a foreign importation, and by some it is regarded only as a variety of Eragrostis majur. It possesses the same habit and characters, differing only in its smaller size and narrower spikelet. A weed. 
Eragrostis pectinacea, Gray.-Meadow Comb-grass.

A native grass of rather attractive appearance, with large diffuse panicles, which are often yathered for dry bouquets. It is frequent here in dry, sandy soil, in open grounds and alongthe borders of fields or woods.

Eragrostis pilosa, Linn.-Slender Meadow-grass.

A slender grass, six inches to a foot high, found occasionally here in dry, sandy soil. Of no value.

Eragrostis Purshii, Schrad.-Southern Spear-grass, Southern Eragrostis.

More common than the last, found along the borders of walks in towns, and not uncommon in cultivated lands. Of no value.

Eragrostis reptans, Nees.-Creeping Meadow-grass.

A low, creeping species, found only in dry, sandy soil. Of no. value.

Eragrostis tenuis, Gray.-Branching Spear-grass.

Taller than the other species of Eragrostis, with a rather narrow and elongated panicle and long and somewhat rigid leaves. Like the other species, it grows in sandy soils, and is without agricultural value.

Erianthus saccharoides, Michx.-Plume-grass, Woolly Beardgrass, Foxtail.

This is a tall, stout grass, four to six feet high, and of striking appearance. It is found in various parts of the State, but it is far from being common. The showy panicle is from five to ten inches long, and is of a silvery white, or, more often, purplish color. Of no agricultural value.

Euchlæna luxurians.-Teosinte, Gautemala-grass.

A grass, recently introduced into cultivation from Central America. It is a very tall and rapid-growing plant, with stalks resembling those of Indian corn, but it tillers at the base like wheat, so that the yield of forage from a comparatively small amount of seed is enormous. It affords a great amount of green fodder, allowing many cuttings during the season, and it may prove valuable for silage.

European Cut-grass._Leersia oryzoides.

Evergreen-grass.-Arrhenatherum avenaceum; more rarely applied to Festuca elatior.

Evergreen Millet._Sorghum Halapense.

Fall Marsh-grass._Spartina cynosuroides.

Fall Red-top.-Triodza cupraa (Tricuspis seslerioides.)

False Guinea-grass._-Sorghum Halapense

False Oat-grass.-Arrhenatherum avenaceum. 
False Red-top.-I'oa serolina.

False Rice.-Leersia oryzoides.

Feather-grass - feneric name for species of Stipa, applied especially to Stipa penthata. Also applied to Liphihloa muronata and Holcus lanatus.

Fescue-grass.-Generic name for species of $F_{\text {istuca. }}$

Fescue, Hard.-Festuca duriuscula.

Fescue, Meadow.-Festuca pratensis.

Fescue, Nodding.-Festuca nutans.

Fescue, Sheep's - Festuca ovina.

Fescue, Tall. - Festuca elatior.

Fescue, Tall Meadow.-Festuca elatior.

Fescue, Wild.-Uniola latifolia.

Festuca duriuscula, Linn.-Hard Fescue.

This is one of the forms of sheep's fescue of rather small size. and of little value except in pastures, and here chiefly because it will thrive on comparatively poor and sandy soil, unfit for the growth of better grasses.

Festuca elatior, Linn.-Tall Fescue, Tall Meadow Fescue, English Blue-grass, Randall-grass, Evergreen-grass.

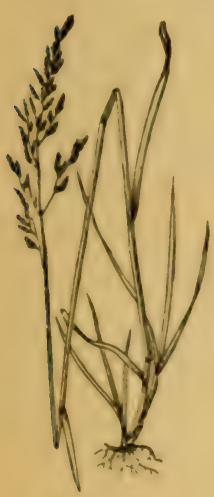

Flg. 15.-Tall Meadow Fescue. Featuca elatior.

This grass is very justly receiving much attention from farmers in the State. It is an exceedingly valuable grass, either for mowing or pasture. It is productive on soils which are not too dry, and being of long duration. it is especially valuable for permanent meadows. It thrives best on moist soils. which are rich in humus, whether marls or clays. It presents several varieties, one of which is known as Festuca pratensis and the other Festuca arund nacea. The last is a very vigorous-growing form, and has done exceedingly well in our experimental plots. In amount of forage produced we have grown nothing equal to it among those species suitable for hay.

\section{Festuca nutans, Willd.-Nodding Fescue.}

This is a native species of fescue which is common in open rocky woods, or along the woody borders of moist meadows. Its stems are rather slender, usually about three feet high, with a loosely flowered and drooping panicle. Of little agricultural value, probably not worth cultivating. 
Festuca ovina, Linn.-Sheep's Fescue, Pinon-grass (in Nevada), Pine Bunch-grass.

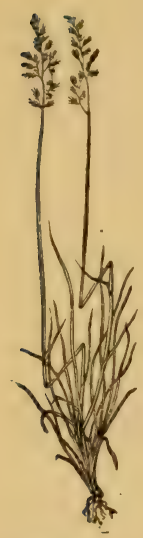

Fig. 16. Sheep's Fes. cue.-Festu. ca ovina.

This grass has been sparingly introduced here in cultivation. It is of some value as a bottom grass when sown with species which do not from their habit of growth fully occupy the soil, and it is also valuable for sheep pastures. It thrives well here, even on soils which are of poor quality. "Its appropriate place in cultivation is on light, dry soils, especially those which are poor, shallow, and silicious. In such cases, it is a great boon to the agriculturist." (Stebler \& Schrœter).

Festuca pratensis, Linn.-Meadow Fescue, Randallgrass.

This is only a variety of Festuca elatior (see above,) being somewhat smaller than that species, with a narrower and fewer-flowered panicle.

Festuca rubra, $L$. var. glaucescens. Tennessee Fescue, Glaucous Creeping Fescue.

This grass was described and figured in Vol. IV, No. 1, of our Station Bulletins, (p. 24, plate III.) It is closely related to the Red or Creeping Fescue of Europe and our more Northern States, and possesses a similar habit of growth. It is an excellent turf-forming grass, and will doubtless withstand well the tramping of stock. It remains green the year round, being little affected by drought or severe winter weather. It grows to the height of one or two feet, has a great mass of fine rootleaves, and may be recommended for pastures, especially upon worn-out soils and hill-slopes.

Festuca tenella.-Slender Fescue.

This is a native annual species, six inches or a foot high, growing only in very dry and sandy soil, along road sides, etc.

Festuca unioloides.-Same as Bromus unioloides, which see.

Fibrous-rooted Wheat-grass.-Agropyrum caninum.

Fin's grass.-Agropyrum repens.

Fine Bent.-Agrostis vulgaris.

Fine Top.-Agrostis vulgaris and A. canina.

Finger-grass.-Panicum sanguinale.

Finger-grass, Hairy.-Panicum sanguinale.

Finger-spiked Beard-grass.-Andropogon provincialis. (A.furcatus is the same.)

Finger-spiked Indian-grass.-Andropogon provincialis.

Finger-spiked Wood-grass.-Andropogon provincialis. 
Fiorin.-Agrostis stolonifera; also A. alba.

Flat-stalked or Flat-stemmed-grass.-Poa cumpressa.

Flat-stalked Blue-grass. - Poa compressa.

Floating Fox-tail._Alopecurus genicu'atus.

Floating Manna-grass.-Glyceria fuitans.

Fly-away-grass.-Agrostis scabra.

Fly-catch-grass.-Leersia lcnticularis.

Fog, Old.-Danthonia spicata.

Fool-hay.-Panicum capillare and Agrostis scabra.

Fowl Meadow-grass.-Glyccria nervata, Poa serotina, and Calama. grostis Canadensis.

Fox-tail.-Setaria slauca, Erianthus saccharoides (F. alopecuroides), Hordeum jubatum, and species of Alopecurus.

Fox-tail, Bristly.-Setaria vertacillata and S. Germanuca.

Fox-tail, English.-Alopecurus pratensis.

Fox-tail, Floating.-Alopecurus geniculatus.

Fox-tail, Green.-Setaria viridis.

Fox-tail, Large._Setaria composita.

Fox-tail, Meadow.-Alopecurus pratensis.

Fox-tail, Wild Water.-Alopecurus aristulatus.

Fox-tail, Yellow.-Setaria glauca.

French Rye-grass, - Arrhenatherum avenaceum.

Fresh-water Cord-grass._-Spartina cynosuroides.

Fringed Brome-grass.-Bromus ciliatus.

Furze-top.-Agrostis vulgaris and A. canina.

Gama-grass.-Tripsacum dactyloides.

German Millet.-Setaria Germanica.

Gilbert's Relief-grass.-Phalaris intermedia.

Glaucous Creeping Fescue.-Festuca rubra, var. glaucescens.

Glyceria aquatica, Sm.-Reed Meadow-grass, White Spear-grass.

A stout grass with upright culms, three to five feet high, growing along the margins of streams and in very wet meadows. Native, but apparently not common; Gattinger records only one locality, and up to the present time I have not observed it within the State. It is a good grass for fodder where it grows spontaneously. (Glyceria grandis, S. Watson.)

Glyceria fluitans, R. Br.-Floating Manna-grass, Common Mannagrass.

This is a very widely distributed species, and is probably to be found within the State, although not yet recorded as occurring 
here. It grows in similar situations with $G$. aquatica, but is more slender in habit and has a more elongated and fewerflowered panicle, with long and narrow spikelets.

Glyceria grandis, Watson.-Same as Glyceria aquatica.

Glyceria nervata, Trin-Fowl Meadow-grass, Meadow Speargrass, Nerved Manna-grass.

This is our most common species, frequent in moist meadows and along streams. It is a leafy perennial grass, one to three feet high, with a loose and nodding panicle. Of some agricultural value, where it grows naturally, and for such locations may be worth cultivating. Glyceria acutiflora, Torr., Glyceria pallida, Trin., and Glycera elongata, Trin., are other species of this genus found in Tennessee, all growing in marshy or very wet places; the last named is found only upon the higher mountains in the eastern part of the State.

Golden Millet-Setaria Italica. var.

Golden Oat-grass.-Avena flavescens.

Goose-grass.-Eleusine Indica, Panicum Texanum, Poa annua.

Grama.-Generic name for species of Bouteloua. Applied sometimes to Muhlenbergia Texana.

Grama, Tall.-Bouteloua hirsuta; Bouteloua racemosa.

Grass-of-the-Andes.-Arrhenatherum avenaceum.

Great Millet.-Sorghum vulgare.

Green Fox-tail._Setaria viridis.

Green-grass.-Poa pratensis; Poa trivialis.

Green Pigeon-grass.-Setaria viridis.

Green Valley-grass._Sorghum Halapense.

Gautemala-grass.-Euchlana luxurians.

Guinea Corn._-Sorghum cernuum.

Guinea-grass.--Panicum jumentorum; erroneously applied to Sorghum Halapense.

Guinea-grass, Alabama._Sorghum Halapense.

Guinea-grass, False.-Sorghum Halapense.

Gymnopogon racemosus, Beauv.-Naked Beard-grass.

A rather common grass in open pine woods and sandy soil along thicket borders. The clustered, wiry stems spring from a short perennial root-stalk, and bear numerous short and rather broad leaves. Blooms in August and September. Of no agricultural value. 
Gynerium argenteum -Pampas-grass.

A well known ornamental grass, cultivated for its large and? handsome silvery-white panicles or "plumes."

Hard Fescue.-Festuca duriuscula.

Hair-grass.-Generic name for species of Deschampsia (Aira). Ap). plied to Deschampsia flexwosa, Agrostis scatra and Muhlenbergia apillaris.

Hair-grass, Bunch.-Muhlenhergia trichopodes.

Hair-grass, Muhlenberg's.-Muhlenbergia capillaris.

Hair-grass, Sea-side.-Muhienbergia capillaris.

Hair-grass, Wood.-Deschampsia flexuosa.

Hairy Finger-grass.-Panicum sanguinale.

Hairy-flowered Paspalum.-Paspalum ovatum.

Hairy Muskit._Bouteloua racemosa.

Hedge hog-grass.-Asprella Hystrix and Cenchrus tribuloides.

Herd's-grass.-Agrostis alba, Agrostis vulgaris and Phleum pratense.

Holcus lanatus, Linn.- Velvet-grass, Velvet Meadow Soft-grass, Velvet Mesquit, Velvet Lawn-grass, Meadow Soft-grass, Woolly

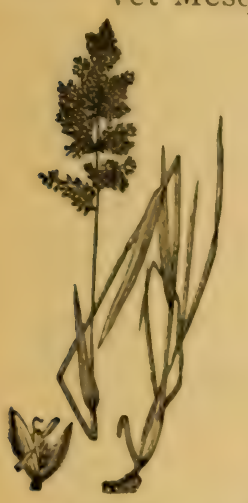

Flg. 1i. Velvet-grass. Holcus lanatus.
Soft-grass, White Timothy, Yorkshire White, Yorkshire Fog, Salem-grass, Feather-grass, Calf-kill, Hungarian Blue-grass.

This grass is covered with soft, whitish hairs, so that to the touch it feels somewhat like velvet. It is a European grass, but is to be found here and there over the State, having been introduced with the seed of other grasses. Owing to its light color it is striking in appearance, and is said to be a valuable grass for light thin soils which are unsuited to the growth of more valuable sorts. It should only be sown in mixtures.

Hordeum pratense, Huds.-Wild Barley, Squirrel-tail-grass.

A native species of barley-grass growing to the height of six to eighteen inches, and reported by Gattinger as common on thin lands. It is probably an annual, and is of little or no agricultural value.

Horse Millet.-Pennisetum (Penicillaria) spicatum.

Hungarian grass.-Setaria Germanica.

Hungarian Blue-grass,- - Holcus lanatus.

Indian Corn.-Zea Mays.

Indian-grass.-Sorghum mutans (.4n.tropogron nutuns), Serghum arenaicum (Andropogon nutans var. aïenaceus), and Andropogon scoparius. 
Indian-grass, Finger-spiked.-Andropogon provincialis.

Indian-grass, Oat-like.-Sorghum nutans.

Indian Millet.-Pennisetum spicatum, Sorghum inlgare, Setaria Italica.

Indian Reed.-Cinna arundinacea.

Italian Rye-grass.-Lolium Italicum.

Ivory Wheat.-Sorghum vulgare.

Japan Millet.-Pennisetum spicatum.

Johnson-grass.-Sorghum Halapense.

Joint-grass.-Paspalum distichum.

June-grass - Poa pratensis, Danthonia spicata.

Kentucky Blue-grass.-Poa pratensis.

Knot-grass.-Paspalum distichum.

Knot-root grass._Muhlenbergia Mexicana.

Large Cane.-Arundinaria gigantea.

Large Crow-foot grass.-Panicum Crus-galli.

Lawn-grass, Velvet.-Holcus lanatus.

Leersia oryzoides, Sw--Rice Cut-grass, Rice-grass, Cut-grass, False Rice, White-grass, European Cut-grass, Prickle-grass.

A common grass along streams and wet borders of thickets. It has very rough leaves and a whitish panicle, which expands in August. Of no value in agriculture.

Leersia Virginica, Willd.-Virginia Cut-grass, White-grass, Smallflowered White-grass.

Common, and growing in similar situations with the last. It is more slender and delicate in its habit than Rice-grass, but is equally valueless.

Leptochloa mucronata, Kunth.-Feather-grass.

An annual weed common in rich cultivated grounds and gardens. It grows to the height of two to four feet, has rather broad leaves and a long, terminal, somewhat feather-like panicle (panicle-like raceme.)

Little Blue-stem.-Andropogon scoparius.

Lolium Italicum, Braun.-Italian Rye-grass.

An excellent grass for rich and rather moist lands. It is a very rapid grower, forms a dense turf, and in Europe is regarded as one of the best grasses for mowing. On heavy clays or on any very dry soil it does not do well; but on good calcareous loams, or marls, or on moist, loamy sands when the soil is in good condition, the yield is large, and "no other grass repays manuring so well." It lasts only for two or three years. 
Lolium perenne, L.-P'erennial Rye-grass, Ray-grass, English Rye-grass, Darnel.

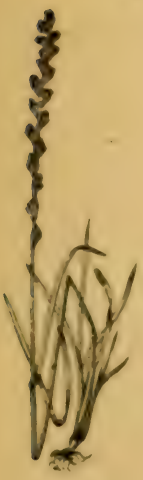

Fig. 18. Rye-grass. Lolium per enne.

This is a perennial, as is indicated by its name, and has been cultivated in England for more than two hundred years, making it one of the oldest of cultivated fodder grasses. It differs from Italian Rye-grass in being distinctly stoloniferous, its darker green leaves which are simply folded (not rolled) in the bud, and beardless head or spike.

Perennial Rye-grass is less tall than the Italian and is probably not so valuable a grass for this region. In moist, cool climates it is a most excellent pasture grass for heavy soils. "Its duration depends very much on the nature of the soil and the climate; on dry light soils, it disappears after the second year; while in moist climates, on good heavy soils, it will persist for seven years, or even longer." (Stebler \& Schroter.)

Lolium temulentum, Linn-Darnel, Poison Rye-grass, Bearded

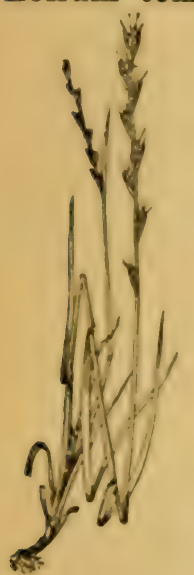

F1g. 19.

Bearded Darnel. - Lolium temulentum. Darnel.

An annual grass from Europe, occasionally found in grain fields. It may be recognized by its general resemblance to Lolium Italicum. The grain of this species "contains a narcotic principle, soluble in ether, which causes eruptions, trembling, and confusion of sight in man and in flesh-eating animals, but it does not affect swine or horned cattle." ("True Grasses.")

Low Spear-grass.-Poa annaa.

Lyme-grass.-Generic name for species of Elymus, applied especially to Elymus Virginicus.

Lyme-grass, Canada.-Elymus Canadensis.

Lyme-grass, Slender Hairy.-Elymus striatus.

Lyme-grass, Virginian.-Elymus Virginicus.

Maize.-Zea Mays.

Manna-grass.-Generic name for species of Glycria. Applied in Germany to Panicum sanguinale.

Manna-grass, Common.-Glyceria fluitans. This is also called Floating Manna-grass.

Manna-grass, Nerved.-Glyceria nervata.

Manna-grass, Pale._Glyceria pallida.

Marsh-grass.-Spartina cynosuroides, Spartina slabra.

Marsh-grass, Fall._Spartina cynosuroides.

Marsh Bent.-Agrostis alba. 
Marsh Oat-grass. - Trisetum palustre.

May-grass._Poa annua.

Meadow-grass, Annual.-Poa annua.

Meadow-grass, Common.-Poa trivialis.

Meadow-grass, Creeping.-Eragrostis reptans.

Meadow-grass, Dwarf._Poa annua.

Meadow-grass, Early.-Poa annua.

Meadow-grass, Flat-stalked.-Poa compressa.

Meadow-grass, Fow1.-Glyceria nervata, Poa serotina, Calamagrostis Canadensis.

Meadow-grass, Pungent.-Eragrostis major.

Meadow-grass, Reed.-Glyceria aquatica.

Meadow-grass, Rough-stalked.-Poa trivialis.

Meadow-grass, Rough.-Poa trivialis.

Meadow-grass, Short-stalked.-Eragrostis Frankii.

Meadow-grass, Slender, Eragrostis pilosa.

Meadow-grass, Smooth.-Poa pratensis.

Meadow-grass, Smooth-stalked.-Poa pratensis.

Meadow-grass, Strong-scented, or Stinking.-Eragrostis minor.

Meadow Cat's-tail grass.-Phleum pratense.

Meadow Comb-grass.-Eragrostis pectinacea.

Meadow Fescue.-Festuca pratensis.

Meadow Fox-tai1._Alopecurus pratensis.

Meadow Soft-grass.-Holcus lanatus.

Meadow Soft-grass, Velvet.-Holcus lanatus.

Meadow Spear-grass._Glyceria nervata.

Mean's grass.-Sorghum Halapense.

Mesquit grass.-Applied generally to species of Bouteloua.

Mesquit, Velvet,-Holcus lanatus.

Mezquit-grass.-Same as Mesquit-grass.

Millet, African.-Pennisetum spicatum.

Millet, Arabian Evergreen.-Andropogon Sorghum var. Halapensis (Sorghum Halapense.)

Millet, Australian.-Same as Arabian Evergreen.

Millet, Cat-tail.-Setaria Italica, Pennisetum spicatum.

Millet, Common-Panicum Miliaceum, Pennisetum spicatum, Milium effusum.

Millet, East Indian._Pennisetum spicatum.

Millet, Egyptian.-Pennisetum spicatum, Andropogon Sorghum.

Millet, Evergreen.-Sorghum Halapense. 
Millet, German.-Sclaria Gormanica.

Millet, Golden.-Sctaria Itulica, var.

Millet, Great.-Sorghum vulgare.

Millet, Horse.-Penniselum spicatum.

Millet, Indian.-Sorghum vulgare, P'nnisetum spicalum and Setariu Itulicia.

Millet, Japan.-Pennisctum spicalum.

Millet, Morocco,-Sorghum Halapense.

Millet, Pearl_-Pennisetum spicatum.

Millet, Polish.-Panicum sanguinale.

Millet-grass, Wild.-Setaria viridis.

Montana Rye.-Triticum Polonicum.

Morocco Millet.-Sorghum Halapense.

Mountain Oat-grass.-Danthonia compressa.

Mountain Red-top.-Agrostis canina.

Muhlenbergia capillaris, K'th.-Sea-sicle Hair-grass, Muhlenberg's Hair-grass.

An upright species with unbranched or simple stems two feet high, very long and rather rigid leaves, and a diffuse, usually purplish panicle. Grows in tufts in dry sandy soil, pine woods, etc. Of no agricultural value.

Muhlenbergia diffusa, Schreb.-Nimble Will, Wire-grass, Dropseed-grass.

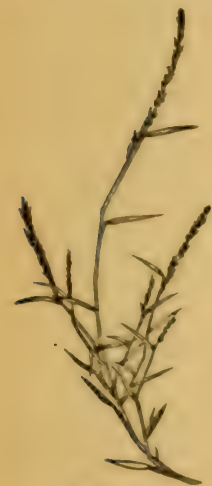

F1g. 20

Nimble Will.

Muhlenbergia diffusa.

A common and well known grass growing on dry hills, in woods, and especially in shaded waste grounds about dwellings. It has a slender, wiry, diffusely-branched and leafy stem, six to eighteen inches high. It is an exceedingly difficult grass to mow, and the turf it forms is equally difficult to break up. Of comparatively little or no agricultural value.

Muhlenbergia glomerata, Trin.-II uhlenberg's-grass, Satin-grass, Wild Timothy.

An upright usually less branched grass than the last, two to three feet high, with a densely flowered narrow panicle two to four inches long. The rootstock is very tough, and closely covered with thickened scales. It usually grows in low grounds, and makes a fair "wild hay," although when mature the stems are quite hard. In some of the Western States it is "recommended as an excellent grass for forage."

Muhlenbergia Mexicana, Trin.-Drop-seed grass, Wood-grass, Knot-root-grass. 
Similar in value and habit to the last, but usually more branched and with a looser-flowered panicle. Grows in sandy soil along the borders of thickets and rivers, doing good service in the latter place by binding the sands with its strong creeping root-stocks.

Munro-grass.-Panicum agrostoides.

Muskit.grass.-Bouteloua rucemosa (B. curtipendula.)

Naked Beard-grass._Gymnopogon racemosus.

Nerved Manna-grass._Glyceria nervata.

Nimble Will._Muhlenbergia diffusa.

Nodding Fescue.-Festuca nutans.

Oat-grass.-Arrhenatherum avenaceum.

Oat-grass, Black.-Stipa avenacea.

Oat-grass, False.-Arrhenatherum avenaceum.

Oat-grass, Golden.-Avena favesiens.

Oat-grass, Marsh.-Trisetum palustre.

Oat-grass, Mountain.-Danthonia compressa.

Oat-grass, Silky-flowered.-Danthonia sericea.

Oat-grass, Spiked Wild.-Danthonia spicata.

Oat-grass, Tall,-Arrhenatherum avenaceum.

Oat-grass, Tall Meadow.-Arrhenatherum avenaceum.

Oat-grass, Taller Wild.-Danthonia sericea.

Oat-grass, Tennessee.-Danthonia compressa.

Oat-grass, Wild.-Applied to species of Danthonia.

Oat-grass, Yellow.-Avena flavescens.

Oat-like Indian-grass.-Sorghum nutans.

Oat-like Sorghum.-Sorghum avenaceum.

Oats, Australian.-Bromus unioloides.

Oats, Sea-side.-Uniola paniculata.

Oats, Wild.-Uniola latifolia, Zizania miliacea, Calamagrostis Nuttalliana.

Old Fog.-Danthonia spicata.

O1d Witch-grass.-Panicum capillare.

Orchard grass. - Dactylis glomerata.

Orcheston grass.-Poa trivialis.

Oregon Rice.-Sorghum vulgare. 
Pale Manna-grass.-Glyceria pallida

Pampas-grass.-Gynerium argentezm.

Pampas Rice.-Sorghum vulgare.

Panic grass.-Generic name for species of Panicum.

Panic Bent grass.-Panicum agrostoides.

Panicum agrostoides, . Wuhl.-Panic Bent-grass, Munro-grass, Redtop Panic-grass.

This is a native, tall, branched and leafy grass, with a "head" somewhat resembling red-top. It grows along the banks of creeks and borders of ponds, and of ten yields a considerable and fairly good native hay. It is reported to have been cultivated in some of the Southern States, and "valued highly" wherever known." In low, moist and rather rich meadows its cultivation may be profitable. It is deserving trial in such locations.

Panicum capillare, Linn.-Old Witch grass, Fool Hay.

A very common native, annual grass, presenting severai varieties. All are worthless. It frequents cultivated fields. sometimes becoming a troublesome weed.

Panicum Crus-galli, Linn.-Barn-grass, Barn-yard-grass, Cock'sfoot, Water-grass, Large Crow-foot-grass.

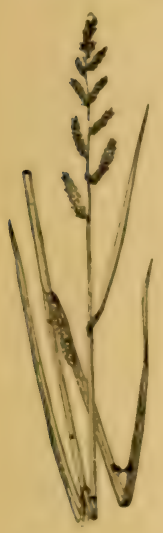

F1g. 21. Barn-yard. grass.-Pan icum Crus. galli.

A well known rank.growing annual, common in rich cultivated lands, especially around dwellings. Some apparently native forms are found along water-courses, \&c. It seeds freely, makes rapid growth during the latter part of Summer, and on bottom lands yields abundantly. It sometimes affords the farmer a good crop of fair hay from land which but for the spontaneous growth of this grass would have yielded him nothing. In many sections this Panicum is only regarded as a weed.

Panicum filiforme, L.- Slender Crab-grass.

A native, annual grass, common in sandy soils, particularly in old fields, flowering in July and August. It is closely related to Crab-grass, and much resembles that grass, but is less diffusely branched and spreading, and is much more slender in all its parts. Of no agricultural value.

Panicum jumentorum, Pers.-Guinea-grass, St. Mary's-grass, ( $P$. maximum, Jacq., is the same.)

This grass was long ago introduced into America, presumably from Africa, and has for many years been cultivated in tropical South America and the islands of the West Indies. In those regions it is spoken of as being "a splendid pasture grass. grow- 
ing to the height of twelve feet, forming dense tufts, and being propagated by the rhizome" (Eggers). It has been introduced

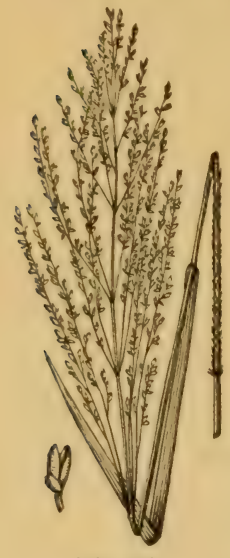

Fig. 22. Guinea-grass. Panicum jumento. rum. into some of the Gulf States, particularly Florida, where it is highly valued. Few plants yield a larger amount of fodder, and it may be cut as often as once a month during the season of growth. If allowed to grow to full size it becomes coarse and unfit for forage. Its stems are killed by the first frosts of autumn, and it seeds only in the warmest parts of the States bordering on the Gulf. Its habit of growing in bunches at once distinguishes this grass from Johrson grass, with which it has been confounded by some.

Panicum miliaceum, Linn.-Millet.

A coarse grass with a rather large, drooping and loosely-flowered panicle, occasionally found in the older settlements in cultivated fields and waste grounds about dwellings. It formed one of the food-grains of pre-historic times, and is still cultivated in China and Japan, and in limited areas in Europe. The grasses generally known here as Millet belong to the genus Setaria, which see.

Panicum molle, Sw. (P. barbinode.)-Para grass, Spanish grass.

A strong growing perennial South American grass, which has long been cultivated in the West Indies, where it is esteemed for pastures. It has recently been introduced into some of the Gulf States. We do not know of any attempts having been made to

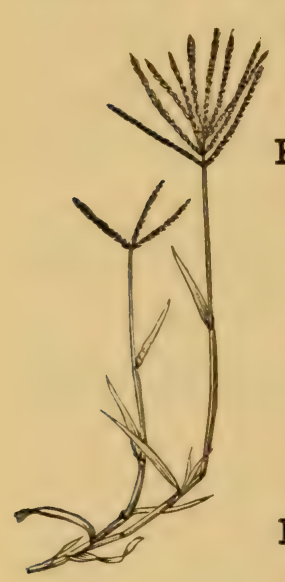

F1g. 23.

Crab-grass.

Panicum sanguinale. grow it in this State. It might succeed and prove a valuable forage plant in lower Middle and West Tennesssee.

Panicum proliferum, Lam.-Sprouting Crab-grass.

A common grass, with rather coarse spreading or ascending much-branched stems two to four feet long. It is often abundant in cultivated fields, springing up with common Crab.grass, and forming sometimes no inconsiderable part of the "poor man's hay." While occasionally useful in the way here indicated, it must be regarded more as a weed than as a hay plant.

Panicum sanguinale, Linn.-Crab-grass, Fingergrass, Hairy Finger-grass, Manna-grass, Polish-Millet.

A well known annual grass, common everywhere in cultivated fields. It is a troublesome weed in gardens 
and among hoed crops, but in grain fields, after harvesting, it ire. quently springs up in such quantity as to yield one, or even $t w 0$, good cuttings of hay. This spontaneous growth affords cxcellent pasturage, as well as hay of the first quality if properly cured. Chemical analyses show that crab-grass is richer in albuminoids and carbohydrates than either timothy or orchard-grass, and, assuming timothy hay to be worth \$1o per ton, crab-grass hay would be worth Sir.to. This is based on chemical analyses made here in 1890 .

Panicum Texanum, Buckl.-Texas Millet, Bottom-grass, Coloradograss, River-grass, Goose-grass, Buffalo-grass, Austin-grass.

An annual grass, common in certain parts of Texas, where it is apparently indigenous, and where, too, it is highly valued for hay, and its cultivation forms a profitable industry. It is a rapicl grower, and on rich sandy soils will yield three tons per acre, and in favorable seasons may be cut three times. It is similar in its habits to crab-grass, and ground that has once become seeded with it will yield crops year after year, these springing up after the removal of the regular crops of corn or grain. It has been grown here at the station successfully, the summer heat and drought having no effect upon it. The stems are branching, leafy, two to four or five feet long (sometimes reaching a length of ten feet), and the production of seed, which affords excellent food for poultry, is abundant.

Panicum virgatum, Linn.-Switch-gaass, Wild Red-top, Black Bent.

A tall perennial species, usually growing in clumps three to five feet high. Gattinger records it as occurring in moist, sandy soil along the Cumberland river and on the highlands and barrens at Tullahoma. The young plants furnish good grazing for stock, but by the time it blooms the stems become hard, and useless for fodder. We do not regard it as worthy of cultivation.

Para-grass.-Panicum molle ( $P$. barbinode.)

Paspalum dilatatum, Poir.-Hairy-flowered Paspalum.

This grass occurs in the Middle and Western part of the State, and where abundant, affords excellent pasturage. It is a perennial, and is particularly valuable as yielding late summer and autumn feed, during which period it makes its principal growth.

Paspalum distichum, Linn.-Knot-grass, Joint-grass.

A low, creeping grass, closely resembling Bermuda-grass in its habit and appearance. It frequents sandy soil along the margins of ponds and river banks, and often does good service in binding the sands liable to wash. It is recommended as a good grass for covering the soils of "sink holes." 
Paspalum ovatum, Nees.-Same as $P$. dilatatum.

Paspalum purpurascens, Ell.-Bull-grass, Purple Paspalum.

This is a strong-growing, much-branched species, which appears to be rare within the State. We have it from one locality only in East Tennessee. The commonest species of this genus (Paspalum) are the smooth Paspalum ( $P$. lave) and the Slender Paspalum ( $P$. setaceum). The former has here much the same value as Paspalum dilatatum, noted above. It is a vigorous growing, succulent grass, with rather large smooth seeds. It is often found intermixed with blue-grass, which it succeeds by four or five weeks, coming into full force after that has nearly disappeared.

Pearl Millet.-Pennisetum spicatum.

Penicillaria spicata, (Willd.) -Same as Pennisetum typhoideum, Rich., Pennisetum spicatum.

Pennisetum spicatum, Willd.-Pearl Millet, Japan Millet, Cat-tail Millet, East India Millet, Horse Millet, Egyptian Millet, Indian Millet, African Millet, African Cane.

This millet grows three to six feet high, and has a dense cylindrical erect "head" (panicle), five inches to a foot long. It is rarely cultivated here, and those who know it hold it in little esteem.

Perennial Rye-grass._Lolium perenne.

Phalaris arundinacea, Linn.-Reed Canary-grass, Ribbon-grass.

A rather tall, leafy perennial, with a narrow panicle growing naturally along the borders of streams and in low wet grounds. It is not common here, nor is it of any special agricultural value. There is a variety of this grass with striped leares, which is sometimes cultivated in gardens as an ornamental plant, and is known as ribbon-grass.

Phalaris Canariensis, Linn.-Canary-grass.

A species introduced into this country from Europe, and sometimes cultivated in the vicinity of our larger cities for its seed, which is used for bird food. It grows to the height of one or two feet, and has a very compact oval or oblong panicle or "head."

Phalaris intermedia, Bosc.-Southern Canary-grass, California Timothy, Reed Canary-grass, American Canary-grass, Stewart's Canary-grass, Gilbert's Relief-grass.

This is a taller and stouter-growing species than the last, with a longer and narrower "head." We have no positive record of its occurrence within the State, but it grows in South Carolina and in the States along the Gulf, where it is held in some estimation for winter grazing. 
Phleum pratense, Limn.-Timothy, Herd's-grass (in Xew England).

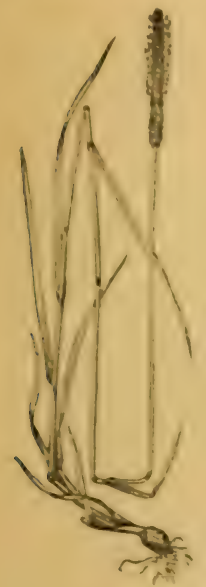

F1g. 21

Tingting. Phlemm pritense. Cat's-tail-grass, Tame Timothy.

One of the best known and most extensively cultivated grasses for hay, sown either alone or mixed with red-top. It succeeds best on moist loams, or clays. On very dry ground the yield is apt to be light; on such soils the base of the stem is often thickened and bulb-like. This grass is a native of Europe, and possibly also of this country, but it is generally supposed to have been introduced here. It is recorded as having been first cultivated in the Carolinas by Timothy Hansen about the middle of the last century.

Pigeon-grass.-Setaria viridis.

Pigeon-grass, Green.-Setaria viridis.

Pinon-grass. - Festuca ovina.

Poa alsodes, Gray.-Wood spear-grass.

A rather slender, native "blue-grass," found sparingly on the higher mountains and along the water-courses in the more mountainous districts. It has here no agricultural value.

Poa annua, Linn.-Early Meadow-grass. Annual Meadow-grass, Dwarf Meadow-grass, Low Spear-grass, Spear-grass, Maygrass, Goose-grass, Suffolk-grass.

A low (three to ten inches) annual species, common everywhere in door-yards and waste places, blooming from February to November. It is a European grass, but has long been estab. lished in this country and become thoroughly naturalized. It is tender and palatable to stock, and its abundance makes it of some agricultural value, as aftording an early bite for cattle before other grasses have made any considerable growth.

Poa arachnifera, Torr-Texas Blue-grass.

This grass was first discovered in Texas, where it is native, and is now being cultivated in several of the Southern States. It has strong, creeping roots (rhisomes), and forms a cense turf. It is especially well-adapted for permanent pastures. Owing to the unusual wooliness of the seeds, it is easiest propagated by root-cuttings. Both seeds and root-cuttings may he ohtained from? the leading seedsmen of New York or Philadelphia. It remains green here throughout the year, and blooms during the latter part of April or early in May. This grass appears to he dineonous; the florets in the fertile plants are very woolly; while thuse of the male or staminate plants are naked. (In Bulletin No. i, of 
Vol. IV., we gave a full-page figure of this blue-grass, and spoke more in detail as to its merits.)

Poa compressa, Linn.-Blue-grass, Smaller Blue-grass, Flatstalked Blue-grass, Flat-stalked Meadow-grass, Creeping Poa, Creeping Spear-grass, Wire-grass.

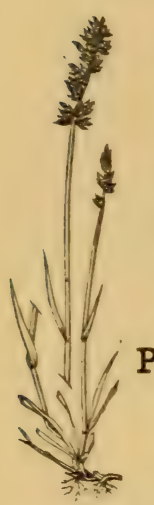

A native of Europe, this grass has become thoroughly naturalized here. Its low habit of growth, strongly compressed or flattened stems and narrow panicle, are characters which enable one to readily distinguish this from Kentucky Blue-grass. It is also more decidedly creeping, and will grow well upon the thinnest and apparently the most sterile soils. There is, perhaps, no better pasture grass than this for dry and poor soils.

Poa flexuosa, Muhl.-Douthern Spear-grass.

A native grass, one to three feet high, found occasionally in woods. Not sufficiently abundant to deserve special notice.

F1g. 25. English

Blue.griss Poa com pressa.

Poa pratensis. Linn.-Kentucky Blue-grass, Blue-grass, Green-grass, June-grass (in New England), Smooth or Smooth-stalked Meadow-grass, Spear-grass, English-grass, Brown-top-grass.

A well known native perennial grass, with creeping underground stolons and upright smooth stems two to four feet high.

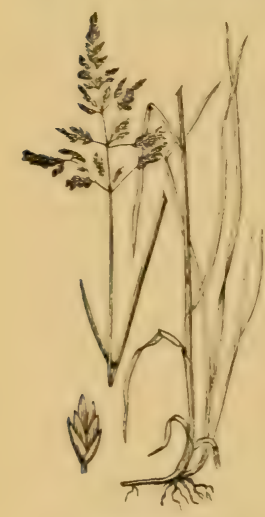

Fig. 26.

Kentucky Bluegras.

Poa pratensis.

It has been called the "King of pasture grasses in the Central Basin of Tennessee," and "whoever has Blue-grass has the basis for all agricultural prosperity." It is not so well adapted for hay as for pasture, but it makes an excellent bottom grass for the meadow. Here it remains green throughout the year, excepting in severe winter seasons, and blooms in May. Poa pratonsis is common to both Europe and America, and grows "wild" in this country from Alaska southward along the Rocky Mountains to Arizona, and in the Eastern part of the continent to the Gulf States. It is only in good soils that it yields well, doing best on those which are strongly calcareous.

Poa serotina, Ehrh.-False Red-top, Fowl Meadow-grass, Duckgrass, Swamp Wire-grass.

This species is a native of the Northern States, growing in low meadows and along streams. It appears to be a grass of excellent quality, growing to the height of two or three feet, and is pronounced a good grass for moist meadows. It - is being 
cultivated at the experiment station with the view of testing its value for this portion of the State.

Poatrivialis, Linn.-Rough Meadow-grass, Rough-stalked Meadowgrass, Green-grass, Orchiston-grass (in Eingland), Cimmon Meadow-grass.

A grass similar in habit to Poa pratensis, but with the horizontal branches at the base on the surface (not under ground) and the flowering stems rough to the touch just below the panicle. It has been cultivated for a long time in England, whence it has been introduced into this country. It is not very well known in Tennessee. It succeeds best where the soil and climate are moist, and can hardly be recommencled for this State.

Poison Rye-grass.-Lolium temulentum.

Polish Millet.-Panicum sanguinale.

Poverty-grass.-Aristida dichotoma, Danthonia spicata.

Poverty-grass, Long-awned.-Aristida tuberculosa.

Poverty-grass, Southern.-Sporobolus vaginceflorus.

Prairie-grass. - Storobolus asper, S. vaginceflorus, Eatcinia abtusata.

Prairie-grass, Australian.-Bromus unioloides.

Prairie Triple-awn.-Aristida oligantha.

Prickle-grass.-Leersia oryzoides.

Pungent Meadow-grass.-Eragrostis major.

Purple Paspalum.-Paspalum purpurascens.

Purple-top.-Triodia cuprea (Triscuspis sesleroides.)

Puss-grass.-Setaria viridis and S. glauca.

Purple Wood-grass.-Andropogon scoparius.

Quack-grass. - Igropyrum repens (Triticum repens.)

Quake-grass.-Agropyrum repens.

Quaking-grass.-Generic name for species of Briza. I rri=a meitia.

Quick-grass.-Agropyrum repens.

Quitch-grass.-Agropyrum repens.

Randall-grass.-Festuca elatior.

Ray-grass.-Lolium perenne.

Ray or Rye-grass, English.-Lolium perenne.

Red Fescue.-Festuca rubra.

Red-top.-Agrostis vulgaris, Calamagrostis Canadensis.

Red-top, Fall.-I riodia cuprea (Tricuspis seslerioides.)

Red-top, False.-Poa serotina, Triodia cuprcea.

Red-top, Mountain.-Agrostis canina. 
Red-top, Ta11.-Triodia cuprea, Agrostis vulgaris.

Red-top, Panic.-Panicum agrostoides.

Red-top, Wild.-Panicum virgatum.

Reed.-Arundinaria tecta.

Reed.grass,-Cynodon Dactylon, Andropogon nutans.

Reed Bent-grass.-Calamagrostis Canadensis.

Reed, Canadian Small._Calamagrostis Canadensis.

Reed-grass, Drooping.-Cinna pendula.

Reed, Indian.-Cinna arundinacea.

Reed-grass, Small._Calamagrostis Canadensis.

Reed, Sweet.-Cinna arundinacea.

Reed-grass, Wood.-Cinna arundinacea.

Reed Canary-grass. - Phalaris arundinacea.

Reed Meadow-grass.-Glyceria aquatica.

Relief-grass, Gilbert's.-Phalaris intermedia.

Rescue-grass.-Bromus unioloides.

Rhode Island Bent.-Agrostis vulgaris, A canina.

Ribbon-grass.-Phalaris arundinacea.

Rice-grass._Leersia oryzoides.

Rice, False-Leersia oryzoides.

Rice, Cut-grass.-Leersia oryzoides.

Rice, Oregon.-Sorghum vulgare.

Rice, Pampas.-Sorghum vulgare.

River-grass.-Panicum Texanum.

Rough Bent-grass.-Agrostis scabra.

Rough Cock's-foot.-Dactylis glomerata.

Rough Meadow-grass.-Poa trivialis.

Roughish Meadow-grass.-Poa trivialis.

Rough-stalked Meadow-grass.-Poa trivialis.

Rush-grass.-Generic name for species of Sporobolus (Vilfa).

Rye-grass.-Elymus Virginicus, Lolium perenne.

Rye-grass, English._Lolium perenne.

Rye, Montana.-Triticum Polonicum.

Rye-grass, French.-Arrhenatherum avenceum.

Rye-grass, Italian.-Lolium Italicum.

Rye-grass, Perennial.-Lolium perenne.

Rye-grass, Poison.-Lolium temulentum.

Rye-grass, Smooth.-Elymus Virginicus. 
Rye-grass, Wild.-Elymus Canadensis, Elymus lïginiaus.

St. Mary's grass. - Panicum jumentorum, Surghum Halafense.

Salem grass. - Ho'cus lanatus.

Sand-bur.-Cenchrus tribuloides.

Sand-spur.-Cenchrus tribuloides.

Satin-grass.-Muhlenbergia glomerata.

Schrader's-grass.-Bromus unioloides.

Scutch-grass.-Cynodon Dactylon, Agropyrum repens.

Sea-side Hair-grass.-Muhlenbergia capıllaris.

Sedge, Broom.-Andropogon Virginicus.

Sedge-grass.-Andropogon Virginicus.

Sesame grass.-Tripsacum dactyloides.

Setaria Germanica, Beauv-German Millet, Hungarian-grass, Bristly Fox-tail.

This is regarded by botanists as only a variety of the Italian Millet (Setaria Italica), and is only found here in cultivation or perhaps springing up from seed on land where cultivated the season previous. The German differs from the Italian Millet in having a more dense or compact and usually erect panicle or "head."

Setaria glauca, Beauv-Fox-tail, Yellow Fox-tail, Bottle-grass, Puss-grass, Pigeon-grass, Summer-grass.

This is a well-known weed, growing everywhere in cultivated grounds. It sends up a number of stems from a single root, each bearing a cylindrical panicle or "head," the bristles of which have a decided yellowish hue.

Setaria Italica, Kunth-Italian Millet, Bengal grass, Cat-tail Millet, Golden Millet, Missouri Millet, etc.

This exists here only in cultivation. It is distinguished from the German Millet by its larger, longer, more loosely-flowered and usually nodding panicles. The millets of this class, that is species or varieties of Setaria, are ready to cut sixty to sixtyfive days from time of sowing. When cut just as heading out, and before blooming, they make a valuable and safe forage, but in more advanced stages the feeder should be exceedingly careful, for when ripe, these millets act injuriously upon the kidneys. They are the refuge of the poor farmer whose other forage crops have failed. They are grown here for the seed, and the product is often used as bird and poultry food.

Setaria verticillata, Beauv.-Bristly Fox-tail.

An introduced grass, similar in habit to the next, but only rarely found. It is peculiar in having the bristles roughened or 
barbed downwards so that the heads (panicles) often become entangled with each other, or readily adhere to passing objects.

Setaria viridis, Beauv--Green Fox-tail, Pigeon-grass, Green Pigeon-grass, Puss-grass, Bottle-grass, Wild Millet.

An introduced grass which has become a common weed in all cultivated grounds, growing along with the yellow fox-tail, which it resembles in habit. It begins to bloom a few weeks earlier (latter part of May or first days of June) than the yellow fox-tail, has more numerous and smaller flowers and green bristles-at least the bristles do not give a yellowish hue to the panicle.

Sheep's Fescue.-Festuca ovina.

Shining Spike-grass.-Uniola nitida.

Short-leaved Beard-grass.-Gymnopogon brevifolius.

Short-stalked Meadow-grass.-Eragrostis Frankii.

Silky-flowered Oat-grass - Danthonia sericea.

Silver Beard-grass.-Andropogon argyrceus.

Slender Crab-grass. - Panicum filiforme.

Slender Fescue.-Festuca tenella.

Slender Meadow-grass.-Eragrostis pilosa.

Slender Spike-grass.-Uniola gracilis.

Smaller Blue-grass.-Poa compressa.

Small Cane.--Arundinaria tecta.

Small-flowered White-grass._Leersia Virginica.

Small Reed-grass, Canadian.-Calamagrostis Canadensis.

Smooth Brome-grass.-Bromus racemosus.

Smooth Meadow-grass.-Poa pratensis.

Smooth Rye-grass.-Elymus Virginicus.

Smooth-stalked Meadow-grass._Poa pratensis.

Smut-grass.-Sporobolus Indicus.

Soft Brome-grass.-Bromus mollis.

Soft Chess.-Bromus mollis.

Soft-grass, Meadow.-Holcus lanatus.

Soft-grass, Woolly.-Holcus lanatus.

Sorghum avenaceum, Chapm.-A variety of Andropogon nutans, Linn., which see.

Sorghum cernuum, Host.-Chicken Corn, Guinea Corn, White Egyptian Corn.

This is treated as a variety of Andropogon sorghum by Hackel. It is a tall and strong growing grass, and just below the denselyflowered panicle the stalk is abruptly bent or recurved so that 
the panicle points downward. It is largely cultivated in tropical and Northern Africa, and in some parts of Southern Asia. where it is used as a cereal. It is only occasionally grown here. and is highly valued as a food for poultry.

Sorghum Halapense, Pers.-Same as Andropogron sorghum, Brot. var. Halapensis, Hack, which see.

Sorghum nutans, Gray.-(Same as Andropogon nutans, Linn.)

There are two well-marked varieties of this grass found within the State. The more common one is the Sorghum acenaceum of Chapman (Andropogon nutans L. var. avenaceus, Hackel.) The other, less frequently seen, is Sorghum nutans of Chapman, (Andropogon nutans L. var. Linncanus, Hackel.) This last is distinguished by its longer beards (awns), much more loosely flowered, darker-colored, and nodding panicles.

Sorghum saccharatum, Pers.-Sweet Sorghum, Chinese SugarCane, African Cane, Broom Corn.

This is regarded by Hackel as only a variety of Andropogon Sorghum. The variety which is cultivated here as Broom Corn he names var. technicus.

Sorghum vulgare, Pers.-This has been reduced by Hackel to a variety of Andropogon Sorghum, characterized by its light colored and rather compact panicles. There appears to be much confusion in our literature as regards the "common" names applied to the varieties of Sorghum. Under Sorghum vulgare we find the following: Sorghum, Sugar-Cane, Broom Corn, Indian Millet, Chinese Wheat, Irory Wheat, Pampas Rice, Chinese Sugar-Cane, African Corn, Guinea Corn, Duora or Durra Corn, Chocolate Corn, Great Millet, Oregon Rice.

Southern Bent-grass.-Agrostis elata.

Southern Canary-grass.-Phalaris intermedia.

Southern Eragrostis.-Eragrostis Purshii.

Southern Poverty-grass.-Sporobolus vaginceflorus.

Southern Spear-grass.-Eragrostis Purshii, Pcia flexusa.

Spanish grass.-Panicum molle.

Spartina cynosuroides, Iilld-Cord-grass, Fresh-water Cordgrass, Marsh-grass, Bull-grass, Thatch-rrass, Slough-grass.

This grass occurs in West Tennessee (Gattinger.) It is a native perennial, three to six feet high, growing in rich soil alongriver banks and borders of lakes. It is said to make excellent hay for horses when cut in good season. In regions where it grows abundantly, as along the Mississippi buttoms, it has been used for making a coarse kind of paper. We do not regard it as worth cultivating. 
Spear-grass.-Poa annua, Poa pratensis.

Spear-grass, Branching.-Eragrostis tenuic.

Spear-grass, Creeping.-Poa compressa.

Spear-grass, Low.-Poa annua.

Spear-grass, Meadow.-Glyceria nervata.

Spear-grass, Southern.-Poa flexuosa, Eragrostis Purshii.

Spear-grass, White-_Glyceria aquatica.

Spear-grass, Wood.-Poa alsodes.

Spider Bent-grass.-Agrostis arachnoides.

Spike-grass-Generic name for species of Uniola, etc.

Spike-grass, Shining.-Uniola nitida.

Spike-grass, Slender.-Uninla gracilis.

Spiked Wild Oat-grass.-Danthonia spicata.

Sporobolus asper, Kunth.-Prairie-grass.

Two or three forms of this native perennial grass are found within the State. It has very long and very slender leaves, and the flowers are usually concealed within the leaf-sheaths. It grows in dry and sterile soil, but apparently is of no agricultural value.

Sporobolus Indicus, R. Br.-Carpet-grass, Smut-grass, Drop-seedgrass.

An introduced grass which has become pretty widely distributed over the State, growing in scattered tufts or patches about dwellings or in old door-yards. Its stems, which grow one to three feet high, are tough and wiry. Its flowers are crowded in a long and slender panicle which, as the season advances, often becomes overgrown by a fungus, and appears as if attacked by smut. Of no agricultural value whatever.

Sporobolus vaginæflorus, Vasey.-Southern Poverty-grass, Prairiegrass.

A common native annual, growing in dry sterile soil. Of no value.

Spring-grass, Sweet-scented.-Anthoxanthum odoratum.

Sprouting Crab-grass.-Panicum proliferum.

Squirrel-tail-grass._Hordeum pratense.

Stewart's Canary-grass.-Phalaris intermedia.

Stink-grass.-Eragrostis minor and major.

Stipa avenacea, Linn.-Black Oat-grass, Feather-grass.

A slender grass growing in open woods along dry ridges, etc. It has a graceful open panicle and long-bearded (awned) flowers. Of no value in agriculture. 
Strong-scented Meadow-grass.-Eragrostis minor.

Suffolk-grass.-Poa annua.

Sugar Cane, African.-Sorghum saccharatum.

Sugar Cane.-Sorghum vulgare.

Sugar Cane, Chinese.-Sorghum saicharatum, S. imlgari.

Summer Dew-grass.-Agrostis vulgaris.

Summer-grass.-Setaria glauca.

Swamp Chess.-Bromus ciliatus.

Swamp Wire-grass.-Poa serotina.

Sweet-scented-grass.-Anthoxanthum odoratum.

Sweet-scented Spring grass.-Anthoxanthum odoratum.

Sweet-scented Vernal.-Anthoxanthum odoratum.

Sweet Reed.-Cinna arundinacea.

Sweet Sorghum.-Sorghum saccharatum.

Sweet Vernal-grass.-Anthoxanthum odoratum.

Switch-grass.-Panicum virgatum.

Syrian-grass.-Sorghum Halapense.

Tall Fescue.-Festuca elatior.

Tall Oat-grass.-Arrhenatherum avenaceum.

Tall Red-top.-Triodia cuprea (Tricuspis seslerioides), Agrostis i'ulgaris.

Tall, Smooth Panic-grass.-Panicum virgatum.

Tall, Thin-grass.-Agrostis elata.

Taller Wild Oat-grass.-Danthonia sericea.

Tame Timothy.-Phleum pratense.

Tennessee Fescue.-Festuca rubra, var. glaucescens.

Tennessee Oat-grass._Danthonia compressa.

Teosinte.-Euchlona luxurians.

Terrell-grass.-Elymus Virginicus and E. Canadensis.

Texan Blue-grass.-Poa arachnifera.

Texas Millet.-Panicum Texanum.

Thatch-grass - Spartina cynosuroides.

Th1n-grass.-Agrostis perennans.

Thin-grass, Tall_-Agrostis elata.

Tickle-grass.-Agrostis scabra.

Timothy._Phleum pratense.

Timothy, Tame.-Phleum pratense.

Timothy, White--Holcus lanatus.

Timothy, Wild._Muhlenbergia glomerata, Sctaria ciriais. 
Tricuspis seslerioides, Torr.-See Triodia cuprea, which is the same.

Triodia cupræa, Jacq.-False Red-top, Tall Red-top, Fall Red-top, Purple-top.

A tall, native perennial frequent in dry, sandy fields. It is a showy grass three to five feet high, blooming from August to October. Apparently of no agricultural value.

Triple-awned-grass.-Generic name for species of Aristida.

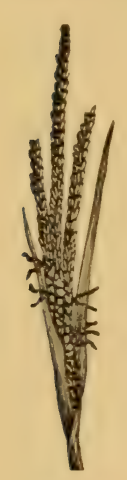

Fig. 27.

Gama-grass Tactyloides

Tripsacum dactyloides, Linn.-Gama-grass, Sesamegrass, Bull-grass.

This grass is occasionally seen in rich soils along rivers and creeks. It grows in large tufts, producing a great mass of broad leaves, which, when young and succulent, are eaten with avidity by stock. The roots are strong and somewhat creeping; the stems are solid and grow from three to seven feet high. The flowers are in slender spikes, these standing singly, or more often, two to three together. When abundant, gama affords a large amount of natural forage, and is valuable to this extent.

Triticum Polonicum, Linn--Polish-wheat, Wild-goose Wheat, Montana Rye, Giant Rye.

A striking species, with large flattened spikes or "heads." It is cultivated to some extent in Europe, but very rarely, excepting as a curiosity, in this country. The grain is long and slender, resembling that of rye, but the yield is small, as there are few kernels in a head.

Triticum sativum, Linn.-Wheat.

To this species belong all our cultivated varieties of wheat, for an account of which the reader is referred to Hackel's "True Grasses," or to the Fourth Annual Report of the New York Agricultural Experiment Station, (I 885.)

Turkey-foot.-Andropogon provincialis.

Tuscarora Rice.-Zizania aquatica.

Twin-grass.-Diarrhena Americana.

Twitch-grass.-Agropyrum repens.

Uniola gracilis, Michx.-Slender Spike-grass.

A slender, native perennial, with narrow, dark-green leares, and a long and slender panicle. It grows to the height of two to four feet, blooming in July and August. Of no agricultural value. 
Uniola latifolia, Mich-Broat-leaved Spike-grass, Wild Fescue, Wild Oats.

This is a strong-rooted native perennial, with broal leaves and a nodding, large-flowered panicle. It grows in damp places along streams and thicket horders, and is sometimes gathered for winter boupuets. Of no value excepting for ornamental purposes.

Upright Chess.-Bromus racemosus.

Uralepis cornuta, Ell.-The same as Triflasis Americana, E11.

Uralepis purpurea. Nutt.-The same as Triflasis furfurca, Chapm.

Valley-grass, Green.-Sorghum Halapense.

Velvet-grass.-Holcus lanatus.

Velvet Lawn-grass.-Holcus lanatus.

Velvet Meadow-grass, Soft.-Holcus lanatus,

Velvet Mesquit.-Holcus lanatus.

Verral-grass. - Anthoxanthum odoratum.

Vernal.grass, Sweet.-Anthoxanthum odoratum.

Virginia Beard-grass.-Andropogon Viroinicus.

Virginia Cut-grass._Leersia Virginica.

Virginia Lyme-grass.-Elymus Virginicus.

Water Fox-tail-Alopecurus geniculatus.

Water Fox-tail, Wild.-Alopecurus aristulatus.

Water-grass.-Panicum Crus-galli.

Water Oats.-Zizania aquatica.

Water Rice.-Zizania aquatica.

Wheat-grass.-Generic name for species of Agrepyrum.

Wheat-grass, Creeping.-Agropyrum repens.

Wheat, Chinese.-Sorghum vulgare.

Wheat, Ivory.-Sorghum vulgare.

Wheat, Wild-goose.-Triticum Polonicum.

White Bent.-Agrostis alba, Andropogon scoparius.

White Egyptian Corn.--Sorghum cernum.

White-grass.-Leersia oryzoides, L. Virginica.

White-grass, Small-flowered.-Leersix L'irginica.

White Spear-grass.-Glyceriz aqualica.

White Timothy.-Holcus lanatus.

White-top.-Danthonia sticata, Agrositis alba. 
White Yorkshire.-Holcus lanatus.

Wild Barley.-Hordeum pratense.

Wild Chess.-Bromus Kalmii.

IVild Fescue-grass.-Uniolia latifolia.

Wild-goose Wheat.-Triticum Polonicum.

Wild Millet-grass.-Setaria viridis.

Wild Oat-grass or Oat-grass.-Species of Danthonia, Andropogon nutans, Arrhenatherum avenaceum.

Wild Oat-grass.-Danthonia spicata, Sorgham nutans, (Chrysopogon nutans.)

Wild Oats.-Uniola latifolia, Zizania aquatica, and Calamagrostis Nuttalliana.

Wild Red-top.-Panicum virgatum.

Wild Rice.-Zizania aquatica.

Wild Rye.-Elymus Virginicus.

W11d Timothy.-Muhlenbergia glomerata, Setaria viridis.

Wild Water Foxtail--Alopecurus aristulatus.

Willard's Brome-grass.-Bromus secalinus.

Wire-grass.-Muhlenbergia diffusa, Poa compressa, Aristida stricta, Cynodon Dactylon, Eleusine Indica, Andropogon scoparius. Also applied to Juncus species.

Wire-grass, Swamp.-Poa serotina.

Witch-grass.-Agropyrum repens.

Witch-grass, Old.-Panicum capillare.

Wood-grass.-Sorghum nutans, Muhlenbergia Mexicana.

Wood-grass, Finger-spiked.-Andropogon provincialis.

Wood-grass, Purple-Andropogon scoparius.

Wood Hair-grass._Deschampsia flexuosa.

Wood Meadow-grass.-Poa nemoralis.

Wood Reed-grass.-Cinna arunäinacea.

Wood Spear-grass.-Poa alsodes.

Woolly Beard-grass.-Erianthus alopecuroides, (E. saccharoides.)

Woolly Soft-grass.-Holcus lanatus.

Yard-grass.-Eleusine Indica.

Yellow Fox-tail:-Setaria glauca.

Yellow Oat-grass.-Avena flavescens.

"Yerba de Para."-Panicum molle.

Yorkshire Fog.-Holcus lanatus.

Yorkshire White.-Holcus lanatus. 
Zea Mays, Linn.-Indian Corn or Maize.

()nly known as a cultivated cereal, and ledieved to have come originally from Central or tropical America. Sixty or more varieties are known, differing in size, and especially in the form, color and size of the kernels.

Zizania aquatica, Michx.-Tuscarora Rice, Water Oats, Water Rice, Wild Rice, Indian Rice.

A tall reed-like grass, which may be found in the Western part of the State, growing in marshy places along the river bottoms and around ponds. It is more common farther north. The grain was formerly gathered by the natives, and used as a cereal.

Note.-Figures 8 and 12 were kindly loaned hy the Agricultural Fxperiment Station of North Carolina. All the other figures of this section were drawn by the writer for Webster's International Dictionary, and used here hy favor of the publishers, Messrs. G. \& C. Merriam \& Co. 


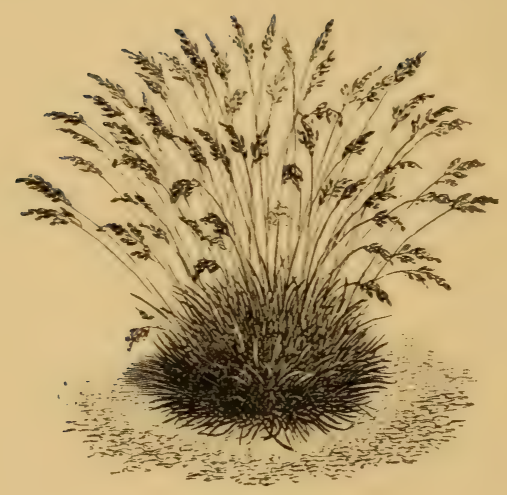




\section{(II.) DESCRIPTIVE TERMS, WITH ILLUSTRATIONS.}

In this section, numerous figures of our native and cultivated grasses are brought together, chiefly for the purpose of explaining the application of the terms used to designate the various parts of grasses. This method of presenting the terms has been adopted in preference to the usual glossary, and by having them finally presented in alphabetical order, with figure references, it is hoped that the present method will prove more satisfactory. By a careful study of the figures and their accompanying descriptions, the reader will hardly fail to gain a fair knowledge of the descriptive terms employed in works on grasses. The figures serve a further purpose of illustrating many of the species named in Section I. By having the Latin name, it is a simple matter to refer to Section I, where this name occurs according to its initial letter, and learn something of the character or habit of the grass.

Note: In this Section-

Figures 29, 5031,35 (in part), 36, 41, 43, 45 47, 48, 51, 54 (in part), 56, 59, (1), 67,68 (in part), 69 (in part), 70 in part), 71 and 72 , are after Nees (Gen. Pl. Fl. Germ., Vol. I.)

“ $\quad 37,38,42,53$ and 55, are after Gray, (Manual of Botany.)

" 32, From Botanical Magazine, Pl. 6414.

"33, 57, aiter Trinius (Spec. Gram. Icon.)

“ 35, Le Maout \& Decaisne (in part.)

" $68,69,70$, after Mull-Guyot (in part.)

" $34,46,61$, loaned by Peter Henderson \& Co.

“25, $44,49,52,58,62,63,64,65$, 66 , loaned by the North Carolina Agr. Expr. Station.

"50, after Beal, (Grasses of North America.)

“ 39, from Hackel's True Grasses. 
Fig. 28. Loliumperenne.-Perennial Rye-grass. Figure showing the habit of growth. At the top of the figure is a portion of one of the narrow spikes, drawn on a larger scale. Here the single spikelets, placed with one edge against the main rachis, are sessile, and hence the inflorescence is a true spike.

Fig. 29. Loliumperenne, L.-Rye-grass. A, upper portion of the inflorescence, which is a true spike. The spikelets stand with one of their edges next the rachis. This is shown more clearly in $B$, which illustrates a portion of the rachis and a single spikelet with two of the lower florets expanded. $E$, palet. $K$, fruit.

Fig. 30. Glyceria fluitans, R. Br.-Manna-grass. $A$, a portion of the paniculate inflorescence. $C$, one of the empty glumes, which is strongly seren-nerved. $E$, palet, strongly two-keeled and bifid at apex. $G$. lodicules, thick and truncate. $K$, grain, the small embryo shown near the base.

Fig. 31. Bromus mollis, L.-Soft Brome-grass. A, a portion of the inflorescence, which is a panicle. $D x E$, a floret seen from behind. The flowering glume is notched at the apex, and awned. $F$, the flower; two small lodicules at the base in front, three stamens with short two-celled anthers borne on slender filaments; two plumose sessile stigmas inserted or attached on the anterior side below the summit of the hairy-topped ovary. $K$, grain seen from in front; the small oblong scar at the base denotes the position of the embryo. $K I$, grain seen from behind: the dark central line is the narrow or linear hilum. 

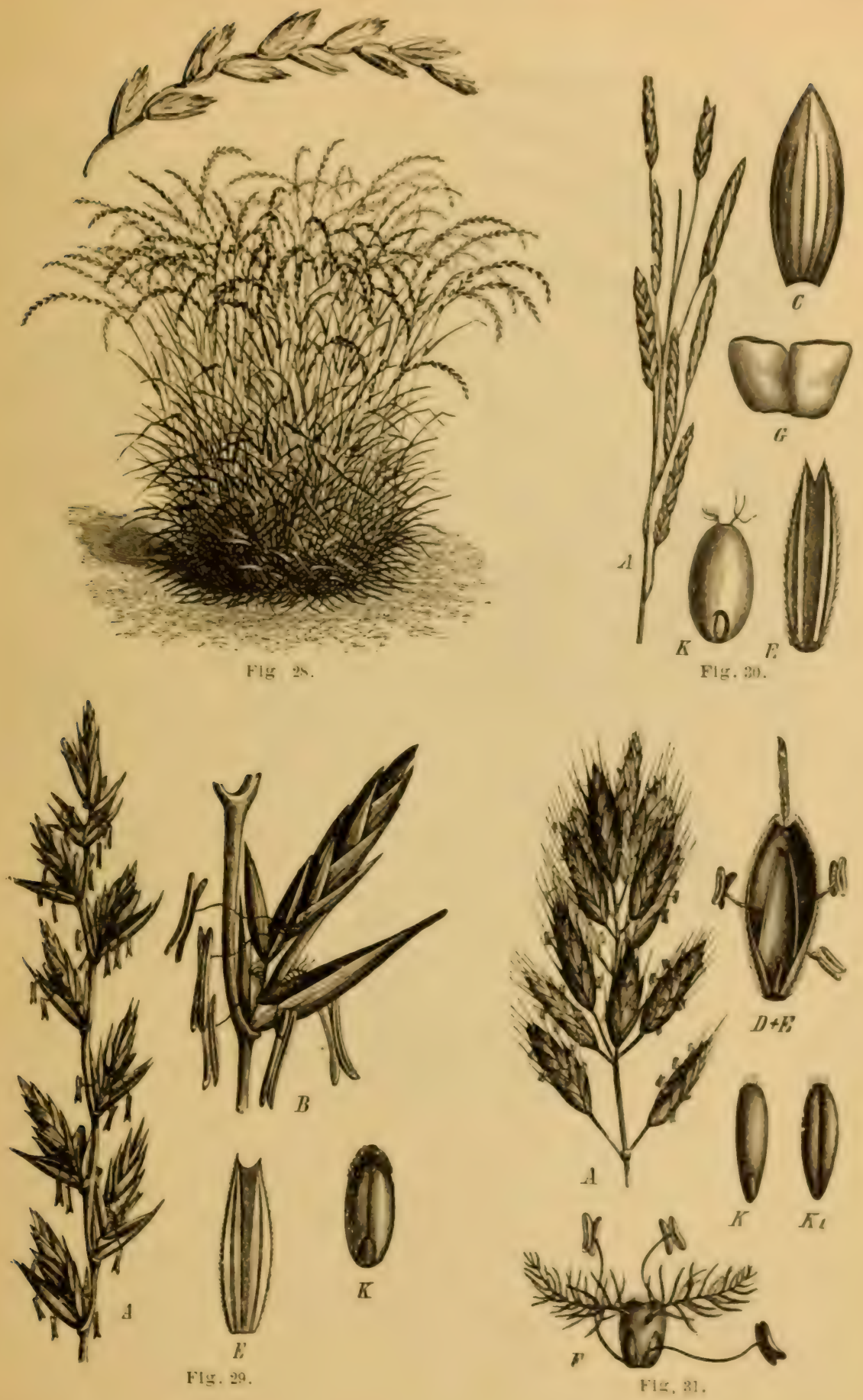

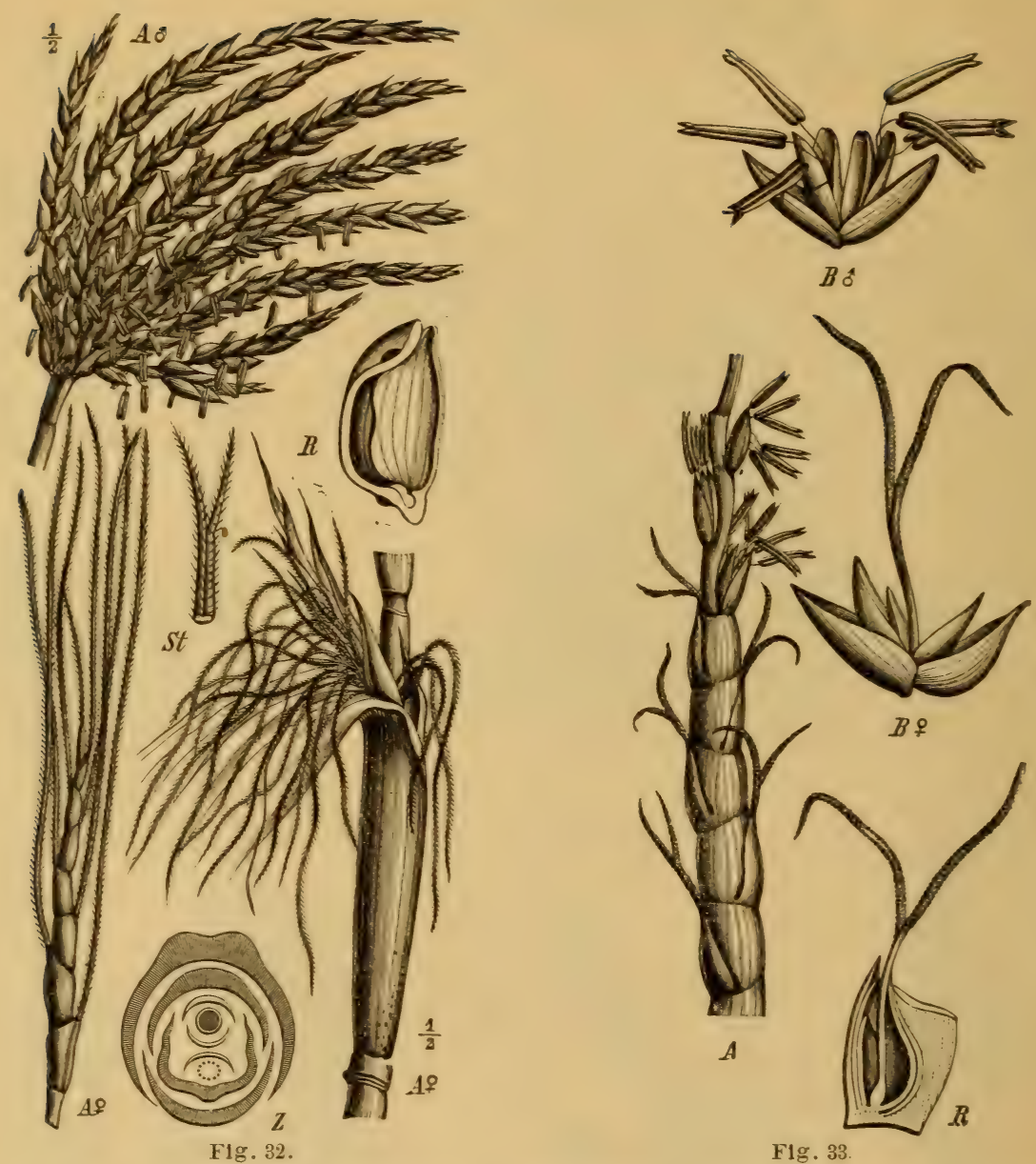

Fig. 32. Euchlana luxurians.-Teosinte. The uppermost cut in the figure shows the staminate or male inflorescence reduced onehalf; to the right below is shown the female inflorescence mostly concealed within the sheathing leaf; to the left below is shown a single female or pistillate spike. $R$, a joint of the rachis of the female spike. St, terminal portion of the stigma.

Fig. 33. Tripsacum dactyloides L.-Gama-grass. A, a portion of the inflorescence, which is a spike, pistillate spikelets below, staminate above. $R$, a joint of the rachis of the pistillate portion in vertical section. Above this is illustrated one of the pistillate spikelets, and at the top of the figure is shown one of the twoflowered staminate spikelets. 


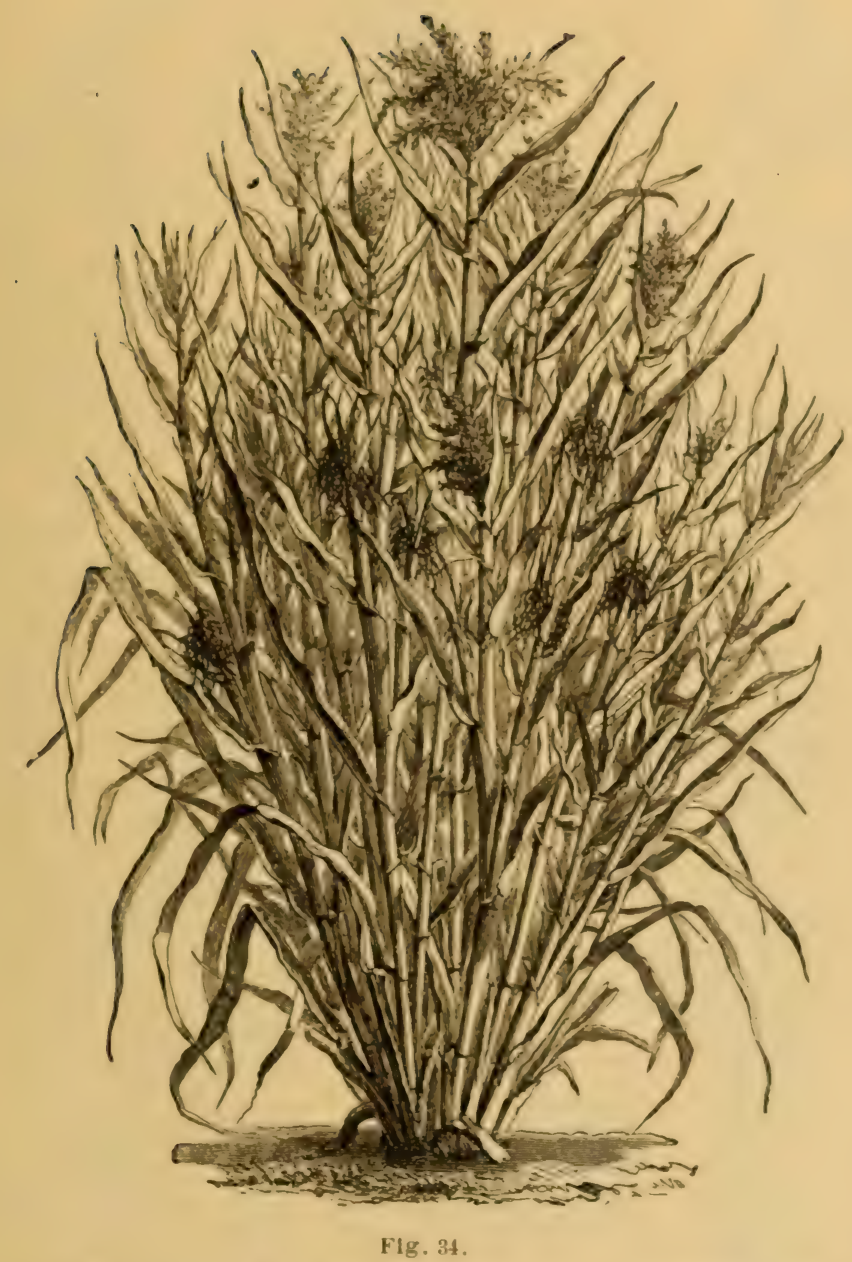

Fig. 34. Teosinte, Euchliena luxurians.-Showing its robust character and habit of throwing up many stalks or culms from a single root. 
Fig. 35. Zea Mays L.-Indian Corn. In the center above is the upper part of single stalk, reduced to I-Io its natural size, showing the terminal male or staminate inflorescence (the "spindle," or "tassel,") and in the axil of the third leaf from the base is the female or pistillate inflorescence enveloped in broad, leafy bracts. At the base of the figure on the right side this female inflorescence is shown more clearly; the hair-like tuft at the apex is formed by the projecting slender styles or stigmas (the "silk.") To the left at the base of the figure is shown an "ear" of corn, the kernels being the matured ovaries from which the styles have disappeared. In the upper left-hand corner of the figure are two staminate spikelets, one sessile, the other raised on a short pedicel. $B$, a female spikelet; $C_{I}, C_{2}, C_{3}$, empty glumes; $D$, flowering glume; $E$ and $E_{I}$, palets; in the center of this figure is the ovary or young grain with a portion of the style attached. $J$, the pistil. $G$, lodicules.

The flowers of Indian Corn are unisexual, the one male or staminate, the other female or pistillate; both are born upon the same plant, but each is in a separate inflorescence. 


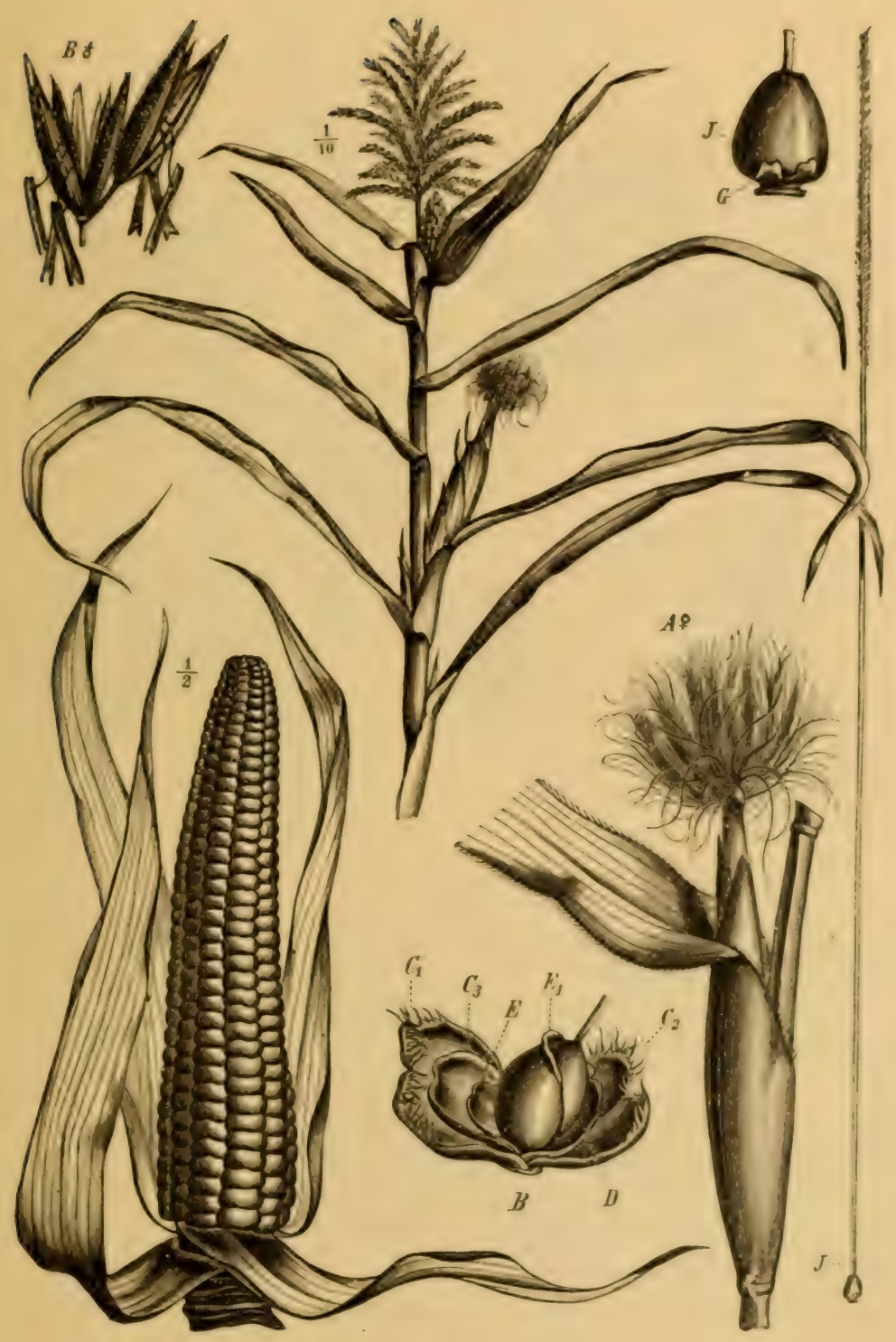

F1g. 35 . 


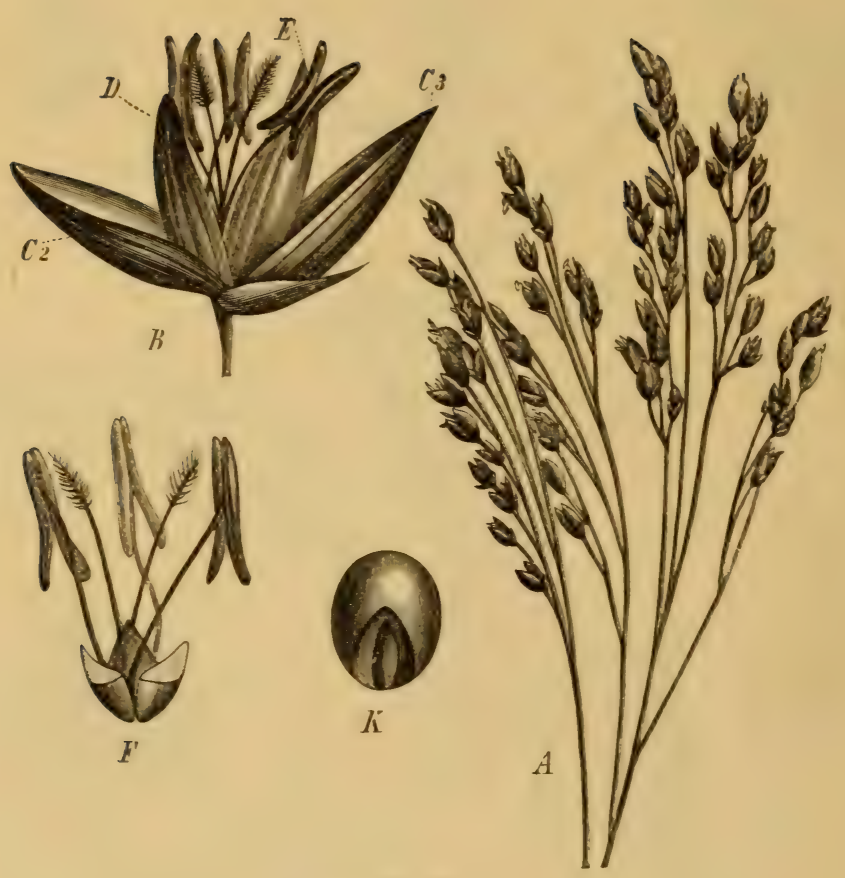

F1g. 36 .

Fig. 36. Panicum miliaceum L.-Millet. A, a portion of the paniculate inforescence. $B$, a spikelet. $C_{2}$ and $C_{3}$, the second and third empty glumes which are nearly equal, and much broader and longer than the first or lowest glume. $D$, flowering glume. $E$, palet. The hermaphrodite flower-having both stamens and pistil-stands between the flowering glume and palet. $F$, flower with the lodicules in front; there are three stamens, and the ovary is terminated by two slender styles with short, feathery stigmas. $K$, fruit seen from the front; the scar on the lower half represents the embryo. 


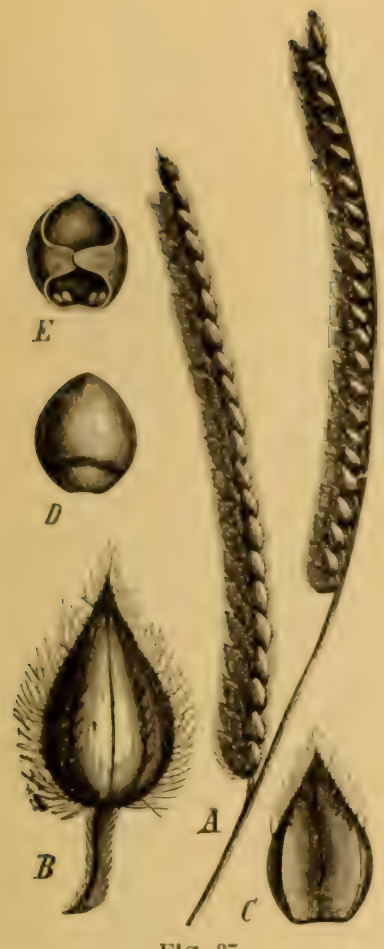

F1g. 37 .
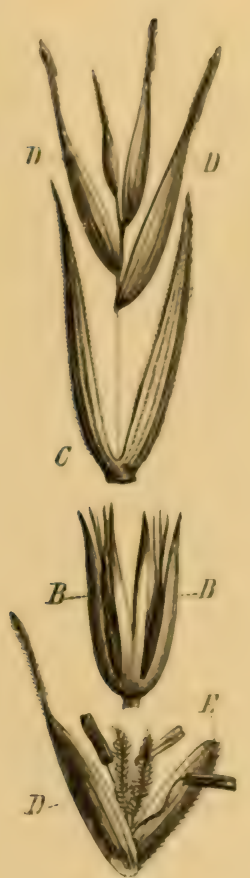

FIg. 38 .

Fig. 37. Paspalum dilatatum, Poir.-A, a portion of the influrescence. There are two one-sided or unilateral racemes; the spikelets are on short pedicels, and crowded so that they are somewhat imbricated, as illustrated. $B$, a single spikelet with its pedicel. $C$, empty glume. $D$, flowering glume. $E$, palet, with prolonged incurved edges.

Fig. 38. Elymus Iirginicus, L. (After Gray).-B, $B$, spikelets somewhat grown together at the base. $C$, empty glumes of one of the spikelets, abore which are the florets; the axis to which the florets are attached is the rachilla. The terminal floret is smaller than the others and sterile. $D$, (lowest figure) flowering glume, which is awned from the point. $E$, palet. Between the glume and palet is the flower. 
Fig. 39. Pennisetum typhoideum, Rich.-Pearl Millet. $A$, upper part of culm, showing the cylindrical spike-like panicle and uppermost lanceolate leaf. $B$, a couple of spikelets, surrounded by numerous ciliated bristles. These fall with the spikelets.

Fig. 40. Panicum sanguinale L-Crab-grass: A, upper portion of a single stem and inflorescence. This last consists of several slender one-sided racemes crowded at the end of the stalk. a, a single spikelet, showing the first and third glumes. $\mathbf{b}$, the same seen from the other side, showing the second glume, which is about one-half the length of the smooth flowering glume which it partly covers. 

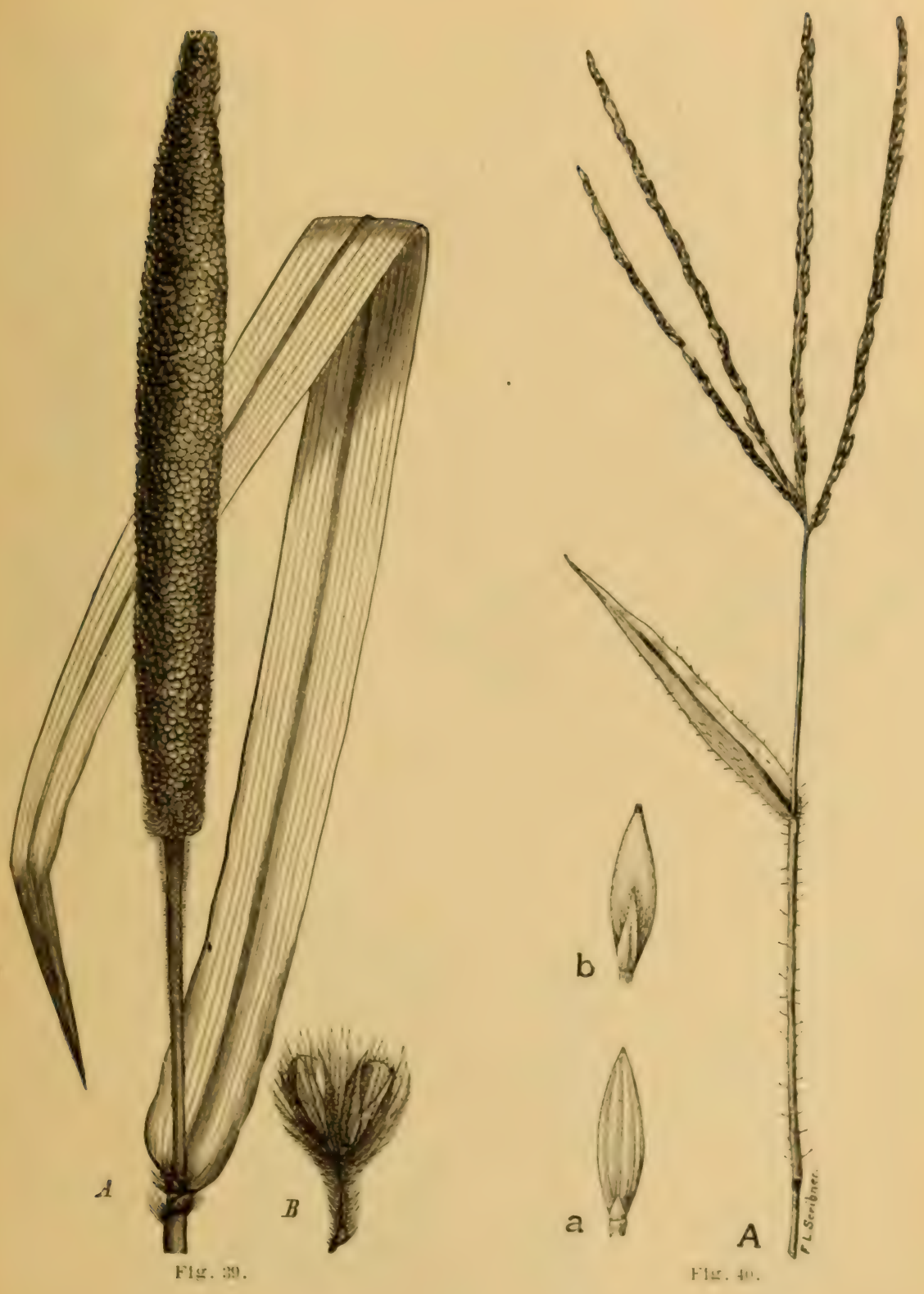
Fig. 4r. Setaria glauca, Beauv.-Yellow Fox-tail, $A$, inflorescence, which is a bristly, cylindrical, spike-like panicle. $B x L$, spikelet with an involucre of bristles. $B$, spikelet. $D$, flowering glume. $E$, palet from which the feathery stigmas are protruding.

Fig. 42. Muhlenbergia diffusa, Schreb., above, Muhlenhergia sylvatica, Torr., below. Upper $B$, spikelet of M. diffusa. Upper $C$, empty glumes of same; these are very small; the flowering glume is terminated by a long, slender awn. $B$, (in lower part of Fig.) spikelet of M. sylvatica; the empty glumes are slightly unequal, the second a little longer than the flowering glume, which is longawned from near the apex. Lower $C$, empty glumes. $D$, flowering glume. $E$, palet.

Fig. 43. Oryza sativa.-Rice. A, a portion of the inflorescence. $B$, a spikelet, the flowering glume is ciliate on the back, like the palet, and raised above the two small lower empty glumes on a short pedicel. $F$, the flower showing the two lodicules at the base in front; stamens six; styles, two, apparently terminal.

Fig. 44. Anthoxanthum odoratum.-Sweet Vernal-grass. Figure showing habit of growth. To the left is the upper portion of a single stalk, showing more clearly the spike-like panicle.

Fig. 45. Anthoxanthum odoratum L.-Sweet Vernal-yrass. $B$, spikelet. $C_{I}, C_{2}$, two outer empty glumes; $C_{3}$ and $C_{4}$, two inner bifid or cleft and awned empty glumes attached to the rachilla at the base of the floret, and at maturity they fall with it. $D$, the flowering glume from which project two feathery stigmas, and the two stamens with long versatile anthers. 

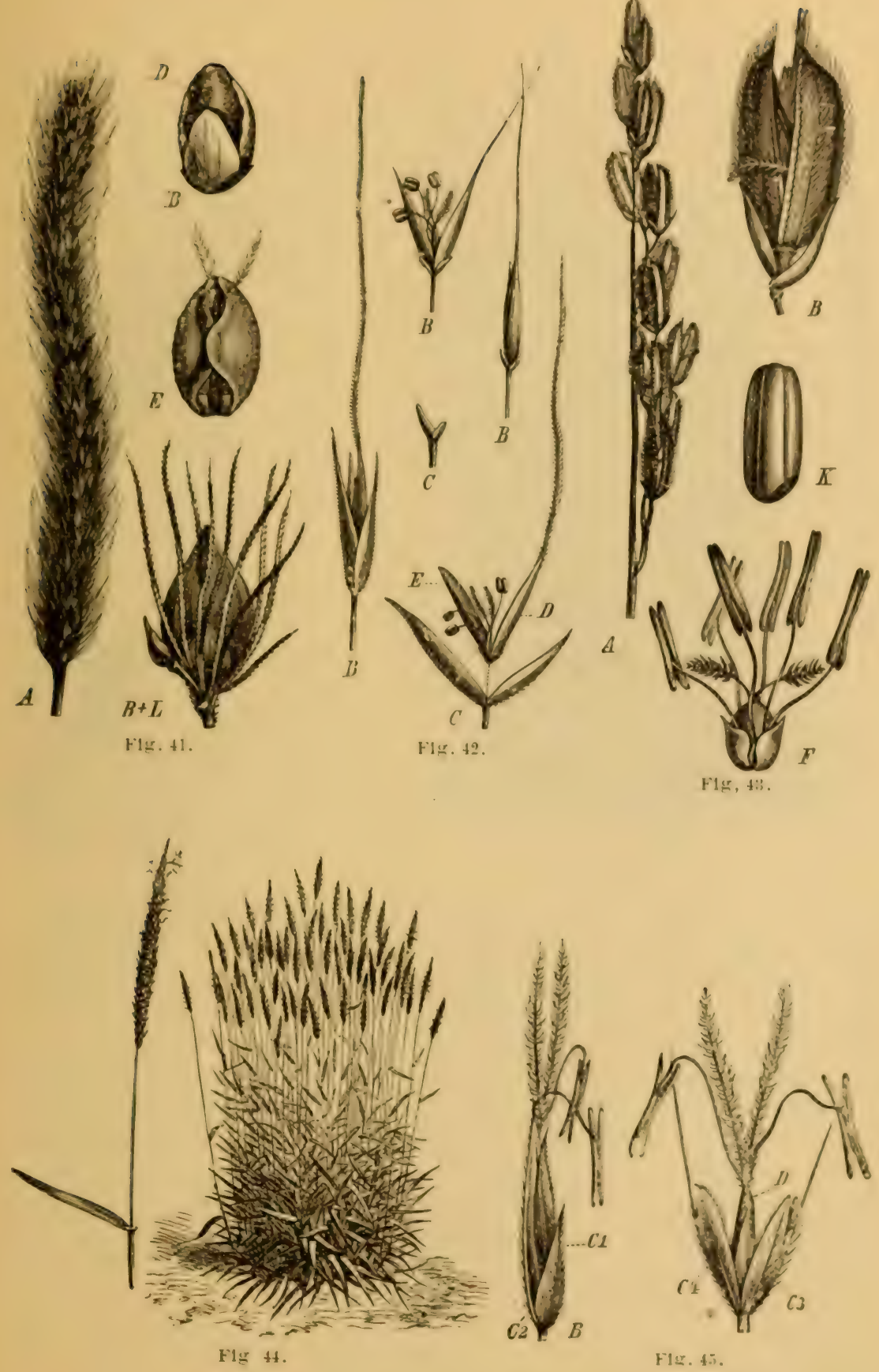

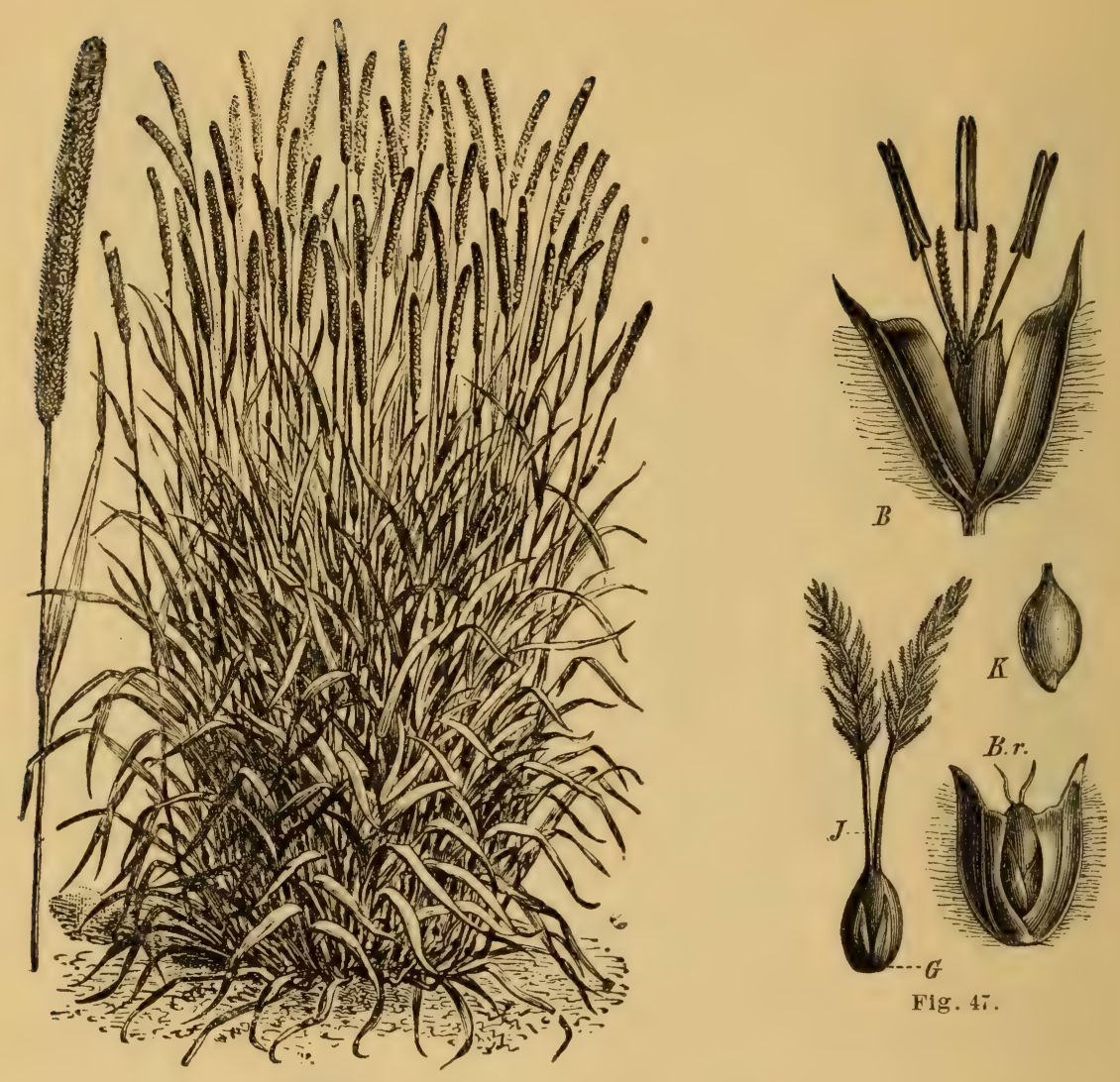

Fig. 4i.

Fig. 46. Phleum pratense.-Timothy. Figure showing the habit of growth of a robust group of the plants. To the left is illustrated an upper portion of a single stalk, to show more clearly the dense, cylindrical, spike-like panicle.

Fig. 47. Phleum pratense, L.-Timothy. $B$, a spikelet; the very abruptly pointed empty glumes, which are ciliate along the keels, are spread slightly to show more clearly the single floret within; the three stamens and two stigmas project beyond the flowering glume and palet. B.r., a mature spikelet containing the ripened fruit. $J$, the pistil, ovary at base, two slender styles terminated by the plumose stigmas $G$, lodicules (two in number) at base of ovary. $K$, fruit. 

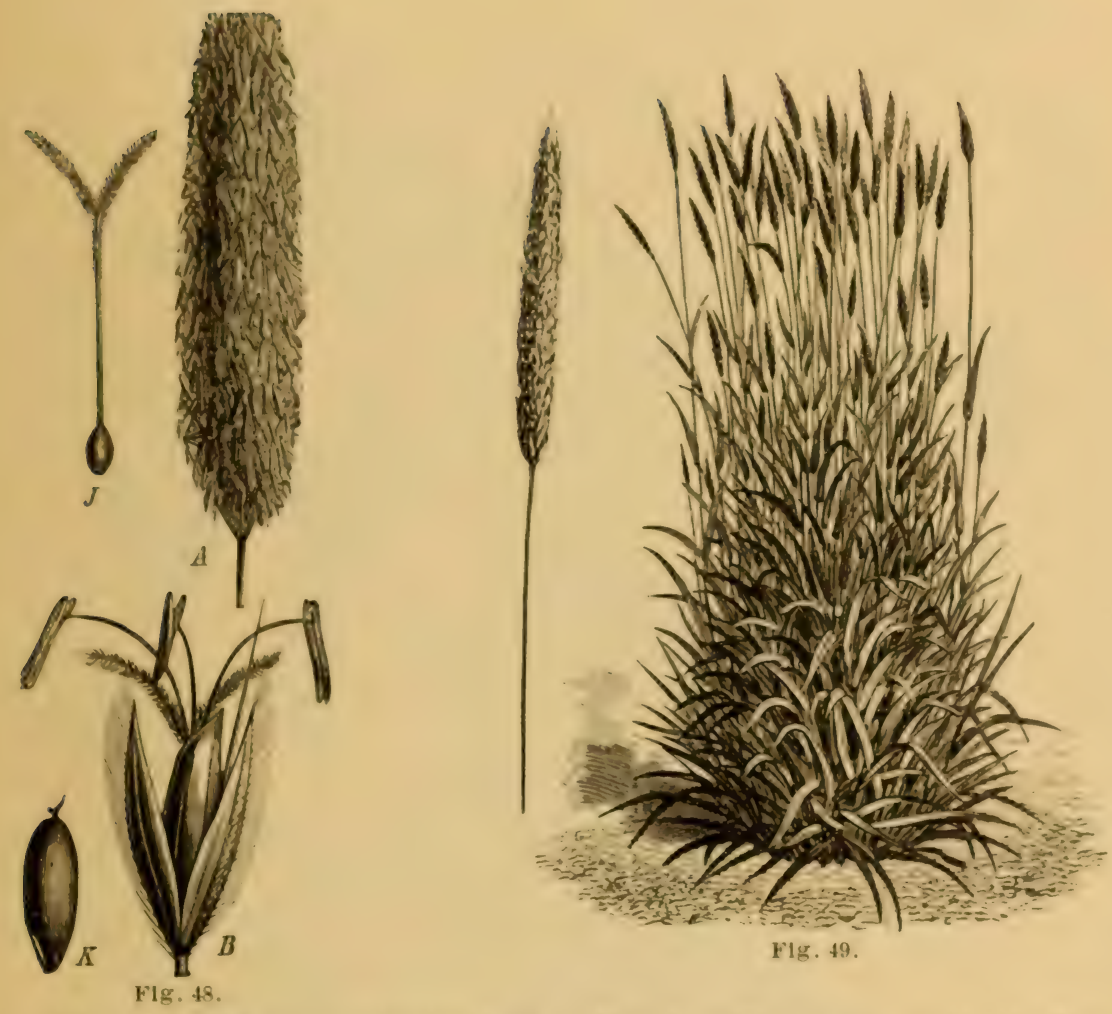

Fig. 48. Alopecurus pratensis, L.-Meadow Fox-tail. $A$, the inflorescence, which is a dense, cylindrical, spikelike panicle. $B$, spikelet. The outer ciliate and nearly equal empty glumes are spread apart above, revealing the upper portion of the awned flowering glume, from whose oblique apex project the three stamens and two feathery stigmas. $J$, the pistil entire, the orary below, the stigmas above, these connected by the long and slender style. $K$, fruit.

Fig. 49. Mlopecurus fratensis.-Meadow Fox-tail. Figure showing habit of growth. To the left is a portion of a single stalk, showing the very narrow spike-like panicle. 

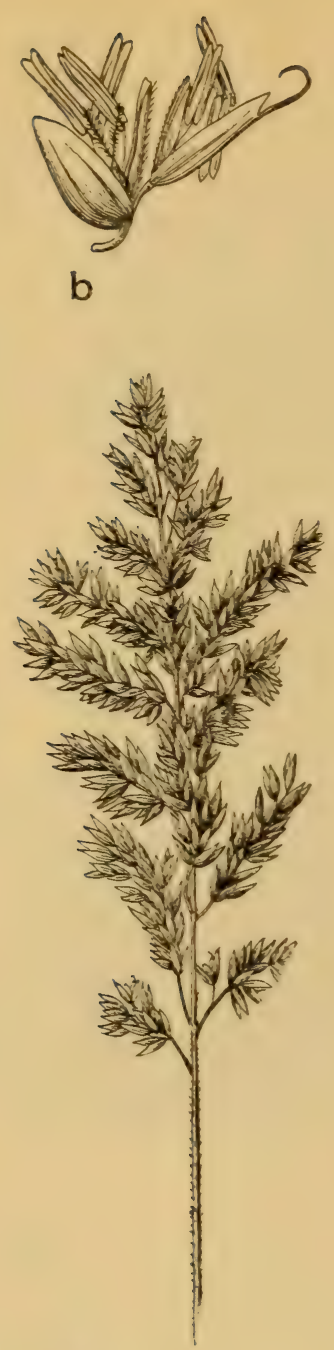

A

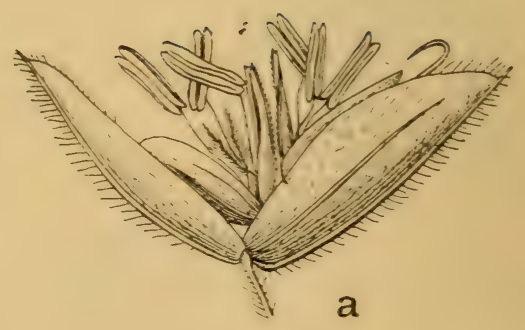

Flg. 50 .

Fig 50. Holcus lanatus, L.--Velvet-grass. A, the inflorescence, which is a rather densely-flowered panicle, with spreading branches. a, a spikelet expanded in flower. $\mathbf{b}$, the same with the large empty glumes removed, showing more clearly the two florets: the first or lowest floret has stamens and pistil, the second, stamens only; the first flowering glume is awnless, the second bears a slender, curved awn.

Fig. 51. Agrostis alba, L.-Red-top. A, inflorescence, a diffuse panicle. $B$, spikelet from same, one flowered. $E$, palet; in this the empty glumes have been removed and the flowering glume, $D$, stands to the right. 


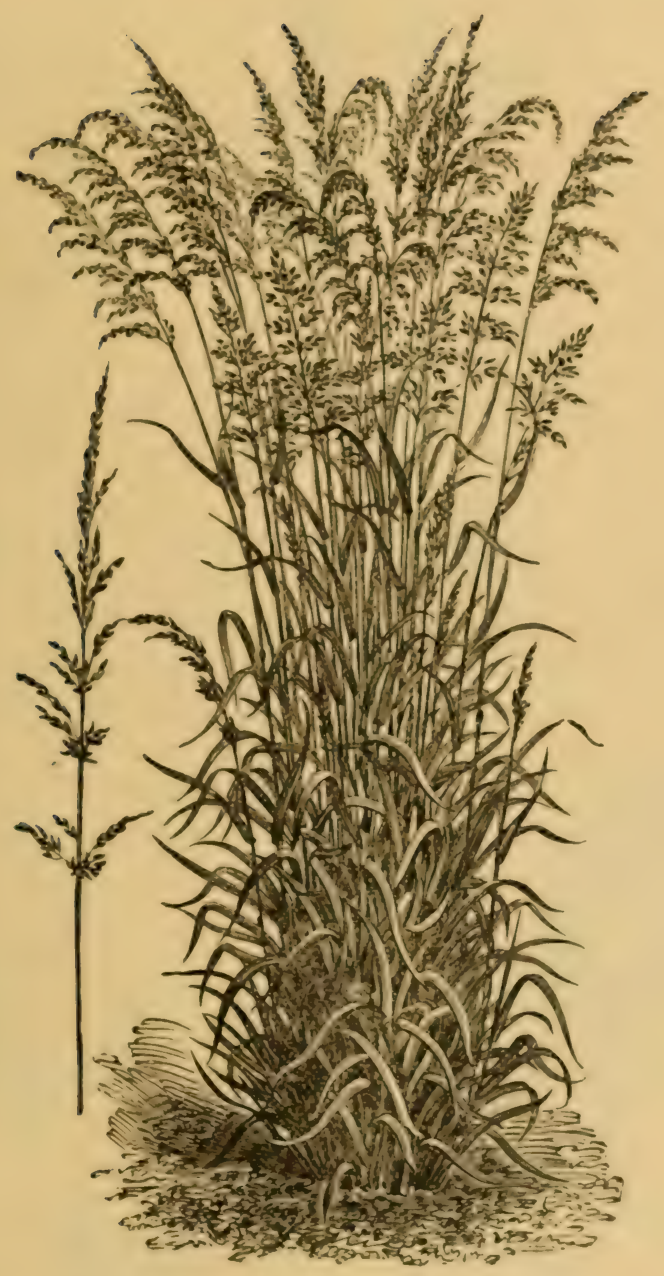

Fig. 52. Arrhenatherum aienaceum.-Tall Meadow Oat-grass. Showing habit of the grass. To the left is a single panicle, the lower branches of which are spreading and branched again. 
Fig. 53. Bouteloua racemosa, Lag.-Tall Grama. A, a portion of the inflorescence showing several of the short diverging or deflexed, unilateral spikes. $C$, empty glumes of a spikelet. $D$, flowering glume, which is three-toothed at apex. $E$, palet. O, three-awned prolongation of the rachilla behind the palet.

Fig. 54. Eragrostis minor, Host.-Candy-grass. $B$, spikelet, many flowered. $D$, flowering glume seen from the back. $E$, palet, ciliate on the curved keels. $G$, lodicule. $R$, rachilla of the spikelet from which the empty and flowering glumes have fallen, leaving the persistent palets.

Fig. 55. Uniola latifoiia, L. $-B$, a spikelet which is about tenflowered. $C$, empty glume. $D$, flowering glume. $E$, palet. Within $D$ and $E$ is the flower, consisting of a single stamen and the pistil, which has two styles and two feathery stigmas. The flower, together with the flowering glume and palet, we term the floret.

Fig. 56. Cynodon Dactylon, Pers-Bermuda-grass. $A$, inflorescence; there are five slender unilateral, diverging spikes all springing from the apex of the stalk or culm; when the spikes arise in this way they are termed digitate. AI, a portion of one of the spikes enlarged seen from the back. A2, the same seen in front. $B$, a single spikelet, which is one-flowered; the first glume is very narrow and sharp-pointed, the second glume is very much broader and rough along the keel. Above the narrow first glume is the broad flowering glume, opposite to which is the palet. Behind the palet there is usually a short bristle-like prolongation of the rachilla, not shown in figure.

Fig. 57. Briza maxima, L.-Quaking-grass. A, a portion of the inflorescence showing three of the large, ovate, many-flowered spikelets. $D$, flowering glume seen from the side. $C$, empty glume. $E$, palet. 


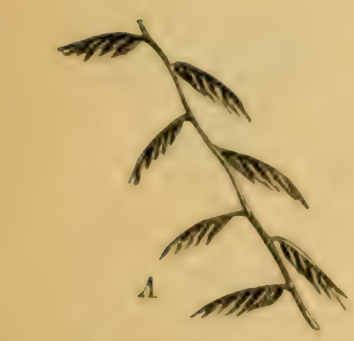

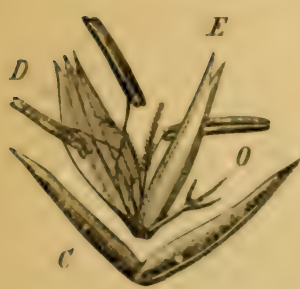

Flg. :3:

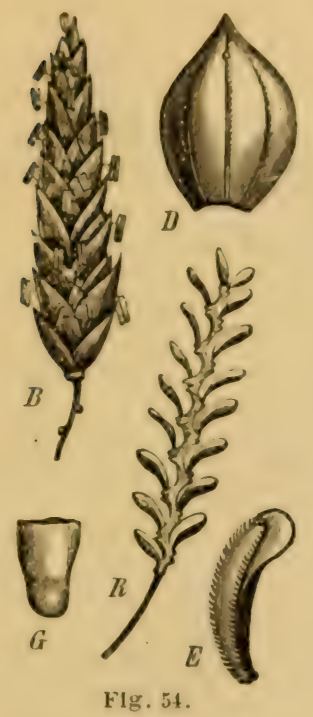

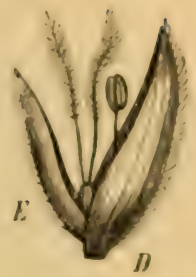

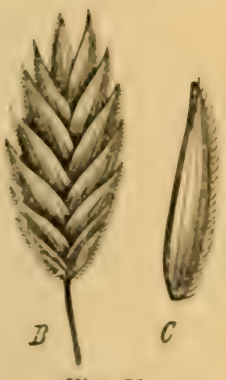

Flg. 55.
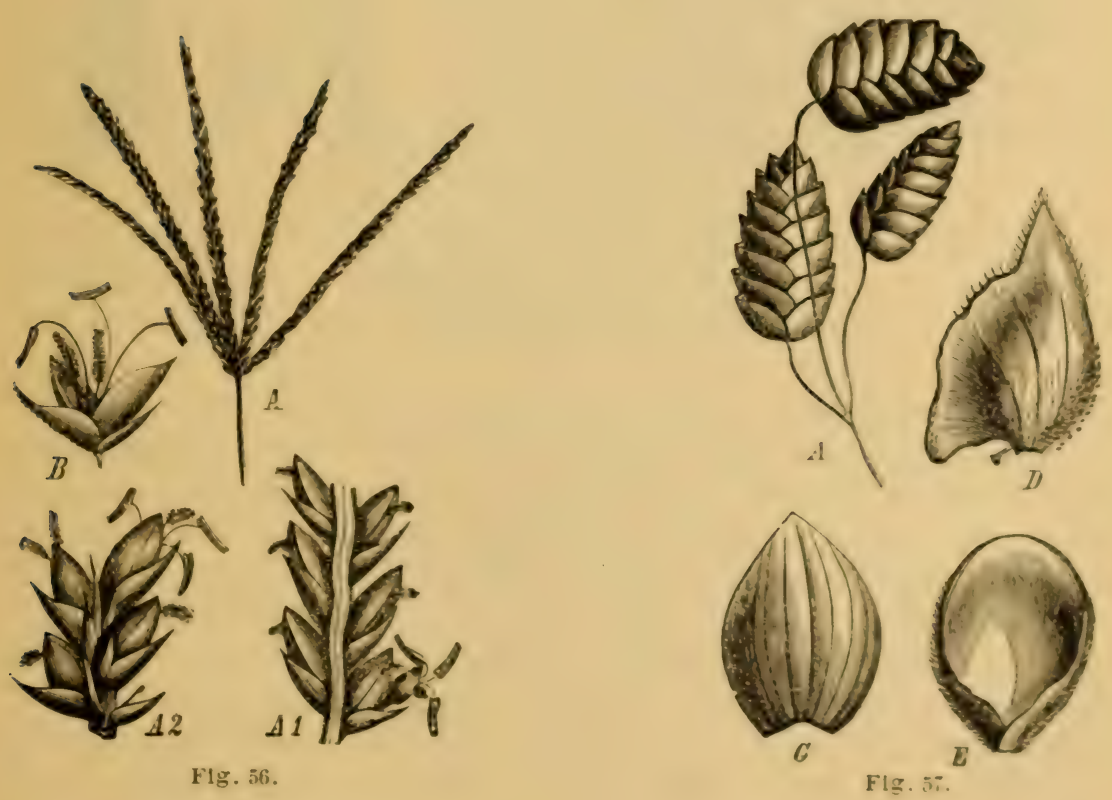


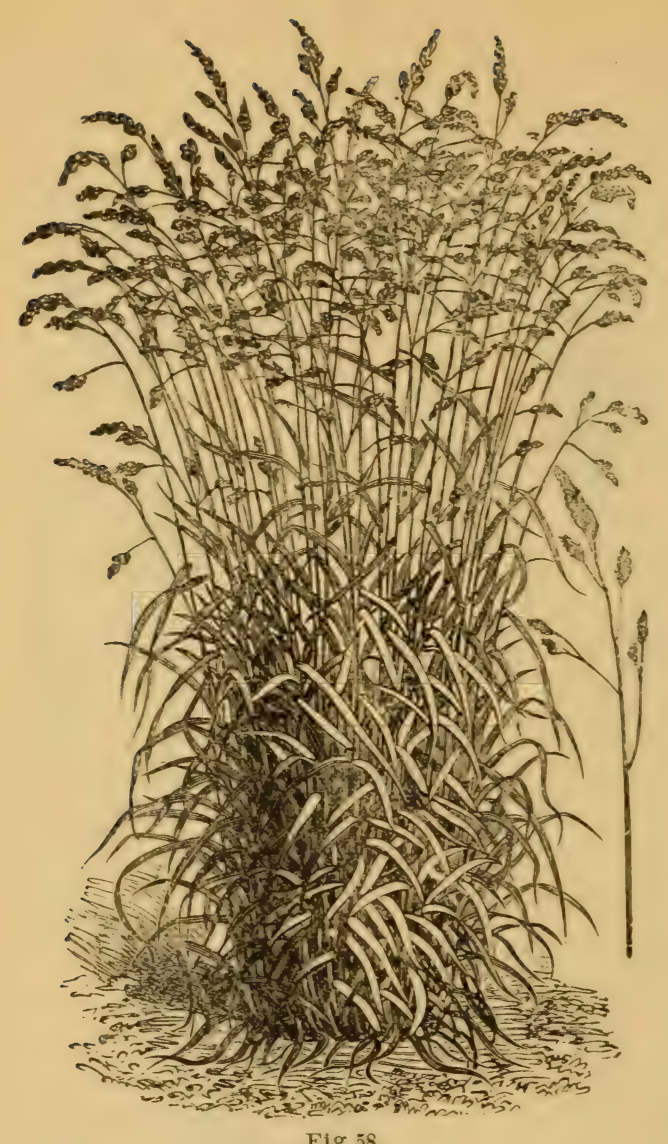

Fig 58 .
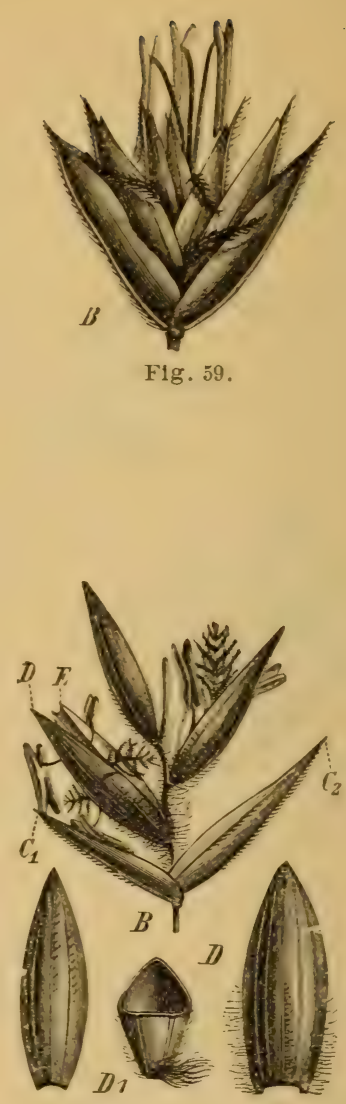

Fig. 60 .

Fig. 58. Dactylis glomerata.-Orchard-grass. A figure illustrating the habit of growth. To the right is shown the inflorescence drawn on a slightly larger scale; the spikelets are crowded in onesided clusters, (glomerate.)

Fig. 59. Dactylis glomerata, L.-Orchard-grass. $B$, spikelet. The stigmas are projecting from the sides of the florets, and extending above the terminal floret are three stamens with long anthers.

Fig. 6o. Poa pratensis, L.-Kentucky Blue-grass. $B$, spikelet. $C I, C 2$, empty glumes. $D$, flowering glume. $E$, palet. The stigmas and stamens are projecting from between the flowering glumes and palets. $D$, fruiting glume in cross section. The lower portion of the flowering glumes, along the nerves, is cluthed with fine woolly hairs. The spikelet is three-flowered; the rachilla extends above the third floret as a slender, naked prolongation. 


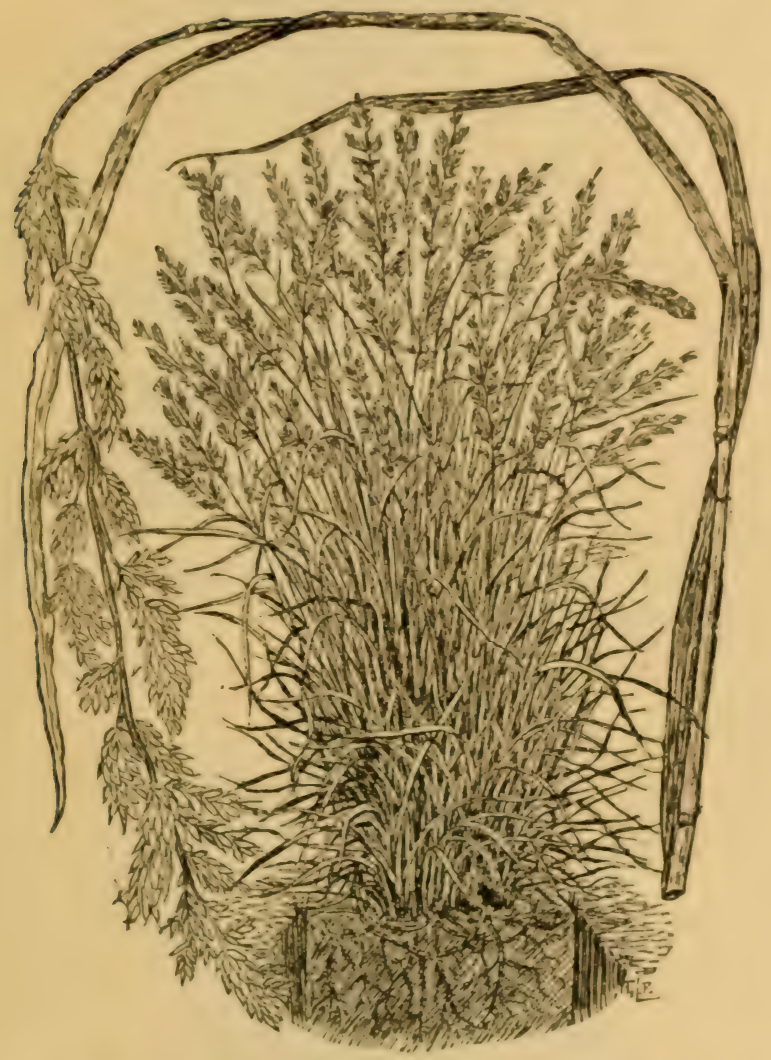

Fig 6r. Poa arachnifera.-Texas Blue-grass. Showing the habit of the grass and its creeping underground stems or rhizomes, popularly called "roots." Drawn over the figure is a single stalk of the grass showing more clearly the leaves and the contracted, rather densely-flowered and interrupted panicle, usually called by the farmer, the "head." 


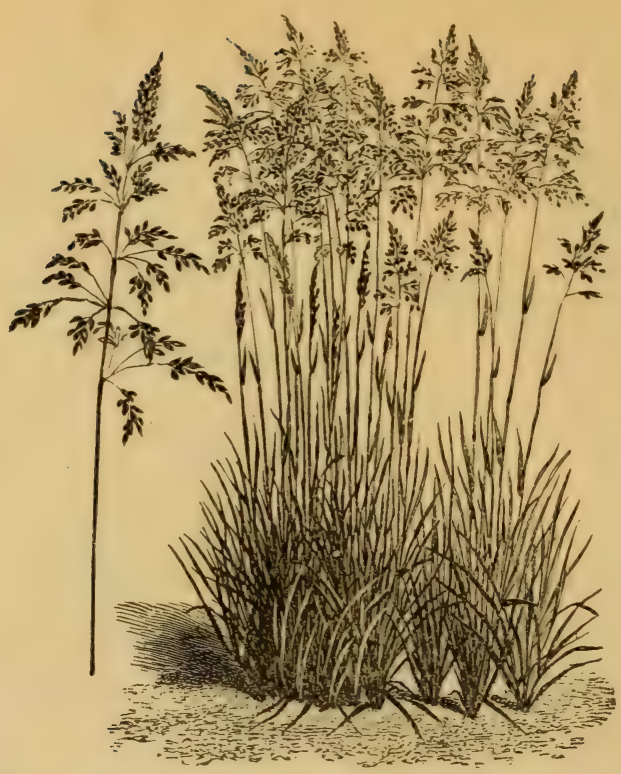

Fig 62. Poapratensis.-Kentucky Blue-grass. Showing the habit of the plant. To the left is the upper part of a single stalk, showing more clearly the inflorescence.

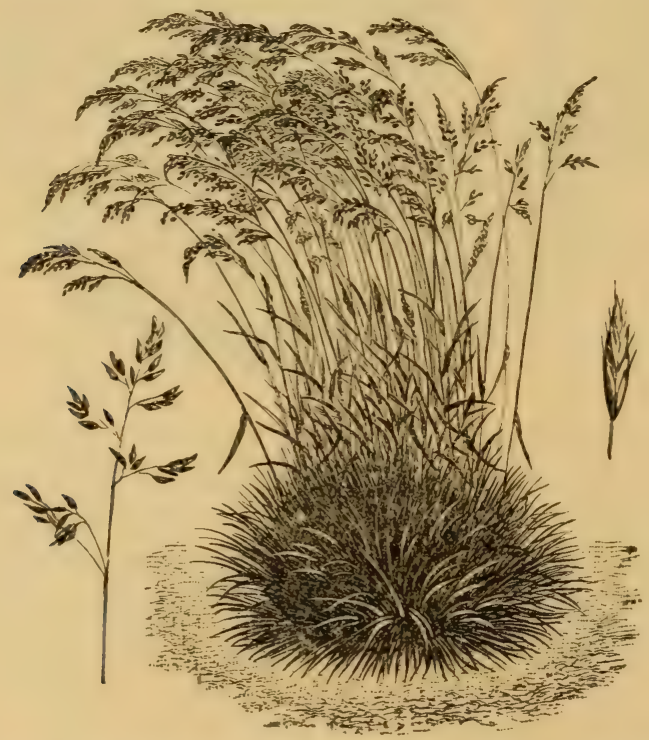

Fig. 63. Festuca duriuscula.-Hard Fescue. A figure showing a bunch of the grass. To the left is a portion of the culm, showing the panicle more clearly, and to the right a single spikelet is illustrated. 


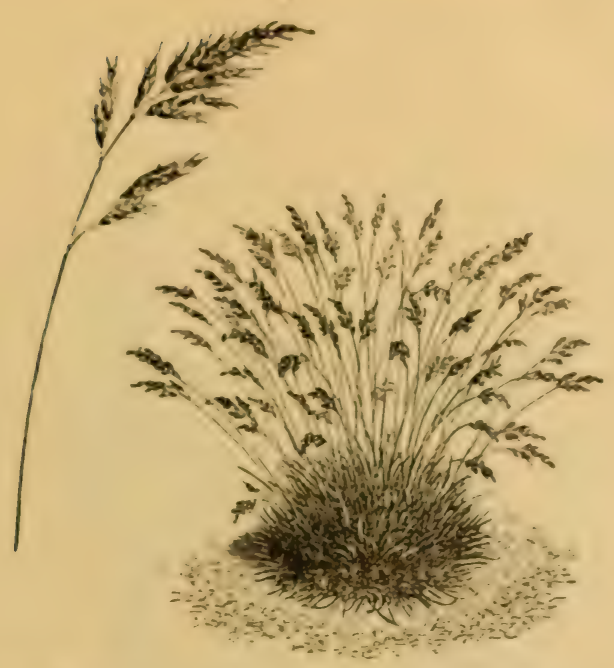

Fig. 64. Festuca orina.-Sheep's Fescue. Figure showing the tufted or cespitose habit of the grass. To the left is shown the paniculate inflorescence drawn on a larger scale.

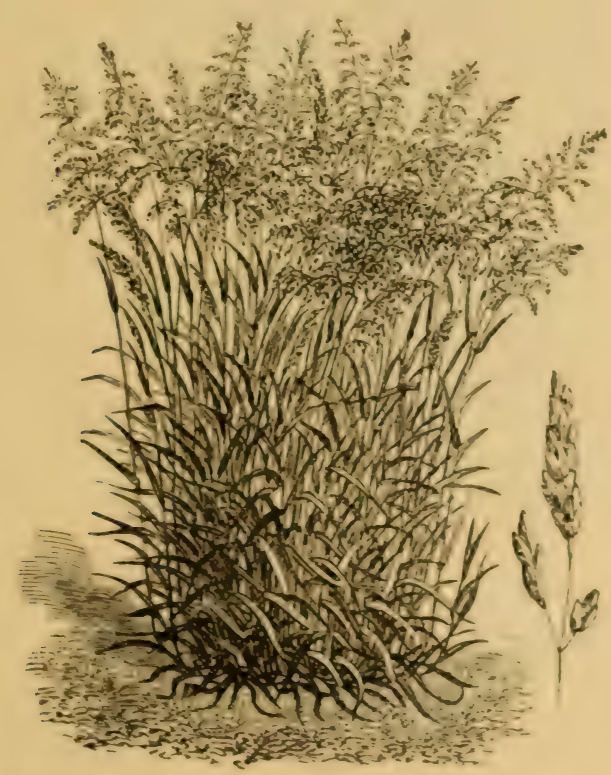

Fig. 65. Poa trivialis.-Rough-stalked Meatdow-grass. An illustration of a group of the plants in flower. To the right is shown a portion of the inflorescence drawn upon a larger scale. 


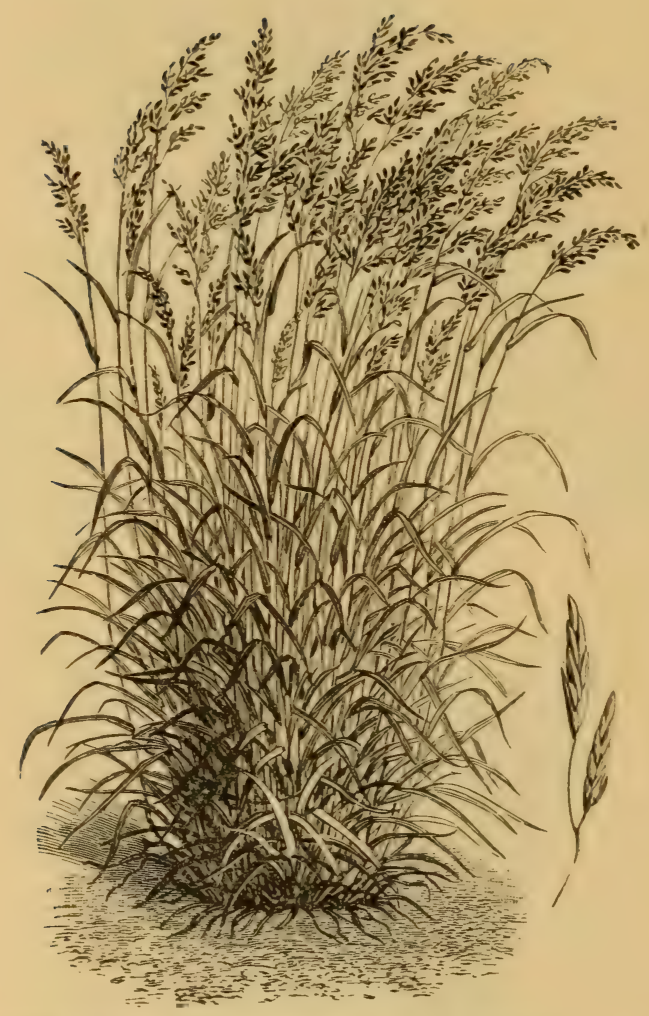

Fig. 66. Festuca elatior.-Tall Meadow Fescue. Shows the habit of growth. To the right are a couple of spikelets, illustrated on a larger scale. 


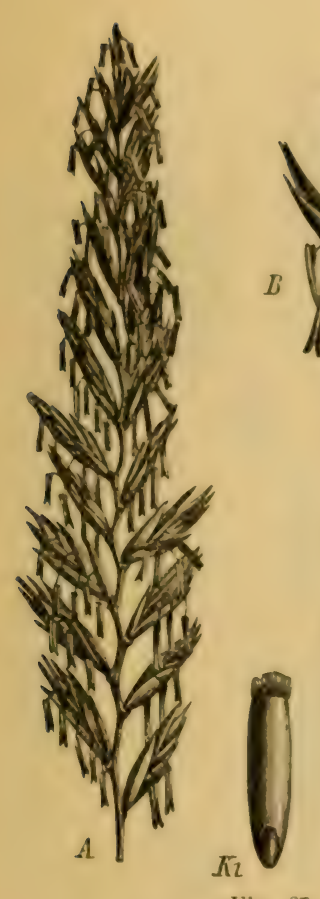

Flg. 6 ?
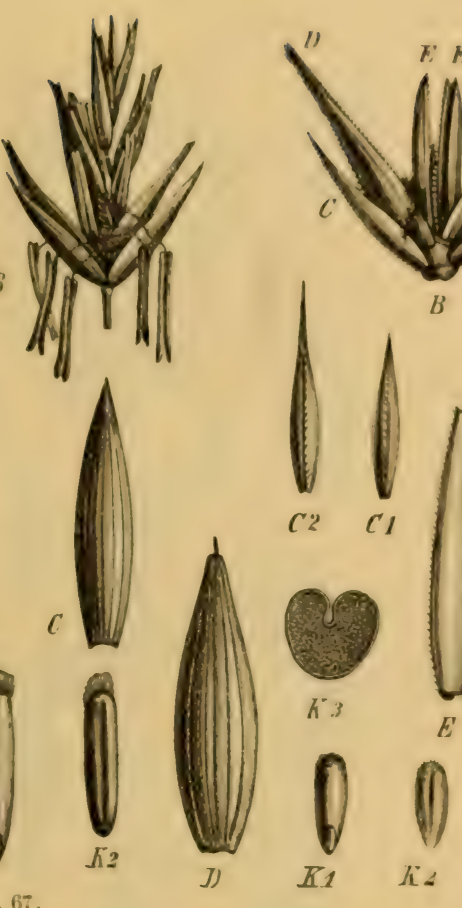

Fig. 67. Agropyrum repens, Beaur.-Couch-grass. A, a portion of the inflorescence, which is a spike. The spikelets are sessile and placed with their sides towards the axis or rachis to which they are attached. $B$, a single spikelet: the pistils and stamens are projecting from the two lower florets, the anthers falling down below. $C$, empty glume. $D$, flowering glume, which is mucronate pointed, as figured. $K$, the fruit or grain, which is pubescent at the apex.

Fig. 68. Secale cereale, L.-Rye. A, the inflorescence, which is a spike, popularly called the "head." $B$, a spikelet, which is twoflowered. $C_{I}, C_{2}$, empty glumes. $D$, flowering glume, which is long awned from the apex. $E$, palet. $K_{r} r K_{2}^{2}$, the fruit or grain, front and side views. $K_{\mathcal{3}}$, the grain in cross-section. 


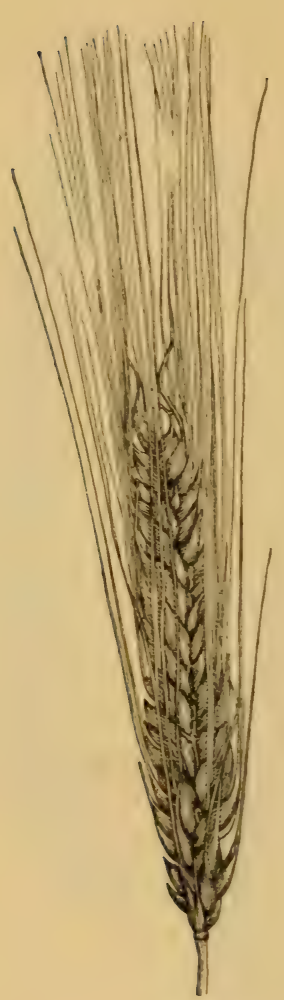

Fig. 69 .
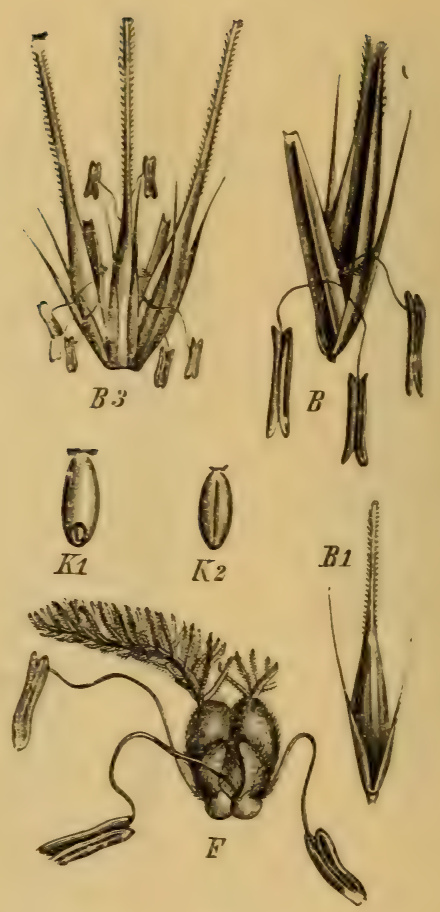

F1g. 70 .

Fig. 69. Hordeum sativum, var. vulgare.-Common four-rowed barley. A single "head" or spike. The flowering glumes are terminated by very long and scabrous awns.

Fig. 70. Hordeum sativum, var. hexastichon.-Six-rowed barley. $B_{3}$, i group of three spikelets, the awns partly removed. $B$, a single spikelet seen from behind, the awn wholly removed. $B \boldsymbol{I}$, a single spikelet seen from in front. $F$, the flower showing the lodicules in front, the stamens, the hairy ovary, one of the sessile plumose stigmas, and a portion of the other. $K_{I}$, the fruit seen from in front, small embryo shown near the base. $K_{2}$, the same seen from behind, showing the linear hilum. 


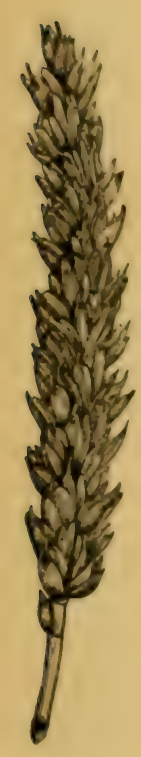

AI
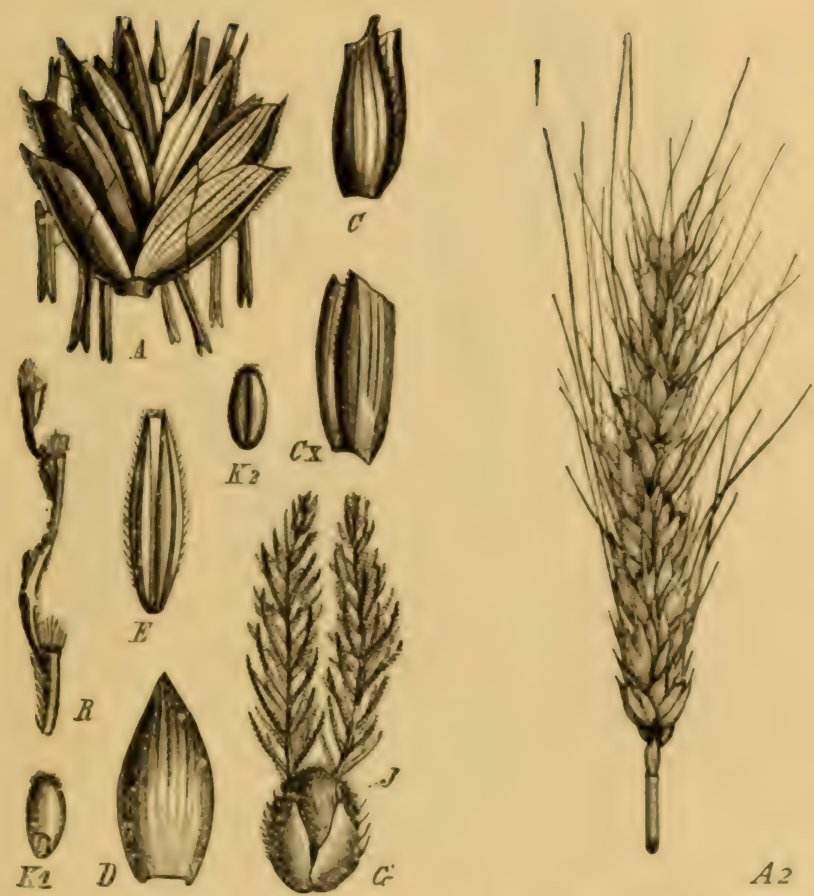

A 2

Fig. 71. Triticum sativum, L.-Wheat. AI, a "head" or spike of Beardless Wheat. $A$, a single spikelet; the two uppermost florets are reduced to small sterile or empty glumes. $C$, empty glume seen from the side. $C x$, the same seen from the back. $D$, flowering glume. $E$, palet. $K_{1}$, grain seen in front. $K_{2}^{2}$, the same seen from the back. $R$, a portion of the rachis or axis of the spike. $J$, the pistil which bears two nearly sessile, plumose stigmas. $G$, lodiculees. A2, a "head" or spike of Bearded Wheat. 


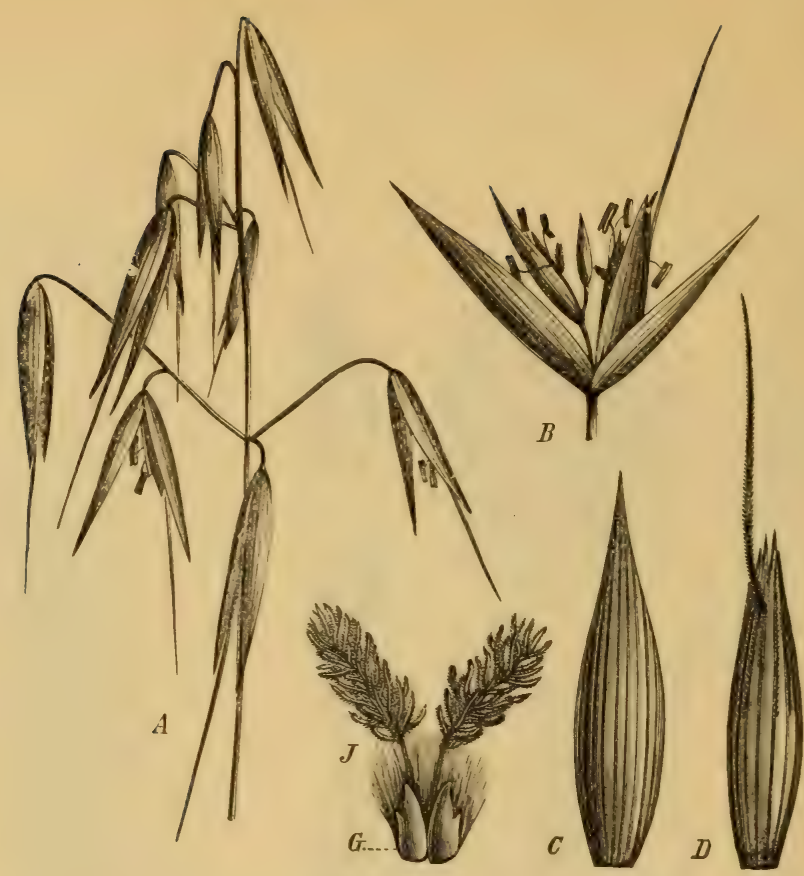

Fig. 72. Avena sativa, L.-Oats. $A$, a portion of the inflorescence which is a simple, open panicle. $B$, a spikelet, two-flowered, with a sterile rudiment terminating the rachilla. $C$, one of the broad, lanceolate empty glumes, $D$, a flowering glume; this bears an awn on the back just below the two-toothed apex. $J$, pistil; the ovary of which is very hairy. $G$, lodicules.

\section{ALPHABETICAL LIST OF TERMS.}

The numbers refer to the foregoing Figures.

Anthers, 3 r.

versatile, 45 .

Cespitose, 64 .

Ciliate, 48, 54 .

Ciliate (glumes), 43 47, 48 .

Digitate, 56.

Embryo, 30.

Filaments, $3 \mathrm{I}$.

Floret, 29, 3I, 55 .

Flowers:

hermaphrodite, 36 .

pistillate-with pistils only.
Flowers (continued)

staminate - with stamens only. unisexual, 35 .

Glumes:

awned, 45, 50, 68 .

awnless, $5 \circ$.

ciliate, 47,48 .

empty, 36, 38, 42 .

flowering, 42, 48, 5 I.

mucronate, 67 .

nerved, 30. 


\section{Glumes (continued)}

sterile, $7 x$.

unequal, 42.

Hermaphrodite flower, 36 .

Hilum, 3 I.

Inflorescence:

female, 32 .

male, 32 .

paniculate, $30,3 \mathrm{I}, 3^{6}, 64$.

pistillate, 35 .

simple panicle, 72 .

spike, 29, 33, 67, 71 .

spike-like, 4 I, 46 .

staminate, 32,35 .

unilateral spikes, 52 .

Lodicules, $30,43,47,7 \mathrm{I}$.

Mucronate, 67 .

Ovary, 48.

hairy, 31, 70, 72 .

Palet, 4I, 42, 5 I.

bifid, 30 .

keeled, 30, 54 .

Panicle, 31, 52.

diffuse, $5 \mathrm{I}$.

simple, 72 .

spike-like, $39,46,48$.

Pistil, $\left\{\begin{array}{l}\text { ovary, } \\ \text { style, } \\ \text { stigma, }\end{array}\right\} 48$.
Raceme:

one-sided, 40.

unilateral, 37.

Rachilla, 36, 60.

prolonged, 53, 60 .

Rachis, 29, $7 \mathrm{I}$.

Rhizome, 6r.

Spike, 29, 33, 67, 71 .

digitate, 56 .

pistillate, 32 .

unilateral, 53 .

Spikelets, 29, 48, 50, 5 I.

female, 35 .

imbricated, 37 .

male, 35 .

many-flowered, 57,59 .

one-flowered, 51, 56 .

pistillate, 33 .

staminate, 33,35 .

two-flowered, 33.

with involucre, $39,4 \mathrm{I}$.

Stamens, 43, 45 .

Stigmas, 47,48 .

feathery, 36 .

plumose, 47.

sessile, $7 \mathrm{I}$.

Style, 48.

Unisexual flower, 35 . 


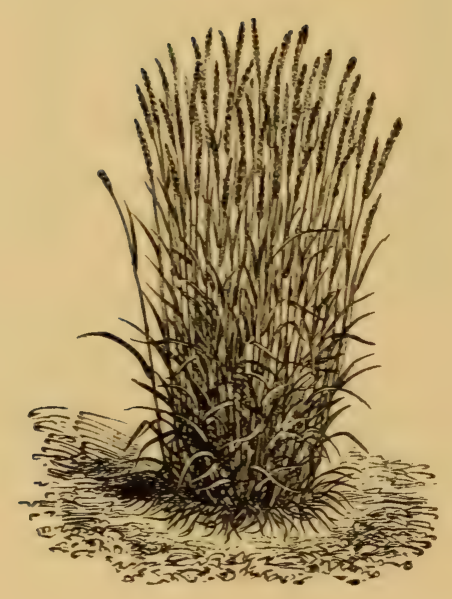




\section{(III.) GRASSES-GRAMINERE.}

CHARACTERS OF THE ORDER,-Fibrous-rooted, annual or perennial, herbaceous plants (among our species Arundinaria alone is woody), with usually hollow, cylindrical (rarely flattened) and jointed stems (culms) whose internodes for more or less of their length are completely enveloped by the sheath-like basal portion of the two-ranked and usually linear, parallel-reined leaves.

Flowers without any distinct perianth, hermaphrodite or rarely unisexual, solitary or several together, in spikelets, these disposed in panicles, racemes or spikes, and consisting of a shortened axis (the rachilla) and two or more chaff-like, distichous bracts (glumes) of which the first two, rarely one or none or more than two, are empty (cmpty glumes); in the axil of each of the succeeding bracts (excepting sometimes the uppermost) is borne a flower, (hence these are named flowering glumes.) Opposed to each flowering glume, with its back turned towards the rachilla, is (usually) a two nerved, two-keeled bract or prophyllum (the palet), which frequently envelopes the flower by its infolded edges. This bract is the prophyllum of the extremely short axis or branch, which supports the flower; its absence indicates that the flower is strictly sessile or inserted directly on the rachilla; the rachilla or axis of the spikelet may or may not be produced beyond the palet. At the base of the flower, between it and its glime, are usually two very small hyaline scales (lodicules); rarely there is a third lodicule between the flower and the palet. Stamens, usually three (rarely two or one, or more than three) with very slender filaments and twocelled, versatile anthers. Pistil with a one-celled, one-ovuled ovary, and one to three, usually two, styles with variously branched, most frequently plumose, stigmas. Fruit, a true caryopsis, rich in albumen. (In Sporobolus and Eleusine the fruit is a utricle, the seed being loose within the thin pericarp.) Embryo small, lying at the front and base of the seed, covered only by the thin pericarp.

The organs or parts of grasses, as in other plants, are those of vegetation and those of repruduction: to the first belong the root, stem or culm, and leaves; to the second the stamens and pistils.

The Roor.-Grass roots are a!ways fibrous. The more or less strong underground rhizomes are often called roots; they are not roots, but are specially modified stems.

The Ster.-Grass stems are always branched at the base, and occasionally in their upper portions. If the branches are all 
apparently at the root, the culms are said to be simple. Sometimes the stems or branches ascend immediately, standing vertically, when they are termed erect; they may spread a little at first, and then assume an erect position, the lowermost joints being bent or kneed; such culms are said to be geniculate at base. The basal branches may lie flat upon the ground and spread more or less extensively, taking root at the usually numerous joints, and at definite points sending up erect flowering branches, or branches bearing leaves only; such grasses are said to have a creeping habit. Again, one or more of the lowermost branches may not come to the surface at a1l, or until it has extended through the soil for a greater or less distance. These form the "creeping roots" of grasses, but as just stated, they are true stems or branches, for they are always distinctly jointed, and at the joints there are scale-like leaves-characters never found in roots. The joints of these underground stems may be very short, and from each node may spring a flowering branch. So condensed may this growth be that the rhizome is entirely concealed, but in perennial grasses it is always present, and in the best turf or sward-forming grasses it is manifest enough. In couch-grass, and especially in Johnson grass, these rhizomes are greatly developed, penetrating the soil in all directions, forming a sward that is excedingly difficult to break.

Grass stems are usually round or cylindrical, rarely flattened, and generally hollow between the joints or nodes (solid or with pith in the Andropogons, Indian Corn, and a few other grasses.)

The LEAves.-The leaves of grasses have two distinct parts: the sheath and the blade. The sheath, or basal portion, usually closely surrounds the stem, and is split or open upon the side opposite the blade, or is entire, then forming a closed cylindrical sheath about the stem. When split, the free edges usually overlap each other. At the top of the leaf-sheath, at the point where the blade originates, there is upon the inside usually a thin and delicate prolongation, often very short, called the ligule. Sometimes the ligule takes the form of a fringe of hairs. The leaf-blade is generaily narrow, usually many times longer than broad, with nearly parallel edges. Such leaves are called linear. From this form the leaves may vary to lanceolate or ovate in outline. Sometimes the narrow leaves have their edges rolled inwards, when they are said to be incolute. Occasionally the leaf-blade is very short, and sometimes it is wanting altogether. As to the surfaces of the leaves and sheaths, they may be smooth or rough, or more or less hairy.

The position of the leaves on the stem is to be noted as affording an easy character for distinguishing grasses from the nearly allied 
sedges. Starting with any leaf on the stem of a grass, the next leaf above will be exactly on the opposite sicle of the stem, while the next or second leaf above will stand directly over the starting point. Such an arrangement is called distichous or two-ranked: i. e., in counting two leaves from the first we pass completely around the stem. In sedges the leaf-arrangement is three-ranked; it is the third leaf from the first which stands directly aloove the first.

THE: Fl.OWERs.-The flowers of grasses possess only the essential organs-the stamens and pistils. Sometimes these organs are separated, when the flowers are either male or staminate (containing stamens only), or female or pistillate (containing pistils only.) These staminate and pistillate flowers may occupy different parts of the same plant or (more rarely) entirely distinct plants. Flowers having both stamens and pistils are termed hermaphrodite.

In each flower there are usually three stamens. These have very slender filaments, and usually versatile, two-celled anthers, which are pale yellow, sometimes nearly white, or purple, or some shade of red. The pistil consists of the ovary and usually two feathery stigmas, which may be sessile or raised on short styles.

The fruit or ripened ovary constitutes the "grain." This is a true caryopsis, i. e., a dry one-seeded fruit in which the outer covering or pericarp is closely adherent to the seed. The "grass seed" of commerce consists of the grain enveloped usually in more or less "chaff."

Arrangement of the Flowers. The arrangement of the flowers in grasses is peculiar. They are situated in what are termed spikelets, either solitary (one-flowered spikelets,) or two or more together (two to several or many-flowered spikelets.) Each flower is located in the axil of a chaff-like bract or glume called the flowering glume. At the base of the spikelet there are usually two bracts or glumes having no flowers in their axils; these are the outer or empty glumes. The axis to which these glumes are attached is termed the rachilla, and between each flower and this rachilla there is usually a two-nerved bract, the palea or palet. In one-flowered spikelets where there is no extersion or prolongation of the rachilla, this palet is apparently opposite the flowering glume. The lower pair of glumes-the empty onesoften differ from each other in size or length, and sometimes, though rarely, one or both are absent. The glumes may be awned or "bearded," or awnless; they may be sharp-pointed, obtuse or toothed at the apex; they may be nerveless or one-to manynerved. As to other variations it is necessary to refer the reader to the larger descriptive works on botany.*

*The more important works relating to grasses are included in section IV. 
The arrangement of the spikelets upon the stem constitutes what is termed the inflorescence, or what we often hear erroneously called the "head." If that portion of the main axis or stem which bears the spikelets is unbranched so that these are sessile (i. e., without pedicels), the inflorescence is a true spike, e. g., wheat, rye-grass; when the main axis is branched, each branch forming a pedicel to a single spikelet, the inflorescence is a raceme. This form is not common. Usually the primary branches branch again and again, resulting in the formation of a panicle. The panicle may be open or widely spreading, as in oats or in Kentucky bluegrass; or, if the branches are very short, it may be narrow and spike-like as in timothy or in meadow fox-tail. All gradations of form between these two extremes occur.

\section{Key to the Genera of the Native and Cultivated Grasses of Tennessee.}

The numbers to the right refer to the numbers at the left.

I. Spikelets one- rarely two-flowered (when two-flowered the second or terminal flower is perfect, the one below being either staminate or neuter,) falling from the pedicels entire, or together with certain joints of the rachis. (Series $\mathbf{A}$.

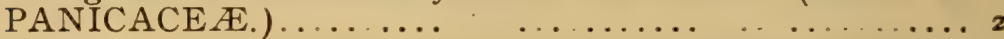

I. Spikelets one- to many-flowered (when more than one-flowered the imperfect flower, if any, is uppermost,) lower empty glumes usually remaining after the fall of the fruiting glumes. (Series B. POACE $A$.) ................. 6

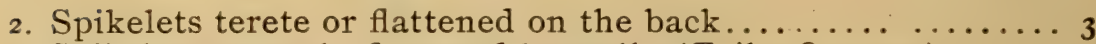

2. Spikelets strongly flattened laterally (Tribe ORYZEÆ)....... I 4

3. Spikelets all unisexual, plants monœcious (Tribe MaydE

3. Spikelets hermaphrodite, or staminate and hermaphrodite, the former standing near the latter.............6 6

4. Pistillate and staminate spikelets each in a separate inflorescence, the former axillary, the latter terminal ... . . 5

4. Pistillate and staminate spikelets in the same inflorescence, the axis of the former articulated between each spikelet. (See Fig. 33.) ..................... Tripsacum.

5. Pistillate spikes distinct, fasciculate, their axes articulated (See Fig. 32.)..................... 1. Euchlæna.

5. Pistillate spikes grown together forming a compound, continuous and much thickened axis (the "cob.")... 2. Zea.

6. Axis of the inflorescence articulated (continuous in the cultivated Miscanthus,) flowering glume hyaline (Tribe AN-

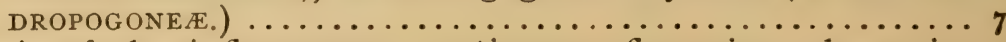

6. Axis of the inflorescence continuous, flowering glume indurated or firmer in texture than the empty glumes (Tribe

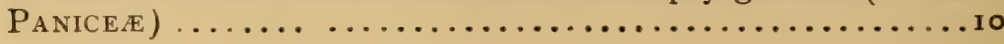


7. Spikelets heterogamous;in pairs, one sessile, hermaphrodite: one pedicellate, staminate or neuter . . . 6. Andropogon.

7. Spikelets all alike

8. Spikelets awnless

4. Saccharum.

8. Spikelets awned

............. 9

9. Racemes forming a broad, fan-shaped panicle .3. Miscanthus.

9. Racemes upon an elongated main axis forming a much branched panicle, branches articulated ...5. Erianthus.

10. Glumes (including the flowering) three .....7. Paspalum.

ro. Glumes four, the lowest usually smaller than the others

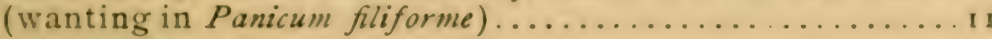

I1. Spikelets surrounded by an involucre consisting of one to many bristles, which are sometimes grown together becoming bur-like..........................

11. Spikelets not surrounded by bristles or special covering.

8. Panicum.

12. Bristles persistent (See Fig. 4r.) ............. Setaria.

12. Bristles falling with the spikelets $\ldots \ldots \ldots \ldots \ldots \ldots \ldots \ldots \ldots \ldots \ldots$

13. Bristles grown together at the base, forming a bur-like covering over the spikelets............. 10. Cenchrus.

13. Bristles distinct.... . . . . . . . . . . . . 11.

14. Spikelets unisexual, monœcious, ovate or elliptical, the pistillate above and the staminate below in the same inflor-

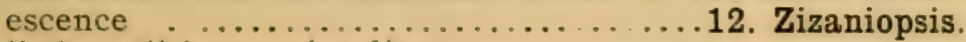

14. Spikelets all hermaphrodite .. ................... 15

15. Empty glumes two, small. (See Fig. 43.) ......13. Oryza.

15. Empty glumes none... ................. 14. Leersia.

16. Culms perennial, woody, leaf-blade articulated with the sheath (Tribe Bambuse.e.) .........64. Arundinaria.

16. Culms annual, herbaceous, leaf-blade continuous with the sheath ............................... I7

17. Spikelets distinctly pedicellate, in racemes or panicles (these sometimes spike-like) ...................... 8

17. Spikelets sessile, in true spikes, (sometimes on very short pedicels and then in one-sided or unilateral racemes) $\ldots .33^{6}$

18. Spikelets one-flowered ......................... 19

18. Spikelets two to many-flowered $\ldots \ldots \ldots \ldots \ldots \ldots \ldots \ldots \ldots \ldots \ldots \ldots \ldots \ldots \ldots$

19. Empty glumes four, the third and fourth very unlike the first and second and falling with the fruiting glume (Tribe Phalaride... ...............................

19. Empty glumes two...........................

20. Third and fourth glumes reduced to narrow scales or bristles, awnless .......................... Phalaris.

20. Third and fourth glumes smaller than the first and second, awned. (See Fig. 45.) .............. Anthoxanthum. 
2r. Grain closely enveloped by the fruiting glume which is firmer in texture than the empty ones. (Sub-tribe Stipea) 22

2r. Grain loosely or not at all enclosed by the hyaline or membranaceous fruiting glumes, (Sub-tribes Phleoidece and

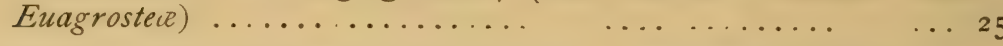

22. Rachilla prolonged beyond the palea

22. Rachilla not prolonged beyond the palea...

20 Brachyelytrum.

23. Flowering glume with a trifid awn

17. Aristida.

23. Flowering glume mucronate-pointed or with a simple awn..24

24. Awn twisted and geniculate

24. Awn straight, sometimes reduced to a mucro

18. Stipa.

\section{Muhlenbergia.}

25. Spikelets in a cylindrical, spike-like panicle, empty glumes ciliate along the keels.

25. Spikelets not in a cylindrical spike-like panicle, empty glumes not ciliate.......................... 27

26. Empty glumes abruptly awn-pointed, persistent; palea present, flowering glumes awnless.... ... 21. Phleum.

26. Empty glumes not awn-pointed, falling with the fruiting glume; palea none, flowering glume awned on the back. (See Fig. 48.) ................. 22. Alopecurus.

27. Flowering glume one-nerved, longer than the empty ones.

7. Fl..................... 23. Sporobolus. ering glume three to five-nerved, shorter than the empty ones............

28. Flowering glume raised on a distinct, naked internode of the rachilla; stamen one .......... 24. Cinna.

28. Flowering glume not raised on a distinct internode of the

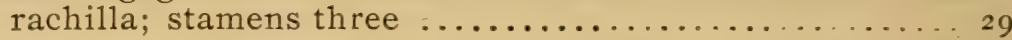

29. Callus with long hairs (at least half as long as the flowering glume); rachilla continued beyond the palea

26. Calamagrostis.

29. Callus naked (or with a few very short hairs only); rachilla not prolonged behind the palea ........ 25. Agrostis.

30. Flowering glumes usually shorter than the empty ones, bearing a twisted or geniculate awn (some cultivated forms excepted) on the back or between the teeth of the bifid apex (Tribe Aveneæ.)...

30. Flowering glumes usually longer than the empty ones, awnless or bearing a (straight rarely bent) awn at or just below the entire or two-toothed apex (Tribe Festuce£.) 44

3r. Flowering glumes thin and scarious, apex irregularly denticulate, slender-awned on the back from near the base. 28.

................ 28. Deschampsia.

3r. Flowering glumes of firmer texture, entire, two-toothed or two-cleft at the apex ......................... 32

32. Spikelets strictly two-flowered, one of the flowers staminate 33 
32. Spikelets two to many-flowered, all the flowers hermaphrodite or the uppermost imperfect or rudimentary . ...... 34

33. Lower flower staminate, its glume long-awned on the back from near the base ............31. Arrhenatherum.

33. Lower tlower hermaphrodite, its glume awnless. 27. Holcus.

34. Fuwering glumes thin and hyaline, carinate, awned from near the apex .............. . . 29. Trisetum.

34. Flowering glumes herbaceo-chartaceous, rounded on the back, two-toothed or bifid at apex, awned between the

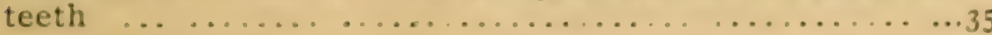

35. Awn terete, proceeding from the mid-nerve only. 30. Avena.

35. Awn flat below, formed by the union of the three middle nerves of the glumes................. Danthonia.

36. Spikelets sessile or nearly so, in two rows along one side of the continuous axis forming unilateral racemes or spikes, these racemed or digitate. (Tribe CHLORIDE Æ) ... ... . 37

36. Spikelets in opposite rows along a jointed rachis, forming a two-sided or equilateral, terminal spike. (Tribe HoRIE...) 59

37. Spikes terminal or nearly so, digitate or whorled. (Fig. 56.) ${ }_{3} \mathrm{~S}$

37. Spikes (or one-sided racemes) scattered along a common axis (usually racemed) $\ldots \ldots \ldots \ldots \ldots \ldots \ldots \ldots \ldots \ldots \ldots$ I

38. Spikes slender, one hermaphrodite flower and a sterile rudiment of a second flower in each spikelet ........ 39

38. Spikes stout, with two to several hermaphrodite flowers in

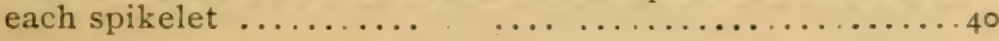

39. Flowering glume and rudiment awned

35. Chloris.

39. Flowering glume and rudiment awnless 33. Cynodon.

40. Axis of the spike projecting beyond the spikelets, second empty glume awn-pointed ....... 39. Dactyloctenium.

40. Axis of the spike with a terminal spikelet, none of the glumes awn-pointed .............. Eleusine.

41. Spikelets strictly one-flowered, no prolongation of the rachilla or rudiment of a second flower, crowded and strongly flattened

34. Spartina.

4. Spikelets two to three-flowered, or at least with the rachilla prolonged beyond the first flower ............... 42

42. Spikes short (one inch or less), flowering glume trifid, the divisions subulate or awn-pointed. (Fig. 53.) 37. Bouteloua.

42. Spikes (or racemes) very slender, filiform, (two to six inches long); flowering glume not trifid ................ 43

43. Spikelets with only one hermaphrodite flower, its glume bearing a slender awn just below the bifid apex .........

43. Spikelets with two to four hermaphrodite flowers, glumes awnless ................... 40. Leptochloa. 
44. Rachilla or flowering glume, at least of the fertile flower, with long hairs which equal or exceed the glumes in length

44. Rachilla or flowering glumes naked or with hairs much shorter than the glumes.................. 47

45. Spikelets unisexual (plants diœcious); the staminate spikelets naked; culms solid ... . . .. ... 41. Gynerium.

45. Spikelets hermaphrodite; culms hollow ... ........... . 46

46. Hairs on the glumes only ............42. Arundo.

46. Hairs on the rachilla only .......... 45. Phragmites.

47. Flowering glumes three-nerved, the middle as well as the marginal lateral nerves silky-villous below, and extended beyond the glumes in to three mucronate points.44. Triodia.

47. Flowering glumes three to many-nerved, lateral nerves not marginal nor extended beyond the glume...........48

48. Flowering glumes three-nerved, falling $w^{i}$ th the grain in advance of the paleas which remain actached to the continuous rachilla. (See Fig. 54.) ..... 45. Eragrostis.

48. Flowering glumes and paleas falling together, each glume carrying a joint of the articulate rachilla . . . . . . . 49

49. Empty glumes three to six at the base of each spikelet.

49. Empty glumes two at the base of the spikelet .... Uniola.

50. Spikelets heart-shaped at the base, glumes ventricose.... (See. Fig. 57.) ..... . ................. B . Briza.

50. Spikelets not heart-shaped, glumes not ventricose $\ldots \ldots \ldots$ I I

5I. Flowering glumes three-nerved, rounded on the back, coriaceous, subulate-pointed........ 48. Diarrhena.

5r. Flowering glumes three to many nerved, herbaceous, membranaceous, or chartaceous ............ $5^{2}$

52. Terminal sterile florets in each spikelet club-shaped, flowering glumes papery-membranaceous with a broad and scarious apex ........

47. Melica.

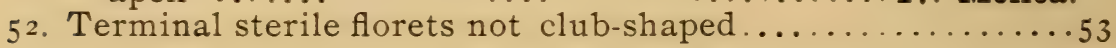

53. Empty glumes nearly equal in length, but very dissimilar; the first narrowly linear, one nerved; the second broadly obovate, folded around the florets, three-nerved. .................. . . . Eatonia.

53. Empty glumes similar, but often of unequal length.

54. Spikelets crowded in one-sided clusters on spreading branches, flowering glumes awn-pointed and strongly ciliate on the keel above .............51. Dactylis.

54. Spikelets not crowded in one-sided clusters ....... . 55

55. Spikelets of two forms, fertile and sterile, the latter pectinate and standing with the fertile; inflorescence terminal, spike-like $\quad . \ldots \ldots \ldots \ldots \ldots \ldots \ldots . \ldots$ 52. Cynosurus.

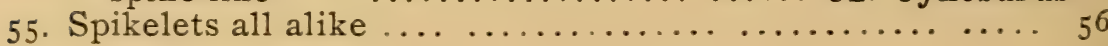


56. Flowering glumes compressed, keeled, usually bearing a tuft of cobwebby hairs at the base, and sometimes soft hairs on the more prominent nerves below. (See Fig. 6o.) 53. Poa.

56. Flowering glumes rounded on the back, naked or pubescent, not cobwebby at base (spikelets much flattened and glumes compressed in Bromus unioloides.)..... .... . 57

57 Styles inserted below the apex of the ovary, which has a hairy, cushion-like summit. (See Fig. 31.) .56. Bromus.

57. Styles terminal; grain smooth ................... 58

58. Flowering glumes awnless, nerves prominent..54. Glyceria.

5. Flowering glumes often awned, nerves indistinct (visible only near the apex)............... 55. Festuca.

59. Spikelets single at each joint of the rachis ....... 60

59. Spikelets two or more at each joint of the rachis ... . . . 63

6o. Spikelets placed edgewise to the rachis; empty glume (except in the terminal spikelet) one. (See Fig. 29.) 57. Lolium.

6o. Spikelets placed with their sides against the rachis, empty glumes two ........................

61. Flowering glumes with a distinct callus, falling at maturity with the grain, which is adherent to the palea. (See Fig. 67.) .................. 58. Agropyrum.

6r. Flowering glumes without a distinct callus, persistent;

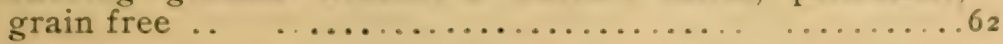

62. Empty glumes subulate, one-nerved

62. Empty glumes subulate, one-nerved .... Secale.

59. Secal
- nerved

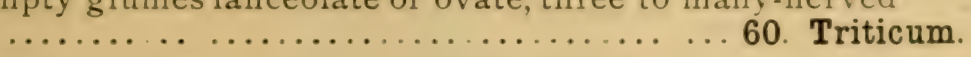

63. Spikelets with only one hermaphrodite flower. 61. Hordeum.

63. Spikelets with two or more hermaphrodite flowers ........64

64. Empty glumes nearly equalling the flowering glumes

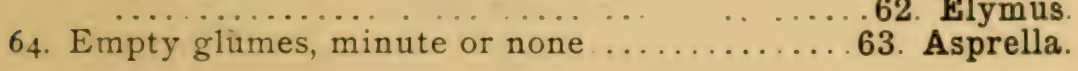

Figures 29, 30, 31, 32, 33, 35, 36, 37, 38, 39, 41, 42, 43, 45, 47, 48, 51, 53, 54, 55, $56,57,59,60,67,68,70,71$ and 72 are from electrotpyes which were obtaineil by purchase from Wilhelm Engelmann, of Leipzig, publishers of "Die Naturlichen Pflanzenfamilien." 


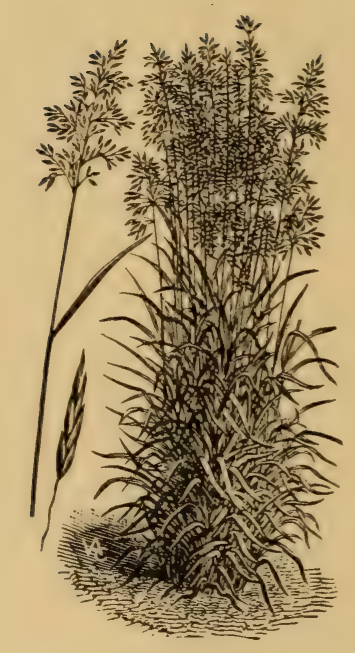




\section{(IV.) WORKS ON GRASSES.}

A list of works more or less relating to grasses in the library of the Station, or belonging to the writer. The former are marked with a *

Aitchison. List of the Graminew of the Kurun bulley. Extr. from Journ. Linn. Soc'y. Aug. 1880, pp. 105-111. A copy in MS.

Andersson, N. T. Graminere Scantinurite. Svo,, 212 pp. plates 12. 1852.

Monommphire Antropoyonearum, I. Anthistiviere. 4to., pp. 27 plate 1. 1556 .

Bailey, F. M. A fern (nueensland Grusses, with short notes, range of ench sprecies, etc. $12 \mathrm{mo}$. pamphlet, pp. 30.1888.

Ball, J. Spicileyium Flore Moroccune. Pub. in Journ. Linn. Soc'y, Vol. XVI. An MS. copy of the Graminea enumerated. 1878.

Batchelor, D. Economic Grossios and the Formation of Permunent Meanturs, Pastures and Lavons. Pamphlet, 8vo., pp. 32, figs. 8.

Beal, W. J. Grusses of Vorth America. Vol. I., Sro, pp. 457, illustrate . A valuable popular work. $1867 . *$

Bentham, G. Notes on Graminere. Extr. from Journ. Linn. Soc'y., Botany XIX, 8 vo., pp. 134. This and Hackel's True Grasses, are invaluable to the student of Grasses.

- Planta Hartwegiana, the Graminer only. An MS. copy. 1839.

Flora Australiensis. Vol. VII., containing the Gruminere. 8vo. The Gramineœ cover pp. 449-670. 1878.

- On the Structure of the Florers in Graminea. Extr. from Journ. Linn. Soc'y, Botany XV. An MS. copy.

- Haml-hork of the British Flora. An MS. copy of the "Grass Family." with parallei notes from Hooker's Student's Flora. Indexed.

Bentham and Hooker. Genera Plantarum. Vol. III, Part II. Contains the Gramineo.

Bessey, C. E. The Grasses and Forage Plants of Nelraska. Two pamphlets. reprints from the Annual Reports of the Kebraska State Agricultural Society for the years 1886 and 1888 .

Boissier, E. Flnra Orientalis. Vol. V. Contains the Graminere, Pp. 432-49:2.

Bolander, N. H. The Melicre. Proc. Calif. Acad. Sciences. Vol. IV. 1s70. An MS. copy.

Buckman, James. The Vatural Ilistory of British Mealore and Pasture Grasses. 12 mo., pp. 73 , plates 2.1858.

Chapman, A. W. Flora of the Southern Enited States. Sro., pp. 1i21. 1560.* And Supplement.

Cosson \& Durieu. Flore D'Algerie. Glumacees. An MS. copy of the "Graminex."

Coulter, J. M. Manuul of Rocky Yht. Botany. 8 vo. pp. XVI., 45̃2, 28. 18s.. The Graminece cover pp. 397-427. 
Courbon, Alfr. Flora de l'Isle de Dissee, Mer Rouge. From Ann. Des. Sci. Nat. 4th Ser., Vol. XVIII. 1862. An MS. copy of the Gramineæ only.

Curtis, William. Practical Observations ( $n$ the British Grasses. Pamphlet 8ro., pp. อ̇, plates 6. London, 1805.

Dame \& Collins. Middlesex Flora. Includes a list of grasses, pp. 14, with notes on distribution and description of species not included in Gray's Manual.

Darlington, Wm. Flora Cestrica. 3rd Edition, 8vo. 1353.

- American Weeds and Useful Plants. Revised with additions by Geo. Thurber.

Desvaux, E. Graminece Chilienses. (Includes Cyperacece.) Svo., pp. 310, with 4to. plates. $185 \tilde{3}$.

Doell, J. C. Flora Brasiliensis, Graminere. II. 3. Folio. Plates 43. (Includes Stipacex, Agrostidea, Arundinacex, Pappophorea, Chloridea, Avenacea, and Festucacece!

Dumortier, B.C. Agrostographice Belyica. Observations sur les Graminees de la Flara Belgique. 8vo., pp. 153, plates 16. 1823.

Dupont, - Gbserrations sur la Gaine des Feuilles des Graminees. Extract from "Journal de Physique dle Chimie et d'Histoire Naturelle." 4to., pp. 7. 1819.

Duval-Jouve, J. L'Arete des Graminees. 4to., pp. 78, plates.

- Etude anatomique de quelques graminees, et en particulier des Agropyrum de l'Herault. 4to., pp. 93, plates 4.

Elliott, S. A Sketch of the Butany of South Carolina and Georgia. 2 vols., pp. $800.1821 . *$

Fernald, C. H. Grasses of Maine. Pamphlet Sro., pp. 70 ; plates (from the U. S. Dept. Agriculture) 42.

Flint, C. L. Grusses and Furage Plants. כth Ed. 8ro., 395 pp., figures 169. 1860.

Fournier, E. Mexicanas Plantes, Graminece. Folio. 160 pp. 1856. (Usually cited "Fourn. Mex. Pl. Enum., Gram."

Gould, J. S. Grasses and their Culture. (Extract from Report of the New York Agricultural Society.) 8vo., 212 pp., plates 74. 1869.

Gray, A. Manual of Botany. 6 Ed. 1890. The Gramineæ cover pp. 623-674, and plates VII-XV, inclusive. Also the 1st and the 5th Editions.

- Revision of the North American Species of the Genus Calamagrostis. Proc. Acad. Nat. Sci. Phila., Oct. 1862. An MS. copy.

- Notes on the Genus Graphephorum. Proc. Am. Acad. Arts and Sci. V. 1861 .

- Report upon S. B. Buckley's "Descriptions of Plants No. 3, Graminea. Proc. Acad. Nat. Sci. Phila. 1862. An MS copy.

- Enumeration of Plants Collected by C. C. Parry in the Rocky Yts. in 1860 or 1861. Amer. Journal Arts and Sciences. Vol. XXXIII. 1862. The grasses only. An MS. copy.

- Enumeration of the Species of Plants Collected by Dr. C. C. Parry and Messrs. E. Hull and J. P. Harbour, on and near the Rocky Mts. in Colorado in 1862. The grasses only. An MS. copy.

Grisebach, A. R. H. The Gramineæ, in Ledebour's Flora Rossica. An MS. copy.

- Flora of the British West Indies. The Gramineæ only. An MS. copy. Indexed.

- Planta Cubensis. The Gramineæ only. An MS. copy.

- Flora Cubana. The Gramineæ only. An MS. copy.

- Planta Wrightianc. The Gramineæ only. An MS. copy.

Hackel, E. Monographia Festucam Europarum, 1882. 8vo., 126 pp. plates 4. 
— The Girue firasses. Translated from "Die Vamrlichen Pflansenfumilien," by F. Lamson-scribner and Ellie A. Sonthworth. Swo.,pl. 22s. Copnously illustrated. New York, Henry Holt \& Co. 1890.

- Momographie Phanermamarum. Edited by A. d C. de Candolle. Val. VI. Aidropogonew. 8vo., pp. 716, plates 2. 1889.

Hemsley. W. B. Biolomin Centrali-Americanu. Botany. The Ciraminear only. Extracted from Vol. III., pp. 47 i-5s9. An MS. copy.

Henderson, J. Hamilnow of the Cirrases of Cireat Brituin und Americu, 12mo. pp. 238. $18 \% 3$.

Hooker, J. D. Ilistributiun of Arete timesses. From Trans. Linn. Soc. Vul. XXIII., pp. 344-347. An MS. copy.

Hooker, J. D. Flure of No Zealand. The Graminea only. An MS copy.

Hooker, W. T. Flura limenli-Americana. The Graminea from Vol. II. An MS. copy.

Howard, C. W. A Minuml of the Cullivation of the Grusses and Furuge Plunts at the Sucth. 8vo., paimphlet, 42 pp. 1881.

Howard, Sandford. Grasses and Herbage Plunts. A prize essay. Extract from Report of the New York Agricultural Society, pp. 237-251. Illustrated. 1855 .

Humboldt, Bonpland \& Kunth. Vura Genera Planturum. Folio. Vol. I. only, in which there are $\$ 2 \mathrm{pl}$., with $4 t$ plates on the Graminea. 1815.

Killebrew, J. B. The Irrisses and Furage Plunts of Tennessee. Sro., pp. D11. Illustrated. (Published by the State.) 1878.

Eunth, C. S. Enumerutio Planutum. Tomus I; Aymstogruphü Synuiticu. svo., pp. 606. 1833.

- Supplementum tomi Primi. 8ro., pp. 436, plates 40. 1835.

- Distritution Methodique de la Famille des Gruminees. Folio. Ip. XI.V, 666. 220 plates. 1835. A very fine and costly work. Csually cited "Kunth Revis. Gram." *

Lange, John. Conspectus Flore Granlanelica. 18s0. The Graminex only. An IS. copy.

Lapham, J. A. Grasses of Wisconsin. 8vo., pp. 92, plates 12.

McCarthy, G. The Best Almicultural Grasses. Bulletin No. 73. North Carolina Agricultural Experiment Station. pp. 100, illustrated. 1890.

Metzger, J. Europacische Cerealien. Folio. 74 pp., plates 20. 1824.

Muhlenberg, Henry. Descriptio Therior Graminum et Planturum Culamarinum America Septentrionalis. 8vo., pp. 2951817.

Munro, William. Monouraph of the Bambusacew. 4vo., pp. 157, plates (i.

- Catalome of the Grasses in the Herharium of Linneus. Extract from the Proc. Linn. Soc'y. Vol. VI. 1862. An M'S. copy.

Murphy, E. A Treatise on Agricultural Grasses. 12mo., pp. St, illustrated. 184.

Nees ab Esenbeck, C. G. Agrostologia Brasiliensis. Sro., pp. 608. 1829.

- Flore Africa Australioris Illustrationes Monagrajhice. I. Graminen. Sro. XX. 49 pp. 1841.

Nuttall, T. Descriptions of Plants Collecter hy Wm. Gambrel in the Rucky Yountains anel L Pper California. Ex. Journ. Acad. Yat. Sci. Phila. An IS. copy of the Graminer. 1848.

- Genera of Wurth American Plants. 2 vols., 12mo., pp. 312 and 254. 1 s1s.

Olcott, J. B. Turimaking Grasses. Reprint from Proc. Conn. Board of Agriculture, 8 vo., pp. 9. 1890. 
- Grass-Gardening. 'From the 14 th Ann. Report Conn. Agr. Expr. Station. 1890 .

Oliver. - Botany of the Speke and Grant Expedition. Trans. Linn. Soc'y. Yol. XXIX. The Graminea, by Prof. Oliver. An MS. copy. Indexed. 1875.

Palisot de Beauvois, A. M. F. J. Essai d'une Nourelle Agrostographie, ou Nouveaux Genres des Graminees, avec Figures Representant les Caracteres de tous les Genres. 8vo.pp. LXXIV. 182 and atlas in 4to. pp. 10, plates $2 \dot{3}$.

Panzer, G. W. F. Iden zu Einer Kunftigen Revision der Gattungen der Graser. 4 to., pp. 62, plates 6.1813.

Phares, D. L. Farmer's Book of Grasses and Other Forage Plants for the Southern United States. 12mo., pp. 148. 1881.

Plues, M. British Grasses. $12 \mathrm{mo}$., 307 pp., many wood cuts and 16 colored plates.*

Porter \& Coulter. Flora of Colorado.

Preston, S. P. Pasture Grasses and Forage Plants. 12mo., xp. 144, illustrated. 1887.*

Reichenbach, L. Agrostrgraplin, Germanica sistens Icones Graminearum quas in Flora Germanica Recensuit. (ed. 2.) 4to, pp. 80, plates 190. 1850.

Scheuchzer, J. Agrostographia sive Graminum. Juncorum, etc. Edito Nova, 8 vo., 512 pp., plates 19. Appendix 92 pp. 1775.*

Schreber, J. C. D. Beschreibung der Graser. Folio. pp. 160, plates 54. 1769.

Sinclair, George. Hirtus Gramineus Wuburnensis. 8vo., pp. 438. Numerous colored plates. 3d edition, London, 1826.*

Stebler \& Schroter. The Best Forage Plants. Translated by McAlpine. 4to., pp. 171, plates 30 (colored.)

Steudel, E. G. Synopsis Plantarum Graminearum. Royal 8vo., pp. 4741855.

Sutton, M. T. Permanent and Temporary Pastures. 8vo., pp. 15̃, plates, colored, $23 . *$

Thurber, G. Gramineæ in Watson's Botany of Culifornin. 4to., pp. 253-328. Proof impressions.

Gramineæ in Botany Wilke's Exploring Expedition. An MS. copy.

Trinius, C. B. Fundamenta Agrostographia. 8vo., X., 214 pp. 1820.

- Clavis Agrostographice Antiquiorus. 8vo., pp 412, plate 1. Coburg, 1822.

- De Graminibus Unifloris et Sesquifloris Dissertatio Botanica, Adjecta Generum ac Specierum e tribu Uni-et Sesquiflorum Plurium Synopsi. 8vo., 314 pp. 5 plates. 1824 .

- Ne Graminibus Paniceis. 8vo., pp. 2891826.

Species Graminum Iconibus et Descriptionibus Illustravit. 'III. Vol. 4to., 360 plates: $1828-1836$.

- Agrostidea I. Vilfea. 4to., 112 pp. 1810.

- Agrostidea II. Callo Rotundo. 4to., 144 pp. 1841.

- Phalaridea. 4to., pp. 63.1839.

- Panicearum Genera Retractavit, etc. 4 to, pp. 267. 1833.

- Graminum Supplementa. 4 to., pp. 1071836.

- Andropogineorum Genera Speciesque Complures Definitionibus Novis. 4to., pp. 229-337. Extr. Mem. Acad. Imp. sc. St.-Pet. 1832.

- Bambusaceas Quastam novas Describit. 4to.,pp. 17. Ext. Mem. Acad. Imp. sc. St.-Pet. 1835 .

- - et Ruprecht, F. J. Gramina Agrostidea, III., Callus obconicus. (Stipacea.) 4to., pp. 189. $18+2$. 
Tuckerman, E. In sime Plan's of Nor Enylume. Sill. Journal, Vol. XI, S. pp. 42-46. 1843. An Is. cupy.

Vasey, George. Cimminew in Wheeler's Report upun l' \&. Cieograpinical sinrveys. Vol. VI. Botany. Ito., pp. 281-297, plates 3. 1878.

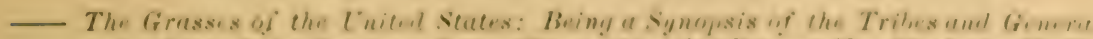
and a List of the simeirs. Sro., 47 pp. (Hpecial Repurt No. 193 of the U. S. Dept. Agriculture.) 18\$3.

- Illustrulions of Worth Americun lipusses. Vol. I. Roy. Svo., plates 100. P'ublished by the U. S. Department of Agriculture, being Bulletin 12 of the Botanieal Division.

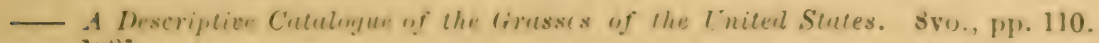
$18 \$ 5$.

The lienus Panicum of the C'nited states. Extract from Bulletin No. s, U. S. Dept. Agr., pp. 20-30.

- Vutes on the Pasiali of Le Conte's Monmaraph. Extract from the Proreedings of Academy of Yatural Sciences of Philadelphia. Pp. 284-290, inclusive. $18 \times 6$.

- Deport of un Incestigution uf the Cirosses of the Arid Districts of himsits, Nebreskin, and Coluralo. Sio., $18 \mathrm{pp}$. Bull. I, of the Bot Iliv. of the U. S. Dept. of Agriculture. 1886.

- Crrases of the South. Sro., 63 pp., plates 16. Bull. No 4, Bot. Iiv. of the U. S. Depr. Agr. 1887.

- The Alfricultural frasses and Furage Plants of the Lniterl Sules. A new and revised edition. Svo., pp. 14. plates 114. (A special Bulletin of the Bot. Div. of the U. S. Dept. of Agriculture.) 1889.

Monouruph of the Grassrs of the Cnited States and British Americu. Part, I, 8 vo., pp. 89. This is Vol. III. No. I, of Contributions from the U.S. Vational Herbarium. 1892.

- Neally \& Tracy. Report on an Inrestigation of the Crrasses uf the Arid Districts of Texas, Nero Mexico, Arizona, Nevada and Utah in 188\%. 8vo., pp. 6C, plates 30. 1888 .

Walpers, W. G. Annales Butunices siystematicie. Vol. VI. pages 801-1120, which includes Graminece, $109 \mathrm{pp}$.

Watson, Sereno. Botany of King's Expedition.* 
$p$ 


Tirth the Fine regars of - Lancon-OCitruen- 


\section{CORRECTIONS.}

Page 7. For "Agrostidia" read "Agrostidea."

"11. Under No. 46, for "hairs an the rachilla" read "hairs on the rachilla."

" 36. For the species of Panicum "observed in Tennessee," read "observed in the United States."

" 38. For "longepedunculatum" read "longipedunculatum."

" 69. For "Brachyelytrum aristatum Beavv." read "Brachyelytrum erectum Becuv."

"69. Fourteenth line from bottom, after "flowering glume" strike out "many-nerved."

" 83. Fourth line from bottom, for "Figure 109" read "Figure 111."

" 89. Line five, for " 141 " read " 134 ."

" 94. For "Triodea" read "Triodia."

" 100. After "Eatonia obtusata" add "Gray." 


\section{UNIVERSITY OF TENNESSEE}

๘. Agricultural Experiment Station

\section{BULLETIN}

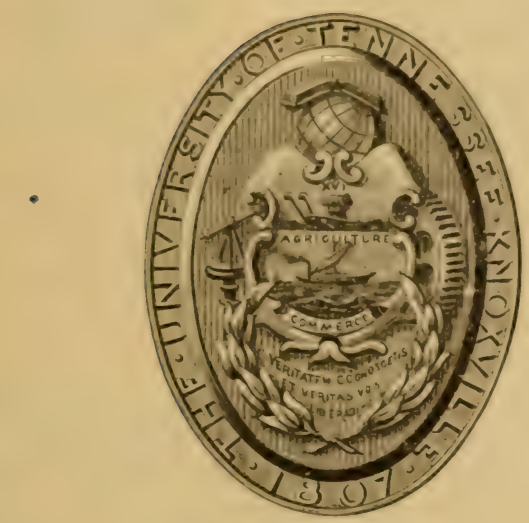

Vol. ViJ.

\section{GRASSES OF TENNESSEE.-PART II.}

Bulletins of this Station will be sent, upon application, free of charge, to any Farmer in the State. 


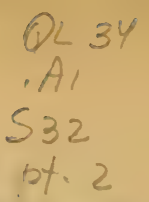

Bulletins of this Station will be sent, upon application, free of charge, to any Farmer in the State.

\section{THE AGRICULTURAL EXPERIMENT STATIION}

\section{OF THE UNIVERSITY OF TENNESSEE.}

Chas. W. Dabney, Jr.. President.

EXECUTIVE COMMITTEE:
M. P. JARNAGIN, -
JOSEPH W. ALLISON,
O. P. TEMPLE,
W. H. JACKSON,

HUGH G. KYLE.

$\begin{array}{lc}\text { TREASURER : } & \text { SECRETARY: } \\ \text { JAMES COMFORT. } & \text { J. W. GAUT. }\end{array}$

THE STA TION COUNCIL IS COMPOSED OF ITS OFFILERS:

PROF. CHAS. F. VANDERFORD, Secretary.

Prof. F. LAMSON-SCRIBNER, Botanist.

DR. C. W. DABNEY, JR., Chemist.

R. L. WATTS, B. Ag., Horticulturist.

S. M. BALN, A.B., Assistant Botanist.

T. B. MCBRYDE, Assistant Chemist.

C. E. CHAMBLISS, Librarian and Clerk.

The Station has facilities for analyzing and testing fertilizers, cattle foods, milk and dairy products; seeds, with reference to their purity or germinating power; for identifying grasses and weeds, and studying forage plants; for investigating the diseases of fruits and fruit trees, grains and other useful plants.

The Station Bulletins and Reports will be sent, free of charge, to any farmer within the State.

Packages by express, to receive attention, should be prepaid.

All communications should be addressed to the

SECRETARY OF THE

\section{AGRICULTURAL EXPERIMENT STATION, \\ KNoxville, TenN.}

The Experiment Station building, containing its offices, laboratories and museum, and the plant-house and horticultural department, are located on the University grounds, fifteen minutes walk from the Custom House in Knoxville. The Experiment farm, stables, milk laboratory, etc., are located one mile west of the University, on the Kingston pike. Farmers are cordially invited to visit the buildings and experimental grounds.

Bulletins of this Station will be sent, upon application, free of charge, to any Farmer in the State. 


\title{
GRASSES OF TENNESSEE.
}

\author{
PART II.
}

BY F. I,AMSON-SCRIBNER.

\section{INTRODUCTION.}

When Part I. of "The Grasses of Tennessee" (Bulletin No. 2, Vol. V., of this Station) was presented as an introduction to a second part, in which all the grasses of the State would be illus. trated and described, it was designed that the second part should be in some degree dependent upon or supplementary to the other, the two together forming a complete volume. Because of the lapse of time since the publication of Part I., and wishing to add to the value and usefulness of the second part, an effort has been made to make it complete in itself, and in doing this considerable matter has been drawn from Part I. The present bulletin, therefore, may be called a handbook of the grasses of the State. Descriptions of all the genera and species known to occur within the State are given, and under the specific descriptions economic notes are added whenever these are deemed of any value or general interest. A good deal of care has been taken in drawing up the descriptions, and if these appear to any one to be two scientific or too technical, it must be remembered that the subject is grasses, and that grasses have organs and parts of organs all of which have names. These names as they appear in the descriptions mean something. and their meaning is as readily learned by those actually interested in the subject as the parts of a horse or cow are learned by those especially interested in horses or cows. Briefly, in the preparation of the descriptions the "language of grasses" has been used. Attempts to aroid technical or "hard words" often result in ob. scuring the meaning of the author, and an undue simplicity of expression is very apt to be offensive by implying a lack of intelli. gence on the part of the reader. Most of the botanical terms employed in the work are explained in the glossary. The work is 
designed not only for farmers but also for agricultural students and botanists. The former, who have little time for reading or study, will learn to know from the illustrations many grasses now unfamiliar to them, and gather from the briefly stated facts relative to the economic values of the several species a great deal that may be of direct use to them. The agricultural students and - botanists of the State have here a means for identifying and classifying any grass now known to occur within the limits of Tennessee, and to acquire a fair idea of their external characters and habits. While this Bulletin is only designed for the use of Tennesseeans, those living in other States may find it helpful at times in determining grasses. None of the species described are limited to the State, and of course the descriptions and illustrations are as applicable in one place as in another. The specific descriptions are for the most part drawn from specimens in hand, and they are usually more complete than those given in our general manuals. The illustrations, which were drawn by Mr. Theo. Holm, of Washington, D. C., were all prepared especially for this Bulletin, and quite a number of the species figured are here illustrated for the first time. 


\section{GRASSES-GRAMINEÆ.}

CHARACTERS OF THE ORIER.-Fibrous-rooted, annual or perennial. herbaceous plants (among our species Arundinaria alone is woody). with usually hollow, cylindrical (rarely flattened) and jointed stems (culms) whose internodes for more or less of their length are completely enveloped by the sheath-like basal portion of the two-ranked and usually linear, parallel-veined leaves.

Flowers without any distinct perianth, hermaphrodite or rarely unisexual, solitary or scveral together, in spikelets, these disposed in panicles, racemes or spikes, and consisting of a shortened axis (the rachilla) and two or more chaff-like, distichous bracts (glumes) of which the first two, rarely one or none or more than two, are empty (empty glumes); in the axil of each of the succeeding bracts (excepting sometimes the uppermost) is borne a flower,(hence these are named flowering glumes). Opposed to each flowering glume, with its back turned towards the rachilla, is (usually) a two-nerved, two-keeled bract or prophyllum (the palea), which frequently envelops the flower by its infolded edges. This bract is the pro. phyllum of the extremely short axis or branch, which supports the flower; its absence indicates that the flower is strictly sessile or inserted directly on the rachilla; the rachilla or axis of the spikelet may or may not be produced beyond the palea. At the base of the flower, between it and its glume, are usually two very small hyaline scales (lodicules); rarely there is a third lodicule between the flower and the palea. Stamens, usually three (rarely two or one, or more than three) with very slender filaments and twocelled, usually versatile anthers. Pistil with a one-celled, oneovuled ovary, and one to three, usually two, styles with variously branched, most frequently plumose, stigmas. Fruit, a true caryopsis, rich in albumen. (In Sporobolus and Eleusine the fruit is a utricle, the seed being loose within the thin pericarp.) Embryo small, lying at the front and base of the seed, covered only by the thin pericarp.

The organs or parts of grasses, as in other plants, are those of vegetation and those of reproduction: to the first belong the root, stem or culm, and leaves; to the second the stamens and pistils.

THE Root,-Grass roots are always fibrous. The more or less strong underground rhizomes are often called roots; they are not true roots, but are specially modified stems.

The Stem.-Grass stems are always branched at the base, and occasionally in their upper portions. If the branches are all apparently at the root, the culms are said to be simple, the visible portion above ground being unbranched. Sometimes the stems or branches stand vertically upright, when they are termed erect: they may spread a little at first. and then assume an erect posi- 
tion, the lowermost joints being bent or kneed; such culms are said to be geniculate at base. The basal branches may lie flat upon the ground and spread more or less extensively, taking root at the usually numerous joints, and at definite points sending up erect flowering branches, or branches bearing leaves only; such grasses are said to have a creeping habit, or are stoloniferous. Again, one or more of the lowermost branches may not come to the surface at all, or only after it has extended through the soil for a greater or less distance. These form the "creeping roots" (rhizomes) of grasses, but they are true stems or branches, for they are always distinctly jointed, and at the joints there are scale-like leavescharacters never found in true roots. The joints of these underground stems may be very short, and from each node may spring a flowering branch. So condensed may this growth be that the rhizome is entirely concealed, but in perennial grasses it is alway: present, and in the best turf or sward-forming grasses it is suffi. ciently manifest. In couch-grass, and especially in Johnson grass. these rhizomes are greatly developed, penetrating the soil in all directions, forming a sward that is exceedingly difficult to break.

Grass stems are usually round or cylindrical, rarely flattened. and generally hollow between the joints or nodes (solid or with pith in the Andropogons, Indian Corn, and a few other grasses). The nodes, familiarly termed the joints, are the points on the culm or its branches from which the leaves originate; they are usually somewhat swollen, the enlargement being either in the culm or, as is very often the case, in the basal part of the leaf. sheath. The space between two nodes is the internode. All branches, excepting those of the general inflorescence, originate in the leaf-axils, that is, within and at the base of the leaf-sheaths, and between the branch and the main axis or stem there always is a longer or shorter two-keeled prophyllum with its back turned towards the main axis. The presence of this prophyllum always indicates the presence of a branch, although the branch may be very much shortened, as in the case of the true floral axis where this prophyllum is the palea.

THE LEAvEs. - The leaves of grasses have two distinct parts: the sheath and the blade. The sheath, or basal portion, usually closely surrounds the stem, and is split or open upon the side opposite the blade, or is entire, then forming a closed cylindrical sheath (vagina) about the stem. When split, the free edges usually overlap each other. At the top of the leaf-sheath, at the point where the blade originates, there is upon the inside usually a thin and delicate prolongation, often very short, called the ligule. Sometimes the ligule takes the form of a fringe of hairs. The leaf-blade is gen erally narrow, usually many times longer than broad. with nearly 
parallel edges. Such leaves are called linear. From this form the leaves may vary to lanceolate or onale in outline. Sometimes the narrow leaves have their edges rolled inward, when they are said to be incolute. Occasionally the leaf-blade is very short, and sometimes it is wanting altogether, the sheath alone remaining. As to the surfaces of the leaves and sheaths, they may be smooth or rough, or more or less hairy. The terms used here are those of general application.

The position of the leaves on the stem is to be noted as affording a ready character for distinguishing grasses from the nearly allied grass-like sedges. Starting with any leaf on the stem of a grass, the next leaf above will be exactly on the opposite side of the stem, while the next or second leaf above will stand directly over the starting-point. Such an arrangement is called distichous or tworanked; i. e., in counting two leaves from the first we pass completely around the stem. In sedges the leaf-arrangement is threeranked; it is the third leaf from the first which stands directly above the first.

The. FLowers.-The flowers of grasses possess only the essential organs - the stamens and pistils. The bracts enclosing these are modified leaves or leaf-sheaths and prophylla. Sometimes the stamens and pistils are separated, when the flowers are either male or staminate (containing stamens only), or female or pistillate (con. taining pistils only). These staminate and pistillate flowers may occupy different parts of the same plant or (more rarely) entirely distinct plants. Flowers having both stamens and pistils are termed hermaphrodite.

In each flower there are usually three stamens. These have slender filaments, and usually versatile, sometimes basi-fixed, twocelled anthers, which are pale yellow, sometimes nearly white, or purple, or some shade of red. The pistil consists of the oz'ary and usually two feathery or plumose stigmas, which may be sessile or raised on short or long and more or less divided styles.

The fruit or ripened ovary constitutes the "grain." This is a true caryopsis, i. e., a dry one-seeded fruit in which the outer covering or pericarp is closely adherent to the seed. The "grass seed" of commerce consists of the grain enveloped usually in more or less "chaff," (glumes and paleas).

Arrangement of the Flowers.-The arrangement of the flowers in grasses is peculiar. They are situated in what are termed spikelets, either solitary (one-flowered spikelets,) or two or more together (two to several or many-flowered spikelets). Each flower is located in the axil of a chaff-like bract or glume called the flowerering glume, (really a leaf-sheath). At the base of the spikelet there are usually two bracts or glumes having no flowers in their axils; 
these are the outer or empty glumes. The axis to which these glumes are attached is termed the rachilla, and between each flower and this rachilla there is usually a two-nerved bract, the palea, the prophyllum to the floral branch. In one-flowered spikelets where there is no extension or prolongation of the rachilla, this palea is apparently opposite the flowering glume. The lower pair of glumes-the empty ones-often differ from each other in size or length, and sometimes, though rarely, one or both are absent. The glumes may be awned or "bearded," or awnless; they may be sharp-pointed, obtuse or toothed at the apex; they may be nerveless or one to many-nerved. As to other variations it is necessary to refer the reader to the larger descriptive works on botany.

The arrangement of the spikelets upon the stem constitutes what is termed the inflorescence, or what we often hear erroneously called the "head." If that portion of the main axis or stem which bears the spikelets is unbranched so that these are sessile (i.e., without pedicels), the inflorescence is a spike, as in wheat or ryegrass; when the main axis is branched, each branch forming a pedicel to a single spikelet, the inflorescence is a raceme. This form is not common. Usually the primary branches branch again and again, resulting in the formation of a panicle. The panicle may be open or widely spreading, as in oats or in Kentucky blue-grass; or, if the branches are very short, it may be narrow and spike-like, as in timothy or in meadow fox-tail. All gradations of form between these two extremes occur.

Number of Species. - There are about thirty-five hundred known species of grasses, varying in size from the moss-like Coleanthus of the North to the tree-like bamboos of the tropics, which tower to the height of a hundred feet or more; and ranging in distribution from Kerguelen Land on the South to the extreme limit of vegetation beyand the arctic circle. There is no order of plants more widely distributed, existing under the greatest diversity of soil and climate, and no order presents such a vast number of individual plants or is so important and directly useful to man.

UsEs.-When we consider that rice, wheat, corn, oats, barley, rye, sorghum, and the millets, sugar-cane and the bamboos are all true grasses, and further that these plants furnish the bulk of the hay crop and pasturage of the temperate regions, we can hardly realize, much less definitely estimate, the great importance of the Graminea, or form any just conception of the part these plants play in our individual and national economy. The fact of the vast importance of the order may be very forcibly presented by trying to picture the result upon the human race, if by chance all these food and forage plants were at once destroyed. 
There are many species which have special value in manufac. tures, arts, and medicine. A few yield valuable perfumes, and some are cultivated for ornament. A mere enumeration of the many and various uses of the bamboos to the natives of Southern and Eastern Asia would fill many pages. Our space does not ad. mit a more detailed account of the uses of grasses, and we can only add here that in all civilized countries continued prosperity and increase of wealth appears to be largely dependent upon the attention given to these plants.

\section{SOME WORKA IOEVOTED WHOLIY OR IN PART TO GRASSES}

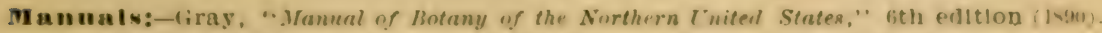
Chapman, "Flora of the Southern United States," editlon with Supplement.

special works:-Bentham, "Notes on Ciruminere." Publlshod in fourn Linn. Soclety, Botany XIX. - Bentham and Hooker, "Genera Plantarum," Vol. III., Part II. Balllon, "Histoire des Plantes, Monographie des Graminees," Parls, 1893. - Hackel, "The True Grasses," Henry Holt \& Co., 1890.__ "Monographire Phanerogamarum." Vol. VI., "Andropogonece," Parls, 1889. K Kunth, "Distribution Methodique de la Famille des Graminees," follo, 1935; “Enumeratio Plantarum," Vol. I , (with Supplement) : "Agros. tographia Synoptica," 1833. - Munro, "Monograph of the Bambusacea." - Pallsot de Beauvols, "Essai $d$ 'une Nouvelle Agrostographie."-Trinlus. "Fundamenta Agrosto. graphire," 1820: "Clavis Agrostographice Antiquiorus," 1822: "De Graminibus Unifloris et Sesquifloris Dissertatio Botanica, Adjecta Generum ac Specierum e tribu Ini-et Sesqui. n) rum Plurium Synopsi," 1824; "De Graminibus Paniceis," 1826; "Species Graminum Inconibus et Descriptionibus, Mlustravit," 3 Vols., 4to., 360 plates, 1522-1836; " Agrostidea I. Vilfea," 1810; "Agrostidia II. Callo Rotundo," 1811: "Phalaridex," 1S39; "Panicea. rum Genera Retractavit," etc., 1893, "Graminum Supplementa," 1836._-Trinlus \& Ruprect, "Gramina Agrostidia, III., Callus obconicus. (Stipacea), 18t2-Vasey, "Illus. trations of North American Grasses;" "Grasses of the Pacific Slope; Illustrated works, published by the U. 8. Department of Agriculture.

Popular Publications:-Beal, W. J., "Grasses of North America;" Vol. I. so., pp. 457, Illustrated; a valuable popular work, 1867.—Bessey, C. E.. "The Grasses and Forage Plants of Nebraska;" In the Annual Reports of the Nebraska State $\Delta$ grlcul. tural Soclety for the years 1586, 1839, and 1892.—-Fernald, C. H., "Grasses of Maine;" pamphlet.—Fint, C. L., "Grasses and Forage Plants," 5th ed., 8 vo., 398 p p., flgures 169 ; 1860.-Henderson, J., "Handbook of the Grasses of Great Britain and America," 1N75. - Howard, C. W., "A Manual of the Cultivation of the Grasses and Forage Plants at the South," 1881. - Killebrew, J. B., "The Grasses and Forage Plants of Tennessee." lllustrated; published by the state, 197s._-Gould, "Grasses and their Culture," In Transactions New York Agricultural Soclety, 1869._Lapham, J. A., "Grasses of Iisconsin;" 8vo., pp. 92, plates 12.-Olcott, J. B., "Turf-making Grasses," reprint from Proc. Conn. Board of A griculture, 8vo., pp. 9, 1890.— "Grass-Gardening, "from the 14th Ann. Report Conn. Agr. Expr Station, 1890_-Phares, D. L., "Farm. er's Book of Grasses and Other Forage Plants for the Southern United States," 12mo., pp. 148, 1881.-Preston, S. P., "Pasture Grasses and Forage Plants," 12mo., pp. 1H. Illustrated, 1887.- Stebler \& Schroter, "The Best Forage Plants;" translated by Mc. Alplne, fto, pp. 171, plates 30 , colored,_-Sutton, M. T., "Permanent and Tempo. rary Pastures," 8vo., pp. 158. plates, colored, 23.-Vasey, George, "Report of an Investigation of the Girasses of the drid Districts of Kansas, Neliraska, and Colorad,." "ro., $18 \mathrm{pp} .$, Bull. I. of the Bot. Dlv. of the U. S. Dept. of Agrlculture, 1886.—- "Grasses of the South," 8vo., 68 pp., plates 16, Bull. No. 4, Bot. Div. of the U. 8. Dept. of $\Delta g r$. 1s:i. - "The Agricullural Grasses and Forage P/ants of the I'nited states;" a new and revised edition, 8vo., pp. 148, plates 114, (a speclal Bulletin of the Bot. DIv. of the U. S. Dept. of Agriculture), 1889._- Neally \& Tracy, "Report on an Inrestigation of the Grasses of the Arid Districts of Texas, Nerc Mexico, Arizona, Nerada, and Ltah in 1887;" 8 vo.. F. 60 , plates 30,1888 . 


\section{Key to the Genera of the Native and Cultivated Grasses of Tennessee.}

The numbers to the right refer to the numbers at the left. The numbers preceding the names of the genera show their position in sequence.

I. Spikelets one- rarely two-flowered (when two-flowered the second or terminal flower is perfect, the one below being either staminate or neuter), falling from the pedicels entire, singly, in groups, or together with certain joints of the rachis. (Series A. PANICACE A.).

I. Spikelets one-to many flowered, when more than one-flowered the imperfect flower, if any, is uppermost, rachilla usually articulated above the lower empty glumes so that these remain after the fall of the fruiting glumes. (Exceptions: Alopecurus, Cinna, Polypogon, Spartina, and Holcus.) (Series B. POACEA.) . . . . . . . . . . . . I6

2. Spikelets terete or flattened on the back . . . . . . . . 3

2. Spikelets strongly flattened laterally (Tribe ORYZE

3. Spikelets all unisexual, plants monœcious (Tribe MAYDEÆ) 4

3 Spikelets hermaphrodite, or staminate and hermaphrodite, the former standing near the latter.

4. Pistillate and staminate spikelets each in a separate inflorescence, the former axillary, the latter terminal .

4. Pistillate and staminate spikelets in the same inflorescence, the axis of the former articulated between each spikelet.

3. Tripsacum.

5. Pistillate spikes distinct, fasciculate, their axes articulated.

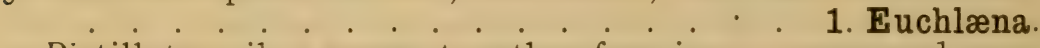

5. Pistillate spikes grown together forming a compound, continuous and much thickened axis (the "cob"). . 2. Zea.

6. Axis of the inflorescence usually articulated, the joints falling with the spikelets, flowering glumes more delicate in texture than the outer glumes: (Tribe ANDROPOGONE.E.)

6. Axis of the inflorescence continuous, flowering glume indurated or firmer in texture than the empty glumes. (Tribe Panice.)

7. Spikelets heterogamous; in pairs, one sessile, hermaphrodite; one pedicellate, staminate or neuter, or reduced to a plumose bristle. . . . . . . . . 7. Andropogon.

7. Spikelets all alike

5. Saccharum.

8. Spikelets awnless

8. Spikelets awned .

9. Racemes forming a broad, fan-shaped panicle 4. Miscanthus.

9. Racemes upon an elongated main axis forming a much branched panicle, branches articulated . 6. Erianthus.

г. Glumes (including the flowering) three 8. Paspalum.

io. Glumes four, the lowest usually smaller than the others (wanting in Panicum filiforme). 
11. Spikelets surrounded by an involucre consisting of one to many bristles, which are sometimes grown together becoming bur-like

II. Spikelets not surrounded by bristles or special covering

9. Panicum.

12. Bristles persistent

10. Setaria.

12. Bristles falling with the spikelets

I3. Bristles grown together at the base, forming a bur-like corering over the spikelets . . . . 11. Cenchrus.

13. Bristles distinct

12. Pennisetum.

14. Spikelets unisexual, monocious, linear, the awned pistillate above and the staminate below in the same inflor. escence

13. Zizania.

14. Spikelets all hermaphrodite

14. Oryza.

15. Empty glumes two, small

15. Empty glumes none

15. Leersia.

16. Culms perennial, woody, leaf-blade articulated with the sheath (Tribe BAMBSE.E.) . . 65. Arundinaria.

16. Culms annual, herbaceous, leaf-blade continuous with the sheath

17. Spikelets distinctly pedicellate, in racemes or panicles (these sometimes spike-like) . . . . . . . . . I

17. Spikelets sessile, in true spikes, (sometimes on very short pedicels and then in one-sided or unilateral racemes). . $3^{6}$

I8. Spikelets one-flowered . . . . . . . . . . 19

18. Spikelets two to many-flowered . . . . . . . . . . . 30

19. Empty glumes four. the third and fourth very unlike the first and second and falling with the fruiting glume (Tribe Phalaridea).

19. Empty glumes two

20. Third and fourth glumes reduced to narrow scales or bristles, awnless . . . . 16. Phalaris.

20. Third and fourth glumes smaller than the first and second, awned

17. Anthoxanthum.

21. Grain closely enveloped by the fruiting glume, which is firmer in texture than the empty ones. (Sub-tribe Stipert) 22

2r. Grain loosely or not at all enclosed by the hyaline or membranaceous fruiting glumes. (Sub-tribes Phleoidec and Euagrostece)

(Sub-tribes Phleoidec and 25

22. Rachilla prolonged beyond the palea 21. Brachyelytrum.

22. Rachilla not prolonged beyond the palea.

23. Flowering glume with a trifid awn

18. Aristida.

23. Flowering glume mucronate-pointed or with a simple awn 24

24. Awn twisted and geniculate

24. Awn straight, sometimes reduced to a mucro

19. Stipa

20. Muhlenbergia.

25. Spikelets in a cylindrical, spike-like panicle, empty glumes ciliate along the keels .

25. Spikelets in open or contracted panicles, empty glumes not ciliate

26. Empty glumes abruptly awn-pointed, persistent: palea present, flowering glumes awnless. 
26. Empty glumes not awn-pointed, falling with the fruiting glume; palea none, flowering glume awned on the back.

23. Alopecurus.

27. Flowering glume one-nerved, longer than the unequal empty ones

24. Sporobolus.

27. Flowering glume three-to five-nerved, shorter than the empty ones

28. Flowering glume raised on a distinct, naked internode of thie rachilla; stamen one. ....... 25. Cinna.

28. Flowering glume not raised on a distinct internode of the rachilla; stamens three

29. Callus with long hairs (at least half as long as the flowering glume); rachilla continued beyond the palea.

27. Calamagrostis.

29. Callus naked (or with a few very short hairs only); rachilla not prolonged behind the palea . . . 26. Agrostis.

30. Flowering glumes usually shorter than the empty ones, bearing a twisted or geniculate awn (some cultivated forms excepted) on the back or between the teeth of the bifid apex (Tribe AvenEE).

30. Flowering glumes usually longer than the empty ones, awnless or bearing a straight (rarely bent) awn at or just below the entire or two-toothed apex (Tribe Festuce 4 ) 44

3r. Flowering glumes thin and scarious, apex irregularly denticulate, slender-awned on the back from near the base

29. Deschampsia.

31. Flowering glumes of firmer texture, entire, two-toothed or two-cleft at the apex

32. Spikelets strictly two-flowered, one of the flowers staminate

32. Spikelets two to many-flowered, all the flowers hermaphro-

dite or the uppermost imperfect or rudimentary ${ }^{33 .}$ Lower flower staminate, its glume long-awned on the back
. from near the base . . . 32. Arrhenatherum.

33. Lower flower hermaphrodite, its glume awnless. 28. Holcus.

34. Flowering glumes thin and hyaline, carinate, awned from near the apex . . . . . . . . . 30. Trisetum.

34. Flowering glumes herbaceo-chartaceous, rounded on the back, two-toothed or bifid at apex, awned between the teeth

Awn terete, proceeding from the mid-nerve only. 31. Avena. nerves of the glumes . . . . . 33. Danthonia.

36. Spikelets sessile or nearly so, in two rows along one side of the continuous axis forming unilateral racemes or spikes, these racemed or digitate. (Tribe CHLORIDE $Æ$ ) . . . . 37

36. Spikelets in opposite rows along a jointed rachis, forming a two-sided or equilateral, terminal spike. (Tribe HoRDEÆ) 59

37. Spikes terminal or nearly so, digitate or whorled . . . . 38

37. Spikes (or one-sided racemes) scattered along a common axis (usually racemed)

38. Spikes slender, one hermaphrodite flower and a sterile rudiment of a second flower in each spikelet . . . . . 39 
38. Spikes stout, with two to several hermaphrodite flowers in each spikelet

39. Flowering glume and rudiment awned

39. Flowering glume and rudiment awnless

36. Chloris.

40. Axis of the spike projecting heyond the spikelets, second empty glume awn-pointed

40. Dactyloctenium.

40. Axis of the spike with a terminal spikelet, none of the glumes awn-pointed

39. Eleusine.

4r. Spikelets strictly one-flowered, no prolongation of the rachilla or rudiment of a second flower, crowded and strongly flattened

35. Spartina.

4I. Spikelets two-to three-flowered, or at least with the rachilla prolonged beyond the first flower

42. Spikes short, flowering glume trifid, the divisions subulate or awn-pointed

38. Bouteloua.

42. Spikes (or racemes) very slender, filiform, (two to six inches long); flowering glume not trifid

43. Spikelets with only one hermaphrodite flower, its glume bearing a slender awn just below the bifid apex

\section{Gymnopogon}

43. Spikelets with two to four hermaphrodite flowers, glumes awnless

41. Leptochloa.

44. Rachilla or flowering glume, at least of the fertile flower, with long hairs which equal or exceed the glumes in length

44. Rachilla or flowering glumes naked or with hairs much shorter than the glumes

45. Spikelets unisexual (plants diocious) the staminate spike. lets naked; culms solid

41. Gynerium.

45. Spikelets hermaphrodite; culms hollow

46. Hairs on the glumes only

43 Arundo.

46. Hairs an the rachilla only

44. Phragmites.

47. Flowering glumes three-nerved, the middle as well as the marginal lateral nerves silky-villous below, and extended beyond the glumes into three mucronate points.

45. Triodia.

47. Flowering glumes three to many-nerved, lateral nerves not marginal nor extended beyond the glume

48. Flowering glumes three-nerved, usually falling with the grain in advance of the paleas which remain attached to the continuous rachilla

46. Eragrostis.

48. Flowering glumes and paleas falling together, each glume carrying a joint of the articulate rachilla

49. Empty glumes three to six at the base of each spikelet

50. Uniola

49. Empty glumes two at the base of the spikelet

50. Spikelets heart-shaped at the base, glumes ventricose

50. Spikelets not heart shaped, glumes not ventricose 
5 I. Flowering glumes three-nerved, rounded on the back, coriaceous, subulate pointed . . . . . . 49. Diarrhena.

$5 \mathrm{I}$. Flowering glumes three- to many-nerved, herbaceous, membranaceous, or chartaceous.

52. Terminal sterile florets, in each spikelet club-shaped, flowering glumes papery-membranaceous with a broad and scarious apex . . . . . . . . . 48. Melica.

52. Terminal sterile florets not club-shaped .

53. Empty glumes nearly equal in length, but very dissimilar; the first narrowly linear, one-nerved; the second broadly obovate, folded around the florets, three-nerved

47. Eatonia.

53. Empty glumes similar, but often of unequal length

54. Spikelets crowded in one-sided clusters on spreading branches, flowering glumes awn-pointed and strongly ciliate on the keel above . . . . . 52. Dactylis.

54. Spikelets not crowded in one-sided clusters

55. Spikelets of two forms, fertile and sterile, the latter pectinate and standing with the fertile; inflorescence terminal, spike-like

53. Cynosurus.

55. Spikelets all alike

56. Flowering glumes compressed, keeled, usually bearing a tuft of cobwebby hairs at the base, and sometimes soft hairs on the more prominent nerves below . . 54. Poa.

56. Flowering glumes rounded on the back, naked or pubescent. not cobwebby at base (spikelets much flattened and glumes compressed in Bromus unioloides.) . . . . . . . . 57

57. Styles inserted below the apex of the ovary, which has a hairy, cushion-like summit . . . . 57. Bromus.

57. Styles terminal; grain smooth

58. Flowering glumes awnless, nerves prominent. 55. Glyceria.

58. Flowering glumes often awned, nerves indistinct (visible only near the apex)

56. Festuca.

59. Spikelets single at each joint of the rachis . . . . . .60

59. Spikelets two or more at each joint of the rachis . . . . 63

6o. Spikelets placed edgewise to the rachis; empty glume (except in the terminal spikelet) one . . . 58. Lolium.

60. Spikelets placed with their sides against the rachis, empty glumes two .

6r. Flowering glumes with a distinct callus, falling at maturity with the grain, which is adherent to the palea

59. Agropyrum.

6r. Flowering glumes without a distinct callus, persistent; grain free.

62. Empty glumes subulate, one-nerved

60. Secale.

62. Empty glumes lanceolate or ovate, three to many-nerved

61. Triticum.

63. Spikelets with only one hermaphrodite flower, 62. Hordeum.

63. Spikelets with two or more hermaphrodite flowers . . 64

64. Empty glumes nearly equalling the flowering glumes

64. Empty glumes, minute or none

63. Elymus.

64. Asprella. 


\section{SERIES A. PANICACE.E.}

Spikelets one-, rarely two-flowered, when two-flowered the second or terminal one is perfect, the first or lower one being either staminate or neuter, rachilla articulated below the empty glumes, the spikelets falling from the pedicels entire, either singly, in groups, or together with the joints of an articulate rachis.

\section{Tribe I. MAYDE $A$.}

Spikelets unisexual, the staminate forming a part of the inflorescence with the pistillate, or each in a separate inflorescence on the same plant. Flowering glumes hyaline or much less firm in texture than the outer ones. Axis of the female spikelets usually articulated.

This is a small tribe, numbering only sixteen species classed in seven genera. They are nearly all natives of the tropics, chiefly in the Old World. Indian Corn or Maize is our best known example of the Maydeæ.

\section{EUCHL屟A Schrad. Ind. Sem. Hort. Gœtt (1832).}

Spikelets unisexual, monøcious, the staminate two-flowered, in pairs, one sessile the other pedicellate, arranged in terminal paniculate racemes; the pistillate one-flowered, sessile and solitary at each joint of an obliquely articulate rachis of a simple spike. The spikes fasciculate in the leaf axils, and each more or less enveloped by a foliaceous bract. Glumes of the staminate spikelets four, acute, the first two membranaceous empty; flowering glumes smaller and like their paleas, hyaline. Stamens three. Glumes of the pistillate spikelets four, the outer one broad and boatshaped, smooth, soon becoming very hard, surrounding the inner glumes and narrow rachis: second glume empty, coriaceous; third glume hyaline, with a palea but no flower; fourth or flowering glume and its palea hyaline. Styles very long, filiform, shortly bifid at the apex.

Tall annuals with long and broad leaves, closely resembling Indian corn in habit.

Species one, with several varieties, in Mexico and Central America.

I. Euchlæna Mexicana, Schrad. (E. luxurians.) Teosinte or Gautemala-grass.

A stout, leafy annual, with upright stalks eight to ten feet high, resembling Indian corn, to which it is closely related botanically: The staminate or male flowers form a "spindle" at the summit of 
the stem, and the pistillate or female spikelets are in short (two to three inches) jointed spikes, which are usually crowded on short branches from the upper leaf-axils. These clusters of spikes are enveloped in broad, leafy bracts, and each spike is also surrounded by a bract. The somewhat flattened and obtusely triangular joints of the spike are about one quarter of an inch long. There is a single spikelet embedded in each joint, its long thread-like style projecting from the bracts like the "silk" of maize. (See figure 32, page 78 of Part I. of "The Grasses of Tennessee."

The variety which has been cultivated in various parts of the South and West has the habit of tillering, or sending up many (twenty to fifty) stalks from the same root. From this habit the bulk of fodder produced on an acre is very large, probably equalled by no other grass. When Teosinte was first introduced into this country, it was referred to by Dr. Asa Gray as "possibly affording an opportunity for one to make millions of blades of grass grow where none of any account ever grew before." It is reported that the average annual crop for three years at the Kansas station was more than twenty-three tons of green forage per acre. It is liked by all kinds of stock and has especial value as a green fodder when other forage is dried up. It may be cut several times during a season, but nearly as good results are obtained from a single cutting before there is any frost. The stalks are tender, and there is no waste in the fodder, whether green or dry. One pound of seed to the acre planted in drills three feet apart and thinned to a foot apart in the drills is recommended.

This grass was successfully grown at the Station in 1889 . No fruit was formed, nor does this variety fruit here, excepting in the warmer regions near thé gulf coast. Last year (1893) a variety was grown at the Station from seed collected in Mexico by Mr. C. G. Pringle. The plants did not tiller, but sent up single stalks in all respects like the Mais de Coyote (Zea canina) which was grown side by side with it. To the casual observer the plants appeared to be all alike, and from a little distance the lot would have been mistaken for a good growth of field corn, eight or nine feet high. In both, the stalks were branched above, and along these branches were formed the small "ears" in the case of Zea canina, and the fascicles of fruiting spikes in the Teosinte, which ripened before frost.

\section{ZEA Linn. Sp. P1. 97 I (1753).}

Spikelets unisexual, monœcious; the staminate two-flowered in pairs, one sessile the other pedicellate, along the numerous branches of a terminal panicle; the pistillate one-flowered, sessile, crowded in several rows along a much-thickened continuous axis arising from the lower leaf-axils, and closely enveloped by numerous large foliaceous bracts. Glumes four, awnless, those of the 
staminate spikelet acute, those of the pistillate very broad and obtuse or emarginate. Grain hard, only partially enclosed by the fruiting glunies.

A well-known tall and striking annual grass, with erect stems and broad leaves. The terminal stamina'e inflorescence forms the "spindle," and the long projecting styles of the pistillate flowers constitute the "silk." The "cob" is formed by the union of the axes of several female spikes into a much-thickened body. Species one, of Am rrican origin, presenting many varieties in cultivation.

\section{Zea Mays Linn. Indian Corn or Maize.}

() ne of the most valued of the cultivated cereals. The many varieties which have originated in cultivation have been variously classified. They differ much in size, in the form, size, color and hardness of the grain, and in the time required for ripening Husk maize, in which the kernels are separately enveloped within broad herbaceous glumes, may approach the native form, which doubtless had its origin in tropical America. Mais de Cojote, referred to under Euchliena, is said to grow wild in some parts of Mexico. Some have regarded this as a distinct species, naming it Zea canina. The stems in this variety are simple or, more often, branched above, and the numerous small ears are borne in the upper leaf axils or along the branches The ears are two to four inches long; kernels rounded and depressed or conical, the rather acute apex pointing forward, in two opposite rows or irregularly four to six rows. The terminal "spindle" is large, with long, lrooping branches.

Aside from its value as a cereal, ordinary field corn is valued and used by many farmers for silage, being cut for this purpose when the kernels commence to "glaze."

\section{TRIPSACUM Linn. Syst. Ed. 10, ii: 126r (1759).}

Spikelets one-flowered, unisexual, the staminate above the pistillate below in the same solitary or digitate and articulate spities. which are terminal upon the culm or its branches. Staminate spikelets in pairs at each joint of the rachis, the pistillatesolitary. Glumes four, awnless, the outer ones in the male spikelets firm and rigid, the inner hyaline; first glume of the pistillate spikelets coriaceous becoming very hard, the second rigid, the third empty. hyaline, as is the fourth. which encloses the femsle flower. Grain enclosed by the hardened lower glume within the excavation of the thickened joint of the rachis.

Tall, coarse perennials, with very long and rather broad lower leaves and strong thick rootstocks.

Species three or four, all American. One in Tennessee. 
I. Tripsacum dactyloides Linn. Gama or Sesame-grass.

Plate I. Figure 1.

Flowering stems solid, three to eight feet high, becoming more or less branched. Spikes four to eight or ten inches long, solitary or two to three together. When solitary, as is usual on the branches, the female portion of the spike is cylindrical.

This grass is occasionally seen in rich soils along rivers and creeks. It grows in large tufts, producing a great mass of broad leares, which, when young and succulent, are eaten with aridity by stock. When abundant, gama affords a large amount of natural forage, and is valuable to this extent.

\section{Tribe II. ANDROPOGONE..}

Spikelets in spike-like racemes, two at each joint of the articulate rachis, one sessile and hermaphrodite, one pedicellate, this last hermaphrodite, staminate, neuter, or reduced to the pedicel alone. Glumes usually four, the first and second empty, larger and much firmer in texture than the others, the third usually empty, sometimes with a staminate flower in its axil very rarely awned, the fourth or flowering glume hyaline, usually awned; awn usually twisted or geniculate.

This tribe contains about four hundred species, divided among twenty-nine genera, of which the genus Andropogon, with one hundred and ninety species, is by far the largest and probably the most important. Sugar Cane belongs to this tribe in the genus Saccharum. Our best known representative of the Andropogoneæ is the common Broom Sedge, Andropogon Virginicus. In the same genus are now classed our species of Sorghum. The members of the tribe are distributed throughout the tropical and warmer regions of both hemispheres.

\section{MISCANTHUS Andersson.}

Spikelets all alike, one-flowered, hermaphrodite, in pairs along the continuous branches of a terminal spreading panicle, the rachilla articulated below the empty glumes. Glumes four, the first two membranaceous nearly equal, empty: the third less firm in texture. empty: the fourth or flowering glume, hyaline, more or less bifid at the apex and usually awned between the teeth. Palea hyaline. Stamens three.

Rather tall, usually showy grasses with the numerous slender racemes of the terminal panicle more or less spreading.

Species seven, in Eastern Asia, Japan, and South Africa. One species introduced and cultivated here for ornament.

\section{Miscanthus Sinensis Anderss. (Eulalia Japonica Trin.)}

A handsome showy grass used for the adornment of lawns, etc. It has long been known to florists under the name of Eulalia Ja- 
ponica. The long and very numerous lower leares are variegated with cross or longitudinal white bands. The rather delicate and somewhat fan-shaped panicles, if cut when just expanding, are valued for winter bouquets.

\section{SACCHARUM Linn. Gen. Pl. ed. I, No. 49 (1735).}

Spikelets all alike perfect, awnless, in numerous jointed racemes, forming much-branched terminal panicles. The somewhat hard. ened first and second glumes empty, equal, awnless, pilose with long silky hairs, especially on the callus. Third glume, when present, empty and hyaline. The fourth or flowering glume awnless or simply mucronate-pointed, hyaline.

Tall erect perennials with usually simple culms, long leaves and ample terminal panicles; the small spikelets surrouncled by long silky hairs. Allied to Erianthus.

Species twelve, chiefly in the tropics of the Old World.

\section{Saccharum officinarum Linn. Sugar Cane.}

Culms many jointed, six to twenty feet high; leaves three to four feet long and two to three inches wide; panicle rather dense. ovatepyramiclal, the racemes two to four inches long; spikelets about two inches long, much exceeded by the hairs surrounding the base.

Native country not known, probably tropical Asia, but now extensively cultivated in all tropical countries and in some of the Gulf States, especially Louisiana, where its product (molasses and sugar) has become a staple of commerce. A number of varieties have been produced, distinguished chiefly by the color and height of stem.

\section{ERIANTHUS Michx. Flor. Bor. Am. i: $5+\left(1 \mathrm{SO}_{3}\right)$.}

Spikelets in pairs, one sessile the other pedicellate, along the articulate and readily disiointing panicle-branches, both alike hermaphrodite. Glumes four: the outer ones sub-equal, firm-membranaceous, the first flattened on the back and more or less bicarinate and two-toothed at the narrow apex, the second somewhat rounded on the back, sharply acuminate-pointed and more or less keeled above. The third and fourth glumes a little shorter than the outer ones, hyaline, the third empty and nearly always awnless, the fourth enclosing a hermaphrodite flower and awned. Palea usually much shorter than its glume, nerveless. Lodi. cules cuneate, ciliate or naked.

Tall, reed-like perennials with the spikeiets in many-jointed racemes, which are sessile along the main axis, forming an ample terminal and usually woolly panicle.

Species about eighteen. in the warmer regions of both hemispheres. Tennessee species, as here treated, four. 
KEY TO THE SPECIES.

I. Spikelets naked at the base, 4-5 lines long. I. E. strictus.

I. Spikelets very hairy at the base

2. Basal hairs not exceeding the spikelet

2. E. BREVIBARBIS.

2. Basal hairs longer than the spikelet .

3. Spikelet 3-4 lines long, awn twisted . . 3. E. contortus.

3. Spikelet 2 lines long, awn straight - 4. E. AlOPECURoides.

\section{Erianthus strictus Baldw.}

\section{Plate I. Figure 2.}

An erect grass three to six feet high, with smooth stems, very long, narrow leaves and close, narrow terminal panicles, six to. twenty inches long. Nodes smooth or sometimes pubescent with short appressed hairs. Ligule membranous, about one line long, irregularly ciliolate and distinctly auricled; leaf-blade one to two feet long, scabrous on the margins, narrowed towards the base and tapering into long filiform tips. Panicle linear-lanceulate, rigidly erect, the appressed and densely-flowered branches one to four inches long; pedicels about one-half the length of the spikelets. Spikelets about five lines long, narrow-lanceolate, naked or with a few short hairs at the base; outer glumes mcre oi less scabrous, subciliate with short, stiff hairs on the keels above; first glune subcoriaceous, lanceolate, strongly two-keeled, usually sevennerved, bicuspidate at the apex; second glume equalling the first, lanceolate, and long acuminate-pointed or subaristate; third glume a little shorter than the outer ones, lanceolate acuminate. smooth, two- to three nerved; fourth glume about the length of the third, thin, membranaceous, smooth, lanceolate, briefly bifid at the apex, three to five-nerved below, the nerves uniting above and extending into a stout, straight awn eight to ten lines long. Palea about one and one-half lines long, ovate-lanceolate, acute, nerveless. Lodicules truncate, smooth. The third and fourth glumes and palea more or less tinged with purple.-September. Tuilahoma (A. Gattinger); swamps near Jackson (S. M. Bain).

\section{Erianthus brevibarbis. Michx.}

\section{Plate I. Figure 3.}

A stout, erect grass three to six feet high, with terminal hairy and bearded panicles six to eighteen inches long. Culm usually silky just below the panicle, with the nodes, at least the upper, sometimes bearded. Sheaths hairy at the throat; ligule membra nous, lacerate; leaf-blade ten to twenty inches long, three $t_{1}$ ) six lines broad, somewhat scabrous, usually pilose near the base, long attenuate pointed. Spikelets three to four lines long, exceeding the copious hairs at the base and twice as long as the pilose subequal joints and pedicels. Sessile spikelet: first glume strongly two-keeled, aculeolate scabrous towards the strongly bidentate apex, seven-nerved; second glume broadly lanceolate, acuminate pointed, scabrous above and ciliate on the infolded edges; third glume a little shorter than the outer ones, lanceolate, ciliate $n n$ the margins above; fourth glume ciliate on the margins, three- 


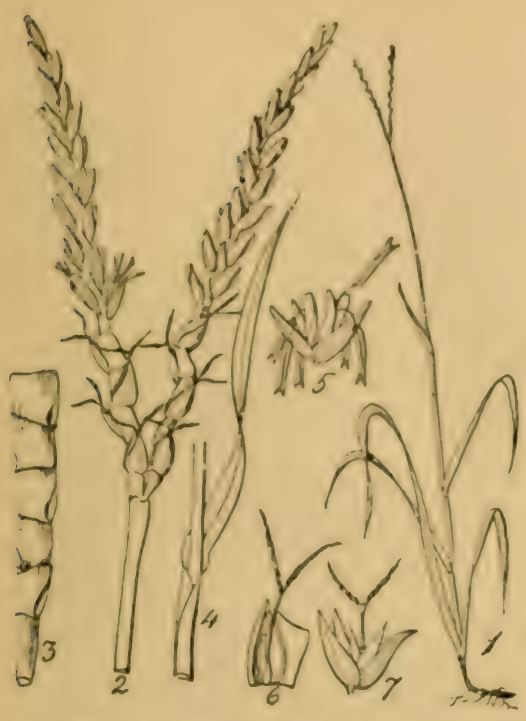

Fig. 1. Tripsacum dactyloides.

2. Inflorescence. 3. Base of the female intlorescence. 4. Upper leaf. 5. Male or staminate splkelet. ס. Female spikelet in section. 7 . Female spikelet expanded.

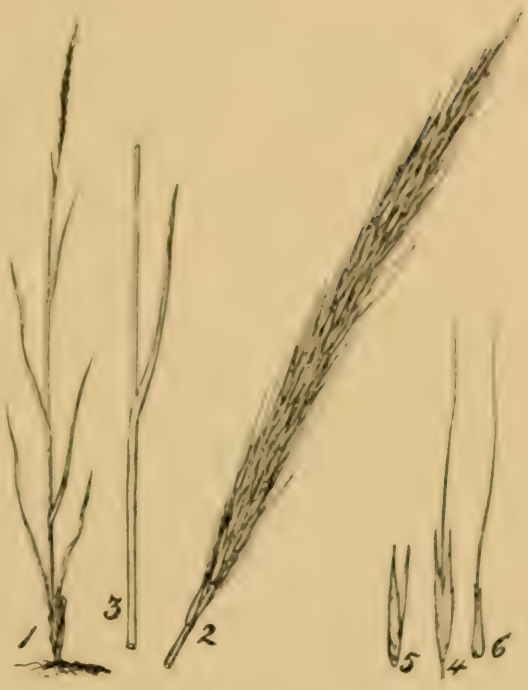

Fig. 2. Erianthus strietus.

2. Panicle, 3. Upper leaf. 4. Splkelet. 5. Empty glumes. 6. Flowering glume

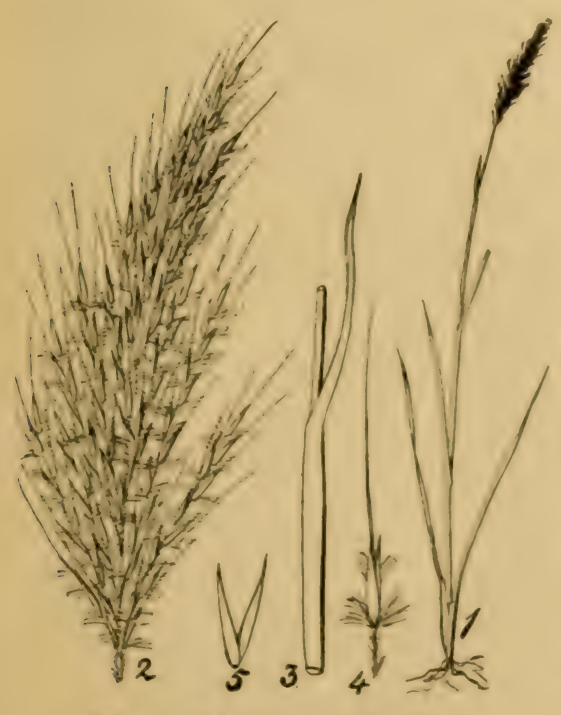

Fig. 3. Erianthus brevibarbis.
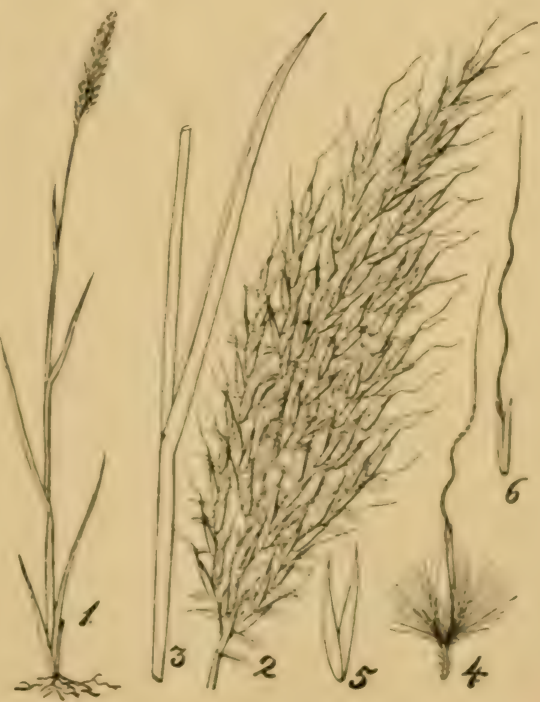

Fiz. 4. Erianthus contortus.

2. Pantcle. 3. Upper leaf. 4. Splkelet. 5. Empty glumes'

2. Panicle 3. Úper leaf 4. Splkelet. 5. Einpty glumes. 8. Flowering glume. 

nerved below and awned between the divisions of the deeply bifid apex; awn seven to ten lines long, slightly twisted, the column not projecting beyond the outer glumes. Palea lanceolate, twothirds as long as its glume. Lodicules more or less ciliate. First giume of the pedicellate spikelet pilose along the margins, with hatirs similar to those at the base-Valley of the Hiwassee (A. Ruth), September, 1893 . Mitchellville, Sumner County. (A. Gattinger.)

\section{Erianthus contortus E11.}

\section{Plate I. Figure 4.}

Culms stout, six to ten feet high, silky-villous near very harry and bearded panicle; nodes bearded with soft appressed hairs. Sheaths shorter than the internodes, smooth, bearded at the throat: ligule irregular, about one line long, finely ciliate, auricled; leaf.blade one to two feet long (the uppermost shorter,) four to twelve line: wide, hairy near the base, margins scabrous, with long, slender tips. Paniclesix to ten incheslong, ovate-lanceolate, or oblong. the joints of the racemes shorter than the sessile spikelets, ciliate with long hairs, as are the pedicels of the primary spikelets. Sessile spikelet three to three and one-half lines long. one-fourth to one half shorter than the copious hairs at the base; first glume broadly lanceolate, seven-nerved, two-keeled, thinly hairy in the back and margins, shortly two-toothed at the apex: second glume as long as the first, acuminate pointed, hairy on the back and ciliate on the hyaline infolded margins above, three to five-nerved; third glume hyaline, a little shorter than the outer ones, ciliate on the margins, usually three-nerved at the base. acute or sometimes awned from the apex; fourth giume shorter than the third, three-nerved at the base, ciliate on the margins, deeply cleft and awned from between the divisions; awn six to seven lines long, twisted, the column projecting beyond the outer glumes. Palea one half as long as its glume, fringed at the apex. Lodicules truncate smooth. Stamens two, about one line long.Specimens collected in the Hiwassee Valley by Prof. A. Ruth have the third glume long-awned, similar to the fourth. This is the only locality at present known within the State.

\section{Erianthus alopecuroi des E11. Plume-grass.}

\section{Plate II. Figure 5.}

An erect grass, with stout, leafy stems three to ten feet high, with rather densely flowered, woolly panicles five to ten inches long. Culms round or slightly flattened near the base, densely villous below the panicle and usually with a dense ring of erect hairs at the nodes, at least the upper ones. Sheaths pilose above and usually densely villous at the summit, with appressed hairs and bearded at the throat: ligule one to two lines long. ciliate: leaf-blade six to twenty-four inches long. tapering towards the base and long acuminate poirted, surface smooth or thinly hairy, margins scabrous. Spikelets about two lines long. less than half the length of the copious ring of hairs at the base. Pedicels of the primary spikelets half the length of the sessile spikelet, this a little exceeding the sparingly pilose joints of the raceme. Sessile 
spikelet: empty glumes smooth or with a few long hairs above, first glume lanceolate acuminate, two-toothed at the apex, scahrous along the keels above; second glume lanceolate acuminate, equaling the first glume and similar in texture: third glume lanceolate acuminate, acute or rarely awned, three-nerved, ciliate on the margins above; fourth glume lanceolate, shorter than the third, three-nerved below and awned from the entire apex, awn straight about ten lines long. Palea small, ovate. Inner glumes and fimbriated lodicules dark purple.-Oakland Station, near Tullahoma (A. Gattinger). August to September.

In the University herbarium there is a specimen from Sumner County ticketed by Dr. Gattinger, "E. brevibarbis." As there is no specimen of $E$. brevibarbis in the collection from Dr. Gattinger, this may be the plant referred to in his "Tennessee Flora" as growing near Mitchellville.

\section{ANDROPOGON Linn. Sp. P1. I045 (1753).}

Spikeleis in pairs at each joint of the articulate and usually hairy rachis of the short racemes or false spikes, one sessile and hermaphrodite with four glumes, the other pedicellate, staminate (very rarely hermaphrodite), neuter, reduced to a mere rudiment or even wholly absent, the hairy pedicel alone remaining. Racemes solitary, in pairs or variously clustered and paniculate, often subtended by a sheathing bract (the spathe.) Outer glumes subequal, much firmer in texture than the inner ones. First glume of the sessile spikelet coriaceous or cartilaginous (rarely herbaceous), flattened or depressed upon the back with one nerve near each margin stronger than the others, forming two keels; second glume more pointed than the first and more or less keeled, at least above; the third glume herbaceous or hyaline, a little shorter than the outer ones, empty; the fourth or flowering glume hyaline, entire, or more or less bifid at the apex and awned. Awn terminal or from between the teeth of the glume, straight or more often twisted in the lower part (the column), bent near the middle and very slender above. Palea usually present, hyaline and nerveless, rarely more than half the length of its glume.

Slender or rather coarse perennials with solid culms, growing chiefly in dry, sandy or poor soil.

Species about one hundred and eighty, widely distributed over both hemispheres, especially in the tropical and sub-tropical regions. Thirty-five species are recorded as being found within the United States. Those enumerated below have been found in Tennessee.

\section{KEY TO THE SPECIES.}

I. Racemes $\mathrm{I}-5$, terminal on the culm or its branches and subtended by a spathe-like bract . . . . . . . . . . 2

I. Racemes in terminal bractless panicles . . . . . . . . 7

2. Hairs on the joints of the rachis and pedicels shorter than the spikelets . . . . . . . . . . . . . 3

2. Hairs longer than the spikelets . . . . . . . . 4 
3. Racemes slender solitary, pedicellate spikelets reduced to one or two empty glumes . . . . 1. A scorarius.

3. Racemes stout, $2-5$ together, digitate; pedicellate spikciet with four glumes, staminate (rarely hermaphrodice or neuter) .......... 2. A. provincialis.

4. The plumose pedicels shorter than the sessile spikelets

4. Pedicels longer than the sessile spikelets . . . . . . . . 5

5. Cpper leaf-sheaths inflated, imbricate: spathes narrow, close. racemes finally exserted on long slender peduncles

5. Lpper sheaths not conspicuously inflated, racemes subses. sile within the loose spathes

6. Branches of the culm short, erect, rather distant, forming an elongated false panicle . . . 5. A. Virginicus.

6. Branches longer and more compound, crowded towards the summit of the culm and more or less spreading, the general inflorescence corymbosely-paniculate

6. A. MACROURUS.

7. Primary branches of the panicle solitary, pedicellate spikelet wanting . . . . . . . . . 7. A. NUtAns.

(a) Spikelets light brown, awn four and one-half to ten lines long, the column straight or nearly so.

(b) Spikelets very dark brown, awn twelve to fifteen lines long, the column distinctly geniculate. var. Linnuanus.

7. Primary branches whorled pedicellate, spikelet present and usually staminate. . 8. A. SORGHUM var. HALEPENSE.

1. Andropogon scoparius Michx. Little Blue-stem, Mountainsedge.

Plate II. Figure 6.

A rather slender perennial, one to three feet high, more or less paniculate-branched above, the single racemes terminal on the culm or branches. Culms somewhat compressed below. Leaf-sheaths carinate, smooth, scabrous or of ten pilose; ligule about a line long, truncate: leaf-blade two to ten inches long, one to three lines wide, very acute, the mid-vein prominent below. Spathe one to two inches long, narrow and acute, or with a short rudimentary blade. apex of the peduncle smooth or sparingly pilose. Racemes partially enclosed within the spathe, or more often exserted, erect in flowering, six-to twelve-jointed, the rachis straight or usually flexuose; joints rather slender, somewhat thickened above, rounded and scabrous on the back, flattened on the anterior face, pilose on the edges from near the middle, the hairs increasing in length towards the apex, abnut one-half the length of the sessile-spikelet. Pedicellate spikelet reduced to a short-awned, narrow crlume, which usually encloses a smaller one, rarely a staminate flower. Pedicel a little shorter than the sessile spikelet, flattened and broader above, spreading when dry: pilose along the edges, the hairs increasing in length above. Sessile spikelet narrow, lanceolate, appressed to the rachis, three to five lines long; first glume 
rigid, herbaceo-chartaceous, sharply two-keeled with narrow, strongly inflexed margins, keels scabrous; second glume about the length of the first, lanceolate, acuminate, or short-awned, onenerved, scabrous on the keel and more or less ciliate on the margins; third glume deep purple or violet, a little shorter than the second, narrowly lanceolate, acute, the infolded margins ciliate on the edge; fourth a little shorter than the third, narrowly oblong, ciliate along the margins, more or less deeply bifid at the apex and awned between the acute divisions; awn four to nine lines long, the closely twisted basal portion (the column) barely exceeding the outer glumes.

Common throughout the State, usually in dry, more or less sandy soil. It is valued in the mountain districts of East Tennessee for grazing, and is there known as Mountain Sedge-grass or Little Blue-stem. It flowers from August to October.

This species is quite variable in its technical characters, and several forms and varieties have been characterized:

I. Typica. Racemes in a long, strict, and usually much-branched panicle, partly or wholly enclosed within the spathe Spikelets three to three and one-half lines long. Sheaths usually pilose.

2. Flexilis. Racemes long-exserted, spikelets smaller (less than three lines).

3. Casia. Sheaths ana spathe pruinose.

4. Serpentina. Rachis of the racemes strongly undulate.

5. Simplicior. Branches simple with rarely more than a single raceme. Spikelets four lines long.

6. Lolioides. Spikelets four and one half to five lines long.

\section{Andropogon provincialis Lam. Big Blue-stem.}

\section{Plate II. Figure 7.}

A stout perennial, two to five feet high, with rather thick racemes, two to five together, terminal on the culm and its branches. Culms smooth, terete, often pruinose below the nodes, branched above; branches single (rarely two or four together) simple. Sheaths smooth or sometimes pilose, those of the sterile shoots usually comıpressed-keeled; ligule very short (one-half to one line) truncate; leaf-blade eight inches to two feet long, two to five lines wide, tapering into long setaceous points, margins scabrous, and often fimbriate near the base. Spathes usually about four inches long, smooth, acuminate-pointed. Racemes at length long exserted, two to eight together, closely approximate along the shortened common rachis, appearing digitate, more or less spreading, densely flowered; joints about one-half the length of the sessile spikelet, usually with a dentate appendage at the imperfectly cupshaped apex, somewhat flattened and ciliate along the edges, the longer upper hairs one-half as long as the pedicel. Pedicellate spikelet lanceolate, staminate, with four glumes; first glume lanceolate, acuminate or mucronate pointed, serrulate-scabrousalong the scarcely infolded margins, smooth on the back or punctate scab. rous above, seven to eleven-nerved; callus naked cr shortly pilose; second glume a little shorter than the first, lanceolate, acute, three 


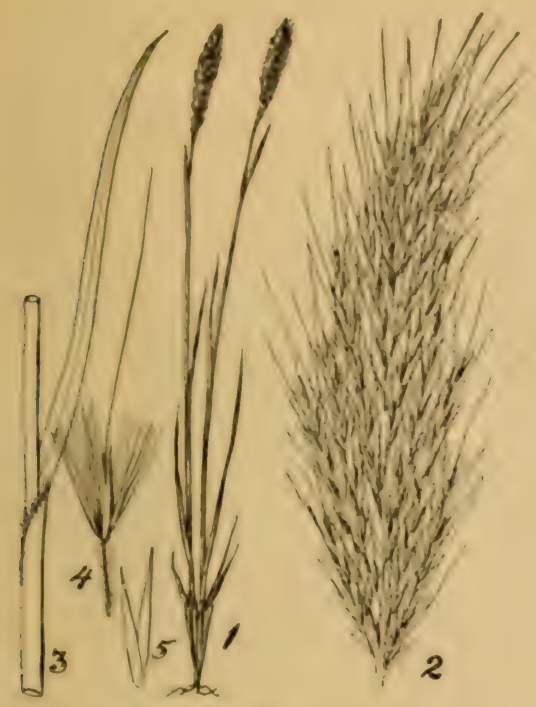

Fig. 5. Erianthus alopecuroides.

2. Pantcie. 3. Upper leaf. 4. Splkelet. 5. Finpty glumes.

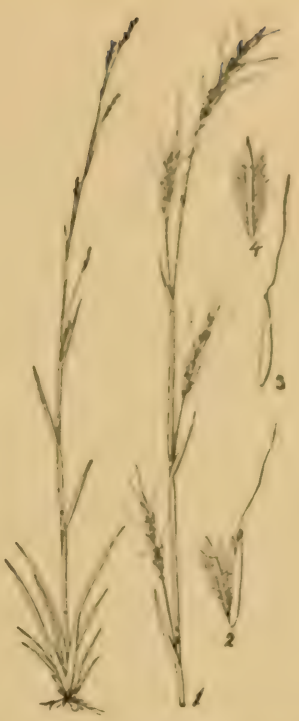

Fig. 6. Andropogon scoparian.

1. Inflorescence, 2. Splkelet and pedlcel of a rudimentary spikelet. 3. Floral glume. 4. Rudimentary splkelet and its pedicel.

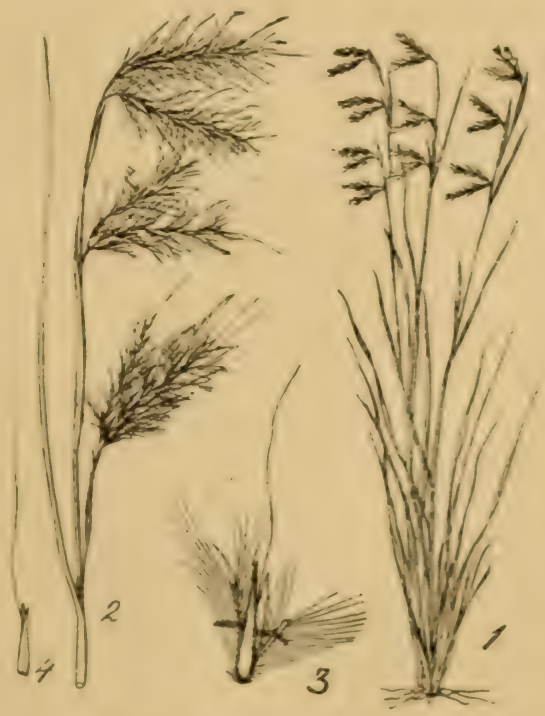

Fig. 8. Andropogon argyrisus.

2. Inflorescence. 3. Splkelet and pedı. cel. 4. Floral glume with Its awn.
1. Upper part of culm. 2. Part of inflorescence. y Fertlle splkelet. (The awned glume should be on the right.) 4. Flower ing glume of fertlle splkelet. 5. Rudiment . ary pedicellate splkelet. 6. Entire plant. much reduced. 

to five nerved, the hyaline margins ciliate; third glume equalling the second, the fourth somewhat shorter, both one-to three nerved. lanceolate and acute. Palea small. Sessile spikelet three and onehalf to five and one-half lines long, narrow-lanceolate, acute; first glume coriaceous, very acute, or sometimes long acuminatepointed, apex minutely bimucronate, margins strongly inflexed, keels aculeolate scabrous, the back punctate scabrous or smooth below, callus barbate, the hairs about one-fourth as long as the glumes; second glume equalling the first, lanceolate, boat-shaped, acuminate or mucronate, one-nerved, keel scabrous, the narrow, infolded and hyaline margins ciliate; third glume a little shorter than the second, lanceolate, imperfectly three-nerved, the infolded margins ciliate; fourth glume somewhat shorter, lanceolate, more or less (leeply bifid at apex, the divisions acute, ciliate on the margins, three-nerved near the base, awned; awn six to eight lines long. with the column slightly exserted from the glumes. Palea one-half to two-thirds as long as its glume, fimbriate at apex. Anthers yellow, one and one-half lines long. Stigmas purple.

This species varies a good deal in the number of the racemes, size of the spikelets, and special characters of the culm and foliage. According to Hackel the callus of the pedicellate spikelet is distinctly barbate in the typical plant. In subvariety furcatus the base of the pedicellate spikelet is smooth, the sheaths often villous. In subvariety Lindheimeri the spikelets are five lines long. the mouth of the sheaths barbate, and the leaves more or less tuberculate-pilose. In the subvariety frcnanthus, the joints of the racemes are about one-third the length of the sessile spikelet, which is three and one-half to four lines long. These varieties may all be found within the State, and also the following: Variety Tennessecnsis Scribn: rachis, pedicels, and outer glumes roughscabrous, hairs yellow; pedicellate spikelet as large as the sessile, hermaphrodite, with the fourth glume sometimes short awned. This variety is based upon specimens found near knoxville. It is well marked, approaching $A$. Hallii.

Big Blue-stem is a strong-growing, native grass, found throughout the State in dry soil, though rarely seen in cultivated lands. In some sections of the country it is valued both for hay and pasture. When young it is readily eaten by stork, the stems being very leafy, but after flowering the stems become hard and woody. and of little value. In certain soils, or under certain conditions, this grass might be worth cultivating. It grows to the height of three or four feet, and like all the Andropogons, blooms late in the season.

\section{Andropogon argyræus Schult. Silver Beard-grass.}

Plate II. Figure 8 .

A rather slender, branching perennial, two to three feet high, the branches all terminating in a pair ci more or less spreading. white 
BULletin VII. 1.

silky-bearded racemes. Sheaths of the sterile shoots compressed, the narrow scabrous leaf-biades much elongated (a foot or more), those of the culm shorter and one and one-half to two lines wide. Spathe narrow, two to three inches long. Common peduncle densely villous at the apex. Racemes finally long-exserted, one and onehalf to two inches long, eight to ten-jointed, the joints densely plumose-bearded, somewhat thickened above, the apex of the articulations cup-shaped, the margin of the cup irregularly dentate. Sterile spikelet reduced to a narrow glume one to one and onehalf lines long, the long-plumose pedicel shorter than the sessile spikelet. Sessile or hermaphrodite spikelet lanceolate, acuminate, about two and one-half lines long, exceeding the joints of the rachis; first glume rigid, narrow lanceolate, long acuminate pointed, the apex entire or minutely bimucronate, sharply bicarinate, with narrow infolded margins, back smooth, much depressed, keels rough-scabrous, callus hairy, the hairs about one-third as long as the glume; second glume equalling the first, lanceolate, acuminate, one-nerved, keeled, keel serrulate-scabrous; third a little shorter than second, hyaline, lanceolate, acute, ciliate on the margins above; fourth about equalling the third, bifid at the apex and awned between the acute divisions; awn seren to eight lines long, somewhat twisted and flexuose near the middle. Palea nearly one line long, ovate, obtuse. Lodicules manifest, broadly wedgeshaped, smooth.

Silver Beard-grass is a native species, found occasionally along the borders of woods, less common in open fields. It grows to the height of two or three feet, and is noticeable for its silvery-white "heads," which appear in September.

\section{Andropogon Elliottii Chapm.}

Plate III. Figure 9.

A slender upright perennial two to three feet high, with a short, sparingly-branched panicle of a few more or less exserted plumose racemes. Upper joints of the culms often densely silky-bearded just below the nodes, with erect appressed hairs. Culm leaves flat, one-half to one and one-half lines wide, the lower five to ten inches long, smooth or pilose near the base, the three to six upper leares approximate, their smooth inflated sheaths imbricated. Panicle simple. four to ten inches long. Racemes in pairs (rarely ternate), three-fourths to one and one-half inches long, the slender flexuose rachis about seven-jointed, plumose, as is the pedicel of the sterile spikelet with long (threelines) white hairs. Pedicellate spikelet reduced to a minute glume, the pedicel longer than the sessile spikelet. Sessile spikelets narrow-lanceolate, about two lines long, hairy on the callus; first glume minutely bimucronate at the narrow apex, depressed between the keels, which are finely aculeolate-scabrous above; second glume as long as the first, one-nerved, keeled above and scabrous on the keel; third glume equalling the first, hyaline, acute, ciliate, empty; fourth a little shorter, hifid at the apex and awned between the acute divisions. Awn slender, seven to twelve lines long, flexuose near the middle, the column projecting a little beyond the glumes. Palea minute. Stamen one. 



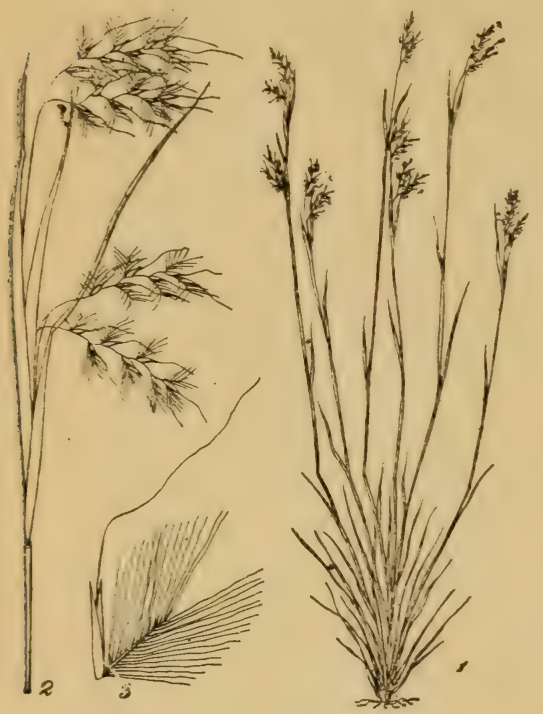

Fiz. 9. Andropogon Elliottii.

2. Upper part of culm and inflorescence. 3. Spikelet and plumose pedicel.

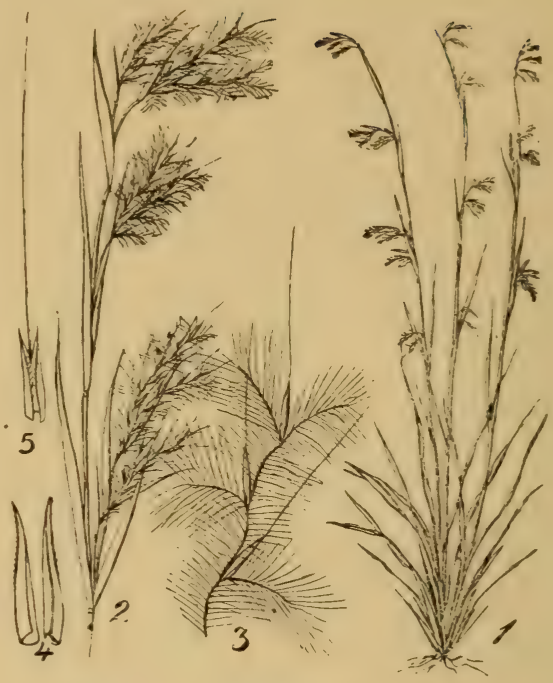

Fig. 10. Andropogon Virginicus.

2. Upper part of culm and inflorescence 3. Portion of one of the racemes with three spikelets. 4. Outer empty glumes. 5. $\Lambda$ wned floral glume.

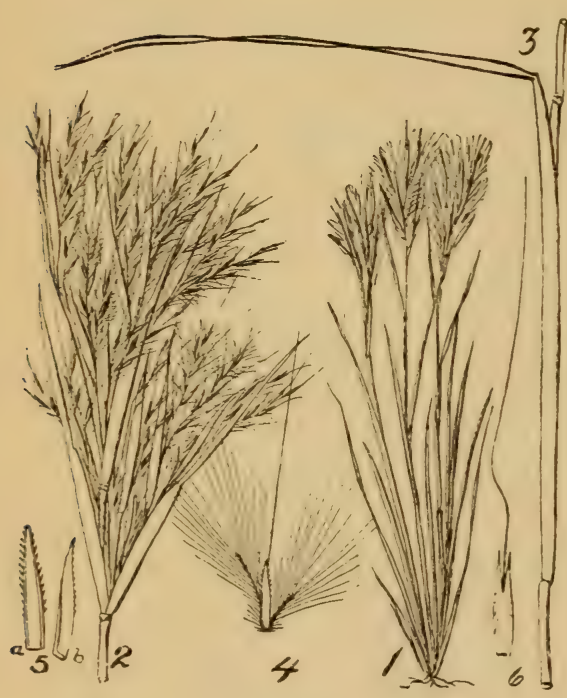

Fig. 11. Andropogon macrourus,

2. Inflorescence. 3. Portion of the culm and upper leaf. 4. Splkelet, joint of the rhachis and pedicel. 5. Outer empty glumes. 6. Awned flowering glume.

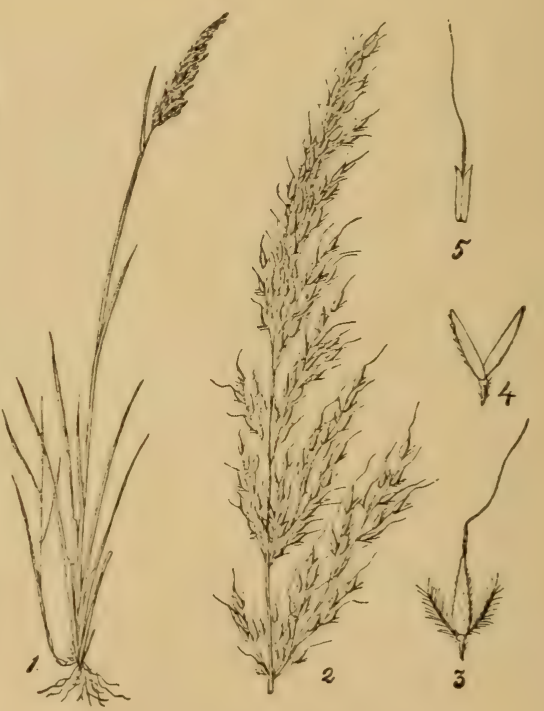

Fig. 12. Andropngon nutans.

2. Inflorescence. 3. Spikelet and pedlcels. 4. Empty glumes. 5. Awned flowering glume. 
Two forms occur within the State:

Var. GENUINA.

Culm leaves one to one and one half lines wide. five to six of the upper sheaths inflated, racemes one and one fourth to one and onehalf inches long. spikelets about two and one-half lines long and the awn about an inch long. Found in the valley of the Hiwassee by Prof. A. Ruth, September.

Var, gRACILIOR Hack.

Culm leaves one-half line wide, only two to three of the upper leaf-sheaths inflated. racemes about one inch long; spikelets one and one-half to two lines long: awn one-half to three-fourths of an inch long. This species is readily recognized by the inflated upper leaf-sheaths, from which project the long and slender peduncles of the white-hairy racemes. The spathes proper are rarrow and closely wrapped around the peduncles. Apparently not very common nor of any agricultural value.

\section{Andropogon Virginicus Linn. Broom-sedge. \\ Plate III. Figure 10.}

A rigidyerect perennial, two to four feet high, with theculms flattened near the base, and a narrow elongated and loosely. branched panicle of silky-bearded racemes, which are for the most part exceeded by and partially enclosed within smooth spathe-like bracts. Sheaths of the sterile shoots at the base strongly compressed. keeled, their leaf-blades two to five inches long, and always more or less folded; lower culm leaves six to twelve inches long, one to two and one-half lines wide, usually flat and more or less long-pilose towards the base. Panicle ten to twenty inches long, the branches short and rather distant, the primary with two to five nodes. Spathe one to two and one-half iriches long, lanceolate, acuminate, smooth. Racemes in pairs (rarely three to five) onehalf to one and one-half inches long. the common peduncle very short (one to two lines), the very slender and more or less flexuose rachis eight-to fifteen-jointed; joints and pedicels of the sterile spikelets clothed with long plumose hairs. Primary and pedicellate spikelet reduced to a slender awn or wholly abient: the pedicel about three lines long. Sessile spikelet narrow-lanceolate, one and three-fourths to two lines long, about one-fourth longer than the joints of the rachis, its callus with a few short hairs. First glume depressed on the back between the two shąrp keels, which are aculeolate-scabrous above, apex narrow and minutely bimucronate: second glume lanceolate, acute, one-nerved, keeled above. glabrous: third hyaline, narrowly oblong, obtuse, glabrous: fourth hyaline, a little shorter than the third, awned between the short and acute divisions of the bifid apex; awn slender, straight, five to seven lines long. Palea minute. Stamen one.

There is probably no native grass better known to our farmers than this. Although when quite young it affords excellent grazing and the mature plants may have some value for silage, it is, on the whole, one of our worst weeds, rendering the formation of permanent meadows very difficult. Constant tillage seems to be the only means of keeping this grass from occupying the land. 


\section{Andropogon macrourus. Michx. Brook grass.}

Plate III. Figure 11.

A stout perennial grass, two to four feet high, with the culms somewhat compressed near the base and a more or less elongated dense panicle, the numerous compound branches usually very much crowded above by the shortening of the nodes of the common rachis, giving the grass the appearance of being "bushybranched" at the summit. Sheaths of the sterile shoots and those of the lower culin leaves compressed, imbricated, smooth, or more or less hairy; leaf-blade of the sterile shoots eight to twenty inches long, those of the flowering culm shorter and two to five lines wide. Panicle four to twenty inches long, the nodes, as well as those of the erect and more or le's fastigiate branches usually barbate with rather long, soft hairs. The sheathing bracts at the base of the racemes one-half to one and one-half inches long, usually scabrous, especially along the mid-nerve. Racemes in pairs. one half to one inch long, the filiform plumose-hairy joints shorter than the sessile spikelet. Sterile spikelet reduced to a minute bract or short awn, its slender, plumose pedicel longer than the sess le spikelet. Sessile or hermaphrodite spikelet about two lines long, narrowly lanceolate. First glume tapering from near the base to the very narrow, ertire or minutely bimucronate apex, twokeeled, the keels aculeolate-ciliate above, callus with a few short hairs; second glume lanceolate, acute; keeled above and scabrous on the keel and imperfectly ciliate along the hyaline margins; third glume lanceolate, acute, hyaline, ciliate along the margins, a little shorter than the second; fourth giume hyaline, about the length of the third, ciliate along the margins, awned between the acute divisions of the bifid apex. Awn slightly twisted or flexuose near the base when dry, straight and very slender above, six to seven lines long. Palea minute or none.

This is rather a stout-growing species, similar in habit to broomsedge, but more robust, and although pretty generally distributed over the State, it is far less common than that grass. It blooms from September to October.

\section{A. nutans Linn. (Sorghum nutans A. Gray). Indian-grass.}

\section{Plate III. Figure 12.}

Culms simple, three to five feet high, terete, smooth, often bearded at the nodes. Sheaths smooth, extending into a rigid ligule one to three lines long; leaf-blade narrowly lanceolate, three to eight lines wide, ten inches to two feet long. narrowed at the base and tapering into a long, slender apex. Panicle six to twelve inches long, lax, or sometimes rather densely-flowered, nodding at the apex; primary branches solitary, straight ascending, repeatedly branching from the base; ultimate branches filiform and a little pilose below the spikelets, straight, or somewhat flexuose. Racemes short, one-to four-jointed (bearing one to four spikelets), joints filiform, flexuose, shorter than the spikelets, ciliate. Spikelets three to four lines long, shining, usually pale, reddish brown (sometimes very dark brown), lanceolate; first glume 
coriaceous, more or less pilose, broadly lanceolate or narrowly oblong, apex truncate, flat or slightly convex on the back, five- to nine-nerved, margins subinvolute; callus short, obtuse, white-barbate; second glume similar in texture, narrower, fewer-nerved and a little longer than the first, obtuse or with a depressed triangular apex; third glume as long as the first, hyaline, nerveless, obtuse, ciliate on the margins; fourth glume a little shorter than the third, ovate-lanceolate, three nerved, ciliate, apex bidentate or bifid, awned between the divisions. Palea small, fringed at the broad apex, sometimes wanting. Pedicel very slender, plumose, shorter than the sessile spikelet, to which it is appressed.

A variable species presenting numerous well-marked varieties, some of which have been regarded as distinct species. Two forms come within our limits.

1. Var. avevaceus (A. arenaceus Michx. A. ciliatus Ell; Sorghum avenacum Chapm.) Panicle rather dense, six to twelve inches long, spikelets lanceolate, three to four lines long, the first glume more or less pilose. second glume glabrous; awn five to ten lines long, its column straight or very slightly geniculate. Lower racemes with only two to three spikelets. In dry, sandy soil, open pine woods, etc

This is a stout perennial grass, four to six feet high, growing in dry soil, along borders of fields, or open woods. It rarely occurs in sufficient abundance to be of any value, and when it has bloomed, its stems are too stout and woody to be eaten by stock. It is not to be recommended for cultivation.

2. Var. Linvianus Hackel. (Sorghum nutuns Chapm. Chysupogon mutuns Benth.) Plate IV. Figure 13. Panicle eight to twelve inches long, lax, branches straight or more or less curved; spikelets linear oblong, very dark brown, three to four lines long, the first glume thinly pilose to the middle, callus one-half line long: second glume glabrous, or sparingly pilose, awn twelve to fifteen lineslong, its column distinctly geniculate near the middle. Ra. cemes ustially reduced to a single spikelet. Steri'e pedicel about the length of the spikelet. This form approaches A. unilateralis.

Dry bluffs near Knoxville.

\section{Andropogon Sorghum Halepense Hackel. (Surghum Halepense Pers.) Johnsun-grass.}

\section{Plate IV. Figure 14.}

A stout, perennial, with smooth, erect, simple culms, three to five feet high, and strong creepirig rootstocks. Leaves elongated, onefourth to three-fourths inches wide, acute; ligule ciliale, and un the back where the leaf-blade juins the sheath there is more or less pubescence. Panicle open, six to twelve inches long, the whorled branches naked below, the three to five flowered racemes clustered towards their extremities. Pedicels of the staminate (rarely neutral) spikelets pilose with stout hairs. Sessile spikelet broadlylanceolate, acute, two to three lines long, pale green or violet, becoming dark or nearly black at maturity. Callus small, ohtuse, shortly and sparseiy barbate. First glume coriaceous, sparingly 
pubescent on the flattened back, five to seven-nerved; second glume similar and equalling the first, convex below, subcarinate above, acute, the hyaline inflexed margins ciliate; third glume a little shorter than the outer ones, membranous, faintly two-nerved, the infolded margins ciliate; fourth glume broadly oval, obtuse, nearly one-half shorter than second, two-lobed or bidentate at the apex, ciliate, awned. Awn five to eight lines long. Palea a little shorter than its glume, nerveless, ciliate.

Johnson-grass is now pretty well known in Tennessee, having been introduced quite generally over the State. There are a few who still regard it as a valuable grass for hay, and certainly its yield is very large and the hay produced is excellent; but there are a great many more who are ready to offer a handsome reward to any one who will free their lands from it. It has strong, underground stems, which grow deeply, taking the soil completely. This habit makes Johnson-grass exceedingly difficult to eradicate, for the least fragment of these underground stems, if left in the soil, serves to produce a new plant. Unless one wishes to give the land up for an indefinite period to this grass, its cultivation ought not to be undertaken.

\section{Tribe V. PANICE A.*}

Spikelets hermaphrodite, compressed from the back or not at all flattened; glumes three or four, when four there is occasionally a staminate flower or a palea in the axil of the third; the uppermost or flowering glume of the hermaphrodite flower is always firmer in texture than the outer glumes, of which the first is usually smaller than the others. Axis of the inflorescence not articulated, the rachilla being articulated below the empty glumes, the spikelets falling off singly from their pedicels.

This is one of the largest tribes in the order Gramineæ. It contains twenty-two genera, with over $6_{3}$ o species. Panicum, the principal genus, is the largest among grasses, numbering three hundred species. The Panicea are very widely distributed throughout the tropical and temperate regions of the world. Crab-grass and the millets (Setarix species) are among our best known examples of this tribe.

\section{PASPALUM Linn. Syst. ed. io, ii. 855 (1759).}

Spikeiets one-flowered, plano-convex, nearly sessile in two to four rows along one side of a continuous narrow or dilated rachis, forming simple racemes, these either solitary or two or more together and digitate or paniculate; rachilla articulated below the empty glumes. Glumes three (rarely only two or four) awnless, usually obtuse, the first two empty, membranaceous, equal or

*Tribes III., Zoysleæ, and IV., Tristegineæ, are not represented in Tennessee. They are small tribes, together having only about sixty specles, chlefly tropical. 
nearly so, and undully as long as the cortilaginous third glame which encloses a palea of similar texture and a hermaphrodite flower. Grain oblong, encloied with the inclurated fruiting glume and palea.

Perennials, very variable in habit, usually growing in moist grounds. Species about one hundred and sixty, widely distrib. uted, especially abundant in the tropical regions of America. There are about forty species and varieties in the United States, chiefly in the Southern districts. The following have been found within the State.

\section{KEY TO THE SPECIES.}

I. Rachis of the racemes thin and membranous, the mar. gins nearly covering the sinall, two-rowed spikelets . . 2

1. Rachis firm, narrower than the two to funr-rowed spikelets 3

2. Rachis projecting beyond the spikelets 1. P. Mcckonatum.

2. Rachis not extending beyond the spikelets

2. P. MEMBRANACEUM.

3. Plants extensively creeping, racemes digitate

3. Plants not excensively creeping, racemes solitary or scattered along the main axis

4. Racemes in pairs at the apex of the culm, widely spreading, spikelets $1 / 2$ lines long acute . . . 3. P. Distichum.

4. Racemes 2 to 6 , very slender, erect or ascending, spikelets I line long . . . . . . . . 4. P. Compressum.

5. Spikelets acute, the margins of the lower glume conspicuously hairy . . . . . . . 5. P. Dilatatum.

5. Spikelets obtuse, outer glumes smooth or nearly so

6. Rachis flat on the back, about a line wide, its margins nearly straight, spikelets mostly four-rowed

6. Rachis narrower, undulating or flexuose, spikelets for the most part two-rowed

7. Culms branching only near the base, racemes 3 to $i$, spikelets $\mathrm{I} / \mathrm{4}$ lines long, flowering glume green

6. P. PUBIFLORUM, var, GLABRUM.

7. Culms branched above, racemes three to twelve, spikelets one line long, flowering glume dark brown and punctate-dotted . . . . . . . 7. P. Boscianim.

8. Racemes 2 to 6 , rather stout, spikelets one and one-half to two lines long.

8. Racemes often solitary, very slender, on long-exserted terminal and frequently lateral peduncles, spikelets one line or less long .

9ulms 3 to 5 feet high, racemes erect or ascending, spikelets two lines long ...... 8. P. Floridanum.

9. Culms I to 3 feet high, racemes spreading, spikelets one and one-half lines long . . . . . . . . 9. P. L.EVE.

10. Leaves 5 to 12 inches long, spikelets one line long, floral glumes with a distinct depression on the back near the base 
Io. Leaves I to $f$ inches long, spikelets three fourths of a line long, flowering glume without any distinct depression on the back . . . . . II. P. LONGIPEdunculatum.

\section{Paspalum mucronatum IIuhl. (I817.) (Paspalum fluitans Kunth. I 829.)}

Plate-IV. Figure 15.

An aquatic grass with branched ascending culms from a creeping or floating base, six inches to three feet long, and numerous slender racemes. Nodes usually bearded. Sheaths lax, smooth, or more or less densely papillate-pilose with spreading hairs; ligule membranaceous, shi.rt, broadly truncate, auriculate; leaf-blade lanceolate, acute, one to six inches long, three to seven lines wide, scabrous. Racemes ten to fifty, slender, one to three inches long, alternate or whorled below, ascending; rachis flat, thin, margins scabrous, covering the spikelets and extending beyond them into an acute tip. Spikelets lanceolate-elliptical, subacute, three-fourths line long, biseriate, rather thinly pubescent with minute glandular hairs; outer glumes very thin, two-nerved, nerves nearly marginal, first glume a little longer than the others, the second with a brown spot near the base.

A form of this species, with rather densely pilose sheaths, was collected by Dr. Gattinger at Richland Station in Sumner county, August 27,1883 . It doubtless grows on the Mississippi bottoms along the western borders of the State. Its recorded range is "river swamps, Virginia to Southern Illinois, Missouri, and Southward." Of no agricultural value.

2. Paspalum membranaceum Walt. (I788) not of Lam. (I791.) (Paspalum Walterianum Schult. Paspalum vaginctum E11.)

Plate IV. Figure 16.

A low, creeping. semi-aquatic grass, with much branched, smooth stems, six to eighteen inches long, with short, flat leaves, and small racemes, the lower ones usually enclosed in the uppermost sheath. Sheaths somewhat inflated, smooth; ligule about one line long, acute; leaf-blade lanceolate or linear, one-half to two inches long, one to two lines wide, acute, rounded at the base, smooth, minutely scabrous on the margins. Racemes two to six on each branch, one terminal, the others alternate below it, one-half to one inch long; rachis flat, thin, one to one and one-half lines wide, many-nerved, smooth, the ciliate-scabrous inflexed margins partially concealing the spikelets, abruptly pointed with a single spikelet at the apex. Spikelets ovate-obtuse, smooth, about one line long, crowded in two rows; outer glumes five-nerved; flowering glume lenticular, rounded-obtuse, a little shorter than the outer ones.

Low, swampy grounds along the Cumberland river near Nashville, (Dr. A. Gattinger), September, I882. Probably grows in similar situations at other points within the State, but this is the only recorded station. It ranges from New Jersey to Florida; originally discovered in South Carolina. Of no agricultural importance. 


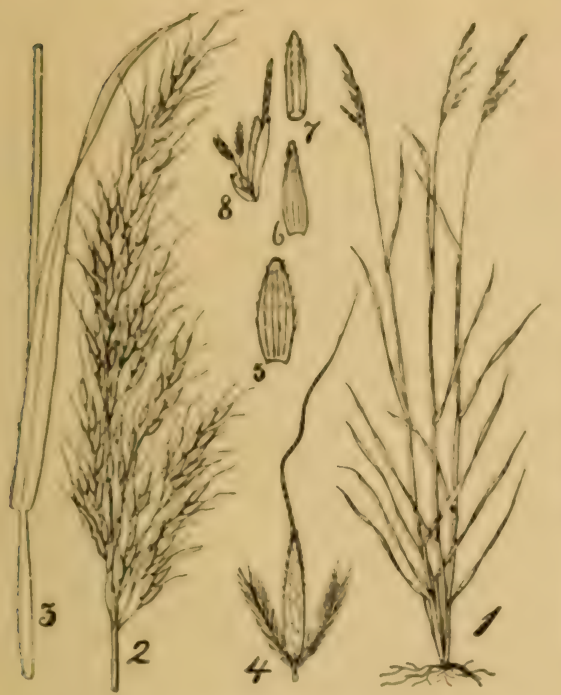

Hi.. 13. Andropogon nutans Linnaanus.

2. I’antcle. 3. Upper leaf. 4. Splkelet. 5. First glume. 6. Second glume. 7. Third glume. ४. Fourth glume, palea and pistll.

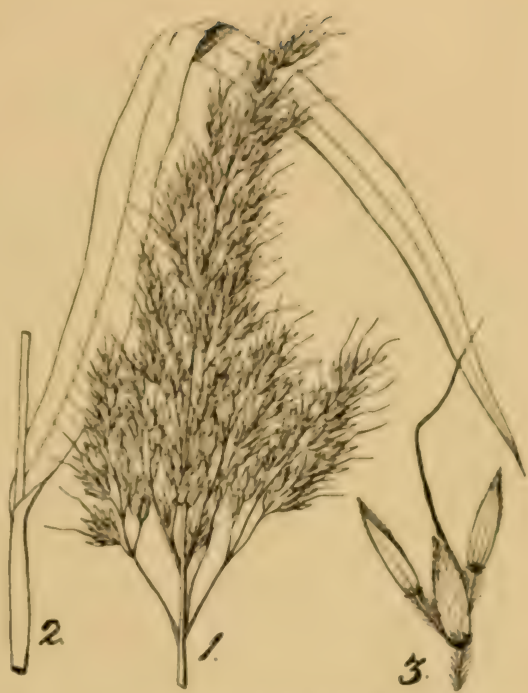

Fig. 41. Andropogon sorghum Halepense.

1. Pantcle. 2. Upper leaf. 3. Splkelet.

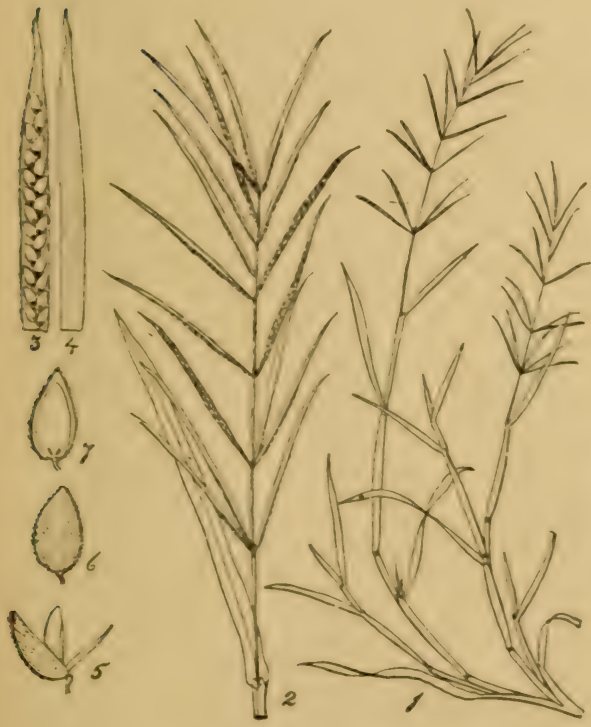

Fig. 15. Paspalum mucrunatum.

2. Inflorescence. 3. Ipper part of the rhachlswith splkelets. front rlew. t. The same. back vlew. 5 splkelet, from the slde i. l.ower empty glume. i. Splkelet showing smooth upper empty glume and margins of lower glume.

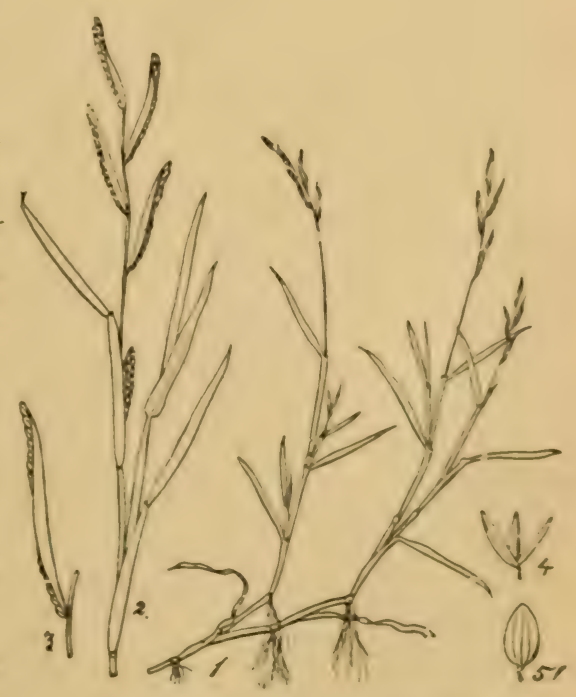

Fig. 16. Paspalum membranacenm.

2. I pper part of the culm, with the racemes. 3. stmele rareme, the splkelets nearls concealea by the hroarl rhaculs. 4 splkelet from the slde 5 spikelet from the front 



\section{Paspalum distichum L. Knot-grass.}

Plate VI. Figure 24.

A prostrate, extensively creeping and much-branched grass, the ascending extremities of the stems and frequent sterile or flower. bearing leafy shoots, six to eighteen inches high. Sheaths smooth or ciliate along the margins and at the throat and base: ligule short; leaf.blacle flat, lanceolate, acute, one to six inches long. one to three lines wide, smooth. Racemes in pairs close together at the apex of the culm or its branches, one to two inches long. rarely a third raceme below; rachis narrow (one half to one line) flat, smooth. Spikelets cblong, acute, about one and one-half lines long, in two close rows, nearly sessile, outer glumes acute, three- to five-nerved, usually thinly and minutely pubescent, a little longer than the acute floral glume which is minutely bearded at the tip. There is sometimes a third outer glume at the hase of the spikelet, either rounded and minute or narrow-lanceolate. acute one-nerved and one-half to three-fourths as long as the spikelet.

Moist, usually sandy soils; along river banks, margins of ponds, "sink-holes," etc. June to October.

This grass is very widely distributed over the tropical and warmer temperate regions of the world. Probably introduced from the South into Tennessee. It has much the same habit of growth as Bermuda grass, but the stems are coarser and the flowering racemes are stouter and nearly always in pairs. It is valuable for holding loose sands where there is moisture, and for covering the soil of "sink-holes" where other grasses usually die out.

\section{Paspalum platycaule Poir. ( $P$. compressum Nees.) Carpet.grass} or Louisiana-grass.

Plate VII. Figure 25.

A slender, erect, or more frequently prostrate and extensively creeping perennial, rooting at the nodes and sending up numerous leafy or flower-bearing branches, six to twenty-four inches high. Culm and branches strongly flattened. Sheaths compressed, the lower imbricate, smooth; ligule short, ciliate; leafblade linear or narrowly lanceolate, two to ten inches long. one to three lines wide, smooth, scabrous on the margins near the rounded or blunt apex. Racemes two to six, subdigitate, one or two of the lower sometimes remote, one to three incheslong, slender, almost filiform, erect or ascending; the apex of the culm frequently divides into two or three flower-bearing branches, which, with the main axis, issue from the upper leaf-sheath; rachis of the racemes very narrow (one-fourth of a line) somewhat flexuose, smooth. Spikelets elliptical, about one line long, subacute, biseriate, scarcely imbricate, closely appressed to the rachis, smooth or more or less hairy; first glume four-nerved, two nerves near each margin, the second two-nerved; flowering glume obtuse, minutely pubescent at the apex and with a distinct depression on the back near the base. 
The prostrate creeping stems of this grass spread rapidly and soon form a dense carpet-like growth, crowding out all other vegetation. It withstands protracted drought, grows well on almost any soil, and in more southern districts is evergreen, yielding good pasturage both summer and winter. Seed sown here (Knoxville) came up and the grass grew well for two years, making a vigorous growth the second season, but it was all killed during the severe winter of $1892-93$. In favorable localities, particularly in the southwestern part of the State, this grass may prove of much value, not only in improving the pasturage, but in preventing the washing of the lands, now so serious in many sections.

\section{Paspalum dilatatum Poir. ( $P$. ovatum Nees.) Hairy-flowered Paspalum.}

Plate V. Figure 19.

An erect or ascending perennial two to four feet high, with compressed sheaths, long narrow leaves, and acute hairy spikelets. Nodes smooth. Sheaths smooth, or the lower more or less bearded, hairy at the throat; ligule short, (one to two lines), decurrent; leafblade narrowly lanceolate, long acuminate-pointed, three to four lines wide, scabrous along the margins, the lower a foot long or more. Racemes two to ten, one terminal, the others alternate below, usually approximate or sometimes two to three inches distant along the main axis, more or less spreading; rachis of the racemes narrow (less than a line), somewhat flexuose and minutely scabrous along the margins. Spikelets four-seriate, one and onehalf to two lines long, depressed (much less convex on the back than in $P$. lave), broadly ovate; outer glumes prominently fivenerved, submucronate-pointed, the lower villous-hairy along the margins and sometimes imperfectly seven-nerved, the upper smooth or thinly hairy; floral glume rounded-obtuse, nearly as broad as long, one-fifth to one-fourth shorter than the outer glumes, lenticular, pale or yellowish green and minutely punctate-striate as is the concave palea.

Found growing along the Mississippi at Memphis, July, I892, probably from seed introduced for cultivation. This grass doubtless has been introduced into the United States from South America; it is spoken of in the highest terms by those who have cultivated it. It affords excellent pasturage, and is particularly valuable as yielding late summer and autumn feed, during which period it makes its principal growth.

\section{Paspalum pubiflorum glabrum Vasey.}

Plate V. Figure 18.

A rather strong-growing species with ascending leafy culms, two to three feet long, branching below and often rooting at the lower joints of the more or less decumbent base. Nodes more or less pilose-bearded with erect hairs. Sheaths smooth, often thinly pilose near the scabrous margins, hairy at the throat; ligule two 



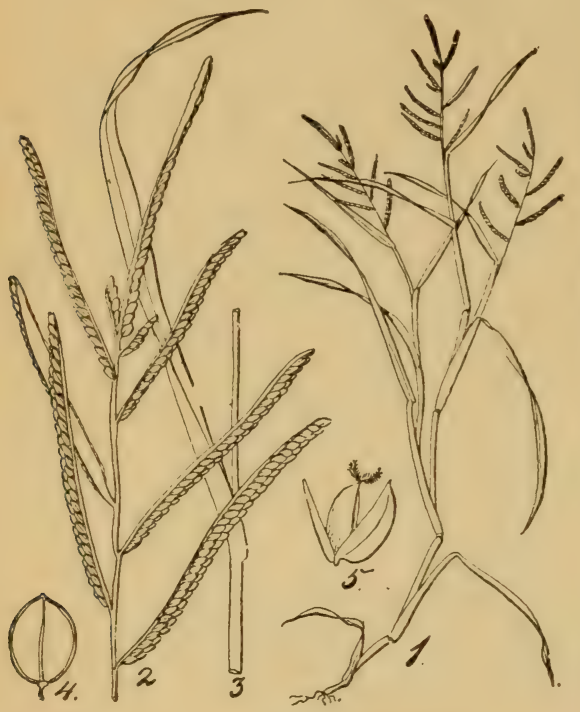

Fig. 17. Paspalum Boscianum.

2. Inflorescence. 3. Upper lear. 4. Splkelet. 5. Splkelet from the side, empty glumes expanded.

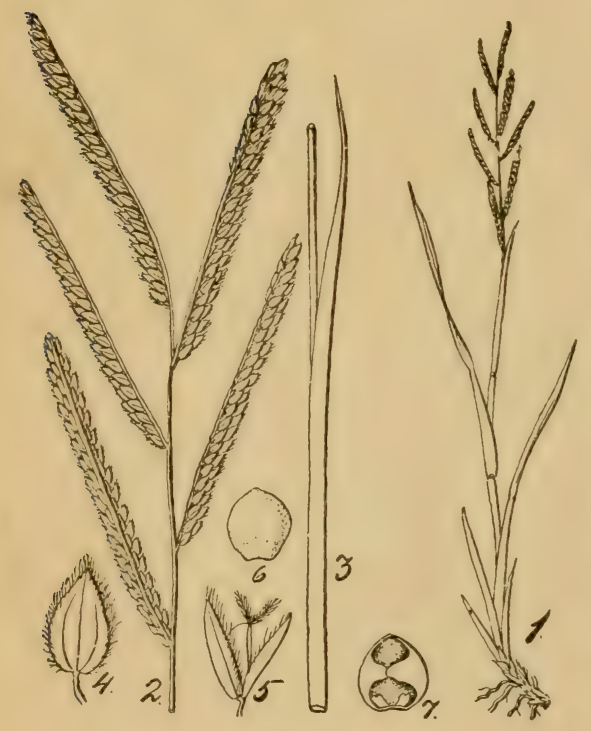

Fig. 19. Paspalum ovatum.

2. Inflorescence. 3. Upper leaf, 4. Spikelet. 5. Splkelet latd open, 6. Floral glume. 7. Palea and lodicule.

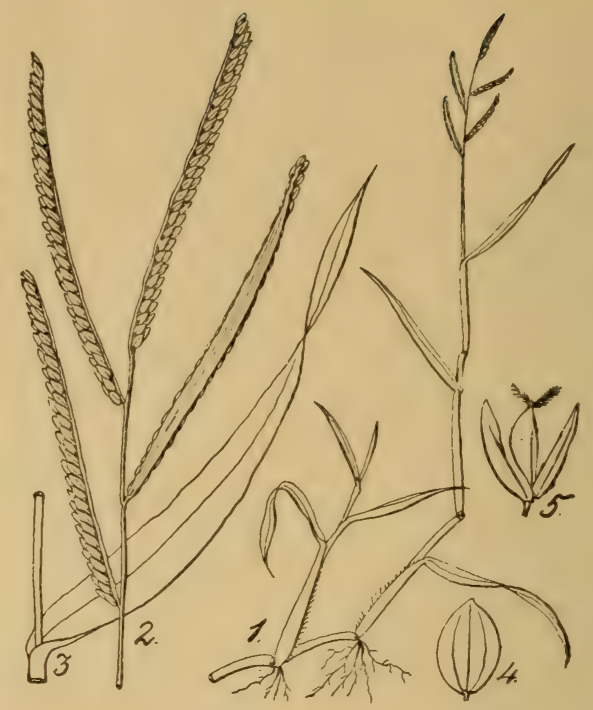

Fig. 18. Paspalum pubiflorum glabrum.

2. Upper part of the culm with the racemes. 3. Upper leaf-blade. 4. Spikelet. 5. Splkelet from the side, empty glumes expanded.

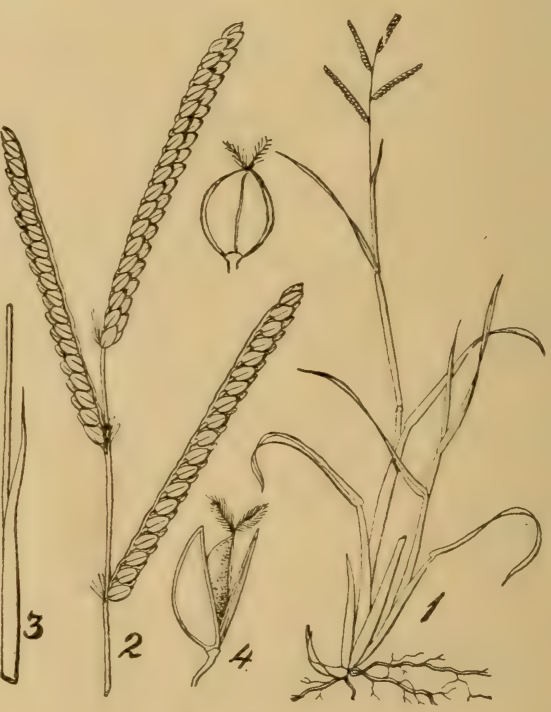

Fig. 20. Paspalum Floridanum.

2. Inflorescence. 3. Upper leaf. 4. Splkelet. 
to three lines long, decurrent; leaf-blade lanceolate, four to ten (in luxurious specimens even eighteen) inches long, three to six or nine lines wide, very acute, somewhat narrowed toward the rounded base, minutely serrulate scabrous and usually ciliate with rather distant hairs along the very narrowly cartilaginous and often finely wavy margins. Racemes three to seven, terminal and alternate near the summit of the stem, horizontal or ascending, one to four to five inches long, rather stout, the upper shorter. bearded in the axils; rachis flat on the back, a line wide, the minutely scabrous margins straight or only slightly undulate. Spikelets densely crowded in four rows, obovate, obtuse, about one and one-fourth lines long, three fourths to one line wide, outer glumes five-nerved, smooth with prominent nerves. Floral glume with a distinct depression on the back near the base.

Note.-This differs from Paspalum pubiflorum, as represented by No. So 4 E. Hall (Texan Coll. $18 ; 2)$, No. 567 Lindheimer $(18+6)$ and No. 45 E. Palmer $\left(1 S S_{7}\right)$, in its spikelets, which are a little shorter, more obovate and have smooth outer glumes. It is evidently of the same species.

Found by the writer along the grassy banks of a small stream at Belle Meade, near Nashville, July 1892, and Dr. Gattinger collected it in the same region in July, is86. Mr. S. M. Bain collected it in Lake county, near the Mississippi, June 1893.

\section{Paspalum Boscianum Flugge. (P.purpurascens E11.)}

Plate V. Figure 17.

A rather stout perennial with ascending branching culms, two to three feet high, long, flat leaves and numerous racemes crowded near the summit of the culm or its branches. Nodes smooth. Sheaths lax, smooth, longer than the internodes, the lower purplish; ligule about a line long, its insertion strongly arched; leafblade six to eighteen inches long, three to six lines wide, scabrous on the margins and gradually tapering to a narrow acute and rough point, sparingly pilose above near the base. Racemes three to twelve, approximate, ascending, one to three inches long, of nearly equal length on each culm or the upper shorter, pilose in the axils, the racemes of the branches often (in herbarium specimens) included in the wide sheaths; rachis flat on the back, its scabrous margins nearly straight. Spikelets crowded, four-seriate, obovate obtuse, one line long, outer glumes glaucous or brownish, five-nerved, smooth; flowering glume very dark brown, shining and minutely punctate-dotted, as is also the palea.

This is without doubt Flugge's Paspalus Boscianus, which was based upon specimens sent him from Carolina. It is more grenerally known as $P$. purpurascens E1l, but Flugge's name antedates that given by Elliott and ought to be taken up. Paspalum confertum LeConte is the same.

Hiwassee Valley (Prof. A. Ruth), September, I892. Allegheny Springs (Lieut. E. E. Gayle), A ugust, r\$go. 
8. Paspalum Floridanum Michx. ( $P$. altissimum Le Conte, $P$. macrospermum Flugge.)

Plate V. Figure 20.

A stout, erect grass, three to four feet high, with long leaves and large spikelets. Nodes smooth. Sheaths somewhat compressed, hairy at the throat, smooth or the lower more or less densely pilose-hairy; ligule short; leaf-blade narrow, linear-lanceolate, ten to fifteen inches long, somewhat scabrous toward the very acute apex, very smooth, or the lower leaves more or less hairy, uppermost leaf-blade very short or wanting. Racemes three to four or seven, erect or ascending, three to five incheslong; bearded in the axils, rachis narrow (about one line), nearly flat on the back, somewhat flexuose along the minutely scabrous margins. Spikelets smooth or somewhat glaucous, about two lines long and threefourths as broad, rounded-ovate, obtuse, crowded in two rows; the smooth five-nerved outer glumes covering the brown obtuse flowering glume, which is punctate striate in fine longitudinal lines, with a distinct depression at base; palea punctate-striate like the glume.

Low, moist fields, West Tennessee, September, I892 (S. M. Bain.) Apparently rare in the State. More abundant near the sea-shore from New Jersey to Florida; its range extends westward to Texas. The habit of this species is indicative of possible value in agriculture. No attempt has been made to cultivate it.

\section{Paspalum læve Michx.}

Plate VI. Figure 21.

Culms ascending, often geniculate at the base, one to three feet long, compressed below, smooth. Lower sheaths, especially of the sterile shoots, strongly flattened, smooth or pilose, usually hairy at the throat; leaf-blade four to five inches to a foot long or more, two to five lines broad, mostly tapering toward the base, very acute at the apex, smooth or more or less papillate-pilose, especially below, scabrous on the margins; ligule membranaceous, less than a line long. Racemes two to five, one terminal, the others lateral and subsessile, more or less spreading, two to five inches long, generally about one inch distant on the main rachis, pilosebearded in the axils; rachis about one-half a line wide, slightly flexuose and somewhat triangular. Spikelets crowded in two rows, on very short pedicels, plano-convex, one and one-half lines lony and nearly as broad, rounded, obtuse at apex, smooth.

Var. pilosum. Sheaths more or less densely pilose, with spreading hairs, leaves narrow, elongated, pilose; racemes less spreading.

Moist grounds, fields, borders of swamps, etc., common. The variety at Tullahoma, Madisonville, and White Cliff Springs, July to October.

\section{ı. Paspalum ciliatifolium Michx.}

Plate VI. Figure 22.

An erect or ascending perennial, usually about two feet high, with long, flat leaves and slender, of ten solitary, terminal and long. 


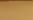




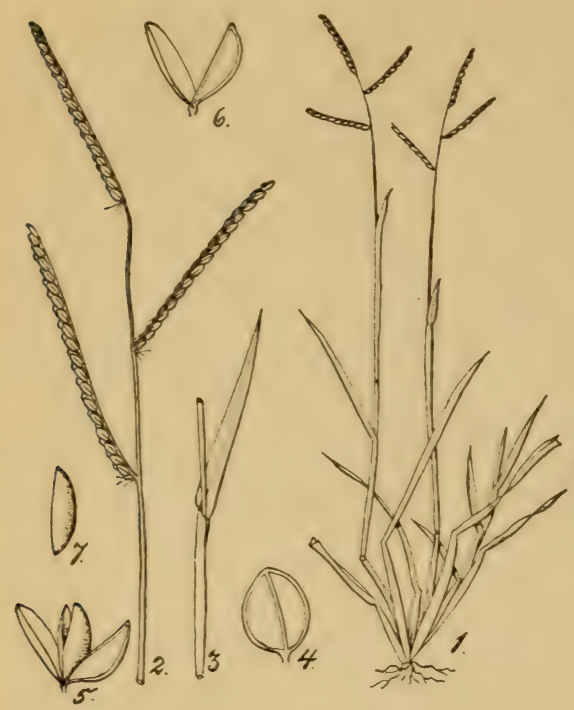

Fig. 21. Paspalum læve.

2. Upper portion of culm, with three racemes. 3. Upper leaf. 4. Splkelet. 5. Splkelet lald open. 6 Empty glumes. 7 Flowering glume, side view.

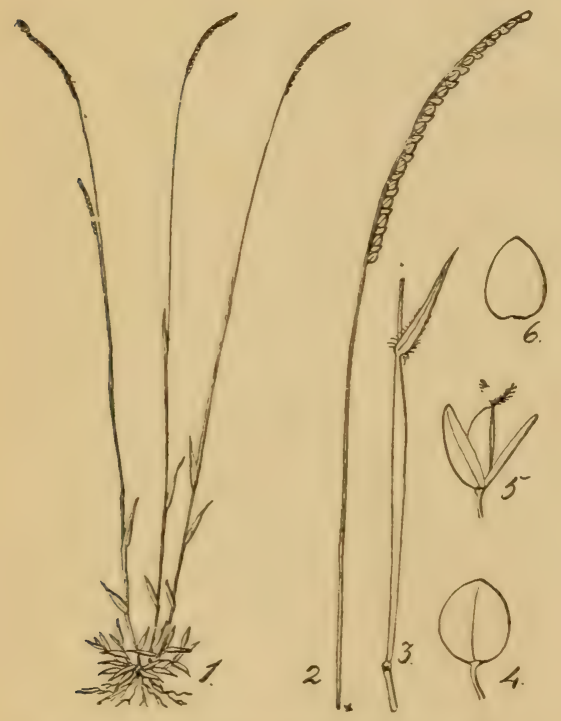

Fig. 23. Paspalum longepedunculatum.

2. Inflorescence. 3. Upper node and leaf. 4. Splkelet. 5. Spikelet laid open. 6. Flow. ering glume.

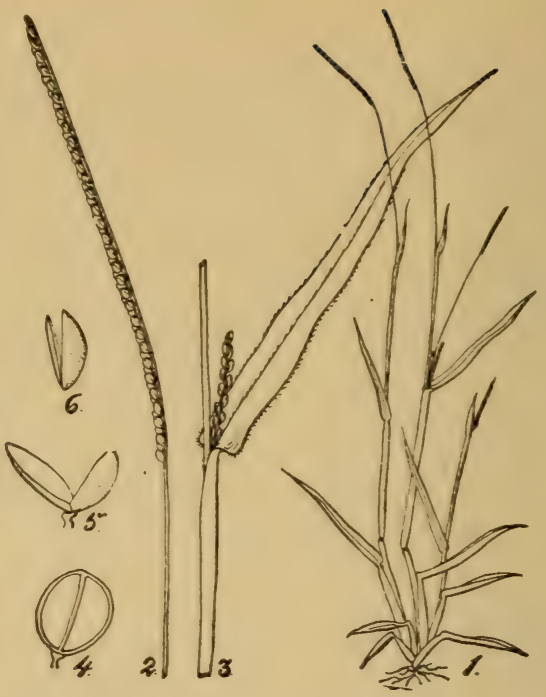

Fig. 22. Paspalum ciliatifolium Mx.

2. Upper raceme. 3. Upper leaf with projecting axillary raceme. 4. Spikelet. 5. Empty glumes. 6. Flowering glume and palea.

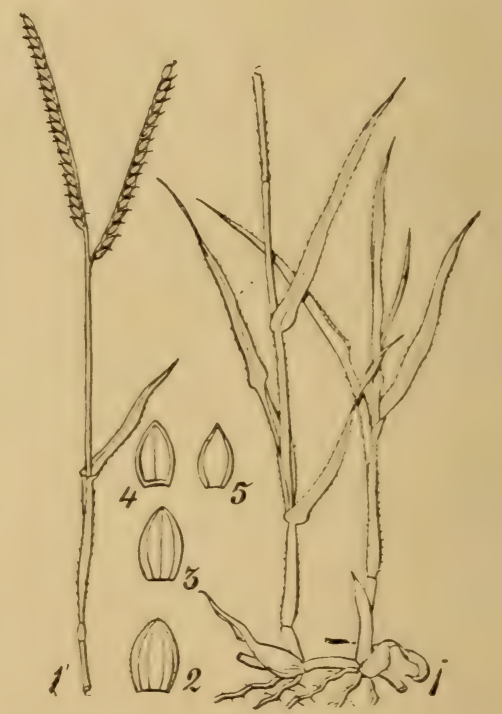

Fig. 24. Paspalum distichum.

1. Upper part of the culm, with the pair of racemes. 2. Lower emptr glume. 3. Upper empty glume. 4. Floral glume. 5. Palea. 
peduncled axillary racemes. Sheaths pubescent with spreading hairs, rarely nearly smooth, the lower usually purplish, the upper ones elongated and somewhat inflated; ligule very short; leafblade five to twelve incbes long, three to six lines wide, usually papillate-pilose on bot? sides and along the narrowly-cartilaginous margins, acute, tapering slightly toward the rounded base, the upper leaf usually cordate. Racemes terminal and axillary, two to four or six inches long, the terminal solitary or with one or two approximate below it, the axillary finally exserted on long naked peduncles: rachis very narrow, somewhat flexuose and triancular. scabrous. Spikelets imperfectly two- to four-rowed, crowded or somewhat lax, one line long and nearly as broad, rounded at the apex, smooth, or the larger glume minutely hairy near the margins above. Flowering glume with a distinct depression on the back near the base. (There is present occasion. ally a small lower glume.)

Not infrequent in grass lands, usually preferring rich, moist soils. July-September.

The leaves in this species are longer, culms more erect, and spikelets larger and less crowded in the racemes than in the next. $P$. setucum Michx., as understood by the author, has narrower leaves, and these with the sheaths more hairy, racemes more slender, the terminal nearly always solitary, the spikelets densely crowded, less rounded and about half as large.

\section{Paspalum longepedunculatum Le Conte.}

Plate VI. Figure 23.

A slender perennial, with reclining or decumbent widely spreading culms, ten to eighteen inches long, short leaves, and long-peduncled, usually solitary, terminal and axillary racemes. Sheaths ciliate along the margins and long-hairy at the throat, otherwise smooth or the lower sometimes pubescent; ligule very short; leafblade one to four inches long, three to five lines wide, lanceolate, more or less clasping the stem by the rounded, subcordate base, acute, papillate-ciliate along the narrowly-cartilaginous margins and along the midnerve, surfaces smooth or somewhat pilose. Racemes one to two inches long, slender, usually somewhat falcate, terminal and solitary, or with a second raceme below, on long ex. serted slender, naked peduncles; rachis very narrow, linear, more or less flexuose, pubescent or pilose at the base. Spikelets plano-convex or obtusely triangular, rounded-obtuse, hardly more than threefourths of a line long, the smooth and shining floral glume a little exceeding the three-nerved outer glumes, and without any distinct depression on the back at the base; first glume smooth or with a few minute glandular hairs.-Sandy or gravelly soil. Knoxville, and White Cliff Springs. Probably common. June to September.

Note.-This may be the $P$. debile of Michaux, a species which Kunth unites with $P$. setaceum Mx., whether correctly or not is uncertain. The grass above described is certainly distinct from $P$. setaceum or $P$. ciliatifolium. Nees (Agrost. Bras. 54) refers $P$. longepedunculatum LeConte and $P$. debile Muhl. to $P$, arenar ium Schrad. 


\section{PANICUM Linn. Sp. P1. 55 (1753).}

Spikelets one-flowered or sometimes with a staminate flower below the hermaphrodite terminal one, in spikes, raremes, or panicles, rachilla articulated below the empty glumes. Glumes four, the first usually much shorter than the others, very rarely wanting; second glume empty, equalling or somewhat shorter than the third, which is empty or has a palea or even a staminate flower in its axil; fourth glume smooth and shining, coriaceous, much firmer in texture than the others. Palea similar in texture to its glume and closely embraced by it. Grain enclosed within the hardened fruiting glume and palea, free.

Annuals or perennials varying greatly in habit of growth, foliage, and inflorescence. Species about three hundred, throughout the tropical and subtropical regions of both hemispheres; a few only in the temperate regions. Several species occur as weeds throughout the civilized world. Nearly ninety species and varieties are recorded as having been observed in Tennessee. The species are difficult to identify, especially those in the group contain. ing Panicum dichotomum, owing to the variations in habit which the several species present at different periods of growth, and the fact that a number of the older published descriptions were based wholly upon one or the other of these stages. In recent published manuals there is very little to aid one in the identification of these species. Aside from this group, which can never be satisfactorily discriminated until the types in European herbaria are consulted, our species are very well marked.

\section{KEY TO THE SPECIES.}

I. Spikelets in one-sided, usually simple racemes . . . . . 2

I. Spikelets variously paniculate . . . . . . . . . . . . 6

2. Racemes slender, digitate or sub-fasciculate, outer glumes softly pubescent or pilose

2. Racemes thick and racemed along the main axis, or somewhat paniculate, outer glumes rough

3. Second glume narrow, about one-half as long as the spikelet

3. Second and third glumes nearly equal .

I. P. SANGUiNAle.

4. Sheaths and leaves glabrous, racemes spreading, spikelets about one line long . . . . . . 2. P. GLABRUM.

4. Sheaths pilose, racemes filiform, erect or ascending, spikelets about three-fourths of a line long . . . 3. P. filiforife.

5. Racemes of unequal length, erect or ascending, approximate, the upper crowded; second and third glumes awned or awn-pointed . . . . . . . . . 4. P. CRUS-GALLI.

5. Racemes nearly equal, spreading rather distant; second and third glumes acute or mucronate-pointed. 5. P. CoLONUM.

6. Spikelets crowded in narrow almost spike-like panicles, the second glume twice as long as the fourth, and gibbous at the base

6. P. GIBBUM. 
6. Spikelets not crowded in spike-like panicles, second glume not gibbous at base

7. Leaves all alike, spikelets acute. (Homophylle.)

7. Leaves dissimilar, those at the base shorter and broader than those above; leaves on the branches usually much smaller and more crowled than those on the primary stem; spikelets blunt or obtuse ( $I^{\prime}$. depauperalum ex. cepted). (Heterophylla) . . . . . . . . . . . I5

8. Perennials

8. Annuals

9. Culms stout, $2-5$ feet high . . . . . . . . . . . 10

9. Culms slender, I-2 feet high . . . . . . . . . . 14

10. Spikelets $\mathrm{I}-\mathrm{I} \frac{1}{2}$ lines long, culms compressed, branching. . I I

10. Spikelets $2-2 \frac{1}{2}$ lines long, culms terete, simple

9. P. VIRGATLU.

Ir. Splkelets $1 \frac{1}{2}$ lines long, fertile floret sessile within the glumes

II. Spikelets $\mathrm{I}-1+$ lines long, fertile floret raised on very short pedicel . . . . . . . . 8. P. AgROSTOIDES.

12. Sheaths somewhat flattened and with the leaves glabrous, first glume broadly obtuse . . . IO. P. PROLIFERUM.

I2. Sheaths pilose or hirsute, first glume acute .

13. Spikelets I line long or less, panicle branches spreading

13. Spikelets it lines long, panicle branches ascending

It Outer glumes striate, palea of the third glume inflated, rigid, as long as the glume and apiculate . . . I3 P. HiA.s.

14. Outer glumes warty-roughened (verrucose), palea of the third glume inconspicuous . . . . 14. P. VERRUCOSUM.

15. Spikelets exceeding r line in length . . . . . . . . . I6

15. Spikelets I line long or less . . . . . . . . . . . . 2 I

16. Leaves ovate or broadly lanceolate, more or less cordate at the base

16. Leaves very narrowly lanceolate or linear

17. Culm stout, 3-4 feet high, sheaths usually rough-hispid 15. P. Clandestinum.

17. Culms more slender, I-2 feet high, sheaths not hispid, smooth or pubescent . . . . . . . . . . . . 18

18. Glume of fertile floret pubescent at the apex, leaves broadly ovate lanceolate, spikelets ovate-elliptical. I7. P. WALTERI.

18. Glume of the fertile floret not pubescent at the apex . . . Ig

19. Leaves broadly lanceolate, thin, and conspicuously manynerved, cordate, clasping at the base, glabrous, as are the sheaths. Panicle compound, branches capillary, naked below; spikelets ovate-elliptical; second and third glumes 7-nerved ....... 21. P. Commutatum.

19. Leaves narrower, nerves not conspicuous, sheaths usually 
papillate-pilose. Spikelets obovate. Panicle nearly simple, few-flowered . . . . . . . i8. P. SCOPARIUM.

20. Culms branching only near the base; leaves erect, one to two lines wide or less; panicle nearly simple, few-flowered; spikelets ovate, acutish, smooth; fourth glume rounded-obtuse, smooth . . . . 20. P. DEPAUPERATUM. 20. Culms branching throughout; leaves of the primary stem 2-3 lines wide, erect or spreading, those of the wiry branches involute filiform. Spikelets oblong elliptical, finely pubescent; fourth glume barbulate at the apex .

19. P. ANGUSTIFOlium.

2r. Culms stout, 3-4 feet high, very densely and softly pubes. cent throughout and viscid when fresh. Leaves of the primary culm 5-ro inches long. Spikelets one line long, rounded-obovate . . . . . . s6. P. viscidum.

21. Culms more slender, not viscid . . . . . . . . . . . 22

22. Ligule entirely wanting . . . . . . . . . . . . 23

22. Ligule present. . . . . . . . . . . . . . . . . . 24

23. Sheaths shorter than the internodes; leaves erect, 2-4 inches long, the uppermost $\mathrm{I}-3$ inches, firm in texture

22. P. SPHEROCARPON.

23. Sheaths longer than the internodes; leaves widely spreading, 4-ro inches long, the uppermost on the primary stem usually 5 or 6 inches long and one-half to one inch wide .23 P. MICROCARPON.

24. Note.-Those who have attempted the study of the following species will understand and appreciate the difficulty of preparing any key which will be satisfactory, and I only now venture the following as a possible aid to their determination:

Spikelets more or less pubescent. Sheaths and leaves densely pubescent.

Leaves firm, nearly erect, spikelets r line long . . . . .

Leaves rather thin, more spreading, spikelets $\frac{3}{4}$ line long 26. P. Pubescens.
lets $\frac{3}{4}$ line long.

27. P. LANUGINOSUM. Sheaths pilose with long deflexed hairs, 24. P. LAXIfLORUM Sheaths and leaves ciliate on the margins. 25. P. Ciliatum. Sheaths and leaves glabrous . . . . 29. P. Nitidum. Spikelets smooth.

Sheaths and leaves pilose . . 28. P. Longepedunculatum.

Sheaths and leaves glabrous.

Nodes smooth . . . . . . 30. P. Dichotomum.

Nodes bearded with reflexed hairs. 3I. P. BARBULATUM.

\section{Panicum sanguinale Linn. Crab-grass.}

Plate VII. Figure 26.

A much-branched leafy annual, more or less decumbent at the base, and often rooting at the lower joints. Culms smooth, one to three or four feet long, ascending; nodes smooth or sometimes bearded with deflexed hairs. Sheaths loose, smooth, or pilosehairy, usually ciliate on the margins; ligule membranaceous, about 


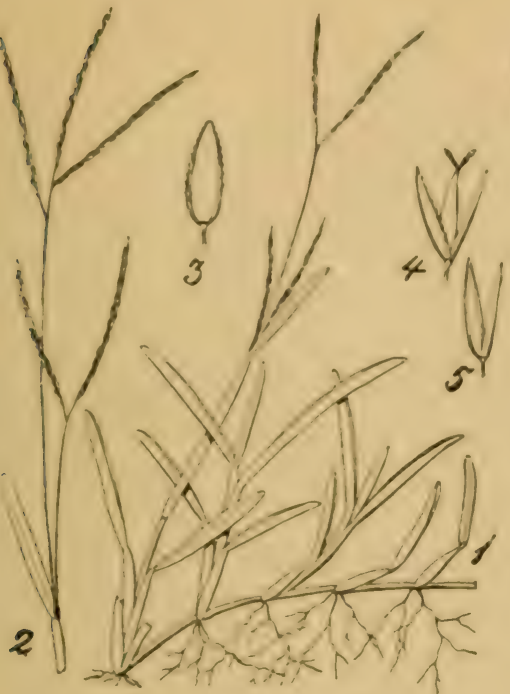

Fig. \&. Paspalum platycaule.

$\therefore$ Inflorescence. s. splkelet, front rlew. 4. Splkeiet lald open, slde vlew. b. Empty glume.

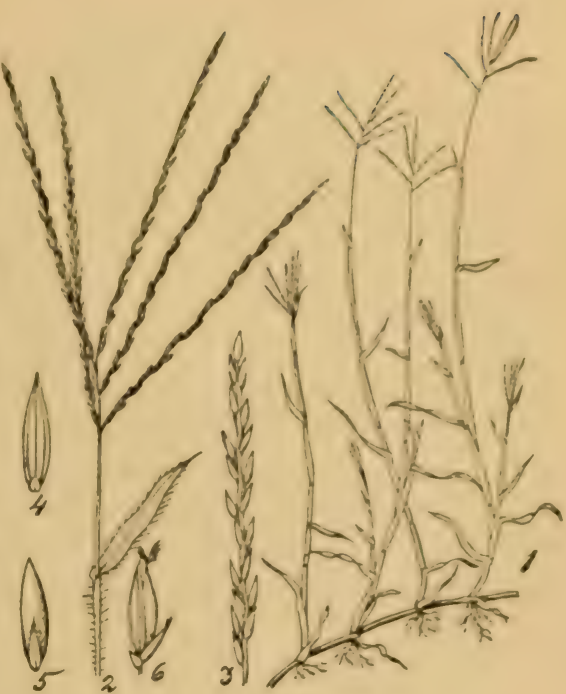

Fig. 26. Panicua sanguinale.

2. Inper leaf and inflorescence. 8 . lor tion of one of the racemes 5. Spikelet, front rlew, 6. Splkelet, slde vlew.

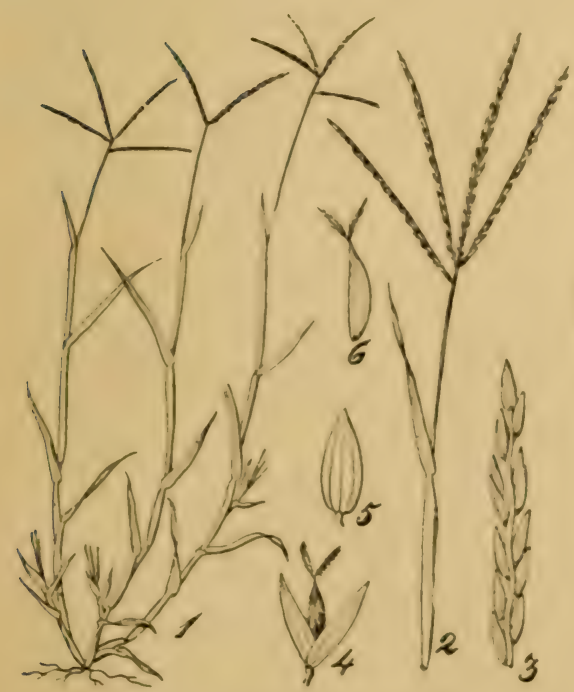

Fig. 27. Panicum glabrum.

2. Inflorescence, 3. Rhachls, 4. Splkelet, slde vlew. 5, spikelet, front vlew. 6. Flowering glume with floret.

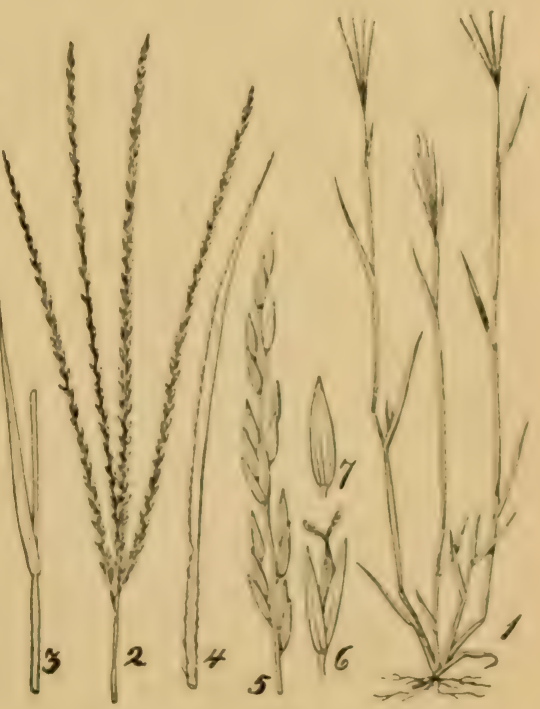

Fig. 28. Panlenm flliforme.

2. Inflorescence. 3. Upper leaf, 4. One of the lower leaves 5 . Part of rhachls with spikelets f. Spikelet, side view. i. spikelet, front view. 

one line long; leaf blade flaccid, two to five inches long. two to four lines wide, flat, acute, scabrous, sometimes sparingly pilose, and with the sheaths sometimes purple tinged. Racemes four to ten, digitate or subfasciculate at the apex of the culm, three to five inches long, usually spreading. Spikelets about one and one-half lines long. lanceolate, acute, in pairs, one nearly sessile, the other distinctly pedicellate; first glume very minute, the second onehalf to two-thirds as long as the spikelet, usually ciliate on the margins and three-nerved; the third a little longer than the fourth, five-nerved, and usually silky-villous along the marginal nerves; fourth glume smooth, very acute.

This is the well-kuown Crab.grass of the South, common everywhere in cultivated fields. It is a troublesome weed in gardens and among hoed crops, but in grain fields it frequently springs up in such quantity after harvesting, as to yield one, or even two, grood cuttings of hay. This spontaneous growth affords excellent pasturage, as well as hay of the first quality if properly cured. Many farmers largely depend upon this grass for their hay, and frum its spontaneous and abundant growth it is often called "the poor man's hay."

2. Panicum glabrum Gaudin. Smooth Crab-grass.

Plate VII. Figure 27.

An annual grass closely resembling $P$. sanguinale in habit, but smooth throughout, excepting a few hairs at the throat of the sheaths, and the spikelets are smaller, about a line in length. First glume very minute or obsolete; second and third glumes nearly equal in length. or the second a little shorter than the fourth, pubescent on the back.

A tall form, twelve to twenty-four inches high, with racemes three to five inches long, is variety Mississippiensis Gattinger. This form is very common about Knoxville.

\section{Panicum filiforme L. Slender Crab-grass.}

Plate VII. Figure 28.

A slender annual, resembling Crab.grass somewhat in habit, but branching only near the base, less leafy, leaves usually erect, racemes less spreading and more slender, the axis being nearly filiform. Distinguished from $P$. glabrum at once by its more slender culms, pubescent or nearly hirsute lower leaf-sheaths, and more slender and less spreading racemes. The spikelets are also smaller, scarcely exceeding three-fourths of a line in length. In this species the first glume is usually wholly wanting, a character which would technically place this grass in the genus Paspalum. The racemes vary in length from one tu four or five inches. Dry sandy soil. August__eptember.

4. Panicum crus-galli Linn. Barnyard-grass.

Plate VIII. Figure 29.

A coarse ascending or erect, leafy annual, one to four feet high, 
with densely-flowered panicles. Culms smooth, often branching near the base; sheaths loose, very smooth, or sometimes densely hispid; ligule none; leaves rather broad, flat, six inches to one or two feet long, smooth or scabrous on the surfaces, margins serrulate. Spikelets densely and irregularly crowded in three or four rows along one side of the short spike-like branches of the panicle; these branches, five to fifteen or twenty in number, are usually simple, the lowermost one to three inches long, becoming shorter and more crowded above, usually erect or ascending. Spikelets about one and one-half lines long; first glume one-fourth to onehalf the length of the spikelets, acute or mucronate-pointed, threenerved; second and third glumes smooth, pubescent or muricatehispid along the nerves; the second five-nerved, awnless or shortawned; the third seven-nerved, at least near the tip, awnless or sometimes long-awned, and with a palea in its axil; fourth or fruiting glume smooth, awnless, or short awn-pointed.

A well-known annual of rank growth, common in rich cultivated lands, especially around dwellings. Some apparently native forms, usually with long awned spikelets, are found along water-courses, etc. It seeds freely, makes rapid growth during the summer, and on bottom lands yields abundantly. It sometimes affords the farmer a good crop of fair hay from land which but for the spontaneous growth of this grass would have yielded him nothing. In many sections, however, Barnyard-grass is only regarded as a weed.

\section{Panicum colonum Linn.}

Plate VIII. Figure 30.

A rather slender annual, closely resembling Barnyard-grass, but more slender throughout. Sheaths and leaves smooth, with scabrous margins. Spikes four to nine, rather distant, the lower about an inch long, spreading or erect. Spikelets with the outer glumes pubescent, simply acute or mucronate-pointed.

This is regarded by some authors as only a variety of $P$. crus . galli. It grows in similar stations, but is much less common.

\section{Panicum gibbum E11.}

Plate VIII. Figure 31.

A stoloniferous perennial, with ascending leafy culms, one to three feet high, and densely flowered, almost spike-like panicles. Culms rather slender, smooth, more or less diffusely branched. Sheaths shorter than the internodes, ciliate along the margins, usually bearded at the throat, the lower more or less papillate-pilose or subhispid with spreading hairs, the upper smooth; ligule very short, minutely ciliate-fringed, broader than the abruptly contracted base of the leaf and subauriculate; leaf-blade lanceolate, acute, abruptly contracted at the subcordate base into a very short broadly margined petiole-like connection with the sheath, two to six inches long, three to eight lines wide, the upper surface often thinly pilose near the base, margins scabrous, ciliate near the base. Panicle sub-cylindrical or fusiform, four to six inches long, the 


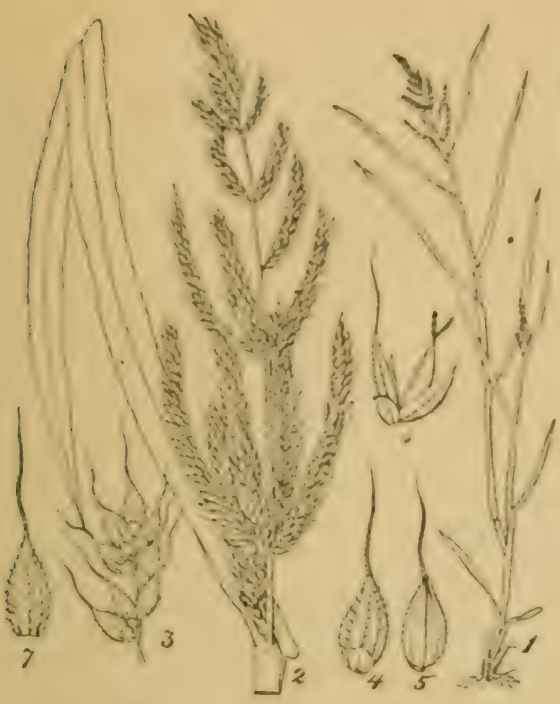

lig. 29. Panicum crua-galli.

2. Inflorescence. 3. Rhachls, with ser. eral splkelets. 4. Splkelet, front vlew. 5. Splkeiet.back view. 6. Splkelet laldopen. 7. Third glume

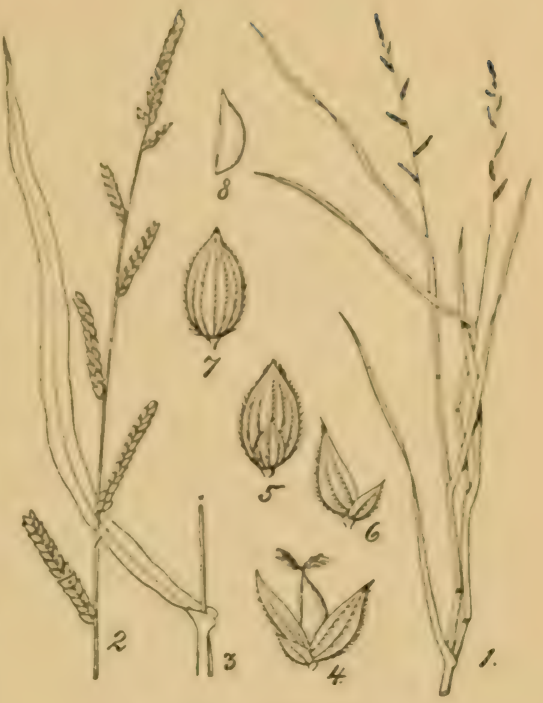

Fig. 3). Panicum culonum.

2. Inflorescence. 3. Upper leaf. 4. Splkelet lald open, slde vlew. 5. Same, front vlew, 6. Empty glumes. 7. Third glume. 8. Flowering glume of the perfect floret.

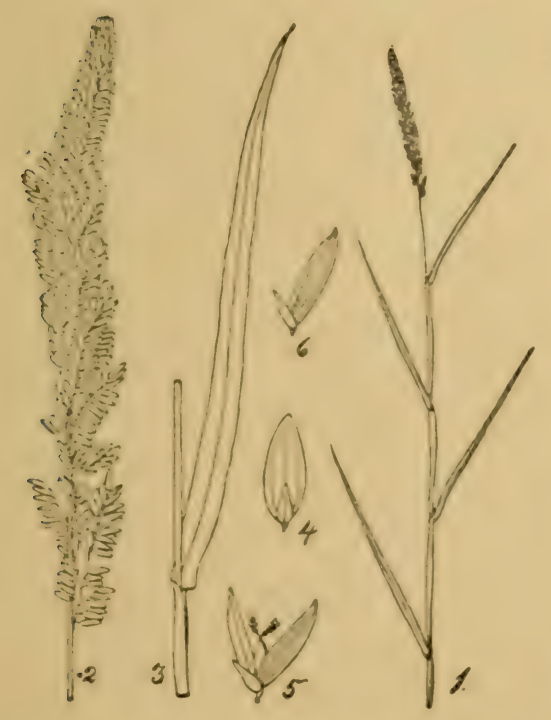

Fig. 31. Panicum gibbum.

2. Panicle. 3. Leaf. 4. Splkelet, front rlew. 5. Splkelet, side rlew, lald open. 6. Outer empty glumes.

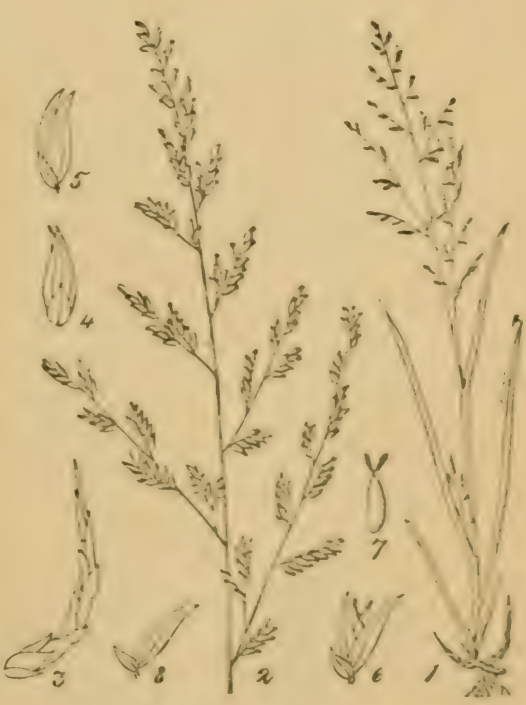

Fig. 32. Panicum anceps.

2. Pantcle. 3. Portion of scalr rblzome 4. Splkelet, front vlew 5. Splkelet, slde vlew 6. Splkelet, slde rlew lald open flowerlng glume with profecilng sllgmas. s. Outer empiy glumes. 

erect, densely flowered, racemose branches one-half to one inch long. Spikelets one and one-half to two lines long. hroadly lance. olate or elliptical-ovate, obtuse or subacute, smooth. First glume narrow, ob:use or acute, three-nerved, about one half a line long: second glume obtuse, gibbous at the base. eleven-nerved, the thiri glume as long as the second, seven-nerved, with a two-nerved palea of nearly equal length; the fourth or floral glume smoth and shining. about one-half as long as the larger outer glumes.

Low wet grounds. Henderson (S. M. Bain, August, I892), Hiwassee valley (A. Ruth. September, IS93). Dr. Chapman gives "Swamps, Florida to North Carolina," as the range of this species.

\section{Panicum anceps Michx.}

Plate VIII. Figure 32.

A rather stout perennial, with flattened stems, two to four feet high, long leaves and spreading panicles. Culms smooth, simple or branched, from very strong, scaly rootstocks. Sheaths compressed, especially the lower ones, usually shorter than the internodes, smooth or more or less pilose with rather long soft hairs: ligule short, membranous; leaf-blade linear-lanceolate, very acute, six to twenty-four inches long, two to five lines wide, smooth or often pilose-hairy on the inner side towards the base, serrulate, scabrous along the margins. Panicle pyramidal, terminal on the culm or its branches, the rather rigid, solitary branches branched to the base, the secondary branches usually appressed. Spikelets crowded,ovate, lanceolate, acute, more or less curved, about one and one-half lines long, exceeding their rough-scabrous pedicels; first glume clasping the base of the spikelet, acute, less than nnehalf as long as the second glume, three-nerved, the strong middle nerve curved and scabrous above; second glume broadly lanceolate, acute, five-to seven-nerved, about the length of the five-nerved third glume, which has a two-nerved palea in its axil; fourth or flowering glume elliptical, oblong, about one-third shorter than the larger outer glumes, its obtuse apex usually bearing a minute tuft of hairs. Palea of the third glume ciliate along the nerves. Common in sandy, usually moist grounds, along streams, etc. August to October.

In luxuriant plants the panicle is sometimes two feet long. In open fields this grass grows in scattered tufts or patches, the flowering stems sometimes springing up in a circle around a sod formed in previous years by the short but strongly matted rhizomes. all vegetation being choked out in the central space. Apparently of little agricultural value.

\section{S. Panicum agrostoides Muhl. Munro-grass or Red-top Panic.}

Plate IX. Figure 33.

A rather stout leafy perennial with somewhat flattened, branching, smooth culms two to four feet high, and open panicles which somewhat resemble those of red top (Agrostis alla). Sheaths compressed, especiaily those of the sterile shoots, longer than the internodes, smooth, usually hairy at the throat: ligule membrana- 
ceous, very short; leaf blade linear, six to twenty-four inches long, more or less carinately f lded near the base, scabrous. Panicle four to ten inches long. terminating the culm and its branches, the uppermost usually double by an erect branch from the upper leafaxil, pyramidal, the scabrous primary branches ascending, widely spreading or even reflexed, the secondary branches usually appressed, pedicels as long as, or more often much shorter than the spikelets, scabrous, and frequently bearing a few long hairs. Spikelets one to one and one-fourth lines long, racemose, scattered or much crowded along one side of the branches, lanceolate or crate, acute; first glume three-nerved, acute, scabrous on the keel above, about one-half as long as the equal five-nerved second and third glumes; third glume has a thin palea which is ciliate on the margins near the apex; fourth glume hard and shining, elliptical or narrowly obovate, one-half to three-fourths of a line long, nearly sessile or raised on a distinct pedicel, apex barbulate with a few short hairs.

Var. elong atum (P. elongatum Pursh). Plate IX. Figure 34. Panicle rather loosely flowered; spikelets one and a half lines long, subacuminate pointed, fertile floret distinctly pedicellate. This is the more common form in East Tennessee. It grows along the banks of streams and in wet meadows, often affording a considerable amount of fairly good native hay. In low, moist and rather rich soils its cultivation may prove profitable.

\section{Panicum virgatum $L$. Switch-grass.}

Plate IX. Figure 35.

A stout, erect perennial three to five feet high, with strong creeping rootstocks, long, flat leaves and ample spreading panicle. Culms smooth, terete. Sheaths smooth, ciliate along the margins above; ligule very short, naked, or densely and long pilose; leafblade ten to twenty-four inches long, two to five lines wide, scabrous on the margins, sometimes pilose above nsar the base, otherwise smooth, long-acuminate pointed. Panicle six to twenty inches long, the branches solitary, or several together, more or less widely spreading, rather rigid, the lower four to ten inches 1nng. Spikelets ovate, acuminate, two to two and one-half lines long; the acuminate first glume about one-half the length of the spikelet, three- to five-nerved; second glume usually longer than the others, five-to seven-nerved, as is the third, which has a palea and usually a staminate flower in its axil; flowering glume smooth and shining, distinctly shorter than the larger outer glumes.

Sandy soil, August to October. Gattinger records $P$. virgatum as growing in moist sandy soil along the Cumberland river and on the highlands and barrens at Tullahoma. When young this grass affords good grazing, but by the time it blooms the stems become hard and practically worthless for fodder. Its cultivation here cannot at present be recommended. It has grown finely in the experimental plots at the Experiment Station, and during the latter part of May the leafage of this grass is large and decidedly attractive to the farmer. 


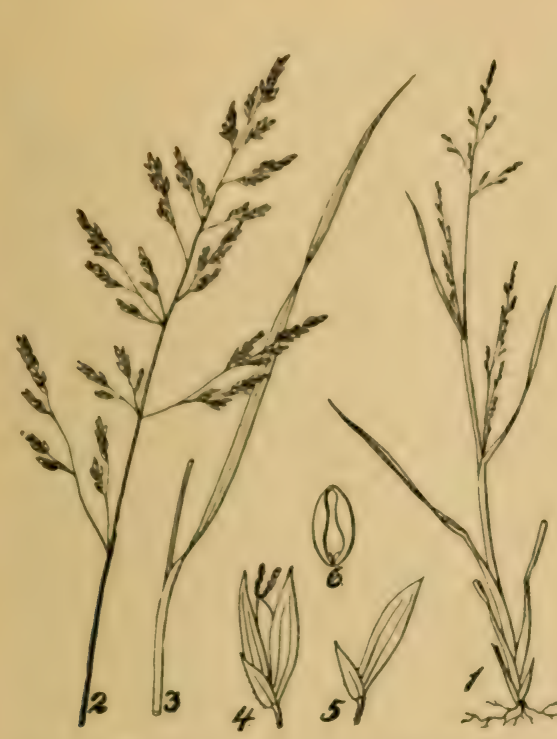

Fig. 38. Panicom agrostoides.

2. Pantcle. 3. Upper leaf. 4. Splkelet. 5. Empty glumes. 6. Graln, with palet and lodicules.

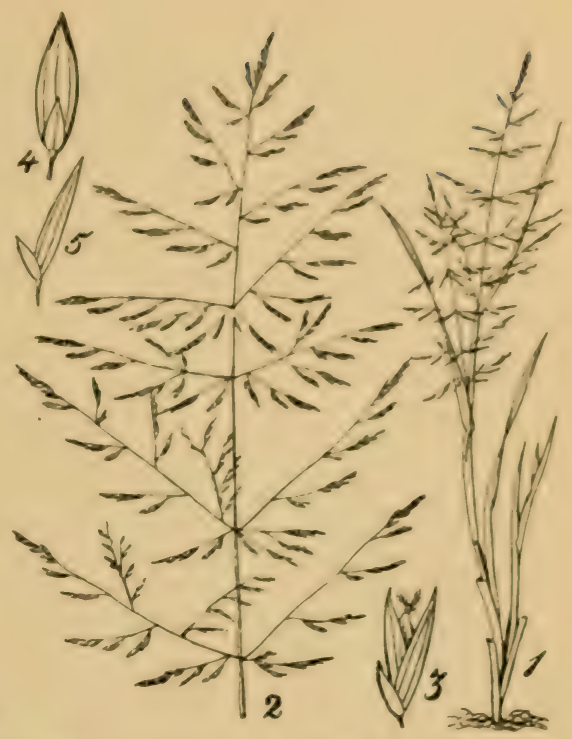

Fig. 34. Panicum agrostoldes elongatum.

2. Panicle. 3. Splkelet, side vlew. 4. Splkelet, front view. 5. Kmpty glumes.

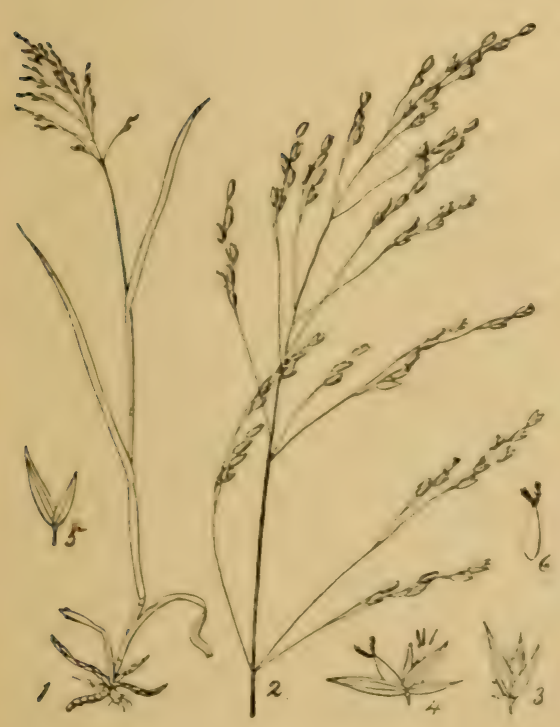

Fig. 35. Panicum virgatum.

9. Upper portion of the panicle. 3. Splkelet. 4. Splkelet laid open. 5. Outer glumes. 6. Fertlle flower, slde vlew.

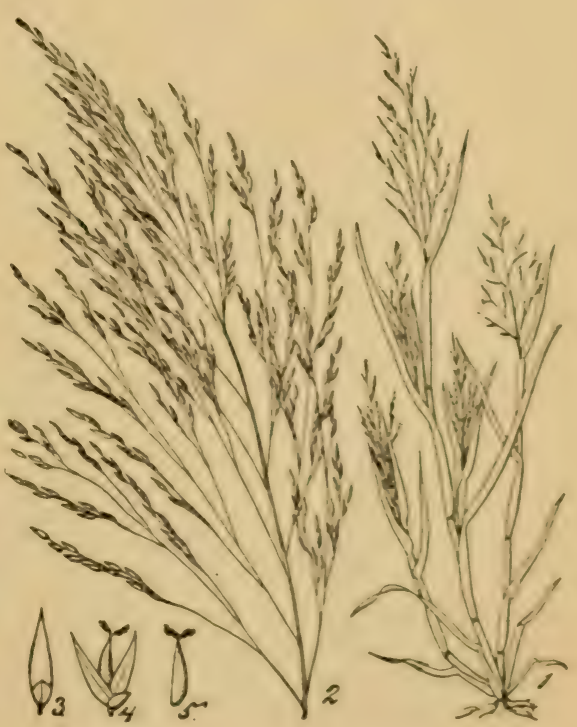

Fle. 36. Panicum proliferum.

2. Upper portion of pantcle. 3. Splkelet, front view. 4. Splkelet, side view. 5. Flowering glume. 



\section{Panicum proliferum Lam. Sprouting Crab.grass.}

\section{Plate IX. Figure 86.}

A smooth, usually much-branched annual, with rather coarse spreading or ascending (rarely erect) stems, two to four or six feet lung. that leaves and diffuse terminal and lateral panicles. Sheaths smooth, lax, somewhat flattened; ligule ciliate; leaf-blade six to twelve or twenty-four inches long, two to ten lines wide, acute, scabrous on the margins and sometimes also on the prominent nerves, rarely pilose on the upper surface. Panicles pyramidal, four or tive to twelve or fifteen inches long, the primary and sec. ondary branches spreading, scabrous. Spikelets rather crowded on short appressed and scabrous pedicels, lanceolate ovate, acute. one to one and one-half lines long, smooth, green or purplish; lowest glume embracing the base of the spikelet, usually obtuse and nerveless, rarely one-to three-nerved, one-fourth to one-third as long as the nearly equal acute five- to seven-nerved second and third glumes, the latter sometimes having a hyaline palea in its axil; floral glume elliptical, subacute, smooth and shining, a little shorter than the larger outer glumes. Anthers suffron yellow.

Common in moist, rich soil, along the banks of streams and rivers or around "sink-holes." If the station of growth happens to becomedry, the grass is more slender and erect, and of ten becomes redish or purplish throughout. When in bloom the saffron-colored stamens are very conspicuous. It is often abundant in cultivated fields, springing ip with common crab-grass, and thus sometimes forms no inconsiderable part of the "poor man's hay." While occasionally useful in this way, and even prized by some, it must be regarded more as a weed than as a hay plant.

\section{1r. Panicum capillare Linn. Old Witch-grass.}

Plate X. Figure 37.

An annual with usually coarse, branching stems, one to three feet long, with very hairy leaf-sheaths and capillary, widelyspreading panicles, terminal on the culm or its branches. Culm geniculate and branching near the base, rarely simple, generally pilose or pubescent below the bearded nodes. Sheaths pilose to densely hirsute, with spreading hairs; ligule very short, densely ciliate; leaf-blade flat, lanceolate or linear, acute, usually thinly hairy on both sides, margins scabrous and ciliate near the base. The hairs throughout spring from small papillae, those on the leafblade being confined chiefly to the principal nerves. Panicle diffuse, three to twelve inches long, the branches solitary, in pairs or rarely whorled, the ultimate branches and pedicels strongly hispid. Spikelets one line long, ovate acute, or abruptly acuminatepointed, smooth; first glume clasping the base of the spikelet. obtuse or acute, one-to three-nerved, about one-third the length of the five- to seven-nerved and nearly equal second and third glumes, the acute tips of these are sometimes minutely pubescent: flowering glume snonth and shining. elliptical, obtuse, or subacute, a little shorter than the laryer outer glumes. Variable. 
Var. (a) vulgaris. Culms stout, sheaths densely hirsute, panicle a foot long or more, the branches widely spreading at maturity, often beçoming deflexed with age; spikelets long pedicelled and dark purple, as are sometimes the capillary panicle-branches. This is a common form in sandy cultivated fields and gardens It is the variety agresie of Dr. Gattinger (Tennessee Flora, p. 94).

Var. (b) campestre Gatt. (1. c.) Plate X. Figure 38. Less stout, the ascending, leafy culms branching throughout, sheaths pubescent; the numerous panicles oval or elliptical, rarely exceeding six inches in length. Whole plant rather pale green. Common along roadsides and cultivated grounds, waste places, etc., - the most common form according to Dr. Gattinger. This may be Panicum Philadelphicum Bernh. ex. Nees. It is $P$. capillare var. geniculatum Scribner.

Var. minimum Engel. Plate X. Figure 39. Low and slender, usually geniculate at the lower joints and much branched below, rarely a foot high; sheaths long-pilose, leaves two to four inches long, one to three lines wide, panicle oval or pyramidal, few-flowered, the small spikelets mostly approximate in pairs or threes near the tips of the spreading branches, their rather short (usually not longer than the spikelet) pedicels appressed. A dwarf, slender variety, usually pale green throughout, the lateral spikelets of the panicle-branches about the length of their appressed pedicels. Frequent in dry, usually poor soils, over the State.

None of the forms have any agricultural value, but are rather to be considered as weeds.

\section{Panicum flexile Scribner.}

\section{Plate X. Figure 40.}

A rather slender erect annual, usually branched and geniculate near the base, one to two feet high, with flat leaves, an open capillary panicle and rather distant, acute spikelets. Culms pilose or bearded at the nodes. Sheaths more or less pilose, the lower sometimes hirsute with spreading hairs; ligule very short, its margin ciliate-fringed; leaf-blade narrow-lanceolate or linear, three to ten inches long, one and one-half to four (usually two to three) lines wide, sparsely ha1ry on both sides, rarely smooth, scabrous on the margins, which are long-pilose near the base, very acute. Panicle five to twelve inches long, narrow-ovate in outline, branches ascending the scabrous spreading pedicels much longer than the lanceolate, acuminate-pointed spikelets. Spikelets one and onehalf lines long; first glume clasping, triangular, obtuse or acute, one- to three-nerved, about one-third the length of the nearly equal second and third glumes, which are five- to seven-nerved; flowering glume narrow, elliptical, subacute, about one-fourth shorter than the larger outer glumes. Dry, sandy soil, common in open pine woods, cedar glades, etc., less frequent in fields. July to October.

Dr. Gattinger remarks that this grass "is characteristic of the cedar glades," and refers to its resembiance to $P$. autumnale. In that species, however, the leaves are shorter, more rigid, and the 


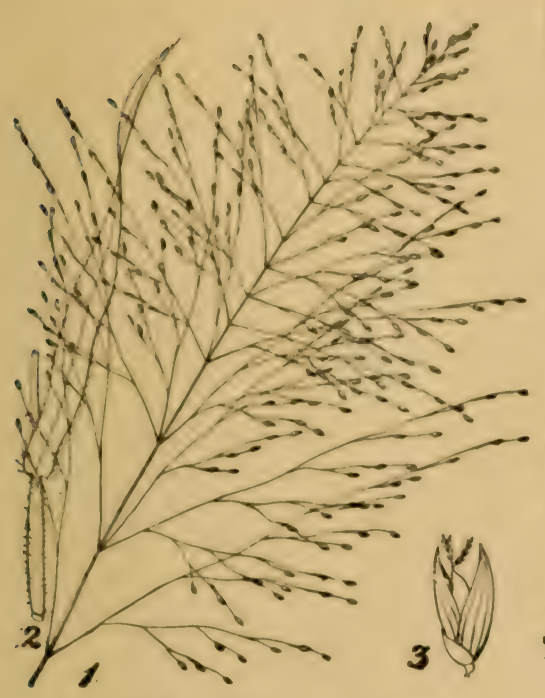

rig. 37. Panicum rapillare.

1. Pantcle. 2. Upper leaf. 3. Splkelet.

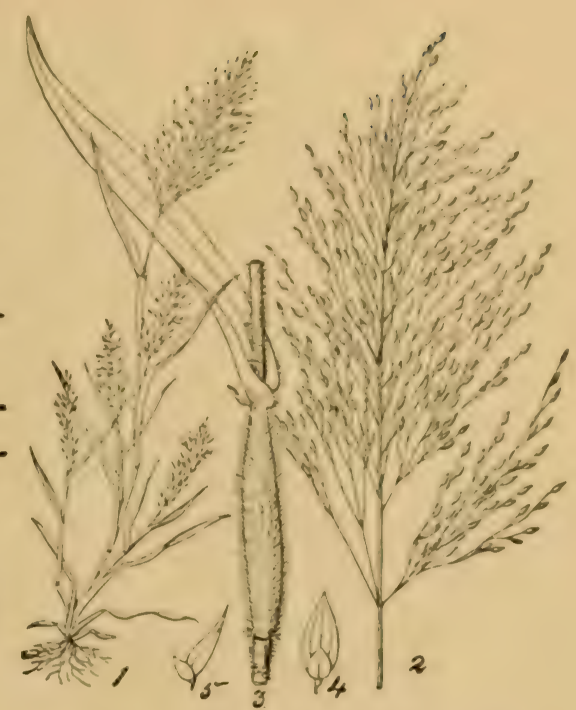

Fig. 35. Panirum capillare campestre.

2. Pantcle. 3. Upper sheath, with leaf. blade. 4. Splkelet, rrint vlew. 5. Empty glumes.

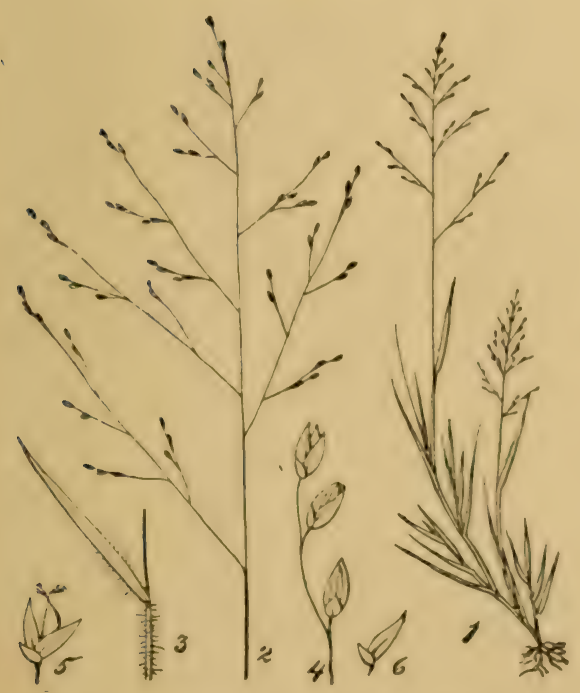

Fig. 39. Panleum capillare minimum.

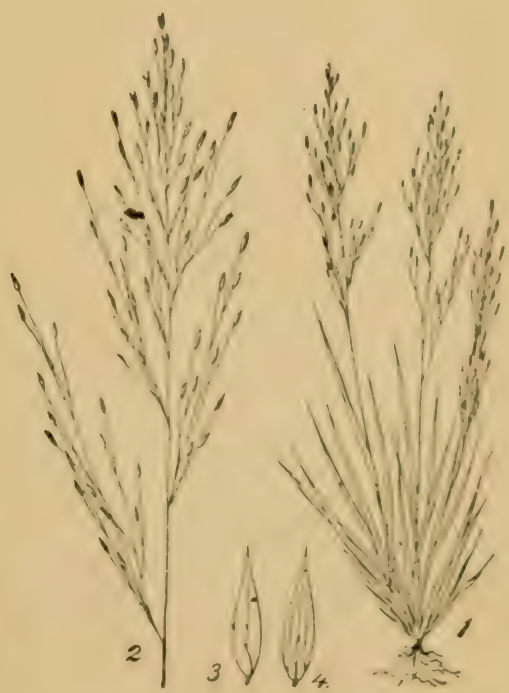

Fig. 40. Panienm flexile.

9. Pantcle. 3. Upper leat. 4. Branch of the pantcle. 5. Splkelet, slie rlew. 6. Outer glumes.

2. Pinlcle. 3. Splkelet, slde vlew. 4 spikelet, front riew. 

primary panicle-branches are widely divergent. This is treated as a variety of $P$. iapillare by Dr. Ciattinger. Judging from the description, it is $P$. diffusum of Pursh, not of Swartz.

\section{Panicum hians E11.}

Plate XI. Figure 41.

A slender decumbent or ascending perenrial, ten inches to two feet high, with rather long, narrow leaves and open panicle, the small spikelets crowded near the ends of the more or less spreading branches. Culms and compressed sheaths smooth or the latter ciliate on the margins above: ligule very short, fimbriate: leaf-blade flat, three to eight inches long, one to three lines wicle, usually pilose near the base, margins minutely scabrous, very acute. Fanicle three to six inches long, pyramidal, the capillary ascending branches solitary or in pairs, the lower one to four inches long. Spikelets smooth, about one line long, usually exceeding the pedicels, glumes more or less spreading; first glume obtuse, three-nerved, one-third to one-half as long as the three-to five-nerved, acute second glume, which equals the spikelet; third glume five-nerved, barely equalling its broad-margined, inflated and apiculate palea; floral glume narrow, ovate, acute, apiculate.

Luw grounds and damp pine barrens; not common within the State. August to October. The spikelets are remarkable for the very large palea of the third glume. Vicinity of Memphis (Dr. Egling) is\$6. West Tennessee (S. M. Bain). Of no recognized agricultural value.

\section{Panicum verrucosum Muhl.}

Plate XI. Figure 42.

A slender, branching perennial, with flat leaves and few-flowered, spreading panicles. Culms very smooth, weak, decumbent or reclining, rarely erect, one to three feet long. Sheaths smooth, much shorter than the internodes, ciliate on the margins above: ligule very short, ciliate; leaf-blade lanceolate, three to six inches long, two to four lines wide, scabrous on the margins, contracted at the base, very acute. Panicle three to eight inches long, capillary, branches solitary or in pairs, the lower two to four inches long, naked below, the secondary branches appressed and few (one to four) flowered. Spikelets about one line long, oval, acute; outer glumes apparently nerveless, the first smooth, one-fourth as long as the second and third, which are tuberculate-roughened (rerrucose), flowering glume abruptly sharp-pointed or submucronate, smooth; palea with a callus-like elevation at the base. Usually found in damp, rich, shaded soils, and readily distinguished by its slender, straggling habit and rough, nerveless outer glumes. Dr. Gattinger reports its occurrence on swampy lands along the Cumberland river and at Tullahoma, Coffee county. Its range is from New England south to Florida. Of no agricultural value.

Note.-The following species constitute a group in which the radical leares are crowded, often appearing like a rosette around the base of the culms. These leaves are usually shorter than those above, and are gen- 
erally ovate or ovate-lanceolate. In the early flowering stage the culms are nearly always simple, and support a single, often long-exserted panicle; later the culms become much branched, and the branches are terminated by more simple, fewer-flowered panicles, which very frequently are partially enclosed in the leaf-sheaths. The primary panicle, and sometimes the first culm leaves, disappear, and there is left a muchbranched grass with numerous, crowded and usually small leaves, and many small, few-flowered, simple panicles.

\section{Panicum clandestinum Linn.}

Plate XI. Figure 43.

A rather stout, ascending or erect and finally much.branched perennial, three to four feet high, with usually very rough-hispid sheaths and broad leaves. Nodes and internodes smooth, or the latter tuberculate-pilose in the upper part. Sheaths usually very rough tuberculate-hispid, rarely nearly smooth, the outer margins ciliate-pubescent; ligule very short; leaf-blade broadly lanceolate, three to eight inches long, one-half to one and three-fourths inches wide, with a clasping rounded-cordate base and very acute apex, surfaces usually smouth, margins minutely serrulate scabrous and often ciliate near the base. Panicle diffuse, that of the primary stem three to five inches long and finally exserted, those of the branches partly or wholly concealed within the leaf-sheaths; branches of the panicle aiternate, decompound to the base, scabrous, as are the pedicels, which are for the most part longer than the spikelets. Spikelets one and one-half lines long, obovate elliptical, smooth or thinly pilose, and usually three-nerved; first glume about one half as long as the nearly equal nine nerved second and third glumes, the latter with a palea in its axil, the inner or fourth glume minutely pubescent at the apex, otherwise smooth. Leaves on the branches shorter and more crowded, and the sheaths more roughly hairy than on the primary stem. The variety pedunculatum $A$. Gray is based upon the early stage of the species. The primary, terminal, exserted panicle disappears after the development of the lateral branches.

Common along the banks of streams, rivers and low thickets. June to September.

\section{I6. Panicum viscidum E11.}

\section{Plate XI. Figure 44.}

A rather stout, erect or ascending, and finally much-branched perennial, two to four feet high, with the culm and sheaths usually densely pubescent with spreading or deflexed, canescent hairs, and all the parts somewhat viscid when fresh. Ligule a dense ring of hairs about one line long; leaf-blade lanceolate, gradually tapering from near the middle to the very acute apex; sub-cordate at the base, softly pubescent on both sides, minutely scabrous on the margins, villous on the back at the point of union with the sheath; basal leaves ovate, two to four inches long, obtuse, those of the primary culm five to ten inches long, five to nine lines wide; the leaves of the branches more crowded and much smaller. Panicle four to six inches long, ovate or sub-pyrainidal, branches compound to the base, the lower ones about three inches long, flexuose. Pedicels nearly capillary, usually much longer than the spikelets. 


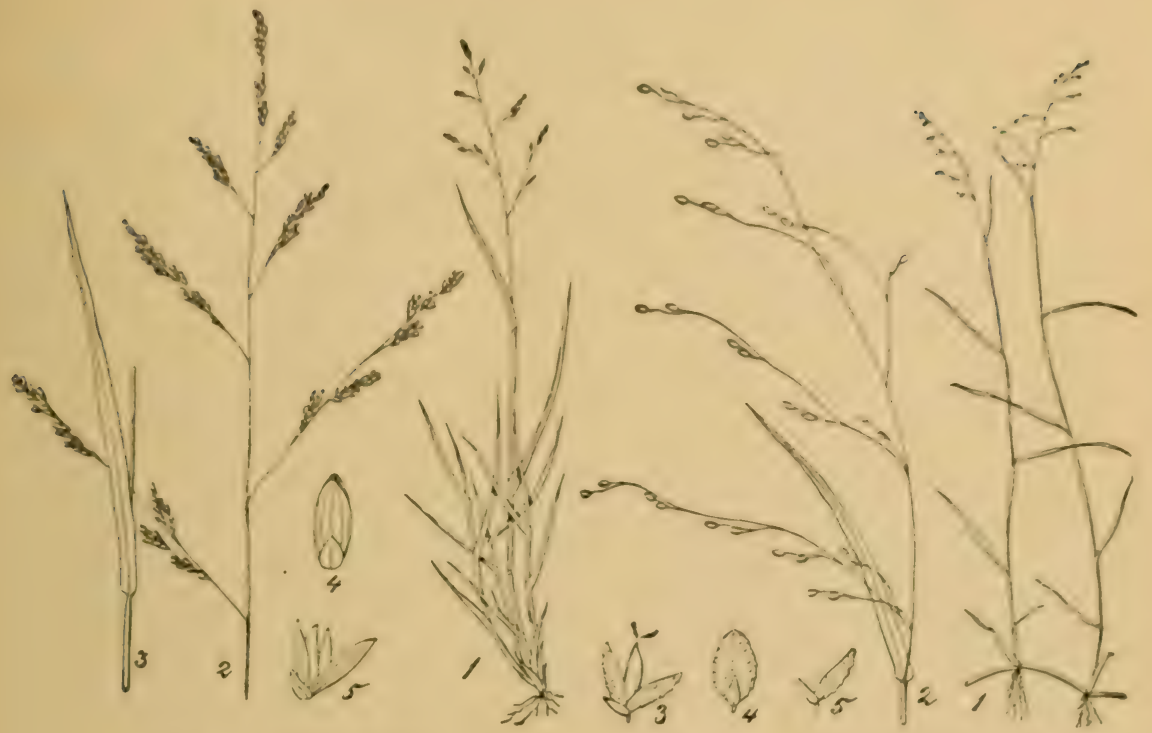

Fig. 41. Panicum hians.

2. Pantcle, 3. Upper leaf. 4. Splkelet, front view. 5. spikelet. side vlew, lald open.
Fig. 42. Panicum verrucosum.

2. Upperleaf and panlcle. 3. Splkelet, slite view. 4. splkelet, front vlew. 5. Outer glumes.

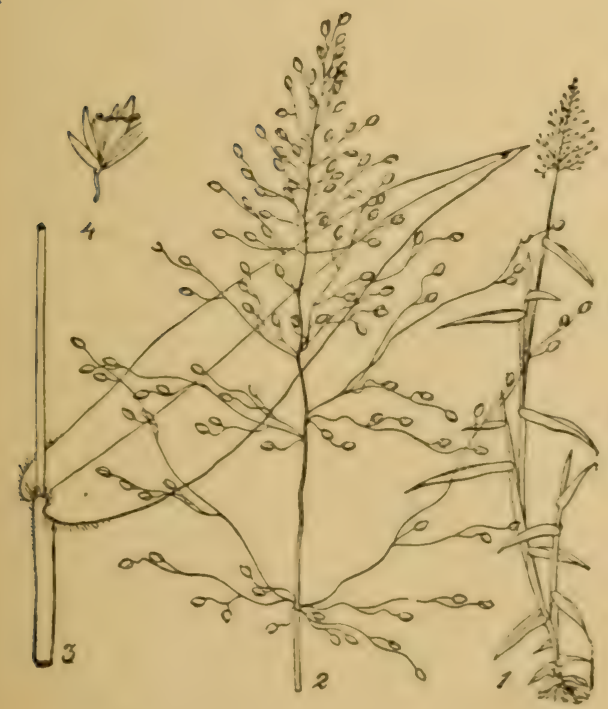

Vig. 43. Panicum clanilestinum.

2. Panicle. 3. Ipper leaf. 4. Splkelet lald open

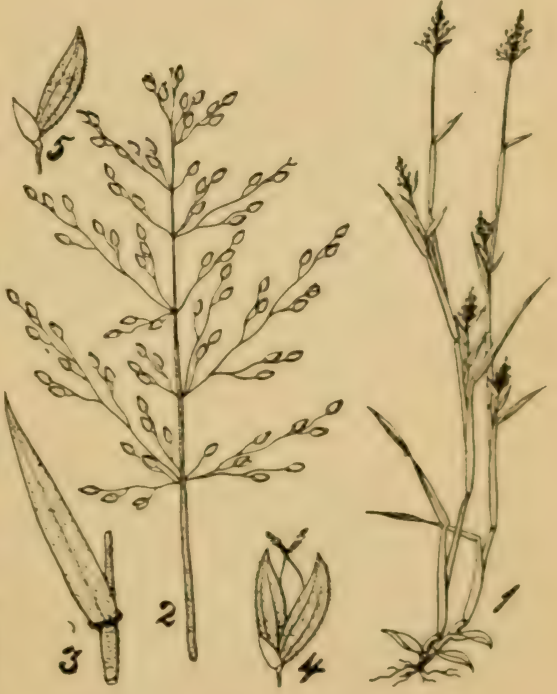

Fig. 44. Panicum viscidum.

2. Panlcle. 8. Cipper leaf. 4. Splkelet. 5. Empty glumes. 

Spikelets one line long, rounded ohovate, very abruptly puinterl. First glume one-fifth 10 onethird as long as the others, usually nerveless; second and third glumes nine-nerved, pubescent; the thirl with a small hyaline palea; the fourth or flowering g!ume smonth. Below each of the nodes there is a smooth space about two lines broad, extending around the stem like a ring. The nearly smooth upper portions of the sheaths and panicle-branches are mottled with irregular yellow or brown, often purple-bor. dered, spots. l'anicles of the branches much smaller and fewerflowered than that of the primary stem.

Low grounds, borders of thickets, etc. June to September. In the Valley of the Hiwassee (A. Ruth). WiVest Tennessee (S. M. Bain).

\section{Panicum Walteri Poir. (P.latifolium Walter and many Ameri-} can authors.)

Plate XII. Figure 45, (as P. latifolium).

A rather slender branching perennial, one to two feet high, with broad ovate or lanceolate leaves and rather large spikelets in fewflowered spreading panicles. Culms finally much-branched above, smooth or pubescent; nodes smooth or bearded with soft spreading or reflexed hairs. Sheaths usually shorter than the internodes, smooth or pubescent, the outer margin ciliate: ligule a fringe of hairs one to two lines long; leaf-blade two to five inches long, four to sixteen lines wide, broadly lanceolate or ovate, acute, cordate and more or less clasping at the base, surfaces smooth or thinly pubescent, margins minutely scabrous. Panicle nearly simple, two and one-half to five inches long, pyramidal, the spreading branches and usually short, appressed pedicels nearly smooth or pilose. Spikelets about two lines long, ovate-elliptical or pyriform, obtuse; first glume one-fourth to one-third as long as the others, threenerved; second and third glumes, elliptical obtuse, nine- to elevennerved, more or less pubescent, the third with a palea nearly as long as itself and sometimes a staminate flower; fourth glume elliptical, its apex pubescent. Common in open woods and thickets. June to July. Remarkable for its broad leaves and large spikelets, which are racemose along the solitary branches of the panicle. This is the $P$. latifolium of most American authors, but not of Linnaus. P scoparium of Elliott and Chapman has a panicle and spikelets hardly to be distinguished from $P$. Walteri. It differs in its more pubescent sheaths and narrower leaves, which are densely pubescent on the lower surface and smooth on the upper.

\section{Panicum scoparium Lam.}

An erect or ascending perennial, with rather slender finally much-branched culms, six to twenty-four inches high, flat, lanceolate leaves and large spikelets in rather small, nearly simple fewflowered panicles. Culms smooth or pubescent; nodes smooth or densely bearded with spreading or reflexed hairs. Sheaths usually shorter than the internodes, papillate-pilose or pubescent, rarely glabrous, bearded at the throat; ligule a fringe of hairs; leaf-blade lanceolate, three to six inches long, three to twelve lines 
wide, acute rounded and more or less clasping at the base, margins scabrous and ciliate near the base, surfaces smooth or with a few scattering hairs, or the under side densely pubescent. Panicle two to five inches long, the few-flowered, solitary and erect or more or less spreading branches scabrous, pubescent or pilose. Spikelets one and one-half to two lines long, ovate or obovate; first glume about one-third the length of the others, acute or obtuse; second and third glumes broadly ovate, conspicuously nine-to elevennerved, nearly smooth or pubescent, the third with a palea; fourth glume smooth and shining, minutely apiculate. Dry fields and open woods. May-June.

A variable species, as here characterized, presenting several well-marked forms or varieties.

Var. genuinum. Stem and sheaths villous; leaves three to six inches long, six to twelve lines wide, densely and softly pubescent on the lower surface, the upper surface smooth, or nearly so; panicle three to five inches long, the large (nearly two lines) spikelets borne mostly near the ends of the branches. ( $P$. sioparium Lam., El1.: P. scoparium major Vasey.) West Tennessee (S. M. Bain). Approaches $P$. Walteri Poir, and treated as a variety of that species by Trinius.

Var. pauciflorum. Plate XII. Figure 46. Stem slender, sheaths and narrow (three to four lines) leaves nearly smooth, except along the margins; panicle smaller and fewer-flowered than in var. genuinum. P pauciflorum Ell., ( $P$. scoparium var. angustifolium Tasey.) Not observed in Tennessee.

Var. minor. Leaves erect, about one-fourth of an inch wide, and with the sheaths often papillate-pilose; panicle one to three inches long; spikelets one and one-half lines long, more rounded and more crowded in the panicle than in the other varieties. Panicle branches and spikelets nearly smooth, or (subvar. pilosum) densely pilose hairy. Midale Tennessee (Gattinger). This is the most widely distributed and best known form of the species.

\section{Panicum angustifolium E11.}

Plate XII. Figures 47,48 , (as $P$. consanguineum).

Culms one to two feet high, at first simple, finally very much branched throughout; slightly pubescent, especially at the nodes. Sheaths shorter than the internodes, more or less pubescent, at least the lower ones; ligule a fringe of rather short hairs; leafblade of the primary stem erect, three to six inches long, two to three lines wide, rigid, very acute, margins scabrous, minutely ciliate near the base. Leaves of the wiry branches very numerous and involute-filiform. Panicles three to four inches long, rather loosely flowered, the scabrous main axis and nearly simple branches flexuose. Spikelets about one and one-half lines long, oblong-elliptical, obtuse or subacute; first glume thin, scarious, nerveless, onefourth as long as the others; second and third glumes finely pubes. cent, obtuse, the second seven- to nine-nerved, the third sevennerved and without a palea; the fourth glume minutely apiculate and slightly barbulate at the apex. Sterile soij, May to June. Henderson (S. M. Bain); also near Knoxville. 


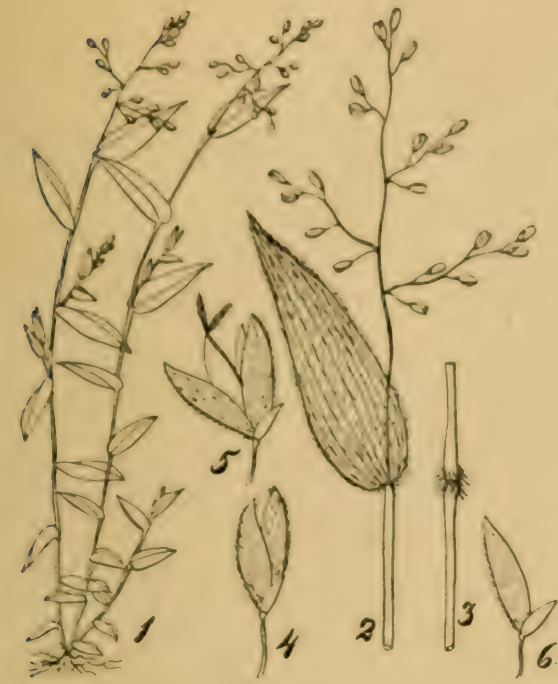

Fiะ. 45. Panicum latifulium.

2. Pantcle and upper leat. 3. Node. 4. Splkelet. 5. Splkelet lald open. 6. Empty glumes.

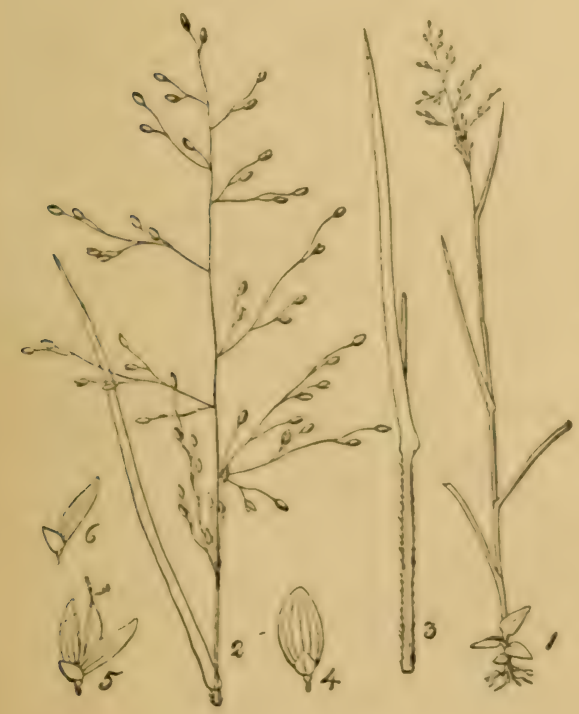

Fig. 47. Panicum consanguineum.

2. Pantcle and upper leaf. 3. Leaf and halry sheath. 4. Spikelet, front vlew. Splkelet, slde vlew. 6. Outer glumes.

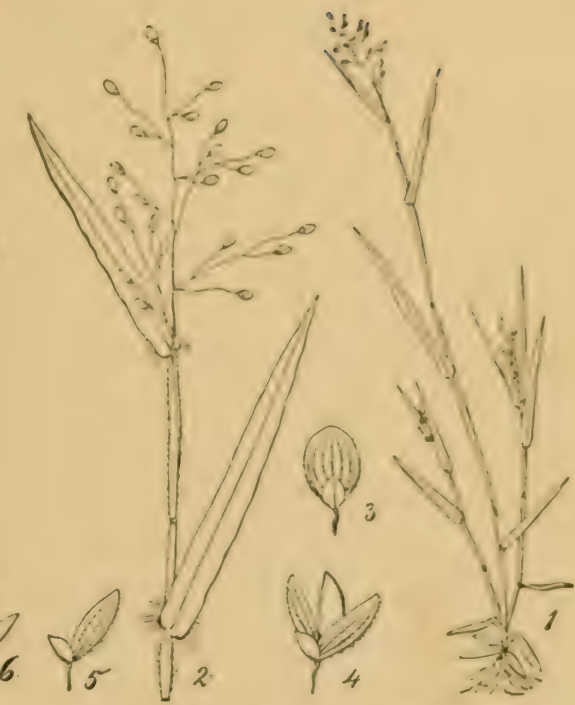

Fig. 46. Panicum pauciflorum.

2. Upper part of culm, two leaves and the pantcle. 3. Splkelet. front vlew. 4 Splkelet, side view. 5. Outer glumes.

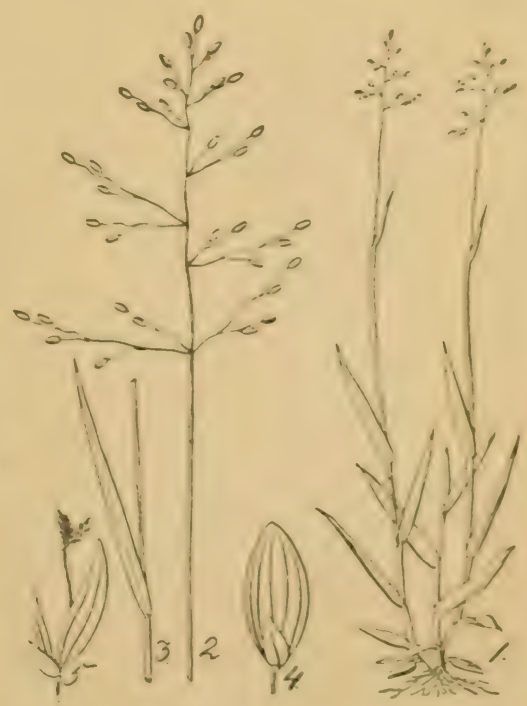

Fiz. 48. Panicum consanguineum ?

2. Pantcle. 3. Upper leaf. 4. Splkelet, front vlew. 5. splkelet lald open, slde vlew. 

In the Tennessee specimens the culms are more leafy and the panicles more pyramidal than in specimens from South Carolina and Florida, and the panicle-branches are widely spreading or deflexed. The much-branched autumnal state of this grass was named $P$. neuranthum by Dr. Vasey.

\section{Panicum depauperatum Muhl.}

\section{Plate XIII. Figure 49.}

Densely cespitose, with slender culms six to eighteen inches high, and very narrow long erect leaves. Culms simple or finally branched near the base, the branches flower-bearing: nodes usually bearded. Sheaths smooth or more or less densely pilose, with soft spreading hairs; ligule a fringe of short hairs; leaf-blade one to two lines wide, three to eight inches long, very acute, often involute, at least when dry, scabrous and sometimes pilose, at least near the base. Panicle one to four inches long, nearly simple, loosely few-flowered, the solitary branches ascending or erect and scabrous. Spikelets one to two lines long (usually one and onehalf lines) orate, acutish, smonth: first glume about one-fourth the length of the second and third, which are prominently seven- to nine-nerved and acute, the third with a small thin palea, fourth glume smooth rounded-obtuse, a little shorter than the second and third. Dry sterile hills and open woods, common. May to June. In the form with pilose sheaths the spikelets are usually smaller than in the smooth form.

\section{Panicum commutatum Schultes.}

Plate XIII. Figure 50.

A rather slender, branching perennial one to two and one-half feet high, with usually smooth, broad, flat leaves and diffuse panicles. Culms smooth or closely and minutely pubescent, especially near the nodes; the nodes often bearded with short appressed hairs. Sheaths shorter than the internodes, ciliate along the outer margin: ligule very short and ciliate-fringed; leaf-blade two to four inches long, one-fourth to one inch wicle, broadly lanceolate or ovate, acute, ciliate along the margins near the cordate-clasping base, surfaces smooth or minutely pubescent. Leaves of the branches often broader and always more crowded than those of the primary stem. Panicle two to five inches long, lax, the capillary branches widely spreading, naked below: pedicels scabrous, much longer than the spikelets. Spikelets one and one-half lines long. ovate-elliptical, obtuse: first glume about one-third the length of the others, obtuse or acute; second and third glumes broadiy orate, seven-nerved, nearly equal, pubescent, slightly exceeding the smooth fourth glume. The third glume has a small palea. ()pen woods, common. June-July.

The leaves of this species are many-nerved, rather thin, and often purple-tinged. They are quite variable in size, but al ways broader than in $P$. nitidum or $P$. dichotomum, and the spikelets are larger than in these species. The panicle is more compound and the 
spikelets rather smaller and less distinctly racemose than in $P$. Walteri, which resembles $P$.commutatum in general habit of growth.

\section{Panicum sphærocarpon E11.}

Plate XIII. Figures 51, 52.

A tufted, erect or ascending perennial, ten to twenty-four inches high, with rather broad, firm and nearly erect leaves, and diffuse many-flowered panicles, usually about three inches long. Culms simple or finally much branched near the base, smooth or usually pubescent with erect hairs at the nodes. Sheaths longer, or more often shorter than the internodes, ciliate along the overlapping or outer margin, otherwise smooth; ligule none; lowermost leaves broadly ovate, many-nerved, minutely roughened along the strongly cartilaginous margins; the leaves of the culm two to four inches long, one-fourth to three-fourths of an inch wide, cordate-clasping at the base, very acute, many-nerved, lower surface smooth, the upper scabrous, margins cartilaginous and minutely serrulate, with a few long hairs near the base; uppermost leaf two to three inches long. Panicle ovate-pyramidal, two to three, rarely four inches long, branches very slender, divided to the base, pedicels usually much longer than the spikelets. Spikelets nearly spherical, less than a line long; first glume minute, the second and third glumes nearly equal, seven- to nine-nerved, minutely pubescent; the third with a small, hyaline palea; fourth glume smooth and shining, very obtuse. Dry open woods and fields. May-June.

This differs from $P$. microcarpon in its shorter, narrower, and more erect leaves, bearded nodes, shorter leaf-sheaths and smaller panicle. It also blooms in advance of $P$. microcarpon and the culms are more often branched. In the open the culms are often nearly prostrate.

\section{Panicum microcarpon Muhl.}

Plate XIV. Figures 53, 54.

An erect or ascending perennial one to three, usually about two feet high, with smooth, broad, spreading leaves and diffuse, manyand very small-flowered panicles, usually four to five inches long. Culms smooth, usually simple or finally sparingly branched. Sheaths smooth, exceeding the internodes, ligule none; basal leaves crowded, ovate, one to two inches long, one-half to three-fourths of an inch wide, many-nerved, with strong cartilaginous and scabrous margins, those above five to ten inches long, lanceolate from a cordate clasping base, very acute, nerves prominent, ciliate on the minutely scabrous margins near the base; the uppermost leaf three to eight, usually five to six inches long and often an inch wide. Panicle three to eight inches long, ovate-elliptical, the very slender branches compound to the base; the capillary pedicels usually longer than the numerous spikelets. Spikelets broadly obovate or nearly spherical, three-fourths of a line long; first glume minute, the second and third nearly equal, seven-nerved, minutely pubescent; the third with a small hyaline palea; the fourth glume white, shining, obtuse. 


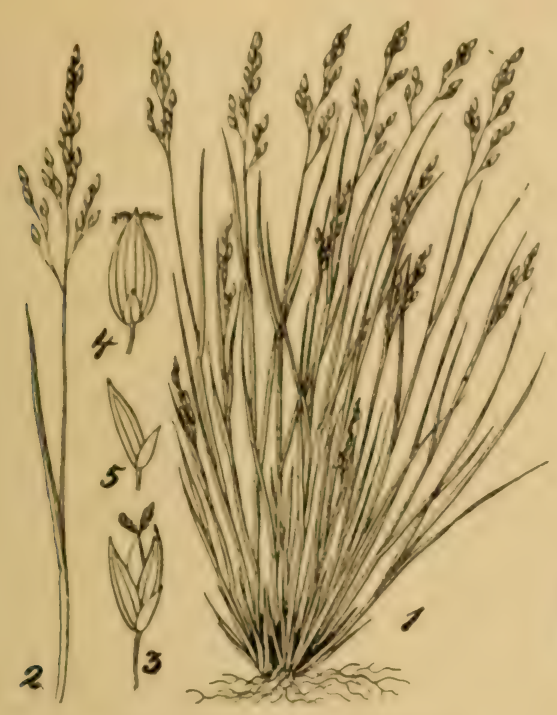

Fig. 49. Panicum depauperatum.

2. Inflorescence and upper leat. 3. Splkelet, side vlew 4. Splkelet, front view. 5. kimpty glumes.

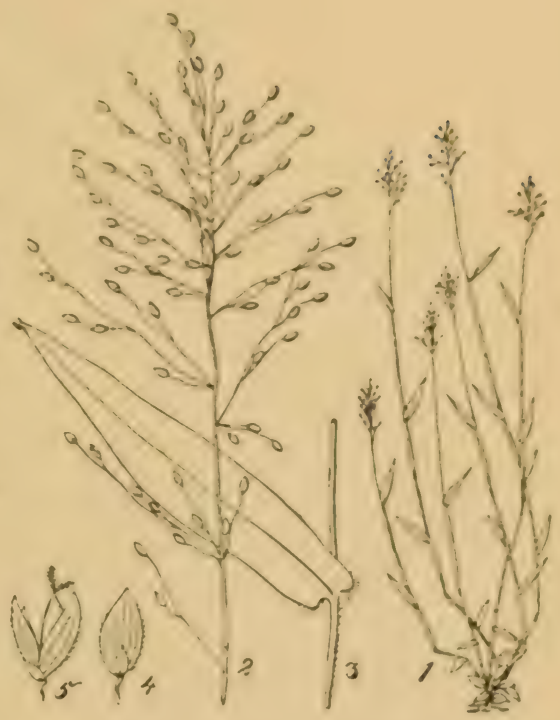

Fis. 50. Panicum commutatum.

2. Panicle. 8. Upper leaf. 4. Splkelet, front vlew. 5. splkelet laid open, slde vlew.

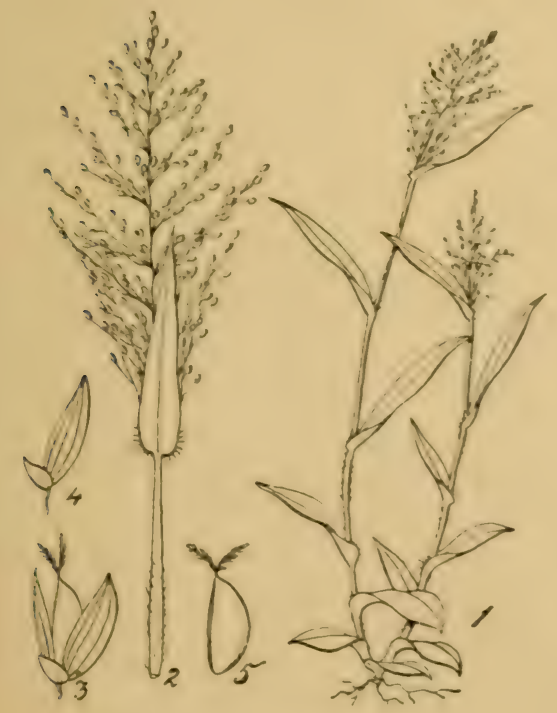

Fig. à1. Panicum sphærocarpon.

2. Lpper leaf and panicle. 3. Splkelet, side vlew. 4. Outer glumes. 5. Fertlle floret.

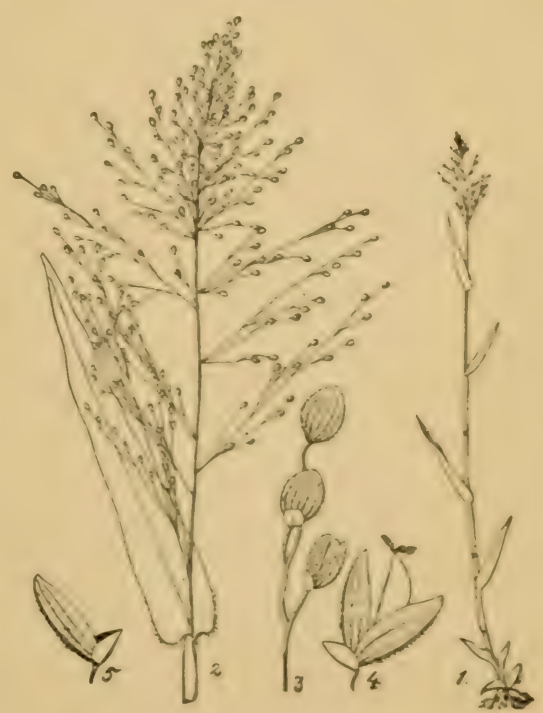

Fiz. 52. Panienm sphærocarpon.

2. Pantcle and upper leaf. 3. Branch of panlcle, with three splkelets. 4. Splkelet, side vlew. 5. Outer glumes. 



$$
\text { - }
$$

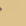




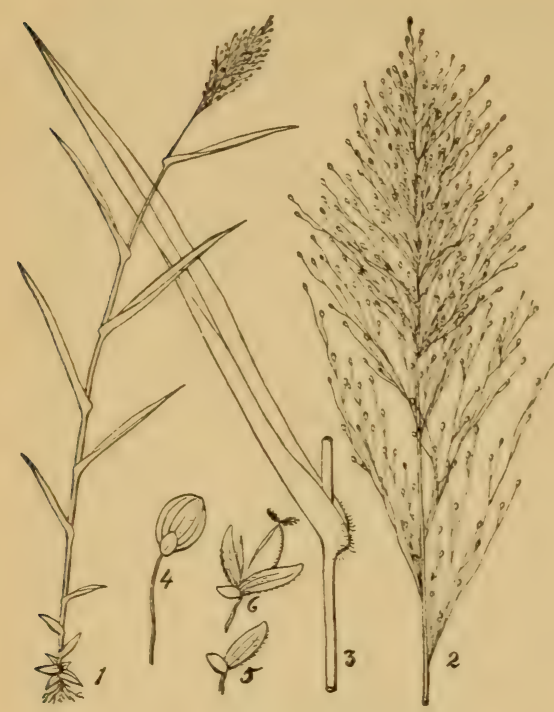

Fig. 53. Panicum microcarpon.

2. Pantcle. 3. Upper leaf. 4. Splkelet, front view. 5. Outer glumes. 6. Spikelet laid open, side view.

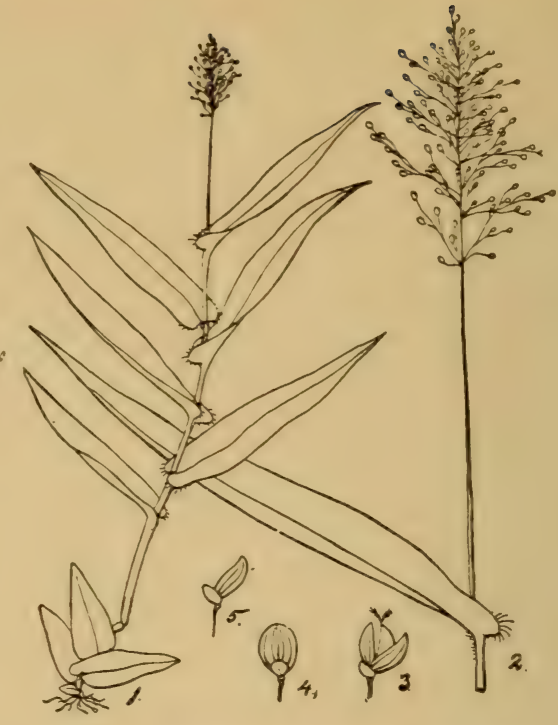

Fig. 54. Panicum microcarpon isophyllum.

2. Upper leaf and panicle. 3. Splkelet laid open, side view. 4. Splkelet, front vlew. 5. Outer glumes.

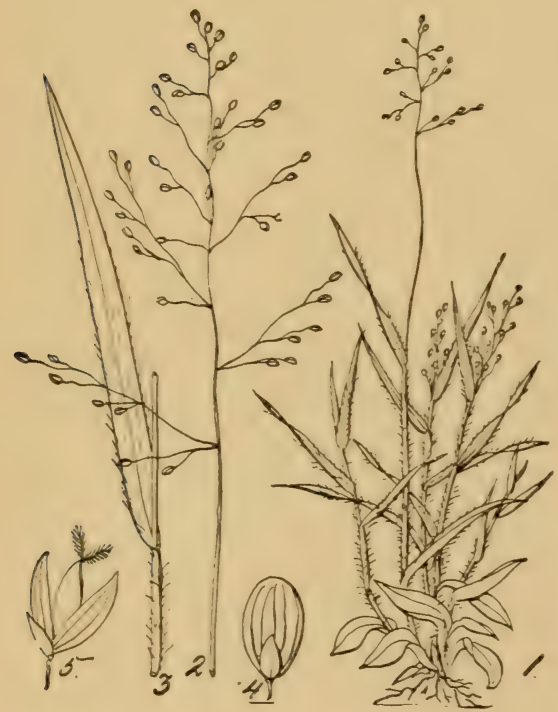

Fis. 55. Panicum laxiflorum,

(from Henderson, Tenn.)

2. Panicle. 3. Upper leaf. 4. Splkelet, front vlew. 5. Splkelet, side view.

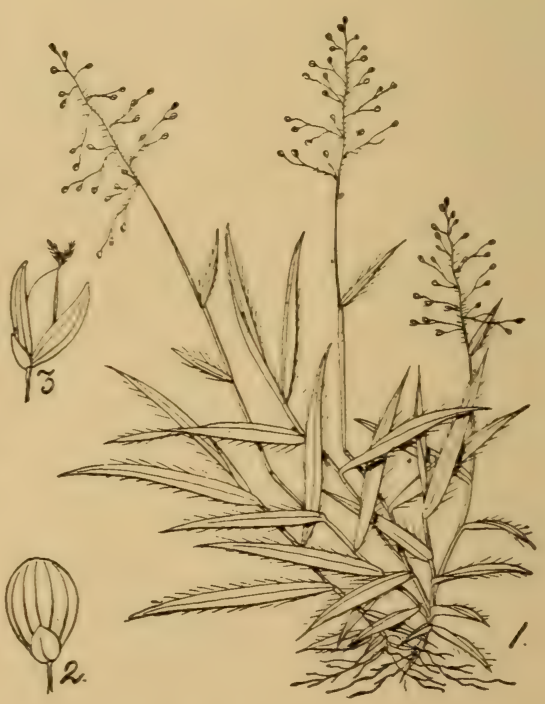

Fig. 56. Panicum ciliatum,

(from Tullahoma, Tenn.)

2. Splkelet, front view. 3. Splkelet laid open. 
The panicle-uranches are somewhat glandular-viscid as in $I$. visidum. Kather common in open woods and horders of thickets, usually in morst ground. June-July. Of no agricultural value. The variety isophllum (Fig. 54) is only a depressed form of the species with crowded leaves.

\section{Panicum laxiflorum Lam.}

Plate XIV. Figure 55.

A slender, tufted perennial, about a foot high, with rather long. pale green leaves and loosely few-flowered panicles. Culms smooth or sparingly pilose, six to eighteen inches high, much branched near the base and more or less geniculate, often rooting at the lower joints; nodes densely pilose, the hairs directed downwards. Sheaths shorter than the internodes, papillate-pilose with spreading or reflexed hairs; ligule a fringe of long hairs; leaf-blade erect, three to five inches long, three to five lines wide, the uppermost scarcely smaller, narrowly lanceolate, long-acuminatepointed, abruptly narrowed at the base, ciliate along the minutely serrulate margins and smooth or thinly pilose on the surfaces: the lowermost leaves of the primary stem crowded, shorter and broaler than the others. Panicles two to three inches long, finally, long exserted, the solitary branches nearly simple, pedicels much longer than the spikelets. Spikelets ovate-elliptical obtuse, about one line long; first glume one-sixth to one-fourth as long as the pubescent, obtuse and nearly equal second and third glumes: third glume with a small palea; fourth glume smooth, white and minutely apiculate at the roundec apex. Distinguished at once from $P$. cilialum, to which it is closely allied, by its longer and proportionately narrower, erect leaves and larger and more loosely flowered panicles. Dry or moist open woods. May-July.

\section{Panicum ciliatum E11.}

Plate XIV. Figure 56.

A censely tufted slender perennial, four to fifteen, usually six to ten inches high, with short leaves and rather few-flowered diffuse panicles. Culms much branched and more or less geniculate near the base, smooth: nodes smooth. Sheaths ciliate along the outer margin; ligule a short fringe of hairs; leaf-blade one to three inches long, two to six lines wide, lanceolate to ovate-lanceolate, acute. usually clasping at the more or less cordate base. ciliate along the margins, surfaces striate, smooth; uppermost leaf one-half to one and one-half inches long. Panicle ovate-pyramidal, one to one and onehalf inches long, main axis and primary branches often pilose. Spikelets about cne line long: first glume one-fourth to one-half as long as the spikelet; second and third glumes nearly equal, obtise seven-nerved, smooth or minutely pubescent, the third with a small palea; flowering glume obscurely apiculate, minutely roughened at maturity.

Quite distinct from $P$. laxiflorum, which it resembles in its habit of branching and thin, pale green leaves. The widely spreading leaves are shorter and proportionately wider, the nodes and sheaths 
are smooth and the panicle is smaller. Open, usually moist woods. June-July. Less common than P. laxiflorum.

\section{Panicum pubescens Lam.}

Plate XV. Figure 58 (as P. dichotomum pubescens).

A slender, finally much-branched perennial, six to twenty inches high, with flat, erect, and rather thick, narrowly-lanceolate leaves. Culms erect or assurgent, usually geniculate at the lower joints, branching throughout, especialiy above, villous or nearly smooth; nodes bearded; sheaths shorter than the internodes, densely villous or pilose, with long spreading hairs, very hairy at the throat; ligule a dense fringe of short hairs; leaf-blades on the primary culm two to four inches long, three to six lines wide, (those of the branches smaller) very acute, rounded at the base and somewhat clasping; margins minutely serrulate-scabrous and pilose; surfaces papillate-pilose with long white hairs, or nearlyglabrous. Panicle of the primary culm about three inches long, ovate or pyramidal, the spreading branches solitary or in pairs, compound to the base, scabrous or pilose; pedicels equalling or exceeding the spikelets in length. Panicles of the branches nearly simple and few-flowered, usually partially enclosed within the leaf-sheaths. Spikelets a line long, obovate, obtuse; first glume about one-fourth the length of the spikelet, obtuse or acute; second and third glumes pubescent, prominently seven-nerved; the third with a small palea; fourth glume smooth and shining, broadly obtuse.

I think this is the $P$. pubescens of Lamarck. Lamarck's description was doubtless based upon an old plant which had become much-branched, and which exhibited only the few-flowered, simple, and nearly sessile panicles of the branches. The plant I have described here is $P$. villosum in the herbarium of Elliott.

The lower portion of the stem and branches of this grass are often strongly geniculate, with arched internodes. The branches are usually appressed and sometimes densely fasciculate towards the summit. The nearly erect and rather thick leaves of this species are quite characteristic. They are firmer in texture than in almost any other species of the group, and the spikelets are a third larger than in $P$. lanuginosum.

$P$. pubescens Lam., as understood by Michaux, was an erect, very much-branched, leafy and scftly pubescent grass, with ciliate, lanceolate leaves, small few-flowered invaginate panicles, and obovate or subglobose, puberulous spikelets. (Michx. Flor. Bor. Amer. I., p. 49.)

\section{Panicum lanuginosum E11.}

Culms slender, one to two feet high, finally much-branched; pubescent with spreading hairs, bearded at the nodes. Sheaths pubescent, usually shorter than the internodes, bearded at the throat; ligule a fringe of long (two to three lines) white hairs; leafblades lanceolate, thin, somewhat spreading, those of the primary 
stem three to four inches long, four to five lines wide, very acute, abruptly rounded and somewhat cordate at the base; leaves of the branches smaller. Panicle two to three inches long, diffuse, the capillary branches more or less spreading, and compound to the hase; pedicels glabrous. Spikelets three-fourths to nearly one line long. oblong-elliptical, obtuse; first glume thin, almost hyaline, nerveless, broadly obtuse, about one-fifth the length of the spikelet; second and third glume seven-nerved, obtuse, pubescent; the third glume with a palea; fourth glume smooth, obtuse. Open woods and thickets, usually in moist soil. June-July.

This grass differs from $P$. barbulatum in being hairy throughout. It is reduced to $P$. pubescens Lam., by Trinius, under a section with branched culms and spikelets less than a line long.

\section{Panicum longipedunculatum Scribn.}

\section{Plate XVI. Figure 61.}

A slender cespitose perennial, six to fifteen inches high, with short, chiefly radical, pilose leaves and diffuse, small-flowered, long exserted panicles. Culms branched at the base and often geniculate at the lower joints, smooth or pilose; nodes more or less bearded with erect hairs. Sheaths rather densely pilose to nearly smooth: ligule a fringe of long hairs: leaf-blade one to two inches long, two to four lines wide, the uppermost one-half to one inch long, acute, cordate-clasping at base, margins ciliate, surfaces striate and silkypilose or nearly smooth. Panicle one to three inches long, ovate. pyramidal, the main axis and primary branches pilose: pedicels capillary and much longer than the spikelets. Spikelets one-haif to two-thirds of a line long, ovate-elliptical, obtuse; first glume onefourth to one-half as long as the others; second and third glumes rounded-obtuse, smooth, faintly five-to seven-nerved; the third with a small palea; fourth glume smooth. Damp woods, White Cliff Springs, July. 1890: Tullahoma, July, 1892 A large form of this species is represented by No. $3597^{*}$ A. H. Curtiss. N. Am. Pl.

Closely allied to $P$. ciliatum, but the nodes and usually the surfaces of the spreading leaves are hairy, and the spikelets are nearly one-half smaller, with very obscurely-nerved glumes.

\section{Panicum nitidum Lam.}

Panicle branching, violet-tinged, empty glumes striate, obtuse. minutely hispid, glume of the fertile flower shining (Lam. III.. I., No. 899. [ [79I]). In his Encyclopedie Methodique, (Tol., IT., p. its [ 1797$]$ ) Lamarck characterizes the species more fully: Culm about a foot high, glabrous, leafy. Leaves two to three lines broad, glabrous except at the mouth of the sheath, which is long and striate. Panicle of medium size, branched, two to three inches long and tinted violet-brown, as are the nodes of the stem. Spikelets oval, obtuse, awnless, striated, slightly hispid, tinged with violet-brown. Grains very shining.

The original specimen upon which this species was based came from Carolina, but Lamarck states that Michaux found it in other parts of North America. Doubtless the plant described by Michaux (Flor. Bor. Am., I., p. $49\left[1 \mathrm{IO}_{3}\right]$ ) was the same as that pub- 
lished by Lamarck, and I venture to insert Michaux's description as it affords some additional characters: Plant glabrous, with slender, erect, simple culms. Sheaths barbate at the throat. Leaves very few, remote linear-lanceolate. Panicle capillary, somewhat contracted, much branched, glabrous. Spikelets very small, ovateobtuse, very minutely puberulous, outermost glume scarcely perceptible.*

Note.-Here we have a species based upon an early stage of the plant while the stems are yet unbranched. The original descriptions of $P$. pubescens, nodiflorum, ramulosum, barbulatum, dichotomum, etc., were drawn from more mature specimens after the culms had become much branched, and the difficulty in determining these plants has largely arisen from this fact. An exact knowledge of the species in this group can hardly be acquired excepting through observation in the field at different periods of their development. I have found little variation in the several species arising from soil or exposure, but the differences between the early grow th and that which appears later is often so great that one unacquainted with the plants in the field would never suspect the identity of the two forms. In all, the panicles which terminate the branches are fewer-flowered and more simple than that of the primary stem. In $P$. latifolium and in $P$. commutatum the leaves of the branches are sometimes broader than those of the primary stem, but in the others these leaves are usually much smaller in every way-in all, these leaves are more crowded.

\section{Panicum dichotomum Linn.}

Panicle simple, culms dichotomously branched (Linn. Sp. Pl. I., p. 58). Linnæus adds that this grass resembles a little tree, the stem being simple below and fasciculate-branched above. This is all we have for the identification of this species among the many forms in this group, in which, as already stated, the culms become much branched as the season advances, the primary panicles disappear and the later panicles on the branches are always simple and few-flowered. The remark that the culms are simple below, giving to the grass the appearance of a little tree, affords the best clue to the plant referred to by Linnæus. As I understand the species, it may be characterized from my material as follows: Glabrous throughout. Culms slender, becoming almost wiry, simple below, becoming much-branched above, branches spreading. Leaves thin, pale green, two to four inches long, those of the branches smaller, sometimes nearly filiform, and widely spreading. Panicle diffuse, branches naked below, lateral panicles simple and fewflowered. Spikelets scarcely a line long; ovate-oblong, outer glumes glabrous. P. barbulatum Michaux may be only a variety of this species, with the nodes bearded.

\section{Panicum barbulatum Michx.}

Culms one to three feet high, slender, finally much-branched, smooth; nodes densely bearded with deflexed hairs; sheaths sparingly pilose or smooth, much shorter than the internodes; ligule a fringe of short hairs, hardly a line long; leaf-blades lanceolate, two to five inches long, three to six lines wide, spreading, acute, narrowed at the base, glabrous; margins minutely serrulate and

*In the case of Panicum nitidum and the three following specles, it has appeared best to present the descriptions of the original authors. The ilmitations of these species are now exceedingly doubtful, and it is hardly possible to identify them without consulting the types. 


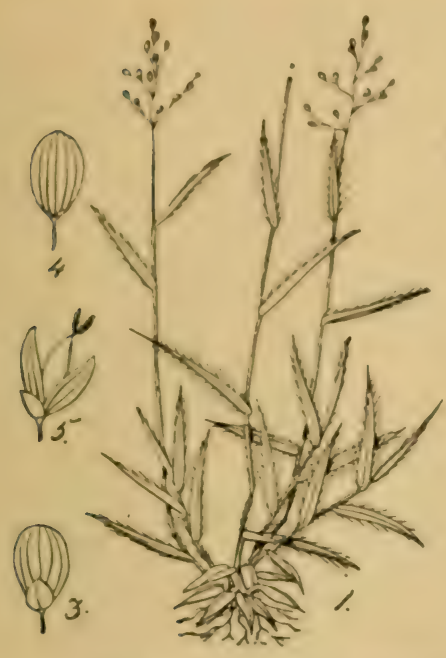

Fig. 57. Panicum di hotomum. (from white Cliff springs.)

2. Panlcle and upper leaf. 3. Splkelet, front view. 4. Splkelet, back vlew. 5. Splkelet, side vlew, lald open.

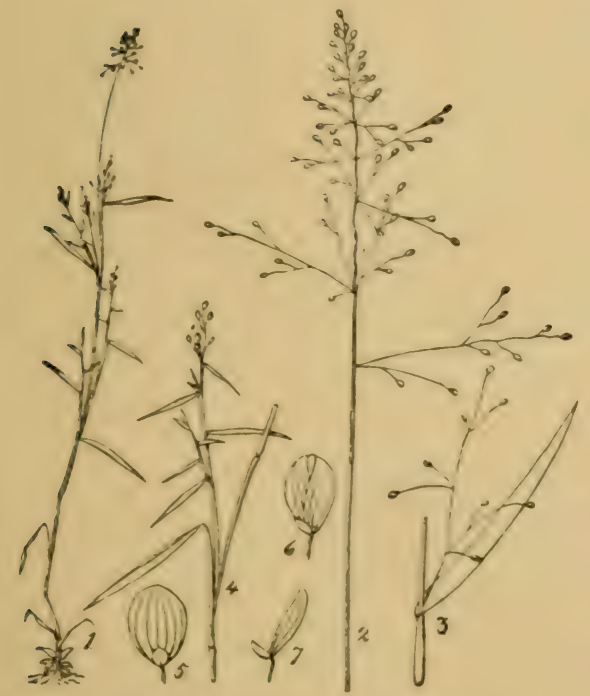

Fig. 59. Panicum nodiflorum.

2. Pantcle. 3. Lpper leaf, with axlllary panicle. 4. Axillary braneh. 5. Splkelet, front vlew. 6. Spikelet, side vlew. 7. wuter glumes.

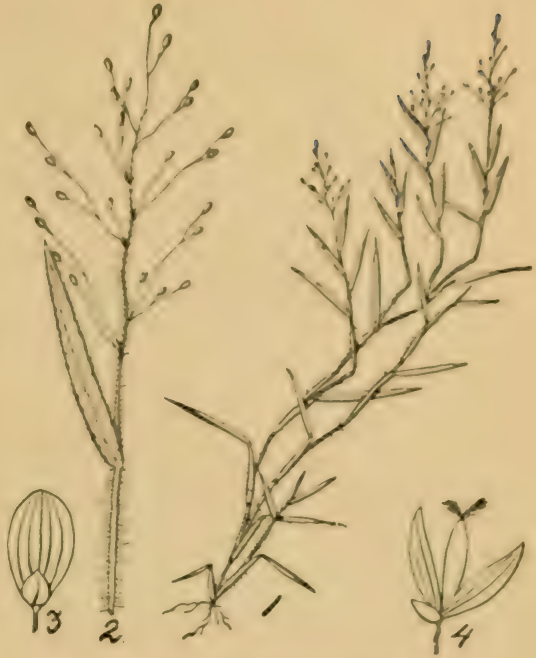

Fig. 58. Panicum dichotomum pubescens.

2. Upper leaf and pantcle. 3. Splkelet, front vlew. 4. splkelet lald open.

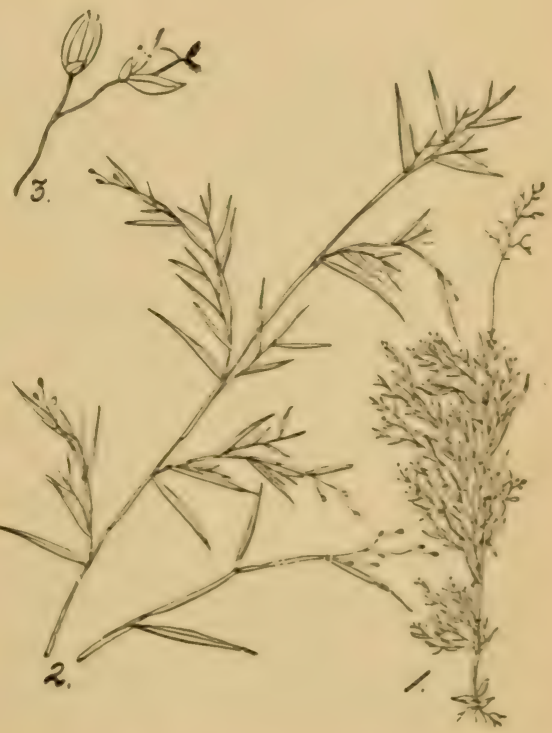

Fig. 60. Panicum ramulosum.

2. Parts of lateral branches. 3. Splkelets. 

sometimes ciliate near the base. Panicle two to four inches long. ovate-pyramidal; branches capillary and compound to the base. Spikelets smooth, about three-fourths of a line long. Common in open woods; May and June.

The leaves of the branches are much smaller than those of the primary stem, and more crowded, and the lateral panicles are small and few-flowered. Michaux characterized this species as a small slender grass with the sparingly-branched culms bearded at the rodes, smooth narrowly-lanceolate leaves, sheaths a little pilose at the throat, small capillary panicles and short-ovate spikelets. (Mich. Flor. Bor, Amer. I., p. 49.)

\section{Panicum ramulosum Michx.}

Plate XV. Figure 60.

A weak, slender, brancining grass, with glabrous culms and sheaths. Nodes somewhat thickened, naked. Leaves linearlanceolate, spreading, smooth, sparingly long-pilose near the base, subciliate. Panicle small, loose, capillary. Spikelets small, ovate-obtuse, all long pedicelled. In woods.

The above characters, drawn from Michaux (Flor. Bor. Am. I., p. $5 \circ[\mathrm{rSO} 3 \mid)$ are those of the later stage of growth of the species. I am unable to do more than guess at its identity with some of our specimers. It may be a variety of $P$. nitidum.

\section{Panicum nodiflorum Lam.}

Plate XV. Figure 59.

Panicles very small, lateral and terminal, glumes ovate. subpubescent, leaves narrow and rather short (Lam. Encycl. Meth. IV. p. 744). Stem very slender, about a foot high, branched. Lateral branches very short, leafy, and each terminated by a small panicle which appears to be lateral. The leaves of the branches are narrow, rather numerous, divergent, pilose near the base and at the entrance of the sheath. Besides the lateral panicles there is a terminal one which does not differ very much from those of the brancnes. These panicles are lax and few-flow ered. The spikelets are pedicellate, small, oval, and pubescent.

Lamarck questions whether this species is truly distinct from $P$. dichotomum.

\section{SETARIA Beauv. Agrost. II3 ( 18 I2).}

Spikelets as in Panicum, but surrounded at the base by few or many persistent, awn-like bristles (aborted branches) which spring from the pedicels below the articulation of the spikelets. Inflorescence a densely many-flowered, cylindrical, or somewhat interrupted, spike-like panicle. Annuals with flat leaves and terminal, bristly spike-like panicles.

Species about ten, in the warmer regions of the world, some cultivated for their grain or for quick grown fodder. Ours all introduced as weeds or escaped from cultivation. 


\section{Setaria glauca Beauv. Yellow Foxtail or Pigeon-grass}

Plate XVI. Figure 62.

An erect annual one to two feet high, with flat leaves and a bristly cylindrical spike-like, densely-flowered panicle, one to three inches long. Culm scabrous just below the panicle, otherwise smooth. Sheaths smooth; ligule a dense fringe of short hairs; leaf-blade three to ten incies long, two to five lines wide, nearly smooth on the dorsal surface, very scabrous on the upper surface and margins, and occasionally pilose near the base. Axis of the panicle densely pubescent. Bristles five to ten to each spikelet, yellowish or rarely purplish. Spikelets ovoid, about one and onehalf lines long. First glume about one half a line long, threenerved, second nearly half the length of the spikelet, five-nerved; the third five-nerved and as long as the transversely rugose flowering glume.

This is a well-known weed, growing everywhere in cultivated grounds. It sends up a number of stems from a single root, each bearing a cylindrical "bristly" head. It continues to bloom throughout the season from June to October.

\section{Setaria viridis Beauv. Green Foxtail, Wild Miilet.}

Plate XVI. Figure 63.

Similar in hahit to Yellow Foxtail. Spikelets about one line long, the nearly equal second and third glumes about the length of the minutely punctate-striate (not transversely rugose) fourth glume.

This is an introduced grass like the Yellow Foxtail, and has become a common weed in all cultivated grounds. It begins to bloom a little earlier than the Fellow Foxtail. The cylindrical panicles are more tapering toward the apex, the more numerous spikelets are smaller and the bristles are usually green.

3. Setaria Italica Kunth. Italian or Golden Millet.

Plate XVI. Figure 64.

This exists here only in cultivation. It is distinguished from the German Millet by its larger, longer, more loosely-flowered and usually nodding panicles. The millets of this class, that is species or varieties of Setaria, are ready to cut sixty to sixty-five days from time of sowing. When cut just as heading out, and before blooming, they make a valuable and safe forage; but in more advanced stages the feeder should be exceedingly careful, for when ripe these millets act injuriously upon the kidneys. They are the refuge of the poor farmer whose other forage crops have failed. They are sometimes grown here for the seed, and the product is often used as bird and poultry food.

4. Setaria Germanica, German or Hungarian Millet.

This is regarded by botanists as only a variety of the Italian Millet, 


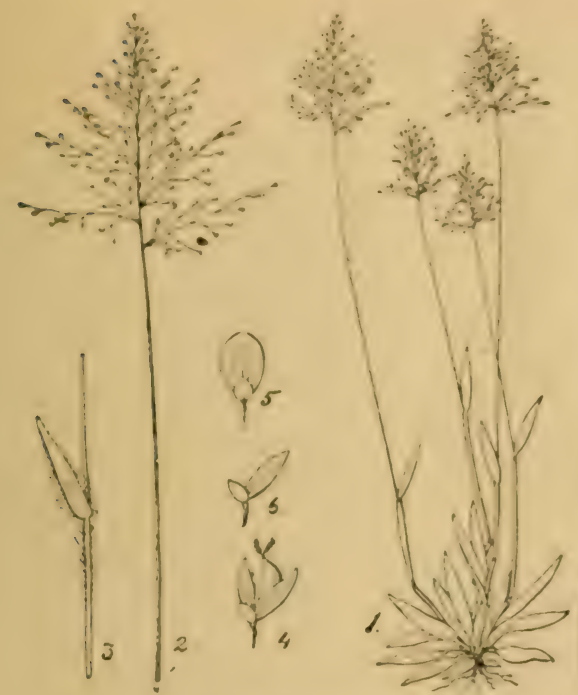

Fig. 61. Panicum longepedunculatum.

2. Panicle. 3. Upper leaf. 4. Splkelet, slde vlew, 5. Spikelet, front vlew, 6 Outer glumes.

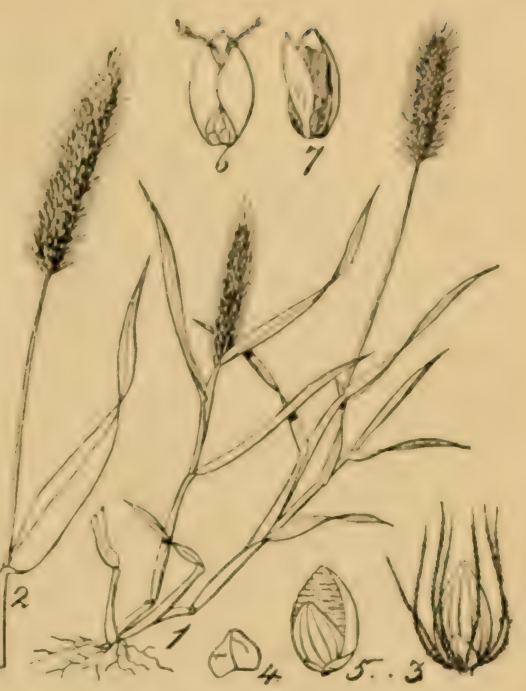

Fig. 62. Setaria glauca.

2. Upper leaf and inflorescence. 3. Splkelet, with its surrounding bristles, 4. Low er empty glume. 5. Splkelet. B. Floral glume, anterlor view. 7 . Staminate floret.

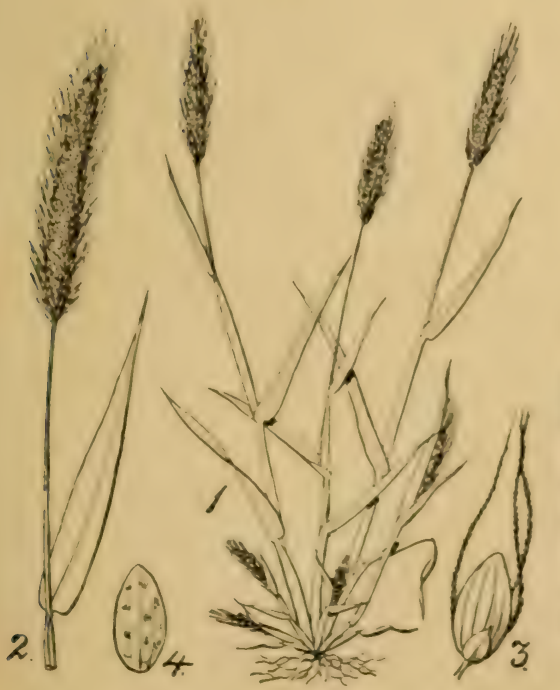

Fig. 68. Setaria viridis.

2. Upper leaf and Inflorescence. 8. Splkelet, with its bristles. 4. Flowering glume.

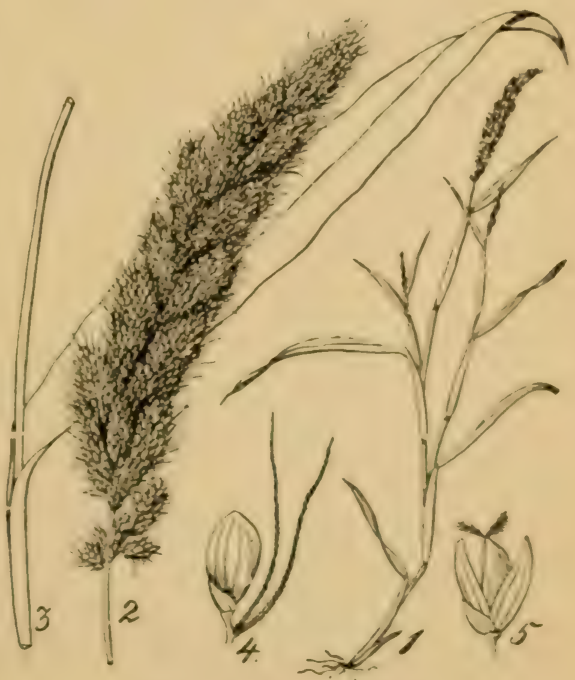

Fig. 64. Setaria Italica.

2. Inflorescence. 3. Upper leaf. 4. Eplkelet, with two bristles. 5. Spikelet lald open. 

and is only found here in cultivation or perhaps springing up irom seed on land where cultivated the season previous. The fierman differs from the Italian Millet in having a more dense or compact and usually erect panicle or "head."

\section{CENCHRUS Linn. Sp. Pl. 1049 (1753).}

Spikelets hermaphrodite. One-flowered (rarely with a male flower below the perfect terminal one). one to four together, with an ovoid or globular involucre of rigid more or less connate bris. tles, forming spiny burs or false capsules, these sessile or nearly so in simple terminal spikes or racemes, falling off with the spikclets. Glumes as in Panicum, awnless. Grain free within the slightlyhardened fruiting glume and palea.

Annual or perennial grasses with spreading or erect culms, bearing few or many more or less crowded "burs" in terminal spikes.

Species about twelre, in the tropical and warmer temperate regions of both hemispheres. One species introduced in Tennessee.

I. Cenchrus tribuloides Linn. Hedgehog-or Bur-grass.

Plate XVII. Figure 65.

Annual, with spreading or ascending much-branched culms, rarely a foot high, somewhat compressed. Leaves flat or simply folded, about six inches long, acute, finely serrulate along the margins; sheaths generally much exceeding the internodes, hairy along the margins and at the throat. Burs containing the spikelets, six to twenty, nearly globose, covered with strong and more or less pubescent barbed spines, becoming very hard at maturity and readily falling off. Along the Mississippi river. JulyAugust.

Reported by Dr. Gattinger as growing along the sandy banks of the Mississippi river. It grows only in sandy soils, but in such lands it may become a terrible pest, and every pains should be taken to exterminate it wherever seen.

\section{PENNISETUM Pers. Syn. I. 72. (1805).}

Spikelets solitary or two to three together, subtended by an involucre of one to many bristles, which are often plumose and fall off with the spikelets at maturity; inflorescence racemose or dense and spike-like. Glumes four, the first empty and smalier than the others; the second usually as long as the spikelet, empty; the third empty or with a palea or with a staminate flower: the fourth or terminal enclosing a pistillate or hermaphrodite flower and palea. Stamens three. Styles distinct or more or less cunnate below: stigmas plumose. Grain included in the rigid fruiting glume and palea, free. Annual or perennial grasses, with simple or branched culms, flat leaves, and usually spike-like panicles terminal on the culm or its branches.

Species about forty, chiefly natives of the tropical and sub-trop- 
ical regions of the Old World, a few in America. Some of the species are cultivated for ornament.

I. Pennisetum typhoideum Rich. Cat-tail or Pearl Millet.

A coarse grass six to eight or ten feet high, with a dense "head" or spike-like panicle an inch in diameter, and six to twelve inches long. It requires a rich soil and a warm climate, and under favorable circumstances in the Southern States will yield a large amount of fairly good forage. It may be cut two or three times during the season.

\section{Tribe VI. ORYZE $Æ$.}

Spikelets usually much compressed laterally, one-flowered, staminate, pistillate or hermaphrodite; empty glumes two or none, the flower being subtended by the floral glume and palea alone, the latter one-nerved and regarded by some as a second glume. Stamens frequently six. Axis of the inflorescence continuous.

A small tribe of about forty species, divided among sixteen genera, mostly confined to tropical America. One of the best known and most extensively used of the cereals, rice (Oryza sativa) belongs here.

\section{ZIZANIA Linn. Sp. Pl. 99 I (1753).}

Spikelets linear, unisexual, monøecious, one-flowered, in large terminal panicles, the female spikelets on the erect upper branches, the male or staminate spikelets on the lower expanded branches of the same panicle. Glumes two, nearly equal, very narrow, awnless, or the outer one in the female spikelet long-awned. Stamens six. Styles more or less connate; stigmas plumose with simple hairs. Grain linear, half an inch long. Tall, aquatic grasses with long flat leaves.

Species one. Widely distributed in North America and northeastern Asia.

\section{Zizania aquatica Linn. Wild or Indian Rice.}

A tall, erect annual, three to ten feet high, with a panicle twelve to twenty-four inches long. Leaves eighteen to thirty-six inches long, and one-half to an inch wide; narrowed toward the base and tapering to a very acute apex. In shallow water along rivers and lakes. August.

This grass has not been reported as occurring in Tennessee, but very likely it may be found in the western part of the State along the Mississippi. The grain is a favorite food of the reed bird, and it is cultivated to some extent by sportsmen with a view to attracting these birds. Some of the larger dealers offer the seed for sale.

14. ORYZA Linn. Gen. P1. I., p. 324 (I79r).

Spikelets one-flowered, hermaphrodite, strongly flattened later. 


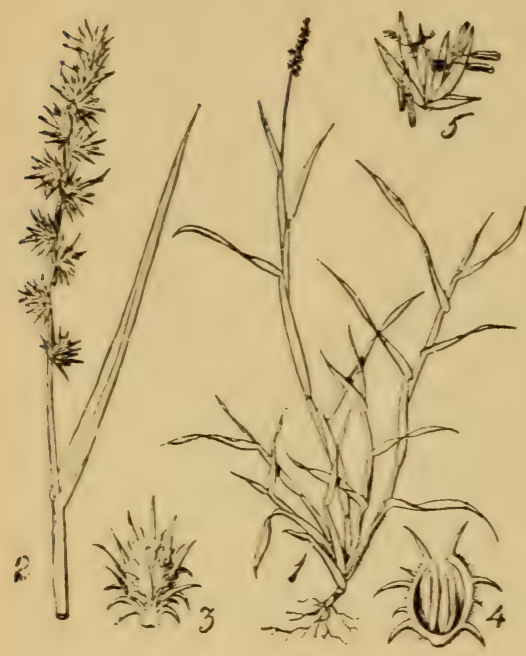

Fig. 65. Cenchrus tribuloides.

2. Upper leaf and Inflorescence. 3. One of the splny burs in which the splkelets are. 4. Burlaid open in section, splkelets shown inside. 5. spikelets.

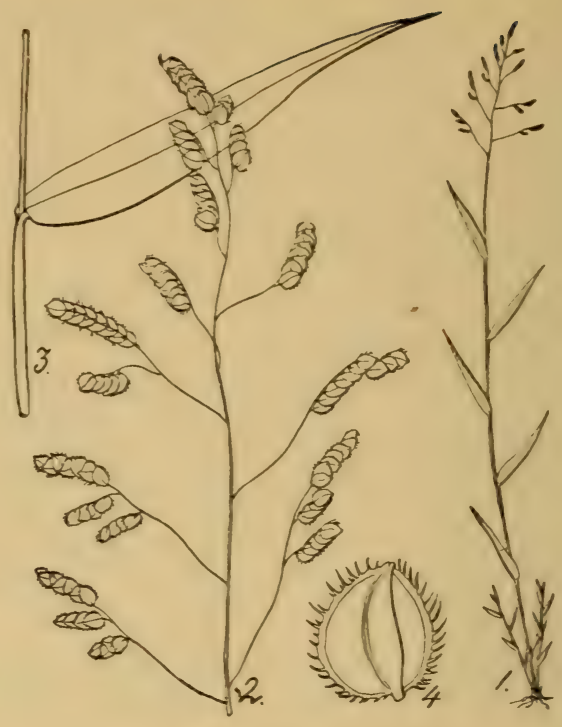

Fig. 66. Leersis lenticularis.

2. Panlcle. 3. Upper leaf. 4. Splkelet, slde vlew.

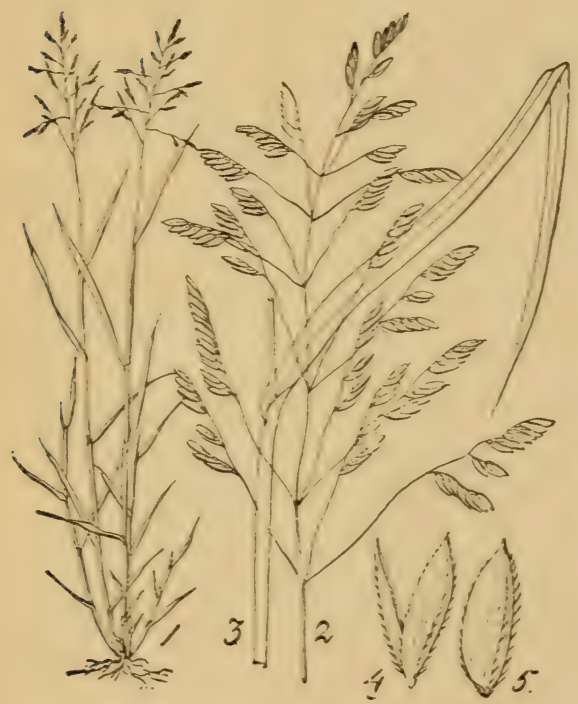

Fig. 67. Leersia orjzoides.

2. Panicle. 3. Upper leaf. 4. Splkelet open. 5. splkelet closed.

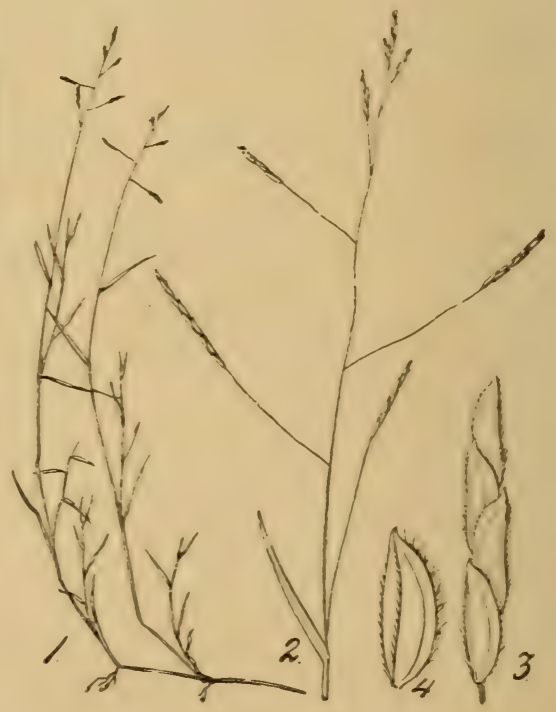

Fig. 68. Leersia Tirginica.

2. Inflorescence. 3. Porilon of branch bear'ng four spike'ets. 4. Spikelet, side rlew. 
ally, in terminal panicles; rachilla articulated below the empty glumes. Cilumes three, the first two small, empty, the third com. pressed keeled, somewhat rigid, usually awnerl. Palea one-nerved, narrow, about the length of the glume. Stamens six. Crain oblong obtuse, closely enveloped hy the fruiting glume. Aquatic grasses with flat leaves and terminal panicles.

species five or six, in the tropics of both hemispheres.

\section{Oryza sativa Linn. Rice.}

This well-known plant furnishes food to a greater number of people than any other cereal. It is known to have been cultivated in eastern countries for more than 4500 years. It has been grown in some of the Southern States-notably South Carolina and Louisiana-for many years, and a variety krown as upland rice is grown to some extent in the western part of Tennessee. There are many varieties, distinguished by the color or size of the fruit and absence or presence of awns.

\section{LEERSIA Swartz. Nov. Gen. et Sp. 2 I ( $7>8 s)$.}

Spikelets one-flowered, hermaphrodite, strongly flattened laterally, articulated with the pedicels. Empty glumes none. Flowering glume chartaceous, bristly ciliate along the keel, awnless. Palea similar in texture and about as long as the flowering glume, but much narrower. Perennials with rough leaves and open paniculate inflorescence.

Species five or six, throughout the tropical and temperate regions of the world. Tennessee species three.

\section{KEY TO THE SPECIES,}

I. Spikelets pale green, less than 2 lines long. L. Virgixica.

I. Spikelets straw-colored, more than 2 lines long . . . . .

2. Spikelets somewhat spreading, less than a line wide

2. Spikelets closely imbricate, is lines broad. L. LeNTICLARIS.

\section{Leersia Virginica Willd. White-grass.}

Plate XVII. Figure 68.

A slender, erect or ascending, usually much.branched leafy grass, two to four feet long, from short, scaly root.stocks. Nodes pubescent, with reflexed hairs. Sheaths retrorsely scabrous; ligule membranous, very short; leaf-blade linear or narrowly-lanceolate, two to five inches long and one to four lines wide, scabrous on both surfaces, and very minutely and sharply scabrous on the mar. gins. Panicle three to five inches long, simple, composed of a few more or less spreading one-sided racemes one to three inches long. Spikelets one and one-half to two lines long. strongly appressed to the branches and closely imbricated: glume very abruptly shortpointed, ciliate on the curved keel, and with a few very short, stiff hairs on the sides, or nearly smooth; palea similar to the glume, but narrower, and with nearly a straight keel. 
Along streams and in wet woods. July-September, common. Of no agricultural value.

\section{Leersia oryzoides Sw. Rice Cut-grass.}

Plate XVII. Figure 67.

A rather stout, rough and usually much-branched grass two to three or four feet high, with flat leaves and an open pale green or straw-colored panicle. Nodes usually bearded. Sheaths auricled on the sides at the apex, strongly scabrous, the points of the minute spines which lie in the depressions of the strix, directed downwards; ligule firm-membranaceous, about a line long; leaf-blade five to ten inches long, three to six or seven lines wide, very acute, contracted and often pubescent at the base, scabrous on both surfaces, the margins very rough, with minute sharp spines which in the lower part of the leaf are directed toward the base and in the upper part are directed forward or toward the apex. Panicle six to ten inches long, the slender ascending branches two to four inches long, naked below, flower-bearing toward the ends. Spikelets two to two and one-half lines long, about three-fourths of a line broad, loosely imbricated; apex of the glumes and palea abruptly pointed, the keels strongly ciliate and with short scattered hairs on the sides. Within the lower sheaths may be found cleistogamic or hidden fruiting spikelets.

Common along streams, wet borders of thickets, etc. Of no recognized agricultural value.

\section{Leersia lenticularis Michx. Large Cut-grass.}

Plate XVII. Figure 66.

A rather stout, branching perennial two to three feet high, from a creeping scaly root-stock, with widely spreading broad leaves and diffuse panicles. Nodes smooth or sometimes downwardly bearded. Sheaths firm, striate, smooth or more often rough, with downwardly-pointing sharp prickles, which lie in the grooves of the striæ, auricled at the apex; ligule firm-membranaceous, about a line long, smooth or sometimes pilose on the back; leaf-blade four to ten inches long, four to eight lines wide, acute contracted toward the base, often pubescent on the upper surface, at least toward the base and on the back where the blade joins the sheath. Panicle four to eight inches long, the branches solitary or in pairs, widely spreading or finally deflexed, flower-bearing near the extremities. Spikelets on very short scabrous pedicels, broadly oval, strongly flattened laterally, two and one-half to three lines long and about two lines broad, closely imbricate, the glume and palea strongly bristly ciliate along the keels.

West Tennessee (S. M. Bain) August-September. The leaves are sometimes striped with longitudinal white bands, as in the cultivated ribbon-grass, (Phalaris arun tinacea picta.) 


\section{Series B. POACE. E.}

Spikelets one- to many-flowered, the imperfect or rudimentary flower, if any, is usually uppermost; rachilla usually articulated above the empty glumes, so that these remain after the fall of the fruiting glume.* In spikelets with two or more flowers, these are separated by a manifest internode of the rachilla, and in such cases the rachilla is usually articulated below each flowering glume.

\section{Tribe VII. PHALARIDEÆ.}

Spikelets more or less laterally compressed, one-or rarely three. flowered. Glumes five, the first two empty and below the articulation of the rachilla; the third and fourth above the articulation, usually empty, very unlike the outer ones, rarely enclosing a stam. inate Hower, sometimes reduced to mere bristles; the fifth glume with a one-nerved or nerveless palea and a hermaphrodite flower.

A small tribe comprising six genera, with about sixty species of comparatively little importance. Several of the species, Sweet Vernal-grass and Vanilia.grass, are remarkable for possessing a peculiar sweet fragrance due to their containing coumarin. Canary-grass is one of the best known members of this tribe.

\section{PHALARIS Linn. Sp. Pl. 54 (1753).}

Spikelets one-flowered, strongly flattened laterally and crowded in a dense ovoid cylindrical or rarely interrupted spike-like panicle (sometimes spreading in flower); rachilla articulated above the first pair of empty glumes. Glumes five, awnless, the first two empty, equal, boat-shaped, and usually winged on the keel; the third and fourth empty, narrow-lanceolate or bristle form, closely appressed to the fifth or flowering glume, which is hard and shining in fruit and closely envelops the grain and palea.

Annual or perennial grasses, with flat leaves and densely-flowered spike-like or capitate inflorescence.

Species about ten, most abundant in Southern Europe. There are two or perhaps three native North American species. One of these, together with a species introduced from Europe, is found within the State.

\section{Phalaris Canariensis Linn. Canary-grass.}

Plate XVIII. Figure 69.

An erect annual, one to three feet high, with flat leaves and a dense, ovoid panicle (head) about an inch long, empty glumes with a broad, sharp keel, with a distinct green line within the white, scarious margins. Third and fourth glumes small, scalelike smooth. Fifth or flowering glume hairy.

* Alopecuris, Cinna, Spurtina. and Holcus in this Serles, have the rachllla articulated below the flrst palr of glumes, and the splkelets fall off entire. 
Introduced from Europe; and sometimes cultivated in the vicinity of our large cities for its seed, which is used for bird food.

\section{Phalaris arundinacea Linn. Reed Canary-grass.}

Plate XVIII. Figure 70.

A tall, leafy perennial, two to four feet high, with smooth sheaths and a narrow, branching panicle four to eight inches long. Spikelets about two lines long, compressed but not winged-keeled as in $P$. Canariensis. Third and fourth glumes reduced to narrow silky scales one-third as long as the perfect floret. Low wet grounds, borders of streams, etc. June-July.

This grass is not recognized here as possessing any value for forage. There is a variety with white-striped leaves, sometimes cultivated in gardens under the name of Ribbon-grass.

\section{ANTHOXANTHUM Linn. Sp. P1. 28 (1753).}

Spikelets one flowered, distinctly pedicellate in narrow spikelike panicles; rachilla articulate above the first pair of glumes. Glumes five, the first and second very unequal, keeled, the third and fourth shorter, empty, hairy, and awned on the back, falling with the flowering glume, the fifth or floral glume short, broad and obtuse, three-nerved, hyaline; palea one-nerved (this is regarded as a sixth glume by some authors). Stamens two. Styles distinct.

Erect, sweet-scented annuals or perennials, with flat leaves, herbaceous culms and narrow spike-like terminal panicles.

Species four, European. The one which comes within our limits is very widely distributed in all temperate countries.

\section{Anthoxanthum odoratum Linn. Sweet Vernal-grass.}

Plate XVIII. Figure 71.

A rather slender, smooth perennial one to two and one-half feet high, the narrow panicle one to two and one-half inches long. Spikelets about three lines long, the unequal outer glumes covering the brown-hairy, awned second pair.

This grass has been introduced from Europe, and is valued on account of its earliness and sweet odor when dry. It can only be recommended in mixtures of seed for pasture lands.

\section{Tribe VIII. AGROSTIDEA.}

Spikelets all hermaphrodite, one-flowered, with three glumes, the first two empty (very rarely wanting) usually as long as or exceeding the third or floral glume. Rachilla sometimes prolonged behind the palea as a naked or plumose bristle. Palea two-nerved, (one-nerved in Cinna), nerveless or (in some Agrostis species) wanting.

This is, next to the Festucea, the largest tribe in the order, numbering 700 species, arranged in 46 genera. The species are dis- 


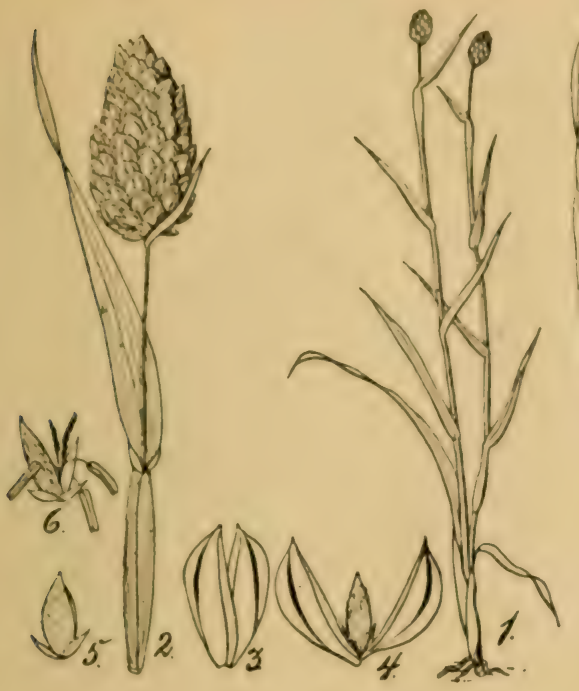

Fig. 69. Phalaris canariensis.

2. Capltate inflorescence and upper leaf. 3. Splkelet. 4. splkelet lald open. 5. Same with the large outer ylumes removed, showing the small scale.like glumes at the base of the floral glume. 6. Floret ex panded.

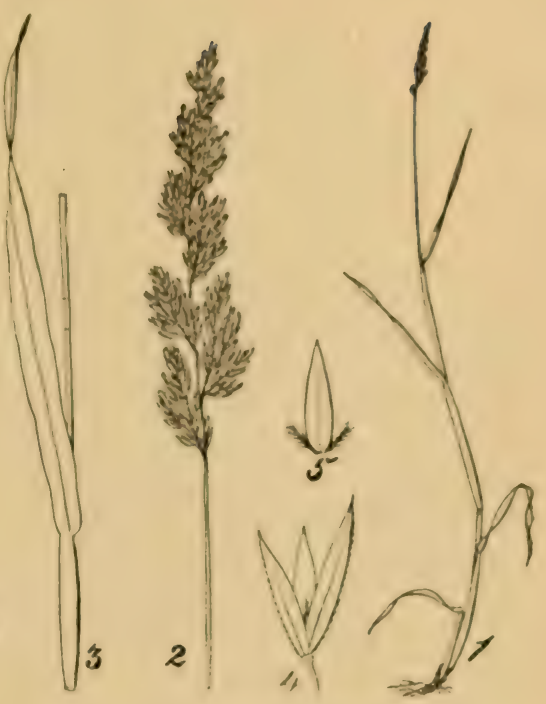

Fig. 70. Phalaris arundinacea.

2. Inflorescence. 3. Upper leaf. 4. Splkelet. 5. Flowering glume. (The empty glumes are not correct in Gray's Manual.,

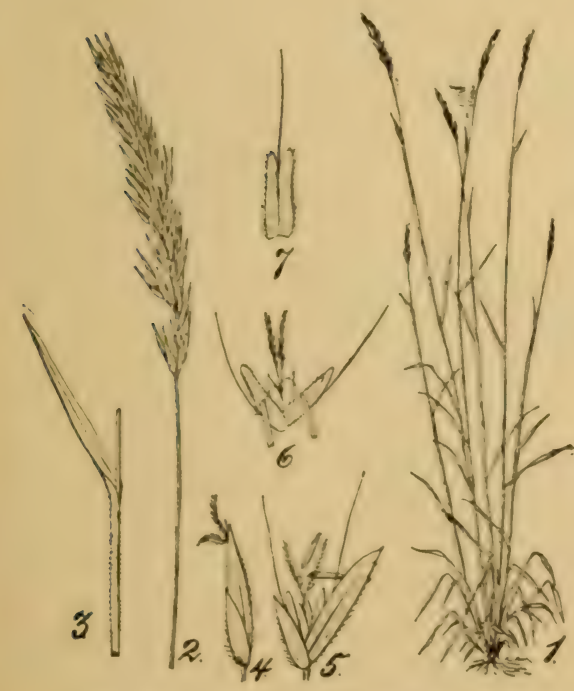

Fig. 71. Anthoxanthum odoratum.

2. Inflorescence. 3. Upper leaf. 4. Splkelet. 6. Floret, with the second pair of empty glumes at the base. 7 . An awned empty glume,

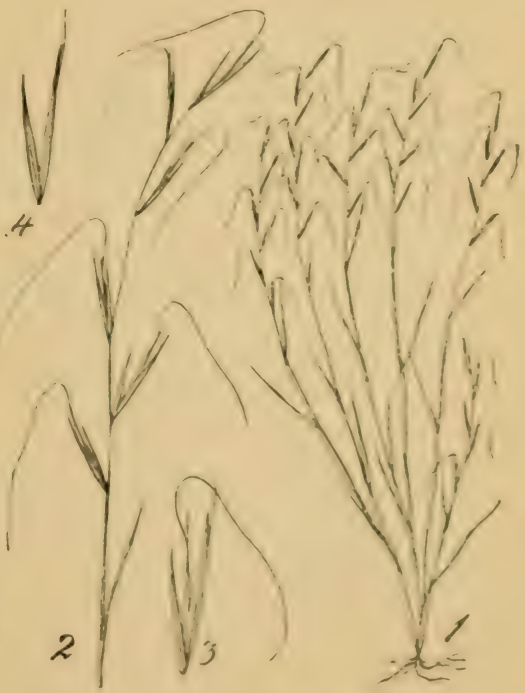

Fig. 72. Aristida ramosissima.

2. Raceme. 3. Splkelet 4. Fmpty glumes. 

tributed throughout all the temperate and colder regions of the world and many occur within the tropics. The grenus Agrostis, from which the tribe derives its name, and from which comes the word Agrostologist, has about 100 species; found in all parts of the world, especially in the north temperate zone. Some of our most important meadow grasses - notably Herd's-grass and Timothybelong to this tribe.

\section{ARISTIDA Linn. Sp. Pl. 82 (1753).}

Spikelets one-flowered, on long or short slender pedicels in terminal, more or less expanded panicles; rachilla articulated above the empty glumes and produced into a hard obconical hairy callus below the floral glume, but not extending beyond it. Glumes three, the first two empty, more or less unequal, acute or bristlepointed, slightly keeled; the third or flowering glume firmer in texture than the outer ones, closely rolled around the flower, the usually short palea terminating in a trifid awn. Grain slender, tightly enclosed by the hardened fruiting glume, but free from it.

Tufted narrow-leaved grasses, chiefly growing in dry sandy or sterile soil.

Species about one hundred, in all the warmer regions of the world. Some thirty-eight species are recorded as growing within the United States, chiefly in the southern portions. The following are found in Tennessee:

\section{KEY TO THE SPECIES.}

1. Awns very unequal in length

1. Awns nearly of equal length

2. Spikelets 6 to 10 lines long, the middle awn an inch long and abruptly recurved . . . . . . I. A. RAmosissima.

2. Spikelets 2 to + lines long, in slender spikes or racemes

3. Middle awn flexuose or coiled near the base, and soon reflexed

2. A. DICHOTOMA.

3. Middle awn not flexuose or coiled near the base, divergent 3. A. GRACILIS.

4. Spikelets 9 to 2 lines long, in loosely few-flowered racemes. awns I to 2 inches long, more or less divergent

6. A. OLIGANTHA.

4. Spikelets + to 5 lines long, in many-flowered spike-like panicles

5. First glume longer than the second, awns much longer than the glumes . . . . . . . . 4. A. PURPURASCENS.

5. First glume shorter than the second, awns about the length of the glumes

5. A. STRICTA.

I. Aristida ramosissima Engelm.

Plate XVIII. Figure 72.

A low, very much-branched grass six to fifteen inches high, with numerous loosely iew-flowered spikes or racemes. Emptyglumes 
six to ten lines long, usually rather strongly three- to five-nerved, exceeding the flowering glume; flowering glume three-awned, awns very unequal, the lateral ones straight, one to three lines long, (sometimes wanting, variety uniaristata), the middle one an inch long and soon abruptly recurved. Dry soil in open ground. Humboldt, West Tennessee, September (A. Gattinger).

\section{Aristida dichotoma Michx. Poverty-grass. \\ PIate XIX. Figure 73.}

A low, much-branched annual six to twenty-four inches high, with few-flowered, spike-like, simple panicles one to four inches long. Sheaths smooth or somewhat scabrous; ligule a minute fringe of hairs; leaf-blade very narrow involute, one to six inches long. Spikelets erect, three to four lines long; empty glumes nearly equal, linear, the upper often mucronate-pointed, equalling or more often exceeding the flowering glume; flowering glume with minute appressed hairs on the back, three-awned, the lateral awns very short and erect, the middle one soon reflexed and flexuose at the base. Callus hairy.

A worthless grass, common in dry, sandy or gravelly fields, etc. September-October.

\section{Aristida gracilis E11. Slender Triple-awn.}

Plate XIX. Figure 74.

A slender, erect grass twelve to twenty-four inches high, branched near the base, the culm and branches terminating in slender, rather densely-flowered racemose or spike-like panicles, three to seven inches long. Rays of the panicle in pairs, erect, one to several-flowered. Sheaths smooth or pilose near the base; ligule a minute fringe of short hairs; leaf-blade three to five inches long, about a line wide, soon convolute. Spikelets two to three lines long (exclusive of the awns); empty glumes one-nerved, narrowly lanceolate, nearly equai, or the lower one a little shorter than the upper, which is usually short-awned or mucronate-pointed; flowering glume usually a little longer than the empty ones, rough and usually spotted on the back, three-awned, the lateral awns straight and one-third to one-half the length of the divaricate or reflexed middle one. Callus hairy. In sandy, gravelly or poor soils; apparently less common than $A$. dichotoma. September-October.

4. Aristida purpurascens Poir. Beard-grass or Purple Triple Awn.

Plate XIX. Figure 75.

A sparingly-branched perennial one and one-half to three feet high, with narrow many-flowered panicles six to fifteen inches long. Sheaths smooth or sometimes pilose, the lower ones imbricated; ligule minute; leaf-blade one to two lines wide, four to twelve inches long, more or less conduplicate. Panicle strict, continuous or interrupted below, the appressed branches often in threes. Lower empty glume four to five lines long, exceeding the second glume, which is about the lergth of the floral glume; flowering glume more or less scabrous on the back, three-awned; awns similar, 


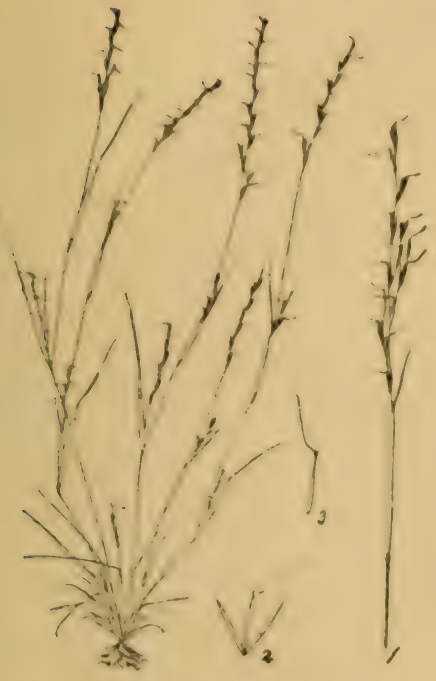

Fig. 73. Aristida dichotoma.

2. Splkelet. 3. Flowering glume.

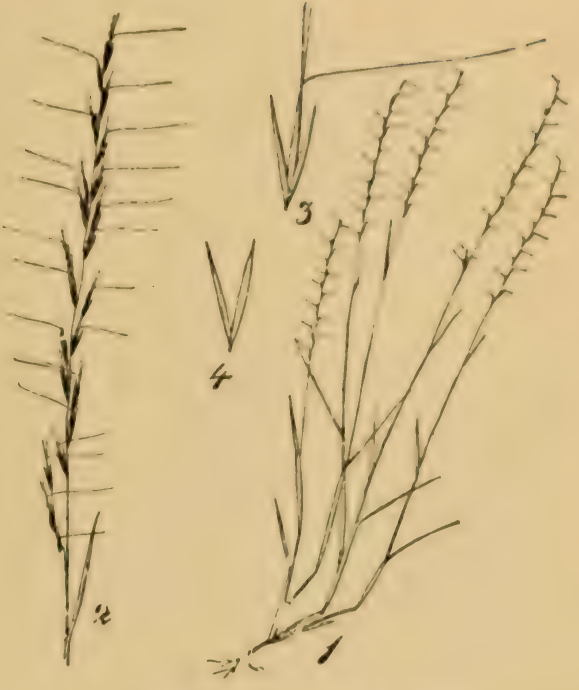

Fig. 74. Aristila gracili.

2. Inflorescence. 3. Splkelet. 4. Empty glumes.

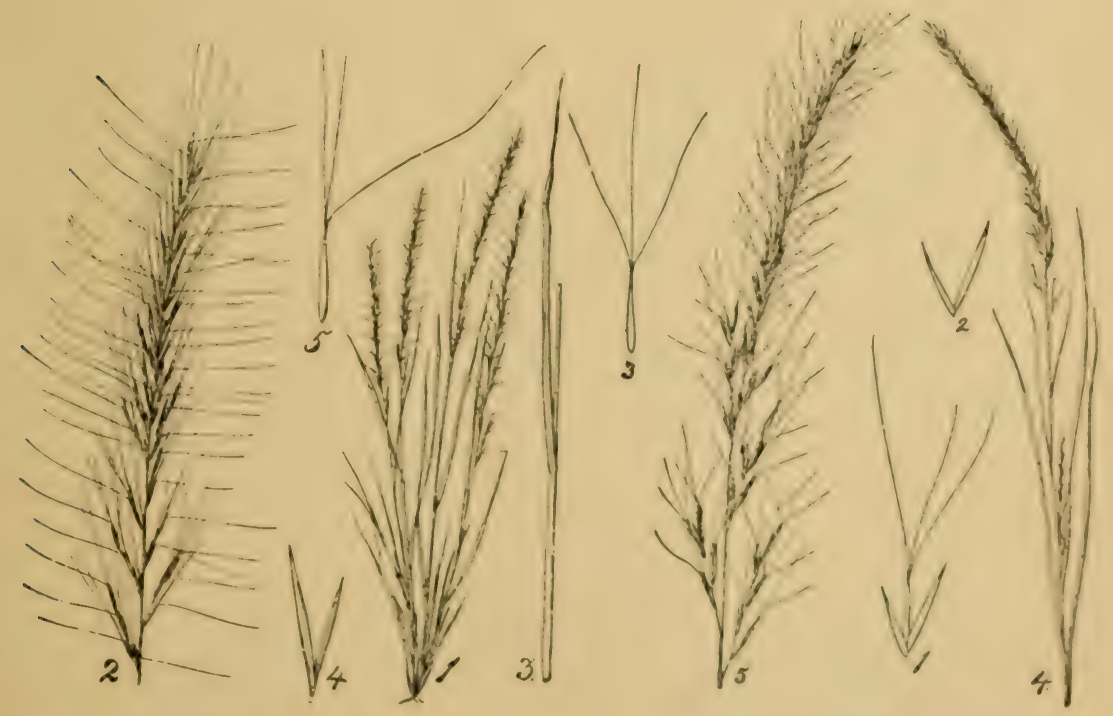

Fig, ;6. Iristida stricta.

Fig. 75, Aristida purpurascejs.

2. Pantcle. 3. Upper leaf. 4. Empty glumes. 5. Flowering glume.
1. Splkelet. 2. Empty glumes. 3. Flowering glune. 

more or less spreading, the middle awn usually about an inch long. slightly exceeding the lateral ones. Callus slemiler-pointed, hary. On dry and usually por soil, common. September-october.

\section{Aristida stricta Michx.}

\section{Plate XIX. Figuro 76.}

This may occur within the State. It resembles A. purpurasiens, but the leaves are more rigid and involute, and the upper enpty glume is distinctly longer than the lower. The awns are shorter (one-half inch), subequal, and all divergent or reflexed.

\section{Aristida oligantha Michx.}

Plate XX. Figure 77.

A tufted annual with slender, hranching culms, six to twelve inches high, narrow leaves and lonsely few-flowered racemes. Sheaths smooth: ligule a fringe of short hairs; leaf-blade two to six inches long, involute filiform, at least when dry. ianicle racemose, four-to six-flowered. Spikelets nine to eleven lines long (exclusive of the awns); empty glumes three-to five-nerved, subeyual, a little shorter than the flowering glume, more or less awn-pointed; flowering glume scabrous, at least above, three-awned, awns nearly equal or the lateral a little shorter, divergent, one to two inches long. Callus soft-hairy, acute.

Dry, gravelly or sterile soil, common. August to October. Of no economic value.

\section{STIPA Linn. Sp. P1. 78 (1753).}

Spikelets one-flowered, usually on long filiform pedicels in expanded or rarely narrow panicles, rachilla articulated above the empty glumes, and produced below the flowering glume into a strong, bearded, obconical and sharp-pointed callus. Glumes three, the first two empty, thin-membranaceous, subequal, acute or bristle-pointed, the third or floral glume narrow, sub-coriaccous. closely rolled around the flower and shorter palea, terminating by a twisted and geniculate simple awn, which is articulated with its apex. Grain terete and closely enveloped by the hardened fruiting glume. Tufted perennial grasses, with very narrow or involute leaves and usually open panicles.

Species about roo, widely distributed throughout the tropical and temperate regions of the world. Twenty-four species are recorded as occurring within the United States, chiefly southwestern. Only one comes within the State.

\section{ז. Stipa avenacea Linn. Black Oat-grass.}

\section{Plate XX. Figure 78.}

An erect perennial one to three feet high with, very narrow leaves and a lax, few-flowered panicle. Lower leaves four to six inches long, the membranaceous ligule one to two lines long. The lower nearly erect rays of the nodding panicle, usually in pairs, and one-to two-flowered. Empty glumes four to four and one-half 
lines long, nearly equal, acute, a little longer than the floral glume. Callus of the floral glume slightly curved, very acute, barbate with brown hairs, the glume scabrous near the apex, where it is minutely hairy. Awn scabrous, one and one-half to two and one-half inches long, twisted below and usually twice bent.

Dry ridges and hill-sides, usually in open woods. Common, growing in isolated tufts. April-June.

\section{MUHLENBERGIA Schreb. Gen. 44 (1789).}

Spikelets one-flowered, hermaphrodite, variously paniculate, rachilla articulated above the empty glumes, forming a very short and usually hairy callus below the floral glume, but not extending above it. Glumes three, the first two empty, membranaceous or hyaline, one- to three-nerved or nerveless, usually unequal and shorter than the floral glume, acute, mucronate-pointed, or sometimes awned; third or flowering glume narrow, smooth or more or less pilose below, three-to five-nerved, awned from the acute apex or from between the teeth of the more or less conspicuously bidentate apex. Awn straight or flexuose. Palea thin, two-nerved, usually about the length of its glume. Stamens three. Styles distinct. Grain closely enveloped by the fruiting glume.

Perennial grasses(rarely annual) with small spikelets and greatly varying habit; culms a few inches to several feet high, simple or much-branched; leaves long or short, flat or strongly involute; panicle narrow and spike-like or open and widely spreading. Formerly included in Agrostis.

Species about sixty, nearly all American; most abundant in Mexico.

\section{KEY TO THE SPECIES.}

I. Culms simple, leaves convolute, panicle with widely spreading capillary branches . . . . . . M. CAPILlaRis.

I. Culms branching, leaves flat, panicle contracted.

2. Empty glumes minute, the lower nearly obsolete

2. Empty glumes one-half as long as or equalling the flowering glume

3. Flowering glume awnless or simply mucronate-pointed 3

3. Flowering glume conspicuously awned . . . . . . . . 5

4. Culms nearly simple, panicle filiform, empty glumes onethird shorter than the flowering glume 3. M. Sobolifera.

4. Culms much branched, panicle densely flowered, empty glumes, at least the second, as long as the flowering glume

4. M. Mexicana.

5. Empty glumes usually bristle-pointed, as long as the flowering glume; culms much branched, panicle linear or narrow-lanceolate . . . . . . . 5. M. svlvatica.

5. Empty glumes acuminate-pointed, shorter than the flowering glume; culms nearly simple, panicle elongated, very slender and loosely flowered . . 6. M. Willdenovir. 


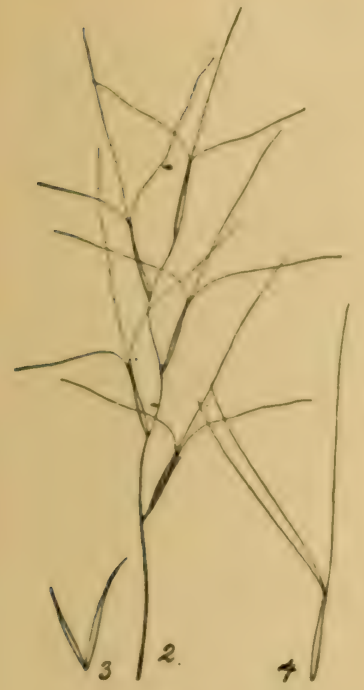

Fig. 77. Aristidu oligantha.

2. Inflorescence. 3. Empty glumes. 4. Flowerlng glume.

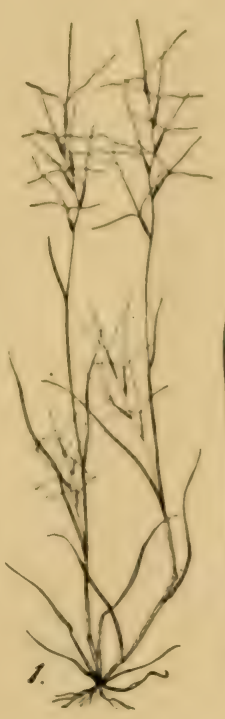

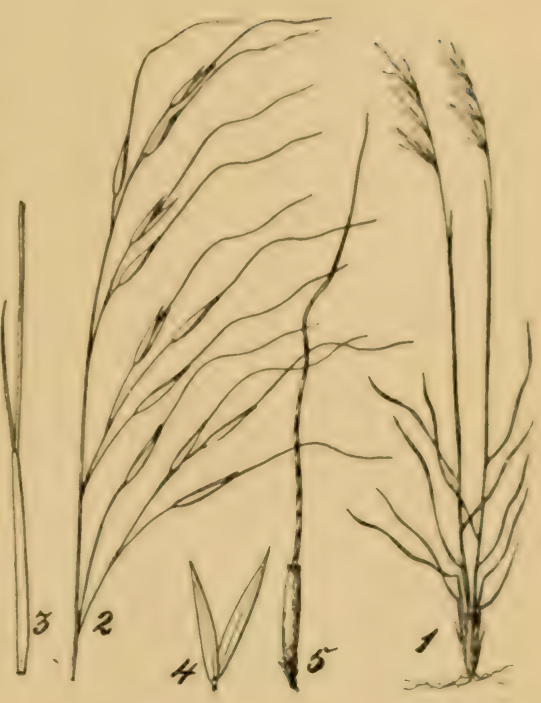

Fig. 38. Stipa arenacea.

2. Pantcle. 3. Upper leaf. 1. Empty glumes. 5. Flowering glume.

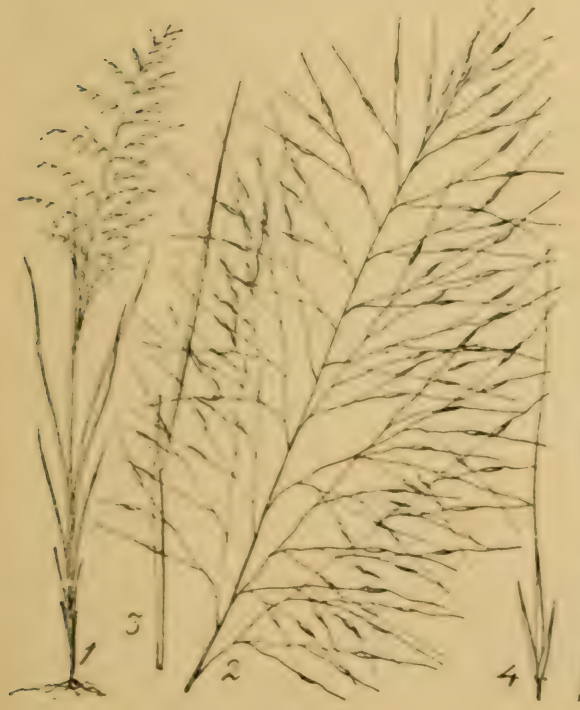

Fig. 79. Muhlenberzia eapillaris.

2. Panlcle. 8. Lpper leaf. 4. Splkelet.

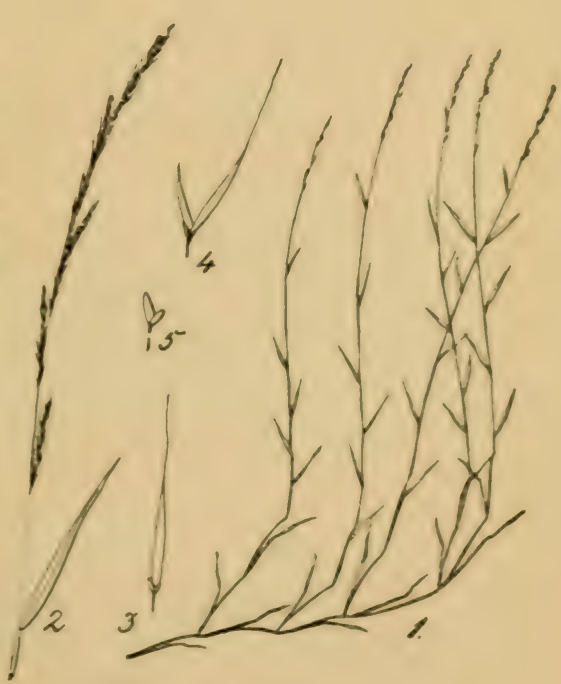

Fig. 80. Muhleubergia difusa.

2. Panicle. 3. splkelet. 4. Splkelet expanded. 5. Empis glumes. 



\section{Muhlenbergia capillaris Kunth.}

Plate XX. Figure 79.

An erect perennial two to three or four feet high, with simple or unbranched stems, long involute leaves and an elegant open capillary panicle six to twenty-four inches long. Nodes three to four. smooth. Sheaths longer than the internodes, smooth; ligule rigid, nne to three lines long; leaf-blade six to cightecn inches long, convolute-setaceous. Panicle branches and long capillary jedicels widely spreading. Spikelets about two lines long. linearlanceolate, purplish; empty glumes nearly equal, one-half to one line long, narrowly ovate or lanceolate, the upper and sometimes the lower bristle-pointed; fowering glume three-nerved, smooth, awned from the apex or from between the bristle-or awn-like divisions of the bifid apex, awn three to four lines long. Palea abut as long as its glume.

In dry sandy soil, open woods. August-September.

\section{Muhlenbergia diffusa Schreb. Nimble Will.}

Plate XX. Figure 80.

A low, ascending perennial with slender, much branched, wiry culms one to two feet long. Sheaths smooth, pilose at the throat; ligule very short: leaf-blade one to two lines wide, one to four inches long, scabrous on both sides. Panicles three to seven inches long. slender, branches erect, rather densely-flowered Spikelets a line long, equalling or exceeding the pedicels: empty glumes minute, unequal, the lower sometimes obsolete; flowering glume narrowly lanceolate, pilose near the base, scabrous on the nerves above, terminating in a slender straight awn one to two lines long; palea equalling the glume. Common on dry hills, in woods, and especially in shaded waste grounds about dwellings. August to October.

This grass is well known by its slender, diffusely-branched and tough, wiry stems. It is exceedingly difficult to mow, and the turf it sometimes forms is equally difficult to break up. It has com. paratively little agricultural value.

Yote:-yuhenteryia glwmeruta Trin. "Wild Timothy." Plate XXI, Figrure 81 , has not been recorled as growing in the state, but very likely it will be found in the mountain regions of East Tennessee. It is a rather stout upright perennial, with nearly simple culms two to three feet hich, and a densely-flowered, narrow panicle two to four inches long. The creeping root-stock is very tough and closely covered with thickened scales. It usually grows in low grounds and makes a fair "wild hay." In some parts of the west it has been recommended as an excellent grass for forage.

\section{Muhlenbergia sobolifera Trin.}

\section{Plate XXI. Figure 82.}

A slender perennial, with more or less branching leafy culms one to two feet high, from creeping scaly root-stocks. Sheaths smooth or slightly scabrous; ligule very short; leaf-blade flat, one to three lines wide, three to five inches long, scabrous. Panicle two to seven inches long, filiform, with erect appressed branches. 
Spikelets crowded, one line long or less. Empty glumes ovatelanceolate acute, mucronate, or subaristate-pointed, nearly equal, one-fourth to one-half shorter than the flowering glume; flowering glume ovate-lanceolate, three-nerved, short mucronate, scabrous on the back, short-pilose toward the base and on the callus; palea as long as the flowering glume. Near Nashville, Harpeth hills, etc., in open rocky woods, probably common. August-September.

Apparently of little or no agricultural value.

\section{Muhlenbergia Mexicana Trin. Mexican Drop-seed.}

Plate XXI. Figure 83.

An upright or ascending, usually much-branched perennial one to three feet high, with a scaly creeping root-stock, numerous flat leaves and contracted densely-flowered panicles Sheaths longer or shorter than the internodes, smooth; ligule one-half a line long or less; leaf-blade one to three lines wide, two to seven inches long. Spikelets about one line long on very short pedicels; empty glumes nearly equal, acuminate-pointed, about the length of the floral glume (a little shorter or sometimes a little longer), scabrous on the keel; flowering glume lanceolate, acute or mucronate-pointed, three-nerved, pilose near the base and on the callus. Palea a little shorter than its glume, very acute.

This species is similar in character to $M$. glomerata, but is usually more-branched and the panicle is less rigid and not so densely flowered. It grows in sandy or rocky soil along the borders of thickets, sometimes doing good service by binding sandy riverbanks subject to wash, by its strong creeping rhizomes. JulyAugust.

\section{Muhlenbergia sylvatica Torr. and Gray.}

Plate XXI. Figure 84 .

A perennial, usually much-branched grass two to three feet high, with strong scaly root-stocks, flat leaves and narrow denselyflowered panicles two to six inches long. Sheaths usually shorter than the internodes, smooth; ligule very short; leaf-blade three to six inches long, one to two lines wide, abruptly sharp-pointed. Panicle lanceolate, or linear (in var. gracilis), green, varying to purple. Spikelets about one line long, equalling or exceeding the pedicels; empty glumes equal, lanceolate-acuminate, one-nerved, one-half as long or about equalling the flowering glume; flowering glume three-nerved, pilose toward the base, scabrous above and terminating in a slender awn two to six lines long. Palea as long as the floral glume (exclusive of the awn), two-nerved, scabrous toward the apex.

Damp woodlands, river bottoms, etc.; common. Of no recognized agricultural value.

\section{Muhlenbergia Willdenovii Trin.}

Plate XXII. Figure 85.

An erect, simple or sparingly-branched perennial one and onehalf to three feet high, with creeping scaly rhizomes, flat leaves, and 


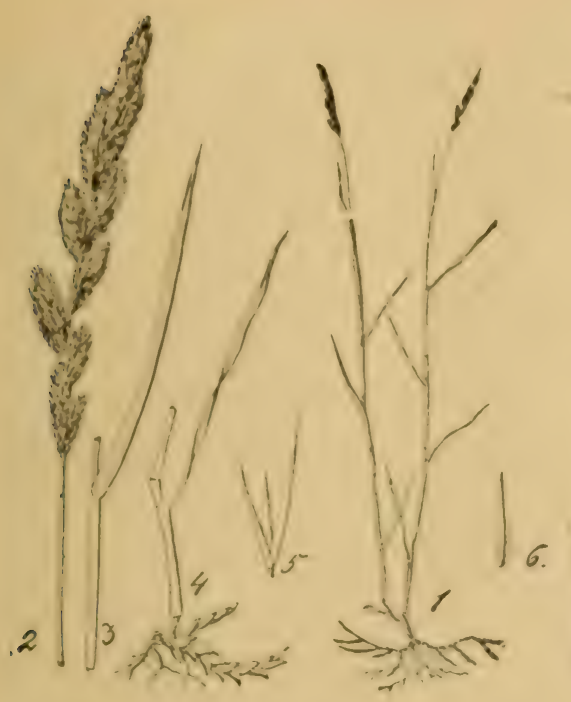

Fig. 81. Muhlenbergia glomerata.

2. Panicle. 3. Upper leaf. 4. Lower part of culm and rblzome. 5. Splkelet. 6. Floral glume.

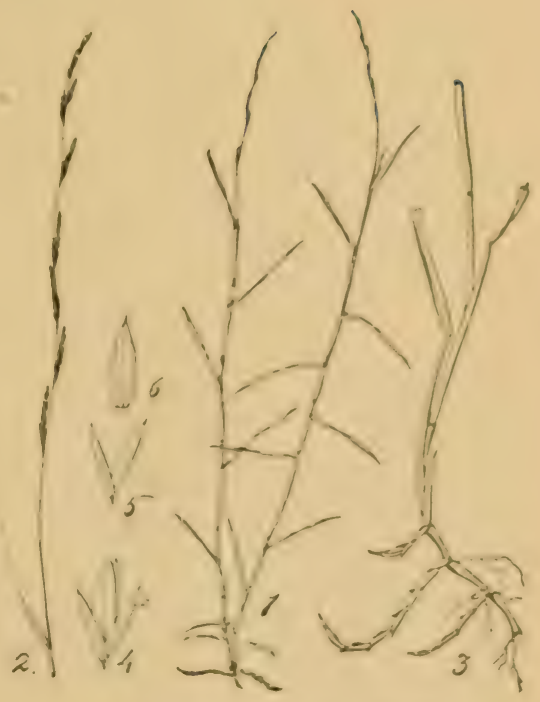

Fig. 82. Yuhlenbergia sobolifera.

2. Pantcle. 3. Lower part of culm and the rhlzome 4. Splkelet. 5. Empty glumes. 6. Flowering glume.

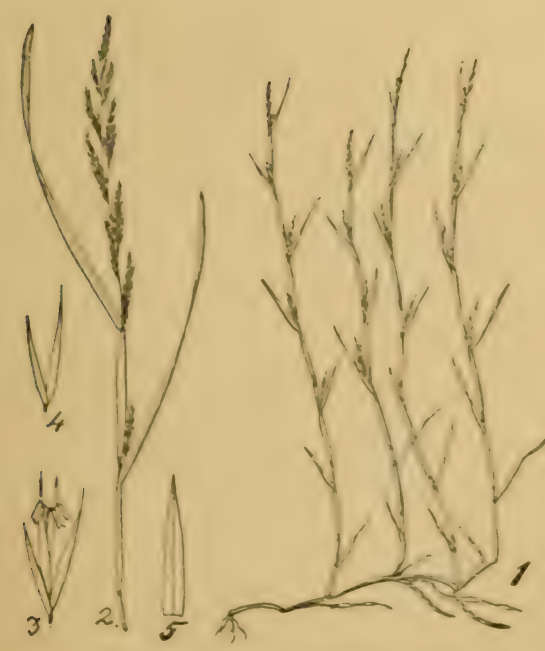

Fig. 83. Muhlenbergia Mexieana.

2. Pantcle. 3. Splkelet. «. Empty glumes. 5. Flowering glume.

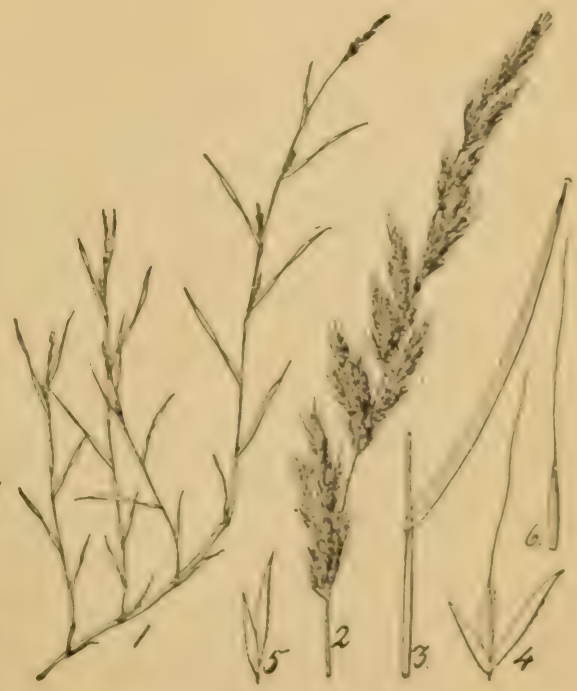

Fig. 84. Muhleubergia sylratiea.

2 Panicle s. tpper leap. 4. splkelet. 5. Empty glumes. 6. Flowering glume. 

rather few-flowered linear panieles. Nedes mumerous, minutely pubescent. Sheaths shorter or longer than the internodes, thinly pubescent; ligule one-half to one line longr: leat-blade one and one-half to four or tive lines broatl, five to six inches long, the lowermost much shorter, scabrous. Pancle six to twelve inches long, the branches single or in pairs, erect. Spikelets one and one half lines long, narrowly-lanceolate: empty glunes ovate, lanceolate-acule, nearly equal, about one half the leogth of the flowering glume: flowering glume three-nerved, pilose at the base, scabrous above, its apex continued into a slender awn about four lines long. Palea about as long as its glume, pilose at the base and nearly to the middle along the margins.

Collected in the mountain region of East Tennessee by Dr. Gattinger, and later by Prof. Ruth. August.

\section{BRACHYELYTRUM Beauv. Agrost. 39) (1812).}

Spikelets one-flowered, long and narrow, few on slender pedicels in a contracted panicle; rachilla articulated above the empty glumes, forming a short, usually smooth and rounded callus below the flowering glume, and continued behind the palea into a slender naked bristle. Glumes three, the first two empty, very small; the third or flowering glume herbaceous, rigid, fivenerved, continuous at the narrow apex into a long straight awn. Palea two-nerved, about equalling the glume. Stamens two (or three). Styles short, clistinct, stigmas elongated-plumose. Grain oblong, enclosed within the fruiting glume and palea.

A perennial grass with simple culms, flat leaves and a few-flowered simple terminal panicle.

Species one, North American.

\section{Brachyelytrum aristatum Beauv. Bearded Short-husk.}

Plate XXII. Figure 86.

Culms one to three feet high from a creeping rhizome, nodes and sheaths downwardly pubescent; leaves lanceolate, three to six inches long, six to seven lines wide. Empty glumes unequal, the first very minute, flowering glume many nerved, lanceolate, four to six lines long (exclusive of the straight awn), ciliate-scabrous along the prominent nerves. Awn three-fourths to one inch long. Continuation of the rachilla behind the palea awn-like, appressed to the palea, one-half to two thirds as long as the spikelet. Dry rocky woodlands. August.

This grass is not infrequent in the open woods, and likely to attract attention on account of its numerous rather broad and spreading leaves, but nowhere does it offer any considerable amount of forage, and it is not recognized as possessing any agricultural merit.

\section{PHLEUM. L. Sp. P1. 59 ( 1753 ).}

Spikelets one-flowered, crowded in dense cylindrical spike-like terminal panicles; rachilla articulated above the empty glumes, not prolonged beyond the floret. Empty glumes two, compressed- 
carinate, equal, usually ciliate along the keels and abruptly mucronate or short awn-pointed. Flowering glume shorter than the empty ones, thin, truncate, awnless, rather loosely enclosing the grain. Stamens three. Styles distinct.

Annuals or perennials with simple culms, from a few inches to three feet high.

Species ten, in the temperate and cooler regions of hoth hemispheres. North American species two, one of which ( $P$. pratense) is claimed to have been originally introduced here from Europe.

I. Phleum pratense, Linn. Timothy, Herd's-grass in New England. Plate XXII. Figure 87.

Culms simple, one to three feet high, panicle one to four inches long, very densely many-flowered. Empty glumes about one line long, the strong ciliate keels projecting into sharp, mucronate points, which are shorter than the glume in length. Floret entirely concealed within the outer glumes, the stamens and feathery stigmas protruding from the apex. June.

One of the best known and most extensively cultivated grasses for hay, sown either alone or mixed with red-top. It succeeds best on moist loams, or clays. On very dry ground the yield is apt to be light; on such soils the base of the stem is often thickened and bulb-like. This grass is a native of Europe, and possibly also of this country, but it is generally supposed to have been introduced here. It is recorded as having been first cultivated in the Carolinas by Timothy Hanson about the middle of the last century.

\section{ALOPECURUS Linn. Sp. P1. 60 ( I 753 ).}

Spikelets one-flowered, crowded in a cylindrical spike-like panicle, rachilla articulated below the two equal and laterally much compressed empty glumes. Flowering glume awned on the back. Palea none. The articulation of the rachilla below the empty glumes forms an exception in the Series Poacea.

Species about twenty. Tennessee species two, one of which has been introduced.

I. Empty glumes acute, $2 \frac{1}{2}$ to 3 lines long . . I. A. PRatensis.

I. Empty glumes obtuse, $\mathbf{I}$ to $\mathbf{I} \frac{1}{2}$ lines long 2. A. Geniculatus.

\section{Alopecurus pratensis Linn. Meadow Foxtail.}

Plate XXII. Figure 88.

An erect perennial one to three feet high, from a short creeping root-stock. Sheaths smooth, the uppermost usually somewhat inflated and longer than the leaf-blade; ligule hyaline, obtuse, about a line long; leaf-blade linear or narrow-lanceolate, acute, the lower four to ten inches long, two to three lines wide. Panicle rather stout, obtuse, two to four inches long. Spikelets flat, two to three lines long; empty glumes distinct or slightly grown together near 


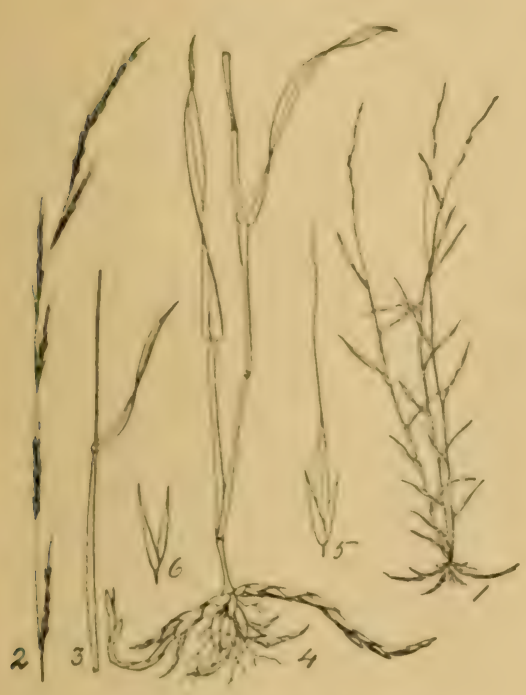

Vig. 85. Muhlenbergia Willdenorii.

2. Pantcle. 3. Lpper leaf. 4. Lower part of culm and rhizome. 5. Splkelet. 6. Empty glumes.

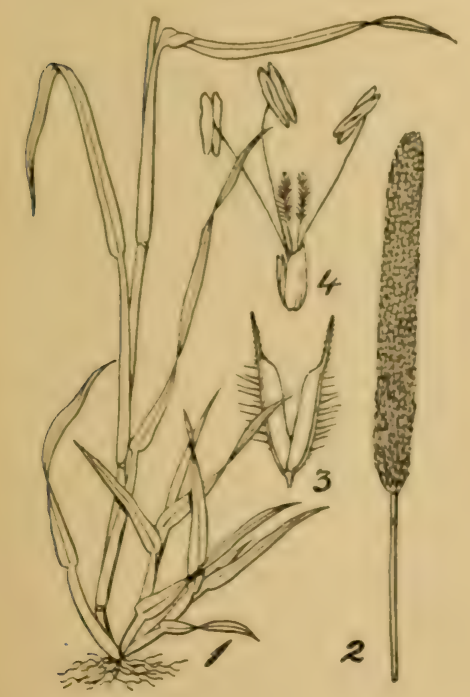

Fig. 87. Phlenm pratense.

1. The base of plant. 2. Intlorescence, 3. Empty glumes. $t$ Floret.

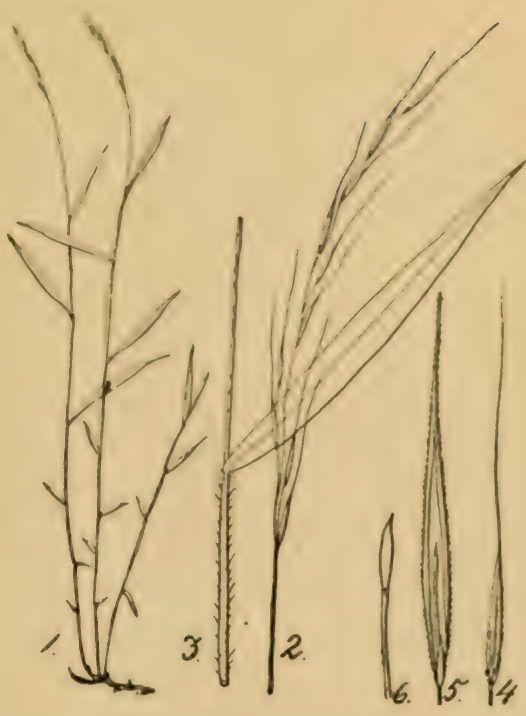

Fig. 86. Brachyelytrum aristatum.

2. Inflorescence. 3. Upper leaf. I Splkelet, side vlew, 5. Splkelet, front view. 6. Continuation of rhachllla and rud!mentary tloret.

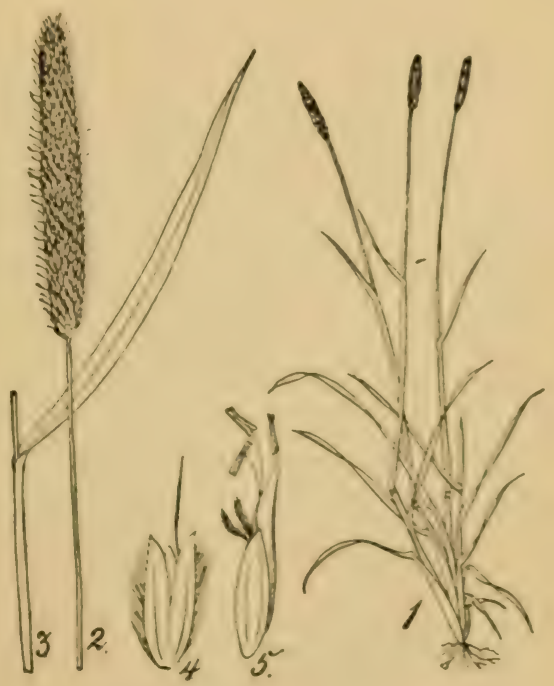

Fig. 85. Alopecurus pratensis.

2. Inflorescence. 3. Upper leaf. $t \leqslant$ splke. let. 5. The awned flowering glume, the stamens and stigmas projecting from the apex. 

the hase, abruptly acute, silky villous on the keels and shortly pilose on the lateral nerves; flowering glume nearly as long as the empty ones, awned on the back near or below the micille; awn slender, slightly twisted and projecting beyond the glumes for more than half its length.

An introduced grass, native of Europe, regarded as valuable for noist meadows and permanent pastures on account of its earliness, blooming here in March and early April. It is very likely deserving of more attention than it has so far received in this State.

\section{Alopecurus geniculatus L. Marsh or Floating Foxtail.} Plate XXIII. Figure 89.

A slender perennial, more or less decumbent, and branched at the base, the lower joints geniculate, the stems finally ascending or erect, six to twenty-four inches high, with rather short, spreading. flat leaves and spike-like densely-flowered panicles, one to three inches long. Sheaths smooth, the upper usually somewhat inflated; ligule one to two lines long: leaf-blades smooth or a little scabrous, the lower three to six inches long, the upper shorter, one to three lines wide. Spikelets strongly compressed laterally, oblong, about one line long: empty glumes rather obtuse, equal, nearly distinct or only slightly connate near the base, silky hairy on the keels and sparingly pilose on the sides: flowering glume a little shorter than the outer ones, awned from near the base: awn very slender, nearly twice as long as the glumes or (in variety aristu'atus Torr.) scarcely equalling them.

A native grass, growing in wet places, along ditches, etc. May -July.

\section{SPOROBOLUS R. Br. Prodr. Flor. Nov. Holl. i: i6g (isio).}

Spikelets one-flowered, pedicellate, in narrow and spike-like or loose and spreading panicles; rachilla articulated above the empty glumes, not produced beyond the flower. Glumes three, round on the back or slightly keeled, awnless, obscurely nerved or nerveless. The two outer glumes empty, usually uncqual; third or floral glume equaliing or exceeding the empty ones. Palea as long as or longer than the flowering glume. Stamens three. Styles short, distinct. Grain free, the pericarp loosely enclosing the seed or very thin and evanescent. Annual or perennial grasses with small spikelets, very various in habit. Species ahout eighty, a few in the Old IVurld, but most abundant in America. Thirty-six species have been recrirded from the United States, of which the following have been observed in Tennessee.

\section{KEY TO THE SPECIES.}

I. Panicle terminal, exserted, 6 to 18 inches long, the crowded spikelets less than I line long ... 3. S. Indicus.

I. Panicles terminal and lateral, i to 6 inches long, partly or wholly enclosed within the leaf-sheaths: spikelets i $t$ () ${ }_{2}{ }_{2}$, lines long 
2. Perennials, 2 to 4 feet high, spikelets 2 to $2 \frac{T}{2}$ lines long. .

2. Annuals, with slender diffuse culms 6 to is inches high, spikelets $\mathrm{I} / 2$ to 2 lines long . . 2. S. VAGINÆfLORUS.

I. Sporobolus asper Kunth. Prairie-grass.

Plate XXIII. Figure 90.

A slender or rather stout perennial, one to three feet high, with usually long, sometimes very long, nearly setaceous leaves. Sheaths smooth; ligule very short; leaf-blade narrow, involute-setaceous above, and in some forms two to three feet long. Panicle contracted, linear, two to four or six inches long, partially or wholly enclosed within the leaf-sheaths. Spikelets two to two and onehalf lines long, mostly acute; empty glumes obtuse or acute, scabrous on the keel above, slightly unequal, shorter than the flowering glume; flowering glume acute or somewhat rounded at the apex, usually pilose below on the back; palea obtuse and about the length of the glume, or sharp-pointed and much exceeding the glume in length.

The form with obtuse glumes and with the palea about the length of the flowering glume, is a stout grass, and was recognized by Trinius as a good species under the name of Vilfa Drummondii. It is Vilfa astora, var. Drummondii Vasey. This variety occurs in Tennessee, along with the species growing in dry sandy soils. The very long-leaved form found on the bluffs near Knoxville is. Sporobolus longifolius Wood.

\section{Sporobolus vaginæflorus Wood. Southern Poverty-grass.}

Plate XXIII. Figure 92.

A slender, cespitose annual, six to eighteen inches high, with very narrow, short leaves, and nearly simple, few-flowered, terminal and axillary panicles, which are mostly enclosed within the somewhat inflated leaf-sheaths. Sheaths rigid, usually purnlish; ligule very short; leaves involute-setaceous, one to four inches long. Panicles linear, spike-like, about an inch long; spikelets one to two lines long; empty glumes nearly equal, acute, as long as or a little shorter than the ovate and abruptly-pointed floral glume, which is usually a little hairy on the back; palea as long as or a little exceeding the flowering glume.

Var. minor (S. minor Vasey). Plate XXIII. Figure 9г. More slender, with the lateral panicles less strongly developed, and with rather larger and more compressed spikelets. This form seems to be somewhat intermediate between $S$. vaginaflorus and $S$. asper. It is much more slender than the latter species, and is at once distinguished from it by its annual habit. Both forms are common in dry sterile soil.

3. Sporobolus Indicus R. Br. Smut-grass.

Plate XXIV. Figure 93.

A tufted, wiry, erect perennial, one to three feet high, with simple culms, and narrow, densely-flowered, spike-like panicles, four 


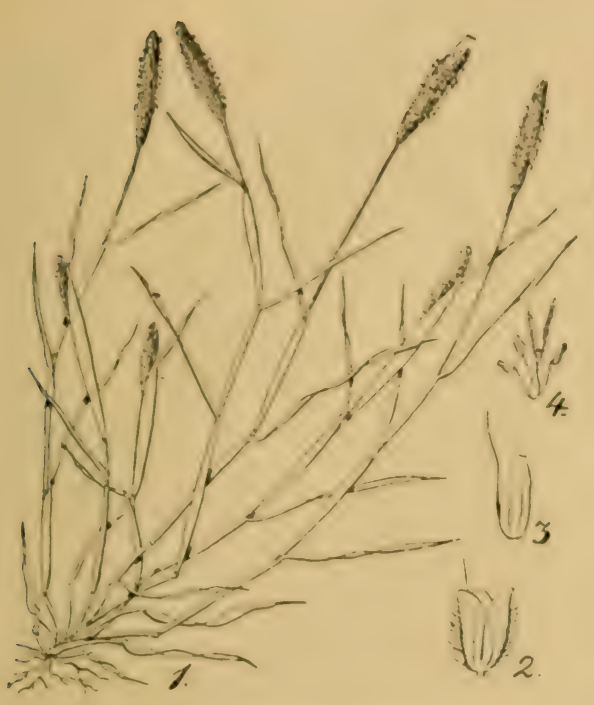

Fiz. 89. Alopecurus geniculatus.

2. Splkelet. 8. Flowering glume, Flower.

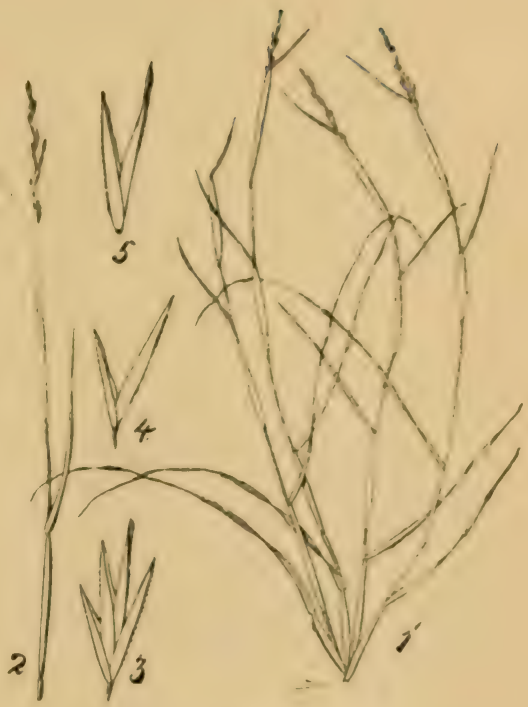

Fig. 90. Sporobolus asper.

2. Flowering branch of culm. 3. Splkelet. 4. Empty glumes. 5. Floret.

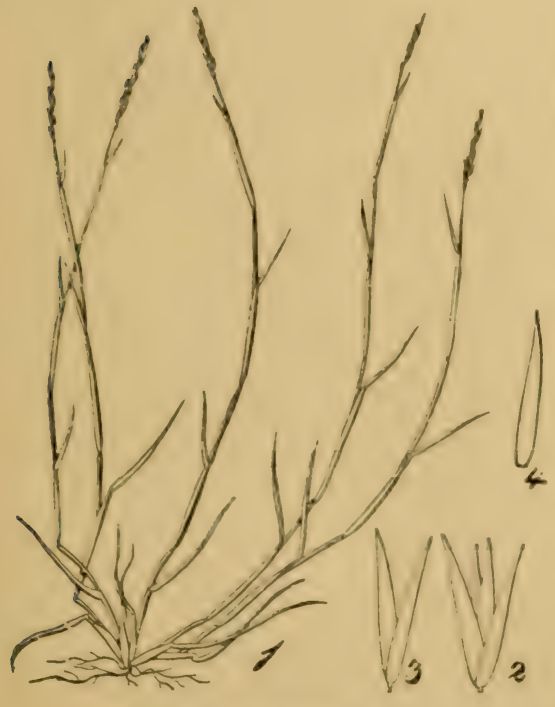

Fig. 91. Sporobolu* minor.

2. Splkelet 3. Empty glumes. 4. Flowering ylume.
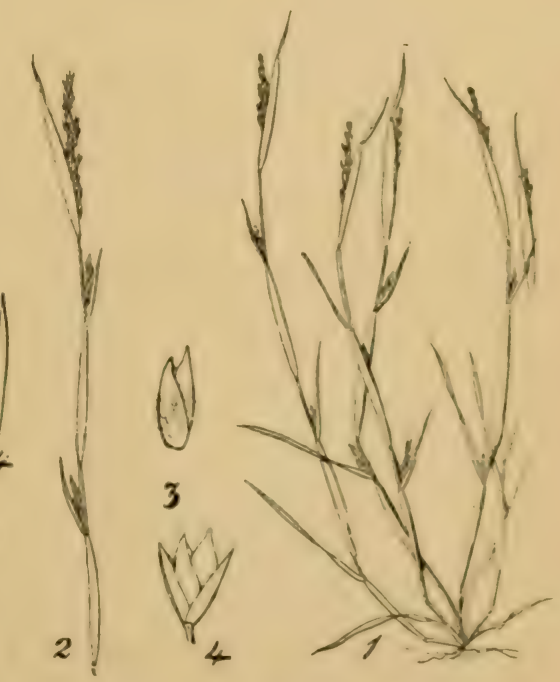

Fig. 92. Sporobolus vaginaflorus.

2. Flowering branch. 3. Splkelet, empty glumes removed. 4. Splkelet. 

to twelve inches long. Sheaths shorter than the internorles. gla. brous: ligule very short; leaves chielly radical, narrow, with long. attenuate pointed tips, glabrous, excepting a few hatrs at the hase.

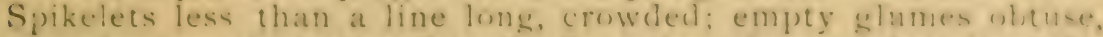
nerveless, much shorter than the flowering glume; palea about the length of its giume, faintly two-nerved. Frain broally ovold, enclosed in a thin loose pericarp.

This is an introduced grass which has become widely distributed over the state, growing in scattered tufts or patches about dwellings and in dry open fields. As the seatson advances, the long slender panicles ofen hecome overgrown hy a fungus, so that they appear as if attacked hy smut; hence the common name of Smut. grass. It has no agricultural value.

\section{CINNA Linn. Sp. Pl. 5 (1753).}

Sipikelets one-flowered, numerous in elongated, terininal, open panicles; rachilla distinctly articulated belnw the emply glumes, as well as above them (the spikelets falling off entire) and produced below the floret into a short and smooth stipe, and usually extending behind the palea as a slender, naked bristle. Flowering glume similar to the outer ones, three-nerved, obtuse, usually with a very short, subterminal awn. Palea apparently one-nerved, keeled. Stamen one. Styles short, distinct. Grain included within the flowering glume and palea, free.

Tall perennial grasses, with numerous flat leaves and manyflowered nolding panicles.

species two, in the northern regions of Europe and America; both species extend into Tennessee.

KEY TO THE SPECIES.

Empty glumes unequal in length, spikelets 2 to 3 lines long I. C. ARUNDINACEA.

Empty giumes equal or nearly so, spikelets less than 2 lines long

2. C. PENDULA.

\section{Cinna arundinacea Linn. Indian Reed-grass or Sweet Reed-} grass.

Plate XXIV. Figure 94.

A tall, leafy grass, three to seven feet high, with simple culms and ample terminal panicles. Nodes usually covered by the smooth sheaths; ligule two and one-half lines long. leaf-biade spreading. five to ten inches long, three to six lines wicle, scabrous on the margins. Panicle six to tifteen inches long, rather densely-flowered, the branches erect-spreading. Spikelets much longer than the pedicels, appressed to the branches, (at least in fruit); empty glumes narrow-lanceolate, very acute, unegual, the second longer than the first and three-nerved; flowering glume about the length of the second glume, obtuse and hyaline at the tip. three-nerved, the midnerve excurrent just below the apex into a very short awn or mucro. Palea shorter than its glume, one-nerved and keeled or sometimes with two closely approximate nerves. In shaded swamps and along streams in wet meadows. August and September. 
There is a woodland form of this species which is smaller throughout. Culms about two feet, panicle four to six inches long, empty glumes with white scabrous margins and tips. In open, rocky woods where the soil is apparently dry. Sometimes mistaken for $C$. pendula. Dr. Gattinger noted this form on Paradise Ridge.

This grass is very leafy and has strong perennial rhizomes, and it may have some value as a native hay in wet, rich lands along streams. Its cultivation cannot at present be recommended.

2. Cinna pentula Trin. Slender Reed-grass.

Plate XXIV. Figure 95.

Culms rather slender, two to three feet high, leaves and sheaths much as in $C$. arundinacea, but the blades rather more scabrous on the nerves. Panicle lax, often few-flowered, the branches capillary and more or less drooping. The glumes less firm than in $C$. arundinacea and the empty glumes nearly equal, otherwise the same.

Found upon Roane Mountain and doubtless occurs in the cold mountain woods of the upper and eastern part of the State. JulyAugust. Of no agricultural value.

\section{AGROSTIS Linn. Sp. P1. 6 (1753).}

Spikelets one flowered, in open panicles, rachilla articulated above the empty glumes, not produced beyond the flower. Empty glumes two, equal or nearly so, acute, longer than the floret. Flowering glume rather broad, less firm in texture than the outer glumes, usually obtuse, awnless, or with a slender dorsal awn. Palea hyaline, much shorter than the floral glume or wholly absent. Stamens three, grain enclosed by the floral glume but free from it.

Annual or usually perennial grasses, with small spikelets in open, usually diffuse, panicles.

Species about 100 , distributed over the entire world, especially in the north temperate zone. In the United States the species are most numerous in the far Northwest. Of the seven species found within the state, six are natives.

KEY TO THE SPECIES.

I. Palea half the length of the flowering glume . 9. A. ALBA.

(a) Ligule 2 to 5 lines long . . . . . var. a. ALBA.

(b) Ligule shorter, truncate

(I) Culms erect . . . . . var. b vULGARIS.

(2) Culms prostrate and rooting at the lower joints, flowering branches ascending .

r. Palea very minute or none . . . . . . . . . 2

2. Flowering glumes awned . . . . . . . . . . . 3

2. Flowering ylumes awnless or rarely short awned (awn not constant) 


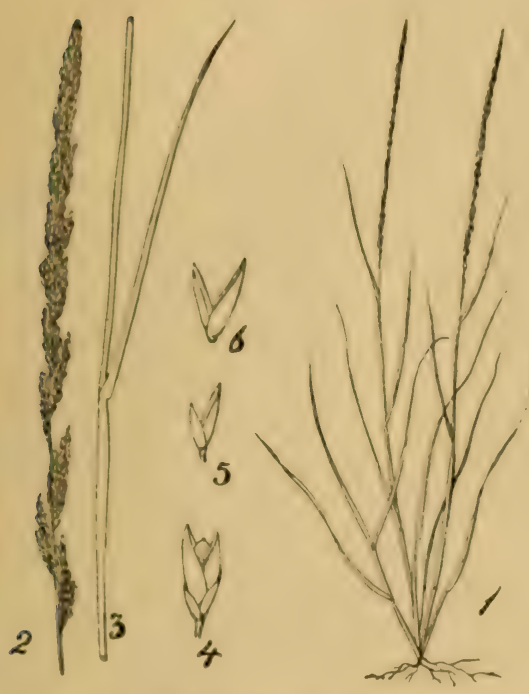

Fig. 98. Sporobolus Indicus.

2. Inflorescence. 3. Upperleaf. 4. Splkelet. 5. Empty glumes. 6. Flowering glume and palea.

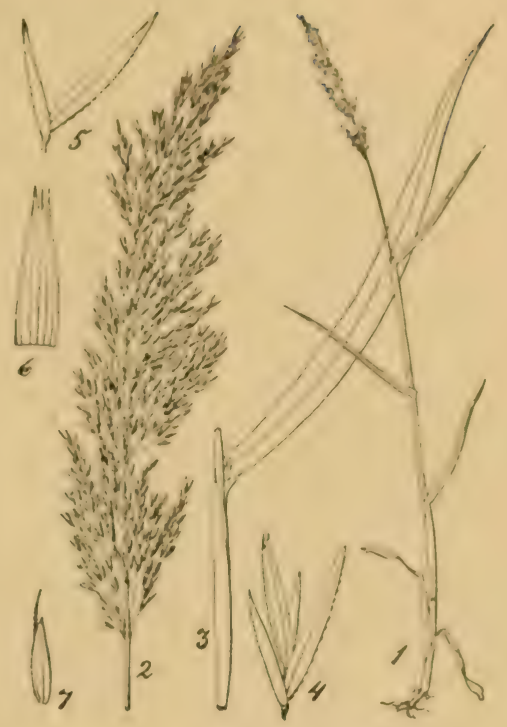

Fig. 94. Cinna arundinacea.

2. Panicle. 3. Upper leaf. 4. Splkelet. 5. Empty glumes. 6. Dorsal view of flow. ering glume. 7. Flowering glume with awn, side vlew.

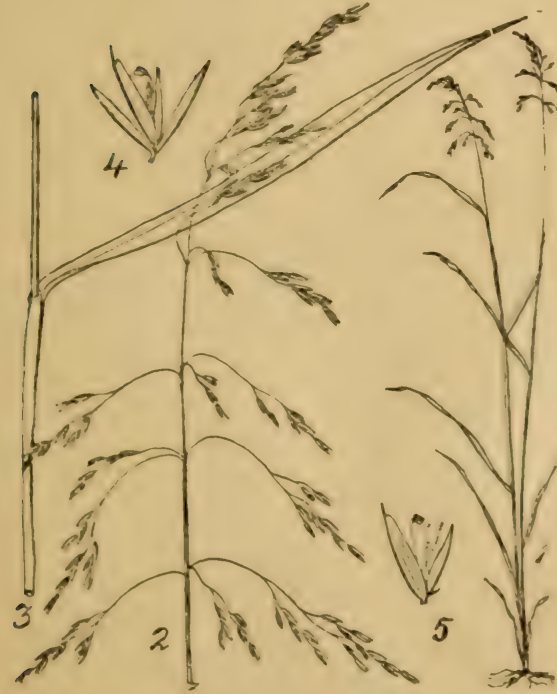

Fig. 95. Cinna pendula.

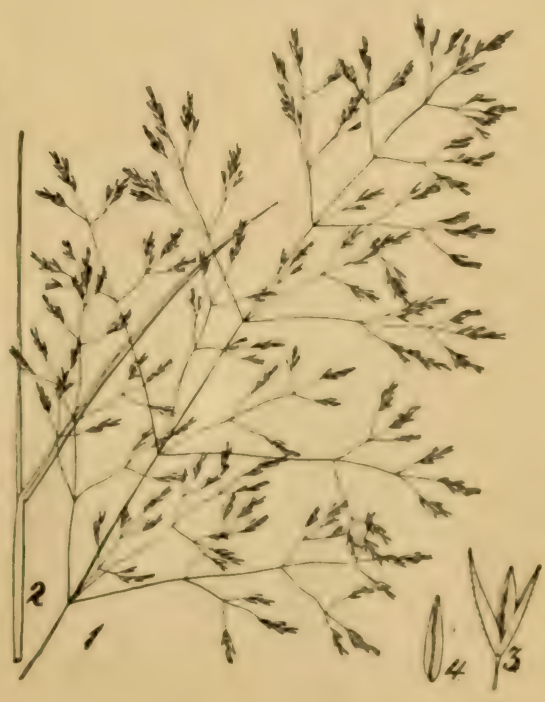

Fig. 96. Agrostis elata.

2. Panicle 3. Upper leaf. 4. Splkelet. 5. Same with the empty glumes removed.

1. Pantcle. 2. Upper leaf. '3. Splkelet. 4. Flowering glume. 

3. Empty glumes equal, awn very slender, flexuose, minutely pubescent, several times longer than the sputielet

8. A. ARACHNOIDES.

3. Empty glumes unequal, awn stouter, geniculate, nut puluescent, about twice as long as the spikelet .

4. Culms 6 to 12 inches high, panicle 2 to 3 inches long, plants alpine . . . . 6. A. rubra Americana.

4. Culms 12 to 24 inches, panicle + to 6 inches long. plants not alpine......... . . . . . canina.

5. Radical leaves involute filiform: panicle branches long and widely spreading: spikelets crowded near the extremities of the branches; flowering one-third shorter than the empty glumes; flowering in April . . 5. A. SCABRA.

5. Radical leares flat, spikelets more scattered on more or less divergent pedicels: flowering late in summer or early autumn

6. Culms weak and decumbent below, leaves numerous, is to 4 inches long, thin and widely spreading, spikelets less than a line long on diverging pedicels. 3. A. PFR RNANS.

6. Culms erect, or geniculate only at the lower nodes, spikelets I line long or more

7. Culms slender, sheaths smooth, flowering glume about onefourth shorter than the thin empty ones.

. 2. A. INTERMEDIA.

7. Culms stouter, sheaths scabrous or conspicuously striate, flowering glumes nearly equalling the firmer empty ones.

8. Leaves erect, with rigid involute tips, panicle-branches ascending, naked below, spikelets appressed and somewhat crowded near the ends of the branches 1. A. EI.ATA.

8. Leaves long and spreading, panicle elongated ( 6 to 12 inches) the numerous, compound and flexuose branches finally widely spreading, spikelets not crowded .

4. A. NovE-ANGLIE.

\section{Agrostis elata Trin.}

Plate XXIV. Figure 96.

An erect, rather stout and rigid perennial, about two feet high. Sheaths scabrous, especially near the top: ligule two to four lines long: leaf blade rather firm in texture, erect, one to three lines wide, four 10 seven inches lons. gradually tapering to the attenuate and rigid involute tips, scabrous. Panicle six to twelve inches long. with rigid, slightly spreading branches; primary branches three to ten at a nocie, verticillately-hranched above the middle: the ultimate branches flower-bearing above the middle, the spikelets usually crowded. Empty glumes nearly erual, lanceolate, acute, about one and one half lines long, minutely pubescent, thick in texture, the keels hispid scabrous, at least toward the tips. Flowering glume a little shorter, minutely hispid on the nerves. Thickets, open wonds, usually in somewhat sandr soil. Angust to October. Common. 


\section{Agrostis intermedia Scribn.}

A slender perennial grass, two feet high, culms erect or geniculate at the lower joints. Sheaths smooth; ligule one to three lines long; leaf-blade one to one and one-half lines wide, four to six inches long, scabrous. Panicle oblong-pyramidal, six to eight inches long, with weak and slender branches (as compared with $A$. elata); primary branches in clusters of two to seven at a node. branching again below the middle. Spikelets about one line long, scattered above the middle of the branches. Empty glumes thin, subequal, lanceolate, acuminate, scabrous on the keels, otherwise smooth. Flowering glume about three-fourths the length of the empty ones. Common in damp places, in thickets and along the borders of woods. August to October.

This approaches $A$. elata, but is more slender with thinner and more numerous leaves. Agrostis perennans astivalis Vasey, (Agrostis perennans of this work) is certainly Trichodium decumbens Michx.; it has weak and for the most part decumbent stems and oval or oblong panicles. Michaux cites Cornucopice perennans as a synonym under Trichodium decumbens.

\section{Agrostis perennans Tuckerman.}

Plate XXV. Figure 97.

A perennial with weak, slender, and mostly decumbent leafy culms, about two feet high. Internodes short. Sheaths smooth, striate, shorter than the internodes; ligule about one line long; leaf-blade flat, thin, widely-spreading, about one line wide, four inches long, acute, scabrous. Panicle oblong, about six inches in length; primary branches in clusters of two to five at a node, branched at or below the middle; the branches and pedicels all widely divergent. Spikelets pale green, a line or lesslong. Empty glumes rather unequal, lanceolate, very acute, rather minutely scabrous on keels. Flowering glume a little shorter than empty ones. Common in moist, shaded places, borders of woods, etc. August to October.

\section{Agrostis Novæ-Angliæ Tuckerman.}

\section{Plate XXV. Figure 98.}

A rather stout, coarse perennial, with culm erect or geniculate at the base. Sheaths striate, mostly exceeding the nodes; ligule one to two lines long; leaf-blade flat, rough on upper or on both surfaces, one and one-half to four lines wide, four to ten inches long. Panicle oblong diffuse, six to twelve inches long, the upper portion often expanding while the lower is yet included in the upper leaf-sheath; primary branches numerous at each node, three to seven inches long, ascending or finally spreading. Spikelets numerous, about one line long. Lower empty glume lanceolate, rather slender-pointed, scabrous on the keel above and serrulate on the upper margins; second glume more blunt, otherwise similar, three-fourths of a line long. Flowering glume equalling the lower empty ones, ovate, obtuse. Palea wanting. Along mountain streams; Roane mountain. July-August. 


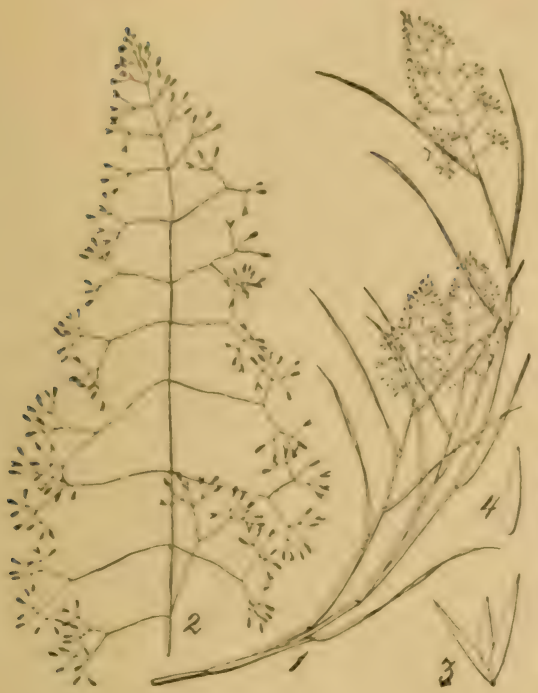

Fig. 97. Agrostis perennans.

2. Panicle. 3. Splkelet. 4. Flowering glume.

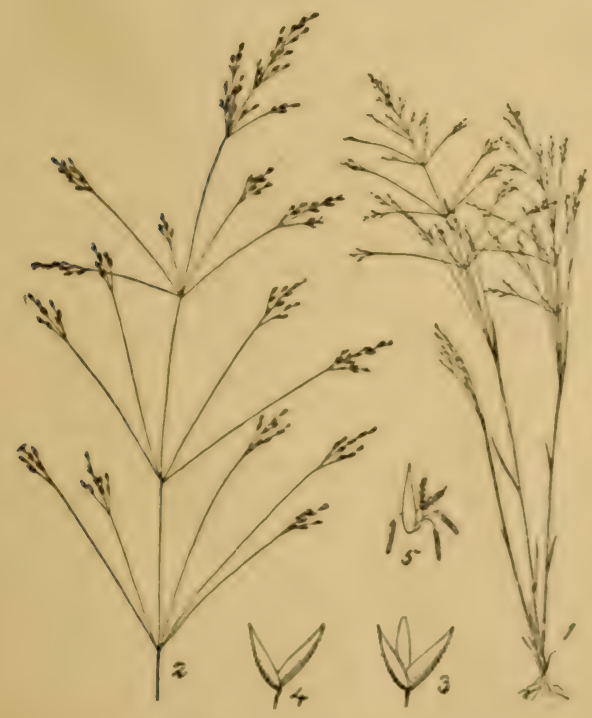

Fig. 99. Agrostis seabra.

2. Panlcle. 3. Splkelet. 4. Empty glumes. 5. Flowering glumes with stamens and pistil.

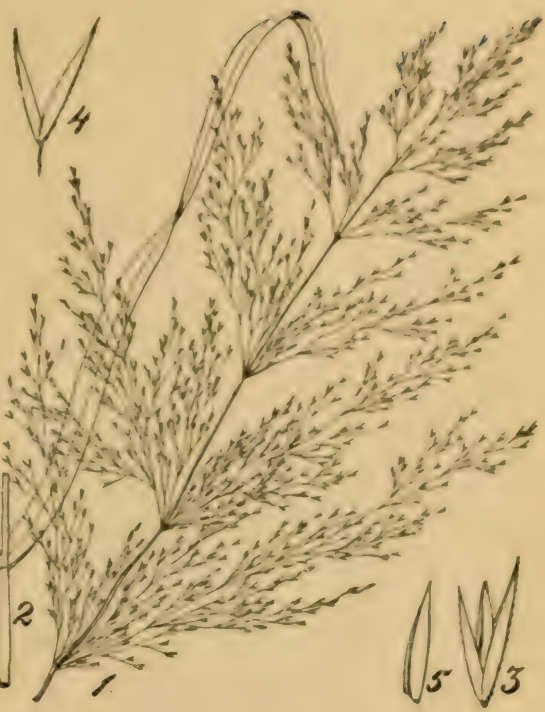

Fig. 98. Agrostis Nora Angliz, Tuekerman.

1. Pantcle, (upper half). 2. Upper leaf. 3. Spikelet. 4. Empty glumes. 5. Flowering glume.

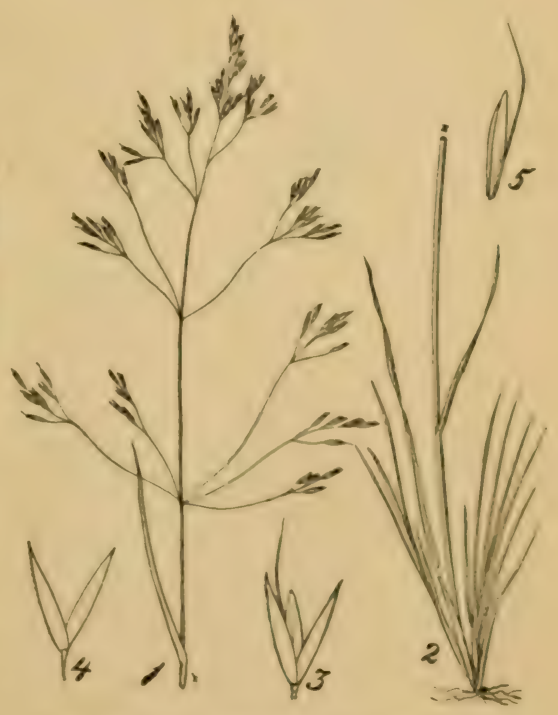

Fig. 100. Agrostis rubra L. Americana.

1. Pantcleand upper leaf 2 . Hase of the plant. 3. splkelet. 4. timpty ־itumes. 5. Flowering glume. 



\section{Agrostis scabra Willd. Fly-away-grass.}

Plate XXV. Figure 99.

An annual (?) erect or somewhat geniculate at the lower joints, six inches to two and one-half feet high. Sheaths striate, smooth or scaibrous: ligule one to two lines long: leaf-blacle erect or ascending, one-half to three-fourths of a line wide, two to four inches long. concluplicate when dry, scabrous especially on the margins and upper surface. Panicle long and lax, the capillary primary branches two to eight at a node, branched above the middle: the spikelets clustered toward the ends of the ultimate branches. limpty glumes lanceolate, acute, with scabrous lieel, about threefourths of a line long, the upper one a little shorter than the lower. Flowering glume rather faintly-nerved, shorter than the empty glumes, awnless or very rarely awned on the back. Palea none. A common grass in dry and sterile, as well as in moist rich lands. It is the earliest to bloom among our species of Agrostis, flowering in April and May. The delicate hair-like branches of the panicle, which are at first erect or ascending, become widely spreading at maturity, and the entire panicle breaks away from the slender culm and is blown about by the wind. Before the panicle has exparded this grass is sometimes gathered by poor people in the vicinity of large towns and sold under the name of "silk-grass," for dry bouquets. This grass is very properly classed with the weeds.

\section{Agrostis rubra Linn, var. Americana. (A. rupestris Chapman not A11.)}

\section{Plate XXV. Figure 100.}

A low, alpine perennial, six to twelve inches high, with a short creeping root-stock. Sheaths striate. smooth; ligule one-half to one line long, decurrent; leaf-blade conduplicate or flat, smonth or with subscabrous margins, one line or less wide, two to five inches long. Panicle pyramidal, two to three inches long: primary hranches three to six on the lower node. usually in pairs above. Empty glumes subequal, nne and one-half lines long, smooth, or the lower hispid on keel above, lanceolate, usually purple. Flowering glume a little less than one line long, ovate, with a truncate tip, awned on the back below the middle, awn twice as long as the spikelet, somewhat twisted and geniculate. Near the summit of Roane mountain. July-August.

\section{Agrostis canina L}

A rather slender perennial, twelve to twenty-four inches high, erect or geniculate at the lower joints. Sheaths nearly smooth: ligule about one and one-half lines long: leaf-blade flat or conduplicate, two to four inches long. one and one half lines wide: scabrous, acute. Panicle pyramidal, four to six inches long: primary branches unequal, five to twelve on the lower node of the axis, the ultimate branches in pairs or several together and apparently verticillate. Spikelets near the ends of the branches, about one and one-fourth lines long. Empty glumes nearly equal, narrowly: lanceolate, very acute, more or less scabrous on the keels: Hower- 
ing glume about one-fourth shorter than the empty ones, minutely toothed at the truncate apex, awned on the back near the middle; awn exserted and somewhat bent.

This description is given here to cover a grass found along the mountain road-side leading to White Cliff Springs, in. Monroe county. It is certainly distinct from the Roane Mountain Agrostis rubra Americana. Collected in July, 1890.

\section{Agrostis arachnoides E11. Spider Bent.}

\section{Plate XXVI. Figure 101.}

A slender annual (?) four inches to two feet high, with rather short, narrow leaves, and capillary, spreading panicle. Sheaths smooth, exceeding the internodes; ligule one to two lines long, acute, cleft; leaf blade flat, two to three inches long, about one line wide, the upper shorter and narrower. Panicle three to twelve inches lorg, primary branches at the lower node about five, usually in pairs above, widely spreading at maturity. Spikelets one-half to one line long; empty glumes nearly equal, scabrous on the keel; flowering glume a little shorter than the empty ones, three-nerved, with two minute bristles at the truncate apex, and a very slender flexuose, minutely pubescent awn on the back above the middle; awn several times longer than the spikelet; palea wanting or very minute. Dry, usually rather poor lands. May-June. Of no value.

\section{Agrostis alba Linn. Herd's Grass or Red-top.}

Plate XXVI. Figure 102.

A well-known perennial of variable habit. Culms smooth, erect or decumbent, and rooting at the base or stolonifercus, one to three feet high. Sheaths smooth; ligule less than a line to four lines long, sometimes firm and herbaceous towards the base; leafblade linear or narrow-lanceolate, four to eight inches long, scabrous. Panicle narrow and with erect and rather densely-flowered branches, or lax and open, the branches widely spreading, four to ten inches long. Spikelets nearly sessile or pedicellate, one to one and one-half lines long. Empty glumes lanceolate, acute, the first scabrous on the keel, the second a little shorter and smooth or scabrous near the apex. Flowering glume a little shorter than the empty ones, obtuse or truncate; palea one-half to three-fourths as long as the floral glume.

Agrostis vulgaris With. Fine Bent, is now united with $A$. alba L., not being regarded as botanically distinct. A. vulgaris, however, is a good agricultural form quite distinct from $A$. alba. Agrostis stolonifera is also classed as only a variety of $A$. alba. Trinius referred these and also some others which have been classed as species, to Agrostis polymorpha Huds.

The forms we have may be separated as follows:

Ligule I to 4 lines long, usually ribbed toward the base. Panicle open, culms erect or geniculate at the lower joints. 


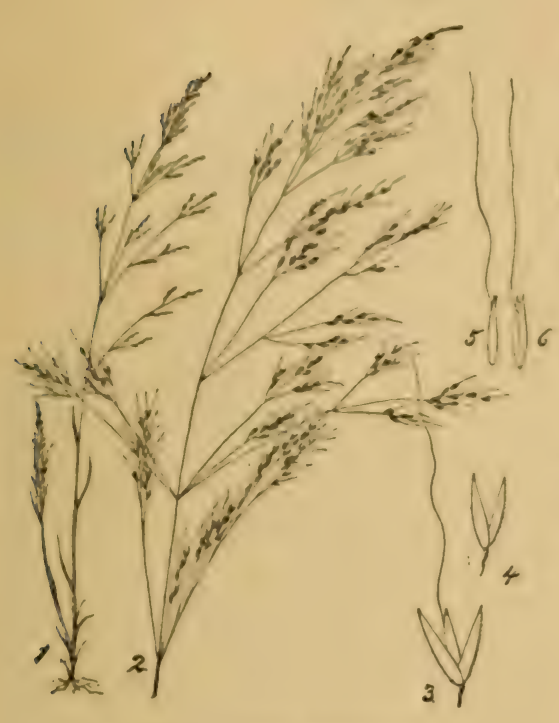

Flg. 101. Agrostis arachnoides.

2. Pantcle. 3. Splkelet. 4. Empty glumes. 5 and 6 . The awned flowering glume.
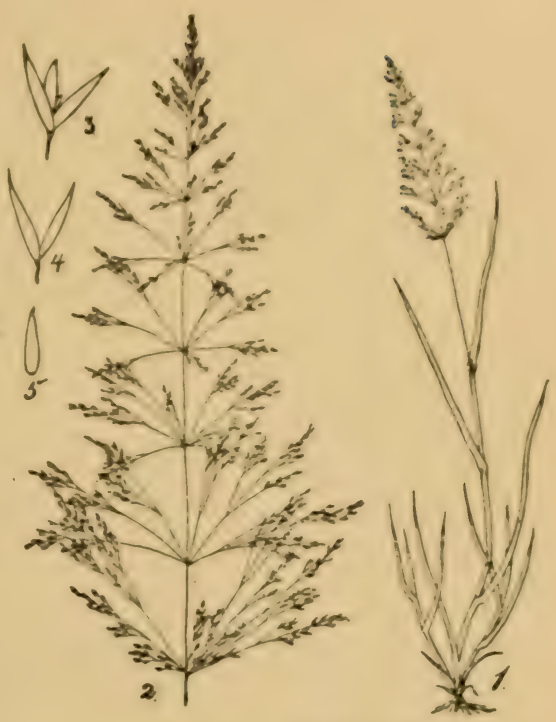

Fig. 102. Agrostis alba.

2. Pantcle. 3. Splkelet. 4. Empty glumes. 5. Flowering glume.

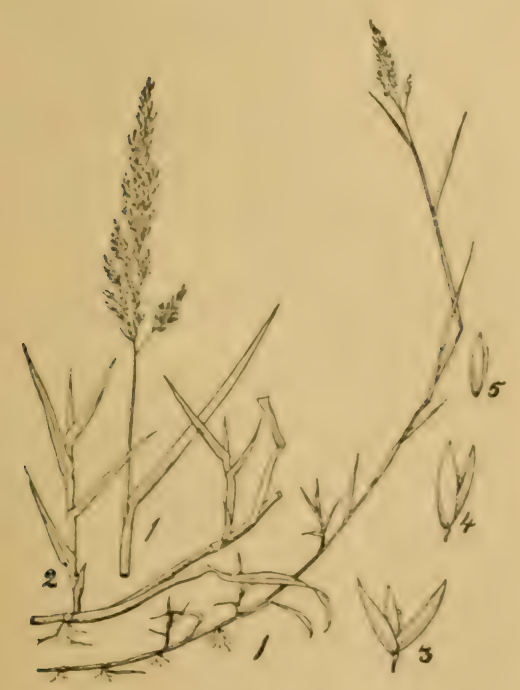

Fig. 103. Agrostis alba stolonifera.

1. Upper leaf and inflorescence. 2. Lower part of the culm. 3 . Splkelet. 4. Empty
glumes. 5. Floret.

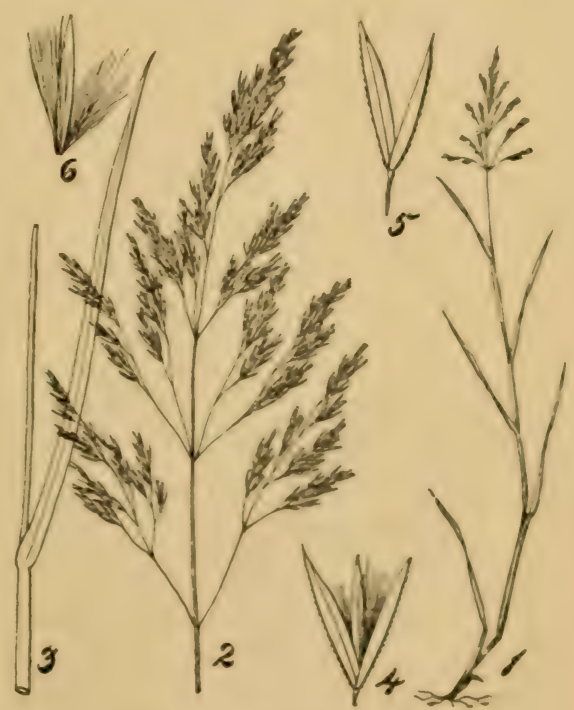

Fig. 104. Calamagrostis Canadensis.

2. Pantcle. 3. Cpperleat. 4. splkelet. 5. Empty glumes. 6. Flowering glume. 



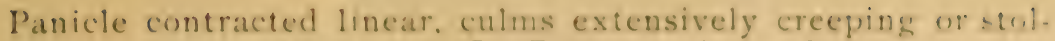
oniferous (Plate XXVI. Figure 103) . A. STOLONIFERA.

Ligule less than a line long, sometimes nearly obsolete; panicle branches spreading, smooth . . . A. vUl.gARIS.

Herd's grass or ked-top has long been known to our farmers, and in its several forms is deemed valuable for permanent meadows and pastures, where the land is not too dry. On gond soil it yields well and makes excellent hay. Some of the forms employed alone, make, under favorable circumstances, the softest and finest turf for lawns.

\section{CALAMAgRostis Aclans. Fam. Pl ii: $31(1,-63)$.}

Spikelets one-flowered, in open or narrow and almost spike-like panicles, rachilla articulated above the empty glumes and produced above the floret (in our species) into a short, hairy pedice?, or bristle. Glumes three, the first two nearly equal and empty. awnless and usually exceeding the third; the third or floral glume usually more delicate in texture than the first and second, surrounded at the base with copious hairs, which sometimes equal or exceed the glume in length, awned on the back, usually from below the middle. Palea more than half the length of its glume, faintly two-nerved. Stamens three. Styles distinct. (irain enclosed hy the floral glume and palea, and more or less adherent.

Tall, often reed-like, perennial grasses, with small spikelets in many-flowered terminal panicles.

Species about rzo, very widely distributed over the world in the temperate and arctic zones and on high mountains within the tropics. Two of the eight species found east of the Mississippi occur within the State.

$$
\text { KEY TO THE SPECIES. }
$$

Panicle loose and open, spikelets $1 / 2$ to 2 lines long.

Panicle strict, branches erect, spikelets 3 to 4 lines long

2. C. Nuttalliana.

\section{Calamagrostis Canadensis Beauv. Blue Joint.}

\section{Plate XXVI. Figure 104.}

An erect, leafy grass, three to five feet high, with smooth, simple culms and open brown or purplish many-flowered panicles, four to eight inches long. Sheaths smooth, striate: ligule two to ihree lines long, membranous; leaf-blade flat, six to eighteen inches long, two to four lines wide, tapering gradually into long filiform tips. Empty glumes ovate-lanceolate, acute, finely strigose. scabrous, awned on the back at or a little below the middle: awn straight, very slender; hairs from the callus as long as the glume.

A species common in the North and widely distributed over the United States and Canada. Here apparently limited to the higher mountain regions of upper East Tennessee. A valuable gras., 
worth much more than generally estimated. Being tall, it will yield much hay per acre. July-August.

\section{Calamagrostis Nuttalliana Steud. Reed Bent.grass.}

Plate XXVII. Figure 105.

A stout, reed like grass, three to five feet high, with a narrow, almost spike-like panicle. Leaves elongated (a foot or more), scabrous, the upper face more or less hairy; ligule two to three lines long. Panicle contracted, four to eight inches long, very densely-flowered. Empty glumes three to four lines long, long acuminate-pointed, strongly scabrous on the keel, the second distinctly three-nerved. Flowering glume a little shorter than the empty ones, rigid, excepting at the hyaline tip, minutely scabrous all orer, copiously hairy at the base, hairs shorter than the glume, exceeded by the tuft at the apex of the otherwise smooth prolongation of the rachilla. Awn from above the middle, rather stout, a little exceeding the glume. Palea distinctly two-nerved, acute, nearly as long as the glume. Grain wholly tree, sparsely hairy all over, with a dense tuft of short hairs at the apex.

Moist grounds, July-August. Our specimens are from Middle Tennessee (Cowan) and the mountains of East Tennessee. The species ranges northward to New England.

\section{Tribe IX. AVENEA.}

Spikelets, two- to several-flowered, outer empty glumes usually longer than the first floral glume; one or more of the floral glumes awned on the back or from between the teeth of the bifid apex (some cultivated forms excepted); awn usually twisted or geniculate. Rachilla, at least at the base of the flowering glume, usually hairy.

A tribe comprising twenty-three genera, and over 300 species, widely distributed in the temperate reginns of both the Old and New World; particularly abundant in South Africa and Australia, a few extending beyond the arctic circle. Several of the species are valued as forage plants. Cultivated Oats, Avena sativa, is the best known example of this tribe.

\section{HOLCUS Linn. Sp. P1. 1047 (1753).}

Spikelets two-flowered, crowded in open panicles, the lower flower raised above the outer glumes upon a curved internode of the rachilla, hermaphrodite, awnless, the upper flower staminate (rarely hermaphrodite), its glume bearing a short curved awn near the apex; rachilla smooth, articulated below the empty glumes and also below the floral glumes. Empty glumes nearly equal, compressed, boat-shaped, longer than the florets. Lodicules (in $H$. lenatus) lanceolate, acute. Stamens three.

Annuals or perennials, with usually flat leaves and densely-flowered terminal panicles. 



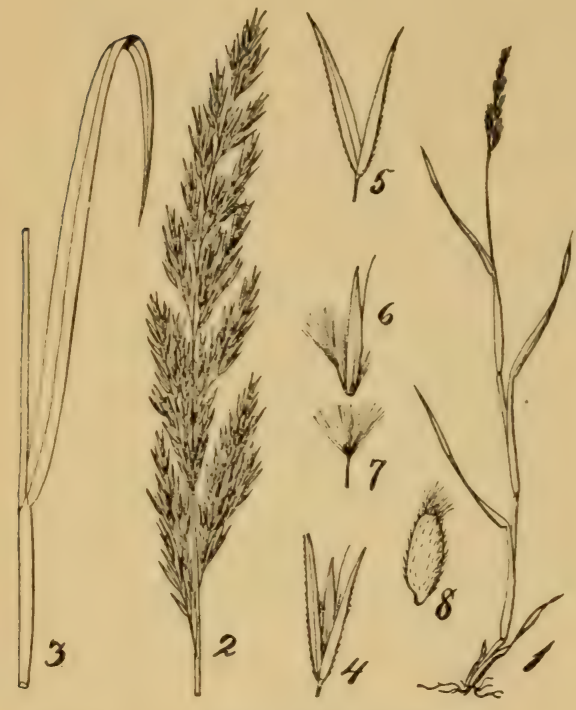

Fig. 105. Calamagrostis Nuttalliana.

2. Panicle. 3. Upper leaf. 3. Spikelet. 5. Empty glumes. 6. Flowering glume. 7 . Rudiments of flower. 8. Grain.

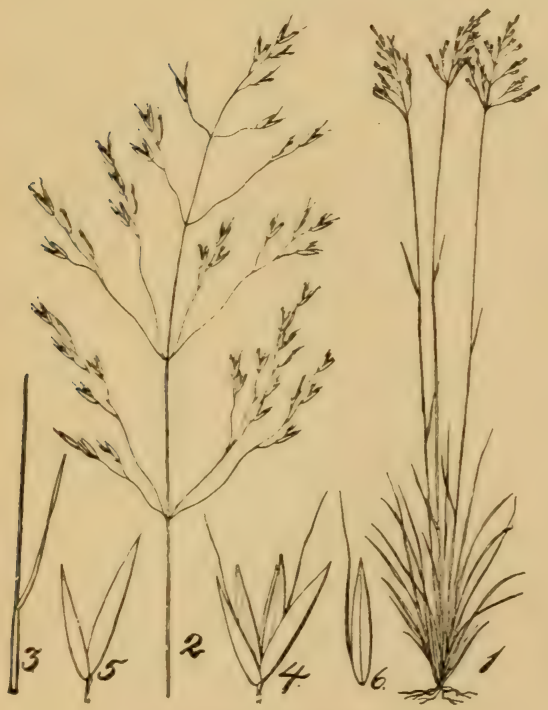

Fig. 107. Deschampsia flexuosa.

2. Panicle. 3 Upper leaf. 4. Spikelet. 5. Empty glumes. 6. Flowering glumes.

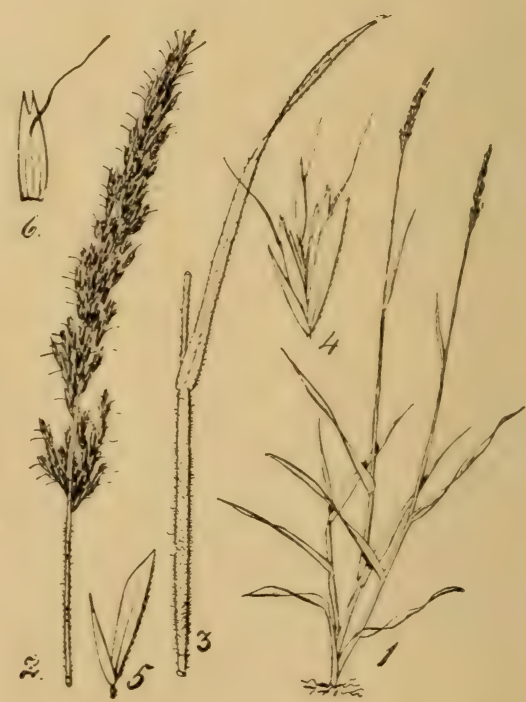

Fig. 108. Trisetum subspicatum, var. molle. 2. Inflorescence. 3. Upper leaf 4. Splkelet. 5. Empty glumes. 6. Flowering glume. 
Species about eight, in burope and Africa; one species, uflen cultivated in mealows and lawns, has become widely dispersed.

1. Holcus lanatus Linn. lelvet-grass or White Timothy.

Plate XXVII. Figure 106.

A perennial grass, one to two feet high. from a creeping rhizome, usually closely puhescent all over with soft, whitish hairs. Panicle two to three inches long, pale or sometimes purple-tinged. Spikelets about two lines long, olutuse: the second empty glume broaler than the first, three-nerved and often short awned at the apex, both ciliate on the prominent keels and thinly pubescent all over; lower floral glume smooth and shining, hecoming indurated in fruit. May-June.

This European grass is found here and there over the state, having been introduced with the seed of other grasses. ()wing to its light color it is striking in appearance, and is said to be a valuable grass for light thin soils which are unsuited to the growth of more valuable sorts. It should only be sown in mixtures.

29. DESCHAIMPSIA Beauv. Agrost. 9r, t. 18, f. 3. (1812).

Spikelets two- (rarely) three-flowered, in terminal panicles; rachilla hairy, articulated above the empty glumes and produced beyond the upper floret as a hairy bristle. Empty glumes two. thin and scarious, lanceolate-acute, nearly equal; flowering glumes subhyaline, truncate, and more or iess regularly two-to fourtoothed, awned on the back. Awn slender, twisted below. Palea narrow, two-nerved. Grain oblong, included within the floral glume and palea, but free from them. Perennials, with flat or convolute leaves, and rather small, shining spikelets in terminal narrow or spreading panicles.

Species about twenty, in the cold and temperate regions of the northern hemisphere and on the high mountains within the tropics. One in Australia. North American species eight, of which one is found within the State.

I. Deschampsia flexuosa Trin. Hair-grass.

Plate XXVII. Figure 107.

A slender, erect perennial about two feet high, with involute bristlefform, mostly radical leaves, and diffuse panicles. Culms smoth, naked above. Branches of the panicle capillary, flexuose. Empty glumes about as long as the florets: flowering glumes two lines long, hairy at the base. Awn twisted and geniculate, exceeding the glumes in length. Palea as long as its glume.

Observed on Roane and Lookout mountains. May and June. Of no agricultural value.

30. TRISETUM Pers. Syn. I. 97. (1805.)

Spikelets two-(rarely three-or five-) flowered, in narrow and 
dense, or loose panicles; rachilla hairy or naked, articulated above the empty glumes and between the florets, prolonged beyond the base of the upper floret as a (usually) hairy bristle. Empty glumes two, awnless, carinate, unequal, usually longer than the floral glumes; floral glumes sub-hyaline, carinate, cleft, or two-toothed at the apex, the teeth sometimes produced into slender awns, awned between or a little below the teeth. Awn twisted and usually geniculate. Palea narrow, two-toothed. Grain smooth. enclosed in the floral glume and palea, but free from them. Cespitose perennials (rarely annuals), with flat leaves and derse spike-like, or narrow, loose panicles.

Species fifty, from the arctic regions through the temperate zone and along the high mountains of the tropics, to the south temperate countries. North American species, nine. There are two native species in Tennessee.

\section{Trisetum subspicatum var. molle Gray.}

Plate XXVII. Figure 108.

A slender, erect perennial six to fifteen inches high, with soft, downy culms, sheaths and leaves, and a contracted spike-like panicle two to five inches long. Spikelets about three lines long, twoto three-flowered: empty glumes about the length of the florets. Awn of the floral glumes exserted, divergent.

Summit of Roane mountain. July. Of no known value in agriculture.

\section{Trisetum palustre Torr.}

Plate XXVICI. Figure 109.

A smooth, upright perennial one to two and one-half feet high, with rather short flit leaves and a loosely-flowered, narrow, yellowish-green panicle. Sheaths loose, smooth, shorter than the internodes; ligule short, lanceolate; leaf-blade about three inches long, with minutely serrulate margins. Panicle about five inches long, its branches capillary. Spikelets compressed, two-flowered, about three lines long; empty glumes nearly equal, keeled, shorter than the florets; flowering glumes lanceolate. the first awnless or short-awned from the tip; the second with a slender, spreading or geniculate awn fruin just below the sharply two-toothed apex. Paleas about one-third shorter than their glumes.

In moist situations. Mountains of East Tennessee. July.

Yellow Oat-grass (Trisetum flivescens) is a recently introduced species which has some recognized agricultural value. It forms loose tufts eighteen inches to two feet high, and grows well on almost all soils. It is especially valuable in mixtures designed for the formation of permanent pastures.

\section{AVENA Linn. Sp. P1. 79. (1753.)}

Spikelets two-to six-flowered, in loose or dense panicles: rachilla articulated above the empty glumes, hairy under the flnwering 


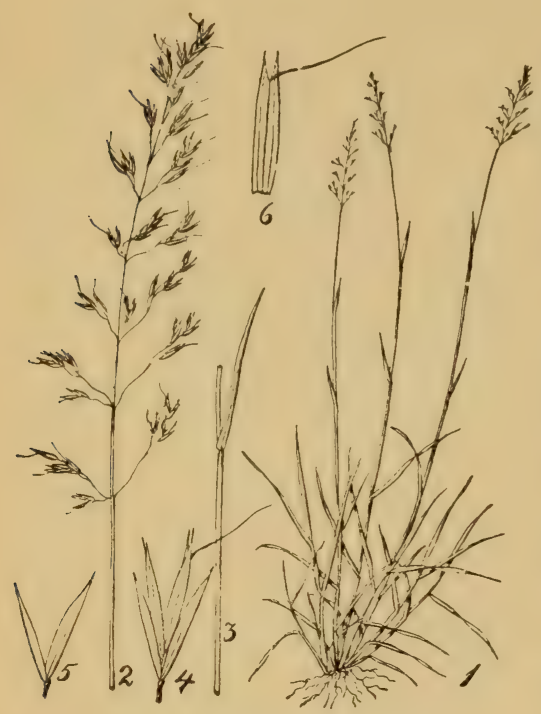

Fig. 109. Trisetum palustre.

2. Panicle. 3. Upper leaf. 4. Spikelet. 5. Empty glumes. 6. Flowering glume of upper floret

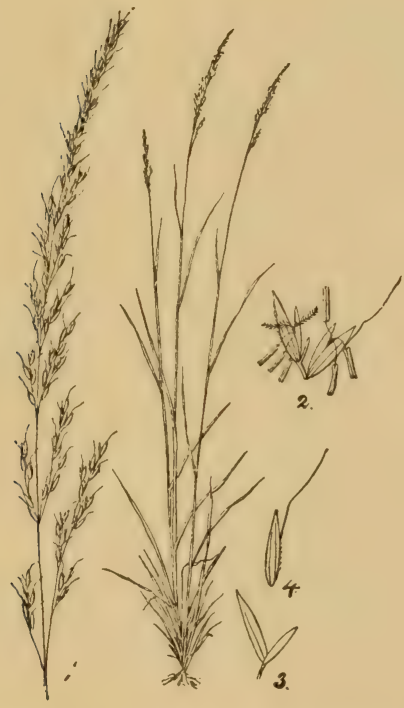

Fig. 111. Arrhenatherum avenaceum.

1. Panicle. 2. Splkelet, with the empty glumes removed. 3. Empty glumes. 4. Awned floral glume.

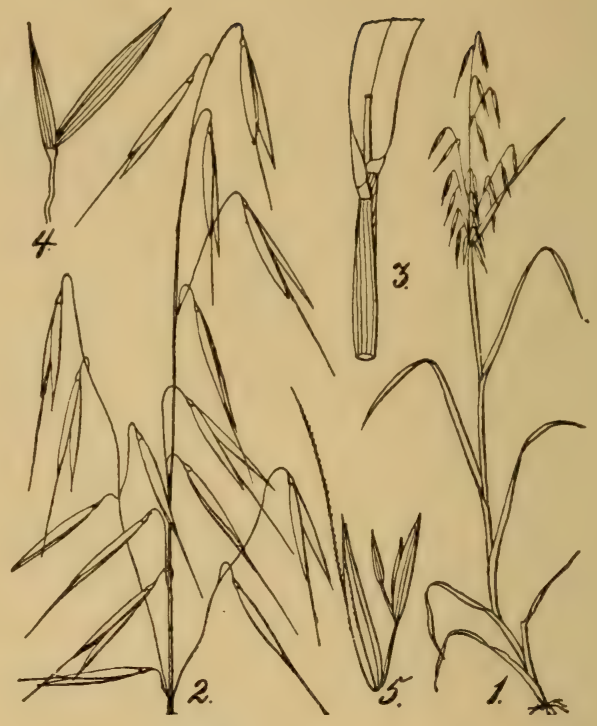

Fig. 110. Arena sativa.

2. Panicle. 3. Upper sheath and lower part of leaf blade. 4. Empty glumes. 5. The three florets.

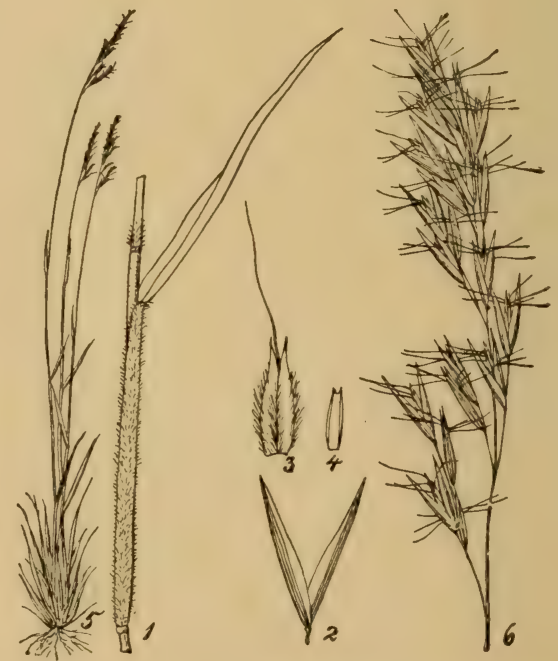

Fig. 112. Danthonia sericea.

1. Part of culm, with leaf. 2. Empty glumes. 3. Dorsal v.ew of the flowering glume, 4. Palea. 
glumes. Emply glumes two, unequal, membranaceous, longer that the flowering glumes. Flowerng glumes rounded on the back, five-to nine nerved, often bidentate or two-toothed at the apex, with a long dorsal twisted awn (the awn may be straight, or even absent, in cultivated forms). Frain pubescent, at least at the apex, frequently adhering to the fruiting glume or palea. Annuals or perennials, with rather large, variously paniculate spikelets.

Species about fifty, widely spread over the temperate and cooler regions of the world. There are two or three native North American species, and two or three others introduced from Europe exist as weeds in some parts of the country. The genus is best known by the common cultivated Oats.

\section{Avena sativa L, Oats.}

Plate XXVII. Figure 110.

A well-known erect annual, two to four feet high, with flat leaves and expanded panicles of rather large, pendulous and usually two-flowered spikelets. Lower flots sometimes awned.

Aiena siticu exisis in many varieties, which have been divided into two classes or races: Panicled oats, with widely-spreading panicle-branches, and Banner oats, with contracted one sided pani. cles. These divisions have been further divided into chaffy and naker fruited varieties. Further varieties are established upon the color or other special character of the grain.

Aiena fatua and 1 . strigosa, introduced into this country from Europe, are classed as weeds.

\section{ARRHENATHERUIM Beauv. Agrost. 55. (i 8 I 2.)}

Spikelets two-flowered in a loose terminal panicle; the first or lower flower staminate, its glume bearing a twisted and geniculate awn on the back near the base, the upper flower hermaphrodite, its glume short-awned from or near the tip, or awnless; rachilla hairy, articulated above the empty glumes, and extending into a short point or bristle behind the palea of the upper flower. Empty glumes unequal, acute, their sides thin and scarious. Flowering glumes firmer in texture than the empty ones, five- to sevennerved, closely approximate. Palea prominently two-nerved. Stigmas sessile.

Usually tall perennials, with flat leaves and long narrow panicles.

Species five or six, in the Old World.

I. Arrhenatherum elatius Beauv. (A. az'enaceum R. and S.) Meadow Oat-grass or Evergreen-grass.

Plate XXVIII. Figure 109.

A tall, perennial grass two to four feet high, rather sparingly leafy, with a narrow terminal many.flowered panicle, six to twelve inches lung; the branches spreading during flowering. Spikelets 
four to five lines long, the second glume larger than the first, three-nerved and about equalling the florets. Awn geniculate near the middle, closely twisted below, divergent above. Grain pubescent, enclosed within the fruiting glume and palea, but free from them.

A highly valued grass, both for winter grazing and for hay. It has been introduced into this country from Europe, where it is regarded as one of the best fodder grasses. As it stands in rather loose tufts, it is best to mix the seed with that of other grasses in order to thicken the sward. It grows rapidly, blooms early, and when cut, dries out readily, and when dry, keeps well. It is not regarded as a suitable grass for moist soils.

\section{DANTHONIA D. C., Flor. Franc. iii: 32 (1805.)}

Spikelets several-flowered, uppermost flower imperfect or rudimentary, rachilla articulated abore the empty glumes. Empty glumes two, longer than the flowering glumes, which are rounded on the back, two-toothed or bifid at the apex, and awned between the teeth; awn formed by the extension of the three middle nerves of the glume. Inflorescence a simple, spreading or narrow panicle.

Species about one bundred, in the temperate and warmer regions of both hemispheres, especially numerous in South Africa. North American species six, three of which come within our limits.

\section{KEY TO THE SPECIES.}

I. Teeth of the flowering glumes short and acute, callus naked or nearly so . . . . . . . . 2. D. Spicata.

I. Teeth of the flowering glumes long subulate-pointed, callus distinctly hairy

2. Leaves of the culm longer than the glabrous sheaths

I D. SERICEA.

\section{Danthonia sericea Nutt. Silky Oat-grass.}

Plate XXVIII. Figure 112.

A rather stout, erect grass, one to three feet high, with usually pubescent sheaths, rather rigid leaves, and large spikelets in terminal panicles. Culms smooth or a little pubescent at the nodes Sheaths densely pubescent, at least in the upper part, very rarely glabrous; ligule a fringe of hairs; culm leaves two to four inches long, two lines wide or less, strigose-pubescent above, sparingly pilose beneath; basal leaves often ten to twenty inches long, usually involute, more or less curling or flexuose and tough. Pani. cle two to four inches long, simple, the few-flowered branches erect or ascending. Empty glumes lanceolate, six to nine lines long, exceeding the florets; flowering glumes about three lines long, rounded and thinly pilose on the back, densely silky bearded 


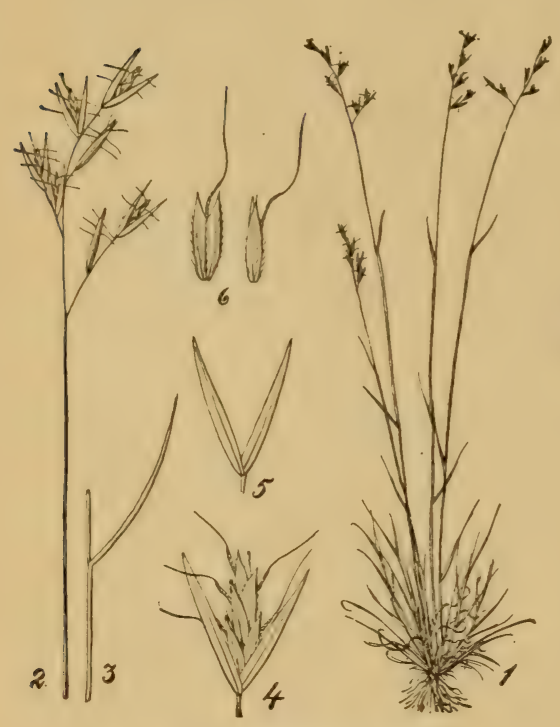

Fig. 113. Danthonia spicata.

2. Panicle, 3. Upper leaf. 4, Splkelet. 5 Empty glumes. 6. Flowering glume.

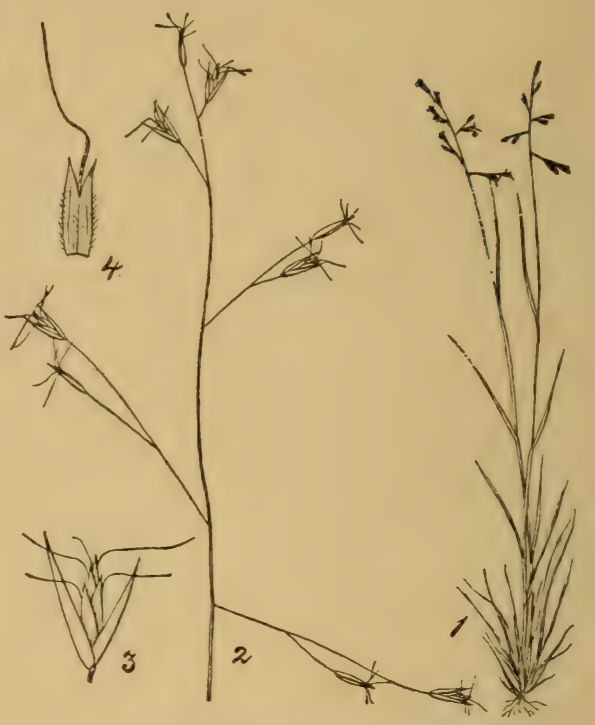

Fig. 114. Danthonia compressa. 2. Panicle. 3. Splkelet, 4. Flowering glume.

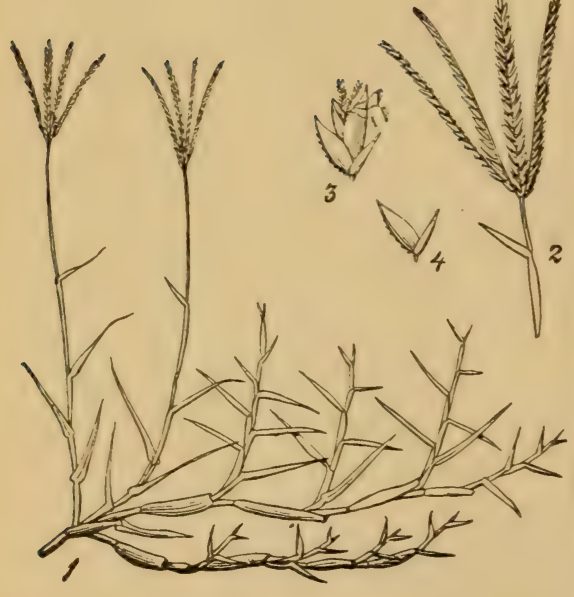

Fig. 115. Cynodon dactylon.

2. Inflorescence. 3. Splkelet. 4. Empty glumes.

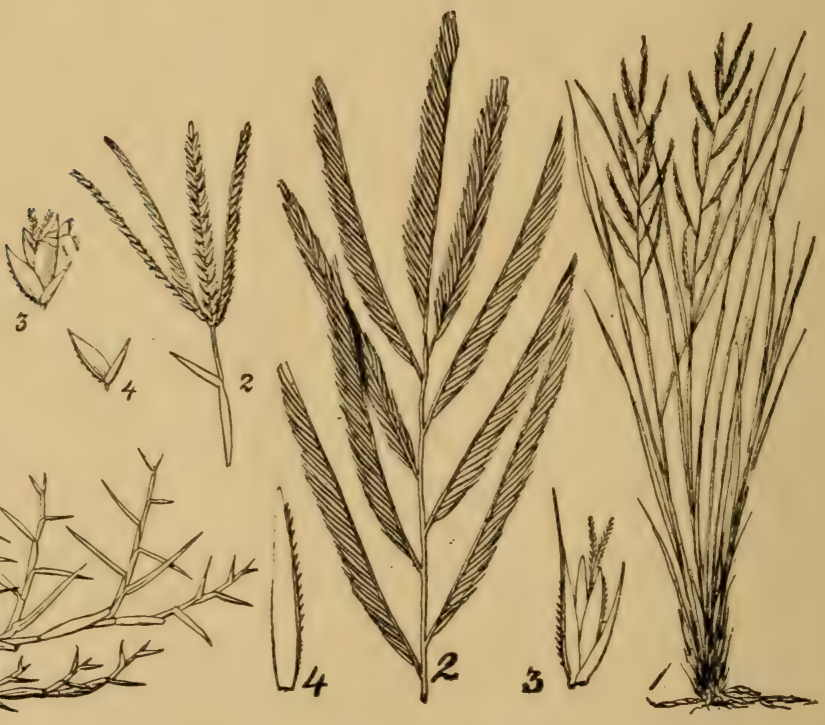

Fig. 116. Spartins cynosuroides.

2. Inflorescence. 3. Splkelet. 4. Flowering glume seen from the side. 
along the margins be low, the hairs a line long: callus harbate: apes of the thowering glume two cleft, the divisions subulate, and one to two lines long; awn alout five lines long, spirally twisted? below, divergent.

In very dry soil on the lower foothills and along the erest of ridges and blutfs in the eastern part of the State. This species is ustually soft hairy all over, and is much stomer than those described below, and does not form a sod. Attempts made to culcivate it at the Experiment Station were unsuccessful.

\section{Danthonia spicata Beauv. Wild Oat-grass.}

Plate XXIX. Figure 113.

it smooth, slender, erect grass, ten to twenty inches high, with a small narrow panicle, the short branches of which spreacl only in flower. Sheaths glabrous, bearded at the throat; hasal leaves numerous, usually involute, and curled or recurved: those of the culm shorter, a line wide or less, glabrous or pilose. Panicle one to two inches long, simple, few-flowered, the short branches usually erect. Empty glumes four to six lines long, exceeding the florets, lanceolate, acute, three nerved helow, with broad scarious margins; flowerng glume about two lines long. sparingly pilose on the rounded back and along the margins below: callus glabrous: apex of the flowering glume ending in two short, usually blunt teeth.

This species is common in dry thin soils, and its presence is usually indicative of impoverished lands. It resembles the next. but does not usually grow so tall, and its basal leaves are shorter and more curly. It is a grass of no agricultural value.

\section{Danthonia compressa Austin. Mountain (lat-grass.}

Plate XXIX. Figure 114.

A slender, erect, tufted perennial about two feet high, with long. narrow basal leaves, and few-flowered spreading panicles two and one-half to four or five incies long. Culms smooth, somewhat flattened. Sheaths smooth, bearded at the throat; ligule a dense fringe of short hairs: lower leaves six inches to a foot long. one line or less wide; leaves of the culm slender, longer than their sheaths. Spikelets four to six lines long: empty glumes lanceolate, about the length of the florets, three-to five-nerved near the base, with broad scarious margins, acute: flowering glume thinly pilose on the back and margins, about two lines long, terminating in two subulate teeth a line long: callus barbate: awns about three lines long, divergent.

This is a common grass upon the higher mountains, and forms the chief bulk of the forage of the so-called "balds." It is figured and fully described in Bulletin No. 4 of Vol. II. of the Station Reports. 


\section{Tribe X. CHLORIDE $\notin$.}

Spikelets one to several-flowered in one-sided spikes or racemes, these racemes digitate or fasciculate, rarely solitary. Flowering giumes usually keeled, entire and unawned, or toothed and with one or three straight awns.

A small tribe of twenty-seven genera and one hundred and fiftyfive species, characterized chiefly by the inflorescence, which is nearly that of Paspalum. The awns, when present, are not dorsal nor twisted as in Agrostidece and Avenea. They are for the most part natives of tropical and subtropical countries; a few are widely distributed as weeds throughout the warmer parts of the world. A number are good turf-forming grasses and are valued for grazing purposes. One of these is the celebrated Buffalo-grass of the western plains, which is remarkable for having the staminate and pistillate spikelets separate and in unlike inflorescences, either upon the same or upon different plants.

\section{CYNODON Pers. Syn. P1. I. 85.}

Spikelets one-flowered, awnless, sessile in two rows along one side of a slender continuous axis, forming unilateral spikes, these digilate at the apex of the peduncle; rachilla articulated above the empty glumes and prolonged tehind the palea of the hermaphrodite floret into a slender, naked bristle. Glumes three, the first two narrow, keeled, usually acute, empty, the third or floral glume broader and usually a little longer than the empty ones, obtuse, more or less pilose on the keel and at the margins. Palea about the length of its glume, two-keeled. Stamens three. Styles distirct. Grain free within the fruiting glume and palea. Low creeping perennials, with short, flat leaves and slender spikes, digitate at apex of the upright branches.

Species four, one distributed throughout the tropical and warmer temperate regions of the world.

\section{ז. Cynodon Dactylon Pers. Bermuda-grass.}

Plate XXIX. Figure 115.

Stems prostrate and extensively creeping, with numerous ascending or upright, leafy and flower-bearing branches. Sheaths smooth, hairy at the throat. Leaves flat, widely spreading, gradually tapering to a very slender acute tip. Spikes three to five, slender, widely spreading, often purplish, one to two inches long. Flowering glume broadly boat-shaped, about one line long, usually ciliate on the keel.

This is a grass with a dual character, a most valuable plant under certain conditions, and a veritable pest when growing where $i t$ is not wanted. It is a valuable pasture-grass for the eastern part of the State at least, but its introduction into new land should be made with caution on account of its habit of taking 
complete possession of the soil, and the difticulty presented in ex. terminating it. It is strictly a summer grass here, for its leaves and stems are turned brown by the first frosts of autumn. It is propagated hy means of sets or rooting stems. These are chopped up with a cutting-knife, and then sown broadcast or dropped in shallow furrows and lightly covered with earth. For holding steep banks, or binding sandy soil subject to wash, this grass is especially valuable. It makes a fair lawn on soils where kentucky bluegrass cannot well be grown.

\section{SPARTINA Schreb. Gen. P1. 43. (1789.)}

Spikelets one-flowered, strongly flattened laterally, sessile, and closely imbricated in two rows along one side of a continuous rachis, forming unilateral spikes which are scattered along a common axis; rachilla articulated below the empty glumes and not produced beyond the floret. (ilumes three, the first two empty, keeled, acute, or bristle-pointed, unequal, the second as long as or often exceeding the third or flowering glume. Stamens three, styles elongated, filiform. Grain narrow, free within the glume and palea. Coarse perennials with strong, creeping root stocks, rigid culms, and long, tough leaves.

Species seven, extra tropical North and South America, and along the coast of Europe and Africa; chiefly maritime, or in the saline regions of the Great Plains. One species in Tennessee.

I. Spartina cynosuroides IVilld. Fresh-water-Cord-grass or Thatchgrass.

\section{Plate XXIX. Figure 116.}

A stout, erect grass two to six feet high, with unbranched smooth culms from strong creeping scaly root-stocks. Leaf-blade one to four ir six feet long, two to four lines wide, rough on the margins, gradually tapering into long filiform tips. Spikes fire to twenty, spreading, racemose along the main axis. Empty glumes unequal, aculeolate-scabrous along the rigid keels, acute or the second long-acuminate or short awn-pointed. Flowering glume serrulate-scabrous along the keel or midrib, which abruptly terminates just below the membranous apex.

Along river banks and lake shores. Iuly-August. West Tennessee, (Gattinger.)

This grass is said to make excellent hay for horses when cut early. In regions where it grows abundantiy, as along the Mississippi bottoms, it has been employed in the manufacture of a coarse kind of paper. It makes an excellent and durable thatch.

36 CHLORIS Sw. Prodr. 25. (1788.)

Spikelets one-flowered, awned, sessile in two rows along one side of a continuous rachis, forming unilateral spikes, these usually sereral together and digitate at the apex of the culm: rachilla articu- 
lated above the empty glumes and produced behind the palea, bearing one or more rudimentary awned empty glumes. Outer empty glumes two, unequal, lanceolate, acute, somewhat keeled. Flowering giume narrow or broad, one to three-nerved, acute or broadly obtuse, truncate, emarginate, or two-lobed at the apex, often ciliate on the back or margins, the middle nerve nearly always produced into a slender awn. Grain free within the fruiting glume. Usually perennial grasses, with flat leaves and showy or attractive inflorescence of usually many digitate spikes.

Species about forty, widely distributed throughout the warmer countries of the world. Several are cultivated for ornament.

\section{Chloris verticillata Nutt.}

A perennial, usually about a foot high, with flattened stems and leaf-sheaths, narrow and abruptly acute leaves and numerous slender, spreading spikes, which are in approximate whorls or verticels near the summit of the stems. Spikelets one to one and a half lines long; lower empty glumes acuminate: both the floral and upper empty glumes awned; awns two to four lines long.

This grass is native to Kansas and regions to the Southwest. It is only rarely seen in cultivation. Chloris elegans and C. barbata are better known, but not more ornamental, species.

\section{GYIMNOPOGON Beauv. Agrost. 4i, t. 9, f. 3 (i $\delta$ I 2.)}

Spikelets one-flowered, subsessile, rather distant along one side of a slender filiform rachis, forming slender unilateral spikes, these 11 merous and scattered along a common peduncle; rachilla articulated above the empty glumes and produced beyond the floret as a slender, often awned rudiment. Empty glumes two, very narrow, subequal, as long as or longer than the floral glumes. Flowering glume broader, three-nerved, bearing a slender, straight awn below the two-cleft apex. Grain enclosed within the rigid fruiting glume, free. Perennial grasses, with short, rather broad and rigid leaves, and numerous slender spikes, which are at first erect, finally divaricate-spreading or reflexed.

Species six, one in Ceylon, the rest American. Two species in the Southern States.

\section{Gymnopogon racemosus Beauv. Naked Beard-grass.}

Plate XXX. Figure 117.

A loosely-tufted ascending or erect grass with short and broad leaves and numerous (fifteen to thirty) slender and widely-spreading spikes irregularly : cattered along the common rachis. Sheaths short, smooth; ligule very short; leat-blade one to two inches long, three to six lines broad, glabrous, acute. Spikes five to eight inches long, flower-bearing to the base. Spikelets rather distant, about three lines long, exceeding the flowering glume. Awn of the flowering glume slender, about three lines long, that of the rudiment shorter.

A common grass in open pine wcods, and in sandy soil along thicket borders. Of no agricultural value. 


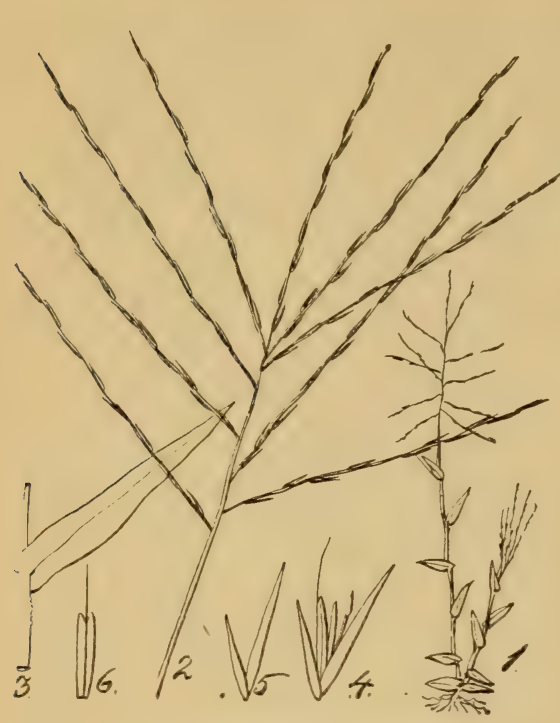

Fig. 117. Gymnopogon racemosus.

2. Panicle. 3. Upper leaf. 4. Spikelet. 5. Empty glumes. 6. Flowering glume.

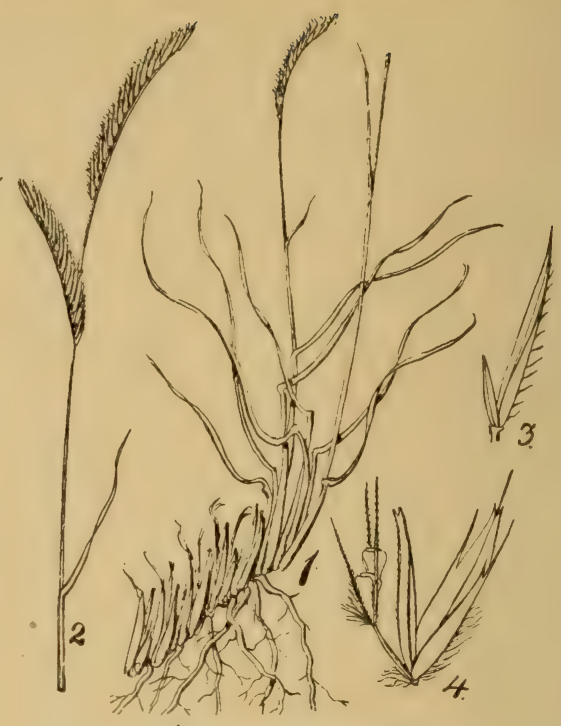

Fig. 118. Bouteloua oligostachya.

2. Upper part of the culm, with two splkes. 3. Empty glumes. 4. Splkelet, whth empty glumes removed.

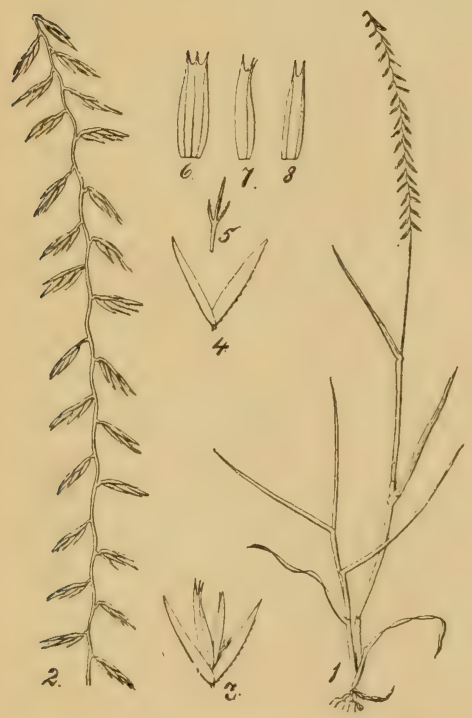

Fig. 119. Bouteloua racemosa.

2. Upper part of inflorescence. 3. Spike. let. 4. Empty glumes. 5. Pedicellate rudi. ment. 6,7. Flowering glume. 8. Palea.

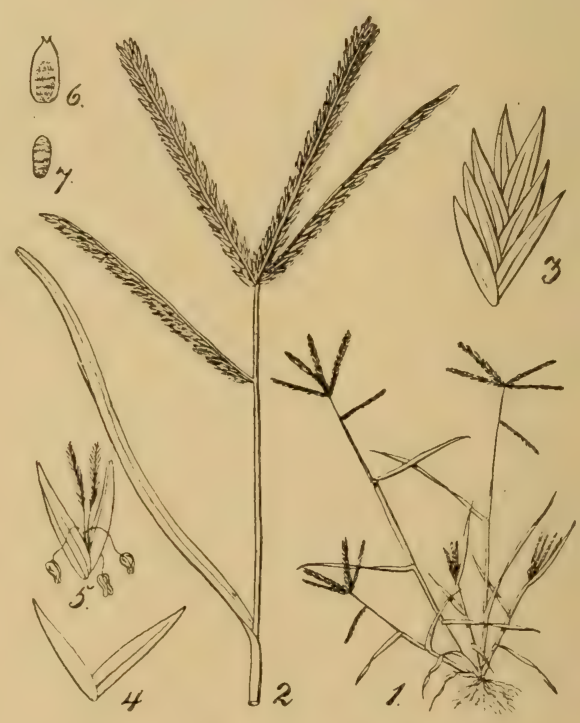

Fig. 120. Elerisine Indica.

2. Inflorescence. 3. Spikelet. 4. Empty glumes. 5. Flowering glume and palea. 6. Fruit. 7. seed. 
The other species ( $\vec{G}$. braifolius Trin.) may ocenr within the State. It is more slender, with shorter leaves and the spikes flow. er-bearing only above the miclale, not to the base as in $G$, ace mosus.

\section{BoUtelouA Lag. Varied. Cienc. $(1 \$ 05), 1+1$.}

Spikelets one- to two-flowered, numerous (rarely two or three or only one), crowded and sessile in two rows along one side of a continuous flattened rachis, which often projects berond the spikelets: rachilla articulated above the empty glumes, the continuation beyond the hermaphrodite lower floret usually bearing a few rudimentary glumes and three awns (rarely at staminate flower). Empty glumes two, unequal, the lower smaller, keeled. Flowering glume broader, three-nerved, three- to five-toothed, or cleft, three of the divisions usually mucronate or awn-pointed. Palea two-nerved and two torthed. Grain enclosed within the glume, but free. Usually low annuals or perennials, with narrow and flat or convolute leaves, the unilateral spikes few or many (rarely solitary) and nearly sessile along a common terminal peduncle.

Species about thirty, all American, most abundant in the dry regions of the southwestern States and Mexico, where they are commonly known as Grama (or Mesquit).

\section{Bouteloua oligostachya Torr. Blue Grama.}

Plate XXX. Figure 118.

A slender perennial six to twenty inches high, with one to five remote, pectinately many-flowered, usually spreading spikes, one to two inches long. Spikelets about three lines long: flowering glumes hairy on the back; palea as long as its glume, with tufted long hairs on each side at the base; pedicel of the rudimentary floret hairy at the tip and bearing several rudimentary glumes and three very short awns.

This grass forms a dense turf, which affiords most excellent grazing for sheep and cattle. In some parts of the West, where it is very common, it is called Buffalo-grass, but it is quite distinct from the grass properly so called. It has been only sparingly introduced into the State, but its cultivation for grazng purposes on dry sandy loam soil is recommended.

\section{Bouteloua curtipendula Terr. Tall Grama.}

\section{Plate XXX. Figure 119.}

A densely-tufted perennial grass, ore to three feet high, with numerous, twenty to sixty, usually spreading or retlexed spikes scattered along the common axis, forming a long. somewhat one. sided raceme eight to fifteen inches long. Spikes one-half inch or less long, nearly sessile, each with three to ten spikelets: flowering glumes with three short awn pointed teeth: the continuation of the rachilla a simple bristle, or bearing at its apex three rery short awns and one to two minute scales. 
This is a valuable pasture $\mathrm{g}$ rass, and has been found at several points within the State. Like Blue Grama, it forms a dense sod, which well resists the tramping of stock. Pasture lands might be improved by the introduction of this species. It prefers dry and somewhat sandy soil.

39. ELEUSINE. Gærtn. Fruct. I. 7, t. I.

Spikelets several flowered, sessile, and closely imbricated in two rows along one side of a continuous rachis which does not project heyond the terminal spikelet: rachilla articulated above the empty glumes. Glumes compressed, keeled, thin but rigid, obtuse, the first two and sometimes the uppermost one empty. Palea a little shorter than the glume, compressed, bicarinati. Seed finely striated and enclosed within a thin pericarp.

Coarse, tufted annuals with the rather stout unilateral spikes digitate or approximate at the apex of the culm.

Species five or six, in tropical and subtropical regions of the Old World. E. Coracana is valued in Africa, India, and some other eastern countries as a cereal. The species we have here is a common weed in all the warmer countries of the world.

\section{Eleusine Indica Grertn Crow-foot or Wire-grass.}

Plate XXX. Figure 120.

A coarse, tufted annual, with erect or spreading stems six to twenty four inches high and digitate spikes. Sheaths compressed and sparingly ciliate; leaf-blade long and narrow, both surfaces glabrous or the upper scabrous and thirly hairy. Spikes five to seven, two to four inches long, digitate at the apex of the culm, often with one or two lower down, widely spreading; spikelets closely imbricated, one and one half to two lines long, three- to sixflowered; glumes obtuse, the first small and one-nerved, the second larger and with the flowering glumes, three- to five-nerved. Seed rugose, enclosed within a thin loose pericarp. Blooming from June to October.

A very common grass in cultivated fields and about door yards. It is generally regarded as a weed, and often becomes a troublesome pest in lawns and gardens.

40. DACTylocteniUm Willd. Enum. Hort. Berol. 1029 (i 809 ).

Spikelets several-flowered, the uppermost imperfect, sessile and crowded in two rows along one side of a continuous axis, forming unilateral spikes, these digitate at the apex of the culm; rachilla articulated above the empty glumes and between the florets. Glumes laterally cumpressed, keeled, the first two empty, the second awn-pointed. Flowering glumes boat-shaped, mucronate pointed. Fruit a utricle, the thin pericarp loosely enclosing the wrinkled, globular seed. Annual, with a more or less decumbent and creeping base, and two to six terminal stout spikes, the rachis projecting beyond the spikelets. 
Species one, appearing as a weed in all the warmer comntries of the world.

\section{Dactyloctenium Ægyptiacum Willd. Crow-foot.}

A low, tufted or creeping grass, with ascending flowering branches rarely a foot high. Leaves about six inches long, flat, ciliate near the base. Spikes three to five, digitate, one-half to one and one half inches lorg. The outer glume of the usually three-flowered spikelets about one line long, the second broader obtuse, or emarginate, with the keel produced into a short dorsal awn; flowering glumes broad, short spreading points.

Not yet recorded as occurring in Tennessee, but probably will be found in the middle or western part of the State. Common farther South.

\section{LEPTOCHLOA Beauv. Agrost. 7 I, t. 15, f. 7. ( 1812.$)$}

Spikelets two to several-flowered, sessile, in two rows along one side of the slender and often numerous branches of a simple panicle; rachilla articulated above the empty glumes. Empty glumes two-keeled, awnless or very short awned. Flowering glumes keeled, three nerved acute, awnless or very short awned, or two-tothree-toothed, and mucronate or short-awned between the teeth. Palea two keeled. Fruit a caryopsis.

Usually tall annuals with flat leaves and elongated simple panicles made up of the numerous and more or less spreading slender spikes scattered along the main axis.

Species about twenty, in the warmer countries of $b$ th hemispheres. In the United States the species are mostly limited to the southwestern Territories. One introduced species occurs as a weed in Tennessee.

\section{Leptochloa mucronata Kunth. Feather-grass.}

Plate XXXI. Figure 121.

An annual one to three feet high, with flat leaves and numerous slender spreading spikes in an elongated simple panicle, six to eighteen inches long. Sheaths hairy; leaf blade three to six lines wide. Spikes two to four inches long, spikelets small, three- to fuur-flowered; empty glumes mucronate-pointed, exceeding or shorter than the flurets.

Common in rich cultivated grounds, gardens, etc. The numerous slender spreading spikes, scattered along the common rachis form a somewhat plume-like inflorescence. Of no agricultural value.

\section{Tribe XI. FESTUCE.E.}

Spikelets two-to many-flowered, usually hermaphrodite, pedicellate in racemes $n r$ panicles, these sometimes dense and spilielike. Fluwering glunes ustually longer than the empty wnes, 
awnless or with one to several straight (rarely bent) awns which are either terminal or borne just below the apex.

This is the largest tribe in the order, numbering seventy six genera and about seven hundred and twenty-five species. It contains the most important meadow grasses of the temperate regions, as well as the more prevalent grasses of the higher mountains within the tropics. The genus $P o a$, which includes Kentucky blue-grass, Texas blue-grass, etc., numbers one hundred species, and an equal number of species are included in the genus Eragrostis. 'The Fescues number eighty species and the tribe takes its name from this genus-Festuca. Orchard grass, Dactylis glomerata, is a well known example of this tribe.

\section{GYNERIUM H. B. Plant. Equin. II., i I 2, t. I I5. (I809.)}

Spikelets loosely two- to many-flowered, diøcious, in large terminal panicles, rachilla articulated above the empty glumes, usually long-pilose, at least in the fertile spikelets. Empty glumes two, narrow and very long, acuminate-pointed. Flowering glumes very narrow, produced into long subulate points, the back and margins clothed with long silky hairs. Flowering glumes in the staminate spikelets usually smooth. Tall, reed-like, perennial grasses, with solid culms and very long, narrow leaves, which are chiefly from the base, and ample, showy terminal panicles.

Species three, in the warmer regions of South America. One species cultivated in Tennessee for ornament only.

\section{Gynerium argenteum Nees. Pampas-grass.}

Culm six to ten feet high, with numerous, very long, narrow leaves and silvery-white panicles one to two and a half feet long.

This grass is highly decorative for lawns, and the large plumelike panicles are used for dry bouquets. In California it is cultivated for these "plumes," which command a ready market in the larger cities. The grass is a native of Brazil and the Argentine Republic, where the long, tough leaves are employed in the manufacture of paper, and a decoction of the stout rhizomes is valued as a diuretic.

\section{ARUNDO Linn. Sp. Pl. I 20 (1753.)}

Spikelets two- to many-flowered, in ample terminal panicles; rachilla articulated above the empty glumes and between the florets, smooth. Florets crowded, hermaphrodite, or the upper or lower staminate. Empty glumes two, narrow, a little unequal. three-nerved, smooth, acute, or acuminate, about the length of the spikelet. Flowering glumes thin, membranaceous, three-nerved, two-toothed at the apex, and mucronate between the teeth, longpilose on the back. Palea hyaline, two-keeled, shorter than its glu ne. Grain smooth, enclosed within the palea and glume, but 
free. Tall and reed-like grasses, with hollow culms, broad, Hat leaves and ample terminal panicles.

sipecies six or seven, distributed thrughthut the warmer ann. tries of the world. No native species in America north of Mexico. One is grown in Tennessee as a decorative plant.

\section{Arundo Donax Linn.}

A tall and stomt leafy peronnial eight to twelve feet high, with large terminal panicles one to two feet long. Leaves sprearling. one to two feet long, two to three inches whle, lancenlate and long attenuate pointed. Spikelets two-to four-flowered. Flowering glumes long pilose on the back, lanceolate, acuminate-pointed with the apex trifid, the midclle division extended into a short straight awn.

A native of southern Europe and Northern Africa. Apparently indigenous in southwestern Texas. Cultivated for ornament in Tennessee. There is an ornamental variety with the leaves striped with white bands.

44. PHRAGMites Trin. Fund. Agrost. I34. ( $1 s_{20}$.)

Spikelets lonsely three-to seven-flowered, in terminal panicles; rachilla articulated above the empty glumes and between the florets, clothed with long, silky hairs; the lowest floret staminate or neuter, those ahove hermaphrodite. Empty glumes unequal, lanceolate, acute, shorter than the florets. Flowering glume glabrous, very narrow and long acuminate-pointed, much exceeding the short palea Grain free. Tall, reed like perennial grasses with stout leafy culms and large terminal panicles.

species two or three, one cosmopolitan, one in Asia and one in South America.

\section{Phragmites communis Trin. Reed.}

Culm six to twelve feet high, with numerous broad (one to two inches) attenuate-pointed leaves one to two feet long. Panicle much branched, ovoid-pyramidal. Splkelets three-to five-flowered, the copious wool on the rachillas about the length of the florets. Swamps and borders of lakes and streams. August.

Not yet reported as growing within the limits of the State. ()f no recognized agricultural value.

\section{TRIODIA R. Br. Prod. 182 . (1810.)}

Spikelets three-to twelve-flowered, nearly terete, in strict or open panicles. rachilla articulated between the florets, smonth or short-pilose, florets hermaphrodite or the uppermost staminate. Empty glumes two, unequal, somewhat keeled, shorter than the spikelet. Flowering glumes membranaceous or subioriaceous, rounded on the back at least below, three-nervert, two-to threetoothed or pointed, the nerves, especially the marginal, silky-villous below and extending (in our species) between the teeth at the apex 
into three mucronate points. Palea broad, concave, with two nearly marginal nerves. Stamens three. Styles short, stigmas plumose. Grain free. Perennial grasses with narrow leaves and variable habit.

Species about twenty-five, widely distributed throughout the temperate zones, with a few in tropical America. Nearly half the entire number of species occur in the United States, chiefly in Texas and the southwestern Territories.

\section{Triodea cuprea Jacq. (Poa seslerioides Michx.) False or Tall Red-top.}

\section{Plate XXXI. Figure 122.}

A stout, erect perennial three to five feet high, with long flat leaves and an ample spreading, usually purple panicle six to twelve inches long Culm leaves and sheaths glabrous; the sheaths at the base of the culm usually crowded and somewhat compressed. Lower leaves one to two feet jong, about one-fourth of an inch wide, very acute, usually hairy near the base; ligule very short, ciliate. Panicle ovate pyramidal, the widely spreading and drooping branches solitary or in pairs, naked below, axils bearded. Spikelets four-to seven-flowered, three to five lines long; empty glumes thin, broadly ovate, acute one-nerved, the larger second glume about two lines long; floral glumes about two lines long, three-nerved, oblong, hairy on the back below and on the marginal nerves for twothirds their length, apex of the glumes four-lobed, the nerves projecting a little between the lobes. Palea a little shorter than the glumes, the keels strongly arched.

A showy grass frequent in dry sandy fields, blooming from August to October. Apparently of no agricultural value.

\section{ERAGROSTIS Beauv. Agrost. 70 ( 1812.$)$}

Spikelets two-to many-flowered, the uppermost flower imperfect, rachilla articulated, but sometimes not breaking up until after the fall of the fruiting glumes. Inflorescence variously panicilate, now close and narrow, the spikelets nearly sessile and crowded, now loosely and widely spreading. Empty glumes two, more or less unequal, usually shorter than the floral glumes. Flowering glumes glabrous, obtuse or acute, awnless, three-nerved, lateral nerves sometimes very faint. Paleas shorter than their glumes, two-nerved, nerves prominent, often persistent after the fall of the fruiting glume.

Annual or perennial grasses with herbaceous stems, of various habit, from two to four inches to as many feet tall, much-branched, or with simple culms.

Allied to Poa, but with three-nerved flowering glumes, which are destitute of any $w$ solliness. 'I'he species are very variable and their limits hard to define.

Species about one hundred, in warm and temperate regions of both hemispheres. Tennessee species, including those introduced, nine. 


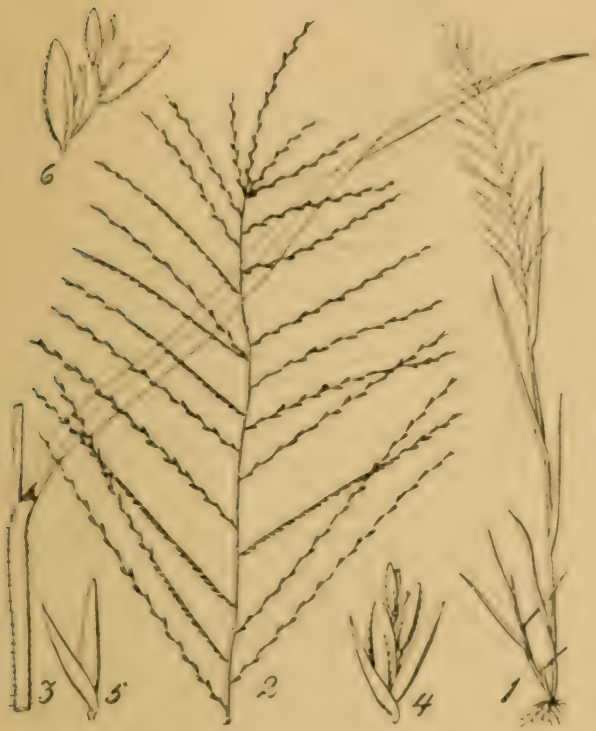

Fig. 121. Leptorhloa mucronata.

2. Inflorescence. 3. Lpper leaf. 4. Splke. let. 5. Empty glumes. 6. Florets.

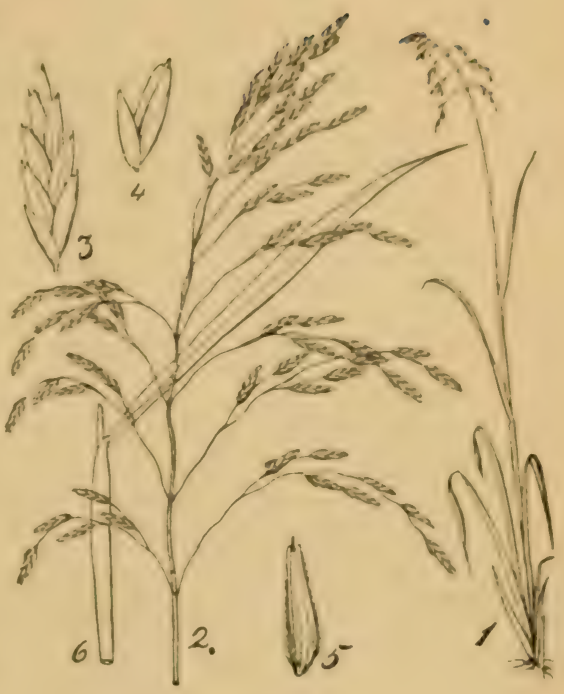

Flg. 122. Triodia cuprea.

2. Pantcle. 3. Splkelet. 4. Empty glumes 5. Floral glume. 6. Upper leaf.

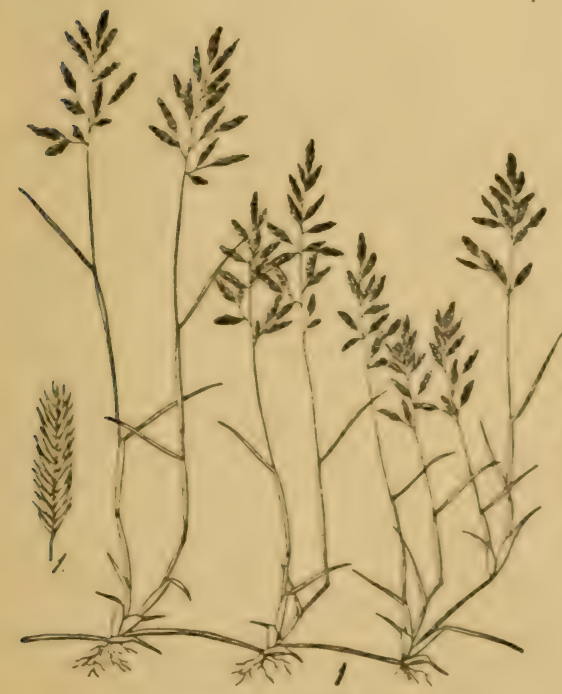

Fig. 123. Fragrostis reptans.

1. Splkelet.

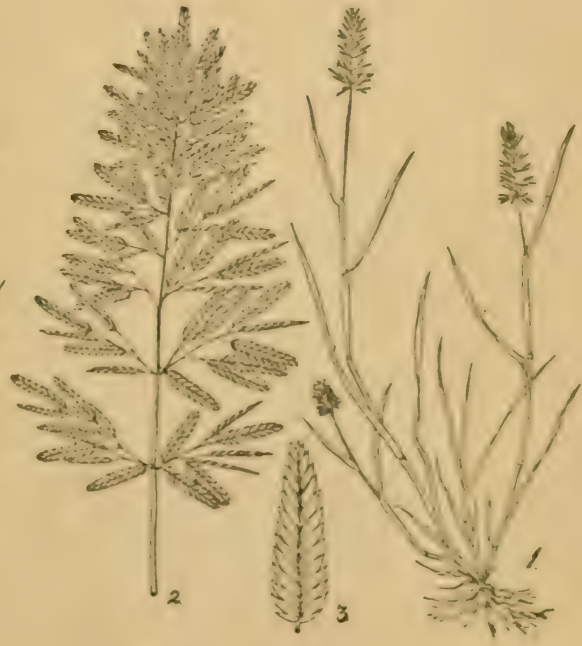

Fig. 124. Eragrostis major.

2. Panlcle. 3, splkelet. 

KEY TO THE SPECIES.

1. Culms prostrate, creeping; spikelets linear lanceolate, manyflowered; florets acute . . . . . I. E. REPTANS

1. Culms not creeping, simple or more or less diffusely-branched below

2. Spikelets small ( $3+$ to $1 / 5$ lines) 2 - to 4 -flowered; glumes acute, lateral nerves obsolete or very faint . . . . . 3

2. Spikelets 2 to 12 lines long, 5-to many-flowered . . . . . 4

3. Low, 3 to 10 inches high, panicle 2 to 5 inches long, spreading, with capillary branches and pedicels . 2. E. FRANku.

3. Taller, panicle 6 to 15 inches long, with widely-spreading capillary branches and pedicels . . 3. E. CAPILlaris.

4. Low, much-branched annuals, spikelets less than a line broad.

4. Spikelets i to $2 \frac{1}{2}$ lines broad, annuals or perennials

5. Spikelets spreading, narrow-linear (about t. of a line broad) lateral nerves of the thin floral glumes very obscure

4. E. PILOSA.

5. Spikelets is to fof a line broad, appressed to the branches, lateral nerves of the floral glumes distinct . 5. E. Puksur.

6. Annual, diffusely branched, panicle 2 to 6 inches long, ovate or oblong; spikelets crowded, pale or dark green: floral glumes obtuse . . . . . . 6. E. MAJOR.

6. Perennials, erect, simple or branched only at the base

7. Panicle narrow, spikelets crowded on very short pedicels; flowering glumes acute and strongly nerved

7. Panicle widely spreading

. E. OXYLEPIS.

8. Primary panicle-branches rigid, widely spreading or the lower deflexed; spikelets purplish . 8. E. PECTINACEA.

S. Primary panicle-branches more slender; spikelets pale or greenish, much shorter than their capillary, flexuose, and diverging pedicels... . . . . 9. E. TENUIS,

1. Eragrostis reptans Nees. Creeping Meadow-grass.

Plate XXXI. Figure 123.

A prostrate, much branched and extensively creeping annual, with ascending flowering branches three to six inches high. Sheaths short, pubescent or smooth; ligule reduced to a fringe of short hairs, leaf-blade one-half to one line wide, usually about onehalf to one and one-half inches long, more or lesspubescent, acute, spreading. Panicle narrow, lax or dense, one to one and one-half inches long, sometimes capitate. Spikelets linear-lanceolate, strongly flattened, one iine or less wide, two to six lines long, tento forty-flowered; empty glumes orate, acute, the first a little longer than the second, hyaline excepting the prominent, green mid-nerve; flowering glume ovate, lanceolate acute, three-fourths to one line long, prominently three-nerved. Palea two-keeled, keels scabrous; grain spherical oblong.

On usually low, sandy soil; common. Ä̈gust-October. Of no agricultural value. 


\section{Eragrostis Frankii Meyer. Short-stalked Meadow-grass.}

Plate XXXII. Figure 125.

A low, diffusely-branched annual, three to fifteen inches high. Sheaths pilose at the throat; ligule less than a line long, lacerated; leaf blade three-fourths to two lines wide, one to seven inches long, flat or conduplicate toward the apex. Panicle ovate or oblong, with spreading, capillary branches and pedicels, the latter mostly longer than the spikelets. Spikelets ovate, about one line long, three- to five-flowered; empty glumes spreading, lanceolate, acute, scabrous on the ketl, about half a line long; flowering glume ovate, acute, obscurely three-nerved. Keels of the palea scabrous. Grain short, oblong. Remarkable for its strong, disagreeable odor when fresh.

Common in low sandy grounds. July-September. Of noagricultural value.

\section{Eragrostis capillaris Nees.}

Plate XXXII. Figure 128.

An erect annual six to twenty-four inches high, branching at the base, the widely-expanding panicle usually much longer than the culm below it. Sheaths and base of leaves more or less hairy, sometimes glabrous; ligule a minute fringe of hairs; leaf-blade four to twelve inches long, three-fourths of a line to two lines wide. Spikelets three-to five-flowered, a line or less long; empty glumes about one-half a line long, equal, hispid on the keel, acute; flowering glume ovate-lanceolate, acute, obscurely three-nerved, about two-thirds of a line long. Palea rough-ciliate on the keels. Grain nearly spherical. The spreading panicle-branches and long diverging pedicels capillary.

Common in dry sandy fields and frequent by roadsides. Of no economic value.

\section{Eragrostis pilosa Beauv. Slender Meadow-grass. \\ Plate XXXII. Figure 127.}

A slender, branching annual six to eighteen inches high, with narrow, flat leaves and a capillary open panicle. Sheaths smooth, hairy at the throat; ligule a fringe of short hairs; leaf-blade two to eight inches long, slender pointed. Panicle three to ten inches long, rather narrow at first, the branches four to eight at the lower node of the main axis, fewer above, all spreading in fruit, axils usually but not constantly pilose. Spikelets one to four lines long, linear. five- to fifteen-flowered, lead-colored or often purplish, about equalling their more or less spreading pedicels: empty glumes ovate-lanceolate, obtuse, rarely acute, about one-half a line long: flowering glumes ovate, obtuse, the lateral nerves very faint or obsolete, about three-fourths of a line long. Palea scabrous on the keels. Grain linear-oblong.

Distinguished from E. Purshii by the narrower and more spreading spikelets, absence of lateral nerves on the flowering glumes, and more numerous primary branches at each node of the main rachis of the panicle. Common in dry, sandy soil. July-September. 


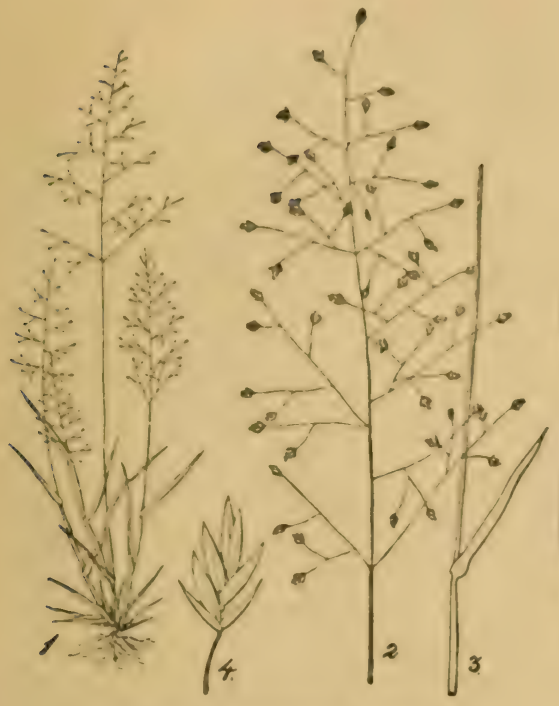

Fig. 125. Eragrostis Frankif.

2. Paricle. 8. Portion of the culm, with leat. 4. spikelet.

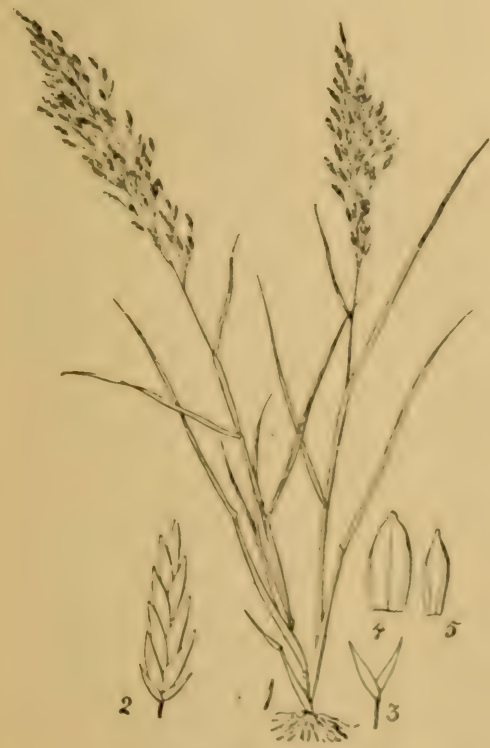

Fig. 127. Eragrostis pilosa.

2. Splkelet. 3. Empty glumes, 4. Flow ering glume. 5. Palea.

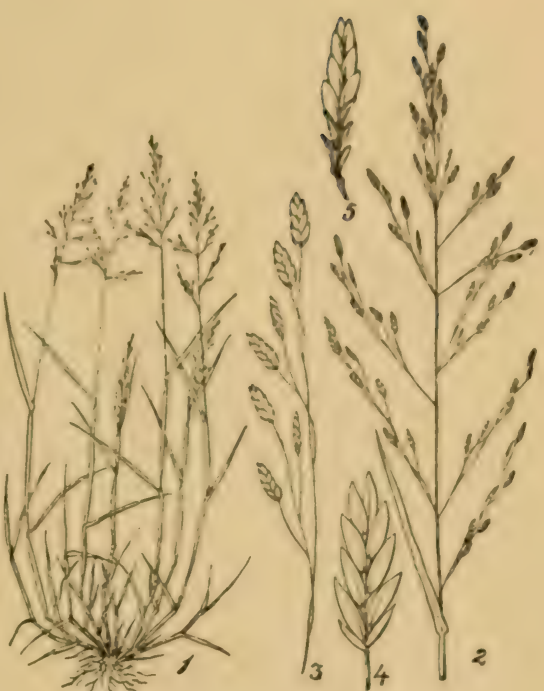

Fig. 126. Eragrostis Purshil.

2. Pantcle. 3. Branch from pantcle. 4 splkelet. 5. Splkelet, from which the lower floral glumes have fallen.

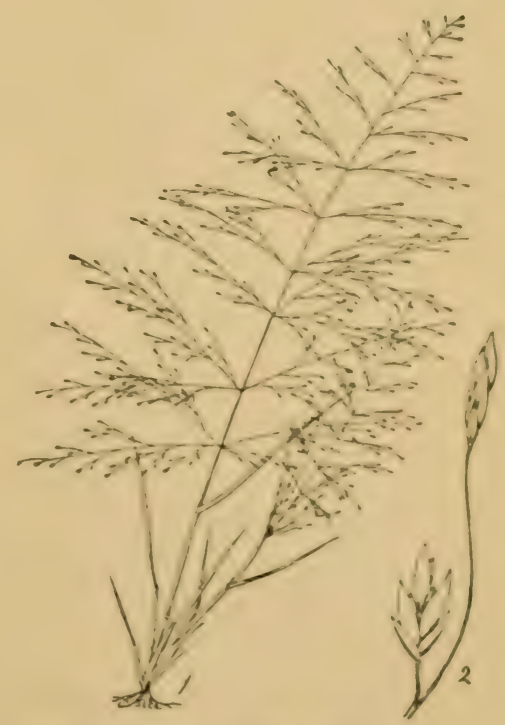

Fig. 128. Eragrostis cepillaris. 2. $\Delta$ branch from the panicle, with two spikelets. 

5. Eragrostis Purshii Shrader. Southern Spear-grass.

Plate XxxII. Figure 126.

An annual five to eighteen inches high, with the erect or ascending stems diffusely branching near the base. Sheaths pilose at the throat, otherwise smooth; ligule a fringe of short hairs; leaf-blade one to seven inches long, one-half to one and onc-half lines wide, conduplicate when dry. Panicle oblong-lanceolate to pyramidal, three to eight or twelve inches long, the widely spreading primary branches solitary or two to three together, the axils not pilose. Spikelets narrow-lanceolate, two to four and one-half lines long. three-to fifteen-flowered, appressed to the branches, nearly equalling or exceeding their capillary pedicels; empty glumes ovate, acute, scabrous on the keel, the longer upper one about one-half a line in length; flowering glume broadly ovate obtuse, distinctly threenervel, scabrous on the keel, about three-fourths of a line long. Palea scabrous on the keels. Grain oblong.

Waste places, along side-walks and in sandy, open grounds, common. Of no agricultural value.

\section{Eragrostis major Host. Stink-grass.}

Plate XxxI. Figure 124.

A rather showy, much branched annual, with erect or ascending stems six inches to two or three feet high. Sheaths striate, smooth. hairy at the throat; ligule a fringe of short hairs, leaf-blade flat, three to ten inches long, one to three lines wide, somewhat scabrous on the upper surface. Panicle elliptical or oblong, the branches usually spreading, spikelets ovate to linear, seven- to fortyflowered, two to eight lines long, one and one-half to two lines broad; empty glumes nearly equal, ovate lanceolate, a line or less long: flowering glumes ovate obtuse, prominently nerved and scabrous on the keel. Palea ciliate on the keels.

Cultivated or waste grounds, especially in light soils. JulySeptember. When fresh this grass emits a strong unpleasant odor.

Eragrostis minor Host, is very closely allied to and by some is regarded only as a variety of $E$. major. It is smaller throughout, with the sheaths often hairy, the five-to fifteen-flowered spikelets oneline or less broad, and the floral glumes not prominently nerved. Much less frequent than E. major.

\section{Eragrostis oxylepis Torr.}

\section{Plate XXXIII. Figure 130.}

A smooth, erect or ascending perennial, six to thirty inches high, with rather broad, showy spikelets crowded in a narrow. often interrupted panicle. Sheaths smonth, striate, pilose at the throat; ligule a minute fringe of short hairs; leaf-blade one to two lines wide, one and one-half to ten or twelve inches long, tapering to a narrow sharp pointed apex. Spikelets sessile, or nearly so, very strongly compressed laterally, two lines wide, three to ten lines long, eight-to twenty-five-flowered; glumes all very acute, the empty ones about three-fourths of a line iong. the flowering 
Bulletin VII. 1.

glume about one and a half lines long. Palea broad, ciliate-scabrous on the keels. Grain terete, smooth, about one-half a line long. Spikelets usually variegated with red and purple.

A native of Texas. Sometimes cultivated as an ornamental plant.

\section{Eragrostis pectinacea Gray. Meadow Comb-grass.}

Plate XXXIII. Figure 131.

An erect perennial one to three feet high, with a short, stout root-stock and large, spreading panicle. Sheaths smooth or hairy in the upper part; ligule a fringe of hairs two to three lines long; leaf-blade two to three lines wide, six to fourteen inches long, more or less pilose on the upper surface. Panicle six to thirty inches long, the rather rigid, widely spreading or deflexed branches bearded in the axils; pedicels somewhat appressed, longer or shorter than the spikelets. Spikelets linear-lanceolate, three-fourths to one line wide, two to five lines long, five- to twenty-flowered; empty glumes three-fourths to one line long, ovate or oblong, sub-acute, scabrous on the keel; flowering glumes about a line long, strongly threenerved, obtuse or rarely acute. Palea densely ciliate on the keels. Grain oblong-spherical, irregularly striate.

A native grass, the large diffuse panicles of which are often gathered for dry bouquets. It is common in dry sandy soil in open grounds and along the borders of fields and woods. JuneSeptember.

\section{Eragrostis tenuis Gray. Branching Spear-grass.}

Plate XXXIII. Figure 129.

A tall perennial, two to five feet high, with a rather narrow, elongated panicle and somewhat rigid leaves. Sheaths firm, smooth, pilose at the throat; ligule nearly wanting; leaf-blade one to two lines wide, six to twenty inches long, glabrous or sparingly hairy. Panicle twelve to thirty inches long, the ultimate branches and long diverging pedicels capillary. Spikelets ovate-lanceolate, about one and one-half lines wide, three to four lines long, two- to six-or ten-flowered; empty glumes narrow-lanceoiate, very acute, nearly equal, one to two lines long; flowering glume ovate-lanceolate, acute, strongly three-nerved, about one and one-half lines long, smooth or scabrous on the keel. Keels of the palea scabrous. Grain very short, oblong, strongly grooved.

Sandy soil, vicinity of Nashville (Gattinger). July-September.

47. EATONIA Rafin. in Journ. de Phys. LXXXIX. 104, (I8Ig.)

Spikelets two- to three-flowered, in narrow, lax, or dense terminal panicles, rachilla articulated above the empty glumes and between the florets, and produced above the upper flower into a slender naked bristle. Empty glumes two, a little shorter than the florets, the first linear and one-nerved, the second broadly obovate, three-nerved, with rather broad scarious margins. Flowering 


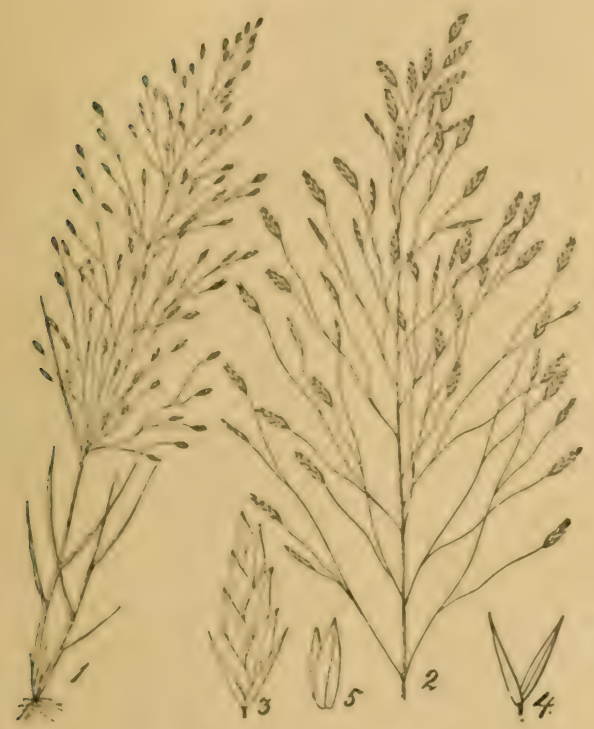

Fig, 129. Eragrostis tennis.

2. Upper part of the pantcle. 3. Rplkelet. 4. Nimpty glumes. 5. Flowering glume and palea.

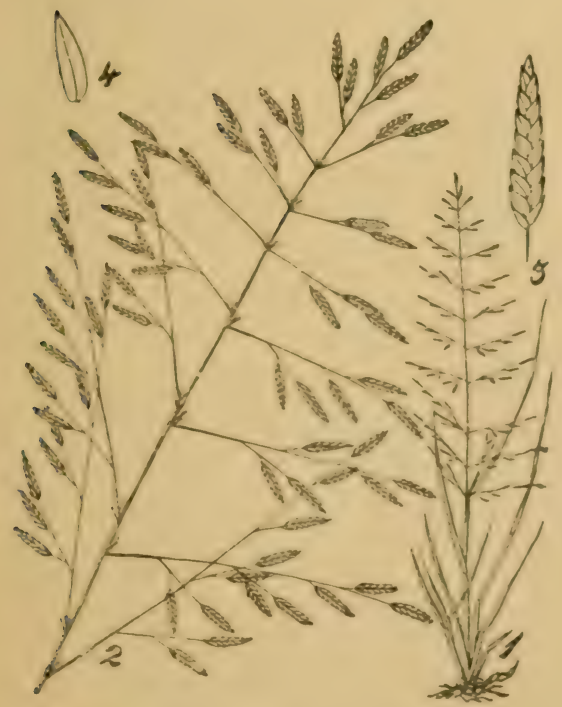

Fig. 131. Eragrostis pectinacea.

2. Pantcle. s. Splkelet. 4. Flowering glume, side vlew.

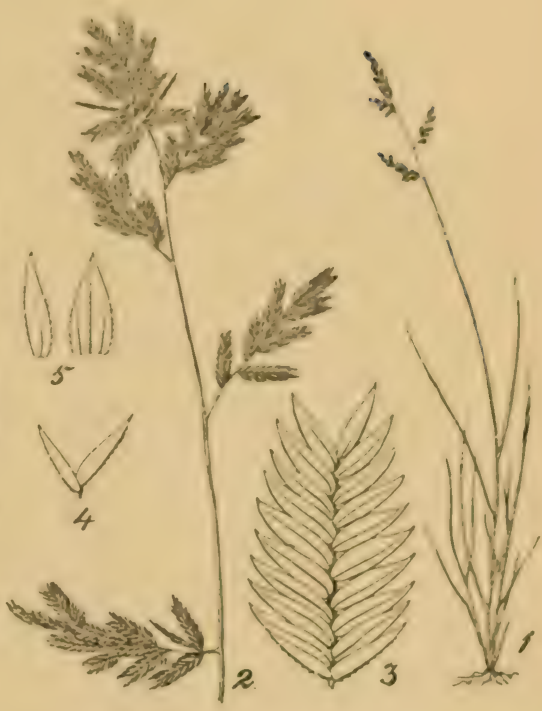

Fig. 130. Eragrostis oxylepis.

2. Panlcle 3. splkelet \& Kmptrglumes. 5. Fluwering glume from the back and side.

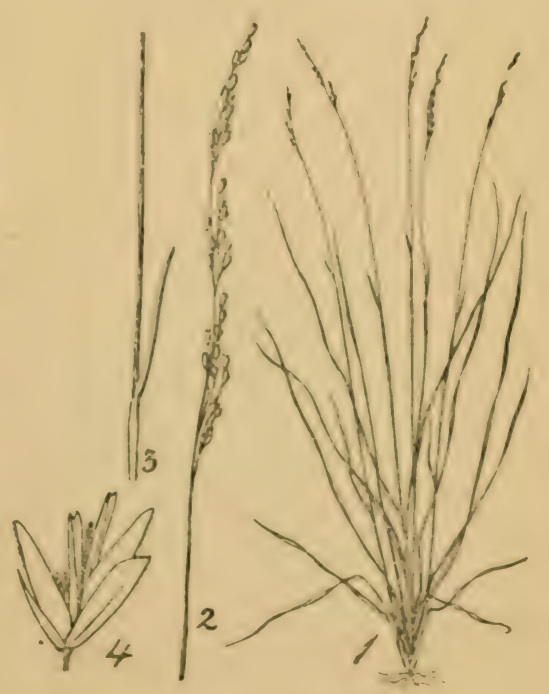

Fig. 132. Eatonis fliformi».

2. Pantcle. 3. Upper leaf. 4. Splkelet. 

glumes usually oistuse and awnless (the second foret sometimes short, awned from the apex). Palea narrow, two-nerved. Styles distinct, short: stigmats plumose. Frain narrow, free.

Rather slender tufted perennials, with usually flat leaves and narrow, but often lax, terminal, many-flowered panicles.

Species three, all natives of the eastern United States, two extending westward to the Rocky Mountains.

KEY TO THE SPECIES.

1. I.eaves involute-filiform, the lower nearly as long as the culm.

I. E. FILIFORMIS.

1. Leaves flat, the lower much shorter than the culm . . . . 2

2. Second glume broadly obovate and very obtuse . . . . . 3

2. Second glume narrower and acutish, leaves 3 to 6 inches long . . . . . . . . 2. E. Pennsyluanica.

3. First glume nearly as long as the third, leaves $i$ to 3 inches long . . . . . . . . . E. DUDLEY

3. First glume $1 / 2$ to $2 / 3$ as long as the third, leaves longer

4. E. OBTUSATA.

\section{Eatonia filiformis Vasey.}

Plate XXXIII. Figure 132.

An erect, tufted perennial, one to two feet high, with very long upper internodes and long involute radical leaves. Sheaths smooth or pubescent; ligule very short or none: leaf-blade filiform-involute, those at the base nearly equalling the culm. Panicle narrow, rather loosely flowered, slender, three to six inches long, the branches erect. Spikelets two-flowered, scattered along the branches, about one and one-half lines long. Lower empty glume linear, acute: the upper narrowly obovate, obtuse: flowering glumes about one line long, somewhat obtuse, smooth, the glume of the second flower occasionally short-awned on the back just below the apex.

Dry hills, Chester county, (S. M. Bain).

\section{Eatonia Pennsylvanica Gray.}

Plate XXXIV. Figure 133.

A slender, pale-green perennial with flat leaves and narrow terminal panicles. Sheaths mostly smooth: ligule about one line long; leaf-blade one to two lines wide, three to four inches long, flat, scabrous on both sides. Panicle slender, three to seven inches long, the branches nearly erect. Spikelets scattered along the branches, two- or occasionally three-flowered; empty glumes a little over one line long: the lower narrowly linear with scabrous keei, the upper narrowly obovate, acute or obtuse, slightly scabrous on the nerves. Flowering glume about one and one-half lines long, acute, somewhat scabrous on the back above. Leaves of about equal length throughout.

Moist meadows over the State. May-Jure. This grass is conspicuous in a meadow on account of its pale-green color. 
3. Eatonia Dudleyi Vasey.

Plate XXXIV. Figure 135.

A slender, erect perennial, one to two feet high, with short flat leaves and nodding panicle. Sheaths smooth or pubescent, usually shorter than the internodes; ligule less than one line long; leafblade one to two lines wide, two to four inches long, smooth or pubescent, those of the upper nodes shorter, often less than one inch long. Panicle slender, three to eight inches long, the branches widely spreading in flowering. Spikelets a little over a line long; lower empty glume broadly linear, mostly rounded at the apex, often almost equalling the upper in width; upper empty glume obovate, obtuse, smooth, except on the midnerve above, onefourth shorter than the spikelet; flowering glume rather acute, that of the upper flower minutely verrucose.

Open dry woods, over the State. April-May.

\section{Eatonia obtusata.}

Plate XXXIV. Figure 134.

A tufted perennial, one and a half to two feet high, with flat leaves and rather densely-flowered nodding panicles. Sheaths smooth or pubescent, longer or shorter than the internodes; ligule about one line long; leaf-blade three to four lines wide, four to six inches long, scabrous on both sides and often downy. Panicle densely flowered, three to four inches long. Spikelets a little over one line long, two- to three-flowered; lower empty glume narrowly linear, cristate, one-nerved, about one line long, the upper of equal length, very broadly obovate, three-nerved, hispid on the dorsal surface; flowering glume oblong, carinate, hispid on the keel above.

The form with pubescent sheaths (Avena mollis Michx.) is that which is most common. This is the E. obtusata var. laxiflora of Gattinger's Tennessee Flora.

\section{MELICA Linn. Sp. P1. 66 (I753.)}

Spikelets two to several-flowered, terete or slightly flattened, in simple racemose, or more or less compound, narrow or dense panicles; rachilla articulated above the empty glumes and between the fertile florets, usually bearing two or three empty, often clubshaped or cucullate glumes at the apex. Empty glumes at the base of the spikelet two, unequal, membranaceous, awnless, threeto five-nerved. Flowering glumes larger, rounded on the back, seven- to thirteen-nerved, margins scarious, awnless or shortawned. Palea broad, two-keeled, shorter than the glume. Stamens three. Styles distinct, stigmas plumose. Grain free.

Perennials, with usually soft, flat leaves, rather large spikelets in lax or dense, usually narrow panicles, sometimes simply racemose.

Species thirty or more, throughout the temperate zones. Some eighteen species belong to the United States, chiefly in the Rocky Mountain and Pacific Coast regions. One in Tennessee. 


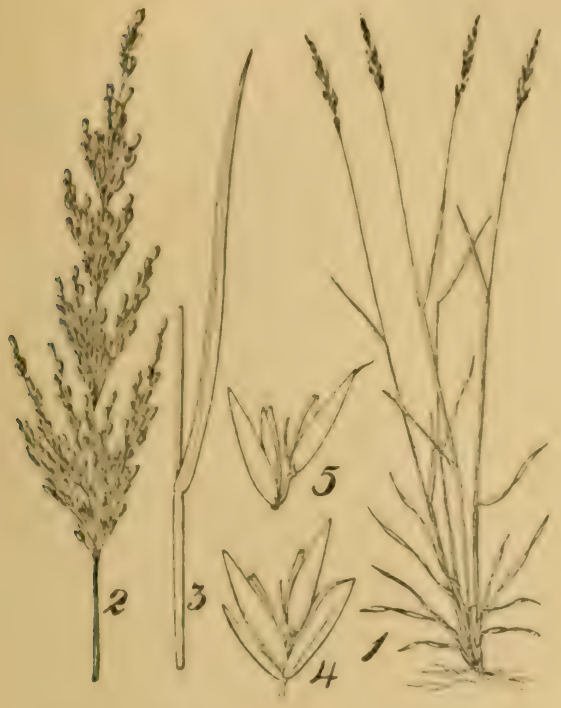

Fig. 133. Eatonia Pennsylvanica.

2. Pantcle. 3. Upper leaf. 4. Splkelet. 5. Two florets.

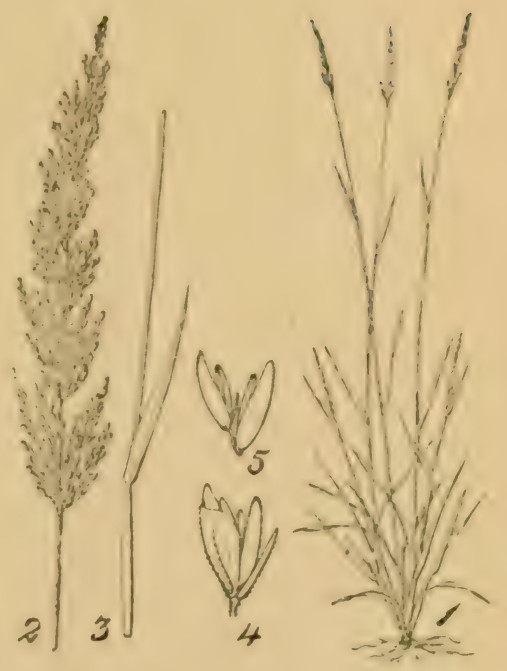

Viz. 134. Eatonia obtusata.

2. Pantcle. 8. Unper leaf. 4. spthelet. 5. Two florets.

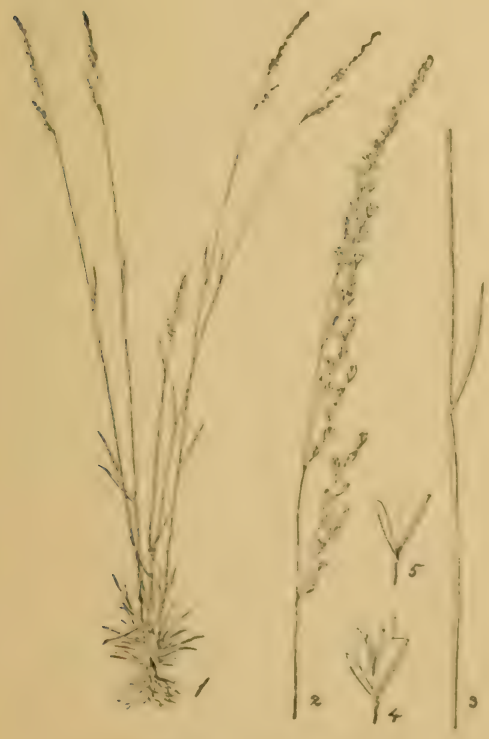

Fig. 18̄. Eatonia Dudleyi.

2. Panicle. 3. Portion of culm, with upper leaf. 4 spikelet. 5. Empts glumes.

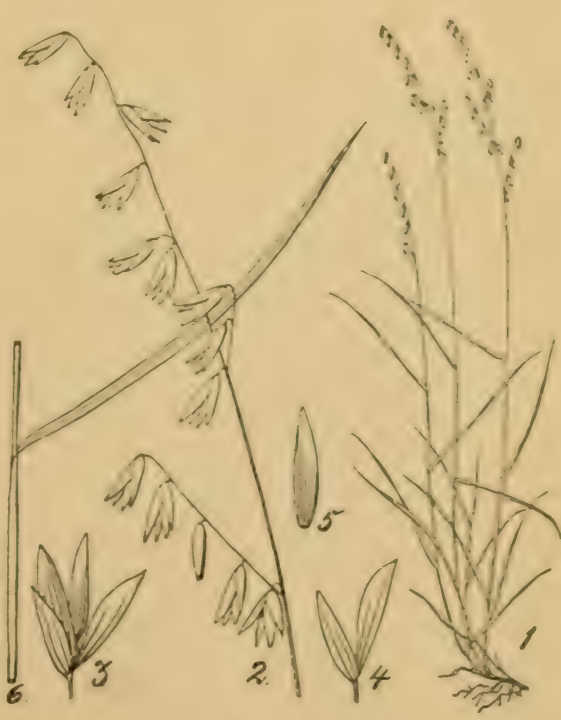

Fig. 136. Meliea mutiea.

2. Panlcle. 3. Splkelet. 4. Empty glumes. 5. Foral glume 6. Portion of the culm with upper leaf. 



\section{Melica mutica Walt.}

Plate XxxIV. Figure 136.

A smooth, slencler, erect grass one to three feet high, with nar. row leaves and nodding spikelets in nearly simple panicles. ['anicle few-flowered, sparingly branched below, often reduced to a simple raceme. Spikelets four to five lines long, with two perfect flowers; empty glumes thin and membranous, subequal, about as long as the spikelet.

Dry open woods. April-May.

11. diffusu Pursh, which may occur within the State, has a more branched panicle, unequal empty glumes, which are decidedly shorter than the three-to four-flowered spikelets.

\section{DIARRHENA Rafin. In Journ. Phys. LXXXIX. 104. (1\&ig.)}

Spikelets three- to five-flowered, few in a narrow simple panicle, rachilla articulated above the empty glumes and between the florets, lower florets perfect, the uppermost one or two sterile. Empty glumes unequal, ovate, awnless, shorter than the florets. Flowering glumes broader, subcoriaceous, rounded on the back, smooth, and shining, three-nerved, acuminate or mucronatepointed. Palea rather broad, two-keeled. Stamens two, or rarely only one. Styles short, distinct; stigmas plumose. Grain larger, usually exceeding the palea and glume, obliquely ovoid and obtusely-pointed. Nearly smooth perennials, with simple culms from a creeping root-stock, flat leaves and few-flowered terminal panicles.

Species two, one in Japan, the other in eastern North America.

\section{Diarrhena Americana Beauv. Twin.grass.}

Plate XXXV. Figure 137.

An erect perennial two to three feet high, with long, narrowlanceolate nearly erect leaves and a few-flowered simple panicle. four to ten inches long. Sheaths scabrous, or sometimes pubescent above; ligule very short, rigid; leaf-blade six to twenty-four inches long, five to twelve lines wide, tapering to a narrow base, very long acuminate-pointed. Panicle-branches erect. Spikelets three to five lines long, three-to six-flowered, the uppermost flowers imperfect; flowering glumes three-nerved, abruptly and sharply acuminate-pointed. Palea broad, two-keeled, keels scabrous. Grain about three lines long, enlarged near the middle. Floral glumes spreading in fruit.

"Rich soil among rocks, here and there."-Gattinger.

\section{UNIOLA Linn. Sp. Pl. 7 I (1753.)}

Spikelets three- to many-flowered, the uppermost one or two staminate or neuter, those below perfect; rachilla articulated above the empty glumes and between the florets. Empty glumes at the base of the spikelet three to six. compressed-keeled, acute, unequal. Flowering glumes firm-membranaceous, com- 
pressed-keeled, acute or acuminate pointed, striate, many-nerved. Palea rigid, two-keeled. Stamens one to three. Styles distinct; stigmas plumose. Grain compressed, oblong, free.

Erect perennials, with simple culms, broad and flat, or narrow and involute leaves, and narrow and few-flowered, or ample, lax, and many-flowered panicles.

Species four or five, all North American. Tennessee species three.

$$
\text { KEY TO THE SPECIES. }
$$

I. Panicle expanded, spikelets i 2 to 8 lines long, 9- to 20 -flowered, drooping on long slender pedicels 3. U. LATIFOLIA.

I. Panicles long and narrow, spikelets 4 to 5 lines long, 4- to 8 -flowered on very short pedicels

2. Sheaths glabrous, leaves I to 3 lines broad. I. U. GRAcilis.

2. Sheaths pubescent, leaves 4 to 8 lines broad

I. Uniola gracilis Michx. Slender Spike-grass.

Plate XXXV. Figure 138.

A slender grass two to three feet high, with long, narrow leaves and a contracted, wand-like nodding panicle six to eighteen inches long. Sheaths smooth, a little bearded at the throat; ligule short, ciliate; leaves nearly erect, six to twelve inches long, three lines wide or less, tapering to nearly filiform, scabrous tips. Spikelets three-to five-flowered, three to four lines long, the glumes spreading in fruit. Empty glumes short, unequal; flowering glumes one and one-half to two and one-half lines long, lanceolate and somewhat acuminate-pointed, scabrous on the keel near the apex. Palea arched, one-fourth shorter than the floral glume, scabrous on the keels near the apex.

Open thickets and along the borders of woods in dry soil. July, August.

2. Uniola longifolia Scribn. Long-leaved Spike-grass.

Culms three to four feet high; panicle six to fifteen inches long, the short rigid branches rather remote and more or less spread. ing. Lower leaves a foot long or more and four to eight lines broad, scabrous near the convolute, slender tips and often pubescent near the base. Sheaths somewhat compressed and more or less pubescent, with a dense ring of soft hairs on the back where it joins the blade.

Habit and inflorescences nearly as in $U$. gracilis, but more robust, main axis and branches of the panicle more rigid. Sheaths pubescent and spikelets somewhat larger. Very distinct from $U$. nitida.

Talley of the Hiwassee (A. Ruth); Tullahoma (Dr. Gattinger.)

3. Uniola latifolia Michx. Broad-leaved Uniola.

Plate XXXV. Figure 139.

An erect grass with rather stout, simple culms two to four feet 


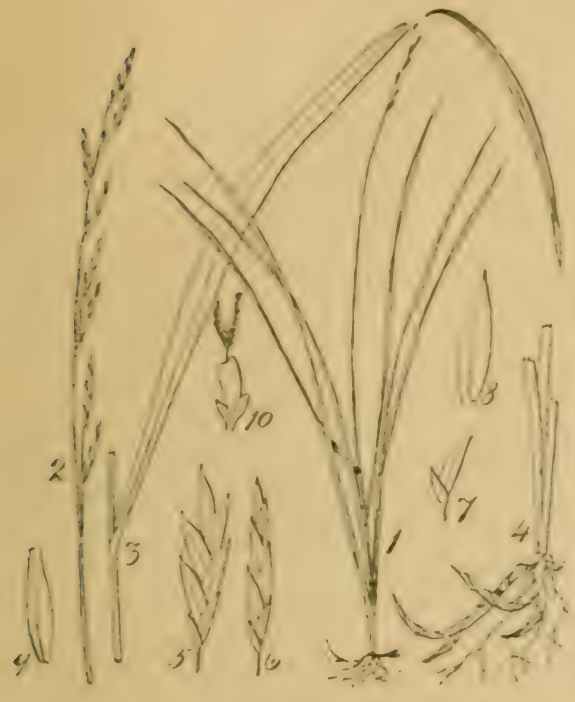

Fig. 137. Diarrhena Americana.

2. Influrescence. 8. Upperleat. 4. Iase of culm with rlizome. 5, f. Splkelets. 7 . fimpty glumes. \& flowering glume.9. Palea. 10 Uvary with lodicules.

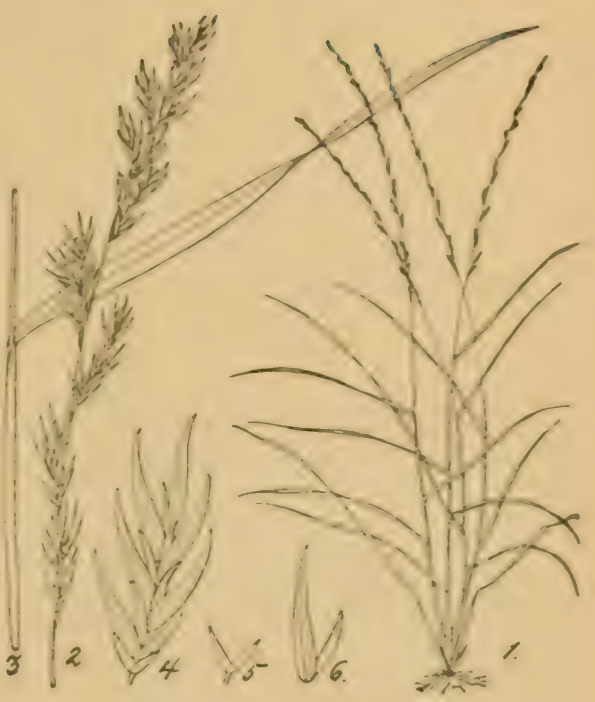

Vig. 139. Uniola gracills.

2. Upper part of inflorescence. 3. Upper lagf. 4 Splkelet. 5. Empty glumes. 6. klowerlng glume and palea.

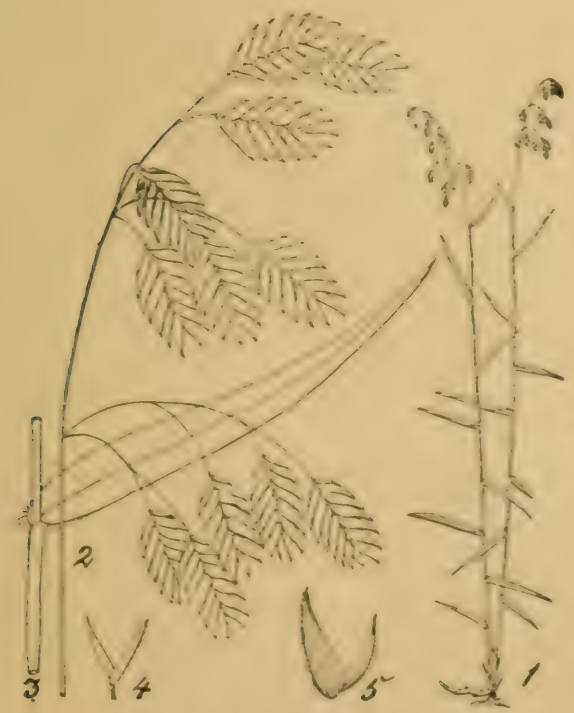

Fig. 139. Eniola latifolia.

2. Pantcle 3 tipper leaf 4. The two lowest glumes. 5 Flowering glume and palea, from the side

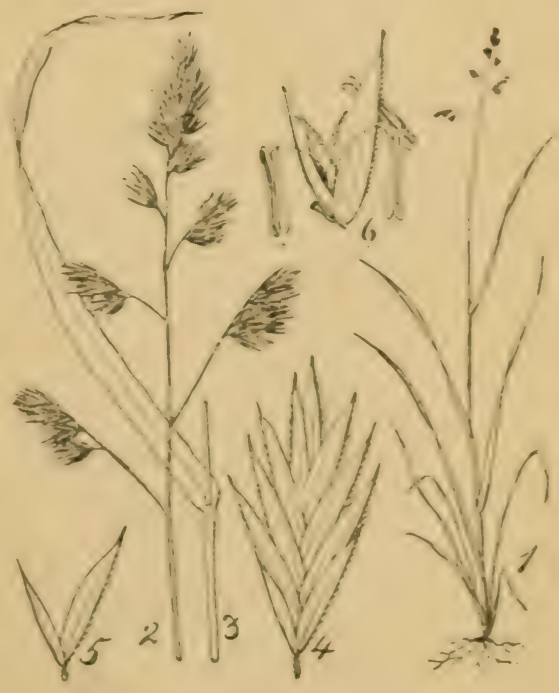

Viz. 140. Dactylis glomerata.

2 Inflorescence. 3. Upper leaf. 4. Splke. let. 5. Empty glumes. 6. Floret, with sta. mens and pistil. 

high, broad spreading leaves and a drooping panicle of large, flat spikelets. Sheaths glabrous; ligule short, minutely ciliate; leaves five to eight inches long, one-half to one inch wide, lanceolate, glabrous. Panicle five to ten inches long. the slender branches spreading. Spikelets nine- to twenty-flowered, ovate, strongly flattened, one to one and a half inches long and about half as broad; flowering glumes ciliate on the keel below, scabrous above, manynerved. Callus with a few short hairs. Palea shorter than the glumes, narrow, strongly curved near the base.

This is a strong-rooted native grass growing along streams and thicket borders, and the showy panicles are often gathered for winter bouquets. It is not recognized as possessing any agricultural value.

51. BRIZA, Linn. Sp. P1. 70 (1753.)

Spikelets many-flowered, rounded-ovate, or heart-shaped, paniculate, rachilla articulated ahove the empty glumes and between the florets; florets crowded, the uppermost usually imperfect. Glumes membranaceous, with broad, scarious margins, strongly concave, rounded on the back and more or less ventricose. Empty glumes two, subequal, shorter than the florets. Floral glumes three- to many-nerved, cordate at the base, awnless. Palea much smaller than its glume, obtuse, two-keeled. Stamens three. Styles short, distinct; stigmas plumose.

Annuals or perennials, with flat or convolute leaves, loosely flowered and open, or narrow and spike-like panicles. Several of the species are cultivated for their graceful panicles, which are used in winter bouquets.

Species twelve, in Europe, North Africa, and the temperate regions of South America, extending north into Mexico. The following may be found here in cultivation.

\section{Briza media Linn. Quaking-grass.}

A slender, erect perennial with rather short flat leaves and capillary spreading panicles. Ligule short, truncate. Spikelets rounded ovate, five-to nine-flowered, on rather long slender pedicels: empty glumes nearly equal, shorter than the first flowering glume.

This is a pretty, ornamental grass, frequently cultivated in gardens.

Briza minor L. is a more slender and annual grass, with elongated acute ligules and smaller triangular spikelets.

Briza maxima L. is a stouter plant than $B$. media, with broader leaves, oblong liguie, and nodding panicles of rather large, ovate, seven-to fifteen-flowered spikelets.

The species are all ornamental and valued for dry bouquets.

52. DACTYLIS. Linn. Sp. P1. 7 I (1753.)

Spikelets three-to five-flowered, nearly sessile in dense fascicles, forming an interrupted, one-sided panicle: rachilla articulated 
above the empty glumes and between the florets. Empty glumes unequal, one- to three-nerved, sharply keeled, acute. Floral glumes five-nerved, short awn-pointed, strongly compressed-keeled, keel conspicuously ciliate-fringed. Palea a little shorter than the glume, two-keeled. Stamens three. Styles distinct; stigmas plumose. Grain narrow, oblong, enclosed, within the fruiting glume and palea, but free. A perennial grass with flat leaves and narrow (or expanded in flower), glomerate panicles.

Species one, with several varieties, native of the north temperate regions of the Old World, but now very widely distributed in cultivation and thoroughly naturalized in this country.

\section{Dactylis glomerata L. Orchard-grass.}

Plate XXXV. Figure 140.

A coarse, erect grass three to four feet high, forming dense tufts. Ligule elongated, membranaceous. Leaves flat, slightly keeled, spreading. Panicle three to eight inches long, the branches spreading in flower, becoming erect and appressed to the rachis. Spikelets compressed, three- to five-flowered, crowded at the ends of the branches in dense one-sided clusters. Flowering glumes two to three lines long, lanceolate, very acute or short awnpointed, ciliate on the keel above.

This is one of the best known and most popular of our cultivated grasses. It will grow well on any soil excepting that which is very wet. It grows well in the shade, no grass being equal to it in this respect, excepting perhaps, the rough-stalked meadowgrass. In pastures it affords a good bite earlier than any other grass excepting the meadow fox-tail. It affords a great amount of aftermath, being exceeded in this respect only by Kentucky bluegrass. Owing to its habit of growing in clumps or tussocks, the land should be seeded heavily, using two and a half or three bushels to the acre. When sown with other grasses, its tendency to form tussocks is very much diminished, and we would recommend that clover, or possibly red-top, always be mixed with our orchard-grass. Although not adding materially to the bulk of hay produced, they will improve its quality and help make a much better sward.

\section{CYNOSURUS Linn. Sp. P1. 7 I (1753.)}

Spikelets of two forms in small fascicles, these forming a dense somewhat unilateral, spike-like panicle; terminal spikelets of the fascicles two- to four flowered, hermaphrodite, the lower spikelets sterile, consisting of many empty glumes. Rachilla of the fertile spikelet articulated; empty glumes two, narrowly lanceolate, acute; flowering glumes broader, membranous, one- to three-nerved, mucronate or awn-pointed. Glumes of the sterile spikelet distichous, spreading, subequal, linear, one-nerved; rachilla not articulated. Stamens three. Styles distinct, short; stigmas loosely 
plumose. Grain oblong, finally adherent to the palea. Annual or perennial, cespitose grasses with flat leaves.

species four or five, in the north temperate regions of the ()ld World.

\section{Cynosurus cristatus Linn. Crested Dog's-tail.}

A slender, erect perennial one to two and a half feet high, with narrow leaves and a rather slender, erect, spike-like panicle. Flowering glumes scabrous in the upper part, mucronate nointed.

This is a grass recently introduced into this country from Europe, where it is used in mixtures to form bottom grass either in meadows or in pastures. It possesses a highly nutritive value, and succeeds well in almost any kind of soil excepting those which are very sandy, and as it is deep rooted, it withstands drought better than some other species, and is said to thrive well in shade. It has some value in lawn mixtures.

\section{POA Linn. Sp. Pl. 67 ( 1753 .)}

Spikelets two-to six flowered, the uppermost flower imperfect or rudimentary, rachilla articulated above the empty glumes. Empty glumes herbaceous, lanceolate or ovate, one- to threenerved, keeled, persistent. Flowering glumes herbaceous or membranaceous, lanceolate or ovate, acute or obtuse, awnless, fivenerved, carinate, falling with the two-keeled palea and a joint of the rachilla; the dorsal or marginal nerves ustually soft-hairy, and often with a tuft of long, cobwebby hairs at the base. Stamens three. Styles distinct; stigmas plumose. Inflorescence paniculate, the branches more or less spreading.

Species about one hundred, in both hemispheres, chietly in the temperate and cooler regions, and on the high mountains of the tropics. North American species about sixty, seven of which are natives of the State.

KEY TO THE SPECIES.

1. Annuals, 3 to ro inches high, roots strictly fibrous . . . 2

I. Perennials, 6 inches to 3 feet high, with a more or less manifest root-stock . . . . . . . . . . .

2. Flowering glume apparently only 3 -nerved and with a tuft of long cobwebby hairs at base . 2. P. CHAPMANIANA.

2. Flowering glume distinctly 5 -nerved, not webbed at base

. . . . . . . . . . . . . I. P. ANNUA.

3. Radical leaves much shorter than the culm

3. Radical leaves nearly equalling or exceeding the culm . Io

4. Culms strongly flattened from a creeping root-stock, panicle I to 3 inches long, narrow, spikelets usually crowded, flowering glumes but slightly compressed, rather rigid and obscurely nerved . . . . . 3. P. Compressa.

(a) Low (6 to 13 inches) panicle dense, flowering glumes naked or with only a scanty web at the base, the indistinct dorsal and marginal nerves nearly or quite smooth . . var. a. compressa. 
(b) Taller ( 2 to 24 inches) panicle-branches spreading, spikelet less crowded, flowering glumes with a conspicuous web at the base and silky villous along the dorsal and marginal nerves below

var. b. laxa.

4. Culms not strongly flattened, panicle open, flowering glume compressed, keeled and plainly 5-nerved (at least when dry) .

5. Pedicels for the most part (in each panicle) shorter than the spikelets

5. Pedicels for the most part (in each panicle) equalling or much exceeding the spikelets . . . . . . . . . .

6. Sheaths and leaves smooth, ligule $1 / 2$ to I line long, broadly truncate 4. P. PRATENSIS.

(a) Radical leaves flat, nearly as broad as those of the culm . . . . . . . . . . var. a. pratensis.

(b) Radical leaves very narrow, involute or filiform, often glaucescent . . . var. b. angustifolia.

6. Sheaths and leaves rough, ligule 2 to 3 lines long, acute. .

7. Flowering glume with a broad, rounded-obtuse or retuse white scarious apex, not webbed at the base . . . .

7. Flowering glume not rounded at the apex, Pebbed at the base

8. Florets nearly or barely exceeding a line in length, rather blunt-pointed, minutely pubescent on the keel for its whole length, and on the margins and over the whole back below . . . . . . . . 7. P. sylvestris.

8. Florets $\mathrm{I} 1 / 2$ to 2 lines long, acute . . . . . . . .

9. Flowering glumes narrow, lanceolate, acuminate, faintly nerved, minutely pubescent on the keel for one-half its length, marginal nerves smooth . . . 8. P. ALsodes.

9. Flowering glumes broadly lanceolate, with rather broad, scarious margins, acute, distinctly nerved (at least when dry) silky-villous along the keel for $3 / 4$ its length and on the marginal nerves below; empty glumes broadly lanceolate, subequal, 3 nerved . . . . . 9. P. Wolfir.

го. Upper culm-leaf short ( $1 / 4$ to r inch) abruptly sharp-pointed, panicle branches capillary, widely spreading and fewflowered above . . . . IO. P. BREVIFOLIA.

10. Upper culm-leaf 2 to 6 inches long, panicle-branches rather short, erect, or slightly spreading, densely many-flowered

II. P. ARACHNIFERA.

I. Poa annua L. Low Spear-grass. Six-weeks grass.

Plate XXXVI. Figure 141.

A low, spreading annual, the erect or ascending, somewhat flattened stems two to twelve inches high. Sheaths smooth, lax; leaf- 
.$$
\text { . }
$$ 


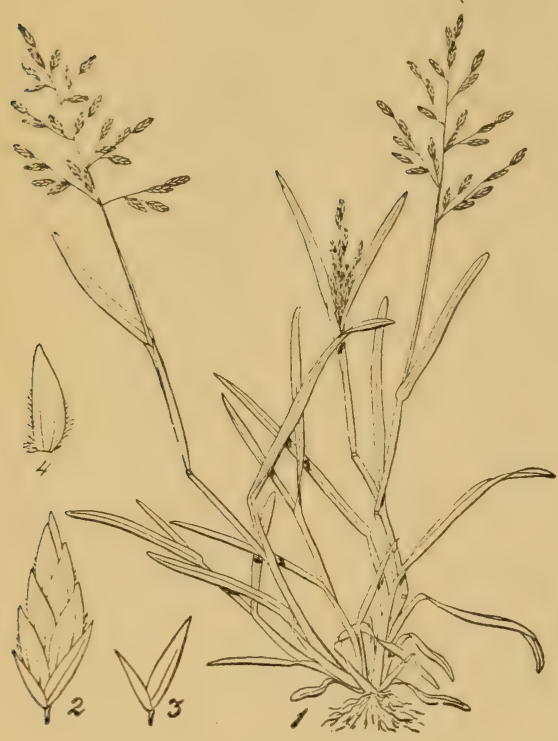

Fig. 141. Poa annua.

2. Splkelet. 3. Empty glumes. 4. Flowering glume from the side.

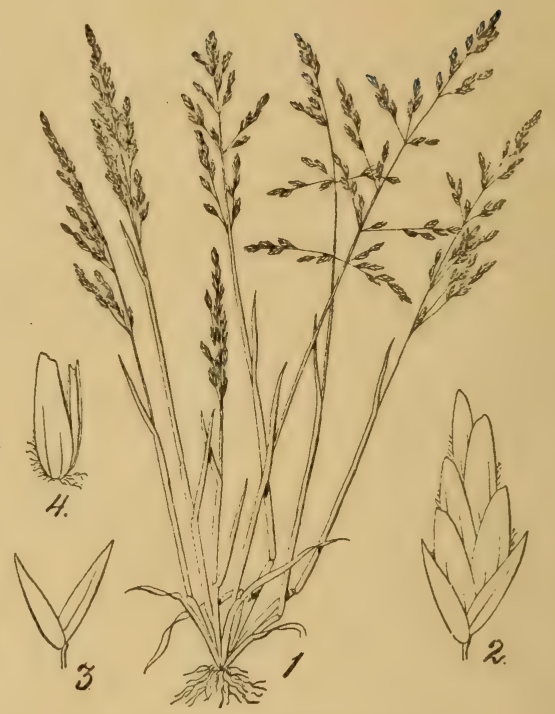

Fig. 142. Poa Chapmaniana.

2. Splkelet. 3. Fmpty glumes. 4. Floret

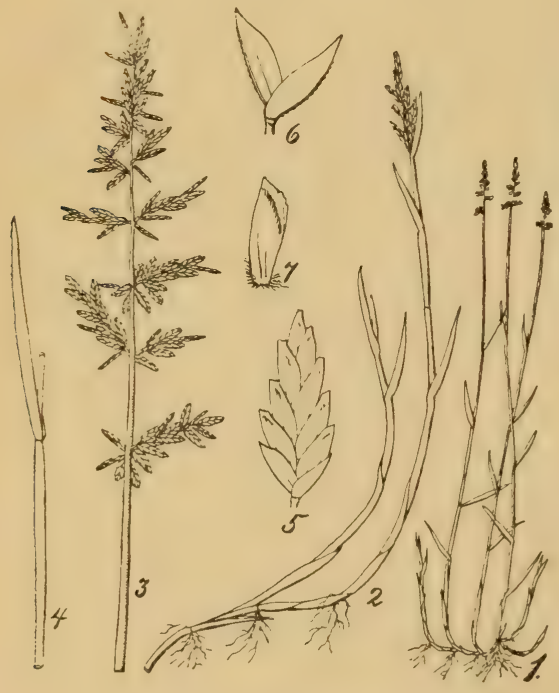

Fig. 143. Poa compressa.

3. Pantcle. 4. Upper leaf. 5. Spikelet. 6. Empty glumes. 7. Fioral glume seen from the side.

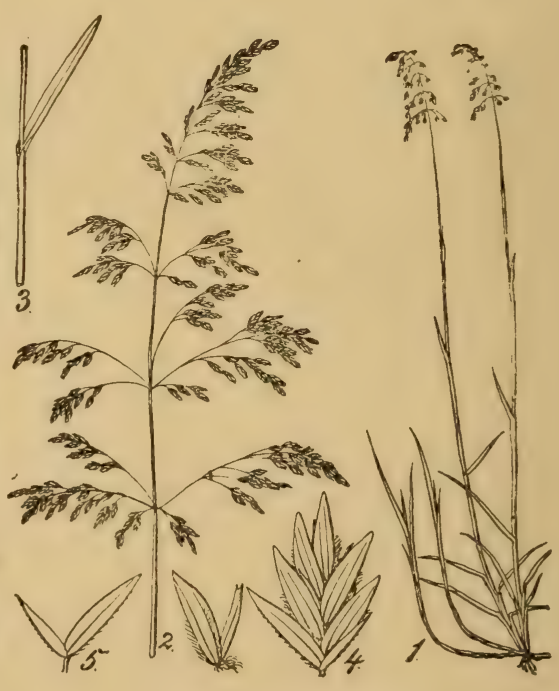

Fig. 144. Poa pratensis.

2. Panicle. 3. Upper leaf. 4. Splkelet. 5. Empty glumes. 
blade flat, smooth, spreading, one to one and one-half lines wide, one to three inches long. Panicle short, pyramidal, the primary branches spreading. solitary or in pairs. Spikelets ovate orohlong. three to six-flowered, about two lines long; empty glumes somewhat unequal, the first one- the second three-nerved; flowering glumes about one line long, distinctly five-nerved, all the nerves more or less hairy below, the base of the flowering glume pilose.

Palea two-keeled, keels hairy.

An introduced grass common everywhere in door yards and waste, mostly moist places. This grass may be found in bloom in almost every month of the year.

\section{Poa Chapmaniana Scribn.}

Plate XXXVI. Figure 142.

An erect annual three to six inches high. Sheaths firm, closely surroinding the stems, striate, mostly shorter than the internodes, usually purplish near the base: leat-blade one-half to one inch long, a line or less wide, usually erect or ascending, flat or conduplicate. Panicle generally narrow, occasionally with some of the branches more or less spreading. Spikelets ovate, about one and one-half lines long, three-to six-flowered; empty glumes nearly equal, orate-lanceolate, acute, the second and often the first threenerved, distinctly scabrous on the keel above: flowering glume ovate, rather obtuse, three-nerved, the nerves silky-villous for nearly their entire length, and at the base there is a small tuft of cobwebby hairs which when extended exceed the length of the glume.

This is the Pou cristata of Chapman's Southern Flora. Found in rather dry sandy soil along the river banks below Knoxville, and by Prof. Ruth in the valley of the Hiwassee; at Nashville by Dr. Gattinger.

\section{Poa compressa L. Blue-grass. English Blue-grass.}

\section{Plate XXXVI. Figure 143.}

A slender but rather rigid perennial with much flattened stems six to twenty inches high, ascending from a more or less creeping base, and usually small narrow panicles. Leaves about one line wide, one to three inches long, abruptly pointed at the tip: ligule one-half a line long. Panicie expanded or more often contracted, one to three inches long, the equal primary branches in pairs; pedicels shorter than the spikelets. Spikelets lanceolate, five-to nine-Howered, two to three lines long: flowering glumes about one and one-half lines long, obscurely five-nerved, with narrow scarious margins, the keel and lateral nerves smooth or silky-hairy below. Palea two-nerved, nerves scabrous.

A native of Europe but thoroughly naturalized in many parts of this country. Its low habit of growth, strongly compressed or flattened stems and narrow panicle, are characters which enable one to readily distinguish this from Kentucky blue-grass. It is further more decidediy creeping, and will grow well upon the 
thinnest and apparently most sterile soils. There is, perhaps, no better pasture grass than this for dry and poor soils.

\section{Poa pratensis Linn. Kentucky Blue-grass.}

Plate XXXVI. Figure 144.

An erect perennial one to three feet high, with smooth stems, flat leaves, open panicle and extensively creeping root-stocks. Sheaths smooth; ligule about one-half a line long; leaf-blade flat, four to ten inches long, one-half to three lines wide, apex abruptly pointed. Panicle pyramidal, three to seven inches long, the primary branches usually in threes or fives. Spikelets about two lines long, three- to five-flowered, mostly on very short, scabrous pedicels; empty glumes a little unequal, the first narrowly-lanceolate and usually one-nerved, the second broader and three nerved, flowering $\mathrm{g}^{-1}$ umes ovate, scarious toward the apex, five-nerved, the nerves silky-hairy below and with a small tuft of cobwebby hairs at the base.

This very well known native has been called the "King of pasture grasses in the central basin of Tennessee," and whoever has Blue-grass has the basis of all agricultural prosperity. It is not so well adapted for hay as for pasture, but it makes an excellent "bottom grass" for the permanent meadow. Here it remains green throughout the year, excepting in severe winter seasons, and blooms in May. Poa pratensis is common to both Europe and America, and grows "wild" in this country from Alaska southward along the mountain ranges to Arizona, and east of the Mississippi it extends southward to the Gulf States. It is only on good soils that it yields well, doing best on those which are highly calcareous.

5. Poa trivialis L. Rough Meadow-grass.

Plate XXXVII. Figure 145.

An erect perennial, one to three feet high, with flat leaves, open panicle and no conspicuous root-stock. Culm rough or scabrous near the summit, not flattened. Sheaths a little scabrous; ligule two to three lines long; leaf-blade three to six inches long, about two lines wide, acute. Panicle narrowly-pyramidal, three to eight inches long. Spikelets ovate, usually two-flowered. Empty glumes strongly keeled, very acute, the lower one-nerved, the upper broader and three-nerved; flowering glume ovate-lanceolate, strongly five-nerved, fringed on the keel with silky hairs, otherwise smooth. Palea smooth.

This grass is closely related to the Kentucky Blue-grass, differing by the absence of any creeping root-stock, the rough stem, longer ligule, more slender panicle, fewer-flowered spikelets, and more prominently-nerved floral glumes. It has been cultivated for many years in England, and is now highly esteemed both in Britain and on the continent of Europe. Its principal use is to form "bottom grass" in permanent meadows. It succeeds best where the climate and soil are rather cool and moist. 

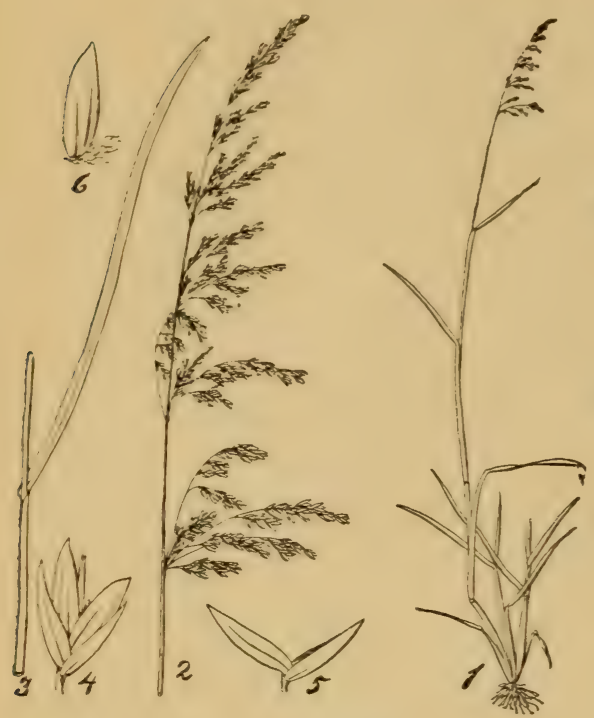

Fig. 145. Poa trivialis.

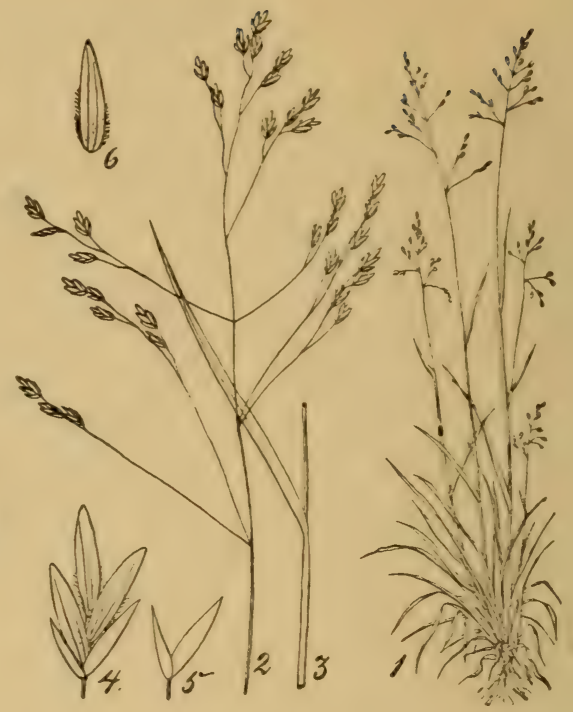

Fig. 146. Poa antumnalis.

2. Panlcle. 3. Upper leaf. 4. Splkelet. 5. Empty glumes. 6. Side view of flowering glume.

2. Panlcle. 3. Upper leaf. 4 Splkelet. 5. Fimpty glume 6. Flowering glume seen from the side.

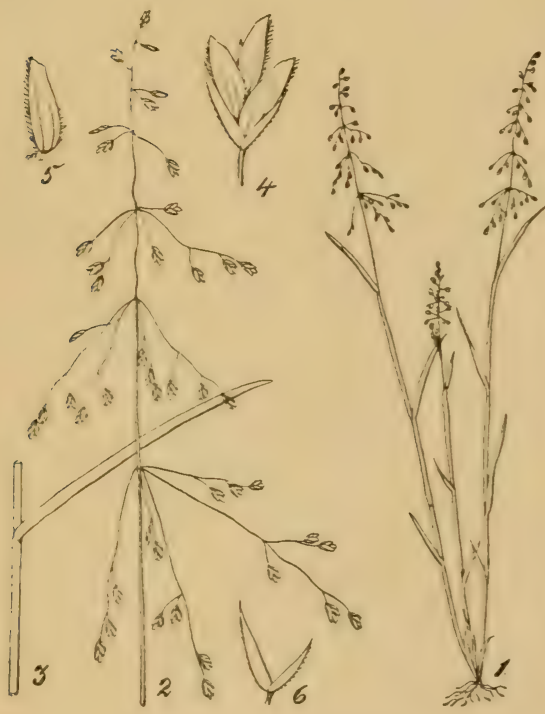

Fig. 147. Poa sylrestris.

2. Panicle. 3. Upper leaf. 4. Spikelet. 5. Flowering glume. 6. Empty glumes.

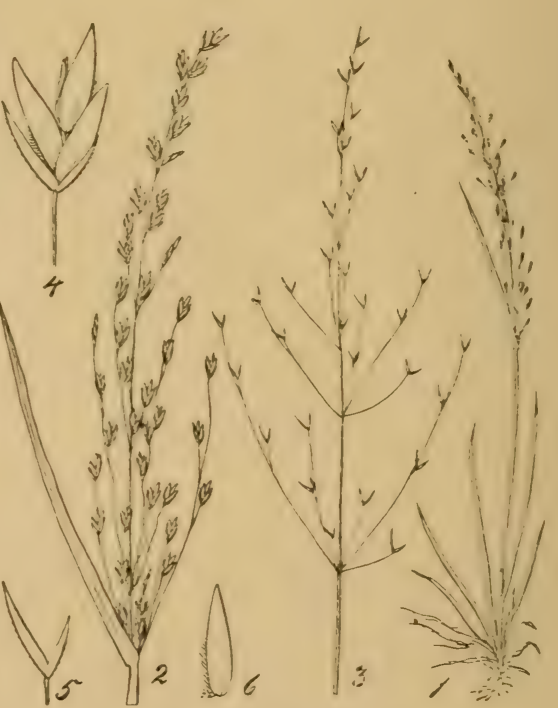

Fig. 148. Poa alsodes.

2. Panicle and upper leaf. 3. Panicle after flowering. 4. Spikelet. 5 Empty glumes. 6. Flowering glume seen from the side. 


\section{Poa autumnalis Muhl. (P. Rexwosa Muhl.)}

Plate XXXVII. Figure 146.

A slender perennial, with erect stems one to three feet high, hat leaves and an open, rather few-tlowered panicle. Sheaths smooth; ligule about one-half a line long; leaf blate three to eight inches long, mostly less than a line wide, scabrous, gradually tapering to a slender, acute apex. Panicle four to five inches long, the long flexuose, tiliform branches in twos or threes, with the few spikelets clustered at the ends. Spikelets oblong, ovate, obtuse, two to three lines long, three- to five-flowered; first empty glume onenerved, the second a little longer, hroader, and obtuse: flwivering glumes about three-fourths of a line long, narrowly lanceolate. hyaline or scarious at the obtuse apex, distinctly five-nerved, the midnerve or keel hairy for its whole length, the dorsal surface pubescent near the base, but with no web. Palea two-keeled, keels scabrous or pubescent.

This grass has long been known as Por flexuosa Muhl., not of Smith nor of Wahlenberg. It is most frequent in dry words, but Gattinger reports it as growing on damp ground, and borders of ponds, especially in the highlands. June-July.

\section{Poa sylvestris Gray. Woodland Blue-grass.}

Plate XXXVII. Figure 147.

A slender, tufted perennial one to three feet high. Stems slightly flattened, erect. Sheaths scabrous or sometimes smooth; ligule one-half to one line long: leaf-blade three to eight inches long. one to two and one-half lines wide, scabrous on the upper surface, smooth beneath, acute. Panicle open, three to eight inches long, primary branches in clusters of three to six, spreading or reflexed. Spikelets ovate, one to one and one-half lines long, two- to four-flowered, shorter than the pedicels. Empty glumes slightly unequal, the first one-the second three-nerved; flowering glumes ovate obtuse, five-nerved, villous on the keel for its whole length and on the marginal nerves below the middle, near the base the entire dorsal surface minutely pubescent, nnly sparingly webbed at the base. Palea two-keeled, keels villous.

Common 1 in rich open woodlands and along thicket borders. April-May.

\section{Poa alsodes Gray.}

Plate XXXVII. Figure 148.

A slender, erect perennial one to three feet high, with flat leaves and a narrow, rather few-flowered panicle. Sheaths rather thin, the upper somewhat scabrous; ligule one-half a line long or less; leaf blade one to two lines wicle, five to twelve inches long. scab). rous. at least toward the acute apex. Panicle narrowly pramidal. the base for a time enciosed in the upper sheath, three to ten inches long, primary branches in threes or fours at the rather distant nodes of the main rachis. Spikelets lanceolate, two-to threeflowered, about two lines long: empty clumes unequal, acute, the 
first one-nerved, the second three-nerved; flowering glume narrowly ovate, acute, very faintly nerved, villous on the keel below and with a narrow cobwebby tuft at the base. Palea two-nerved, nerves scabrous.

Summit of Roane Mountain and upper forks of the Tellico river. May-June.

\section{Poa Wolfii Scribner.}

Plate XXXVIII. Figure 149.

A slender perennial one to three feet high, with a loose nodding panicle. Sheaths rather loose, mostly shorter than the internodes, the lower scarious; ligule one-half a line long; leaf-blade three to six incheslong, one to two lines wide. Panicle slender, lax, three to six inches long, primary branches two to three, rarely more, at each node of the main rachis. Spikelets ovate, two to three lines long, three- to five-flowered; empty glumes nearly equal, three-nerved; flowering glumes strongly keeled, lanceolate, five-nerved, silky-villous along the margins and keel and with a copious long web at the base. Keels of the palea villous. This grass has been confounded with $P$. alsodes and $P$. autumnalis. It is closely allied to the latter, but both empty glumes are threenerved, the flowering glumes are more acute and have a tuft of long webby hairs at the base.

Lavergne, in the cedar glades, May-June. (Gattinger.)

\section{Iо. Poa brevifolia Muh1.}

\section{Plate XXXVIII. Figure 150.}

An erect perennial with a running root-stock, short culm-leaves, very long radical leaves, and a widely spreading, few-flowered panicle. Sheaths long, striate; ligule one-half to one line long; leaf-blade about two lines wide and three to twelve inches long, the uppermost culm-leaf one-half an inch long or less. Panicle pyramidal, the primary branches in clusters of two to six at each node of the axis, widely spreading. Spikelets ovate-lanceolate, three to four lines long, three- to six-flowered; empty glumes acute, slightly unequal, the first one- the second three-nerved; flowering glume about two lines long, lanceolate, with an acute scarious apex, fivenerved, the keel and marginal nerves hairy, sparingly webbed at the base. Palea two-nerved, nerves hairy.

Along mountain slopes and river bluffs, East Tennessee. March and April.

\section{I. Poa arachnifera Buckley. Texas Blue-grass.}

Plate XXXVIII. Figure 151.

A rather strong growing perennial one to three feet high, with an extensively-creeping root-stock, long leaves and narrow denselyflowered panicle. Sheaths firm, striate, smooth; ligule about one line long; leaf-blade flat, scabrous on the upper surface, smooth beneath, the lower six inches to two feet long, the upper two to four inches long, one to two lines wide, blunt-pointed at the apex. Spikelets ovate-lanceolate, two to four lines long, three- to seven- 


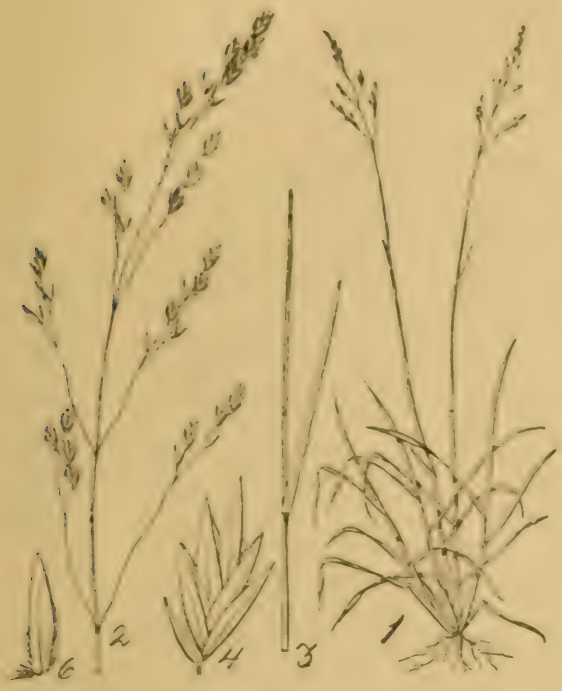

Fig. 149. Poa Wolni.

2. Paifcle. 3. Upper leaf. 4. Splkelet. 6. Slde vlew of floral glume.

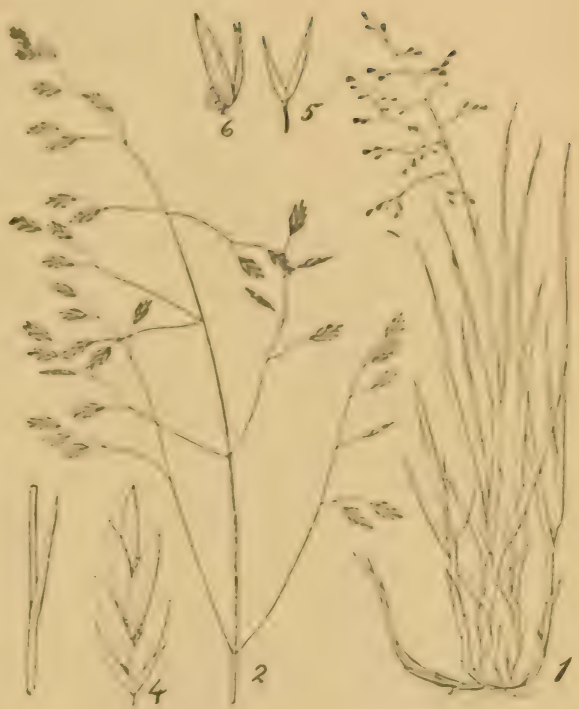

Fig. 150. Poa brevifolla.

2. Panlcle. 3. Upper leaf. 4. Splkelet. 5. Empty glumes. 6. Floret.

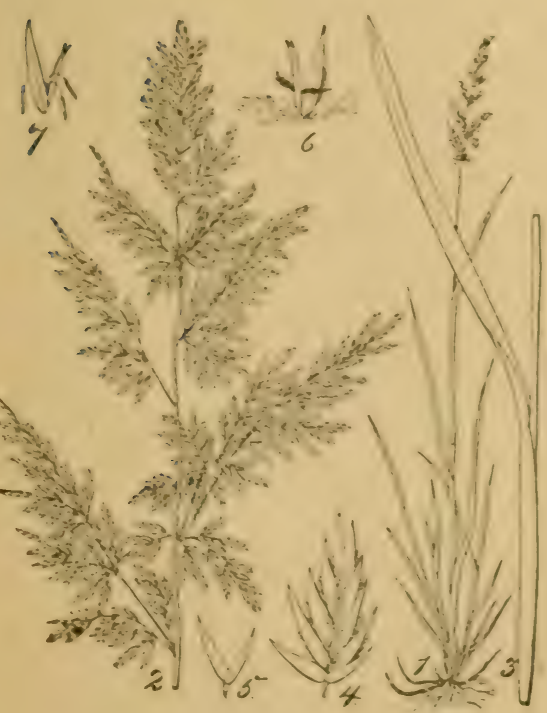

Fig. 151. Poa arachnifera.

2 Inflorescence expanded. :. Ipperleac 4 Splkelet. 5. Empty glumes.

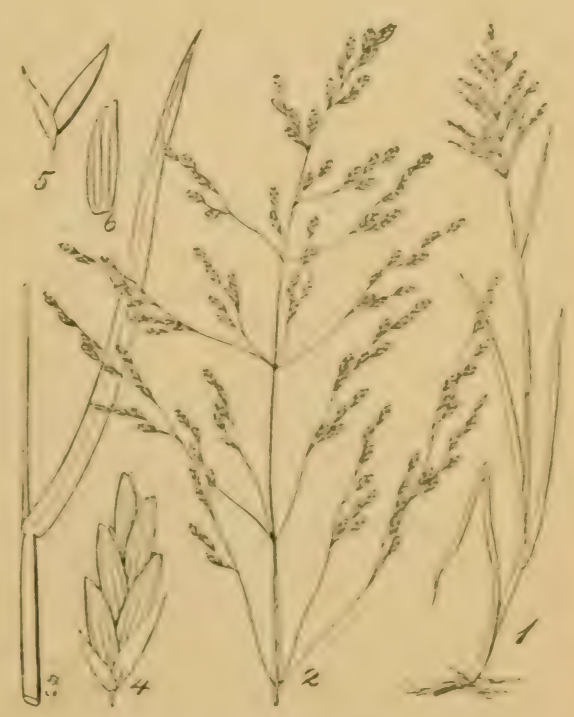

Fig. 152. filyceria aquatica.

2. Panicle. 3. Lpper leas. 4. Splkelet. 5. Empty glumes. 6. Flowering glume. 

flowered; empty glumes unequal, acute, the first one-nerved, the second ihree-nerved, scabrous on the keels; flowering glumes five-nerved; in the fertile plant the nerves are hairy and there is a very copious tuft of long cobwebby hairs at the base; in the sterile or staminate plants the flowering glumes are smooth. Paleas two. keeled, keels hispid and subaristate-pointed. Staminate and pistillate plants alike, differing only in the woolliness of the flowering glumes.

This grass was first discovered in Texas, where it is a native, and is now being cultivated in several of the Southern States. It has strong, creeping roots (rhizomes), and forms a dense turf. It is especially well adapted for permanent pastures. (Owing to the unusual woolliness of the seeds, it is easiest propagated by root. cuttings. Both seeds and root-cuttings may be obtained from the leading seedsmen of New York, Philadelphia, Richmond, Va., Augusta, Ga., New Orleans, etc. This grass remains green here throughout the year, making its chief growth during the winter months, and blooms during the latter part of April or May.

\section{GLYCERIA R. Br. Prod. I, I79. (1810.)}

Spikelets few-to many-flnwered, terete or slightly flattened, in narrow or spreading panicles; rachilla articulated between the florets, usually snooth. Flowers hermaphrodite or the uppermust imperfect. Empty glumes at the base of the spikelet two, unequal, shorter than the flowering glumes, obtuse or acute, one- to three-nerved. Flowering glunies smooth or scabrous, roundeci on the back, herbaceous, excepting at the scarious and usually blunt apex, five-to nine-nerved, nerves usually prominent and parallel. Palea a little shorter than the glume, two-nerved. Stamens two or three. Styles short, distinct; stigmas plumose. Grain oblong. smooth, free, or when dry slightly adherent to the palea

Usually tall, aquatic, perennial grasses, with flat leaves and generally diffuse terminal panicles.

Species about sixteen, widely dispersed in the temperate regions of both hemispheres, chiefly North American. Tennessee species five.

KEY TO THE SPECIES.

I. Spikelets ovate or oblong, I to 4 lines long

I. Spikelets linear, 6 to 12 lines long

2. Panicle narrow, elongated (6 to $\mathbf{I}_{2}$ inches); spikelets 3 - to 4-flowered, appressed to the erect branches 3. G. ELONGATA.

2. Panicles diffuse

3. Culms slender, ascending from a creeping or decumbent base; panicle nearly simple; spikelets narrow, 3 to + lines long: flowering glume minutely dentate . 4. G. PAI.InA.

3. Culms stouter, erect, panicle compound, spikelets ovate or oblong, I to 3 lines long.

4. Culms 3 to 5 feet high; sheaths mostly smooth; panicle usually 10 to 12 inches long..... I. G. AQUATICA.

4. Culms I to 3 feet high; sheaths strongly scabrous; panicle usually 4 to 5 inches long

2. G. NERVATA. 
5. Flowering glumes obtuse, not exceeded by the blunt palea.

5. Flowering glumes acute, shorter than the lon. F. FLUITANS. palea . . . . . . 6. G. arutiflora.

I. Glyceria aquatica Smith. Reed Meadow-grass.

Plate XXXVIII. Figure 152.

A stout perennial, three to five feet high, with an ample, open panicle, and rather broad, flat leaves. Sheaths mostly smooth and closed nearly to the top; ligule about one line long; leaf-blade three to six lines wide, ten to twenty inches long, smooth on the lower surface, scabrous above. Panicle oblong-pyramidal, eight to sixteen inches long, branches finally widely spreading. Spikelets narrowly oblong, five- to seven-flowered, usually purplish, one and one-half to three lines long; empty glumes ovate-lanceolate, obtuse or acute, slightly unequal, the second the larger, about one line long; flowering glume ovate, obtuse, about one line long, strongly seven-nerved. Paleas two-toothed, about equalling their glumes.

Wet grounds. Reported by Dr. Gattinger as growing near Nashville. Probably not uncommon in other parts of the State.

\section{Glyceria nervata Trin. Fowl Meadow-grass.}

Plate XXXIX. Figure 153.

A leafy perennial, one to three feet high, with an expanded, nodding panicle. Sheaths scabrous; ligule one to two lines long, broadly truncate; leaf-blade two to five lines wide, six to twelve inches long, more or less scabrous above, abruptly acute. Panicle three to twelve inches long (usually four or five inches), pyramidal, the spreading branches usually drooping. Spikelets one to two lines long, three- to seven-flowered, obtuse; empty glumes, rather broadly ovate, less than one-half a line long; flowering glumes truncate-obtuse, three-fourths to one line long, and strongly seven-nerved. Paleas two-toothed. Very variable in size.

Common in moist meadows over the State, and for such localities is regarded of some agricultural value. We do not know that any attempts have been made to cultivate it.

\section{Glyceria elongata Trin.}

Plate XXXIX. Figure 154.

An erect perennial, two to three feet high, with flat leaves and narrow, rather densely-flowered, elongated panicles. Sheaths smooth, closed nearly to the summit, where there is a cartilaginous border; ligule very short; leaf-blade two to three lines wide, six to twelve inches long, smoothish below, very scabrous on the upper surface. Panicle eight to twelve inches long, drooping at the apex, the erect branches flower-bearing to the base, the short pedicels appressed. Spikelets three- to four-flowered, about two lines long; empty glumes acute, the second the larger, and nearly as long as the first floral glume; flowering glumes broadly ovate, sub-acute, rigid, about one line long, seven-nerved. 


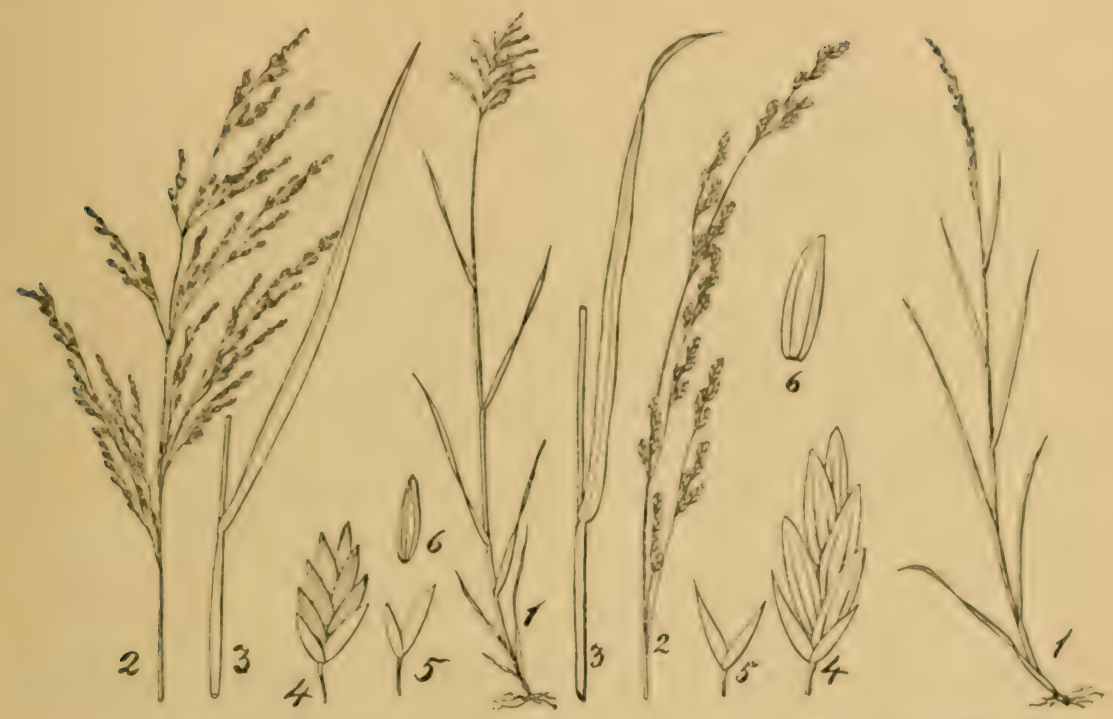

Fig. 15:3. filyceria nervata.

Fig. 154. Glyceria elongata.

2. Pantcle. 8. Upper leaf. 4. Splkelet. 5. Empty glumes. ti. Flowering glume.

2. Pantcle. 3. Upper leaf. 4. Splkelet, 5. Empty glumes. it. Slde riew of flowering glume.

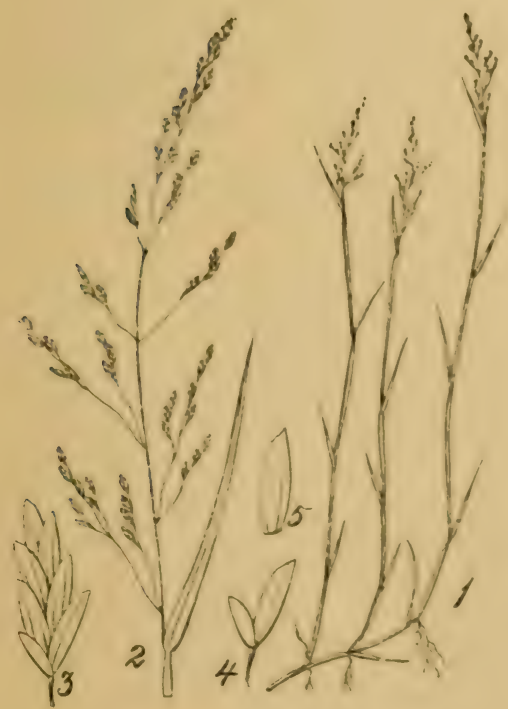

Fig. 15o. Glyceria pallita.

2 Panlcle. 3. splke'et. 4. Empts glumes. 5. Flowering glume seen from the side.

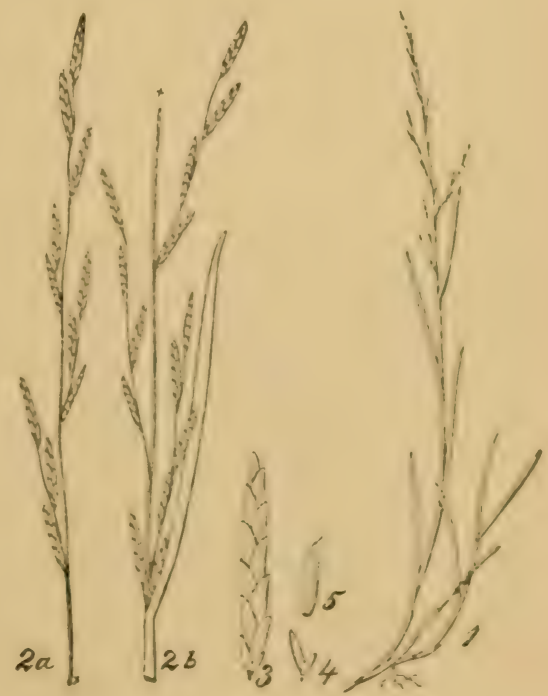

Fig. 156. Glyceria flultans.

2a. Apex of panicle. 2b. Lower part of pantcle and upper leaf. 3. Splkelet. 4. Empty glumes. 5. Flowerlng glume. 

Found on Roane Mountain, July 29, 1889. Common in the New England and Middle States.

\section{Glyceria pallida Trin.}

Plate XXXIX. Figure las.

A perennial with slender stems one to three feet long, ascending from a more or less decumbent base. Sheaths smooth; ligule one to fwo lines long; leaf-blade one to two lines wide, two to six inches long, scabrous, acute. Panicle three to six inches long, lax, the few-flowered branches ascending. Spikelets rather narrowly ob. long, three to four lines long, loosely four- to nine-flowered; empty glumes ovate, the second three-nerved, about one line long. a little exceeding the one-nerved lower glume; flowering glumes one and one-half lines long, minutely dentate at the obtuse apex; distinctly seven-nerved. Palea lanceolate, two-toothed.

Wet places, margins of slow streams, ponds, etc. Reported by Dr. Gattinger as growing in a bog. near Ducktown.

\section{Glyceria fluitans R. Br. Manna.grass.}

Plate XXXIX. Figure 156.

An erect grass three to five feet high, with somewhat flattened culms, long leaves and a narrow panicle a foot long. Lower panicle-branches finally spreading. Spikelets linear, cylindrical, onehalf to one inch long, seven-to thirteen-flowered; empty glumes broad, hyaline, faintly nerved near the base, the first about one and one-half lines long, the second a little longer; flowering glumes about three lines long, seven nerved, scabrous, obtuse, entire at the apex or obscurely toothed.

In swamps and wet muddy places. June-August.

This grass is widely distributed over the world. It makes excellent fodder and is valuable for swampy meadows. In some parts of Europe the grain is gathered and used for food.

\section{Glyceria acutiflora Torr.}

Plate XL. Figure 157.

A low perennial with ascending stems one to two feet high, and narrow few-flowered panicles. Sheaths mostly smooth, closed for a part of their length. Panicle narrow, the erect branches mostly in pairs, one very short and bearing a single spikelet, the other elongated and bearing one to three spikelets. Spikelets one to one and one-half inches long, five-to twelve flowered. Empty glumes unequal, the first about half the length of the second; flowering glumes lanceolate-acute, three to four lines long, sevennerved and minutely roughened on the back. Palea narrow. acuminate and bidentate or cleft at the apex, much exceeding the floral glume.

Ponds near Nashville, (Gattinger).

56. FESTUCA Linn. Sp. Pl. 73.

Spikelets several-flowered, pedicellate, in narrow and dense or 
loose and spreading panicles; rachilla articulated above the empty glumes and between the florets. Empty glumes at the base of the spikelets two, more or less unequal, narrow and acute. Flowering glumes rounded on the back, at least below, acute (rarely obtuse) or tapering into a straight awn, faintly three- to five-nerved, not webbed at the base. Stamens three. Styles very short, distinct; stigmas plumose. Grain elongated, furrowed, frequently adnate, or grown to, the palea or floral glume.

Usually cespitose, perennial (rarely annual) grasses of varying habit.

Species about eighty, in all parts of the world, especially the temperate regions. Many are valuable forage plants.

KEY TO THE SPECIES.

I. Plants annual; panicles strict, somewhat one-sided, florets awl-shaped, awned or awn-pointed . . . . . . . 2

ı. Plants perennial . . . . . . . . . . . . . . . . . 3

2. Empty glumes nearly equal; awns 2 lines long or less

Empty exceeding the florets . . . . . 2. F. Myurus.

3. Leaves very narrow, convolute-setaceous, at least those at the base. Plants tufted or cespitose . . . . . . . . 4

3. Leaves flat, those of the culm 2 to 4 lines wide . . . . . 5

4. Plants strictly cespitose, with no creeping rootstock 4. Plants with a manifest rootstock or stoloniferous 3. F. ovina. - 4. F. RUBRA CERULESCENS.

5. Culms 2 to 5 feet high. Spikelets 5 to 9 lines long, 5- to roflowered; flowering glumes herbaceous, with scarious margins . . . . . . . . . 5. F. Elatior.

5. Spikelets 2 to 3 lines long, 3-to 4 -flowered, flowering glumes rigid or subcoriaceous .

6. Spikelets broadly obovate, crowded at the ends of the branches; flowering glumes obtuse, somewhat turgid . .

6. F. SHORTII.

6. Spikelets lanceolate, not conspicuously crowded, flowering glumes acute

7. F. NUTANS.

I. Festuca tenella Willd. Slender Fescue.

Plate XL. Figure 158.

A slender, erect annual, six to eighteen inches high, with short, nearly subulate leaves, and a simple, somewhat one-sided panicle. Culms, nodes, sheaths, and leaves smooth, or minutely pubescent; leaves two to four inches long, very narrow. Inflorescence a narrow raceme, simple, one to seven inches long; branches erect, or in robust plants somewhat divergent. Spikelets three to five lines long, lanceolate, six-to fourteen-flowered; empty glumes nearly equal, slightly keeled, scabrous on the keel, shorter than the floral glumes, the first very narrow, one-nerved, the second broader and three-nerved; flowering glumes about two lines long, very narrow 


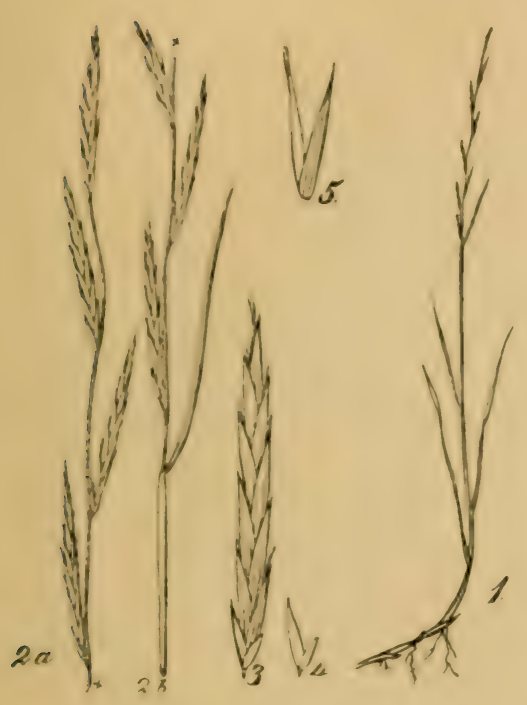

Fig. 157. Glyceria acutiflora.

$2 a$. Cpper part of inflorescence $2 b$ Lower part of Inflorescence and upper leaf. 3. Splkelet. 4. Empty glumes. 5. Flowering glume and palea.

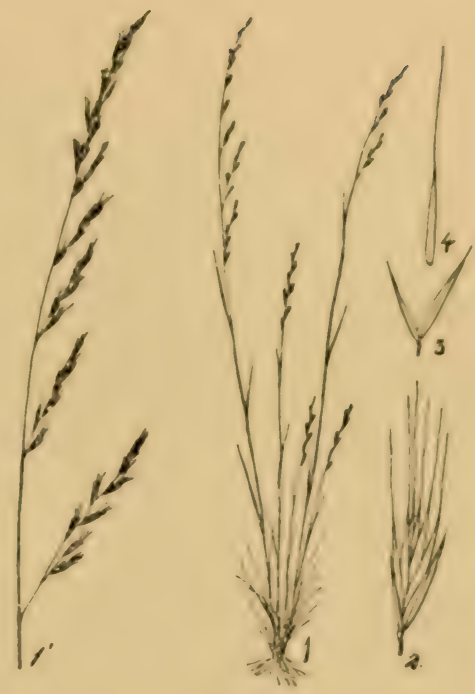

Fig. 158. Festuca tenella.

11. Panicle. 2. splkelet. 3. Empty glumes. Fiowering glume.

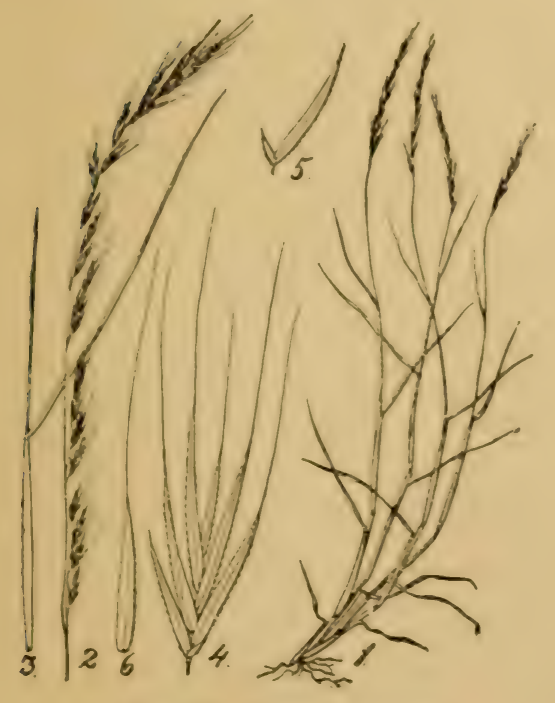

Fig. 159. Festuca myurus.

2. Inflorescence. 3. Upper leaf. 4. Splkelet. 5. Empty glumes. 6. Flowering glume.

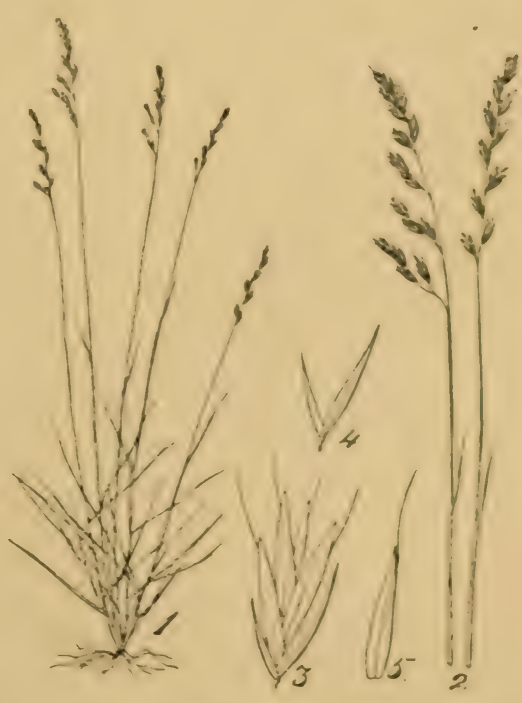

Fig. 160. Festuca ovina.

2. Inflorescence. 3. Splkelet. 4. Empty glume. 5. Flowering glume. 

or subulate, rounded on the back, scabrous above, ending in a slender awn; awn nearly as long as the glume, or shorter, and even sometimes wanting.

Dry, sterile soils, common. May-June. ()f no agricultural value.

\section{Festuca Myurus Linn.}

Plate XL. Figure 159.

An erect or ascending, rather slender annual, one to two feet high, with a narrow, somewhat one-sided panicle five to ten inches long. Sheaths smooth, ligule short, auricled, leaf-blade very narrow, involute in drying, smooth or scabrous on the upper surface. Panicle branches erect, appressed. Sipikelets narrow, four to six lines long exclusive of the slender awns; empty glumes very unequal, the first one-half to one line long, the second two to three lines long: flowering glumes two to three lines long, nearly terete, scabrous above and usually with a few long hairs on the margins, awned. Awn four to six lines long. Palea slender, acute, scabrous on the keels above. Grain linear, one and one-half lines long, pubescent at the apex.

In open, dry fields, not common. June-July.

\section{Festuca ovina Linn. Sheep's Fescue.}

Plate XL. Plate 160.

A rather low, densely cespitose grass, with numerous and very narrow basal leaves, slender culms a foot high or less. Roots fibrous, with no creeping rootstocks. Leaves closely folded, appearing setaceous; ligule auriculate. Panicle short, somewhat one-sided, the usually solitary branches spreading in flower. Spikelets three-to seven-flowered; flowering glumes about three lines long, nearly terete, mucronate or short-awned.

Only sparingly introduced in cultivation. A valuable grass for sheep pastures. It is well suited for light, dry soils, especially those which are thin and silicious.

+. Festuca rubra Linn. var. glaucescens Hack. 'Tennessee Fescue. Plate XLI. Figure 161.

A slender perennial, one to two feet high, with erect or ascending stems, and very narrow, usually glaucous leaves. Rootstock creeping. Sheaths and leaves smooth; the lower leaves twelve to eighteen inches long, those above on the culm shorter and minutely strigose on the upper surface. Panicle lax, nodding. Spikelets four to five lines long, five- to six-flowered; empty glumes unequal, the first one and one-half lines long and one-nerved, the second two to three lines long and three-nerved; flowering glumes about three lines long, mucronate or short awn-pointed, scabrous near the apex.

Along the Cumberland river near Nashville (Gattinger).

This grass is closely related to the Red or Creeping Fescue of Europe and of our more northern States, and possesses a similar habit of growth. It is an excellent turf-forming grass, and will 
doubtless endure the tramping of stock. It remains fresh throughout the year, being little affected by drouth or severe winter weather. It produces a mass of fine root-leaves, and may be recommended for pastures, especially upon worn-out soils and hillslopes.

\section{Festuca elatior Linn. Meadow Fescue. Randall-grass.}

Plate XLI. Figure 162.

Perennial. Culms erect, two to five feet high. Sheaths striate, smooth; ligule very short, lacerate; leaf-blade four to fifteen inches long, linear-lanceolate, flat or convolute in drying, smooth or scabrous on the margins. Panicles four to fifteen inches long, simple or compound, contracted before and after flowering, erect or more often nodding at the apex. Spikelets lanceolate, 11sually about six lines long, five- to ten-flowered; empty glumes unequal, the first one- the second three-nerved, acute; flowering glumes lanceolate, acute or mucronate-pointed, indistinctly five-nerved.

Variety PRATEnsis Hackel ( $F$. pratensis Huds.). Plate XLI. Figure 163 . Culms one to three feet high. Panicle five to eight inches long, oblong or linear, somewhat one-sided, usually erect, nearly simple, the branches solitary or the lower in pairs, with few (one to four) spikelets.

Variety ARUndinaCEA Hackel. ( $F$. arundinacea Schreb.) Plate XLI. Figure r64. Culms three to five feet high. Panicles compound, eight to fifteen inches long, nodding at the apex, the lower branches bearing many (four to fifteen) spikelets. Spikelets elliptical, seven to nine lines long, five- to eight-flowered.

Tall Fescue, also called Tall Meadow Fescue and Randallgrass, is an exceedingly valuable grass either for mowing or pasture. It is productive on soils which are not too dry, and being of long duration, it is especially valuable for permanent meadows. It thrives best on moist lands which are rich in humus, whether marls or clays. The variety pratensis is smaller than the species with narrower and more erect panicles. The variety arundinacea is a tall, vigorous growing form, with long and abundant basal leaves. In the experimental plots at the Experiment Station this form did exceedingly well, surpassing nearly all other species in the quantity of forage produced suitable for hay.

\section{Festuca Shortii Wood. Short's Fescue.}

Plate XLII. Figure 165.

Culms about three feet high. Sheaths smooth; ligule very short; leaf-blade four to seven inches long, two to three lines wide, acute, scabrous. Panicle four to seven inches long, nodding, the scabrous branches in pairs, naked below, the lower ones two to four inches long. Spikelets obovate, two to three lines long, three- to four-flowered, usually much longer than the pedicels; empty glumes lanceolate, acute, slightly unequal, the first one-nerved the second three-nerved, scabrous on the keels, usually about the 


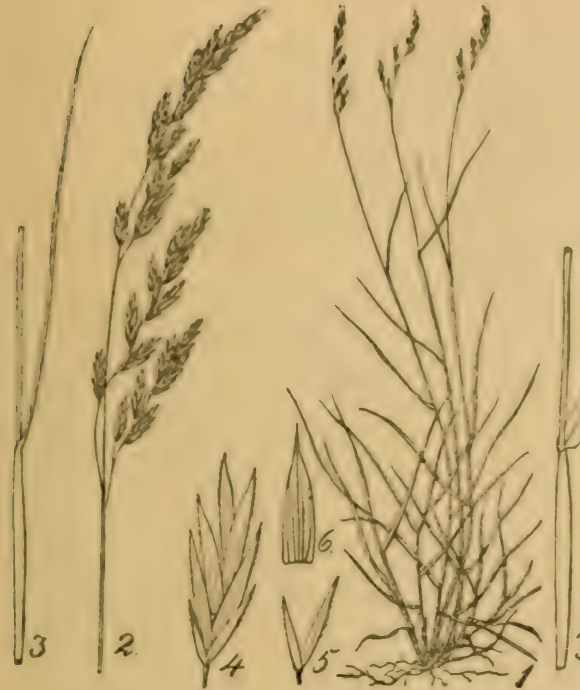

Fig. 161. Festuca rubra glancescens.

2. Inflorescence 3. Upperleaf. 4. spike. let. 5. Empty glume. 6. Flowering glume.

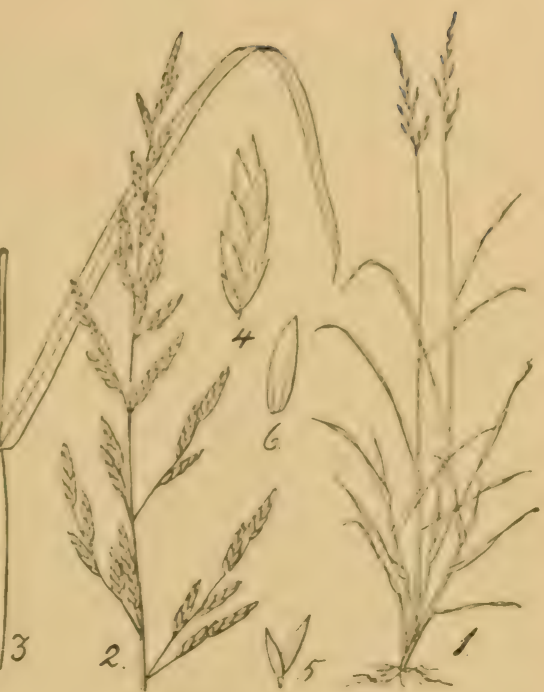

Fig. 162. Festuca elatior.

2. Pantcle. 3. Upper leaf. 4. Splkelet. 5. Empty glumes. 6. Flowering glume

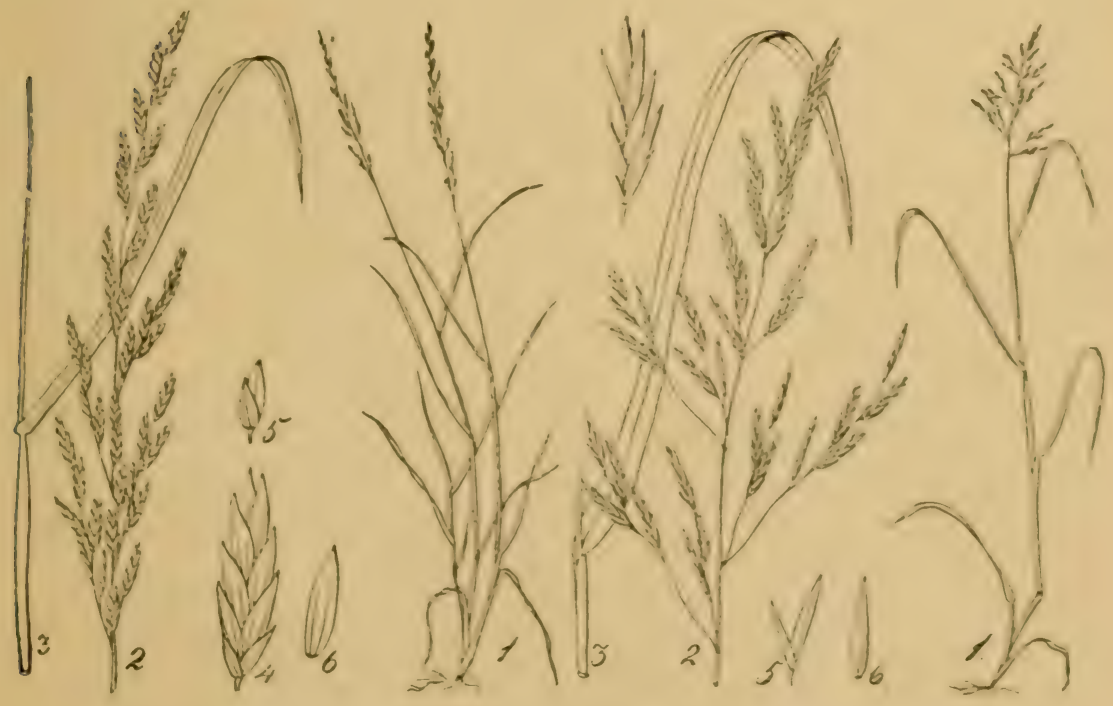

Fig. 163. Festuea pratensis. s. side rlew.
Fig. 161. Festuca arundinaces.

2. Panicle. 3. Upper leaf. 4. Splkelet. 5. Empty glumes. b. Flowering glume. 

length of the approximate floral glumes; flowering glumes $t w o$ to two and one-half lines long, rigid, ovate-oblong, rounded on the back, obtuse, obscurely nerved. Palea broad, strongly two-keeled, about as long as the glumes. Grain obovate, pubescent at the apex.

Treated by some authors as merely a variety of ficsuca nutans, from which it is distinguished by its coarser and usually taller culms, broader and almost turgid spikelets, which are more crowded at the ends of the panicle-branches.

\section{Festuca nutans Willd. Nodding Fescue.}

\section{Plate XLII. Figure 166.}

An erect perennial with simple smooth stems two to three feet high. Sheaths smooth or sometimes pilose, striate; ligule short and irregularly dentate; leaf-blade linear-lanceolate, six to twelve inches long, strongly nerved, somewhat scabrous, dark green. Panicle slender, diffuse, at length nodding, the long, scabrous branches usually in pairs and naked below. Sipikelets about three lines long, ovate-lanceolate, two- to five-flowered; empty glumes unequal, lanceolate, acuminate pointed, scabrous on the keel; flowering glumes rigid or somewhat coriaceous, rounded on the back, acute, smooth and apparently nerveless.

Borders of thickets and moist woodlands, common. May-June. Of little agricultural value.

\section{BROMUS Linn.}

Spikelets few - to many flowered, slightly or more rarely strongly flattened laterally, in panicles, or rarely racemed; rachilla articulated above the empty glumes and between the forets; florets hermaphrodite or the uppermost imperfect. Empty glumes at the base of the spikelet two, unequal, acute, or the second shortawned, one- to five-nerved, shorter than the flowering glumes. Flowering glumes keeled or more often rounded on the back, fiveto nine-nerved, usually two-toothed at the apex, and awned from the back just below the point or from between the teeth, sometimes awnless; awn straight or divergent. Palea a little shorter than the glume, two-keeled. Stamens usually three. Stigmas plumose, sessile, springing from below the hairy cushion-like apex of the ovary. Grain furrowed and grown to the palea.

Annual or perennial grasses, with flat leaves and rather large, erect or pendulous spikelets.

Species about forty, most abundant in the north temperate zone. There are about twenty-five species in the United States, of which several are introduced.

\section{KEY TO THE SPECIES.}

I. Spikelets strongly flattened; glumes many-nerved and all sharply keeled; flowering glumes entire, acute, awnless or very short-awned ... . . 7. B. UNioloides.

I. Spikelets not strongly flattened, the glumes few-nerved, rounded on the back, at least below, sometimes narrow and keeled and then long-awned . 
2. First glume 3-to 5-nerved, the second 5-to 7-nerved; flowering giumes broad and rounded on the back; spikelets ovate or lanceolate

2. First glume $\mathrm{I}_{-}$, the second 3 -nerved; flowering glumes narrow and somewhat keeled on the back, at least above.

3. Panicle erect, closely contracted, at least in part; whole plant, including the spikelets, softly pubescent . 4. B. MOLLIS.

3. Panicle usually nodding and more open; spikelets glabrous.

4. Flowering glumes and paleas about equal in length; awns shorter than the glumes, usually a little flexuose, sometimes nearly wanting, sheaths glabrous . 3. B. SECALinus.

4. Flowering glumes decidedly longer than the paleas; awns straight, about the length of the glumes; sheaths often pubescent .

5. B. RACEMOSUS.

5. Plant annual, I to 2 feet high, awns much longer than the very narrow flowering glumes. . . . 6. B. STERILIS.

5. Plants perennial, 3 to 5 feet high, awns shorter than the flowering glumes, or wanting

6. Spikelets awnless; panicle-branches spreading in flower, erect in fruit; rootstock creeping .. . 2. B. INERMIS.

6. Spikelets short-awned; no creeping rootstock

I. B. CILIATUS.

I. Bromus ciliatus Linn. Fringed Brome-grass.

Plate XLII. Figures 167, 168.

An erect perennial, with culms three to four feet high, smooth; sheaths striate, the upper smooth, the lower often retrorsely hairy; leaves six to twelve inches long, thinly pilose on the upper surface. Panicle expanded, the slender spreading branches scabrous. Spikelets nearly an inch long, about seven-to twelve-flowered; first glume very narrow, one-nerved; the second broader, threenerved, very acute; flowering glumes six to eight lines long, sevennerved, more or less clothed with appressed hairs, awned; awn two to six lines long.

In variety purgans Gray, the flowering glumes are clothed all over the back with short appressed hairs.

\section{Bromus inermis Leyss. Hungarian Brome-grass.}

Plate XLIII. Figure 169.

An erect perennial, two to five feet high, from a creeping rootstock. Sheaths striate smooth, or the lower ones pilose; ligule short, lacerate; leaf blade four to eight inches long, three to four lines wide, somewhat scabrous, the lower often sparingly pilose. Panicle four to six inches long, erect, the scabrous, unequal branches spreading in flower, becoming erect in fruit. Spikelets twelve to eighteen lines long, narrowly oblong or linear, five- to seven-flowered; rachilla pubescent; empty glumes unequal, the acute first glume one-, the obtuse second glume three-nerved; flowering glumes sub-carinate or rounded on the back, rather broadly scarious at the nbtuse or emarginate apex, awnless or very shortawned. 


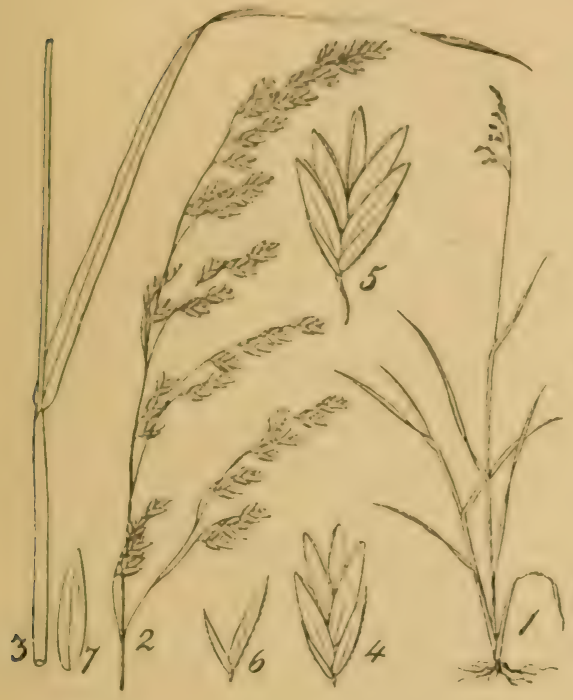

Fig. 165. Festuca Shortii.

2. Pantcle. 3. '́nper leaf. 4. Splkelet in anthesis. 5. Splkelet post-anthesis. b, Empty glume. 7. Flowering glume.

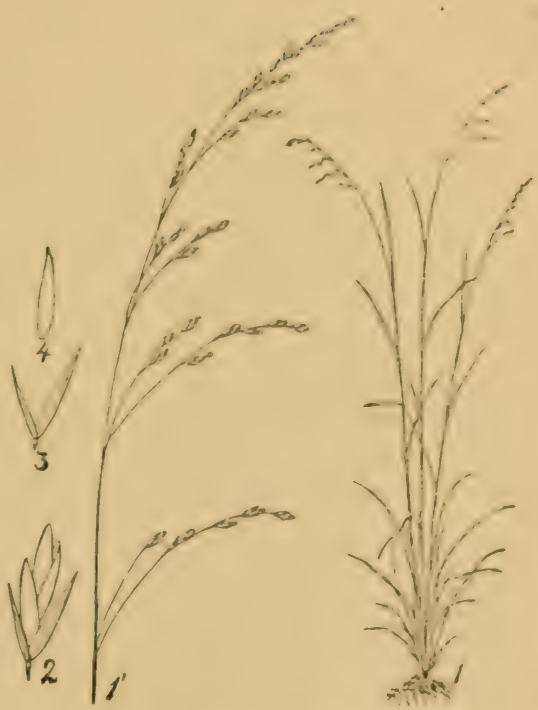

Fig. 166. Festuca nutans.

11. Panicle 2. splkelet. 3. Enpity glumes. 4. Florai glume.

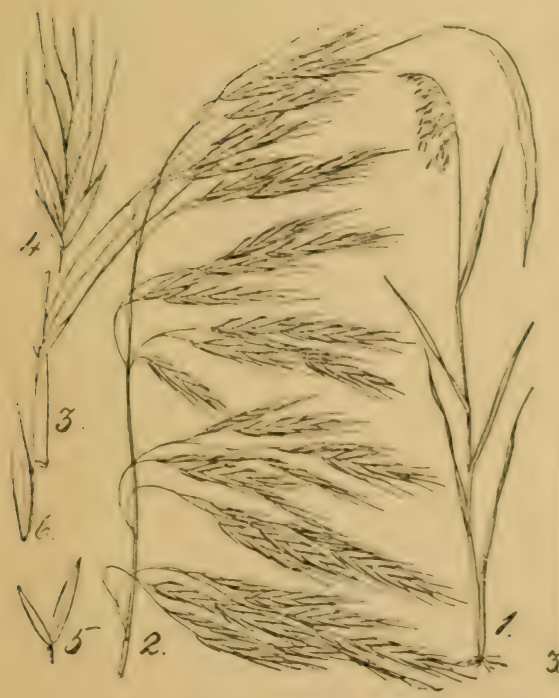

Fig. 167. Bromis elliatus.

2. Pantcle. :3. Lpper leaf. 4. Splkelet. 5. Empty glumes. (i. Floral glume.

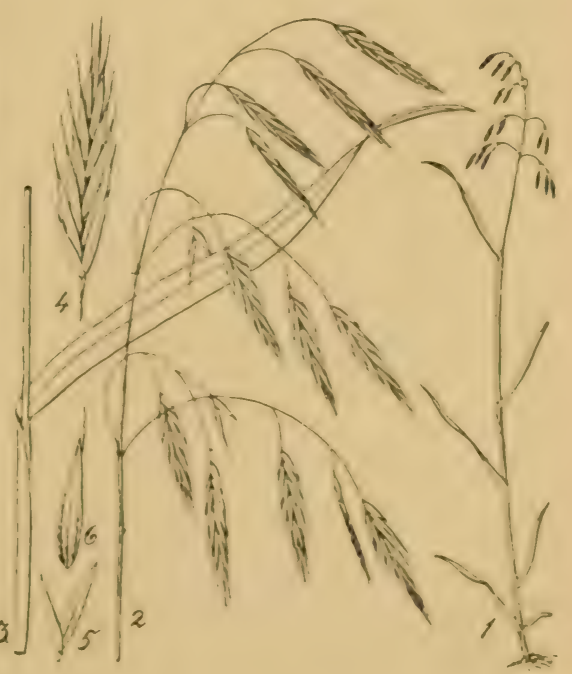

Fig. 168. Bromus eiliatus purgans.

2. Panicle. 3. Ipper leaf. \& splkelet. 5. Empty glumes. if. Flowering glume. 

This is a grass recently introduced from Europe, of considerable promise both for hay and pasture. It is strongly stoloniferous, and quickly makes a thick, firm turf. It has grown exceedingly well in the grass plots at the Experiment Station, and young plants from fall-sown seed survived the winter when many other species were destroyed by frosts. The strong perennial character of this Brome-grass, and its unusual drought-resisting powers, are qualities which recommend it for many portions of the State. It thrives well on dry ioose soil, but, of course, the better the soil the greater the yield. Its nutritive value is comparatively low, and in undertaking its cultivation the fact that it produces long underground stolons, which are somewhat difficult to eradicate from the soil, should be kept in mind.

Bromus erectus Huds, is a species closely allied to B. inermis, but is readily distinguished by its very narrow and longer lower leaves, more compressed spikelets and awned floral glumes.

\section{Bromus secalinus Linn. Chess. Cheat.}

Plate XLIII. Figure 170.

An erect annual two to three feet high. Culms smooth or pubescent at the nodes. Sheaths striate, smooth, scabrous, or sometimes pilose; ligule short, blunt; leaf-blade six to twelve inches long, rather broadly linear, smooth beneath, more or less rough and pilose on the upper surface Panicle four to eight inches long, erect, the more or less compound branches spreading, even in fruit. Spikelets six to ten lines long, oblong-ovate, turgid. sixto twelve-flowered, pendulous in fruit; empty glumes oblonglanceolate, acute, the first three- to five-, the second seven-nerved: flowering glumes ovate-oblong, obscurely seven-nerved, smooth or minutely downy along the margins and toward the apex, becoming nearly cylindrical in fruit. Palea obtuse, strongly-nerved; nerves toothed or fringed with distant bristles.

This is an annual introduced from Europe, and is more or less abundant in grain fields over the State, and should be classed as a troublesome weed. The idea that Cheat or Chess is degenerated wheat is without any foundation whatever in fact. Cheat seeds will produce Cheat and only Cheat, and it is certain that wherever these plants appear, they were preceded by the seed, which may have been introduced with the grain, or brought by birds or animals from other fields.

\section{Bromus mollis Linn. Soft Chess.}

Plate XLIII. Figure 171.

An erect annual grass one to three feet high, with the sheaths and leaves and the spikelets of the erect panicle softly pubescent. Ligule short, obtuse; leaf-blade four to six inches long, two to three lines wide, acute. Panicle two to three inches lorg, oblong. compact, the short branches erect or a little spreading in flower. 
Spikelets six to eight lines long, six-to ten-flowered, ovate or oblong-lanceolate, somewhat flattened, downy, erect; empty glumes lanceolate, acute, the first three-, the second five-to sevennerved; flowering glumes oblong, lanceolate, prominently sevennerved, with slender straight awns as long as the glumes.

Open waste places, not common.

\section{Bromus racemosus Linn.}

Plate XLIII. Figure 172.

An annual one to three feet high, with a nearly erect, sparingly-branched panicle. Branches of the panicle slightly spreading and somewhat nodding at the tips. Spikelets ovate-oblong, six to nine lines long, five- to ten-flowered; flowering glumes round on the back, somewhat ventricose, shining, awned. Awns straight, about as long as the glumes.

This species is quite distinct from Bromus mollis; the panicle is more open and often nodding, the spikelets are a little larger and more turgid, the nerves of the glumes less prominent, and the leaves and sheaths are never soft-downy.

A very common grass in cultivated fields and waste places, often mistaken for Chess.

\section{Bromus sterilis Linn.}

\section{Plate XLIV. Figure 173.}

An annual, with erect, rather slender, leafy stems, twelve to twenty-four inches high, smooth. Sheaths striate, more or less pubescent, at least the lower ones, with deflexed hairs; ligule short, obtuse; leaf-blade linear, soft and downy on both sides, with a few longer hairs on the margins near the base. Panicle six to ten inches long, nodding, with widely spreading, nearly simple branches. Spikelets pendulous, lanceolate, six-to ten-flowered; empty glumes narrow-lanceolate, long acuminate-pointed; flowering glumes lanceolate, scabrous, somewhat compressed, sevennerved; awn about an inch long, exceeding the glume; palea notched at its apex, the nerves strongly fringed.

In dry fields and waste grounds, introduced. Not common. Worthless.

\section{Bromus unioloides H. B. K. (Ceratochloa australis Spr.) Rescue- grass.}

Plate XLIV, Figure 174.

An erect, usually annual grass, one to three feet high, with more or less pubescent, flat leaves, and usually nodding loose panicles of rather large, strongly flattened spikelets. Sheaths and leaves scabrous; ligule rather long, obtuse. Panicle in vigorous plants large, with widely spreading branches. Spikelets oblong-lanceolate, eight to sixteen lines long, six-to ten-flowered; flowering glumes about six lines long; glumes all strongly compressed from the sides and keeled.

This grass has been introduced into some sections of the State, 


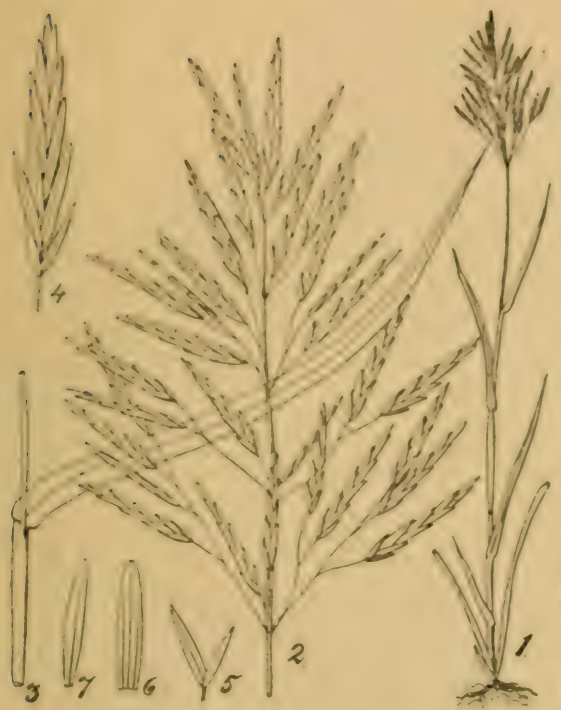

Fiz. 11,9. Bromus inermis.

- 2. lantcle. : Unper leat 4. Splkelet. 5. Empty glumes. 6, 7 . Floral glume.

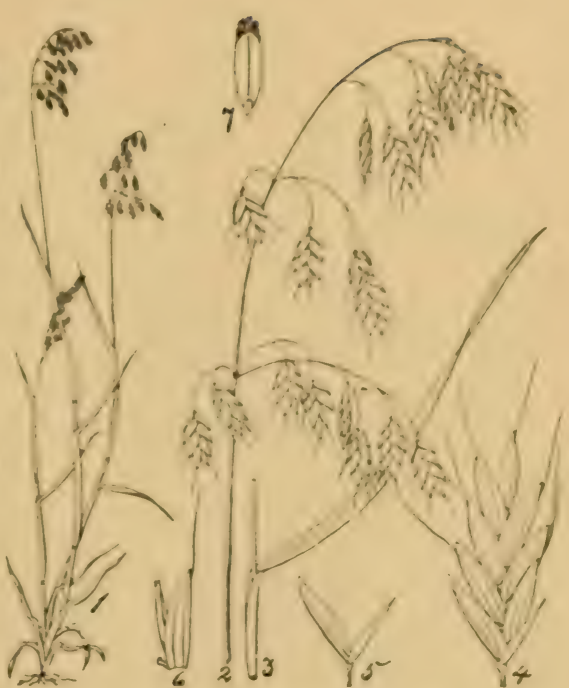

Fig. 170. Bromus secalinus.

2. Pantcle 3. Upper leai t. Srikelet. 5. Empty glumes Floral zlume an!l palea 7. Caryonsis.

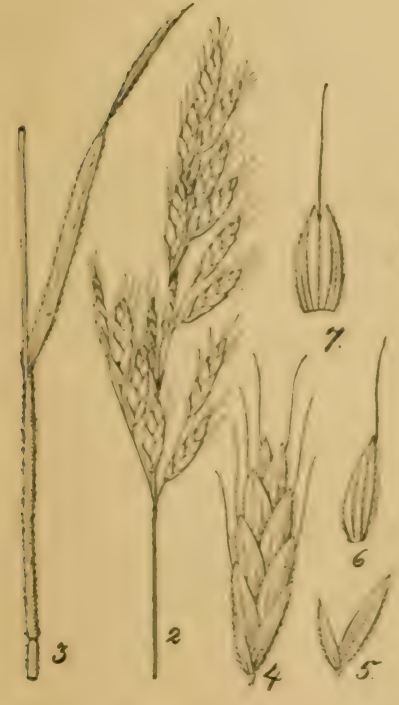

Fig. 171. Bromus mollis.

2. Panicle. 3. Unper leaf. 4. Splkelet. 5. Empty glumes. if. Floral glume. side rlew. T. Floral glume, back rlew.
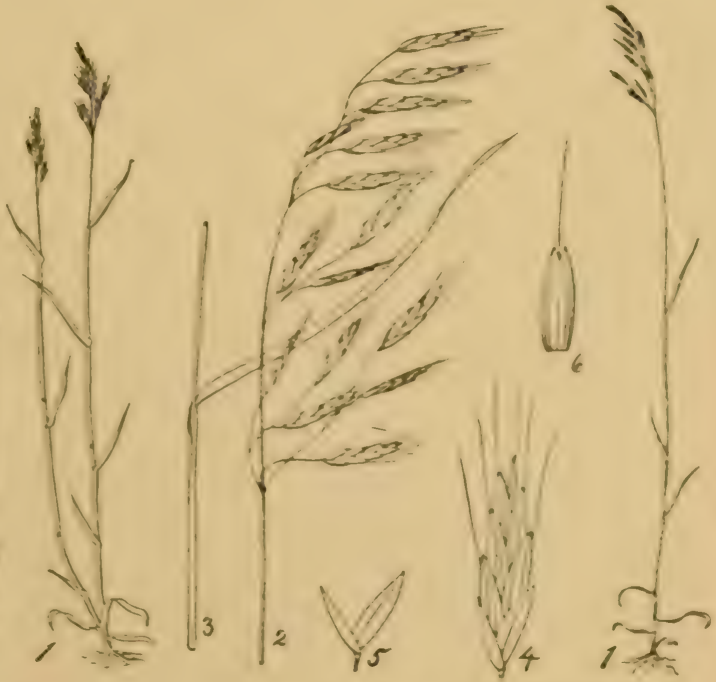

Fig. 172. Bromus racemosus.

2. Pantcle. :3. Lipper leaf. 4. Snlkelet 5. Empty glumes. 1i. Dorsal vlew of flow. ering glume. 

and is esteemed valuable for winter grazing. If grazed cirsely or frequently mowed, the roots will often live for several years, like those of a perennial grass.

Schrader's Brome-grass. Australian ()ats and Arctic-grass are other names for this Bromus.

\section{Tribe XII. HORUE.E.}

Spikelets one- to many-flowered, usually hermaphrodite, sessile along the common rachis, forming a simple or compound spike.* Glumes awned or awnless.

A small tribe of twenty genera and about one hundred and thirty species. It is an important division, however, for it includes rye, barley and the many varieties of wheat. English and Italian Rye-grasses (Lolium species) are the chief meadow grasses of the tribe.

\section{LOLIUM, Linn. Sp. Pl. 83 .}

Spikelets several-flowered, solitary and sessile in alternate notches of the continuous rachis, forming a slender spike, one edge of each spikelet placed against the rachis; rachilla articulated between the florets. Empty glumes at the base of the spikelet one ( $t$ wo in the terminal spikelet), on the side away from the rachis (exterior) shorter than or exceeding the florets. Flowering glumes rounded on the back, five- to seven-nerved, nerves converging above, apex obtuse, acute, or awned. Palea two keeled. Stamens three. Styles very short, distinct; stigmas plumose. Grain smooth, adherent to the palea. Annual or perennial grasses, with simple erect culms, flat leaves and simple terminal spikes.

Species six, in Europe, North America, and temperate Asia. Two, with several varieties, introduced into the United States.

\section{KEY TO THE SPECIES.}

r. Empty glumes as long as or exceeding the spikelet .

I. Empty glumes shorter than the spikelet 3. L. TEMULENTUM.

2. Flowering glumes awnless

2. Flowering glumes awned

I. L. PERENNE.

2. L. Italicum.

\section{Lolium perenne Linn. Perennial Rye-grass.}

Plate XLIV. Figure 175.

A smooth, leafy perennial, one to three feet high, with slender terminal spikes three to ten inches long. Spikelets about six lines long, five-to twelve-flowered, rather distant or crowded above; einpty glume much shorter than the spikelet: flowering glumes obscurely nerved, obtuse, cuspidate, or very short awnpointed.

*strictly speaking the splke is simple when the sesslle splkelets are one-flowered, and compound when more than one-flowered. 
Perennial Rye-grass is a native of the Old World, and has been cultivated in England for more than two hundred years. In moist cool climates it is a most excellent pasture grass for heavy soils. Under favorable conditions it will last for seven years or more. It is probably not so valuable a grass as the Italian Rye-grass, from which it differs in being distinctly stoloniferous, in its darkergreen leaves, which are simply folded (not rolled) in the bud, and in its awnless floral glumes.

\section{Lolium Italicum A. Br. Italian Rye-grass. \\ Plate XLIV. Figure 176.}

A biennial or perennial grass two to three feet high, with slender, usually somewhat nodding terminal spikes. Sheaths nearly smooth; ligule very short, scarious; leaf-blade four to eight inches long, two to three lines wide. Spikes six inches to nearly a foot long; spikelets five to eight lines long, six-to fifteen-flowered; flowering glumes scabrous near the summit, awned. Awn slender, about the length of the glume.

Introduced and cultivated to some extent. Italian Ray-or Ryegrass is an excellent grass for rich and rather moist lands. It is a very rapid grower, forms a dense turf, and in Europe is regarded as one of the best grasses for hay. On heavy clays or on any very dry soil it does not do so well, but on good calcareous loams or marls, or on moist loamy sands when the condition of the land is good, the yield is large.

\section{Lolium temulentum Linn. Bearded Darnel.}

Plate XLV. Figure 177.

An annual, with smooth stout culm, two to three feet high. Sheaths scabrous; ligule short. Spike six to twelve inches long. Spikelets five-to seven-flowered; empty glumes sharp-pointed, as long as the spikelet; flowering glumes turgid, awned or awnless, shorter and broader than in $L$. perenne.

In grain fields and waste places, not common. The grain of this species is narcotic in its effect upon man and flesh-eating animals.

59. AGROPYRUM Gaertn. Nov. Cormm. Petrop. I 4 , P. I., 539 ( 777 .)

Spikelets three to many-flowered, closely sessile, and single at each notch of a narrow terminal spike, the side of the spikelet placed next to the axis; rachilla articulated above the empty glumes under each flowering glume; flowering glumes rounded on the back, or slightly keeled above, five- to seven-nerved, acute or awned from the apex, rarely obtuse. Palea two-keeled, bristlyciliate on the keels. Grain pubescent at the apex, usually adherent to the palea.

Perennial grasses, with erect simple culms and terminal, often bearded spikes ("heads"). 


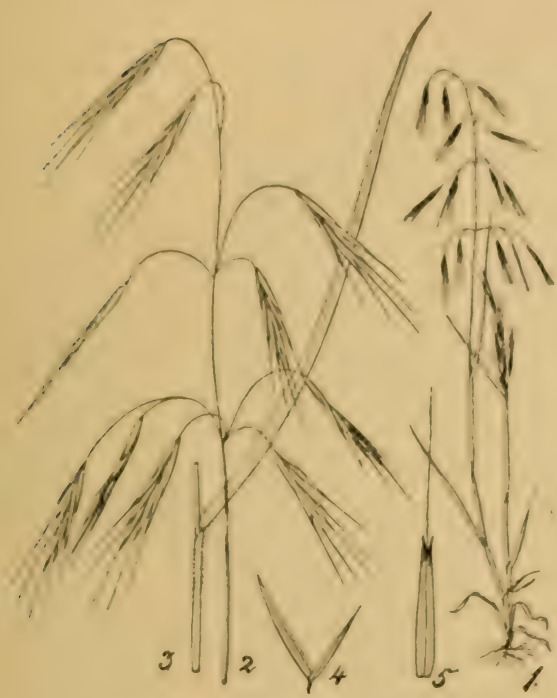

Fig. 173. Bromus sterilis.

2. Pantcle. 3. Upper leaf. 4. Empty glumes. 5. Flowering glume, dorsal vlew.

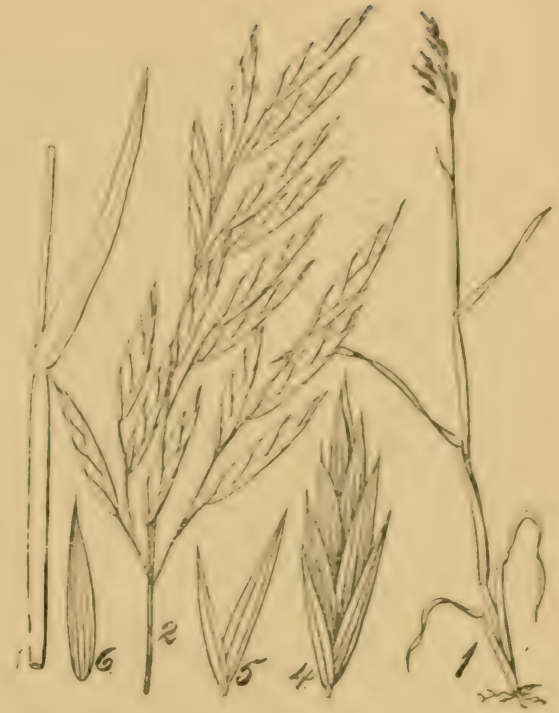

Fig. 174. Bromus unioloides.

2. Panicle. 3. I pper leaf. 4. Splkelet. 5. Empty glumes. 6. Flowering glume.

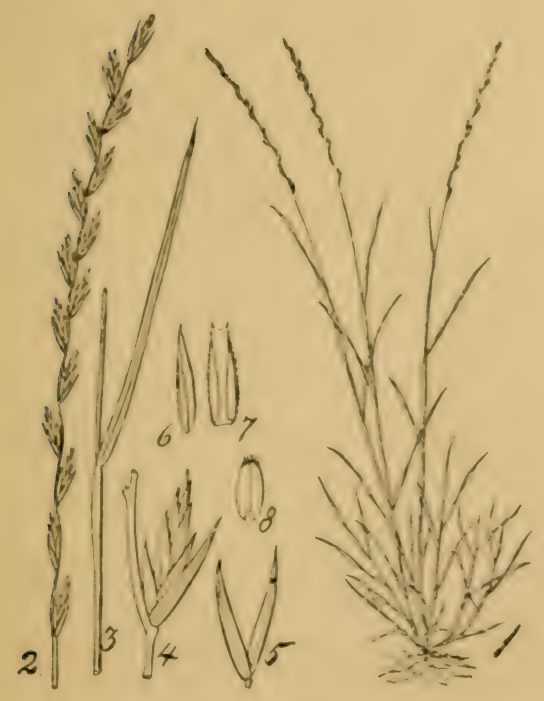

Fig. 17o. Lolium perenne.

2. Inflorescence-a splke. 3. Topper leaf. 4. Splkelet. With a portion of the rhachls. 5. Empty glumes of the terminal spikelet.

6. Floral glume. $\tau$. Palea. 8. Caryopsis.

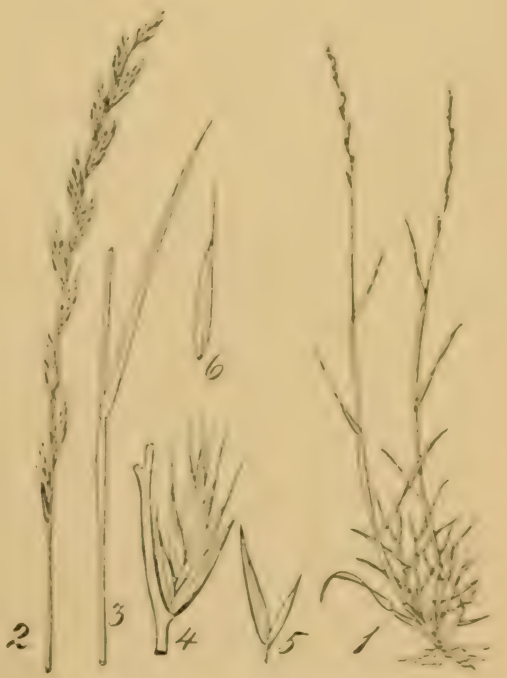

Fig. 176. Lolium Italicum.

2. Splke. 8. Upper leaf. 4. Lateral splkelet with a portion of the rhachis. 5. kmpty glumes of the terminal splkelet. 6 . Fioral glume. 

Species thirty-two, distributed throughout all temperate countries. Eight species, with several varieties, occur in the United States. Two of these are reported by Dr. (jattinger as being found in Tennessee.

v. Agropyrum repens Beauv. Couch grass or Witch-grass.

Plate XLV. Figure 178.

Culms one to three feet high, from an extensively creeping, jointed rootstock. Sheaths striate, usually smooth; ligule very short; leaves four to twelve inches long, smooth, scabrous, or sometimes pubescent above. Spikes three to ten inches long, erect. Spikelets four- to eight-flowered; empty glumes five- to seven-nerved, obtuse or notched, acute or short-awned; flowering glume nerved near the apex, awnless or sometimes short-awned.

Sparingly introduced in cultivated grounds. In some parts of the Eastern and Middle States it is abundant in open fields. It is a good grass for hay, but its strong creeping rhizomes, which spread rapidly in all directions, render it one of the worst weeds in cultivated lands, hardly less difficult to eradicate than Johnsongrass.

2. Agropyrum caninum Reichenb. Bearded Wheat.grass.

Plate XLV. Figure 179.

A rather slender grass, one to three feet high, with no creeping rootstock. Sheaths smooth, or the lower hairy; ligule short; leaf-blade flat, pubescent above, smooth below. Spikes more or less nodding, three to six inches long. Spikelets three- to sixflowered, the florets rather distant; empty glumes three-to fivenerved, acute or long-awned; flowering glumes nerved near the tip, with awns nearly twice their length.

This grass is recorded by Dr. Gatttinger as occurring within the State, but not frequent. It is more common in the Northern States, especially in the mountain districts. It differs from wheat in its more slender stems and perennial habit, and from Agropyrum repens in its strictly fibrous root and long-bearded spikelets.

\section{SECALE Linn. Gen. N. 97.}

Spikelets two-, rarely three-flowered, solitary and sessile at the notches of the rachis, forming a spike; rachilla produced above the florets into a slender stipe. Empty glumes two, rigid, narrow, acuminate or subaristate-pointed; flowering glumes broader, compressed-keeled, five-nerved, awned from the point; palea a little shorter than the glumes, two-keeled. Stamens three. Styles very short, distinct; stigmas plumose. Grain oblong. sulcate, pilose at the apex, free. Annual grasses with flat leaves and dense terminal spikes, the rachis of which is usually articulated.

Species two, in Europe and Asia. One, Rye (Secule cereale), known here in cultivation. 


\section{Secale cereale Linn. Rye.}

An annual grass, four to six feet high, with linear-lanceolate leaves and terminal, somewhat flattened, linear, bearded spikes four to six inches long. Culms simple, erect, hairy near the spike; sheaths striate, smooth; ligule short, dentate; leaf-blade smooth on the lower surface, scabrous on the upper surface and margins. Empty glumes linear-subulate, nearly equal, scabrous, bristlypilose at the base; flowering glumes ventricose, acuminate, compressed near the apex and terminating in a long, scabrous awn.

\section{TRITICUM Linn. Gen. N. 99.}

Spikelets two-to five-flowered, solitary and sessile at the joints of the rachis, forming dense terminal spikes; rachilla articulated between the florets; lower flowers in each spikelet hermaphrodite, the upper staminate or imperfect. Empty glumes at the base of the spikelet two, rigid, usually shorter and narrower than the flowering glumes, short-awned or awnless; flowering glumes oblong, ventricose or rounded on the back, sometimes keeled above, five- to nine-nerved, awned or awnless; palea two-keeled, keels ciliate. Stamens three. Styles very short; stigmas plumose. Grain ovoid or oblong, sulcate, hairy at the apex, free or adherent to the palea. Annual erect grasses with terminal cylindrical spikes.

Species (including the section Egilops) about fifteen, natives of the Old World.

\section{Triticum sativum Linn. Wheat.}

An annual, with terete simple culms two to five feet high. Leaves narrowly lanceolate, striate. usually scabrous on the upper surface. Sheaths striate, smooth; ligule short, truncate. Spike three to six inches long, dense, four-sided, axis compressed, rather broad, margins hirsute; spikelets broadly obtuse, three- to five-flowered; glumes ventricose obtuse, mucronate or awned.

This cereal is one of the most important members of the grass family. It presents many varieties based upon the presence or absence of awns, color of the chaff, hardness of the grain, etc. In Egyptian Wheat the ordinarily simple spike, which forms the "head," is compound or branched.

\section{HORDEUM Linn. Gen. N. 98.}

Spikelets one-flowered, two to three together at each joint of the rachis, sessile or on very short pedicels, forming a spike; rachilla articulated above the empty glumes and continued behind the palea into a naked bristle which sometimes bears the rudiment of a second floret. Lateral spikelets usually imperfect, and raised above the central one; empty glumes two, very narrow or subulate, rigid, persistent; flowering glumes lanceolate, rounded on the back, five-nerved above, awned; palea shorter than the glume, twokeeled. Stamens three. Styles very short, distinct. Ovary hairy at the top. Grain sulcate, adherent to the palea. 


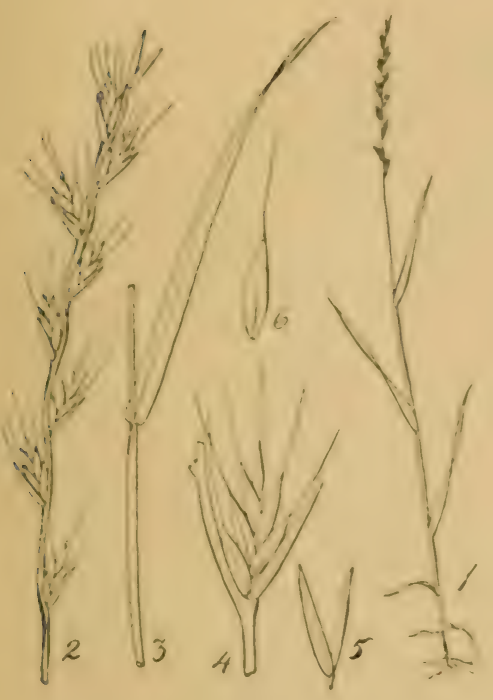

Fig. 177. Lolium temulentum.

2. Splke. 8. Upper leaf. 4. Splkelet. 5. Impty glumes of the terminal spikelet. 6. Flowerlug glume.

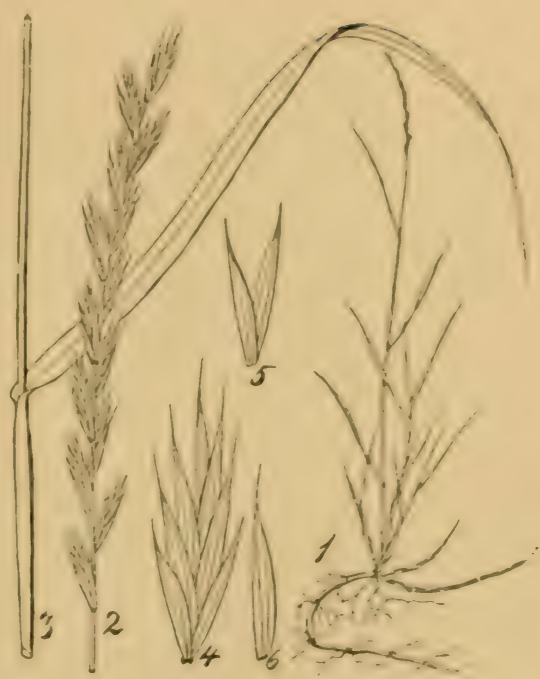

Fig. 178. Agropyrum repens.

2. Splke. 3. Upper leaf. 4. Splkelet. 3. Empty glumes. 6. Flowering glume.

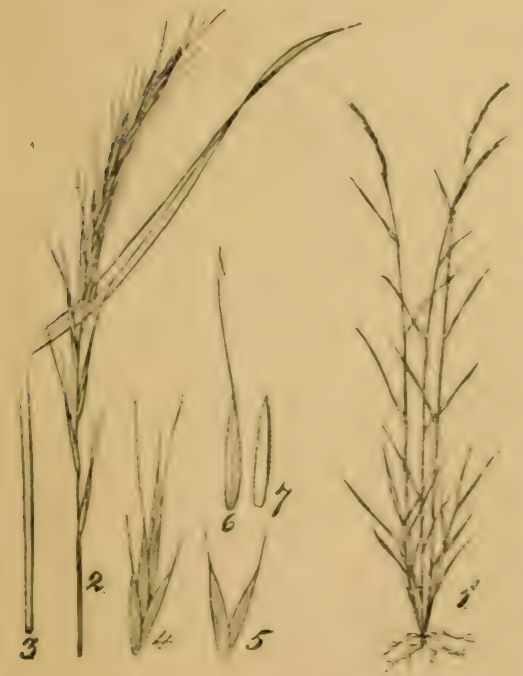

Fig. 179. Agropyrum caninum.

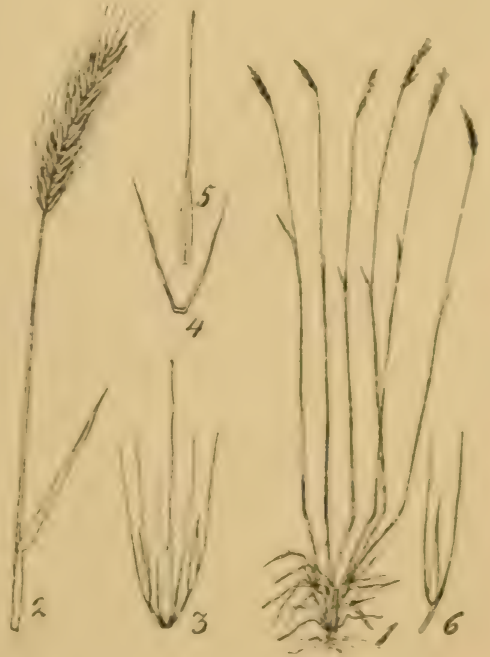

Fig. 180. Hordenm pratense.

2. Spike. 3. Upper leaf. 4. Spikelet. 5 Empty glumes. 6. Flowering glume. Palea.

2. Splke. 3. Cluster of splkelets. 4. Lowest pair of empty glumes. 5. Flowering glume. 6. Neutral splkelet. 

Annual or perennial grasses with terminal cylindrical spikes and awned spikelets. Species about sixteen, in both hemispheres.

\section{ז. Hordeum pratense Huds. Wild Barley.}

\section{Plate XLV. Figure 180.}

A slender grass, six to twenty-four inches high. with rather shirt, flat leaves, and narrow terminal spikes one to three inches long. Culm usually geniculate at the lower joints; sheaths and 'eaves smooth or pubescent. Empty glumes all setaceous; lateral splikelet:s imperfect, the awn-pointed florets pedicellate within their glumes; floret of the central spikelet perfect, cylindrical, three to four lines long. awned; awn three to six lines long. Rachis of the spike readily breaking up at the joints. Not uncommon on thin soils. May.

This grass has the habit of an annual, and is apparently of no agricultural value.

\section{Hordeum pusillum Nutt.}

Plate XLVI. Figure 181.

An annual four to ten inches high. Culms more or less geniculate at the lower nodes. Sheaths smooth, the uppermost often inflated and enclosing the base of the spike; leaf-blade one to three inches long, usually a little pubescent on the lower surface. Spikes narrow, one to three inches long. Empty glumes rigid, the four internal ones of each group dilated above the base, those of the central spikelet sublanceolate, all awn-pointed; outer glume of the imperfect lateral spikelets setaceous. Flowering glume of the central spikelet awned; awn about equalling those of the empty glumes. Florets of the lateral spikelets awnless, or nearly so.

In similar situations to the last, which it resembles, but from which it is readily distinguished by the dilated empty glumes.

\section{Hordeum vulgare Linn. Barley. Four-rowed Barley.}

Annual, two to three feet high, smonth. Leaves linear-lanceolate. keeled, nearly smooth; sheaths striate, smooth, auricled at the throat; ligule very short. Spikes three to four inches long, somewhat four-sided, rachis flattened, pubescent on the margins. Spikelets with one perfect floret: empty glumes narrowly linear, pubescent, terminating in a slender awn; flowering glume five-nerved, scabrous near the apex, long-awned; awn flattened, keeled, somewhat three-nerved, serrulate on the margins.

Cultivated chiefly for malt for brewing.

In Hordeum distichum, or Two-rowed Barley, the florets of the lateral spikelets are staminate or neuter, and awnless; the spikes linear and compressed.

\section{ELYMUS Linn. Sp. P1. 83 (1753).}

Spikelets two-to six-flowered, the uppermost imperfect, sessile, in pairs (rarely in threes or fours) at the alternate notches of the continuous or articulate rachis, forming terminal spikes: rachilla 
articulated above the empty glumes and between the florets. Lower empty glumes two, nearly equal, rigid, narrow, one- to three-nerved, acute or awn-pointed, persistent, and subtending the florets like an involucre. Flowering glumes shorter than the empty ones, rounded on the back, obscurely five-nerved, obtuse, acute or awned from the apex. Paleas a little shorter than the glumes, two-keeled. Stamens three; styles short; stigmas plumose. Ovary hairy at the apex. Grain adherent to the glumes and paleas.

Erect grasses with flat leaves and closely-flowered terminal spikes.

Species about twenty, in the temperate regions of the eastern and western hemispheres.

KEY TO THE SPECIES.

I. Glumes and axis of the spike smooth, empty glumes lanceolate, short-awned . . . . . . . I. E. Virginicus.

I. Glumes and axis of the spike not smooth; empty glumes awl-shaped or aristiform, rather long-awned . . . . .

2. Empty glumes and florets rough, with short stiff hairs; spike 4 to 9 incines long . . . . . . 2. E. Canadensis.

2. Empty glumes and florets pilose, with spreading hairs; spikes 2 to 4 inches long . . . . 3. E. Striatus.

r. Elymus Virginicus Linn. Virginia Lyme-grass.

Plate XLVI. Figure 182.

An erect, smooth grass, two to three feet high, with rigid terminal spikes which are often partly included in the upper leafsheath. Sheaths striate, smooth or hairy; ligule short; leaf-blade six to twelve inches long, two to four lines wide, acute, scabrous. Spikes three to five inches long, the rachis smooth or scabrous. Spikelets two- to three-flowered, smooth; empty glumes lanceolate, thick and rigid, strongly nerved, awn-pointed; flowering glumes lanceolate, rounded on the back, awned.

Along streams, in the borders of woods and thickets, common. July-August. This grass has the appearance of possessing some agricultural value, but it forms no turf, and by the time it blooms the lower leaves are all dead, and the stems rather hard.

2. Elymus Canadensis Linn. Canada Lyme-grass or Terrell-grass. Plate XLVI. Figure 183.

A rather stout, smooth grass, three to five feet high, with flat, green or glaucous, scabrous leaves, six to twelve inches long. Sheaths smooth. Spikes four to nine inches long, exserted, nodding; rachis hirsute. Spikelets mostly in pairs, three- to fiveflowered, with rigid glumes; empty glumes subulate, three- to fournerved at base, awn-pointed; flowering glumes rough-hairy or nearly smooth, usually long-awned.

Variety glaucifolius Gray, is glaucous throughout.

Frequent in low thickets along streams and in rich open woods. 


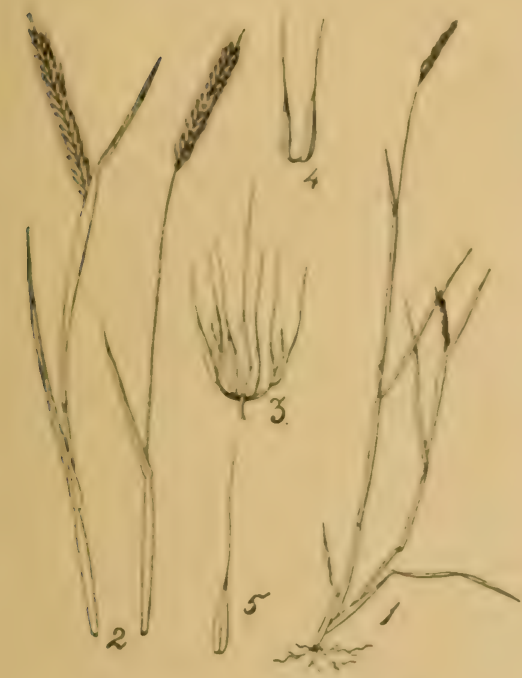

Fig. 181. Hordeum pusillam.

2. Upper portion of culm and splke-old and young. 8. Cluster of spikelets 4. Empty glumes of perfect floret. 5. Flowering glume.

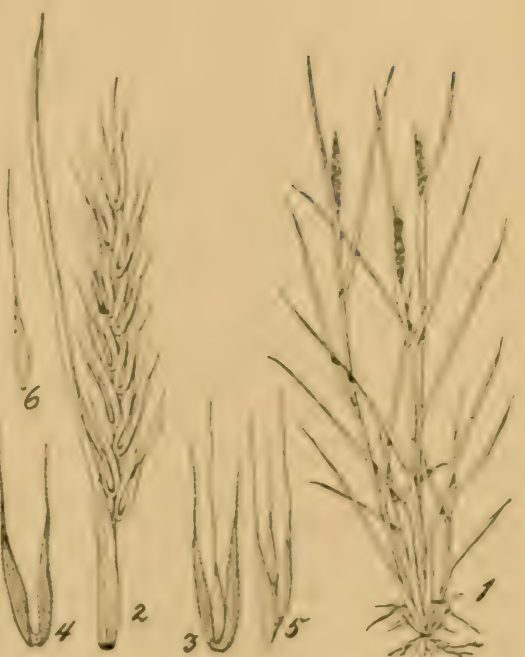

Fig. 182. Elymus Virginicus.

2 Upper leaf and splke. 2. splkelet. 4 Empty glumes. 5. Three florets. 6. Flowering glume, side vlew.

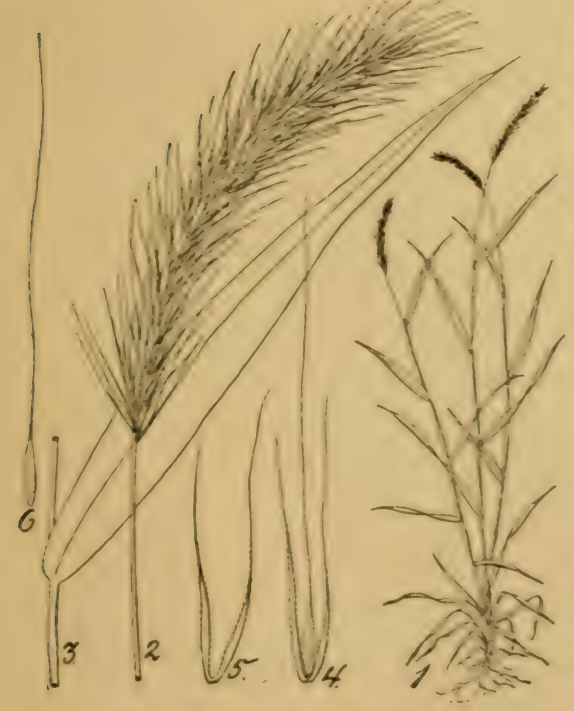

Fig. 188. Elymus Canadensis.

2. Inflorescence. 3. L'pper leaf t. Splkelet. 5. Empty glumes. 6. Flowering glume.

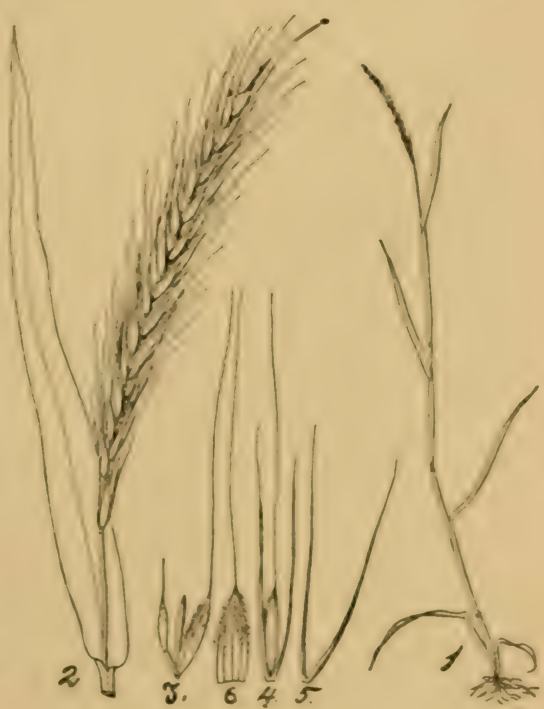

Flg. 184. Elymus striates.

2. Inflorescence and flowering leat a Florets of a sntkelet. 4. sptkelet. 3. Fmpty glumes. 6. Flowering glume, dorsal view. 

The heads resemble those of Rye, and for this reason the grass is often called "Wild Rye." It has no recognized agricultural value.

3. Elymus striatus Willd. Slender Lyme-grass.

Plate XLVI. Figure 184.

A slender grass, two to three feet high, with bristly, nodding spikes. Sheaths hairy, or the upper smooth; leaves six to eight inches long, pubescent on the upper surface, scabrous on margins. Spikes two to four inches long; rachis villous. Spikelets one- to threeflowered, pilose-hairy; empty glumes awl-shaped, awnpointed, one- to three-nerved, two to three times the length of the florets; flowering glumes three lines long, with slender awns about twelve lines long.

Var. villosus Gray has hairy glumes and villous sheaths. Thickets along streams, rather common. July-August.

\section{ASPRELLA Willd. Enum. I32 (1809).}

Spikelets two- to four-flowered, solitary or more often two to three together, raised on short, callus like pedicels at each joint of the continuous rachis of the terminal spike; rachilla articulated below each flowering glume. Empty glumes one or two, awn-like or bristle-form, usually present in the lower spikelets of each spike, much reduced or entirely wanting in the upper. Flowering glumes narrow, rigid, smooth, and rounded on the back, long-awned from the apex. Palea strongly two-keeled.

Perennials, with flat leaves and terminal, bearded spikes.

Species four, two North American and two of limited range in the Old World. Only one species occurs in Tennessee.

\section{Asprella Hystrix Willd. (Filymus Hystrix Linn.) Bottle-brush.}

Plate XLVII. Figure 185.

Culms three to four feet high, smooth. Sheaths smooth or minutely scabrous above, ligule very short, its edge shortly and finely fringed, leaf-blade five to ten inches long, three to eight lines wide, more or less scabrous. Spikes three to six inches long, the rachis much flattened and ciliate along the edges; the internodes about one-fourth of an inch long. Spikelets about one-half an inch long, at first erect, widely spreading in fruit. Empty glumes awn-like, usually present in the lower spikelets, which they sometimes equal in length. Awns of the flowering glumes about an inch long. Straight or sometimes divergent.

Rocky woods, thickets, and fence rows, over the State. JuneJuly.

Apparently of no agricultural value, for it never grows at any point in sufficient abundance to yield an appreciable amount of forage. Its returns from cultivation have yet to be determined by trial. 


\section{Tribe XIII. BAMBUSEA.}

Spikelets two-to many-flowered, (rarely only one-flowered) in racemes or panicles. Empty glumes at the base of the spikelet two to several; flowering glumes many-nerved, awnless or very rarely short-awned. Culms woody, at least near the base, and perennial; leaf-blade usually with a short petiole, articulated with the sheaths from which it finally separates.

A comparatively small tribe of twenty-three genera and about one hundred and eighty-five species. The species are confined chiefly to the regions within the tropics. Many of them are of very great importance to the natives of the countries where they grow, and manufactured articles of bamboo, either for use or for ornament, are now a part of the commerce of the world. The bamboos are remarkable for their woody stems and often arborescent or tree-like habit, some of the species being seventy-five to ninety feet high. In parts of India they form extensive forests. One species in this tribe has leaves four to fifteen feet long, by three to nine inches wide; another, a Cuban species, has leaves two to three inches long and as fine as a horse-nair. Fleshy and edible applelike fruits are found in this tribe.

\section{ARUNDINARIA Michx. Flor. Bor. Amer. i: 73 (1803).}

Spikelets two- to many-flowered, large, laterally compressed, in racemes or panicles; the rachilla articulated above the empty glumes and between the florets; flowers hermaphrodite or the upper imperfect. Lower empty glumes unequal, the first sometimes wanting; flowering glumes longer than the empty ones, keeled, many-nerved, acute or mucronate-pointed. Paleas as long as the glumes, prominently two-keeled. Lodicules three. Stamens three. Styles two or three; stigmas plumose. Grain oval or narrowly oblong, furrowed.

Tree-like or shrubby grasses, with perennial, simple or branched culms and flat leaves, which are shortly petiolate and articulated with the sheath.

Species about twenty, natives of Asia and America, two in the southern United States.' Several eastern species have been introduced into gardens and cultivated for ornament.

\section{Arundinaria gigantea Chapm. (A. macrosperma Michx.) Cane.}

Plate XLVII. Figure 186.

Culms perennial, fifteen to thirty-five feet high, with hirsute nodes, and numerous, usually fasciculate, flower-bearing branches. Sheaths shorter than the internodes, striate; ligule one to three lines long, lacerate-fimbriate; leaf-blades lanceolate, one to two inches wide, surfaces scabrous or pubescent beneath, margins serrulate. Panicles lateral, composed of a few simple racemes. Spike- 


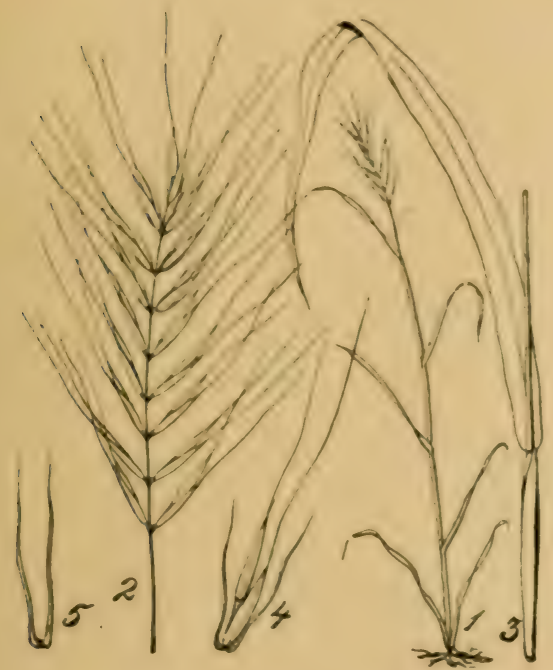

Fig. 185. Asprella Hystrix.

i. Inflorescence. 3. Upper leaf. 4. Splkelet. 5. Empty glumes.

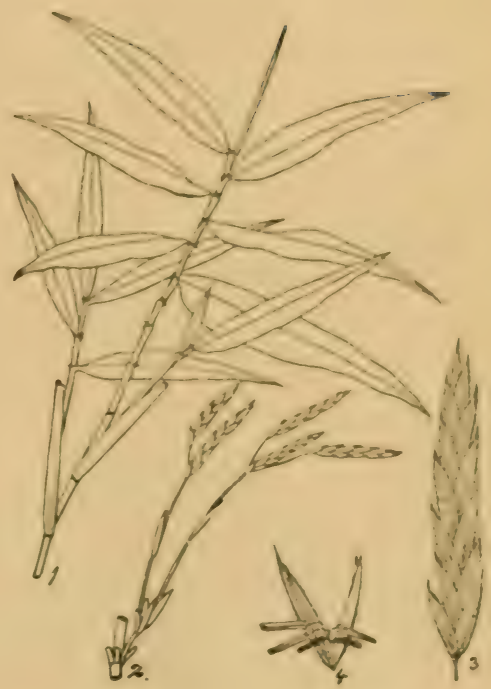

Fig. 186. Arundinarla macrosperma.

1. A Branch. 2. Portion of the Inflor. escence. 3. Splkelet. 4. Floret, showing floral glume, palea, stamens and pistil.

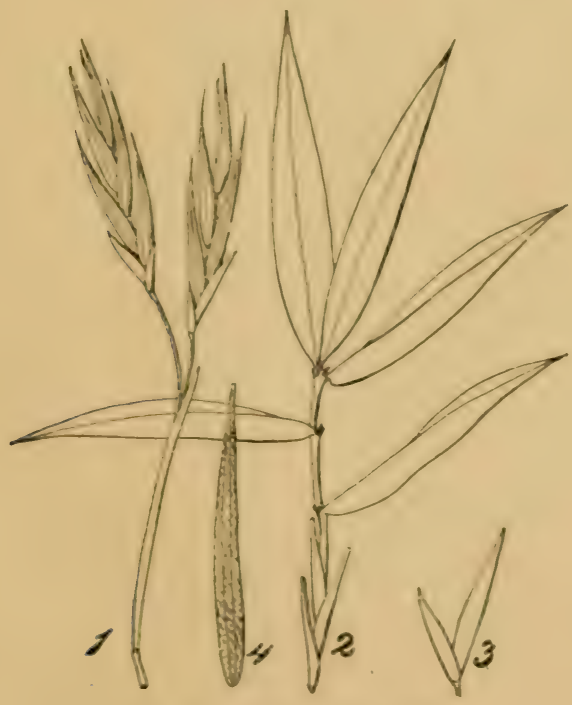

Fig. 187. Arundinaria tecta. 

lets lanceolate, one to three inches long, ten-to fifteen-flowered; lower empty glumes unequal, the first one to three, the second four to eight lines long: flowering glumes about eight lines long, nineto eleven-nerved, pubescent on the back, margins hirsute, awnpointed.

This is the largest of our grasses, and forms the well-known cane brakes of the South. The hard woody stems vary from onehalf an inch to nearly three inches in diameter at the base, and gradually taper to the summit. After blooming, the plants die, but at just what age they come into blonm is not known. All kinds of stock are fond of the young plants which grow up rapidly in rich soil, and in the winter months the leaves and young shoots afford a considerable amount of forage for grazing animals. Cane serves a great variety of purposes. It is used for fishing poles, scaffolding, blow-guns, pipe stems, water pipes, splints for baskets, chair-bottoms, mats, etc.

2. Arundinaria tecta Muhl. Small-cane. Switch-cane.

Plate XLVII. Figure 187.

Perennial, cespitose, three to fifteen feet high, glabrous, suffru. ticose, branching towards the summit, with terminal simple racemes. Sheaths longer than the internodes; ligule bristly; leaves lanceolate, flat pubescent beneath, four to twelve lines wide; racemes at the summit of the branches or frequently on leafless radical culms. Spikelets ten to fifteen lines long, seven- to tenflowered, on pubescent pedicels an inch long: empty glumes unequal, the first very small, slightly ciliate, flowering glume acuminate-pointed and slightly ciliate on the margins; palea shorter than its glume. Rarely found in bloom.

Arundinaria tecta has been treated by some authors as a variety of Arundinaria gigantea. Although possibly not specifically distinct, the two are found growing together under like conditions, and under these circumstances the one is readily distinguished from the other. Arundinaria tecta grows as far north as Maryland. 


\section{ABBREVIATIONS OF THE NAMES OF AUTHORS CITED.}

Adans. Adanson, Michel.

Anders. Andersson, Nils Johan.

Austin. Austin, Coe Finch.

Baldw. Baldwin, William.

Beauv. Palisot de Beauvois, A. M F. J.

Benth. Bentham, George.

Bernh. Bernhardi, Johann Jacob.

A. $B r$. Braun, Alexander.

R. Br. Brown, Robert.

Buckley. Buckley, S. B.

Chapmon. Chapman. "Alvan Wentworth.

D. C. De Candolle, Augustin Pyramus.

Ehrh. Ehrhart, Friedrich.

Ell. Elliott, Stephen.

Engelm. Engelmann, George.

Flugge. Flugge, Johann.

Gartn. Gærtner, Joseph.

Gaudin. Gaudin, Jean Francois Gottlieb Philippe.

Gr., Gray. Gray, Asa.

Hackl. Hackel, Eduard.

Huds. Hudson, William.

H. B. Humboldt, F. Alexander von, and Aime Bonpland.

H. B. . H. Humboldt, F. Alexander von, Aime Bonpland, and C. S. Kunth.

Jacq. Jacquin, Nicolaus Joseph.

Lag. Lagasca, Mariano.

Lam. Lamarck, J. B. A. P. Monnet.
Le Conte. Le Conte, John.

Leyss. Leysser, Friedrich Wilhelm. L., Linn. Linnæus, Carolus, or Carl von Linne.

Mey. Meyer, Errıst (Heinrich F.).

Michx. Michaux, Andre.

Muhl. Muhlenberg, Henry ( H. Ernst).

Nees. Nees von Esenbeck, Christian Gottfried.

Nutt. Nuttall, Thomas.

Pers. Persoon, Christian Hendrik.

Poir. Poiret, Jean Louis Marie.

Rafin. Rafinesque-Schmaltz, C. S.

Reichb. Reichenbach, H. G. L.

Rich. Richard, Louis Claude Marie.

$R . \& S$. Roemer, J. J., and Joseph August Schultes.

Schrad. Schrader, Heinrich A.

Schreb. Schreber, Johann C. D.

Schult. Schultes, Joseph August.

Scribn. Seribner, F. Lamson-

Spr. Sprengel, Kurt.

Smith. Smith, J. E.

Steud. Steudel, Ernst Gottlieb.

Sw., Swartz. Swartz, Olof.

Torr. Torrey, John.

Trin. Trinius, Karl Bernhard.

Tuckerm. Tuckerman, Edward.

$V$. Vasey, George.

Walt. Walter, Thomas.

Willd. Willdenow, Carl Ludwig.

With. Withering, William. 


\section{INIEX AND GLOSSARY OF TERMSS.}

The flgures in broad-faced type refer to the lllustrations.

Aculeolate. Prickly. Armed with F- small prickles.

Acuminate. Tapering to a point.

Acutiflora. Acute flowered.

Agropyrum. Greek, Field Wheat. 122. caninum Reichb., $179 \ldots 123$.

repens Beauv.. 178...123.

A + ROSTIDE E. 62 .

Agrostis. Greek, Of the fleld.

Agrostis. 74 .

alba Linn., $102 . .41,78$.

arachnoides Ell., 101...78.

canina $\operatorname{Linn}, 77$.

elata Trin., 96...75.

intermedia Scribn, 76 .

Novæe-Angliæ Tuckerm., 98...76.

perennans Tuckerm., $\mathbf{9 7 . . . 7 6 . ~}$

polymorpha Huds. 78.

rubra Linn. var. A mericana, 100 77.

rupestris Chapm., $100 . .77$.

scabra Willd., 99...77.

stolonifera, Linn., $103 . .79$.

vulgaris With. 78,79 .

Agrostoides. Like Agrostis.

Alba. White.

Albumen. The food material stored in the grain or seed, sometimes in the cotyledons of the embryo, for the nourishment of the plant during germination.

Alopecuroides. Like Fox-tail.

Alopecurus. Greek, Fox-tail. 70. geniculatus Linn., $89 . .71$. pratensis Linn., $\rightarrow$...70.

Alsodes. Growing in woods. Altissimum. Tallest.

Anceps. Two-edged.

A NDROPOCONE.E. 16.

Andropogon. Greek, A man's beard. 2).

argyræus Schult., 8...23.

avenaceus Wichx. 27.

Elliottii Chapm.. 9...24.

Hallii Hackl. 23.

macrourus Vichx, $1 \mathbf{1}, 26$.

nutans Limn., $12 . .26$.

provincialis, Lam., 7...22.

provincialis var. Tennesseensis Scribn. 23.

scoparius Mich $x, \boldsymbol{6} \ldots 21$.

Sorghum Halepense Hackl., 1 \&... 27.
Andropogon unilateralis. 27.

Virginieus Linn., 10...16, 25.

Angustifolium. Narrow-leaved.

Annua. Annual.

Annual. Lasting but one year, or a single season. Monocarpicfruiting but once.

Anther. The part of the stamen containing the pollen. In grasses the anthers, at maturity, are two-celled and are attached to the slender filaments either at one end, when they are basifised, or near the middle, when they are versatile.

Anthoxanthum. Greek, Yellow flower 62 .

odoratum, Linn., >1..61.

Apiculate. Ending in a short-pointed tip.

Appressed. Lying close to, or flat against some other body.

Aquatic. Applied to plants growing in water.

Aquatica. Aquatic.

Arachnifera. Bearing a spider webreferring to the web-covered Howers in Poa arachnifera.

Arachnoides. Cobweb-like.

Arenarium. Of sandy soil. Growing in sand $y$ soils.

Argenteum, Silvery.

Argyraus. Silvery.

Aristatum. Awned.

Aristida. Latin, Bearded or awned. 63.

dichotoma Michx., $\mathbf{7}$ \&...64.

gracilis Ell., z 1...64.

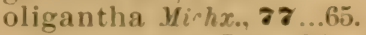

purpurascens Poir.. $\mathbf{7 5 . . 6 4 . 6 4 . ~}$

ramosissima Engelm., $\mathbf{7} \mathbf{2}$...63.

stricta Michx, $\mathbf{7 6}$...65.

Arrhenatherum. Greek. From arrhen, male, ather a point; the staminate florets awned. 83.

avenaceum $R$. \& S., 11...83.

elatius Beauv., 11...83.

Articulated. Jointed, or breaking up into joints.

Arundinacea. Reed-like. Arundo-a reed.

Arundinaria. (Cane.) Latin, a reed. 128. 
Arundinaria gigantea Chapm., $186 \ldots$ 128.

macrosperma Michx., 186...128.

tecta Muhl., 187...129.

Arundo. Latin, a reed. 92.

Donax Linn. 93.

Asper. Rough.

Asprella. Latin, Diminutive of asper. 127.

Hystrix Willd., 185...127.

Auricle. An ear-shaped appendage.

Auricled or Auriculate. Furnished with auricles.

Autumnale. Autumnal.

Avenacea. Oat-like.

AVENEÆ. 80.

Avena. Latin, Oats. 82.

fatua Linn. 83.

mollis Michx. 100.

sativa Linn., 110...83.

strigosa Schreb. 83.

Awn. A bristle-like appendage. Bearded wheat is awned wheat; in beardless wheats the awns are absent. The awns may be straight, or variously bent and twisted; they may be terminal, produced from the apex of the glumes, or they may spring from the back of the glume, when they are said to be dorsal.

Awned. Furnished with awns.

Awnless. Without awns.

BAMBUSE 128.

Barbata. Barbate, bearded.

Barbate. Furnished with rigid, usually reflexed points or short bristles. Bearded.

Barbellate. Minutely bearded.

Barbulatum. Latin, barbellate.

Barley. 125.

Four-rowed. 125.

Two-rowed. 125.

Wild. $180 \ldots 125$.

Barnyard-grass. 29...39, 40.

Bearded. Awned. Furnished with long stiff hairs.

Bearded Darnel. 17z ...122.

Bearded Short-husk. $86 \ldots 69$.

Bearded Wheat-grass. 179...123.

Beard-grass. 75...64.

Naked. $117 \ldots 88$.

Silver. 8...23.

Bent-grass, Reed. 105...80.

Bermuda-grass. $115 . .86$.

Bicarinate. Two-keeled.

Bicuspidate. With two sharp and rigid points.

Bifid. Divided into two lobes. Twocleft.

Bimucronate. Tipped with two short and sharp teeth or points.

Biseriate. Two-rowed, in two series.

Black Oat-grass. 78...65.
Blue Grama. 118...89.

Blue-grass. $113 . .107$.

English. 14:...107.

Kentucky. 11...108.

Texas. 151 ...110.

Woodland. I: ...109.

Blue Joint. 101...79.

Blue-stem, Big. 22.

Little. 21.

Bottle-brush. 185...127.

Bouteloua. From C. Bouteloua, a Spanish author. 89.

curtipendula Torr., 119...89.

oligostachya Torr., $18 . . .89$.

Brachyelytrum. Greek, Short husk. 69.

aristatum Beauv., 86...69.

Bract. A more or less modified leaf or leaf-sheath subtending the panicle branches, the spikelets or the flowers. The empty and floral glumes are bracts.

Brevibarbis. Short-haired.

Brevifolius. Short-leaved.

Briza. Greek, To nod, 103. maxima Linn. 103.

media Linn. 103.

minor Linn. 103.

Broad-leaved Uniola. 189...102.

Brome-grass, Fringed. 167, 168...118. Hungarian. $169 . .118$.

Bromus. Greek, Food. 117.

ciliatus Linn., 167, 168...113.

ciliatus Linn., var. purgans Gray. 118.

erectus Huds., 119.

inermis Leyss., $\mathbf{1 6 9}$...118.

mollis Linn., 171 ...119.

racemosus Linn., $17 \cdot . . .120$.

secalinus Linn., 170 ...119.

sterilis Linn., $178 \ldots 120$.

unioloides $H$. B. $K_{0}, 171 \ldots 120$.

Brook-grass. $11 . .26$.

Broom-sedge. 10...25.

Bur-grass. 65...57.

Cærulescens. Bluish.

Calamagrostis. Greek, Reed-grass, 79

Canadensis Beauv., I01...79.

Nuttalliana Steud., 105...80.

Callus. The projection or extension of the rachilla or axis of the spikelet below the point of attachment of the glumes.

Campestre. Growing in fields.

Canada Lyme-grass. 18:...126.

Canary-grass. $69 . .61$.

Reed. 70...62.

Cane. $186 \ldots 128$.

Canina. Canine, from Canis, a dog.

Capillare. Hair-like.

Capillaris. Capillary. Hair-like. Slender or fine as a hair.

Capillary. Hair-like. Said of a panicle when the branches are hair-like in fineness. 
Capitate. Head-shaped. In a dense globular or nearly globular cluster. 1:32.

Capsule. A dry fruit which naturally breaks open in some deflnite manner.

Carinate. Keeled.

Carpet-grass. 2a...31.

Cartilaginous. Gristly, flrm in texture but flexible.

Caryopsis. A seed-like fruit, as the grain of grasses, in which the thin pericarp is adnate or grown to the seed.

Cat-tuil Millet. 58.

Cenchrus. Greek, Ancient name of millet. 57.

tribuloides Linn., $65 . .57$.

Ceratochloa australis spr., $17 \mathbf{1}$...120.

Cespitose, or Crespitose. Having many stems growing from the same root, forming a tuft or tussock.

Chartaceous. Like writing-paper in texture.

Cheat. $170 \ldots 119$.

C'hess. 170 ...119.

Roft. 171 ...119.

CHLORIDEA. 86.

Chloris. Greek, Green. 87. barbata. 88 .

elegans. 88.

verticillata $\mathrm{Nutt} .88$.

Chrysopogon nutans Benth. 27.

Ciliate. Fringed with hairs.

Ciliatifolium. Ciliate-leaved.

Ciliatus. Ciliate.

Ciliolate. Minutely ciliate.

Cinna. Greek, Ancient name for grass. 73.

arundinacea $\operatorname{Linn} ., 9 \mathbf{1}$...73.

pendula Trin., $\mathbf{2 . 5}$...74.

Clandestinum. Hidden or concealed.

Cleft. Bplit or divided less than half way to the base.

Cleistogamic, Cleistogamous. Fertilized in the bud, without the opening of the flower. Concealed fertilization.

Column. Applied to the lower, twisted portion of the awn in Andropogonere.

Comb-grass, Meadow. 121...98.

Communis. Common.

Compound. Branched more than once.

Compressa. Compressum. Compressed. Flattened.

Conduplicate. Doubled or folded lengthwise so that the sides are applied face to face like a folded sheet of paper.

Connate. United or grown together, as where the bases of two opposite leaves are united around the stem. so that it apyeara to pass through them.

Continuous. Not articulated or jointed; not breaking up into joints.

Contortus. 'Twisted.

Convolute. Rolled up from the margins.

Cordate. Heart-shaped.

Cord-grass, Fresh-water. $116 . .87$.

Coriaceous. Isather-like in texture.

('ornucupia perennans. 76.

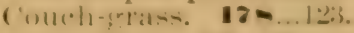

Crab-grass, $\mathbf{2 6} 6.38$.

ilencler. 2\$...39.

finooth. 27 ...39.

s̀prouting. $\mathbf{a t 6 . . 4 3 .}$

Creeping Fescue. 115.

Creeping Meadow-grass. 1:2:..95.

Crested Ioy's-tail. 105.

Cristatus. Crested.

Crowfoot. 91.

Crowfoot-grass. 1:20...90.

Crus-galli. Cock's-foot.

Cuneate. Wedge-shaped.

Curtipendula. Shortly pendent.

Cuspidate. Pointed. Ending in a sharp stiff point.

Cut-grass, Large. $66 . .60$.

Rice. 67...60).

Cynodon. Greek, Dog-tuoth. sti.

Dactylon Pers., $11.5 . .86$.

Cynosuroides. Cynosurus-like.

Cynosurus. Greek, Dog-tail. 104.

cristatus Linn., $10 \%$.

Dactylis. Greek. A finger. 103. glomerata Linn., $1 \mathbf{1 0 . . 1 0 4 .}$

Dactyloctenium. Greek, Finger-comb. (4).

Egyptiacum Willd.. 91.

Dactyloides. Finger-like.

Dactylon. Digitate.

Danthonia. After Danthoine, a French botanist. 84 . compressa Austin, $111 . .85$. sericea $\mathrm{Nuth.,1 \mathbf {1 } \mathbf { 1 } . . 8 1 .}$ spicata Beauv., 11:...85.

Darnel, Bearded. 177...12*2.

Debile. Weak.

Decumbens. Decumbent.

Decumbent. Reclining. Applied to stems when they recline upon the surface of the earth, but have the apex ascending.

Decurrent. Continued downward, as the sides of a leaf may be continued down the stent.

Deflexed. Bent or directed downward.

Dentate. Furnished with teeth. Toothed.

Denticulate. Minutels toothed.

Depauperatum. Impoverished.

Deschampsia. After Deschamps, a French botanist. 81 . 
Deschampsia flexuosa Trin., 107...81.

Diarrhena. Greek, Twice male-stamens two. 101.

Americana Beuuv., $187 . . .101$.

Dichotoma. Dichotomous. Dichotomum. Forked. Twice-branched.

Diffusa. Diffuse. Diffusum. Spreading, or loosely and widely expanded.

Digitate. Radiating from a common point, or like the fingers on the hand.

Dilatatum. Expanded or dilated; usually broadened and becoming leaf-like.

Diœeious. Said of plants having staminate and pistillate flowers which are borne upon separate individuals.

Distichous. Distichum. Two-ranked. In pairs. Arranged in twos, or in two rows on opposite sides of a common axis.

Divergent. Spreadingwidely. When like parts incline very much away from each other. Diverging.

Dog's-tail, Crested. 105.

Drop-seed, Mexican. \$8...68.

Eatonia. After Eaton, an American botanist. 98 .

Dudleyi Vase!.. $135 . .100$.

filiformis Vasey. 1:52...99.

obtusata Gro\%. $181 . .100$.

Pennsylvanica Gray. 183...99.

Elata. Tall.

Elatior. Taller.

Elatius. Tall.

Elegans. Elegant. Beautiful.

Eleusine. 90.

Indica Goertn. $\quad 120 . .90$.

Elliptical. Oval or in the form of an ellipse.

Elongata. Elongatum. Elongated. Extended or lengthened out.

Elymus. Greek, Rolled up, or enveloped. 125.

Canadensis Linn., 18:...126.

Canadensis Jinn., var. glaucifolius, Gray. 126.

Hystrix Linn., $\mathbf{8 5 . . . 1 2 7 . ~}$

striatus Willd., 181...127.

striatus Willd. var. villosus. 127.

Virginicus Linn., $182 . .126$.

Emarginate. Slightly notched at the summit.

Embryo. The young plant as it exists in the seed.

English Blue-grass. 18 ...107.

Eragrostis. Greek, Lovely grass. 94. capillaris Nees., $128 . .96$.

Frankii Meyer., 125...96.

major Host., $121 . .97$.

minor Host., 97.
Eragrostis oxylepis Trrr., $180 . . .97$.

pectinacea Gray., 131...98.

pilosa Beauv., 127...96.

Purshii Schrad., 126...96, 97.

reptans Nees., $123 . . .95$.

tenuis Gray., 129...98.

Erianthus. Greek, Wool flower. 17. alopecuroides Ell., $\mathbf{5} . .19$.

brevibarbis Michx., $\mathbf{3}$...18, 20.

contortus Ell., 4 ...19.

strictus Baldwo, 9...18.

Euchlæna. 13.

luxurians. 13.

Mexicana Schrad. 13.

Eulalia Japonica Trin. 16.

Evanescent. Disappearing, applied to veins which do not reach the margins.

Evergreen-grass. 111...83.

Excurrent. Projecting, or running out beyond.

False. Appearing like something which it is not.

Red-top. $122 . .94$.

Fasciculate. In bundles originating from or near the same point.

Feather-grass. 121...91.

Fescue, Creeping. 115.

Meadow. $162 . .116$.

Nodding. r66...117.

Red. 115.

Sheep's. 160 ...115.

Short's. $165 . .116$.

Slender. $158 . .114$.

Tennessee. 161...115.

Festuce E. 91.

Festuca. Latin, Stalk, straw. Ancient name of some kind of grass. 113.

arundinacea Schreb. 116.

elatior Linn., $162 . .116$.

elatior Linn. var. arundinacea. $161 . .116$.

elatior Linn. var. pratensis, $\mathbf{1 6 3}$ ...116.

Myurus Linn., $159 \ldots 115$.

nutans Willd., 166...117.

ovina Linn., $160 . .115$.

pratensis Huds. 116.

rubra Linn., var. glaucescens Hackl., 161...115.

Shortii Wood., 16.5...116.

tenella Willd., $158 . .114$.

Filament. In grasses, the threadlike stalk which supports the anthers.

Filiform. Thread-like.

Filiforme, Filiformis. Thread-like. Fimbriated. Fringed.

Flavescens. Yellow. Yellowish.

Flexile. Easily bent, but elastic. Flexible.

Flexuosa. Flexuose.

Flexuose. Wavy or bending gradually in opposite directions. 
Floating Foxtail. $\$ 9 . .71$.

Floret. Each flower of a spikelet, together with its subtending glume and palea, is called a floret.

Fluituns. Floating.

Fly-away-grass, 99 ...77.

Foliaceous, Leaf-like.

Four-rowed Barley, 125.

Fowl Meadow-grass, 153...112.

Foxtail, Floating. $\$ \mathbf{9 0 . . 7 1 . ~}$

Green, 63: 56

Marsh. $\boldsymbol{- 0 . . . 7 1}$

Meadow. $8-. . .70$.

Yellow. 62...56.

Fresh-water Cord-grass. $116 \ldots 87$.

Fringed Brome-grass. 118.

Fusiform. Spindle-shaped.

Gama. 16.

freniculate. Bent like a bent knee.

Geniculatus. Kneed, bent at the nodes.

German Millet. 56.

Gibbous. Swollen or enlarged on one side.

Gibbum. See gibbous.

Gigantea. Gigantic.

Glabrum. Glabrous, a surface destitute of pubescence. Smooth.

Glandular. Gland-bearing; also gland-like.

Glauca. See glaucous.

Glaucescens. Somewhat glaucous.

Glaucifolius. Glaucous-leaved.

Glaucous. Covered or whitened with a bloom. Pale-bluish or greenish - white.

Globose. Spherical. Round like a ball.

Glomerata. Glomerate.

Glomerate. Heaped up. Densely clustered in small heaps, or in irregular heads.

Glume. The usually chaff-like bracts of a spikelet which simply subtend one another-empty glumes; or bearing flowers in their axils - flowering glumes.

Glyceria. Greek, Sweet. 111.

acutiflora Torr., 157 ...113.

aquatica Sm., 152...112.

elongata Trin., 151...112.

fluitans $R . B r ., 156 \ldots 113$.

nervata Trin., 1.53...112.

pallida Trin., $155 \ldots 113$.

Golden Millet. 61...56.

Gracilis. Graceful. Slender.

Grama. Blue. 118...89. Tall. $119 . .89$.

Green Foxtail. 63...56.

Guatemala-grass. 13.

Grmnopogon. Greek, Naked Beard. 88. brevifolius Trin. 89.
Gymnopogon racemosus Beauv, kr.

Gynerium. Greek, from gyne, female, and erion, wool-the female florets are woolly. 92.

argenteum Nees. 92.

Hair-grass, $107 . .81$.

Hairy-flowered Paspalum. 18...32.

Halepense, From Aleppo, a city of Ayria.

Hedgehog-grass $\mathbf{6 5}$...57.

Herbaceous. Used in contra-distinction to woody. Having the color and texture of a leafgreen and somewhat succulent.

Herd's-grass. $10 \% 2.78$

Herd's-grass, New England. $\boldsymbol{- \gamma}$....70.

Hermaphrodite. Said of flowers which contain both stamens and pistils.

Heterogamous. Flowers of more than one kind, differing in sex.

Heterophyllæ. Dissimilar leaves. Bearing leaves of more than one kind or shape.

Hians. Gaping.

Holcus. Greek, To extract. lanatus Linn., $106 . .81$.

Homophyllæ. Leaves of one kind. Bearing leaves all of one kind or shape.

HORDE.E. 121.

Hordeum. The ancient Latin name for Barley. 124.

distichum. 125 .

pratense Huds. 1 $00 . .125$.

pusillum Nutt, 1-1...125.

vulgare Linn., 125.

Hungarian Brome-grass. $169 . .118$. II illet. 56.

Hyaline. Transparent.

Imbricate. Overlapping, like the shingles on a roof or the scales on a fish.

Indian Corn. 15.

Indian-grass. 26.

Reed-grass. \$ 1 ...73.

Rice. 58.

Indicus. Indian.

Indurated. Hardened.

Inermis. Awnless.

Inflorescence. The arrangement of the flowers; or in grasses the spikelets upon the stem.

Intermedia. Intermediate, standing between.

Internode. The portion of the stem, culm or axis between two nodes.

Involucre. Bracts or other protective organs surrounding a flower, or group of flowers.

Italian Millet. 61...56.

Rye-grass. $176 \ldots 122$. 
Italicum. Italian.

Johnson-grass. $27,28$.

Keeled. Having a keel or central ridge.

Kentucky Blue-grass. 1M...108.

Knot-grass. 24...31.

Lrve. Smooth.

Lanatus. Woolly.

Lanceolate. Shaped like the head - of a spear or lance.

Lanuginosum. Woolly or downy. Clothed with a fine, soft, matted pubescence.

Large Cut-grass. $\mathbf{6 6} . . .60$.

Latifolia. Broad-leaved.

Lax. Loose, not compact.

Laxiflorum. Loosely-flowered.

Leersia. After Leers, a German botanist. 59.

lenticularis Michx., 66...60.

oryzoides $\$$ w., $67 . .60$.

Virginica Willd., 68...59.

Lenticular. Lenticularis. Having the form of a double convexlens

Leptochloa. Greek, Slender grass. 91. mucronata Kunth, 121.. 91.

Ligule. A prolongation from the inner side of the leaf-sheath where the latter joins the blade.

Line. One-twelfth of an inch.

Linear. Narrow, many times longer than broad, with nearly parallel sides.

Lodicules. Small and delicate scales at the base of the flower, which serve to separate the flowering glume and palea during the period of bloom.

Lolium. Ancient Latin name. 121. Italicum A. Br., $176 \ldots 122$ perenne Linn., 175...121. temulentum Linn., 178...122.

Longifolia. Long-leaved.

Longipedunculatum. Long peduncled, or long stalked.

Long-Ieaved Spike-grass.. 102.

Louisiana-grass. $\mathbf{2 5}$...31.

Low Spear-grass. 141...106.

Luxurians. Luxuriant.

Lyme-grass, Canada. $188 . . .126$.

Slender. 184...127.

Virginia. 182...126.

Macrospermum. Large-seeded.

Macrourus. Large-tailed.

Mais de Coyote. 14, 15.

Maize. 15.

Major. Larger.

Manna-grass. 156...113.

Marsh Foxtail. 89...71.

Maxima. Largest.

MAYDEA. 13.

Mays. From maiz or mahiz, the native name of Indian Corn.
Media. Intermediate in size.

Meadow Comb-grass. 181...98. Fescue. 162...116.

Foxtail. 88...70.

Meadow-grass, Creeping. 128...95.

Fowl: 15:...112.

Reed. 152...112.

Rough. 145...108.

Short-stalked. $\mathbf{1 2 5}$...96.

Slender. 128 ...96.

Oat-grass. 111...83.

Melica. An old name. Italian, from mel, honey. 100.

Melica diffusa Pursh. 101. mutica Walt.,..186...101.

Membranaceous. Like a membrane, thin and flexible, aud usually translucent.

Membranaceum. Membranous.

Mexican Drop-seed. 83...68.

Microcarpon. Small-fruited.

Millet, Cat-tail. 58

German. 56.

Golden. 61...56.

Hungarian. 56.

Italian. 64. 56 .

Pearl. 58.

Wild. 68...56.

Minimum. Smallest.

Miscanthus. 16.

Sinensis Anders. 16.

Molle. Soft.

Monocarpic. Fruiting but once.

Monøeious. Plants with the stamens and pistils in separate flowers but on the same individual.

Mountain Oat-grass. $114 . .85$.

Mountain-sedge. 21.

Mucro. An abrupt, short, sharp point.

Mucronata. Mucronate.

Mucronate. Mucronatum. Tipped with a short, sharp, rigid and abrupt point.

Muhlenbergia. After Muhlenberg, an American botanist. 66 .

capillaris Kunth, $\mathbf{7 9}$...67.

diffusa Schreb., 80...67.

glomerata Trin., 81...67.

Mexicana Trin., 8s ...68.

sobolifera Trin., 82...67.

sylvatica Torr., and Gray. 84...69.

Willdenovii Trin., 85...68.

Munro-grass. 83...41.

Mutica. Awnless.

Naked Beard-grass. 117...88.

Nervata. Nerved.

Nerves. The ribs or veins of leaves, glumes, etc.

Neuranthum. Nerved flowers. Outer glumes of the spikelet nerved.

Neuter. Having no sex. Being without either stamens or pistils. 
Nimble Will. $\boldsymbol{\infty}$...65\%.

Nitidum. Shining or glossy.

Nodding Fescue. 166...117.

Node. In grasses the point of the stem from which originate the leaf-sheaths and branches. The limits of the internodes. The swelling at the nodes may be in thestem itself or in the basal portion of the leaf-sheath.

Nodiflorum. Flowering or flowerbearing at the nodes.

Novæ-Anglix. New England.

Nutans. Nodding.

Oat-grass, Black. 7×...65.

Meadow. 111...83.

Mountain. $111 . .85$.

Silky. 112...81.

Wild. $113 . .85$.

Yellow. 82.

Oats. $110 . .83$.

Oblong. Longer than broad with the sides nearly parallel.

Obovate. Inverted egg-shaped, the point of attachment being at the narrower end of the ovate form.

Obtusata. Obtuse.

Odoratum. Fragrant.

Officinarum. Of an officinal character. Officinal.

Officinal. Applied to plants used in medicine or the arts.

Old Witch-grass.

Oligantha. Few-flowered.

Oligostachya. Few-spiked.

Orehard-grass. 1...104.

Oryza. 58.

sativa Linn. 59.

ORYZEA. 58.

Oryzoides. Rice-like.

Ovary. The lower portion of the pistil which contains the seed.

Ovate. Egg-shaped.

Ovatum. Ovate or egg-shaped.

Oxylepis. Sharp scale, referring to the very acute or sharp-pointed glumes-Eragrostis oxylepis.

Palea. The prophyllum of the flowering branch of a spikelet. The palea is usually two-keeled, with its back toward the rachilla in several - flowered spikelets, or opposed to the second glume in one-flowered spikelets.

Pallida. Pale.

Palustre. Marshy. Growing in marshy places.

Pampas-grass. 92.

PANICACE.A. 13.

PANICEE. 28.

Panicle. A loose and more or less hranched inflorescence. with pedicellate flowers or spikelets.

Paniculate. In a panicle.

Panicum. The Latin name. 36. agrostoides Muhl., ass...41.

agrostoides var. elougatum. 42.

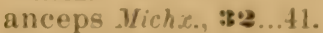
angustifolium Ell., 17, 1*...48.

autumnale, Bosc. 44.

barbulatum Mirhx., 53, ist.

capillare Linn., $\boldsymbol{* 7 . . . 4 3 .}$

capillare var. campestre Gatt., :5 ...44.

capillare var. geniculatum Scribn. 4 .

capillare var. minimum. s9...44. ciliatum Ell., $\mathbf{5} 4 \mathbf{b} . .51$.

clandestinum Linn., $183 . .46$.

clandestinum var. pedunculatum A. Grul, 46 .

colonum Linn., :BO...40.

commutatum Schul., 50...49, 54 .

consanguineum. $17, \mathbf{1 0 . . . 4 8 .}$

crus-galli Linn., -29...39, 40 .

depauperatum $\boldsymbol{M}$ (ch)., 19...49.

dichotomum Linn., 36, 49, 54, 55 .

dichotomum pubescens. $\boldsymbol{5} \mathbf{\$} . .52$.

diffusum Pursh. 45.

elongatum Pursh. 42.

filiforme $\operatorname{Linn.,} \cdot \mathbf{2}-. .39$.

flexile Scribn., \$0...44.

gribbum Ell., a 1...t0.

glabrum Faudin, 27 ...39.

hians Ell., $11 . .45$.

lanuginosum Ell., 52.

latifolium Walter. $\mathbf{1 5 . . . 4 7 .}$

laxiflorum Lrm.. $\mathbf{5 . 5} . .51$.

longipedunculatum Scribn,, 61... 5).

microcarpon Wuhl., 5.5. 51...50.

neuranthum Vasey. 19.

nitidum Lam., 49, 53.

nodiflorum Lam., .59...54, 55.

ovatum Vees. 32.

Philadeiphicum Bernh., 44.

proliferum Lam.. $\mathbf{3 5 5} . .43$.

pubescens Lam., 50..52,54.

ramulosum Michx., 60...54, 55.

sanguinale Linn., $\mathbf{2 6}$...38.

scoparium $\operatorname{Lnm.,47,48.}$

scoparium var. angustifolium Vasey. 48.

scoparium var. genuinum. 48.

scoparium major $V r x+y .48$.

scoparium var, pauciflorum. 16 ... 48.

sphærocarpon Ell., 50, $\mathbf{5 1}, \mathbf{5 \cdot 2}$.

verrucosum Yuhl., $\mathbf{1 2} . .45$.

virgatum Linn., $\mathbf{3 5}$...42.

viscidum Ell., 11...46,51.

Panicum Walteri Poir.. 15...t7, 50, 54. Papillæ. Minute nipple-like projections.

Papillate. Bearing minute nippleshaped projections. 
Paspalum. Greek, said to be an ancient name for Millet. 28. altissimum Le Conte. 34. arenarium Schred. 35. Boscianum Flugge, 17...33. ciliatifolium Michx., 22...34, 35. compressum Nees. 31. debile Mich $x$., 35.

dilatatum Poir., 19...32. distichum Linn., $21 . .31$. Floridanum Kichx., 20...34. fluitans Kunth, 15...30. Hairy-flowered. 19...32. læve, Vichx., 21 ...34.

læve var. pilosum. 34. longipedunculatum Le Conte, $\mathbf{2 8}$ ...35.

macrospermum Flugge. 34. membranaceum Walt., $16 \ldots 30$. mueronatum Muhl., $15 . . .30$. platycaule Poir., $\mathbf{2 5}$...31. pubiflorum glabrum Vasey, 18...32. purpurascens E'll., 33.

setaceum Vichx., 35 .

vaginatum Ell., 16...30.

Walterianum Schult., $16 . .30$.

Pauciflorum. Few-flowered.

Pearl Millet. 58.

Pectinate. Finely and regularly cleft or divided so as to resemble the teeth of a comb.

Pedicel. The stalk of a flower or a spikelet.

Pedunculatum. Of the peduncle, or furnished with a peduncle. Pedunculated.

Pendula. Pendent, hanging downward.

Pennisetum. Latin, Feather awn. 57. typhoideum Rich. 58.

Perennans. Perennial.

Perennial. Lasting three or more vears. Fruiting for several years in succession.

Perennial Rye-grass. $175 \ldots 121$.

Perianth. The name given to the floral envelope which encloses or subtends the stamens and pistils. The term embraces the calyx and corolla of flowers possessing these organs.

Pericarp. The outer covering of the grain or of fruits.

Persistent. Remaining attached after the fall of similar, or of other parts with which it is compared.

Phalaride e. 61.

Phalaris. The ancient Greek name. 61.

Phalaris arundinacea Linn., 70 ...62. Canariensis Linn., 69...61.

Phleum. The old Greek name. 69. pratense Linn., *z...70.

Phragmites. Greek, phragmos, a hedge. 93.
Phragmites, communis Trin., 93.

Pigeon-grass. 62...56.

Pilosa. Pilose.

Pilose. Clothed with straight-soft hairs. Hairy.

Pistil. The female organ of the flower, consisting of ovary and stigma, the latter usually being raised above the ovary on a longer or shorter support called the style.

Pistillate. Said of flowers which have pistils only, or are without stamens.

Platycaule. Broad-stemmed.

Plume-grass. 19.

Plumose. Feathery or feather-like.

POACE E. 61.

Poa. Greek, Fodder. 105.

alsodes Gray, 148...109.

annua Linn., $1 \mathrm{s1}$...106.

arachnifera Buckley, 151...110.

autumnalis Muhl., 146...109.

brevifolia Muhl., 150 ....110.

Chapmaniana Scribn., 142...107.

compressa Linn., 148...107.

cristata. 107.

flexuosa Muhl., 146...109.

pratensis Linn., 14....108.

seslerioides Michx., 120...94.

sylvestris Gray, 147...109.

trivialis Linn., $\mathbf{1 4 5}$...108.

Wolfii Seribn., 149...110.

Polycarpic. Fruiting several times or for several years in suceession. Perennial.

Poverty-grass. $\mathbf{7 3} . .64$

Southern, $92 \ldots 72$.

Prairie-grass. 90...72.

Pratense. Meadow. Growing in meadows.

Proliferum. Proliferous. Producing offshoots.

Prophyllum. The primars leaf of an axis or branch. (Plural, prophylla.)

Pruinose. Covered with a whitish or glaucous bloom.

Pubescens. Pubescent.

Pubescent. Covered with soft, short hairs.

Pubiflorum. Hairy-flowered.

Punctate. Dotted.

Purple Triple-awn. 75...64.

Purpurascens. Purplish, or inclining to purple.

Pusillum. Small.

Quaking-grass. 103.

Raceme. An inflorescence in which the flowers or spikelets are supported on pedicels along a common axis.

Racemosus. Racemose.

Rachilla. The axis of the spikelet, 
the continuation of the branch to which the empty and flowering glumes are attached.

Rachis. The axis or continuation of the stem to which the branches of the inflorescence are attached.

Ramosissima. Branching in the highest degree. Very much branched.

Ramulosum, Ramulosus. Full of little branches.

Randall-grass. $162 \ldots 116$.

Red Fescue. 115.

Red-top. $102 \ldots 78$.

False, $22 . . .94$.

Panic. ss...41.

Tall. 12ez...94.

Reed. 93.

Bent-grasi. $105 \ldots 80$.

Canary-grass。 $\mathbf{7 0} \ldots 62$.

Reed-grass, Indian. \$...73.

slender. $\mathbf{~ . 5 . ~} 74$.

Sweet. 9...73.

Reed Meadow-grass. 152...112.

Reflexed. Directed downward.

Repens. Creeping.

Reptans. Creeping and rooting.

Rescue-grass. 17 \&...120.

Retrorsely. Directed or pointing

Rice. 59. downward or backward.

Cut-grass. $67 . .60$.

Indian. 58.

Wild. 58.

Rough Meadow-grass, 145...108.

Rugose. Wrinkled. Rough.

Rye. 124.

Rye-grass, Italian. $176 \ldots 122$.

Perennial. 175...121.

Saccharum. Latin, Sugar. 16, 17. officinarum Linn. 17.

Sanguinale. Bloody.

Sativa. Sativus. Cultivated.

Scabra. Seabrous, rough.

Scabrous. Rough. Said of surfaces covered with little points or very short, rigid hairs.

Searious. Thin, dry and membranous. Margins of glumes are scarious when very thin and membranous and not green.

Seoparium. Of a broom.

Secale. Origin of name doubtful. 124. cereale Linn., 124.

Secalinus. Rye-like.

Sericea. Sericeous. Silky.

Serrulate. Minutely and sharply toothed.

Sesame-grass. 16.

Seslerioides. Sesleria-like.

Sessile. Without any stalk or pedicel.

Setaceous. Bristle-like.

Setaceum. Setaceous.
Setaria. Latin, Seta, a bristle. 50. (iermanica. 56 .

glauea Beauvo, 62...56s.

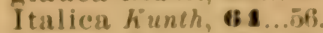

viridis Benuv, 6 s....56.

Sheath. Applied to the tubular or convolute portion of the leaves of grasses which usually embraces a portion of the stem.

Sheep's Fescue. 160.115.

Short-husk, Bearded, -6...69.

Short-stalked Meadow-grass. 12... (4i.

Silky Oat-grass. 112...84.

Simple. Unbranched.

Six-weeks grass. $111 \ldots 106$.

Slender Crab-grass。2-...39.

Fescue. 1.5 ...114.

Lyme-grass. 1-1...127.

Meadow-grass. 127...96.

Reed-grass. $\mathbf{9 \pi} \ldots 74$.

Spike-grass. 1:s-...102.

Triple-awn. 7 1...64.

Small-cane. 1>7...129.

Smooth Crab-grass. $27 . . .39$.

Smut-grass. $93 \ldots 72$...

Sobolifera. Shoot-bearing.

Soboliferous. Applied to creeping stems, which are slender, and creep along horizontally below the surface of the earth, emitting roots and new plants at intervals.

Soft Chess. $171 \ldots 119$.

Solitary. Standing alone-single.

Sorghum avenaceum Chapm., 27.

Halepense Pers., 27.

nutans A. Gray. 26.

nutans Chapm., 27.

Southern Poverty-grass. 92...72. Spear-grass. 1:26...97.

Spartina. Greek, A cord. 87. .

Spartina cynosuroides Willd., $116 .$. 87.

Spathe. A sheathing bract, enclosing or subtending the flowers or inflorescence.

Spear-grass, Low. 111...106.

Spear-grass, Southern. 126...97.

Sphærocarpon. Round-fruited.

Spicata. Spiked.

Spider Bent. $101 . .78$.

Spike. An inflorescence in which the flowers or the spikelets are sessile along the common rachis.

Spike-grass, Long-leaved. 102.

Slender. 1:s-...102.

Spikelet. A small or secondary spike. In grasses, a special inflorescence consisting of a more or less elongated axis-the rachilla,-and two-ranked imbricated bracts-glumes-in the axils of some of which the flowers are borne. 
Sporobolus. Greek, a seed to throw. 71 .

asper $K$ unth, $\mathbf{2 0}$...72.

Indicus R. Br., \$8...72.

longifolius Wood, 72.

minor Vasey, 91...72.

vaginæflorus Wood, 92...72.

vaginæflorus, var. minor. 91...72.

Sprouting Crab-grass. $\mathbf{3 6}$...43.

Stamen. The male, or pollen-bearing organ of a flower. The parts of a stamen are the filament and the anther. The latter contains the pollen, the former is the supporting stalk.

Staminate. Having stamens only. Male flowers.

Sterilis. Barren. Applied to plants which are infertile, also used to indicate that they grow in barren or sterile soils.

Stigma. The part of the pistil which receives the pollen. In grasses the stigmas are usualiy plumose or feathery, this plumose part being raised above the ovary on longer or shorter styles.

Stink-grass, $121 \ldots 97$.

Stipa. Greek, of uncertain meaning, 65 .

avenacea Linn., 78 ...65.

Stolonifera. Stoloniferous, which see.

Stoloniferous. Producing offsets or running shoots from the base.

Striæ. See Striate.

Striate. Grooved or furrowed. Marked with striæ.

Stricta. Strictus. Erect or straight.

Strigosa. Covered with short, stiff hairs. Strigose.

Strigose. Covered with short, stiff and appressed hairs.

Style. The stalk which supports the stigma, or raises the stigma above the ovary. See pistil.

Subaristate. Nearly or somewhat awned.

Subciliate. Slightly or somewhat ciliate.

Subspicatum. Somewhat or nearly spicate.

Subulate. Awl-shaped.

Sugar-cane. 17.

Sweet Reed-grass. 94...73.

Vernal-grass. 71...62.

Switch-cane. 187 ...129.

grass. $\mathbf{3 5}$...42.

Sylvatica. Sylvestris. Relating to woods or wood-land.

Tall Graina. $119 . .89$.

Red-top. 192...94.

Temulentum. Drunken.

Tenella. Delicate or small.

Tennessee Fescue. $161 . .115$.

Tenuis. Slender.
Teosinte. 13.

Terete. Cylindrical, not flattened or compressed.

Terrell-grass. 18:...126.

Texas Blue-grass. 151...110.

Thatch-grass. 116...87.

Timothy. 81...70.

Timothy, white. 106...81.

Tribuloides. Tribulus-like. Tribulus-three-pointed.

Trichodium decumbens. 76 .

Trifid. Three-parted.

Triodia. 93. cuprea Jacq., $122 . .94$.

Triple-awn, Purple. 75...64. Slender. 7 i...64.

Tripsacum. Greek, to thresh. 15. dactyloides Linn., 1...16.

Trisetum Latin. Three bristles. 81. flavescens, 82.

palustre Torr., $109 . .82$.

subspicatum var. molle Gray, 108 ...82.

Triticum. The classical name. 124. sativum Linn. $12 t$.

Trivialis. Common.

Truncate. Ending abruptly as if cut off transversely.

Tuberculate. Covered with small wart-like excrescences or tubercles.

Twin-grass. I37...101.

Two-rowed Barley. 125.

Typhoideum. Typha-like. Typhathe generic name of Cat-tail, a marsh plant.

Unilateral. One-sided. Disposed or arranged along one side.

Unilateralis. Disposed along one side. One-sided.

Uniola. Ancient Latin name of some plant. 101.

broad-leaved. 189...102.

gracilis Michx., $138 . . .102$.

latifolia Michx., 139...102.

longifolia Scribn. 102.

nitida. 102.

Unioloides. Uniola-like.

Unisexual. of one sex-either staminate (male) or pistillate (female).

Vaginæflorus. Sheath-flowering.

Vaginatum. Sheathed.

Vanilla-grass. 61.

Velvet-grass. $106 . . .81$.

Ventricose. Swelling out on one side.

Vernal-grass, Sweet. 71...62.

Verrucose. Warty.

Verrucosum. See verrucose.

Versatile. Said of anthers when attached near the middle so that they freely swing to and fro.

Verticillata. Verticillate. Whorled. 
INDEX AND GLOgSARY.

Vilfa Drummondil. 72.

Villous. Densely clothed with soft and rather long hairs.

Virgatum. Twig-like. Slender, straight and erect.

Virginia Lyme-grass. 1-2...126.

Virillis. Green.

Vireid. Sticky.

Viscidum. Viscid. Coated with a sticky fluid.

vulgare. Vulgaris. Common.

Wheat. 1:4.

Wheat-grass, Bearded. 179...123.

White-grass. 68...59.

White-rrass, Timothy. $106 . .81$.

Whorled. Arranged in a ring or circle, in the same plane, around the supporting axis.
Wild Barley, $\quad \mathbf{0} \ldots 12 \%$,

Millet. $6 \mathbf{s} \ldots 56$.

()at-grass, $113 \ldots 85$.

Rice. 58.

Wire-grass, 120...90.

Witch-grass。17-..123.

grass, Old. :57 ...43.

Woodland Blue-grass. 1 17 ...109.

Yellow Foxtail. 62...6̈6.

Yellow Oat-grass. 82.

Zea. Greek, of obscure meaning. 14. Mays Linn., 15.

canina. 14,15 .

Zizania. 58.

aquatica $\operatorname{Lin} n_{\circ}, 58$.

ZOYSIE.E. 28. 






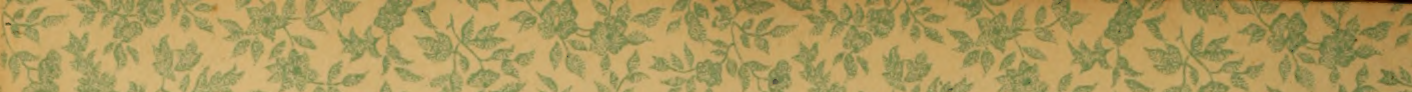

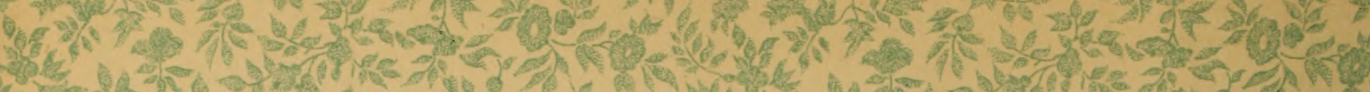

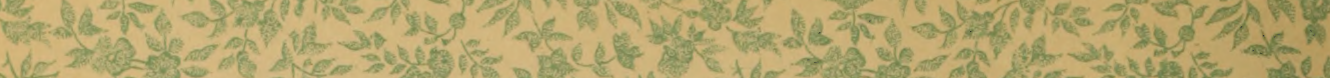

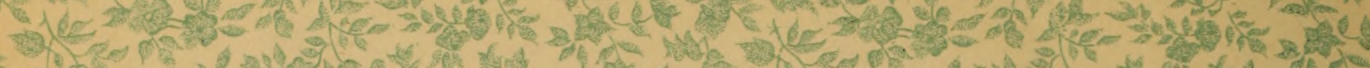

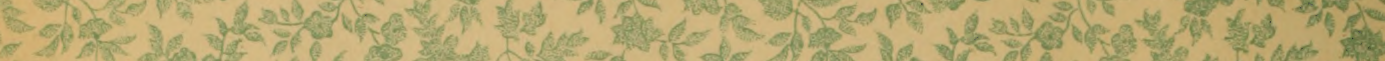
(xor

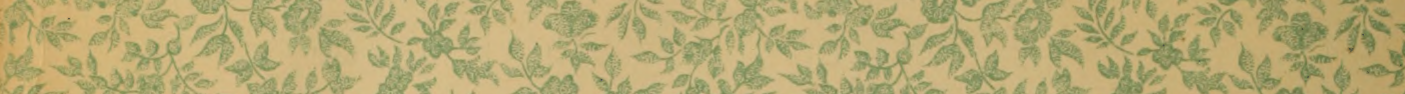
(16)

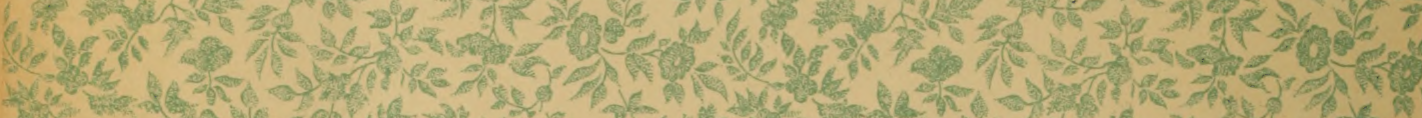

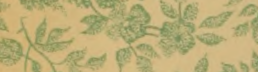

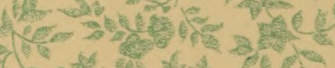
10 . T-5.

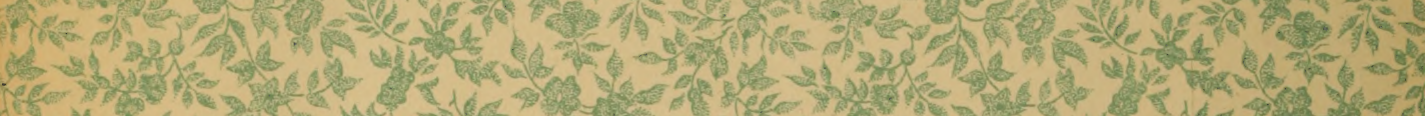
(1) 15 \%

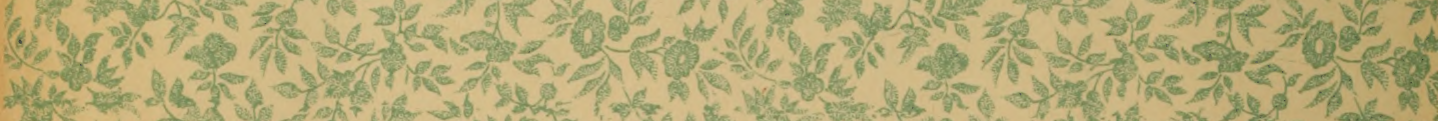
A -

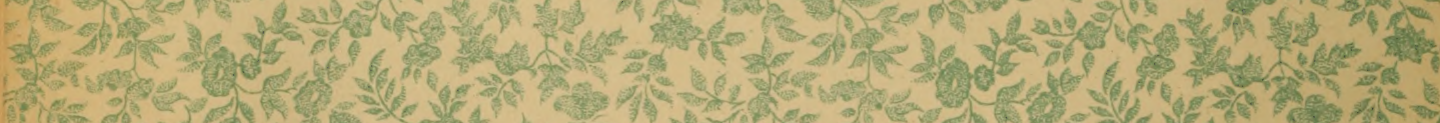

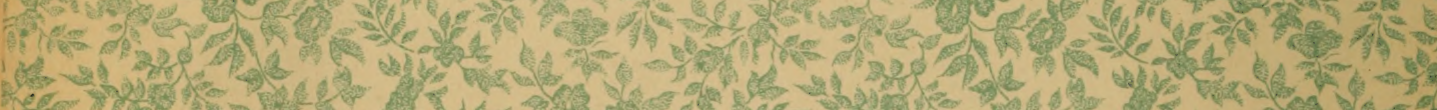

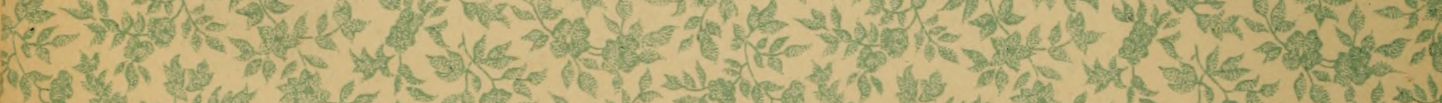

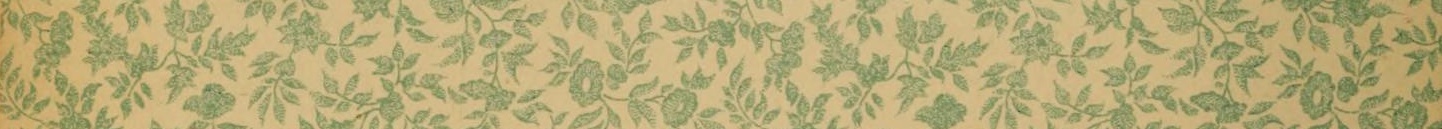

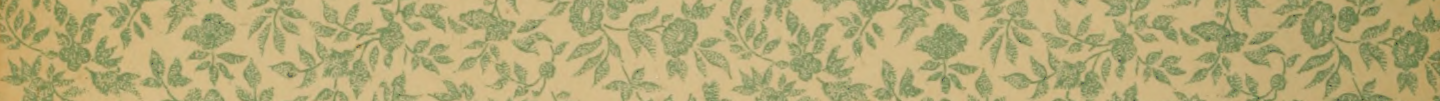

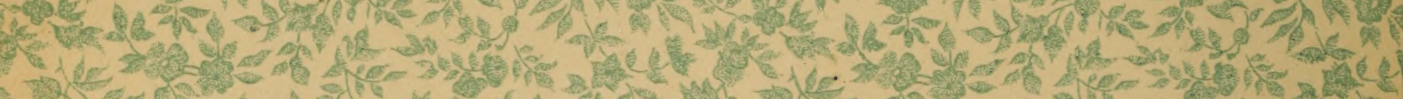
W - be

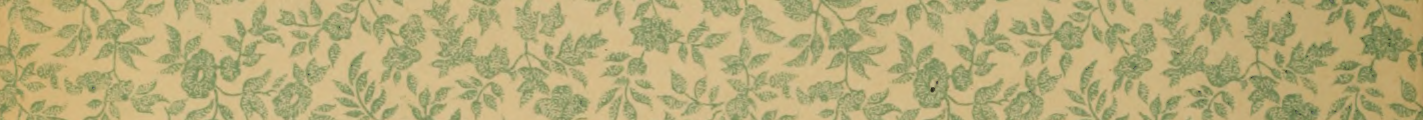

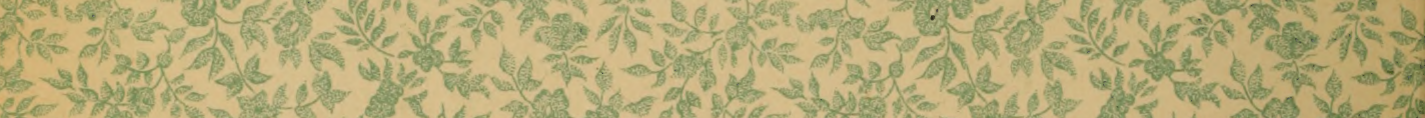
Le to 1.8.

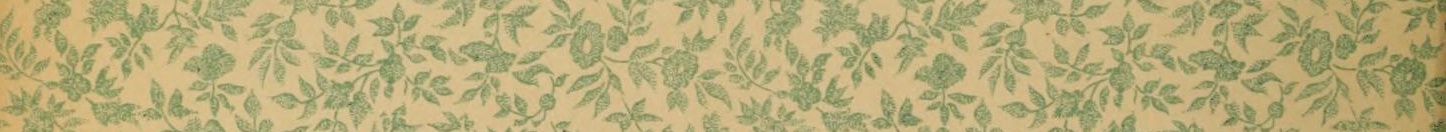

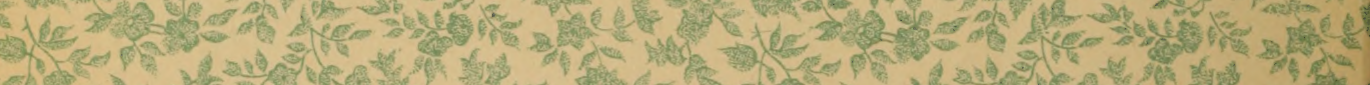

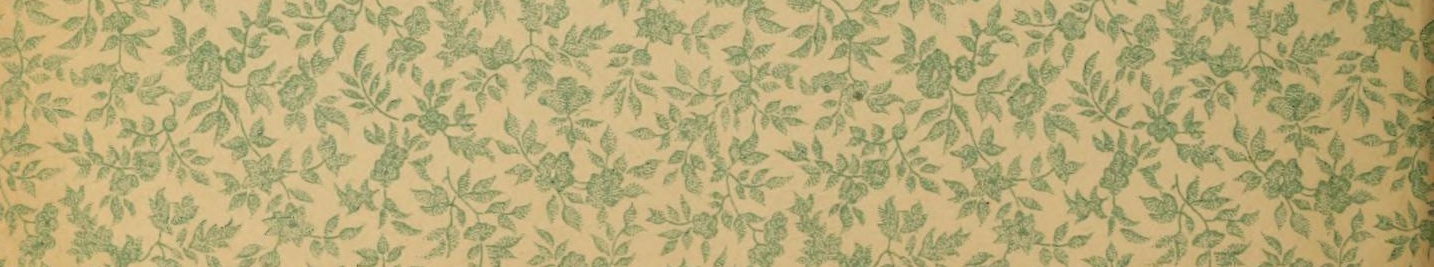




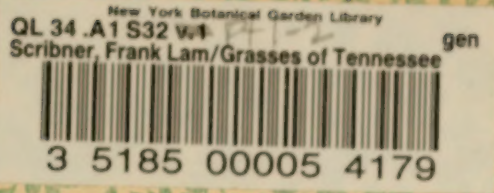

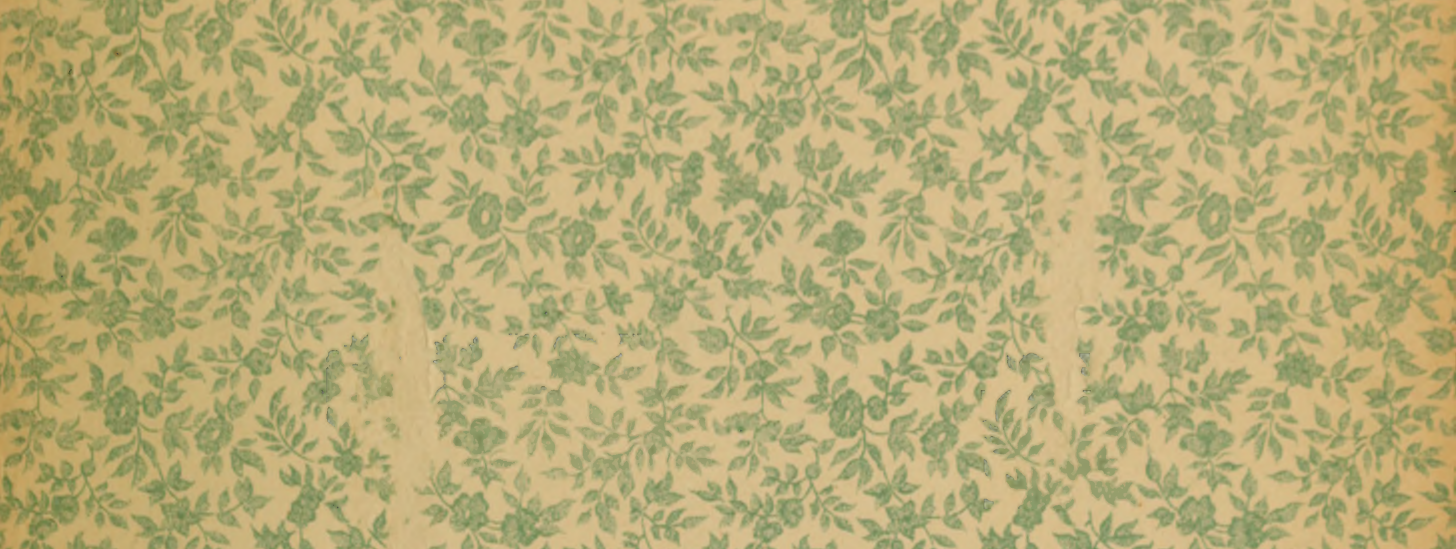
4.6.

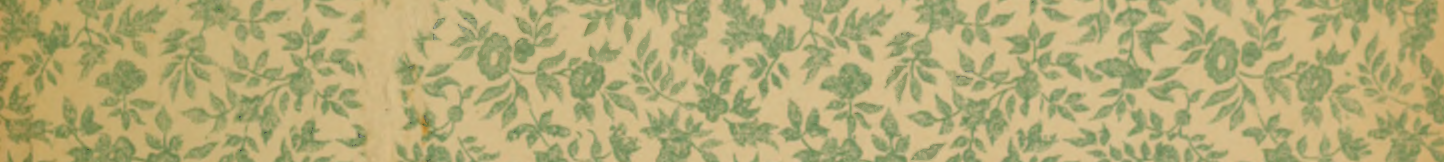

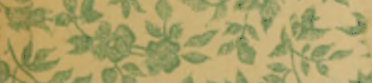
(3) a

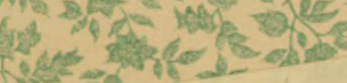

1.

ore yos? s.t. Th $\Rightarrow$, - I ( 7.

\section{(}


